\title{
NORTHMOST AISTTRALIA
}

R.LOGAN IACK 


$$
\text { Yix } 631
$$




NORTHMOST AUSTRALIA 
Digitized by the Internet Archive in 2007 with funding from Microsoft Corporation 


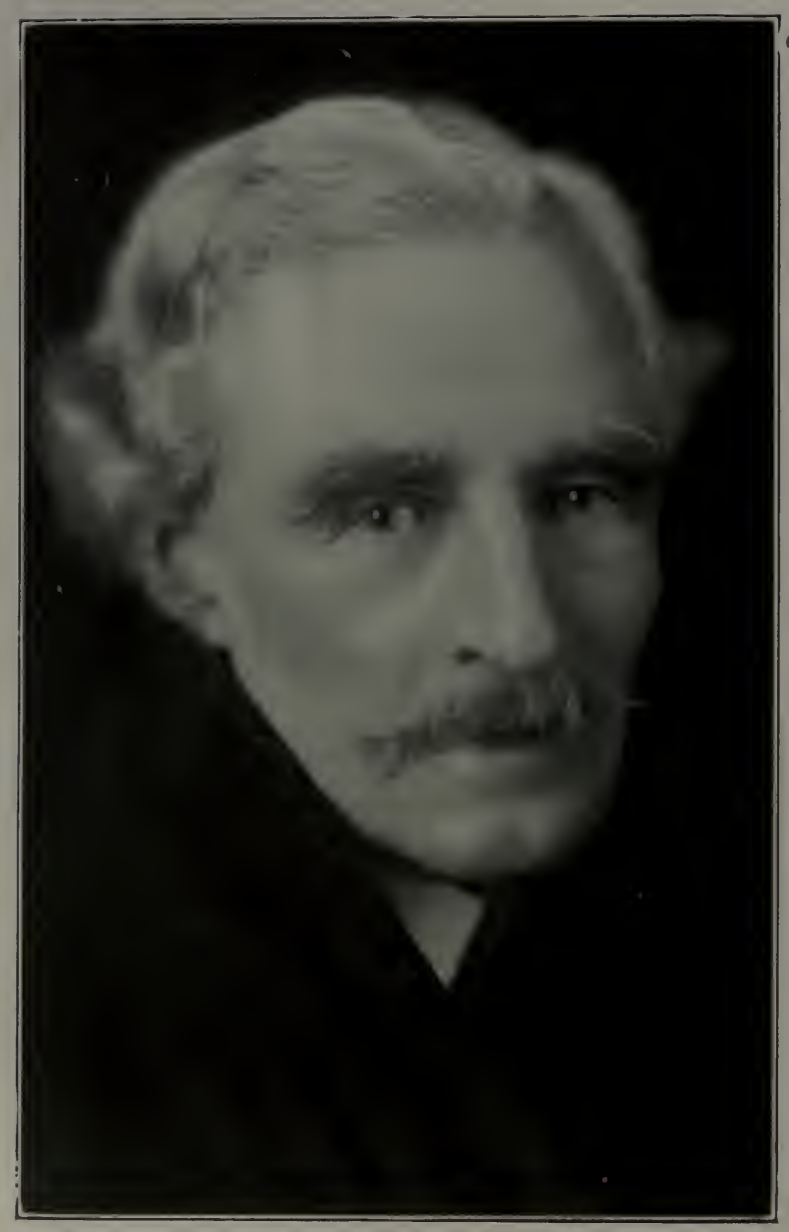

ROBERT LOGAN JACK, I920. 
Ji2.5n

\section{NORTHMOST AUSTRALIA}

THREE CENTURIES OF EXPLORATION, DISCOVERY, AND ADVENTURE IN AND AROUND THE CAPE YORK PENINSULA, QUEENSLAND

WITH

A STUDY OF THE NARRATIVES OF ALL EXPLORERS BY SEA AND LAND IN THE LIGHT OF MODERN CHARTING, MANY ORIGINAL OR HITHERTO UNPUBLISHED DOCUMENTS, THIRTY-NINE ILLUSTRATIONS, AND SIXTEEN SPECIALLY

PREPARED MAPS

\section{BY \\ ROBERT LOGAN JACK}

LL.D., F.R.G.S., F.G.S., M.Inst.M.M.

EX-GOVERMMENT GEOLOGIST, QUEENSLAND, PREVIOUSLY OF THE GEOLOGICAL SURVEY OF SCOTLAND

"BANDBOOK OF QUEENSLAND GEOLOGY"; "THE MINERAL WEALTH OF QUEENSLAND"

"THE BACK BLOCKS OF CHINA," ETC.

AND JOINT-AUTHOR (WITH ROBERT ETHERIDGE, JUNIOR) OP

"THE GEOLOGY AND PALFONTOLOGY OB QURENSLAND AND NEW GUINEA"

IN Two Volumes

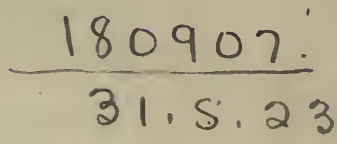

VoL. I

SIMPKIN, MARSHALL, HAMILTON, KENT E CO. LTD., \& STATIONERS' HALL COURT : : LONDON, E.C.4 


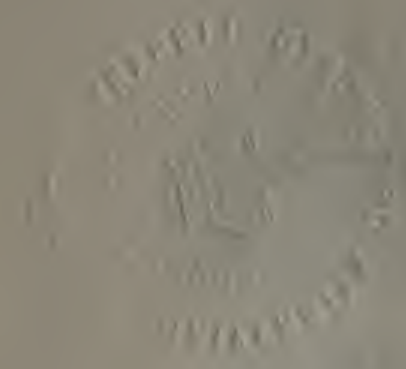

Copyright 1921

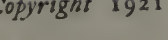




\title{
C O N T E N T S
}

\author{
VOL. I
}

Chapter

I. Introduction $\quad$.

II. Australia Distinct from New Guinea. Magelhaen, Quiros and Torres . . 6

III. Voyage of the "Duyfken" to New Guinea and the Cape York Peninsula, 1605-6.

IV. The Voyage of the "Pera" and "Aernem," I623: I. The Sailing Orders . .

V. The Voyage of the "Pera" and "Aernem," I623, continued: II. General Observations ON THE Expedition and ON THE "Pera" Narrative . $\quad$. $\quad$. $\quad$. 3

VI. The Voyage of the "Pera" and "Aernem," I623, continued : III. The Outward Voyage

VII. The Voyage of the "Pera" and "Aernem," I623, continued: IV. The Return Voyage of THE "PERA" . . . . .

VIII. The Voyage of the "Pera" and "Aernem," 1623, continued: V. The "Aernem".

59

IX. Tasman's Voyage of 1644 • • • • 6I

X. Voyages of the "Buijs" and "Rijder," 1756 : VAN Asschens and Gonzal • • 75

XI. Cook in "Endeavour," I770 • • • 82

XII. Quiros, Torres and Cook and the Vaugondy and Dalrymple Maps • . . $\quad$ - 92

XIII. Bligh : Voyage of "Bounty's" Launch, I789 97 
CGAPTER

XIV. The Voyage of the "Pandora," I79I : EdWARd EdWARds • • • • . 104

XV. Bligh, I788-92, continued: Second Voyage through Torres Strait With the "Providence" And "Assistant," I792.

I 12

XVI. The "Hormuzeer" and "Chesterfield" (Bampton and Alt), I793 • . . II8

XVII. Flinders, I79I-I8I4 : EARLy Life and Voyage to Australia in the "Investigator," $180 \mathrm{I}-2$. . . . . . .

XVIII. Flinders, continued: With the "Investigator" from Sydney to the Gulf of Carpentaria, I 802

XIX. Flinders, continued: "Investigator's" Return TO SYDNEY, $1802-3$. . . . .

XX. Flinders, continued: With the "Cumberland" to Torres Strait, I803-Captivity at Mauritius, i $803^{-10}$, and Close of his CAREer

XXI. Phillip Parker King in the "Mermaid," I819, AND IN THE "BAthurst," I82I.

XXII. Wreck of the "Charles Eaton," I834, AND SEARCh For Survivors, 1836 . .

XXIII. H.M.S. "Beagle," Wickham and Stokes, I839-4I : The Norman River and Normanton and the Albert River and Burketown

XXIV. "L'Astrolabe” AND “LA Ż̀LÉe," I840: Dumont-D'URville • • . 169

XXV. Blackwood and Yule, I843-5-H.M.SS. "Fly," "Bramble" and "Prince George" and the Pinnace "Midge" . . .

XXVI. Leichhardt's Overland Expedition : From Brisbane to Port Essington, I 844-5 -Brisbane to the Lynd River. 
XXVII. LeichHardt's Overland Expedition, I844-5, continued: The Lynd Valley.

XXVIII. Leichhardt's Overland Expedition, I844-5, continued.

XXIX. Leichhardt's Overland Expedition, I844-5, continued.

XXX. Kennedy's Expedition, i848 : The East Coast and the Coast Range . . . . 202

XXXI. Kennedy's Expedition, I848, continued: From the Coast Range to the Palmer . . 212

XXXII. Kennedy's Expedition, 1848, continued: From the Palmer to the Pascoe . .

XXXIII. Kennedy's Expedition, I848, continued: The Forlorn Hope-From the Pascoe to Cape YORK . . . . . .

XXXIV. Kennedy's Expedition, 1848, continued: Voyage of the "Ariel "-Traces of KenNedy and the "Pudding-Pan Hill" Party

XXXV. Kennedy's Expedition, I 848, continued: Voyage OF THE "FrEAK"-SEARCh For RELICS OF Kennedy and the "Pudding-Pan Hill" PARTY . . . . . .

XXXVI. Kennedy's Expedition, 1848, continued: Carron's Party at the Pascoe River • 243

XXXVII. H.M.SS. "Rattlesnake" and "Bramble," 1847-50: Stanley and Yule . . .

XXXVIII. The North Australian Exploring Expedition, I855-6: GREGORY . . . . . 266

XXXiX. The Burke and Wills Expedition, 1860-6i . 274

XL. Burke and Wills Search Parties in QueensLAND : LANDSBOROUGH, WALKER AND McKinLAY, $186 \mathrm{I}-2$. $\quad$ • . $\quad$. 278 
Xhiptrr The Journey of Frank and Alexander Jardine, I 864-5: From Rockhampton to Somerset -Carpentaria Downs, via Einasleigh River, to the Mouth of the Etheridge RIVER • • • • • • • • 289

XLiI. The Jardine Brothers' Expedition, I864-5, continued: From the Einasleigh River to the Mouth of the Staten River, de FACTO

XLiII. The Jardine Brothers' Expedition, continued: Staten River, de facto, to Jardine River 302

XLIV. The Jardine Brothers' Expedition, continued: The Jardine River and the Problem of the Escape River.

XLV. The Jardine Brothers' Expedition, continued: Reconnaissance by the Brothers and Eulah • • • • . •

XLVI. The Jardine Brothers' Expedition, continued 334 XLVII. Somerset and Its Background • • 338 XLVIII. Daintree, I863-7I • • • • • 348 XLIX. Moresby : First Cruise of the "Basilisk" to Torres Strait, I871 • • . 352

L. Moresby, continued: Second Cruise of the "BAsilisk" in Torres Strait, I873 • 360 


\section{LIST OF ILLUSTRATIONS}

VOL. I

R. Logan Jack, 1920 .

Frontispiece

Photo. Johnson Sydney.

Abel Janszoon Tasman, $1664^{1}$.

Reproduced from Jose's History of Australasia.

JAMES CooK, 1772

Reproduced from Glasgow Issue of Cook's Voyages, 1807.

William Bligh, I8I2 .

Reproduced from Jose's History.

Matthew Flinders, i8II .

Reproduced from Scott's Life of Flinders.

Phillip Parker King

Reproduced from Feldheim's Brisbane Old and New.

J. Beete Jukes, I870

Photo. from Bust by Joseph Watkins, R.H.A.

Ludwig LeichHardt, 1844

Reproduced from Long's Stories of Australlan Exploration.

Edmund Besley Court Kennedy, I 847 •

Reproduced from Long's Stories of Australian Exploration.

William Carron, 1870

Reproduced from Journ. Roy. Soc., N.S.W., Vol. 42.

Sir Augustus Charles Gregory, I898

Photo. lent by Hugh Macintosh, Brisbane.

Robert O'Hara Burke, I860

Reproduced from Long's Stories of Australian Exploration.

William John Wills, I 860

Reproduced from Long's Storles of Australian Exploration.

William Landsborough, 1870

Reproduced from Feldheim's Brisbane Old and New.

1 In this case, and some others, the date of the portrait is conjectural. 
JoHn McKinLAY, I 870

Reproduced from Feldheim's Adelaide Old and New.

Frank (LEFT) AND Alick JARDine (RIGHT), 1867 • • • • 288 Reproduced from Byerley's Jardine Expedition.

FRANK JARDINE, 1917 •

Reproduced from Queenslander of roth November, I917.

Richard Daintree, I871 • • • • • • • • 336

Reproduced from Dunn's Founders of the Geological Survey of Victoria.

William Hann, 1873 .

Reproduced from Photo. lent by his daughter Mrs. Charles Clarke, Maryvale.

Norman TAYlor, 1873

Reproduced from Dunn's Founders of the Geological Survey of Victoria.

Thomas Tate, 25Th June, I9I3 (7Ist Birthday).

Reproduced from Photo. lent by his daughter Mrs. Leake, Maxwellton, Queensland. 


\section{LIST OF MAPS \\ VOL. I \\ (See Index Map)}

A. CAPe York to New Guinea = Queensland 4-mile Map, Sheet 2i B, with Additions from Admiralty Charts. Shows Sea Routes of "San Pedro" (Torres), I606; "Duyfken" (Janszoon), 1606; "Pera" (Carstenszoon and Sluijs) and "Aernem" (von Coolsteerdt), I623; "Limmen" (Tasman), I643; "Rijder" (Gonzal), 1756; "Buijs" (Asschens), I756; "Endeavour" (Cook), I770; "Bounty's" Launch (Bligh), I789; "Pandora" and Her Boats (Edwards), I791 ; "Providence" (Bligh) and "Assistant" (Portlock), 1792; "Hormuzeer" (Bampton) and "Chesterfield" (Alt), I793; "Investigator" (Flinders), I 802 ; "Cumberland" (Flinders), I 803; "Mermaid" (King), I818; "Isabella" (Lewis), 1836; "Tigris" (Iggleston), 1836; "Astrolabe" and "Zìlée" (Dumont-D'Urville), I840; "Fly" (Blackwood), "Bramble" (Yule) and "Prince George," I 843-5; "Rattlesnake" (Stanley), I849; "Basilisk" (Moresby), 1871-3: and Land Routes of Kennedy and Jackey-Jackey, I848; F. and A. Jardine, 1865 ; Jack, I880; Bradford, I883.

B. Orford Ness to Cape Weymouth and Vrilya Point to Albatross $\mathrm{BAY}=$ Queensland 4-mile Map, Sheet 2IA, with Additions from Admiralty Charts. Shows Sea Routes of "Duyfken," 1606; "Pera" and "Aernem," I623; "Limmen," I644; "Buijs," 1756; "Rijder," 1756; "Endeavour," 1770; "Bounty's" Launch, 1789; "Investigator," I 802 ; "Fly," "Bramble" and "Midge," I 843 ; "Rattlesnake" and "Bramble," I848; "Ariel" (Dobson), I 848; "Freak" (Simpson) and her Whaleboat, 1849: and Land Routes of Kennedy, 1848; F. \& A. Jardine, I865; Jack, I880; Pennefather, I881 ; Bradford, I883; Hey, I895; Embley, 1897.

C. Lloyd Bay to Stewart River = Parts of Queensland 4-mile Maps $20 \mathrm{C}$ and $20 \mathrm{D}$, with Additions from Admiralty Chart. Shows Sea Routes of "Endeavour," I770; "Bounty's" Launch, I789; "Bramble" (Yule), I843; "Rattlesnake" and "Bramble," I 848; "Dart," I896-8 : and Land Routes of Kennedy, I848; W. Hann, I872 ; Jack, I879-80; Bradford, 1883; Embley, 1884-96; Dickie, I901 ; Dickie, Dick and Sheffield, r9ro.

D. Albatross Bay, to Cape Keerweer, Gulf of Carpentaria = Part of Queensland 4-mile Map, Sheet 20D, with Additions from 
Admiralty Chart. Shows Sea Routes of "Duyfken," 1606; "Pera" and "Aernem," I623; "Limmen" (Tasman), I644; "Buijs," I756; "Rijder," I756; "Investigator" (Flinders), I802: and Land Routes of F. and A. Jardine, 1864-5; Embley, 1884-95; Hey, 1892-1919; Meston, 1896 ; Jackson, 1902 .

E. Cooktown to Princess Charlotte Bay = Queensland 4-mile Map, Sheet $20 \mathrm{~A}$, with Additions from Admiralty Charts. Shows Sea Routes of "Endeavour" (Cook), I770; "Mermaid" (King), I819; "Bathurst" (King), I821 ; "Fly" (Blackwood) and "Bramble", (Yule), I 843 ; "Rattlesnake" (Stanley) and "Bramble" (Yule), I848; and Land Routes of Kennedy, 1848; Hann, 1872; Mulligan, 1875; Jack, 1879; Bradford, I883 ; Embley, I884.

F. Hamilton and Philp Goldfields and Westward to the Gulf of Carpentaria, with the Kendall, Holroyd, Edward, Coleman And Mrtchell Rivers = Queensland 4-mile Map, Sheet 20B, with Additions from Admiralty Chart. Shows Sea Routes of "Pera" and "Aernem," I623; "Limmen" (Tasman), I644; "Investigator" (Flinders), 1802: and Land Routes of F. and A. Jardine, 1864; Hann, I872; Mulligan, 1875-95; Jack, 1879-80; Embley, I874-1896; Bradford, 1883 ; Dickie, I901.

G. Cape Grafton to Weary Bay and Cairns to Palmer River = Queensland 4-mile Map I8C and Part of I8D, with Additions from Admiralty Chart. Shows Sea Route of "Endeavour" (Cook), 1770: and Land Routes of Leichhardt, 1845 ; Kennedy, I848 ; Hann, 1872 ; Mulligan, 1873-75; Dickie, I901.

H. Palmer, Mitchell, Lynd, Staten and Gilbert Rivers, and Part of THE Gulf of CARPEnTARIA = Queensland 4-mile Map, Sheet I8D and Part of $19 \mathrm{C}$, with Additions from Admiralty Charts. Shows Sea Routes of "Pera" and "Aernem, I623; "Limmen" (Tasman), 1644; "Beagle" (Stokes), 1841 : and Land Routes of Leichhardt, I845; F. and A. Jardine, I864 ; Hann, 1872 ; Mulligan, I875 ; Embley, 1884-7; Dickie, I89ı. 


\section{ACKNOWLEDGMENTS}

The author desires specially to record his thanks to the undernoted persons and institutions. References to many others who assisted him will be found in the text.

Agar, Bernice, Sydney.-For special pains in the production of photographs of R. Logan Jack, Janet Simpson Jack and James Simpson Love.

Angus \& Robertson, LTD., Sydney.-For permission to produce portraits of Tasman, Bligh and Flinders from books published by them.

BRADFORD, John R., Brisbane.-For permission to publish his report (1883) on the Exploration preliminary to the construction of the Cape York Telegraph Line; for information which proved instrumental in tracing my lost maps; and for much useful information which is embodied in the text.

BraDY, A. B., Under Secretary for Works, Queensland.-For copies of documents relating to Mulligan's explorations.

BYERs, T. J., Hughenden.-For portrait of Mulligan and much information.

ClARK, MRs., Maryvale, Queensland.-For portrait group of members of the expedition led by her father, William Hann; for Biographical Details $r e$ members of the expedition and Daintree and for other information.

CRosbie, Mrs. J. D., Cairns.-For portrait of her late husband, James Crosbie, biographical notes and other information.

Cullen, E. A., Harbours and Rivers Department, Brisbane.-For information $r e$ Batavia River and Port Musgrave.

Dick, (THE LATE) James, Cooktown.-For information re prospecting in Cape York Peninsula, communicated in correspondence from I9I I till his death in I916. His many letters amounted almost to collaboration. Indirectly, as is explained in the introductory chapter, he may be said to have brought about the expansion of a proposed annotated version of my reports on the $1879-80$ expeditions, on which I was engaged when the correspondence began, into a history covering three centuries of exploration.

Dunn, E. J., formerly Government Geologist of Victoria.-For permission to reproduce portraits of Norman Taylor and Richard Daintree from his Founders of the Geological Survey of Victoria.

Dunstan, B., Government Geologist, Queensland.-For a search in his office for copies of my lost maps; and for the loan of official documents left by me.

EMBLEY, J. T., Melbourne.-For portraits of himself; for a special article on his expedition (1884) with Clark, and for information $r e$ the Mcllwraith and Macrossan Ranges, the Western Rivers, the discovery and occupation of pastoral country in the north, etc. The assistance rendered by him in some portions of this work amounted to collaboration.

Foot, Mrs. W., Cardington, Queensland.-For portrait of her father, 
William Hann, and for information re the Hann expedition, the Etheridge and Gilbert Rivers, etc.

GreEn, D., Townsville.-For many contributions of newspaper articles re northern explorers and pioneers, and for gratuitous advertisements in the newspapers controlled by him with the object of eliciting information required by me.

Heeres, J. E., LL.D., formerly Professor at the Dutch Colonial Institute, Delft, afterwards at the University of Leiden.-For permission to quote from the English translation of his exhaustive work on $T$ he Part borne by the Dutch in the Discovery of Australia, 1606-1765, and to his publishers, "The Late E. J. Brill Company, Limited," Leiden, for their consent.

Hey, Rev. Nicholas, late of the Mapoon Aboriginal Mission.-For geographical and ethnological notes; for notes on explorations by the missionaries, and especially for assisting in the identification of what I believe to be "Coen Revier" of the "Pera" and "Aernem" Expedition.

JонNson, L., Sydney.-For special care in the reproduction of old portraits from originals in some instance faded or damaged.

Jones, Rev. John, Church of England Board of Missions, Sydney.-For information re Aborigines of the Mitchell Delta, etc.

Leake, Mrs., Merriula, Maxwellton, Queensland.-For portrait of her father, Thomas Tate; for documents relating to the wreck of the "Maria," in which he took part, and for other information.

LeEs, William, Brisbane.-For assistance and encouragement in my work. For several years back he continually contributed any writing which came under his observation as a journalist, and which appeared to bear on the subject of my study. His extensive knowledge of the North of Queensland and his wide reading enabled him to amass knowledge most useful to me.

Love, James Simpson, Townsville.-For information regarding recent developments in North Queensland. He was the youngest member of my Second Expedition (1879-80), and has since been in a position to acquire a very intimate knowledge of the Cape York Peninsula.

Macgregor, the late Sir William, G.C.M.G., etc. Administrator and Lieutenant Governor of British New Guinea, Governor of Lagos, Governor of Newfoundland and Governor of Queensland. But for his death (on 4th July, I9I9) this book would have been dedicated to him in grateful recognition of his services to science and of his personal and stimulating interest in my geographical and geological work and in the historical questions which I had under investigation. He wrote me on 29th December, I9I6: "I am glad to learn that you have on the stocks a work of the kind you mention. I should indeed consider it a very real honour to have it dedicated to me, for I know well that it would be the standard of reference for future generations when personally we are long off the scene."

Macintosh, Hugh, Brisbane.-For portraits of Sir Augustus Gregory and Sir Thomas McIlwraith, and for a mass of information re explorations, surveys, dates, names, etc., in answer to my inquiries extending over the last decade. His long experience in the Survey Office made him an unrivalled authority on such matters. 
McLaren, John, Utingu, near Cape York.-For information re the Coco-nut plantation and conditions in the Cape York district generally.

MaIDEN, J. H., C.M.G., Government Botanist, Sydney.-For permission to reproduce portrait of William Carron from his Records of Australian Botanists, and for botanical notes.

Marshald, Henry, Under Secretary for Mines, Brisbane.-For the text of James Dick's report on the Dickie, Dick and Sheffield traverse of the Mcllwraith Range; for a search in the archives of the Department for my missing map; for statistical and other information.

Mrtchell Library, Sydney, and Hugh Wright, Librarian.-For access to books and maps and special facilities for the examination of Kennedy and early Dutch-Australian Literature and documents.

Moffat, Miss E. L., Sydney.-For portrait of her father, the late John Moffat.

Parliamentary Library, Brisbane, and J. Murray, Librarian.-For official statement $r e$ construction of Cape York Telegraph.

Parliamentary Library, Sydney, and F. Walsh, Librarian.-For access to Books, Newspaper files and documents and facilities for the perusal of Kennedy and other documents.

Paterson, Frank J., Toowoomba, Queensland.-For information which assisted in tracing my lost maps and for reminiscences of the survey and construction of the Cape York Telegraph.

Postmaster General's Department (Federal) and J. McConachie, Deputy P.M.G., Queensland.-For copy of Bradford's report on Cape York Telegraph Survey (1883-4), with maps, and for permission to publish.

Public Library, Sydney, and W. H. Ifould, Librarian.-For access to Parliamentary papers and documents.

Public Library, Melbourne.-For access to books and maps.

QueEnslander Newspaper, Brisbane.-For permission to reproduce portrait of Frank Jardine.

Spowers, Allan A., Surveyor General, Queensland.-For maps of the Department of Lands, and officially authenticated information $r e$ explorations and surveys.

WeBB, W. J., Cooktown.-For special article on the Cooktown-Palmer Rush (1873); for portraits of Dickie, Dick and himself; and for notes on early prospectors.

Whiтcombe AND Tombs, Melbourne.-For permission to reproduce portraits of Leichhardt, Kennedy, Burke and Wills from books published by them.

White, C. T., Government Botanist, Queensland.-For botanical notes, and especially for notes and references re Gastrolobium. 


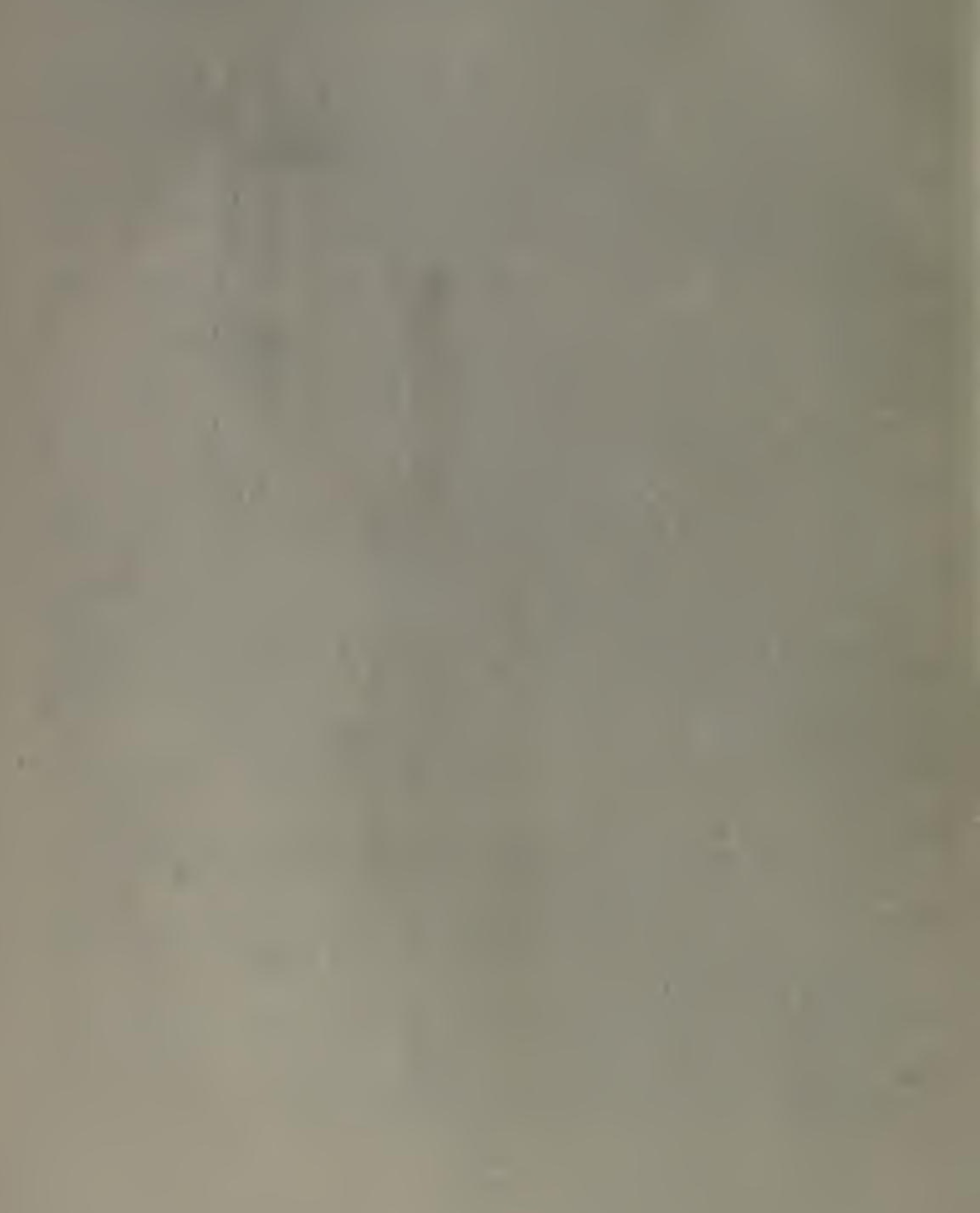




\section{NORTHMOST AUSTRALIA}

\section{CHAPTER I \\ INTRODUCTION}

THE Cape York Peninsula, forming, as it does, the link binding the two great islands of Australia and New Guinea, is necessarily of the highest importance from a geological, ethnological, zoological, botanical, historical, political and strategical point of view.

It so happens that the Peninsula is the first part of Australia to which authentic written history refers. On the earliest landing of Europeans there arose the complex questions which obtrude themselves whenever civilisation comes into contact with barbarism.

My practical interest in the Peninsula began with a tour made in 1879 in the course of my Geological Survey work. On my way to the recently rushed and still more recently abandoned "Coen" gold diggings, I crossed the base of the then almost unknown Cape Melville Peninsula, where I found indications of auriferous country, and also the rivers south of Princess Charlotte Bay, down which the unfortunate explorer Kennedy had struggled in vain to keep his appointment with the relief ship twenty-two years earlier. From the Coen, I was only able to push out to the north for a period inexorably limited by the condition of my horses and the quantity of food remaining in my saddle-bags. Even under these conditions, however, I penetrated for some distance into the McIlwraith Range, and on the heads of the river which I named the Peach (unaware that it was the river named the Archer by the Brothers Jardine, who crossed it near its mouth) I found widespread evidence of the presence of gold and tin.

From the Laura Telegraph Office, from Cooktown, and ultimately from my headquarters at Townsville, I made such communications as were possible in anticipation of a complete report to the head of the Department of Mines, which administered the Geological Survey.

My individual impression was that the reefs in the district traversed were of more importance than the alluvial gold, but there had been neither means nor time at my disposal to enable me to satisfy myself of the value of either, and this view I duly represented in my correspondence with the Department. 
The desire of the Government, and of the eager diggers throughout Queensland, was to discover an alluvial goldfield on the pattern of the Palmer, which was by that time approaching exhaustion.

A party of miners, headed by James Crosbie, volunteered to go and settle the question of the existence of payable alluvial gold, and they asked for and obtained government assistance, and I was instructed to lead them to the spot. In addition, a prospecting party was equipped, with money subscribed in Cooktown, and sent out to anticipate the expedition subsidised by the Government.

The combined geological and prospecting parties left Cooktown on 26th November, 1879, and striking out from the "bend of the Kennedy" on the Cooktown-Palmerville road, reached the "Peach" (Archer) River on 2oth December. The prospectors commenced operations at once, and were rewarded with " prospects" which led them into the jungle-clad recesses of the McIlwraith Range. Here, to their disappointment, although prospects were obtained here and there, the creeks and gullies were found to run over almost bare rocks, their beds being too steep for the retention of any quantity of alluvial "washdirt." On 3oth December, the wet season set in. For the remainder of our time in the field, the creeks were too swollen for the "bottom" to be reached where there was any washdirt at all, or the ground was too sodden to carry our horses. There were long and vexatious delays when it was neither possible to work nor to travel. Nevertheless, we continued, during breaks in the bad weather, to cross the Mcllwraith Range and touch the Macrossan Range. Regaining the summit of the McIlwraith Range, we followed it to its northern extremity, where the valley of the Pascoe River separates it from the mountain mass which we named the Janet Range. It was found that the Pascoe River bounds the Janet Range on the south and east, and we practically followed it down till we had finally to cross it where it took an easterly course towards the Pacific. We had already made up our minds that it was safer to chance the unknown in the north than to return to Cooktown across several great rivers, now all certain to be flooded. No sooner had we left the Pascoe than we entered on the Bad Lands or Wet Desert of "heath" and "scrub" without anything for horses to live on. From the Pascoe to the Escape River, our course must have coincided in many places with Kennedy's on his "forlorn hope" journey, and we repeated many of his experiences, as told by his surviving companion Jackey-Jackey, but happily not the series of disasters which resulted in his own death and the disasters which overtook the two parties he left behind to await the relief he went to bring. The natives displayed in our case, as in Kennedy's, a persistent hostility which hampered our 
movements and partially incapacitated me during the final stages of the journey. Horses died of starvation or poison, and the men of the party were running perilously short of food-the journey having been prolonged beyond our calculations-when we reached Somerset on 3 rd April, 1880.

Kennedy's maps and journals (1848) perished with him, and what we know of his expedition is taken (as far north as the Pascoe River) from the narrative written by William Carron, one of the three survivors, and (north of the Pascoe) from the "statement" of the black boy Jackey-Jackey, another of the survivors and the only one of the thirteen men to make the complete journey from Rockingham Bay to Somerset. The Geological and Prospecting Party's route only coincided for a short distance, from the head of the Jardine River to its westward bend, with that of the Jardine Brothers (1865). Day after day, during the whole of my journey, I was mapping the mountain ranges, rivers and other features of the country, checking my latitudes by star-observations whenever the night sky was clear enough, and as far as charting was concerned we were in virgin ground.

My report on the two expeditions was completed at my Townsville office in the winter of 1880 and sent to the Minister for Mines, Brisbane, with the relative map, which had taken a good deal of time, subject to interruptions by other duties. The report was printed and officially issued on 14th September, 1881, without my having had any opportunity of seeing it through the press, and to my astonishment the map-which might have been supposed to be of the first importance-was omitted. What became of the map and of my "office copy" will be seen in Chapter LXVII.

After the map had reached Brisbane and before my report was published, my map had been reduced to a smaller scale and embodied in official maps issued by the Department of Lands. In that form, however, my charting was open, in parts, to an interpretation which I could never have sanctioned.

In 1913, when I had been out of the government service for about fourteen years, and when for the first time some degree of leisure had begun to fall to my share, I commenced to prepare a revised and corrected issue of the report, with its map reconstructed from my notes, with the intention of offering it to the Govornment for republication (the report itself having been long out of print). Some progress had been made when my friend James Dick, of Cooktown, sent me proofs of a pamphlet in which he proposed to summarise the narrative of the Geological and Prospecting Expeditions. When I had gone over the proofs, correcting them only in so far as statements of fact were concerned, I fully realised how misleading my original narrative must have been, misprinted as it was, and unaccompanied by the map which 
formed its most essential part. I resumed my task with renewed vigour, and with a wider scope, and Mr. Dick, up to the date of his death, assisted me in many ways through his local and personal knowledge, happily of more recent date than mine. I am grateful to his memory, and am conscious that he was, in a sense, "the only begetter of these ensuing lines."

Between 1880 and 1913 , a great deal of charting of the interior had been accomplished by the Departments of Lands and Mines, although even now that work is incomplete. The new lines gave me, when I was recharting the lost map, an opportunity of correcting my sketching to correspond with actual surveys.

The first lesson to force itself upon me was that my estimates of distances covered had been influenced by fatigue or difficulties on the one hand (leading to over-estimation) or by good-going and good-feeding for the horses on the other (leading to underestimation).

The second lesson was that, even in the direction of my course, I had in many instances strayed to the right or left, as a ship may steer a definite course and yet make leeway owing to the pressure of forces incorrectly estimated, or even not recognised. In short, the personal equation had to be introduced and allowed for before I could hope to reconcile my supposed with my actual position on any given date.

Long before I had finished the revision of my own narrative, it had become evident that its significance could not be fully understood without a critical study of the diaries of explorers who had gone before me and whose paths I had crossed from time to time. This led me back from Mulligan to Leichhardt, and as one by one the writings of honoured pioneers came under my review, I subjected them to the tests already applied to my own, and to the best of my ability substituted where the writers were for where they thought they were, and made the necessary allowances and corrections. Then it seemed that the story might as well be continued to the present date by the addition of the developments which have taken place since 1880 through the instrumentality of surveyors, explorers and prospectors. Some of the actors are, happily, still alive, and these have rendered material assistance by the contribution of original matter. Among these are Webb, Bradford, Paterson and Embley. To the lastnamed gentleman, especially, I am indebted for assistance rendered doubly valuable by his prolonged residence in the Peninsula, and which, in some parts of the work, almost amounted to collaboration.

While dealing with land explorers it was borne in upon me that they owed some of their difficulties and many of their errors to an imperfect comprehension of the work of earlier maritime explorers. They were not, indeed, to be blamed for this, as in few instances could they have perused the narratives or seen the 
charts of the sea-adventurers. As it was, the Dutch sailors named "reviers," or inlets, on the Gulf coast, and subsequent explorers of the interior, almost without exception, made bad guesses at the connection of their rivers with the inlets on the coast line. I do not propose any reform so drastic as to restore their original names to the western rivers of the Peninsula, but content myself, after years of research, with distinguishing the original, or right, or de jure names from the de facto names, the product of pardonable misidentifications sanctioned, in many cases, by half a century of popular and official usage. I have, I hope, succeeded in making it clear that, in many instances, the de facto names are in reality not those bestowed by the earliest explorers, but rather what are called "complimentary" names.

From the preceding explanation, it will be understood that this work began, so to speak, in the middle, and followed lines dictated by the questions which arose during its progress. It was ultimately realised that it would be advisable to arrange it in chronological order, so that the tale told by each explorer might be compared with the facts ascertained by his predecessors and at the same time be complete in itself. Of no less importance was the consideration of precisely how much knowledge each explorer had of the achievements of his predecessors; and this point has exacted very careful study. I am forced to the conclusion that in most instances the later explorers knew very little about their predecessors, having taken what little they knew at second hand and without having had access to important documents, some of which, indeed, only came to light after their own time.

While aiming at chronological order, it must be conceded that it is not always possible to observe it strictly. It may be that the stories of two observers overlap; or a statement may demand historical investigation into the past; or, again, it may be convenient at once to trace the outcome of a newly discovered fact downwards to the present time. Hence a certain amount of repetition is inevitable, as facts or statements are viewed by one observer after another from a different angle.

It is impossible to define the exact base of the Cape York Peninsula, and in writing of it one must occasionally follow its pioneers beyond its southern boundary, however liberal or elastic the definition of the latter may be. The historian of France needs no excuse for referring to happenings in Germany or Italy. In a parallel way, what was commenced as a history of the Cape York Peninsula has come to include Torres Strait, the "Gulf" country west to the boundary of Queensland and the Pacific country as far south as Bowen.

SYDNEY, $30 t b$ September, 1920. 


\section{CHAPTER II}

\section{AUSTRALIA DISTINCT FROM NEW GUINEA. MAGELHAEN, QUIROS AND TORRES}

Sixteenth- and Seventeenth-century Ideas of the Great South Land. Was New Guinea Part of it ? Spanish and Portuguese Knowledge. The Dauphin Chart. Dutch Ideas. Bull of Pope Alexander VI. The Spanish Main. England and Holland in the Field. Magelhaen's Voyage to the Philippines. His Death. Did his Officers touch Australia? Quiros discovers Santa Cruz and tries to establish a Colony. Wytfliet's Belief that New Guinea was distinct from the Great South Land. Spanish Knowledge of the Strait. Quiros' New Expedition. Flacship and Consorts separate at Espiritu Santo (New Hebrides). Quiros takes that Island to be Part of the South Land. Torres disproves this. Laying-out the New Jerusalem. Torres' Report discovered in 1762. Quiros' Report discovered in 1876. Torres' Voyage. Strikes the South Side of New Guinea. Clears Torres Strait, probably by the Bligh Channel, about 24th September, i606. Does not claim the Strait as his own Discovery and probably made for it on Information already in his Possession. Reaches the Moluccas about 28th November, 1606. Successfully conducts LitTte War at Ternate. Reaches the Philip pines about 12th May, 1607.

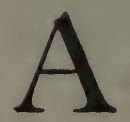

MASS of vague and fragmentary evidence points to the conclusion that by the middle of the sixteenth century Spanish and Portuguese navigators had become aware that New Guinea was separated by a strait from a continent lying to the south. The knowledge was, however, jealously guarded. A significant passage occurs in an Fnglish edition, published in Louvain in 1597 , of CoRNELIS WyTFLIET's Descriptionis Ptolemica Augmentum (1597):

"The Australis Terra is the most southern of all lands. It is separated from New Guinea by a narrow strait. Its shores are hitherto but little known, since, after one voyage and another, that route has been deserted, and seldom is the country visited, unless when sailors are driven there by storms. The Australis Terra begins at two or three degrees from the equator, and is maintained by some to be of so great an extent that, if it were thoroughly explored, it would be regarded as a fifth part of the world." 1

The inference, as pointed out by Collingridge, is inevitable that Wytfliet referred to sources of information other than Dutch.

Collingridge adduces" reasonable support for his contention that the western coast of Australia had been "charted" (although the word "sketched" might be more appropriate) by the Portu-

1 Collingridge, Discovery of Australia, p. 219.

2 British Association for the Advancement of Science: Sydney meeting, 1914. See also his work, The Discovery of A ustralia, Sydney, 1895, p. 172, where the "Dauphin Chart," dated 1530-1536, is reproduced. 
guese and the eastern coast by the Spanish prior to the year I 530. In the Dauphin Chart, on which this conjecture is founded, the point identified as Cape York is, however, not depicted, as it really is, south of New Guinea, but as lying west of Timor and in the latitude of the north coast of Java. The supposed Gulf of Carpentaria has for its western limit the eastern end of Java, and from its south-western corner what may be called a strait or channel, or still more correctly a canal, runs westward between "Jave" on the north and "Jave la Grande," or Australia, on the south. The supposed Gulf of Carpentaria is, according to the map, interrupted by a few islands, and on it is written, in the Portuguese language, the legend "Anda ne Barcha" (no ships come here)." Collingridge conjectures that the French compiler of the map, ignorant of Portuguese, copied this legend from an older Portuguese map, under the impression that it was the name of the Gulf or of the group of islands.

In the sixteenth century, the islands between Asia and Australia came to be well known to European adventurers. In I5I2, Portugal took possession of the Molucca group, the centre of the "Spice Islands," and this possession speedily grew to great commercial importance and passed into the hands of Spain. Magelhaen "discovered" the Philippines in $\mathbf{1 5 2 0}$ and Spain annexed them fifty years later. Meantime the Dutch and the English were on the alert and looking for a foothold.

As far back as July, I493, a Bull of Pope Alexander VI had fixed a north and south line of demarcation between the claims of Portugal and Spain to future discoveries. Portugal was to occupy the hemisphere to the east and Spain the hemisphere to the west of that line, which was placed 100 leagues $\left(5^{\circ} 43^{\prime}\right)^{2}$ west of the Azores and Cape Verde Islands. The generosity of the Pope was no doubt fully appreciated by the two beneficiaries, but the line was not quite satisfactory to either of them; besides, it was ill-defined, because some six degrees of longitude extend between the westmost Azores and the eastmost Cape Verdes. A private arrangement or treaty was therefore made on 4 th June, I 494, by Don Juan II of Portugal on the one hand and Isabella and Ferdinand of Spain on the other, whereby it was agreed that the line should run 370 leagues $\left(21^{\circ} 9^{\prime}\right)$ west of the Cape Verde Islands.

Assuming $25^{\circ} \mathrm{W}$. to be the mean longitude of the Azores and Cape Verde Islands, the bull of 1493 bisected the globe by the meridians of $40^{\circ} 43^{\prime} \mathrm{W}$. and $149^{\circ} 17^{\prime} \mathrm{E}$., the latter meridian giving to Portugal the islands of the Pacific west of the eastmost cape of New Guinea and to Spain all those east of that cape. The treaty

1 The equivalent of the phrase in modern Spanish, viz. "Barcas no andan," differs so little from the Portuguese that some hesitation may be felt in settling the question on the sole evidence of language. Blank ignorance of Portuguese on the part of a French cartographer is rather a bold assumption. The most genuinely learned men of these days were to be found among the compilers of maps.

2 I $7 \frac{1}{2}$ Spanish leagues = I geographical degree. 
of 1494 cut through the globe by the meridians of $46^{\circ} 9^{\prime} \mathrm{W}$. and $133^{\circ} 5 \mathrm{I}^{\prime} \mathrm{E}$.

It must be remembered that Columbus had just discovered the West Indian Islands a year before the issue of the papal bull. The mainland of America was discovered in 1497 by SEBAstian САвот, a Venetian in the service of Henry VII of England. Then the passage of the SPANISH MaIN, the sphere of influence granted to Spain, became, for Europe, a question of very practical politics, over which much blood was to be shed, as other nations claimed the freedom of the sea. It was not till I 588 that the question was settled by the decisive defeat of the Spanish armada by the English fleet.

Had the nations outside of Spain and Portugal admitted the validity of the bull, the greater part of Australia would have belonged to Portugal, and a slice of the eastern coast, covering Sydney, Brisbane and Rockhampton, would have been Spanish. By the treaty (which was a sort of reciprocal Monroe doctrine), the western half of Australia would have been Portuguese and the eastern half Spanish.

It is needless to say that no other maritime powers ever assented to the partition between Spain and Portugal of all lands to be discovered in the future. The title of the two Powers was soon to be disputed by the rising maritime nations England and Holland. Moreover, the definition of the treaty line in the Pacific raised, between Spain and Portugal themselves, questions which brought them to the verge of war.

Here, then, was an excellent reason why Spaniards and Portuguese should preserve secrecy or practise deceit regarding the location of discoveries in the vicinity of the boundary line, whether by bull or treaty. The interest of a Portuguese tempted him, sometimes beyond his strength, to place his discovery west, while a Spaniard was tempted to place his discovery east of the boundary line in the Pacific. Secret instructions must have been issued to navigators by the authorities of both countries, in consequence of which they would systematically misrepresent their longitudes, and the truth would be arrived at by the authorities on reading the reports and charts with the aid of a "key."

Granting that the "Dauphin Chart" was compiled in parts from Spanish or Portuguese originals and that the land shown to the south of Java really represents the northern portion of Australia, which was already, early in the sixteenth century, vaguely known to both Spanish and Portuguese, the westward-moving of the new continent was clearly in the interest of Portugal, and the warning or danger signal "ships do not (or cannot or must not) come here "-in other words, " not navigable" -was|clearly a "bluff." It was, therefore, probably a Portuguese map which was drawn upon for the information given in the Dauphin chart. 


\section{MAGELHAEN AND CANO}

Magelhaen, a Portuguese who had taken service with Spain, set out with five vessels from Luzar on 20th September, I519. After passing through the strait which now bears his name, he reached the Philippine Islands, where he was killed by the natives. Only one ship of his squadron returned to Europe, via the Cape of Good Hope, carrying eighteen persons, all very sick. This ship was the "Victoria," Captain Juan Sebastian del CANo. The "Victoria" sailed via the Moluccas to Timor. Thence she must have gone south-westward till "certain islands" were discovered under the tropic of Capricorn. As this land, according to Cano, was only roo leagues $\left(5^{\circ} 43^{\prime}\right)$ from Timor, it is more likely to have been the continent of Australia (somewhere between Onslow and Carnarvon, Western Australia) than Madagascar, as has been assumed by some writers. Whether Cano actually landed here is uncertain, but it may be taken for granted that in these days no ship could afford to neglect an opportunity of landing for the purpose of taking in water.

\section{TORRES}

A Spanish expedition under Alvaro Mendana de Meyra, with Pedro Fernandez de Quiros as second in command, sailed from Callao on 9th April, 1595, and discovered the island of SANTA CRUZ (lat. $11^{\circ}$ S., long. $166^{\circ}$ E.), where an attempt was made to establish a colony. The result was a disastrous failure, and Mendana's death took place soon after. WYTrLiET's MaP $\left(1597^{1}\right)$ shows, in the same latitude as the southmost Solomon Islands $\left(10^{\circ} \mathrm{S}.\right)$, a strait dividing Nova Guinea and Terra Australis, and this is actually the latitude of Torres Strait. The map has a note stating that Terra Australis is "separated from New Guinea by a narrow strait. Its shores are hitherto but little known, since, after one voyage and another, that route has been deserted, and seldom is the country visited unless when sailors are driven there by storms." In this harmless statement, there is surely no ground for Collingridge's accusation of fraud on the part of the Dutch, or of a desire to filch the credit of the discovery of the strait. Collingridge adduces a good many fragments of evidence that both the Spanish and the Dutch were well aware of the existence of the strait before the end of the sixteenth century, but after Wytfliet's admission there was a growing tendency on the part of the Dutch to deny the existence of such a strait, and several failures on their part to verify it only strengthened this doubt. They doubted more and more until the question was finally settled by Cook in 1770 .

1 The Discovery of Australia, by George Collingridge, 4to, Sydney, 1895, p. 218. 
That the strait was known to Spaniards early in the seventeenth century is proved by a remarkable document, dating from somewhere between 16I4 and 1621. This is a Memorial which Dr. JeAn Luis Arias, a lawyer in Chili, writing on behalf of a number of priests, addressed to King Philip III, urging more vigorous exploration, on humanitarian and religious grounds. NEw Guinea is referred to in it as " a country ENCOMPASSED WITH WATER."

Quiros, who persisted for years in urging the colonisation of Santa Cruz and the further exploration of the South Land, was at last given the command of an expedition, which left Callao, Peru, on 21st December, 1605. He hoisted his flag on the "San Pedro y San Pablo" (usually referred to in narratives as " $\mathrm{El}$ Capitano," or the Flagship), with, as his Captain or Chief Pilot, JuAn Ochao DE Bilbaho. This officer was not a man of his own choice, but was forced upon him by the Viceroy at Lima, whose relative and protegé he was. In the course of the voyage he was disrated and replaced by the Junior Pilot Gaspar Gonzalez DE LeZA. Torres commanded the "San Pedro" (usually called, "for short," the "Almirante," or Lieutenant's ship). A zabra, or tender, named the "Tres Reyes," was in charge of PEDro Bernal Cermeño.

The flagship parted company with her consorts at the island of Espiritu Santo, and thereafter the two fragments of the expedition pursued separate courses. It is only with the section commanded by Torres that the historian of the Cape York Peninsula is directly concerned, but the full significance of 'Torres' voyage cannot be correctly estimated without some consideration of the events which preceded the separation.

Quiros and Torres were among the last of Spain's navigators of the first order : by the time their expedition set out, Spain's influence in the Pacific was on the wane. The records of their experiences met with the usual fate of such documents. In accordance with what had become almost a matter of routine, they were at first jealously kept secret. Pigeon-holed, they were in due time forgotten, only to be unearthed, piece by piece, through the diligence of patriots, politicians and historians. In reviewing the progress of discovery subsequent to Quiros and Torres, it is necessary to remind ourselves that at any given date the information available was limited to such documents as had come to light, and the problems confronting new explorers were not at all those which would have been before them had they been fully aware of what had already been done. It may be confidently asserted that had the various reports of Quiros and Torres been given to the world in their true chronological order, the course of history would have differed widely from what it has been. Up to comparatively recent times the achievements of Quiros were only known at second hand, and chiefly through the meagre references by Torres, Arias and 
Torquemada. It was only in 1876 that the text of Quiros' VoYAGE was given to the world by Justo Zaragoza, whereupon clouds of tradition and misconception were dispelled. Practically the whole of the Quiros documents have been skilfully marshalled by the late Sir Clements Markham for the Hakluyt Society in the two volumes published in 1904. The chief items in the QuirosTorres bibliography are enumerated in the footnote. ${ }^{1}$

On leaving Callao, the expedition steered WSW. into $26^{\circ}$ south latitude, somewhere in the vicinity of Easter Island, when, from considerations of the lateness of the season and other reasons, Quiros turned his ships towards WNW. His original intention had clearly been to go much further south, as may be seen from the text of his directions to Torres :-

"You are to be very diligent, both by day and night, in following the 'Capitano' ship, which will shape a WSW. course until the latitude of $30^{\circ}$ is reached, and when that is reached, and no land has been seen, the course will be altered to NW. until the latitude of $10^{\circ} 15^{\prime}$; and if no land has yet been found, a course will be followed on that parallel to the west in search of the Island of Santa Cruz. There a port will be sought in the bay of Graciosa, in $10^{\circ}$ of latitude and I,850 leagues from the city of The Kings [Lima] to the South of a great and lofty volcano standing alone in the sea, about 8 leagues from the said bay. The Captain who arrives first in this Port, which is at the head of the Bay, between a spring of water and a moderate-sized river,

1 Historia del Descubrimiento de las Regiones Austriales hecho por el General Pedro Fernandez de Quiros, publicado per Don Justo Zaragoza, 3 vols. Madrid, 1876. This document was written by Quiros' Secretary Luis de Belmonte Bermudez, and signed by Quiros for authentication. (English translation by Markham, 1904.)

The Voyages of Fernandez de Quiros, I 595-1606, translated and edited by Sir Clements Markham, 2 vols., I904. Hakluyt Society.

True Account of the Voyage that the Captain Pedro Fernandez de Quiros made by order of His Majesty to the Southern Unknown Land, by Gaspar Gonzalez de Leza, Chief Pilot of the said Fleet (translated by Markham, r9o4). Corroborates Bermudez. The author confines himself to facts, courses and latitudes, and ignores the insubordination or mutiny.

Torquemada's Voyage of Quiros, Seville, I6I5 (translated by Markham, r904). A sketchy account compiled from the documents available in r6r5.

Torquemada is to Quiros as Hawkesworth to Cook.

Relation of Luis Vaes de Torres, concerning the Discoveries of Quiros, as his Almirante [Lieutenant]. Manila, July 12th, r607. A copy fell into the hands of Alexander Dalrymple, 1762, and he published the Spanish text in Edinburgh in 1772. Dalrymple afterwards translated the Relation into English, and it was first printed in Burney's Discoveries in the South Seas, 1806 . Reproduced by Collingridge and also by Markham.

Charts of Diego de Prado y Tobar. Sent from Goa in 1613 . They are four in number and represent (I) Espiritu Santo, and (2,3, and 4) Localities in Southern New Guinea, and give the dates of the discoveries.

Markham observes:- " All the maps are signed by Diego de Prado y Tobar, who thus claims to be their author. The Surveys were no doubt made by Torres himself or by his Chief Pilot Fuentidueñas. Prado y Tobar may have been the draughtsman." The charts were discovered about 1878 , and were reproduced by Collingridge and Markham.

Two letters to the King sent by de Prado 24th and $25^{\text {th }}$ December, r6r3, enclosing the above charts, and also a general chart of Torres' Discoveries (which has not been found). Printed by Collingridge and Markham.

The Arias Memorial (r6I4-I62I).

A Voyage to Terra Australis in the Years 1801,1802 and 1803 in His Majesty's Ship the "Investigator," by Matthew Flinders, R.N., 2 vols, fcp. London, r914, vol. i., pp.vii, $\mathrm{x}, \mathrm{xi}$.

See also, The Discovery of Australia before 1770, by George Collingridge, 4to. Sydney, 1895. The First Discovery of Australia and New Guinea, by George Collingridge. Sydney, 1906. The Part borne by the Dutch in the Discovery of Australis, by J. E. Heeres, LL.D. Leiden and London, I899. Life of Tasman, by J. E. Heeres, fol. London, 1898. 
with bottom from 40 to 35 fathoms, is to anchor there and wait there three months for the other two ships. When together, a resolution will be taken as to what further shall be done, in compliance with His Majesty's orders. If by chance the other ships do not arrive, the Captain before he departs, is to raise a Cross, and at the foot of it, or of the nearest tree, he is to make a sign on the trunk to be understood by him who next arrives, and to bury a jar with the mouth closed with tar, and containing a narrative of all that has happened and of his intentions. Then he will steer SW. as far as $20^{\circ}$, thence NW. to $4^{\circ}$, and on that parallel he is to steer West in search of New Guinea. After coasting all along that land, he is to proceed to the Country of Manila, by the Island of Luzon of the Philippines, in $14^{\circ}$ North, thence by the Eastern Indies to Spain."

Much confusion has arisen, and much speculation has been indulged in, owing to a doubt as to the correct interpretation of references by Torres to the " prescribed latitude." "The general and very natural impression has hitherto been that Quiros was under orders not to turn north until he had reached a certain southern latitude, the precise situation of which he and Torres were ordered to keep secret.

The narrative of Bermudez (as the mouthpiece of Quiros), only recently given to the world, proves conclusively that there was no mystery and no intentional concealment. Quiros, as a matter of fact, received no orders from Spain, and the valedictory epistle of the Governor of Peru did not restrict his discretionary powers,

The expedition was manned by 130 seafarers and six priests. The flagship and the "Almirante" were vessels of 150 and 120 tons respectively.

Quiros had barely gone to sea when he began to be ill, and he was more or less of an invalid during the whole of the voyage. From the occasional references to headaches and other symptoms, a layman would conjecture that he had got a "touch of the sun" at Lima. At all events, he was frequently too ill to take his proper place of command and was under the necessity of leaving to subordinates many decisions which were among his own obvious duties. The narrative (written, it must be remembered, by a faithful admirer) naively shows him to have been by turn querulous, weak, timid and vacillating, although ever honestly and even zealously solicitous for the glory of his God and the advantage of his King. His sentiments, as reported by Bermudez, were humane, honourable and far ahead of his time, and I do not think they were cant, such as flowed readily enough from the pens of some previous and contemporary navigators. His shortcomings may charitably, and I think justly, be set down as symptoms of his malady.

The too early abandonment of the initial WSW. course was unfortunate for Quiros, who, had he persevered, would probably have anticipated Tasman's discovery of New Zealand. Torres protested against it and endeavoured to induce Quiros to carry out his original intention of touching $30^{\circ} \mathrm{S}$. before " diminishing his latitude," but to no purpose. 
There is reason to believe that Quiros was influenced in his decision to steer WNW. no less by the insubordinate, if not mutinous, conduct of a section of his crew than by the lateness of the season. Probably enough, with a commander of greater firmness, the ugly word " mutiny" would never have been heard.

Having reached, approximately, the latitude of $10^{\circ} \mathrm{S}$., the expedition steered west for VERA CRUZ, driven by the imperative need for fresh water and firewood. These requisites, however, were obtained at an island named Toumaco, and the project of making for Vera Cruz was abandoned.

By this time, the insubordination on the flagship had to be dealt with. The ringleader was the Chief Pilot, or Captain, Juan Ochoa de Bilbaho, for whom Quiros considered that a sufficient punishment was to be relieved of his office and sent on board the "Almirante"-a proceeding which was perhaps a little hard on Torres. Ochoa was replaced by Gaspar GonZalez DE LezA, Junior Pilot.

A bitterly spiteful enemy of Quiros, and necessarily a supporter of the disrated Captain, was Diego de Prado y Tobar, who, according to his own account, voluntarily accompanied Ochoa and boarded the "Almirante" at Toumaco. In allowing an officer of the flagship to desert openly and to side with a degraded malcontent, it seems to me that Quiros displayed a weakness which was most reprehensible, unless it was to be pardoned as a "symptom" of his illness. Be this as it may, we owe to the desertion of Prado, as will afterwards appear, a much fuller knowledge of Torres' subsequent proceedings than we should have had if Prado had not accompanied Torres for the remainder of the expedition. In the letters already referred to, Prado states that : "I went as Captain of the ship 'Capitano,' knew what took place on board and took part in it, and as it was not in conformity with the good of Your Majesty's Service, I could not stay. So I disembarked at Toumaco and went to the 'Almirante,' where I was well received." The assertion that he was Captain is sheer impudence, as there can be no question that the Captain was Ochoa. Prado was perhaps a "mate" of some sort, and the sailing of the ship may at some time have temporarily devolved upon him in the course of duty, but beyond this there was never any justification for his claim. His version of the story is that he gave Quiros timely warning of the mutinous disposition of the "Capitano's" officers and crew, and he insinuates that Quiros either did not believe him or stood so much in fear of the malcontents that he made things so unpleasant that he (Prado) was glad to exchange into the "Almirante."

At Toumaco, the natives were understood to say that large lands (which, of course, might prove to be the desired South Land) lay to the south, and the course was changed accordingly. In latitude $15^{\circ} 40^{\prime} \mathrm{S}$. and longitude $176^{\circ} \mathrm{E}$., the promised land 
seemed to have been reached at last, on 30th April, I606. Good harbourage was afforded by the Gran BAYA DE SAN FELIPE Y Santiago (Saints Philip and James), otherwise the Port of Vera $\mathrm{C}_{\mathrm{RUZ}}$ (True Cross), thus going one better than Mendano with his Santa Cruz (Holy Cross). On the banks of the Jordan Rrver, at the head of the bay, the site for the great colonial city, the New Jerusalem was selected. The country was at first called the Land of Espiritu Santo (Holy Ghost), but as Quiros became convinced that it was part of the great Southern Continent, he expanded the title to Australia del Espiritu Santo, ${ }^{1}$ and took formal possession, in the name of his Sovereign, of " all lands then seen, and still to be seen, as far as the South Pole." The grandiose names bestowed illustrate not only the innate piety but also the weakness for superlatives which characterised the Spaniard of the seventeenth century.

It has been argued (e.g., by the late Cardinal Moran) that Quiros, with three ships under his command, could not have spent five weeks at the Island of Santo without discovering that it was no part of a continent. The fact remains that he did believe it to be continental, although from the first Torres did not agree with him. Quiros approached the island predisposed to believe as he did. The elaborate ceremony which marked his stay, including the nomination of municipal officers, the erection of a votive church and the inauguration of an order of Knighthood of the Holy Ghost, sufficiently attested the sincerity of his belief. The ceremonies and the hopes to which they testified were, indeed, as Sir Clements Markham observed, in the light of our present knowledge, not a little pathetic.

In after years the conviction obsessed him, till he besought his King and the world to believe that he had added to the Spanish Crown a territory of hardly less importance than that gained by the discoveries of Columbus. He died, broken-hearted, shouting this belief into deaf ears.

The argument that Quiros had time enough to ascertain that Santo was an island is sufficiently answered by the fact now clearly discernible from the narrative of Bermudez, that the exploration which took place during the five weeks was confined to the "Gran Baya " and its environs, and that Quiros, in the flagship, was never outside of the bay until the day when he finally departed from it, to be driven out of sight of land and separated from his two consorts. Unexpected confirmation of this fact is supplied by the CHART OF THE GRAN BAYA (brought to light as recently as 1878 ) signed by PRADO, which shows so many anchorages inside the bay that it may easily be believed they account for as many of the

1 Markham supports the view that the name should read-as it sometimes does, spelling in the seventeenth century being capricious-Austrialia, a claim to Austria being signified in one of the titles of the King of Spain. 
thirty-five days as were not spent ashore. The chart, whether the credit of the surveying or only of the draughtsmanship belongs to Prado, agrees so well with modern Admiralty Charts of that portion of the island, that there can be no question of the accuracy of Captain Cook's identification-made, of course, without the assistance of Prado's Chart, which, in 1770, lay unknown in the Spanish archives.

Sir Clements Markham, for many years President of the Royal Geographical Society, had no difficulty in admitting the honesty of Quiros' belief that he had discovered the southern land, and wrote of his approach to the Island of Espiritu Santo :-

"Island after island, all lofty and thickly inhabited, rose upon the horizon, and at last he sighted such extensive coast-lines that he believed the Southern Continent to be spread out before him. The islands of the New Hebrides Group, such as Aurora, Leper, and Pentecost, overlapping each other to the south-east, seemed to him to be continuous coast-lines, while to the south-west was the land which he named Austrialia del Espiritu Santo. All appeared to his vivid imagination to be one continuous continental land."

The expedition, as has been mentioned, remained in the Bay of Saints Philip and James for thirty-five days, viz., from 3 rd May to 8th June, 1606, the numerous anchorages laid down on Prado's chart showing how thoroughly the shores must have been examined. The sailors made themselves very much at home and behaved with such arrogance, cruelty and rapacity that the natives treated them with well-merited hostility, and although Quiros " deplored "such excesses, he seems to have taken no suitable steps to stop them, beyond formally prohibiting profane swearing and other unseemly practices. It is noteworthy that the outrageous conduct of Prado was so far condoned that he figured in the list of officers of the municipality of the New Jerusalem as Depositario General. This term is translated by Markham as "General Storekeeper," but in my opinion, the fact that Prado carried off with him, among other things, the manuscript, or at least a copy, of the new chart of the bay and its environs, favours the view that the office held by him was the more responsible one of receiver or recorder.

The three vessels left the bay on 8th June, presumably with the intention of coasting along the continent to the north-west, or, should Espiritu Santo prove to be a cape, of running south-west to $20^{\circ} \mathrm{S}$., north-west to $4^{\circ}$, and west on that parallel to the coast of New Guinea, given an open sea, in accordance with the spirit of the instructions given to Torres for his guidance in the event of a separation. As soon, however, as they cleared the cape which formed the north-western horn of the bay, they met with a strong wind from the south-east and endeavoured to get back into the bay for shelter. In this attempt the "Almirante" and the tender succeeded, but the FLAGSHIP was blown further and further to 
leeward and in the morning succeeding the first night was out of sight of land and hopelessly SEPARATED FROM HER CONSORTS. Quiros himself was "below," too ill to direct the conduct of his vessel. Prado asserts, indeed, that Quiros was a prisoner in the hands of mutineers, but as he was not on board and could only have obtained his information at second hand, and, moreover, was prejudiced and malicious, the statement may be disregarded. Quiros himself, as he complained, had enemies on board, discontented and sulky, but there can be no doubt of the loyalty and devotion of his new Captain, de Leza, and his Secretary, Bermudez, who, perhaps jointly, conducted affairs during Quiros' incapacity.

The "Capitano," having reached $10^{\circ}$ S., the latitude of Santa Cruz, without seeing the island, being probably between it and the Solomon Group, it was resolved on 18 th June to make for Acapulca. unless some friendly port should first be discovered suitable for refitting and repairing the ship. On a NE. by $N$. course the line was crossed on 2nd July. The course was shortly altered to NE., and lay, in all probability, between the Marshall and Gilbert Islands. Having reached $38^{\circ} \mathrm{N}$. latitude, the vessel steered ESE. until North American land was sighted in $34^{\circ}$, on 23rd September. The Mexican coast was then followed to the SE. and Acapulca was reached on 23rd November, I606. Only one death occurred during the voyage, that of an old priest. Quiros, who landed without resources, was coldly received. He, however, managed to reach Madrid on 9 th October, 1607. The remainder of his life was spent in making passionate appeals to the King for the means to prosecute his discoveries and develop the imaginary continent in the interests of Spain. Wearied by his importunities, the Government got him out of the way by giving him an open letter to the Governor at Panama, who was instructed to assist him to his object, at the same time sending another letter in which the Governor was secretly instructed to string him on and delay him ad infinitum. Fortunately for himself, he died on the voyage to Panama (1609I6Io) unaware of the treachery of which he was to be the victim. He was only fifty years of age, but was, says Markham, "worn out and driven to his grave by Councils and Cornmittees with their futile talk, needless delays and endless obstructions."

The flagship having disappeared, Torres waited and searched for it for fifteen days, before feeling himself free to form his own plans for carrying out the instructions given him by Quiros. $\mathrm{He}$ weighed anchor on 26th June, and commenced the voyage which took him through the passage on which Dalrymple afterwards conferred the name of TORRES STRAIT.

Torres' relation or report on this voyage occurs in the form of a letter from Manila, dated 12th July, I607, addressed to the King of Spain, and is, so far as is known, the first recorded account of the passage of Torres Straits. Had this report been published 
at once future explorers would have followed different lines from those now marked by history. We have already seen how this report disappeared. There are indications that Robert de Vaugondy had got some inkling of it, or of charts relating to it, between 1752, when his map of the region showed no strait, but only a "bight" on the western side (the Dutch idea), and 1756, when his map showed the strait. The report was, in fact, discovered at Manila ${ }^{1}$ in 1762 , when a copy fell into the hands of Alexander Dalrymple, who printed the Spanish text in Edinburgh in $\mathbf{1 7 7 2}$, as an appendix to his Charts and Memoirs. He had not, apparently, mastered its contents, or grasped its significance, in I770. Years later, he translated it into English, and permitted Captain James Burney to print the translation in his Discoveries in the South Seas in I806. Dalrymple, in fact, only knew of 'Torres' achievement at second hand, and chiefly through the references of Arias, when Cook sailed in the "Endeavour" in 1768.

Up to the last quarter of the eighteenth century, the references to the voyages of Torres, second hand and unauthenticated as they were, contained in Arias' Memorial (written between 16I4 and I64I) were practically all that were known to the world of Torres and Torres Strait.

The last, and not the least important, of the sources of information regarding Torres have come to light as recently as 1878 . These are CHARTs signed by PRADo, and purporting to have been drawn during his voyage with Torres. It appears that Napoleon I looted the treasures of the Spanish Archives in a wholesale fashion and sent them to Paris. "There," says Collingridge," "they were found some years ago by a friend of mine, who caused them to be restored to their original owners, and acquainted me with their existence." They were reproduced in the Bol. de la Soc. Geografica de Madrid, tom. iv, January, 1878, and, with two letters of Prado, dated 24th and 25th December, 1613, again reproduced by Collingridge. ${ }^{3}$ Possibly, as Markham suggests, the surveys were the work of Torres or his Sailing Master, Fuentidueñas, and only the draughtsmanship is to be credited to Prado; but in any case the charts are undoubtedly authentic and in accuracy of surveying bear comparison with modern Admiralty work. Fortunately, Torres followed the pious custom of his time in naming places discovered by him after the Saint or Saints whose festivities appeared in the Calendar of the day, and thus we get several important dates for which no other authority can be cited.

Our sources of information regarding 'Torres' important voyage are, therefore, practically limited to (I) Torres' Letter to p. Io.

1 Flinders' Voyage to Terra Australis in I801, I802 and I803, London, I814, vol. i,

2 First Discovery of Australia, p. 122.

The First Discovery of A ustralia and New Guinea, Sydney, I906, pp. 246-256. 
the King of Spain, (2) Prado's Charts and Letters and (3) the Arias Memorial. In the order in which these became known to the world they should read (1) Arias, (2) Torres and (3) Prado.

It may be here observed that Torres apparently wrote without having the charts before him, as he is vague and unreliable as to latitudes; that Prado's charts contain latitudes which agree with modern official maps; and that the Priests for whom Arias wrote had to rely, to a great extent, upon hearsay evidence and were not able to quote from either Torres or Prado, although it is possible that they had seen the general map of the work of the expedition referred to by Prado in one of his letters, and which is still missing.

In spite of short rations, rough winds and the unwillingness of his crew, Torres, after leaving Espiritu Santo, sailed south-west and claimed to have passed, by one degree, the latitude indicated by the sailing orders. In other words, he reached $21^{\circ} \mathrm{S}$. $\mathrm{He}$ considered that he had thus proved Espiritu Santo to be an island. In reality he demonstrated that if it was a part of the mainland at all it must have been a cape jutting out from it to the northeast. Having now passed the "prescribed latitude" by a degree without seeing land, he altered his course to the north-west, and again (probably about the latitude of Princess Charlotte Bay, Queensland) to the north-east, and "FELL IN WITH THE BEGINNING of New Guinea," and after coasting to the west for five days, landed on what he named Tiera de Buenaventura on 18 th Fuly, 1606. Collingridge clearly identifies this land as BAsIlisk Island, so named by Captain John Moresby, R.N., in $1873 .{ }^{1}$ West of Basilisk Island lies Hayter Island, which is separated from New Guinea proper by the narrow China Strait.

Torres then sailed along the south coast of HAYTER IsLAND (which he failed to distinguish from the mainland of N. Guinea) and westward along the south coast of New Guinea, noting "many ports, very large, with large rivers and many plains." "In these parts," he says, "I took possession for Your Majesty," adding: "We caught in all this land twenty persons of different nations, that with them we might be able to give a better account to Your Majesty." Shoals extending to the west were skirted, and eventually cleared, according to Torres, in $\mathrm{II}^{\circ} \mathrm{S}$. lat.

Having thus passed through Torres STrait, Torres hugged the coast of what is now Dutch New Guinea, mainly on a north-west course, landing in many places and "taking possession for Your Majesty," and noted that the natives had "iron, China bells and other things, by which we knew we were near the Molucas." At last the point was reached "where New Guinea comes To AN END, fifty leagues before you reach the Molucas." Here the adven-

1 See Prado's Chart No. 2 and Discoveries and Surveys in New Guinea and the D'Entrecasteaux Islands, London, 1876. 
turers found MAHOMEDAN RESIDENTS, with whom they traded for such of their immediate necessities as they could afford to pay for with cloth. The Mahomedans "gave them news of the events of the Molucas" and spoke of Dutch ships.

Torres in his report gives impossible latitudes in and about the Gulf of PAPUA, and the inference is inevitable that he was writing from memory and without having the charts of his voyage, or perhaps even his log, before him. Therefore, the southmost point $\left(\mathrm{I}^{\circ}\right)$ at which he says he cleared the strait is open to grave doubt, especially as it is actually nineteen minutes south of Cape York.

Prado's No. 3 Chart" shows the expedition in "The Great Bay of St. Laurence and Port of Monterey" (modern Orangerie Bay), lat. $10^{\circ} 25^{\prime}$ (Prado has it $10^{\circ} 10^{\prime}$ ), long. $149^{\circ} 40^{\prime}$, with the legend "Discovered by D. Luis Vaes de Torres, Io August, I606." This careful survey, which agrees admirably with modern charting, is sufficient evidence of a sojourn of at least a few days, while the sketched rectangular subdivision of the coast land into what are probably agricultural areas or PLANTATIONS suggests that the site was considered to be well adapted for a settlement.

In Prado's No. 4 Map, of the Bay of S. Peter of Arlanca (lat. $3^{\circ} 40^{\prime} \mathrm{S}$., according to Prado, more correctly $3^{\circ} 5^{\prime}$, according to modern charts, long. $134^{\circ} 7^{\prime} \mathrm{E}$.), we have no difficulty in recognising, with Collingridge, TrITON BAY, in Dutch New Guinea, nor in identifying the "IsLA DEL CAP an. LuIs VAES DE Torres" with the modern Aiduma Island. A legend on the map reads: "Discovered by D. Luis Vaes de Torres, I8th October, I606."

The passage of Torres Strait, therefore, took place between the dates of 'Torres' touching at Orangerie Bay, Ioth August, and Triton Bay, 18th October. Considering that, once he had cleared the reefs and banks of the Gulf of Papua, and taken a north-westerly course along the Dutch New Guinea coast, his difficulties were over, it would only be reasonable to assign two-thirds of the time to the voyage east and one-third to that west of the turning-point. On this assumption, the approximate date of clearing the strait would be $24 t b$ September.

Torres' report was written at Manila and dated I2th July, 1607, and he states that he had been in that city for two months, thus fixing the date of his arrival at the Philippines approximately at I2th May.

The time employed between Triton Bay (18th October) and the Philippines (I2th May), nearly seven months, has now to be accounted for. If we allow ten days for bargaining with the Mahomedans at Triton Bay and leaving New Guinea "where it comes to a termination fifty leagues before you come to the

1 See Collingridge's Discovery of Australia, p. 25 I. 
Molucas," the time to be accounted for is narrowed to the period between 28 th October and I2th May.

At the outside, the run from the west end of New Guinea to Batchian (lat. $0^{\circ} 37^{\prime}$ S., long. I $17^{\circ} 36^{\prime}$ E.), at the south-east end of the Moluccas, in a sea already well known to the Spanish, could hardly have taken more than a month, so that we may provisionally date 'Torres' arrival there at 28 th November.

On his arrival at Batchian, Torres met a priest who had about one hundred Christian followers, within the territory of a friendly Mahomedan king. The priest, says Torres, "begged me to subdue one of the Ternate islands inhabited by revolted Mahomedans, to whom Don Pedro de Acunha had given pardon in Your Majesty's name, which I had maintained; and I sent advice to the M. de Campo, Juan de Esquival, who governed the islands of Ternate, of my arrival, and demanded if it was expedient to give this assistance to the King of Batchian; to which he answered that it would be of great service to Your Majesty, if I brought force for that purpose. On this, with 40 Spaniards and 400 Moors of the King of Batchian, I made WAR, and in only four days I defeated them and took the fort and put the King of Batchian in possession of it in Your Majesty's name, to whom we administered the usual oaths, stipulating with him that he should never go to war against Christians and that he should ever be a faithful vassal to Your Majesty."

Assuming a week to have been occupied by the journey of Torres' messenger, and another week for the four-days' missionary war and preparations for the voyage, it was probably about I 2 th December when Torres himself sailed for Ternate (lat. $0^{\circ} 48^{\prime} \mathrm{N}$., long. $127^{\circ} 18^{\prime} \mathrm{E}$.). He probably did not take more than three days to reach the latter port, say $15^{\text {th }}$ December.

It is likely enough that Torres stayed for some time at Ternate, where he was well received by Esquival, the Governor, for he did not, as we have seen, arrive at MANila till about I 2 th May, and the voyage of about 1,200 knots could hardly have taken five months.

The Moors, or Mahomedans, near the eastern extremity of New Guinea ('Triton Bay ?), says Torres, "gave us news of the events of the Molucas and told us of Dutch ships." Collingridge observes ${ }^{1}$ that "the events of the Molucas were of a stirring nature at that time," and raises the question of whether the Dutch expedition of 1606 could have been sent out in consequence of the Dutch having heard of 'Torres' discoveries.

The "Duyfken's" cruise along the coasts of New Guinea and the Cape York Peninsula took place within the limits set by the yacht's departure from Bantam on I 8th November, 1605, and its return in or before June, 1906. It is therefore simply impossible that the Dutch could have heard, prior to the despatch of the

1 Discovery of A ustralia, p. 236. 
"Duyfken," of the doings of Torres, who only reached Ternate on I2th December, 1606. In fact the "Duyfken" had returned to port before Torres had got in touch with civilisation near the western extremity of New Guinea.

In Torres' narrative, there is not a word implying that he laid any claim to the discovery of a passage between New Guinea and Australia. On the contrary, everything points to his having made for a passage regarding which he was already in possession of some information, and there is a great deal of evidence that the passage had already been used many times by Spanish and Portuguese, although its existence was hidden from the Dutch and English. The fact that Prado carefully labels the charted landing-places on the south coast of New Guinea as having been discovered by Torres in no way supports the claim (which Torres never made) to the discovery of the strait itself.

The narrow sea (ninety-eight knots across) known as Torres Strait, between New Guinea and Cape York, is crowded with islands and coral reefs, among which a newcomer would be lucky indeed, as well as bold and skilful, if he found an east and west passage. Modern surveys have laid down nine such practicable passages, known, in their order from north to south, as Napoleon, Bligh, Bramble, Yule, Simpson, Dayman, Prince of Wales, Normanby and Endeavour. The question is, by which of these did Torres clear the strait ?

As Torres himself gives an impossible northern latitude for his voyage in the Gulf of Papua, and the southern latitude $\left(\mathrm{II}^{\circ}\right)$ he assigns to the strait is no less impossible, for the reason that it would have brought him well into Queensland, there can be no doubt that he was speaking from memory, and in round numbers, without, for the time, having access to the documents which would have enabled him to make accurate statements. On the other hand, his description of the point where he was able to turn from a southerly to a north-westerly course is of the highest value. "Here," he says, "there were many large islands and there appeared to be more to the southward." Such a description would be ludicrously incorrect if written from any point of view whatever in $\mathrm{II}^{\circ} \mathrm{S}$. lat., but it fits admirably what would be seen by an observer passing through the Bligh Channel ( $10^{\circ} 20^{\prime} \mathrm{S}$.). This is the second channel which Torres could possibly have found, and I eliminate the first, or Napoleon, channel because it is obviously hard to enter and barely navigable without the aid of steam. Torres was, in fact, sailing west, with Jervis and the Belle Vue Islands on his right and the two large islands, Mulgrave and Banks, on his left, while catching glimpses of Hammond, Wednesday, Thursday, Friday, Horn and Prince of Wales Islands still further to the south. I cannot, therefore, agree with Collingridge's suggestion that CAPTAIN CooK in 1770 merely 
rediscovered, in his Endeavour Strait, the channel used by Torres in 1606. No exception can be taken to the name of Torres being applied to the whole of the strait, but the merit of finding channels among its dangerous reefs is considerably greater than if the reefs had been visible islands. 


\section{CHAPTER III}

\section{VOYAGE OF THE "DUYFKEN" TO NEW GUINEA AND THE CAPE YORK PENINSULA, 1605-6}

Early Portuguese and Spanish Knowledge of New Guinea. Dutch Possessions in the East. "Duyfken" visits Ceram to collect Information about New Guinea (1603). "Duyfreen's" Voyage to New Guinea (1605-6). Nine Men killed by Natives in New Guinea Proper. Torres Strait passed unobserved. Southward along Eastern Shore of Gulf of Carpentaria. A Man killed by Natives at Carpentier Inlet. "Duyfken" turns back at Cape Keerweer.

" HE discovery of NEw GuINEA is most commonly credited to the Portuguese. In the early days, these people-then famous for their brave efforts in exploration and settlement-held Malacca ${ }^{1}$ and the Spice Islands (i.e., the Moluccas). In 1527, one Jorgo de Meneses was sent from Malacca to the latter islands. He attempted a new route by going round the north of Borneo, and is said to have then discovered New Guinea. He called the new island Papua, because of the fact that the natives of the Molucca Islands called the New Guinea aborigines 'Papuans,' on account of their woolly hair. Next in order came the Spanish navigator Alvaro de Saavedra, in 1537. In 1545 his countryman Ortis de Retes, proceeding to take a more southerly course to the Moluccas, in order to catch more favourable winds, sighted the island, and imagined he was the discoverer, and named it Nueva Guinea. The island first appeared on Mercator's chart of $1569 . "$ "

The Dutch had been more or less in possession of Java since I 597, but even within the first decade the necessity for expansion had begun to be felt, and had a spur been needed it would have been supplied by the rivalry excited by the comings and goings of the Spanish and Portuguese. The Dutch "General United East India Company," founded in 1602 , was a power in the East for three centuries, until its functions were absorbed by the Government of the Netherlands.

On Ioth April, I602, at Banda Island, on board the ship "Gelderlant," a general meeting of ships' officers was held by order of Admiral Wolphert Hermanszoon. The meeting drew up instructions for the yacht "Duyfken" [sic], Skipper Willem Corneliszoon Schouten, and Supercargo Claes Gaeff.

The ship was to proceed to the island of Ceran [sic], calling at certain ports, e.g., Queuin, Quelibara, Quelilonhen and Goulegoulij, where trade might be expected, and to enquire whether anything was to be had besides sago, what was the commerce of

1 (Malay Peninsula.)

2 " Kaiser's Lost Domain, Late German New Guinea. Early Settlement and Development," in Sydney Morning Herald, 27th May, 1916. 
the port and to what places, what commodities were in demand, how far their navigation had extended, if they knew anything of Nova Guinea, and if they had sent ships there or had been visited by ships from that country.

The above instructions were entered in the "Gelderlant's" $\log$ of roth April, 1602, and under date 15th May following a note gives what appears to be a brief summary of the report brought back by the "Duyfken" :-

"They [the Ceramites, when interrogated] can say nothing definite respecting the island of New Guinea, but say that white people live on the south side, inhabited by Portuguese, but they had seen no Portuguese ships. They can give no information about their [the New Guineans'] commerce and products." 1

The language of the note is somewhat involved, but it may be taken to mean "white people, possibly Portuguese." Portugal had been in possession of the Molucca Islands, then usually referred to as the Spice Islands, since 1512, and it is more than likely that in the course of nearly a century her sailors had acquired some knowledge of the not very distant southern coast of New Guinea proper and had even spent some time on the land.

In 1605, Jan Willemszoon Verschoor, Manager of the Dutch East India Company at Bantam, Java, sent out the "Duyfken" on a voyage of discovery, under command of Willem Janszoon. The Subcargo (Junior Supercargo?) was JaN LodewiJs vaN RosingIJN.

There is much room for doubt as to whether the "Duyfken" was (I) the 6o-ton yacht of the expedition which was equipped in 1603 , was commanded by Steven van der Hagen, and came out to the East Indies, or (2) the 30-ton yacht attached to the expedition which left the Texel in Holland on 2nd April, I595, and which sailed by Madagascar, reaching the south-west coast of Sumatra on Ist June, 1596, called at Bali in 1597, turned back on 26th February of that year, and returned to Holland via the south coast of Java and the Cape of Good Hope, reaching the Texel on 14th August, $1597 .^{3}$

No description of van der Hagen's 60-ton "Duyfken" is available, beyond the statement of her tonnage. The Texel "Duyfken" is described as " a small yacht of 30 tons, carrying 20 men, and having 2 large and 6 small guns, with 2 bombards," and her master was Simon Lambertsz(oon) Mau. The other vessels of the expedition were of 400, 400, and 200 tons respectively. It is reasonable to suppose that this "Duyfken" acted as a tender to the larger vessels, and it is unlikely that in addition to her armament and twenty men she could have had carrying

1 The Part borne by the Dutch in the Discovery of Australia, 1606-1765, by J. E. Heeres, LL.D., Professor at the Dutch Colonial Institute, Delft. Published by the Royal Dutch Geographical Society in Commemoration of the Twenty-fifth Anniversary of its Foundation. Leiden, E. J. Brill ; London, Luzac \& Co., I889, p. 3.

2 Collingridge, pp. $216,222,240$. 
capacity for native "trade" and stores for her crew sufficient for a voyage of seven months. In the course of the voyage on which she is first heard of, she probably drew supplies periodically from the larger ships of the expedition. I incline, therefore, to the opinion that the 6o-ton yacht was the one which Willem Janszoon commanded from November, I605, to June, I606.

The "Duyfken" left Bantam for New Guinea on 28th November, I605, and was back at BANDA IsLAND in or before June, I606. Janszoon visited $K_{E I}$ and ARU IsLANDS and made the coast of New Guinea in $5^{\circ}$ south latitude. He then followed the land south-eastward, passing Torres STRAIT without settling the question of whether or not there was a passage, although less than six months later Torres left the New Hebrides and made for the strait, evidently guided by previous information. Still under the impression that he was off the New Guinea coast, Janszoon kept the land in sight to $13 \frac{3}{4}$ degrees of south latitude. Instructions drawn up for the use of ABEL TAsman in 1644 refer to the "Duyfken's" voyage in these terms:-

"It being ascertained that vast regions were for the greater part uncultivated and certain parts inhabited by savage, cruel, black barbarians, who slew some of our sailors, so that no information was obtained touching the exact lie of the country or the commodities obtainable or in demand there ; our men having, from want of provisions and other necessaries, been compelled to return and abandon the discovery they had begun, only registering in their chart, by the name of KEERWEER, the extreme point of the discovered land in $133^{\circ}$ south latitude ${ }^{1}$ [correctly, $13^{\circ} 5^{\prime} \mathrm{S}$.]."

John SARIs, an English shipmaster, resided in Bantam for five years in the capacity of factor for the English East India Company, which had been established in 1600." He kept a diary, in which the following entries obviously deal with the "Duyfken," although the vessel is not named :-

" 18 th Nov., 1605 [old style $=28$ th November, new style]. - Heere departed a small Pinasse of the Flemmings ${ }^{3}$ for the discovery of the land called Nova Guinea, which, it is said, affordeth great store of Gold.

" 15 th Fune, 1606 [old style $=25$ th June, new style].-Heere arrived Nockhoda [i.e., Skipper] Tingall, a Kling man from Banda, in a Java Juncke. . . . He told me that the Flemmings ${ }^{3}$ Pinasse which went upon discovery for Nova Ginny was returned to Banda, having found the iland ; but on sending their men on shoare to intreate of Trade, there were nine of them killed by the Heathens, which are maneaters. So they were constrained to returne, finding no good to be done there."

The States of Holland and West Friesland had given the (Dutch) General United East India Company certain advice

1 Quoted by Heeres, p. 5 .

2 Observations of Captain John Saris of Occurrents which happened in the East Indies during his Abode at Bantam, from October, 1605, till October, 1609, in Hakluytus Posthumus or Purchas, His Pilgrimes. By Samuel Purchas, B.D., vol. iii, p. 490, of new edition. Glasgow, James Maclehose \& Sons, MCMV.

"Heeres, translating into Dutch, substitutes " Hollandse " for "Flemmings." 
touching a charter for the Australia Company, and a Memorandum, dated 2nd August, 1618, was laid before the East India Company as a basis for the reply. It is argued in this document that the Australia Company should be excluded from the southern parts between the meridian of the east end of Ceylon and that lying Ioo miles east of the Solomon Islands, because the East India Company had already busied itself with this part of New Guinea, instancing the explorations, about 1606, by the "Duyve" ("Duyfken") by Skipper Willem Janszoon and Supercargo Jan Lodovijkszoon van Rosingijn, "who made sundry discoveries on the said coast of Nova Guinea, as is AMPLY SET FORTH IN THEIR Journals." Heeres remarks that therefore the journals of the expedition must have been extant in 1618. They were extant, I have no doubt, in 1623 , when Carstenszoon sailed the "Pera" along the west coast of Cape York Peninsula. Indeed, a close reading of the "Pera's" log gives the impression that the "Duyfken's" charts and journals were the daily study of the officers of the "Pera." Yet there is no reference in Tasman's instructions, drawn up in 1644 , to the charts and journals of the "Duyfken."

The "Pera's" log, hereinafter quoted at length, contains the following entry, dated IIth May, I623:-

"In the afternoon we sailed past a large river (which the men of the 'Duyfken' went up with a boat in 1606 , and where one of them was killed by the missiles thrown by the blacks). To this river, which is in lat. $11^{\circ} 4^{\prime}$, we have given the name of Revier de Carpentier ${ }^{1}$ in the new chart."

I take this to be evidence of Carstenszoon's familiarity with the "Duyfken's" charts and journals.

There is no absolute certainty that any of the "Duyfken's" men, who "went up " the Carpentier River "in a boat," set foot on the land. The man killed by missiles may have been speared in the boat. If any of the crew landed, this is the EARLIEST RECORDED LANDING of white men in Australia.

The exact locality of the greater disaster which, according to the Kling skipper, resulted in the death of nine of the "Duyfken's" crew, is not stated. It may, however, be presumed that the slaughter took place at CAPE KEERWEER, and finally determined the abandonment of the enterprise. The loss of nine men, added to the loss of one at the Carpentier River, must have left a 30or even a 6o-ton vessel very short-handed.

The probability that the "Duyfken" made still another voyage to New Guinea, including possibly the Cape York Peninsula, has been argued from the following passage in $A$ Narrative and Fournal of the Voyage made from Bantam to the Coast of Choromandel and

1 This river is now named the Skardon (see Queensland 4-mile Map, Sheet 21A). 
other Parts of India, by Paulus van Solt, in the rears 1605, 1606, $1607,1608:-$

"On the 4th of March, 1607, through God's mercy, arrived before the Castle [of Victoria, Amboyna]. . . . Here we found the yacht 'Duyfken' which had come from Nova Guinea [was van Nova Guinea gekommen]." 1

When van Solt arrived at Amboyna, only nine months had elapsed since the "Duyfken" had put in to Banda on her return from her famous voyage. She might very well have made another voyage to New Guinea in that time, but on the other hand, she may only have been, pointed out to van Solt as the vessel which had made the adventurous and disastrous voyage, the fame of which had not yet been forgotten.

At the time when Torres made his way through the strait between New Guinea and Australia - a strait which had probably been known to others before him-and when Janszoon sailed past the western opening of the passage and coasted Australia for 250 miles to the south, never doubting that he was following the coastline of New Guinea, Queen Elizabeth was not long dead and William Shakespeare was still a living force. The events occurring in the Cape York Peninsula some three centuries later were contemporaneous with the gay adventure of Germany in setting forth, carrying "sword and fire, red ruin and the breaking up of realms," for the acquisition of "world-domination," her title being that she was strong enough to take whatever she coveted, and found instead the "downfall" which had been ironically alluded to in her boasting as the absurd and wholly unimaginable alternative.

Through the first three centuries of Australian history, contemporary events in Europe affected more or less the course of exploration. The reader will be apt to reflect, as an example, on the bearing of the Napoleonic wars on the career of Flinders, and I venture to assert that Australian history is no isolated phenomenon, but will be best understood by a reader who can picture to himself what, at any given date, was happening in other portions of the globe.

1 Heeres, p. 6. 


\section{CHAPTER IV}

\section{THE VOYAGE OF THE “PERA” AND “AERNEM" (1623) \\ I. THE SAILING ORDERS}

Minute Summary of Previous Discoveries and Failures. Instructions to explore and sUrvey the Coast of the South LaNd aNd inquire into its Commercial Resources. To make Treaties with Native Kings. To take possession of any Land of Sufficient Value. To capture some Natives, who may in Time GIVE UsEFul InFormation.

$\mathrm{R}$

EPORTS having reached Batavia of the loss of the English ship " Triall" and the perilous experiences of three Dutch ships, the "Wapen van Hoorn," "Amsterdam" and "Dordrecht," on the north-western coast of Australia, the Governor and Council of the East India Company at Batavia resolved to dispatch an expedition for further explorations of the Southern Land. Instructions were accordingly made out for the yachts "Haring" and "Hasewint." Unforeseen circumstances having, however, prevented these yachts carrying out the orders, they were taken over by the "Pera" and "Aernem."

The full text of the instructions is given by Professor HeEres in his Commemoration Volume, The Part borne by the Dutch, together with an English translation by Mr. C. Stoffel. The latter is followed hereunder, except that I have occasionally employed an English word or two which appeared " more agreeable to the text " than the expression selected by the translator.

“INSTRUCTIONS FOR THE YACHTS 'HARINGH' AND 'HASEWINT,' SELECTED FOR THE JOINT EXPLORATION OF THE SOUTHERN LAND.

"INASMUCH as our Superiors earnestly enjoin us to despatch hence some yachts, with the object of making discoveries in the Southern Land; and since, moreover, experience has taught, through great perils incurred by several of our ships, and still more through the destruction of the English ship 'Triall' on the said coast, how necessary it is to have full and accurate knowledge of the true position of this land, 80 that further misfortunes may henceforth be prevented as much as is possible; and as, moreover, it is desirable that this land, or any inhabited portion thereof, should be explored, so as to ascertain whether any trade with them might be worth while ;

"THEREFORE, for the purpose before mentioned, we have resolved to fit out the yachts 'Haringh' [herring] and 'Hasewint' to undertake the voyage and to discover as much regarding the resources of these regions as God Almighty shall permit.

"You will accordingly set sail from here together, run out of Sunda Strait, and steer your course from the western extremity of Java to the South Land, keeping as . 
close to the wind as ever you can, so as not to be driven too far west by the southeasterly winds which generally prevail in these waters. You may therefore run on as far as the thirty-second or thirty-third degree if you do not before that fall in with the land. If you should have sailed so far, and yet have seen no land, you may conclude $^{1}$ that you have fallen off too far westward, for sundry ships coming from the fatherland have accidentally come upon the South Land before these latitudes. In this case, you will have to shape your course eastward and run on in that direction until you sight land.

"In running over to the South Land aforesaid, you will have to keep a careful lookout, as soon as you get in $14^{\circ}$ or $15^{\circ}$, seeing that the said English ship 'Triall,' when in $20^{\circ} \mathrm{IO}$ ' S. lat., got on certain sunken rocks, which, according to the observation of the English pilot, extend for 7 miles north-east and south-west, although no dry land was visible. Nevertheless, the men who saved themselves in the pinnace and boat and arrived here stated that about $13^{\circ}$ or $14^{\circ}$ they had seen masses of reeds, wood and other drift floating about in the sea, from which they concluded that there must be land or islands somewhere in the neighbourhood. The aforesaid sunken rocks on which the ' $T$ riall' was wrecked ought, according to the report of the Englishmen, to be due south of the west cape of Java.

"Having reached the South Land in the said latitude or near it, you will then sail along the same as far as lat. $50^{\circ}$, in case the land extends so far south, but if the land should come to an end before you have oversailed the said latitude, and should be found to trend eastward, you may follow it in that direction for a little, but if you find no further southward extension possible, you had better turn back. You will do the same if the land should turn westward. On the return voyage you will run along the coast as far as it extends to the north, and next eastward or otherwise as the land goes, and thus follow the land as close and as far as possible and as you judge your provisions will suffice for the return home, even if, in so doing, you should sail round the whole land and emerge to southward.

"The main object for which you are dispatched on this occasion is that from 45 or 50 degrees, or from the furthest point to which the said land shall be found to extend southward between these latitudes, up to the northmost end of the South Land, you are to discover and survey all capes, forelands, bays, lands, islands, rocks, reefs, sandbanks, deeps, shallows, roadsteads, winds, currents and whatever else appertains to the same, so that they may be charted and noted, with their true latitudes, longitudes, bearings and conditions. You will moreover land in various places and carefully observe whether they are inhabited, and what sort of people and country there are, what towns and villages there are, their government, their religion, their policy, their war-equipment, their waters, their vessels, their fisheries, and their commodities and manufactures, and more especially what minerals they have, such as gold, silver, tin, iron, lead and copper, as well as precious stones and pearls, and what vegetables, animals and fruits these lands afford.

"To all of which particulars and whatever else may be worth noting you will pay diligent attention, keeping a careful record or journal with reference thereto, that we may get full information of all your doings and experiences and the Company may obtain due and perfect knowledge of the natural resources of these lands in return for their heavy outlay.

"To all the places which you touch at, you will give appropriate names, choosing for the same either the names of the United Provinces or of the towns therein, or any other dignified names. Of all which places, lands and islands, the Commander and Officers of the said yachts will, by order and pursuant to the Commission of The Honourable the Governor-General, Jan Peterszoon Coen, sent out there [i.e., to the East Indies] by their High Mightinesses the States General of the United Netherlands, together with Messieurs the Directors of the General Chartered United East India Company in these parts, by solemn declaration signed by the Ships' Councils, take formal possession, and in token thereof, besides, erect a stone column in such places as

1 It will be observed that no direct observation for longitude is suggested. 
shall be taken possession of, on which should be recorded in bold, legible characters the year, the month, the day of the week and the date, the person by whom, and when such possession has been taken on behalf of the States General above mentioned. You will likewise endeavour to enter into friendly relations and make covenants with all such kings and nations as you shall happen to fall in with, and prevail upon them to place themselves under the protection of the States of the United Netherlands; of which covenants and treaties you will likewise cause proper documents to be exchanged with the other parties.

"All lands, islands, places, etc., which you shall take possession of, as aforesaid, you will duly mark in the chart, with their true latitude, longitude and bearings, together with the names newly conferred on the same.

"According to the oath of allegiance which each of you, jointly and severally, has sworn to the Lords States General, His Princely Excellency and Messieurs the Directors, none of you shall be allowed to secrete, or by underhand means to retain, any written documents, journals, drawings or observations touching the expedition, but every one of you shall be bound on his return here faithfully to deliver up the same without exception.

"According to the writings of Jan Van Huygen [van Linschoten] and the opinion of several others, some parts of this South Land are likely to yield gold, a point into which you should inquire as carefully as possible.

"We also give you, for an experiment, divers ironwares, cloths, 'coast' dresses [Heeres explains, in a footnote, 'from the coast of Coromandel '] and linen stuffs, which you will show and try to dispose of to such people as you may meet with, always carefully noting what articles are found to be most in demand, what quantities might be disposed of, and what might be obtained in exchange for them. We also send you samples of gold, silver, copper, iron, lead and pearls, that you may inquire whether these articles are known to the inhabitants and might be obtained there in any reasonable quantity.

"In landing anywhere you will exercise extreme caution, and never go ashore or inland unless well armed, trusting no one, however simple the people may appear to be, or how plausible, but be always ready to stand on the defensive, so that no disaster may overtake you, such as, God knows, has often happened in like cases. Should any people come out to you from the land, you will take the like care that they suffer no harm from our men.

"Coming to the northern extremity and east side of the South Land, you will diligently enquire whether any sandalwood, nutmegs, cloves, or other aromatic fruits grow there. Item, if there are any good harbours or conveniently situated or fruitful lands, where colonies might be planted which might be amply self-supporting. In 2 word, let nothing pass you unobserved, and whatever you find bring us a full and particular report of it, by which you will do the States of the United Netherlands a service and lay up special honour for yourselves.

"In places where you meet with people, you will, by dexterity [behendlicheyt] or otherwise, get hold of some adults, or, still better, young lads or girls, to the end that they should be brought up here, and later, when opportunity offers, be broken in at the said quarters.

"The command of these two yachts is given to JAN Vos, who, during the voyage, will carry the flag, convene the Council and preside therein, by virtue of Our Special Commission granted to the above-named Vos for that purpose.

"Given in Fort Jacatra the 29th September, Ao. I622."

No better instructions could have been drawn up to serve for the guidance of sailors setting out on a voyage of discovery with the object of acquiring geographical and commercial knowledge, although some clauses indicating what was expected, such as the references to kings and nations and treaties of alliance, may raise 
a smile on the faces of those who have come to know what was the actual condition of affairs. In other parts, the language employed is intentionally and diplomatically ambiguous. A notable instance is the instruction regarding the CAPTURE OF sLAVES. The word "behendlicheyt" meaning literally "handihood," might be rendered as dexterity, adroitness, ingenuity, strategy, smartness, trickery or treachery, and the addition of "or otherwise" left no room for delicate scruples. The sailors made no mistake in interpreting their orders to mean that they were to capture slaves, with a minimum of friction, if possible, but in any case to capture them somehow. It is not so written, but it is easy to understand that the voyagers were expected, by the capture of "adults, or, still better, young lads or girls," to do something substantial towards recouping the expenses of the expedition. Ample evidence will be found in the log of the "Pera," which carried out the instructions originally drawn up for the "Harengh" and "Hasewint," that this was the true meaning of the instructions. One hundred and thirty-three years later, the Dutch ship " Rijder " was carrying on the same tactics as were employed by the "Pera," and on the same western shore of the Cape York Peninsula. Even while the "Pera" was at sea, Torres was at work on the same lines, for his Spanish masters, on the southern shores of New Guinea; only he was more successful, as he records with satisfaction that in the course of the voyage he had captured twenty persons.

Early in the seventeenth century, the idea that there was anything reprehensible in slavery had barely suggested itself to the European mind, and I desire to point out that the Dutch were neither better nor worse than their contemporaries. If their proceedings appear simply abominable to readers in the twentieth century, there can be no doubt that those of their contemporary rivals were dictated by the same principles and carried out by the same methods.

At the present day we are confronted by the spectacle of savage populations dying out wherever they come in contact with comparatively civilised men. Belated Christianity, benevolence, philanthropy, charity or fair dealing seem alike powerless to arrest the working of what appears to be a natural law. In these circumstances, it is open to argument that for savage races a probationary period of SERVITUDE is preferable to its only alternative, EXTINCTION. 
CHAPTER V

THE VOYAGE OF THE "PERA" AND "AERNEM" (1623)

\section{GENERAL OBSERVATIONS ON THE EXPEDITION AND ON THE "PERA" NARRATIVE}

Sailing Orders for the Ships, with a "Covering Letter" containing Further Instructions. Journal of Jan Carstenszoon, Commodore, kept on the "Pera." English Translation. The Command of the Ships and the " Full Council." Captain of the "Aernem" and nine others killed by Natives of New Guinea Proper. Expedition passed "Torres Strait" satisfied that it was only a Shallow Bight and that the Cape York Peninsula formed Part of New GuineA.

7 HE history of the voyages of the "Pera" and "Aernem" in 1623 may be studied in the original records of the Dutch East India Company by those who have the opportunity. They consist, in the first place, of a " covering letter," dated 3rd January, I624, from the Governor-General and Council to the Directors of the Company, and secondly, what is entitled Fournal kept by Jan Carstensz. (oon) on bis Voyage to Nova Guinea.

The letter states that, in January, 1623 , Governor VAN Speult dispatched from Amboina the yachts "Pera" and "Arnbem" for the purpose of cultivating friendly relations with the inhabitants of Queij, Aroe and Tenimber and of exploring the land of Nova Guinea. The above-named islanders, it is further stated, had of their own free will placed themselves under the rule and protection of the States of the United Netherlands and promised to come and trade with the fortresses of Banda and Amboina. For the remaining portion of the voyage, along the land of Nova Guinea (which was described as a barren country, inhabited by absolutely barbarous, cruel savages), the Directors were referred to the enclosure itself.

The second document, the Journal, was printed in full by L. C. D. Van Dijk, in 1859, in Mededlingen Oost-Indisch Archief : No. I, Twee Togten naar de Golf van Carpentaria. The portions relating to Australia were subsequently printed by Professor Heeres (Leiden, E. J. Brill ; London, Luzac \& Co.) in his work The Part of the Dutch in the Discovery of Australia, 1606-1765, issued by the Royal Dutch Geographical Society on its twenty-fifth anniversary, in 1899, together with an English translation by $\mathrm{Mr}$. C. Stoffel. The Journal itself is bald and businesslike, makes no pretensions to literary form, and is even careless as to grammatical 
accuracy. Stoffel's translation, on the other hand, is a dainty piece of work. It is as if he had rewritten a plain tale with the object of suiting it for acceptance by a high-class magazine. He has, indeed, while taking no serious liberties with the facts, presented the tale in the garb of early seventeenth-century English, the trick of which he has caught admirably. The only fault to be found with the translation is that it is better than the original. In the following pages, I have ventured, while freely acknowledging my indebtedness to the Dutch translator, to present an almost literally translated English version which, in my opinion, more nearly reflects the rough-hewn story of the author.

The Report is in the form of a DIARY kept on board the "Pera," and is probably in the main a transcription of the ship's log, and is signed by Jan Carstenszoon, the Commodore of the Expedition. It is headed "Journal kept by Jan Carstensz," that being the contraction in common use at a time when surnames denoted only that the person known by a certain Christian name was the son (zoon) of somebody else.

Although the "Pera" and "Aernem" took over the orders originally drawn up for the "Haringh" and "Hasewint," the SKIPPER of the "Pera," Jan Sluijs, was not in the position which was to have been occupied by Jan Vos, who, presumably, was the skipper of one of the two vessels. Vos, it was intended, should "carry the flag, convene the Council and preside therein." In short, he was not only to command his own ship but to be commodore of the expedition as well. The SKIPPERs of the "Pera" (Stuijs) and "Aernem" (Meliszoon) had no higher status than that of SAILING MASTERS, and although most of the hard work was assigned to them, they were evidently of less importance than the merchants or traders (kooplieden), as witness the order of precedence observed in the Aru and Queij inscriptions.

A democratic institution, viz., a "Full Council" of the assembled officers of both ships, ${ }^{1}$ seems to a modern lay reader to have been well calculated to destroy all order and discipline, and yet there is no evidence that on these two ships any serious trouble resulted.

From a reference in the $\log$ to a resolution of the Council on a certain date, which resolution is not mentioned in the log of that date, there is reason to suppose that the proceedings of the Council were recorded in a separate minute book, which has been lost, or lost sight of.

It would be interesting to know the names of all the adventurers who set out in 1623 and who lighted upon the Cape York Peninsula, but no list is given in the log, only a few names being mentioned incidentally, while a few more can be gathered from other documents.

1 The composition of the Full Council is explained in Tasman's instructions.

$1-3$ 
Jan Carstenszoon, "Opper Coopman" (Upper merchant, or trader or supercargo) on the "Pera," acted as Commodore of the expedition. The Assistant Supercargo of the "Pera" was Pieter Lingtes or Lintiens. The Skipper was Jan Sluijs. The Upper Steersman (Chief Mate) was Arend Martenszoon de Leeuw, and the Under Steersman (Second Mate) was Willem Joosten van Coolsteerdt, who was made skipper of the "Aernem" on the death of Meliszoon, the original master (Ioth February, 1623). The number of the crew is nowhere stated, but at any rate it was large enough to furnish a boat's crew of thirteen men on occasion. A CARPENTER and an "ASsisTANT" are referred to, but it is not clear whether the latter was the carpenter's apprentice or a midshipman. A CORPORAL and TEN MUSKETEERS are mentioned, but it is doubtful whether these were marines or sailors armed for the occasion. There was also a BARBER-SURGEON, and a " JUREBASS," who was an expert swimmer and who died of liver complaint or of the operation performed by the barber. Stoffel is unable to give an English equivalent for " jurebass" and no more can I, nor can any Dutchman whom I have had an opportunity of consulting. We must, therefore, for the present be content to define a Jurebass as "a person who performs jurebassial functions." My conjecture wavers between a slave, prisoner, convict or hostage on the one hand and a lent or temporarily impressed local pilot on the other.

The "Aernem" set out on the voyage under command of Dirk Meliszoon, assisted by an unnamed FIRST MATE and a SECOND mate named Jan Janszoon. On roth February, I623, Meliszoon was killed by natives of New Guinea, together with an " assistant" (midshipman ?) named JAN Willemszoon VAN DEN BRIEL and eight others. After this disaster, VAN Coolsteerdt, second mate of the "Pera," was given command of the "Aernem," and Janszoon, the "Aernem's" second mate, was made FIRST mate.

It is beyond the scope of this study to follow the fortunes of the expedition except in so far as they are connected with the Cape York Peninsula, but it may be mentioned that the "Pera's" officers completed their voyage under the mistaken impression that they had demonstrated the continuity of CERAM and New GUINEA, although pre-existing maps showed this stretch of land to be divided into a chain of islands. When DE LEEUW-evidently some time after the voyage-drew his famous sketch-chart, he must have been satisfied of the error of this conclusion, as he showed the islands. The expedition abandoned the search for the alleged opening now known as TorRes STRAIT, believing that it DID NOT EXIST, and coasted Australia for eight degrees southward, having failed to realise that New Guinea was a distinct island. On the other hand, they furnished the earliest account of a portion of Australia and added materially to the knowledge of New Guinea. 
CHAPTER VI

THE VOYAGE OF THE “ PERA " AND “AERNEM" (1623), continued

\section{THE OUTWARD VOYAGE}

Attack by New Guinea Natives. Bows and Arrows. A Native killed. False Cape, Frederick Henry Island (supposed to be part of New Guinea). Eastward along South Coast of New Guinea. Entangled in the "Dry Bight." Satisfied that there is no Strait between New Guinea and the South Land. Poor Sailing Qualities of the "Aernem." A Meeting of the Council. Ships visited by New Guinea Natives, for whom "Trade" had no Atrractions, but who would give Something for a Boy. Too wary to be caught. Ineffectual Attempt to land on New Guinea Coast. Escape from the "Dry Bight" into Deep Water. Australia (CApe York Peninsula) sighted and lost sight of. Sighted again near Cape Keerweer. A Difficult Landing. Atrempt to attract Natives. Another Landing near Mouth of Mitcheli River. No Natives. Another Landing. The Natives and their Weapons. A Native captured. Death of the "Jurebass" under an Operation by the Barber-Surgen. A Landing for Firewood. An Attack by Natives repulsed. Latitude of $17^{\circ} 8^{\prime}$ S. Reached. Meeting of Council. Return decided on. Reward offered for Capture of Natives A Landing for Water. Another Landing. Native Footprints. Memorial Tablet erected. Staten Inlet named (Accident Inlet, one of the Mouths of the Gilbert River). Flinders mistakes Position of Staten Inlet.

[BRITISH ADMIRALTY CHART NO. 447, "WESTERN APPROACHES TO TORRES STRAITS," CORRECTED UP TO AUGUST, I900.]

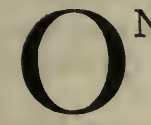

N I t $t h$ March, 1623, the "Pera" and "Aernem" anchored off a promontory, which they named VALSCH CAEP (False Cape), the western extremity of what is now distinguished as Frederick Henry Island, and is separated from the mainland of New Guinea by the narrow Princess Marianne or Dourga Channel. From this point, the "Pera's" log, dealing with an attempt to find an eastward passage through the suspected Torres Strait, the "Dry Bight" which was supposed to be "all there was" to it, and the cruises along the western coast of the CAPe York Peninsula, is reproduced almost verbatim.

"In the morning of the $12 t b$ [March, 1623], the breeze from the NW. In the forenoon, I, personally, rowed to the land, with the two boats well manned and armed, in order to see if there was anything worthy of note there; but when we had got within a musket shot from the land, the water became so shallow that we could not reach it, whereupon we all of us went through the clay up to our waists and with great difficulty reached the beach, where we saw a number of fresh human footprints. On going a short distance into the bush, we saw 20 or more huts made of dried grass, 
the huts being so small and cramped that a man could hardly creep into them, from which we could sufficiently conclude that the natives must be poor and miserable specimens of humanity. We afterwards tried to penetrate somewhat further into the bush, in order to ascertain the nature and situation of the country. As we were returning, a number of BLACKS sprang out of the bush and let fly their ARRows at us very furiously and with a horrible shouting, wounding a carpenter in the belly and an apprentice in the leg. They also made signals to other blacks to come to their assistance. Being thus hard pressed, we fired three or four muskets at the blacks, killing one stone dead, which utterly took away their courage, and they dragged the dead man into the bush. Being so far from the boats and a very difficult path to travel, we returned, rowed out and went on board. The same day, at low water, we saw a great shoal, extending SE., S. and SW. from us, where we had been with the yachts on the IIth. The said shoal stretches fully 4 miles [ 16 minutes] WSW. and W. by S. of the land or hook, to which has been given in the new chart the name of VALsch CAEP, and which is in lat. $8^{\circ} 15^{\prime} \mathrm{S}$. [really $8^{\circ} 21^{\prime}$ ] and about 70 miles [ 280 minutes] east [really SE.] of Aru.

"Note that the land which we have touched at, as above mentioned, is low-lying and half-submerged to the north, so that a large part of it is under water at high tide. In the south it is somewhat higher, and here some men inhabit it, and possess huts, but so far as we could ascertain it is barren, although closely covered with tall, wild trees. The men are quite black and naked. Their hair curls, like that of the Papuans. They wear certain fish-bones through the nose, and through the ears pieces of the bark of trees, a span in length, so that they look more like monsters than human beings. Their weapons are ARROWS AND BOWs, with which they are very expert.

"On the 13 th, the wind N.: good weather and the current stronger to west than to north. We got under sail in the forenoon, course WNW. to get in to deeper water, and when we had run a short distance we got about 8 feet, upon which we turned back, and towards evening anchored in 2 fathoms.

"On the 14th, good weather, the wind N. by W., and the current, as before, strong to the SW. At midday, both boats sent out to take soundings, and they went fully 2 miles WNW. of the yachts without finding anywhere more than $1 \frac{1}{2}$ or 2 fathoms of water. The same day, it was found practicable to set up again the 'Aernem's' main topmast (which had been lowered because it was useless in the calm weather), for which the weather was now every day becoming more suitable.

"On the 15th, wind NNE., good weather, and the current as strong as before. At midday, got under sail, on a tide coming from the NW., in the hope of getting clear of the shoals, but after beating about till towards evening, we were forced by contrary currents to anchor in 3 fathoms.

"The 16 th, good weather, the wind NE. by E. Got under sail before midday. In the course of the day the wind dropped. Towards evening the wind veered round to WSW. Course NNW. along the shallows, in $2 \frac{1}{2}$ and 2 fathoms. In the evening, anchored in 3 fathoms. We have found that in these parts the currents set very strongly to SW., as before mentioned, and that the water rises and falls fully $I \frac{1}{2}$ and 2 fathoms at each tide.

"The 17 th, the wind E. in the morning. Thereupon we set sail, course WNW. and W. by N., getting into deeper water, about 5 fathoms. At noon the latitude was $8^{\circ} 4^{\prime}$. In the evening we anchored in 6 fathoms, having sailed WSW. 4 miles [16 minutes].1

"In the morning of the $18 \mathrm{th}$, good weather, the wind W. In the afternoon we set sail, with a rising tide coming from the W. Course SW. by S., in 6 fathoms. When we had got into water deeper than 7 and 8 fathoms, course changed to SE. by E., and ESE., in 10, 12, 14, 18, 20, 26 and 28 fathoms. Towards evening, we went over to E., having sailed from morning to evening on the course first mentioned $5 \frac{1}{2}$ miles [22 minutes] and from evening to morning E., 9 miles [ 36 minutes].

1 Carstenszoon's " miles" are Dutch "Leagues," of four minutes ( 16 to a degree). 
"On the Igth, course E. and wind W., having VALSCH CAEP NNE., 5 miles [20 minutes] off, the land extending N. by W. The water being now 24 fathoms deep here, went over to ENE., making 4 miles [16 minutes], got 6 fathoms, so we cast anchor about 4 miles from the land.

"On the 20th, wind NNE., good weather, course as before, in 6 fathoms. In the evening we anchored in $5 \frac{1}{2}$ fathoms, having this day sailed $7 \frac{1}{2}$ miles [ 30 minutes].

"On the morning of the 21 st, we again set sail, the wind NNW. and the course NE., for 4 miles [ 16 minutes], in 4 fathoms. In the afternoon we made 8 miles $\mathrm{E}$. In the evening anchored in 7 fathoms, just beyond an island lying a mile or more south of the mainland. ${ }^{1}$ A quarter of a mile N. by E., and S. by W. of the islet is a rock, on which two leafless trees are standing.

"On the $22 n d$, the Council having been convened, it was finally resolved to land with the two boats properly manned and armed, seeing that the coast here is covered with coco-nut trees, and is also higher, better looking and more fruitful than any country which we have seen hitherto : afterwards when we failed to get ashore because of mud-flats, we rowed to the before-mentioned islet, and let go the anchor in order to visit it. While we were so engaged, the yacht 'Aernem' got adrift, owing to the force of the current and the wind, and ran foul of the bows of the 'Pera,' much damage being done to both ships. . . . This prevented any further sailing for some days, and indeed had God not specially looked after them, both yachts would have gone ashore.

"On the $23 r d$, good weather, and the Council having been convened once more, I proposed to try every possible means to get the 'Aernem' into sailing trim again and in the first place another rudder so as not to delay the voyage, but there was absolutely no means of doing this because in neither of the yachts were there any spare rudders or old ones which could be cut down. Prevented thus from making a proper job of it, it was finally resolved (to expedite the voyage and not have the yacht lagging behind) that with the materials available a rudder should be constructed Javanese or Chinese fashion. For this purpose the 'Pera' will have to give up her main topmast, the rest of the required wood to be fetched from the land, and we shall stay here until the rudder has been made.

"On the 24 th (while the rudder was being made) the subcargo, ${ }^{2}$ with both the boats, went to the aforesaid island to get water for the 'Aernem' (which was very short of it) and came on board in the evening with four firkins full, after great trouble.

" On the 25th, the yacht 'Aernem' again seaworthy (Praise God!) with good weather and a favourable wind got under sail once more, course E., in $5 \frac{1}{2}, 6$ and $6 \frac{1}{2}$ fathoms along the land. In the evening, in $2 \frac{1}{2}$ fathoms and 2 miles off the land, we cast anchor, having sailed ten miles [40 minutes] this day.

"Note that the island hereinbefore mentioned lies in $8^{\circ} 8^{\prime} \mathrm{S}$. lat. $\left[8^{\circ} 16^{\prime}\right.$ according to modern charts.-R. L. J.] about a mile N. and S. [i.e., S.] of the mainland, as aforesaid, is pretty high and is well timbered with wild trees on the east side and quite bare on the west. It is about a quarter of a mile in circumference and is surrounded by many boulders and rocks (on which plenty of oysters grow). The soil is very good and suitable for all sorts of plants and cereals. It carries, by our estimate, upwards of 100 full-grown coco-nut trees, with many young ones coming on, and also some bananas and oubis, with fresh water, which comes trickling through the clay in small rills and may be caught in pits dug for the purpose. There are also a great many bats (vleermuijsjen) which live in the trees, for which reason in the new chart we have given the island the name of VleErmuijs EijlandT. We have seen no huts or human beings on it, but found unmistakable signs that men had been there before. [The island appears on modern charts as Habeeke Island.-R. L. J.]

1 The wording (" near an island lying a mile or more south and north of the mainland ") is ambiguous, but the island, which was afterwards named Vleermuijs Eijlandt (Bat I.) must have been south of the land. The island and rock are easily identified on modern charts as Habeeke Island and Sametinke Rock.-R. L. J.

2 Ondercoopman, Under Trader, Sub-Cargo, or Assistant Supercargo. 
1 " On the $26 t h$, good weather, the wind NNW., course SE. by E. along the land in 5 fathoms. In the forenoon four canoes put out from the land and eventually, on our waiting for them, boarded us. There were altogether 25 BLACKs, who had nothing with them but their weapons. They called out and made signs that we should come on shore. We threw them some small pieces of iron and coral, at which they showed great satisfaction. Gold, silver, nutmegs and cloves, which were shown to them, they paid little or no attention to, though they were willing to accept them as presents. Their canoes are very skilfully made out of a single piece of wood, and some are so large that they will carry 20 or more blacks. Their paddles are long, and they used them standing or sitting. The men are black and tall and carry themselves well, with big and strong limbs and curled hair like the Kaffirs, which some of them bind on the neck with a knot, while others let it hang loose down to their waists. They have little or no beard. Some of them have two, and others three, slits through the nose, in which they carry tusks of boars, or the 'teeth' of swordfish. They are stark naked and have their privates enclosed in a conch-shell (which is fastened to the waist with a piece of twine). They have no rings of gold, silver, copper, tin or iron on their bodies, but occasionally they have them of turtle-shell, from which it may be inferred that their country yields no metals, nor any wood of value, being all low and submersible land, as indeed we have found it to be. There were also among them some not provided with paddles, but wearing two strings of human teeth round their necks, and excelling the others in ugliness, carrying on the left arm a hammer, with a handle of wood, with at one end a black conch-shell, the size of a fist, and at the other, by which it is held, a three-sided bone not unlike a staghorn. For one of these hammers they were offered a rug, coral (beads) and iron, which were refused, though the savages were quite willing to barter one for one of the boys, to whom they had taken a fancy. It seems likely that those who carry the aforesaid hammers belong to the nobility or military. The people are cunning and suspicious and by no finesse 2 could they be induced to come near enough to let us catch one or two with the nooses which we had prepared for the purpose. They carried also in their canoes some human thighbones, which they repeatedly held up to us, but what they meant by this is unknown to us. At last they asked for a rope to tow the yacht to land, but found it too hard work and quickly paddled back to the land.

"In the evening anchored in 3 fathoms about 3 miles from land, and sailed this day 13 miles [ 52 minutes].

"In the morning of the $27 t h$ the wind WNW., stiff breeze, course SE. by S. and SE., 7 miles, and ESE. 5 miles, in $5 \frac{1}{2}, 5$ and 3 fathoms. In the evening anchored in $5 \frac{1}{2}$ fathoms $3 \frac{1}{2}$ miles from land. A quarter of a mile landward a shoal was seen, on which the 'Aernem' got stuck, but afterwards (God be praised!) got off again.

"On $28 \mathrm{tb}^{3}$ set sail again, the wind NW., course E., close to the land, in varying depths, such as $7,9,12,4$ and $5 \frac{1}{2}$ fathoms. At midday the latitude was $9^{\circ} 6^{\prime},{ }^{4}$ having sailed 5 miles, and thence till evening we ran E. by S. 4 miles, in $18,12,9,7,5$ and 2 fathoms, when we dropped anchor, and sent the boat out to sound. The water having been found to deepen towards the land, the anchor was lifted and we sailed closer in and anchored in 4 fathoms 3 miles from the shore." [This was probably near Tarŭdarŭ Point, at the east end of Heath Bay.-R. L. J.]

"In the morning of the $29 t h$, the wind NNW, mild weather. In the forenoon it was deemed advisable to send off the boat of the 'Pera' with I 3 men and the Steersman of the 'Aernem' (victualled for 4 days) to take soundings and follow the land, extending to ENE., for 7 or 8 miles. [SEE MAP A.]

"On the $30 t h$, the wind N., good weather, so that we also sent the boat of the

1 At the head of this paragraph the words "Clapper Cust" (Coco-nut Coast) occur as a marginal note.- $R$. L. J.

2 A sly allusion to the terms of the sailing orders. - R. L. J.

3 This day the modern boundary line between Dutch and British New Guinea waters was passed.-R. L. J.

- According to modern charts, the northmost navigable waters here (in Heath Bay) are about $9^{\circ} 3^{\prime} \mathrm{S}$. 


\section{VOYAGE OF THE “PERA" AND “AERNEM"}

'Aernem' to take soundings in various directions for 2 or 3 miles out from the yachts. At low water we saw several sandbanks and reefs lying dry, to wit: ESE., SSW. and W. In the afternoon the 'Aernem's' boat came back, having found shoals in every direction for two miles out. Towards evening the 'Pera's' boat also returned, and from the Steersman we learned that they had been about 8 miles E. by S. and ESE. of the yachts, and at that distance had found very shallow water, such as 7,8 , 9 and ro feet, which continued for more than a mile, the depth thereafter increasing to $2,2 \frac{1}{2}, 3,5$ and 7 fathoms ; that the land stretched E. and E. by N., being very low and muddy and overgrown with a tangle of brushwood and wild trees.

"On the 3 Ist, the wind NNE., with rain. After midday I went personally, with both boats, to one of the reefs, to see how things were between the yachts and the land, which area had fallen dry with the low tide. In the afternoon the skipper of the 'Pera' was commanded to take the boat, properly manned and armed, to the land, in order to ascertain what could be done for the service of our masters, and to parley with the people, and, if practicable, get hold of one or two. Very late in the evening, the boat returned, and we were informed by the skipper that, although it was high water, they could not come nearer than a pistol-shot to the land, owing to the mud and shoals, and that the low and submersible land was full of brushwood and wild trees.

"NotE.-Having heard the above-written reports regarding the shoals to the east, we are sufficiently assured (to our great regret) that it is not possible any longer to trace the land which we have followed so far to the east. Having sailed into the shoal as into a trap, we must get out the same way, trying one direction and another and taking advantage of the ebb; and having attained deeper water, first run south to the I6th degree, or even further, should it be found advisable, and then turn the bow northward along the coast of New Guinea, according to our previous resolution come to on 6th March. 1 We were now, as before mentioned, in lat. $9^{\circ} 6^{\prime} \mathrm{S}$. [say $9^{\circ} 1^{\prime}$. - R. L. J.] and about 125 miles east of Aru, and, according to the chart furnished to us, ${ }^{2}$ and the estimates of the skippers and steersmen, not more than 5 miles from New Guinea, so that the space between us and the aforesaid New Guinea appears to be a bight, which, because of its shoals, we have named the Drooge Bocht [Dry Bight] in the new chart. ${ }^{3}$ To the land which we have followed up to date, we have, by resolution, given the name of the Westeinde van Nova Guinea (West End of New Guinea), seeing that we have in reality found the land to be an UNBROKEN whole, although marked as islands, such as Ceram and the Papues, in the charts, owing to misunderstanding and misleading information."

"April Ist, the wind W. by S., good weather. Weighed anchor, and with the ebb coming out of the NE., drifted with the stream $I \frac{1}{2}$ miles SW., and anchored in 6 fathoms.

"On the $2 n d$, wind W. by N. Tried to get away to the W., on the ebb, in 4, 5 and 6 fathoms. During the whole day variable winds. Towards evening, anchored in 4 fathoms, 3. miles from the land, and this day advanced W. and W. by N. 4 miles.

"On the $3 r d$, sailed again at daybreak, the wind N., course WNW., in 7, 2 and I $\frac{1}{2}$ fathoms, the water in these parts being of greatly varying depths, so that the lead

1 The fact that this resolution is not mentioned in the diary of 6th March leads to a presumption that the minutes of meetings of the Full Council were kept in a separate book; this would be an interesting document.-R. L. J.

"They must have been furnished with the "Duyfken's" charts.-R. L. J.

3 A marginal addendum to this note (presumably made by the writer of the Diary itself) reads: "The Drooge Bocht, where we had to leave the west end of New Guinea, is in $9^{\circ} 20^{\prime} \mathrm{S}$. lat."

- The charts available in 1623 already showed the insularity of Ceram, and clusters of islands extending eastward and almost bridging over the space separating Ceram from New Guinea. An observer sailing eastward to the south of these islands (especially if insufficiently acquainted with charts of the region) might be pardoned for regarding the land as unbroken from Ceram to New Guinea. The information in possession of the Spanish and Portuguese of the period was by no means " misleading." -R. L. J. 
had to be used all the time. In the afternoon, anchored in 4 fathoms, having drifted with the ebb $2 \frac{1}{2}$ miles.

"On the $4 t h$, the wind NE. by N., good weather. Set sail again. In the afternoon, anchored in 7 fathoms, out of sight of land, having drifted with the current 8 miles W. by $N$.

"Notr.-Here, after immense difficulty and peril, we had again (God be thanked!) got clear of the aforesaid shoals, between which and the land we had sailed as into 2 trap. The shoals extend S. and N., from 4 to 9 miles out from the mainland, and are Io miles from $\mathrm{E}$. to $\mathrm{W}$.

"On the 5 th, we sailed again at daylight, the wind ENE., on courses varying between SW. and S., whereby we got into deeper water, from 14 to 26 fathoms, and sailed 18 miles [ 72 minutes] this day ["het etmael," a day of 24 hours: hence, probably, from daylight of the 5 th to daylight of the 6th.-R. L. J.].

"On the $6 t h$, the wind SW., with rain, course SE. At night, latitude $9^{\circ} 45^{\prime}$, and sailed in the day ESE. II miles. [How was the night latitude determined ?R. L. J.]

"On the 7 th, the wind SE., course E., in 15 or 16 fathoms water, and till evening sailed 4 miles. At night turned SE., and towards daylight [of the 8 th. - R. L. J.] anchored in 4 fathoms, but as the yacht swung to the anchor came on 2 fathoms, and during the night sailed 3 miles.

"In the morning of the 8 th, saw distinctly many stones lying on the bottom, but to have such a change in the water (as from 26 fathoms) showed that the land here (though unseen) must be very dangeroús to touch at, and it was only through God's providence that the yachts were not wrecked. Got under sail at noon, being in $10^{\circ} 15^{\prime}$, the wind W. by S., and later on variable, till next morning [9th], sailed 6 miles SSW., in 10 and $11 \frac{1}{2}$ fathoms."

[Editorial Note.-The Admiralty chart shows, in lat. $10^{\circ} 15^{\prime} \mathrm{S}$. and $14 \mathrm{I}^{\circ}$ E., a reef or shoal reported by the "Glamis Castle" in I88I, and it was probably here that the "Pera's" captain was alarmed by the sudden shoaling of the water in a cable's length. -R. L. J.]

"On the 9 th, the wind NE., with rain, course SE. In the evening wind SE. Therefore anchored in II fathoms, and this day sailed 5 miles.

"In the morning of the Ioth, the wind ENE., course SE., in 9, 10 and II fathoms. In the evening wind SE., whereupon anchored, having sailed 5 miles.

" On the I $t h$, the wind E. by N., 2 fair breeze, course SSE., lat. at noon II $^{\circ} 30^{\prime}$. For the whole of this day and night tried, with varying winds and courses, to get south, and in the 24 hours sailed 22 miles [ 88 minutes]. Course held SE. [SEE MAP B.]

"In the morning of the $12 \mathrm{th}$, the wind SE., good weather, and at sunrise saw the land of Nova Guinea (being low, with neither mountains nor hills), I $3 \frac{1}{2}$ fathoms, clay bottom, course SSW., noon latitude $\mathrm{II}^{\circ} 45^{\prime}$, and sailed in the 24 hours SW ro miles [40 minutes]."

[Editorial Note.-The men on the "Pera" first saw Australia, which they believed to be continuous with New Guinea, on 12th April, 1623, probably from a distance of about 35 knots, the nearest land being that west of Port Musgrave. My many attempts to chart the "Pera's" course across the western entrance to Torres Strait only serve to convince me that Carstenszoon overestimated the distances covered, and this tendency probably reflected the mood of the navigators after their escape from the 


\section{VOYAGE OF THE “PERA" AND “AERNEM"}

"Drooge Bocht" and their belief that they were at last making satisfactory progress.-R. L. J.]

"In the morning of the $13 t h$, the wind SE. by E., being in 24 fathoms, the forementioned land still in sight, and of the same character as before, course SW. Midday latitude $12^{\circ} 53^{\prime}$. For the rest of the day and night, with the wind as above, and on

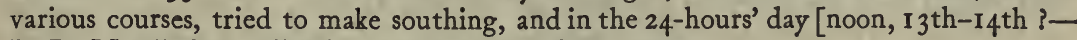
R. L. J.] sailed 22 miles [88 minutes] on a SW. course.

"On the I 4 th, the wind E. by W., course S. by E., in Io, I I, I 2, I3 and $I_{4}$ fathoms, parallel to the land. At midday the latitude was $13^{\circ} 47^{\prime}$, and the land out of sight. For the rest of the day and the whole of the night, with diverse winds and on different courses, in $7,6,5,4,3$ and $2 \frac{1}{2}$ fathoms, we tried to get the land alongside [i.e., changed the course as much as possible to the east.-R. L. J.]. [SEz MAP D.] Towards daylight [ $\left.{ }^{5} \mathrm{th}^{\mathrm{t}}\right]$, we were so near it that we might have recognised persons on the strand. [This must have been at, or near, CAPE KEERwEER, where the "Duyfken" turned back.-R. L. J.]

"On the I5th, in the morning, the wind strong from the east, course S. by E., in 3 and $2 \frac{1}{2}$ fathoms, along a bank which lies about a mile from the mainland. At midday the latitude was $14^{\circ} 30^{\prime}$. [SEE MAP F.] The land which we have hitherto seen and followed extends S. and N., and is low and without variety, and in some places has soft, sandy beaches. Near midday the wind dropped, and we ANCHORED, having sailed II miles [44 minutes] south. Great volumes of smoke being visible on the land, the assistant supercargo ${ }^{1}$ was ordered to land, with both boats, duly manned and armed, and was specially enjoined to use his utmost endeavours in the interests of our Masters. On the return of the boats in the evening, the assistant supercargo reported that the boats could get no nearer than a stone's-throw to the beach, in which a man would sink to his middle, but that they had seen, in various places, BLACKs emerging from the bush, while others were hiding in the scrubs. They therefore sent one of the hands of the boat ashore, with pieces of iron and beads tied to a stick, in order to attract the blacks. And so, as nothing else could be done, and night was coming on, they turned back. [The anchorage must have been approximately in $14^{\circ} 40^{\prime} \mathrm{S}$. lat.-R. L. J.]

"In the morning of the I6th (Easter Day), wind E. Set sail, course S. by E. Midday latitude $14^{\circ} 56^{\prime}$. Anchored in the evening in $5 \frac{1}{2}$ fathoms, having sailed S. I $\frac{1}{2}$ miles [ 42 minutes. This distance from the last anchorage would give the position about $15^{\circ}$ S.-R. L. J.]

"In the morning of the $I 7 t h$, the wind S. by W., with rain, and the tide setting to the S. At noon, the wind E., so made sail, course S. by W., in $4 \frac{1}{2}$ fathoms, along the land. Towards evening the wind dropped, anchored on the ebb, and I, personally, with both boats properly furnished, landed, and with the party went a long way inland, finding a level, fine country, with few trees, and good soil all about for planting and sowing, but, so far as we could make out, absolutely without fresh water. Nor did we see any human beings, or even signs of them. At the edge of the sea, sandy, with a fine beach, and abundance of excellent fish. [This anchorage was probably a little south of the principal mouth of the Mitchell River.-R. L. J.]

"In the morning of the $\mathrm{I} 8 \mathrm{th}$, the wind ENE., course S. by W., along the land. About midday, in $3 \frac{1}{2}$ fathoms, clay bottom, having seen persons on the beach, we anchored, and the skipper of the 'Pera' was ordered to row ashore with both boats armed for defence. Later in the afternoon, when the boats returned, the skipper reported that as soon as the party had landed a great mob of BLACKs, some with arms and some without, had come up to them, and were so bold and free as to touch the men's muskets and try to take them off their shoulders, and in fact, wanted to take everything they thought they might have use for. These being kept interested with

1 In the "Summary Extract" of the Journal, this officer's name is given as PIETER Lintiens. The inscriptions at Aru and Queij Islands spell it Lingtes.-R. L. J. 
iron and beads, an opportunity was espied, and one of them was seized by a string which he had round his neck and taken on board the boat. The others who were on the beach made a great hubbub and outcry, but those who were concealed in the bush remained there. The said people are pitch black, thin in body, and stark naked, with basket-work or nets round their heads. As regards their hair and figure, they are like the blacks of the coast of Coromandel, but they seem to be less cunning, bold and wicked than the blacks at the west end of New Guinea. Their weapons, some of which we are bringing with us, are assegais, shields, clubs and sticks about $\mathrm{I} \frac{1}{2}$ fathoms in length, and are not so formidable as those we have seen among other blacks. As regards their manners and policy, and the nature of the country, Your Worships will in time perhaps be able to elicit some information from the captured blacks, to whom I refer you. [This day's diary concludes with the following curious passage, which, although omitted by Heeres, no doubt because of its irrelevancy, is here reproduced, as given by Van Dijk, because of its reference to two members of the ship's company who are not mentioned elsewhere.-R. L. J.]

"The same day, the slave assigned to us (?) [medgogeven Jurebasse] at Aru, after having been ill for two days, had an intolerable pain in his liver, and consented to be opened by the barber, when there was to be seen much congealed blood, which had overrun the heart, and this had evidently been the cause of his death.

"On the $x \mathrm{gth}$, the wind SE., so we stayed where we were, and as the yachts were found to be almost out of firewood, the skipper of the 'Pera' went ashore, with both the boats duly manned and armed, and when the men were engaged in cutting it, 2 large party of BLACKs more than 100 in number, came upon them, and tried all sorts of tricks to take them by surprise and club them ['den clop te geven ']. Out of this the necessity arose to fire two shots, whereupon they fled, one of them being hit and having fallen. Such of our people as penetrated further inland observed many weapons, and brought some away as curiosities. On their march they also saw many human bones in different places, from which it may be safely presumed that the New Guinea blacks [the crew thought they were still in New Guinea.-R. L. J.] are cannibals, and when hungry do not spare one another."

[Editorial Note.-I conjecture that the scene of the landings of 18 th and 19th April must have been about $15^{\circ} 17^{\prime}$, or 17 English miles N. by E. of Angeram Mission Station.-R. L. J.]

"On the $20 t h$, the wind SE., got under sail, course SSW. At noon, with the ebb tide running from the south, anchored in $3 \frac{1}{2}$ fathoms in clayey bottom, and the skipper was ordered to land, with both boats duly prepared for defence, and make careful observations, as far as time and place should allow. On his return in the evening, he informed us that a very strong surf covered the beach, so that he could not get near it, still less land. [This was probably about 3 miles north of Angeram Mission Station.-R. L. J.]

"In the morning of the $2 \mathrm{Ist}$, the wind SE., set sail, course SW., along the land. At noon, lat. $15^{\circ} 38^{\prime}$. In the evening, anchored with the ebb, in $3 \frac{1}{2}$ fathoms. [Say $15^{\circ} 50^{\prime}$, or about 30 miles S. by W. of Angeram.-R. L. J.] [SeE MAP H.]

"In the morning of the $22 n d$, the wind ENE., course S. Midday latitude $16^{\circ} 4^{\prime}$. Towards evening, the wind being W. by N., anchored in $2 \frac{1}{2}$ fathoms about a mile from land. [Approximately $16^{\circ} 9^{\prime}$.- - R. L. J.]

"On the $23 r d$, the wind NNE., stiff breeze, set sail, course SSW., in $3 \frac{1}{2}, 3,2 \frac{1}{2}$ and 2 fathoms, clay bottom, along the land. Midday latitude $16^{\circ} 32^{\prime}$. For the rest of the day, tried to get south, with variable winds. Towards evening, anchored in 3 fathoms close to the land.

"On the $24 t h$, the wind E. by S., course SSW., in $2 \frac{1}{2}, 3 \frac{1}{2}$ and $4 \frac{1}{2}$ fathoms, clay bottom, along the land. Midday latitude $17^{\circ} 8^{\prime}$. [SEE MAP M.]

"Item.-This same day, the Council having been convened, the question was submitted by me whether it would be advisable to sail further south: that, after 
several speeches regarding the difficulties which were to be expected, it was agreed that we might get into a huge bight, and it is evident that hereabouts in these climes in the east monsoons north winds prevail, just as south [north ?] of the line in the forenamed monsoons south winds do, and so we might fall on a lee shore. On which considerations, it was judged to be best for the interests of our Masters, and was determined and resolved to TURN BACK, and to follow the coast of New Guinea northward as far as it may be practicable; also to touch at various places and examine them carefully, and then shape our course for Aru and Queij. ... It was further proposed by me, and ultimately agreed to, to offer to the boats' crews for each black captured on the land and brought on board ten reals of eight, and that, to this end, the crews may use greater care and diligence, so as to do our Masters signal service, for which they might expect to reap due recognition.

" On the 25th, the skipper of the 'Pera' was ordered to land, with both boats well manned and armed, and especially to look out for fresh water, with which we are now very poorly provided. About midday, the skipper returned and reported that he had sunk pits at various places on shore, but could find no water : also that they had seen 7 small huts on the beach, made of hay, and 7 or 8 blacks, who would not stop to parley. In the afternoon, I, personally, taking both boats, went up a salt inlet for about half a mile [about $2 \frac{1}{3}$ English miles.-R. L. J.], and then, with the party, walked a good way into the land, which was under water [salt water ?-R. L. J.] in many places, recalling the Waterland in Holland, so that it may be presumed that further into the interior there may be great lakes or marshes. We also saw many footprints of men, and the tracks of large dogs, going from south to north; and since by resolution it has been determined to begin the return voyage from here, we have, in default of stone, nailed to a tree a wooden tablet, on which the following words were engraved:- - Anno 1623 den $24 n$ April sijn hier aen gecomen twee jachten wegen de Hooge Mogende Heeren Staten Gen'.' ['In the year I623 the 24th April hereto came two yachts on behalf of the High and Mighty Lords States General.'] The addition of the aforesaid river is denominated the Staten River in the newly made chart." [A marginal note reads :- "The Staten Revier is in latitude $17^{\circ} 8^{\prime}$."This was the latitude of the anchorage.-R. L. J.]

[Editorial Note.-The exact position of the inlet named the "STAten Revier" by the Commodore of the Expedition is open to question-within certain narrow limits.

The position is not defined with sufficient accuracy by the midday solar observation of 24th April.

On that date, the "Pera" sailed southward till midday, close to the land, as indicated by the soundings, which had a maximum of $4 \frac{1}{2}$ fathoms. At noon, the sun was taken, and gave the latitude $17^{\circ} 8^{\prime} \mathrm{S}$. As soon as the latitude had been calculated and noted, orders were given to let go the anchor, and probably the anchorage was an (English) mile or two south of $17^{\circ} 8^{\prime}$, and very near the beach. We may assume that it was 2 miles south of the noon position, or, say, $17^{\circ} 10^{\prime}$, i.e., 4 (English) miles north of Accident Inlet. The "Pera," no doubt, waited some time for the arrival of the "Aernem" (which always lagged behind), in order that the officers of both ships might meet in "full council" on board the "Pera." The question of sailing further south or turning back having been discussed at some length, the latter course was decided on, and by this time the afternoon was too far advanced for a landing. 
The skipper of the "Pera" was "ordered" to land on the 25 th, and to look out for fresh water. He landed, there can be no doubt, on the nearest beach, where he saw huts and a few natives, and dug unsuccessfully for water. There is no indication whatever that he landed at, or because he saw, any "revier" or inlet. He returned to the "Pera" at noon.

In the afternoon, the Commodore (Carstenszoon) took the two boats and, having found a "salt inlet," rowed up for some $2 \frac{1}{3}$ (English) miles. The probability is that he searched to the south for an inlet, the coast-line to the north having already been seen from the ship the day before. Assuming the anchorage to have been $17^{\circ} 10^{\prime}$, there were only 4 (English) miles to go before falling in with Accident InLet, in $17^{\circ} \mathbf{1} \mathbf{2}^{\prime}$, one of the mouths of the Gilbert River. It was this inlet, there is every reason to believe, which was named the Staten Revier. It would have been 9 (English) miles from the anchorage to the nearest inlet to the north, viz., the (erroneously named) Van Diemen Revier ( $\left.17^{\circ} 3^{\prime} \mathrm{S}.\right)$, which is another mouth of the Gilbert, known inland as the Smithburne River, and the 18 miles of rowing at sea, added to $4 \frac{2}{3}$ on the inlet, would have taken so much of the afternoon that the landing party would not have had daylight enough to do all that they did on shore.

There is no ground whatever, now that we have the information furnished by the log of the "Pera," for continuing to hold the belief embodied in Flinders' chart (1802) and all subsequent official maps, that the "Pera's" Staten River runs into the Gulf of Carpentaria between latitudes $15^{\circ} 24^{\prime}$ and $15^{\circ} 30^{\prime} \mathrm{S}$.

The party left the boat and walked some distance, over country which was partly "under water "- presumably stagnant salt water, lying in "claypans." Thereafter they scratched an inscription on a wooden slab, which they nailed to a tree before returning to the ship.-R. L. J.] 
Coasting Northward from Staten Inlet. "Azrnem" lags behind and disappears. Two Landings and Unsuccessful Search for Water. "Pera" continues Northward Voyage. Nassau Inlet named. Mișidentification by Subsequent Observers. Further Search for Water. Successful at last (ist May) in the Mitchell River Delta. The Watering-place recorded. Carstenszoon's Poor Opinion of the land and People. The Vereenichde Inlet (the Principal Mouth of Leichhardt's Mitchell River) named. Landing at Cape Keerweer (5th May). Warlike Natives. Landing (7th May). Formidable Opposition by Natives. Anchor South of Pera Head in Latitude $13^{\circ} 7^{\prime} \mathrm{S}$. Landing next Morning (8th May). Track Native Footprints northward to the Coen Inlet. Collect Esculent Herbs and carry them to Boat. Natives appear. A Native captured by a Ruse. Another killed. Flinders' Misidentification of Carstenszoon's Coen River. False Pera Head = Rijder's Hoek. Landing at Pera Head (9th May). Another Watering-place. Across Albatross Bay. Round Duyfken Point. Landing South of Port Musgrave (roth May). Sand-dunes. Footprints. Natives refuse to parley. Port Musgrave (Estuary of Batavia River) not observed. Inlet (Skardon River, de facto) named Carpentier

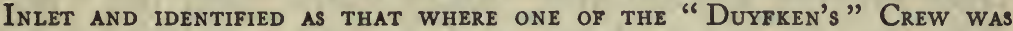
killed. Landing at this Inlet. Encounter with Natives. Van Spult InLet, Where Ships can dip Fresh Water (one of the Mouths of the "Jardine" River) recorded as a Watering-place. Woody, Wallis and Prince of Wales Islands. Sandbanks and Shoals finally cleared (22nd May). Sail for Amboina.

" N the 26th [April, 1623], as in this place there was no water (whereof there was great need), as we could hold no parley with the savages, and as nothing of importance could be done, set sail again, the wind ENE., stiff breeze, course N. along the land. [SEE MAP M.] At midday latitude $16^{\circ} 44^{\prime}$. In the evening anchored in 4 fathoms close under the land. [S $\mathrm{SeE}$ MAP H.]

"Notr.- That the yacht 'Aernem,' because of its poor sailing qualities and the small liking and inclination for the voyage which the skipper and steersman had shown, had on various occasions and at different times seriously delayed the voyage, for the 'Pera' (which was leaking badly and had to get more than 8,000 strokes of the pump every 24 hours) was nevertheless obliged to seek and follow her every day for 1,2 or more miles to leeward.

" On the 27 th, the wind E. by S., good weather, the skipper of the 'Pera' rowed ashore, with both boats, duly provided for defence, to look for fresh water, and sunk several holes, in which none was found; whereupon we set sail, course SE. by E.,1

1 An obvious mistake, as (I) a SE. by E. course would have run the ship ashore, (2) the coast here runs NNE. to SSW., and (3) the " Pera" made thirty-eight or forty minutes of northing between morning and noon.-R. L. J. 
along the land. Midday latitude $16^{\circ} 30^{\prime}$, wind W. by N. So we made for the land, two full hours before sunset, with foresail only, so as not to outpace the 'Aernem' (which was a howitzer shot behind us), and in the evening, in 3 fathoms, $1 \frac{1}{2}$ miles from the land, hung out a lantern, that the 'Aernem' might keep clear of us when dropping anchor, but this proved useless, because it is quite clear that, with deliberate malice and perversity, and contrary to the instructions and resolution, she ran away from us and shaped a course for Aru (to have a good time there) ; but that time will show."

[The few particulars available regarding the subsequent proceedings of the "Aernem" will be mentioned later on.-R. L. J.]

"In the morning of the $28 t h$, the wind E. by S., lovely weather, the skipper landed here with the boat, to look for water, and sunk several holes in the sand, without finding any : therefore set sail, course NE. by N., in 2, 3, 4 and 5 fathoms, along the land, and had got $2 \frac{1}{2}$ miles [10 minutes] when a violent land wind drove us off the land, and we anchored in 3 fathoms: and the BLAcks made on the land such a great fire and smoke that we could hardly see the shore. In the night, in the first watch, again set sail, and, having gained $3 \frac{1}{2}$ miles NNE., anchored in 2 fathoms.

"In the morning of the $29 t h$, wind SE., good weather, course NE. by E., ran $\mathbf{I} \frac{1}{2}$ miles along the land, in $2 \frac{1}{2}$ and 3 fathoms, and anchored in 2 fathoms, and here also, as before, landed to look for water. Several pits were dug, a good way in from the shore, and no fresh water was found. Here the BLAcKs showed themselves at a distance, but were too shy to parley, nor did we succeed in luring any towards us by any sort of strategy. At noon, in the latitude of $16^{\circ} 10^{\prime}$, we passed an inlet which is named the REviER NASSAU in the chart, and having satisfied ourselves [by landing or by observation from the sea ? $-\mathrm{R}$. L. J.] that nothing profitable could be done here, set sail again, the wind E., course NNE., along the land, and in the evening anchored in $2 \frac{1}{2}$ fathoms."

[Editorial Note.-The inlet, in lat. $16^{\circ} 10^{\prime}$, named the NASSAu by Carstenszoon was, no doubt, the mouth of the unnamed creek between Leichhardt's "Rocky Creek" and the "Staaten River" of modern land maps. The creek in question has been traced from east to west through the pastoral blocks Rocky No. 2, Wynola No. 4 and Wynola No. 3 for a distance of about I 3 miles. It may be referred to as the NASSAU de jure, to distinguish it from the Nassau de facto, which falls into the Gulf in lat. $15^{\circ} 55^{\prime}$. The lower course of the Nassau de facto has been named the Nassau from an erroneous identification of it with the Nassau de jure, while its upper course is known as Dunbar Creek. This creek or river is one of the mouths of Leichhardt's Mitchell River.

The Nassau de jure traverses the continuous deltas of the Mitchell and the Staaten de facto, and in times of high flood would probably be found to be connected with both rivers, as in the whole of this coastal flat the mouths of the large rivers anastomose in a manner which could only be satisfactorily traced in flood seasons (when nobody goes there) with the aid of a canoe. It is, perhaps, more likely that a canoe survey would prove the Nassau de jure to be a trickle emanating from the Mitchell River than from the Staten River de facto.

Although it is quite clear that the inland rivers have, in many cases, been erroneously identified with the "reviers," or inlets, 


\section{VOYAGE OF THE “PERA" AND “AERNEM"}

named by the Dutch navigators, a wholesale RENAMING of the rivers would be IMPRACTICABLE at the present day. The names of the inland rivers have been irrevocably fixed by the fact that they have entered into history, into literature, into official maps, proclamations and other documents, and even into title deeds. In the circumstances, all that can now be done is to distinguish between the inlets named by the Dutch (de jure) and the watercourses to which the Dutch names have been erroneously applied in the first place, to be afterwards sanctioned by usage (de facto). It must, however, be clearly understood that the de facto names are not names conferred by the Dutch navigators, but names given in compliment to them.-R. L. J.]

"In the morning of the $30 t h$, the wind SE., steady weather, course NNE., in 3 fathoms, along the land. At noon, latitude $15^{\circ} 39^{\prime}$, and anchored in $2 \frac{1}{2}$ fathoms, and here, as before, LANDED with the boat to look for fresh water and try to fall in with natives, and after diligently digging several pits found nothing. Then set sail again and in the evening anchored in $2 \frac{1}{2}$ fathoms [say, $15^{\circ} 30^{\prime}$ S. - R. L. J.]. [SEE MAP F.]

"May.-In the morning of the Ist, the wind E., and the skipper again went ashore with the boat, and in three holes which were dug found fresh water (which forced its way through the sand), and we did our best to take in a supply. About 400 paces north of the outermost hole sunk was a little lake (lagoon) with fresh water, but the water collected in the pits was thought to be better.

"In the morning of the $2 n d$, the wind ENE., and later in the day SW., continued taking in water.

"On the $3 r d$, continued taking in water as before, the wind NE., and about midday SW., and I LANDED personally with ro musketeers and went a good way into the thick bush, without meeting any human beings. The land here is low and flat, the same as hitherto, and continues so as far as $15^{\circ} \mathbf{2 0}^{\prime},{ }^{1}$ but very dry and barren, for during all the time we have been ashore here and have explored the same and examined it to the best of our ability, we did not see a single fruit-bearing tree nor anything thatm an could make use of. There are no mountains or heights, so that it may safely be presumed that there are no metals, nor any valuable timbers, such as sandalwood, aloe or calumba, and in our judgment this is the dryest and barrenest region that could be found in the world. And even the men are more miserable and unsightly than any I have seen in my age and time. Here they use no implements, large or small, which results from the scarcity of large trees, of which there is not one on the whole coast.? This is near the place we were $\mathbf{a t}^{\mathbf{3}}$ on the voyage out on Easter Day, 16th April, and we have, in the newly made chart, called it the WaterplaEts (Watering-place). At this place, in the more sheltered localities, are fine and good-looking sandy beaches, with delicate fish." [A marginal note reads : "De Waterplaats leijdt op de hoochte van I 5 gr., 30 minuten." Van Dijk and Heeres agree in this.]

\footnotetext{
[Editorial Note.--In the marginal note, the verb is evidently "liegen," " to lie." Writers of the early seventeenth century

1 "Leijt op de hoochte van I5 gr. 20 min." Here the verb employed is obviously "leiden," "to lead to."-R. L. J.

2 This sentence is obscurely expressed in the original, but I think I have got the drift of it. Mr. Stoffel translates it: " As there are no large trees anywhere on this coast, they have no boats or canoes, whether large or small."-R. L. J.

3 They did not land on the 16th, but on the following day, after a few hours' run in the afternoon, the anchor was dropped, on the failing of the wind, "towards evening," and Carstenszoon went ashore, and remarked on the flat, good-looking land, with few trees. The probability is that, writing on 3 rd May, he inadvertently referred to the landing as having taken place on the I6th instead of the I7th April.-R. L. J.
} 
were trammelled by no canons of spelling. In the text, the writer meant to convey that the dry and barren country he described extended from the Watering-place to $15^{\circ} 20^{\prime}$ (his knowledge of its extent having been derived from the observations made on the outward voyage), and in the marginal note he estimates the position of the Watering-place as $15^{\circ} 30^{\prime}$, or 10 minutes south of the place touched at on 16th (correctly, 17th) April. Accepting this as correct, the Watering-place was about 8 English miles SSW. of Angeram Mission Station, at the mouth of Topsy Creek.-R. L. J.]

"In the morning of the 4 th, the wind ENE., good weather, course N. in $7 \frac{1}{2}$ fathoms, the land plainly in sight. At noon the latitude $15^{\circ} 12^{\prime}$, and a little to the north an inlet was seen, which we have named the Vereenichde Revier. Wind W., course NNE., near the land for the whole of the night."

[Editorial Note.-Evidently the " main" mouth of the river which Leichhardt afterwards named the Mitchell. The latter name has been too well established by usage for a restoration of the original name to be practicable at this date.-R. L. J.] [See Map D.]

"In the morning of the 5 th, the wind E., course N. Noon latitude $14^{\circ} 5^{\prime}$. Shortly afterwards, the wind W., whereupon made for the land and anchored in 2 fathoms, and I personally went ashore with the boat, duly armed. The BLAcks came towards us offensively with their weapons, but afterwards took to flight. Then our party walked some way inland, and found, leaning against trees, specimens of their weapons, such as assegais and callaways, which we did not disturb, except that we tied pieces of iron and beads to them to attract the blacks, of which, however, they took little notice, but, in the course of several advances, they insolently held up their shields and launched them at the muskets. These men, like all the others, are lank and meagre of body, and quite naked, but malignant and cruel by nature. [Cape Keerweer.R. L. J.]

"In the morning of the $6 t h$, the wind E., whereupon set sail, course N., in 3 and 4 fathoms, along the land. At noon, the wind W., in latitude $13^{\circ} 29^{\prime}$. In the evening, E., $3 \frac{1}{2}$ fathoms, anchored $\left[13^{\circ} 20^{\prime} \mathrm{S}.\right]$.

"In the morning of the 7 th, the wind SE., fine weather, and the skipper rowed to the shore in the boat, having been most strictly ordered to treat the BLAcks well and attract them with iron and beads and capture one while they were engaged with these things. At noon, when they returned, we were given to understand that on their arrival upwards of roo blacks, with their weapons, had collected on the strand and in a very hostile mood sought to prevent the landing; that a musket shot was fired (to frighten them), whereupon they fled and retreated into the bush, whence they tried every method and trick to surprise and overpower our men. In features and build these people are the same as those we have seen before, pitch black and quite naked, but some of them had their faces painted red and others white, with feathers stuck through their noses. Set sail at noon, wind E., course N., along the land, being then in latitude $13^{\circ} 20^{\prime}$. [West of mouth of Archer River.-R. L. J.] Towards evening, wind $W$. , and anchored in $3 \frac{1}{2}$ fathoms.

"In the morning of the 8th, wind ESE., good weather, and I LANDED personally with 10 musketeers. We saw numerous footprints of men and tracks of dogs (going from south to north). We therefore spent some considerable time in following the said footprints, which took us to a river, where we plucked very delicate vegetables 
or pot herbs. When we had got into the boat again, the BLAcks emerged with their weapons from two different points of the bush and came out on the strand. There we enticed them with iron and beads which we held out, till we got close to them, and one of them, who had dropped his weapon, was seized round the waist by the skipper, and then the quartermaster threw a noose round his neck, by which he was dragged to the boat. The others, seeing this, tried to help the captive, furiously throwing their assegais, so that, in our defence, one of them was shot dead, and the others ran away, upon which we embarked without further delay. These men are, like all the others, pitch black and quite naked, with a braided net on their head. Their weapons are assegais, callaways and shields. Beyond this, we cannot give any account of their manners or their ceremonies, or of how the land is populated, on which points we could throw no light, with the few opportunities which we had for exploration or examination. As to what relates thereto, Your Worships may in time, please God! get something out of the captive, to whom I refer you. The above-named river lies in latitude $13^{\circ} 7^{\prime}$, and is entitled the Revier Coen in the new chart. In the afternoon, the wind W. Set sail, course N., along the land, and in the evening anchored in 3 fathoms." [Marginal Note.- "The Revier Coen lies in lat. $13^{\circ} 7^{\prime}$."]

[Editorial Note. - It is quite clear from the narrative that the "Pera" anchored on 7th May in lat. $13^{\circ} 7^{\prime}$, and that on the following morning a party landed, probably on a beach, and without having observed any inlet, but having found human footprints, followed them north to a river which they named the Cozn (the Coen, de jure). ${ }^{1}$ Nothing is said as to whether the water was fresh or salt, the only observation made being that the neighbourhood yielded esculent herbs (pigweed ?). There cannot be a river of any importance in this locality, as the Ward River, running from north to south, a few miles to the east, restricts the possible catchment area of the Coen within very narrow limits.

The name Coen has been irrevocably attached to a river (the Cozn, de facto) rising near the Pacific coast in lat. $13^{\circ} 50^{\prime}$ and which falls into the still larger Archer River, which empties into the Gulf of Carpentaria in $13^{\circ} \cdot 20^{\prime}$. GoLD was found in this river in 1876 , by a party of prospectors, who erroneously identified it with Carstenszoon's Coen River. The establishment of a township named Coen, with a post and telegraph office, followed in due course. As it had become impossible to confer a new name on the Coen, de facto, the Survey Office has begun to call the river of the goldfield the South COEN, to distinguish it from the Coen, de jure, which it would be an historical injustice to omit from the map. It remains to be seen whether the name of South Coen will receive popular recognition.

It is quite clear that the landing party had for their walk north and south only the time between daylight and noon, when they returned to the "Pera," less the time taken by (breakfast ?), rowing ashore, tracking the footprints, gathering herbs, fighting

1 In the course of the "Investigator's" survey, Flinders landed on 7 th November, 1802 , at an inlet in $12^{\circ} 13^{\prime}$ S., which he described in his Chart as "INLET, PROBABLY COEN R. OF THE OLD CHARTS." It was a most unfortunate misidentification, which has given rise to much confusion. What Flinders took to be the "COEN RIVER of the old charts " is now charted as the Pennefather River, but had been called the Prince Revier by Tasman in 1644 . 
and rowing to the ship. It was just after noon when they came alongside, and the latitude of the anchorage ( $13^{\circ} 7^{\prime}$ S.) having been taken, the anchor was lifted, and the "Pera" resumed her northward voyage. I conclude that they walked about four miles north, and the same distance back, which would put the Coen Rrver in $13^{\circ} 4^{\prime} \mathrm{S}$. latitude. Mr. N. Hey, of the Mapoon Mission, informs me that precisely in this position is a creek, which is the only watercourse between False Pera Head ( $12^{\circ} 58^{\prime}$ S.), and the mouth of Ina Creek ( $13^{\circ} 12^{\prime}$ S.). This must be Carstenszoon's Coen Revier. The subject is discussed in greater detail in the chapters devoted to Mr. J. T. Embley's Explorations and Surveys and Missionary Explorations.

It may be noted here that Flinders' "Chart of Terra Australis," I802-3 (Admiralty Chart No. 1043), gives the name of "False Pera Head" to a small promontory in lat. $13^{\circ} 7^{\prime}$, while on Sheet $20 \mathrm{D}$ of the modern 4-mile map of Queensland issued by the Department of Lands the name is given to a promontory about 3 minutes south of Pera Head, which is in $12^{\circ} 55^{\prime}$. Although I am not aware on what ground the change was made, I accept it as authoritative, especially as what Flinders called False Pera Head had been named Rijder's Hoek in 1756 by Jean Etienne GonZaL. - R. L. J.]

Note in THE Diary. - " Wherever we have landed, we have treated the blacks or savages with especial kindness by every means in our power, such as offering them presents of iron, beads and cloth, so as by this pretence to win their friendship and be allowed to penetrate some distance inland and make a reliable report on what we saw. But, notwithstanding all this care and fair seeming, ${ }^{1}$ the blacks everywhere met us with the most marked hostility, so that in most places our landings were attended with great peril. Thus, and for various other reasons afterwards to be mentioned, it has not been possible to learn how Nova Guinea is populated, what sort of people and soil there are, what towns, what inhabited villages, what distribution of wealth, what religion, what politics, what preparation for war, what waters, what shipping, what raw materials, what manufactures, or what ores of gold, silver, tin, iron, lead, copper or quicksilver are to be had. In the first place, in any further landings, we should have to look out for rain which, at times when need for muskets might arise, would be very damaging to them, whereas the weapons of the savages would not be injuriously affected. Secondly, the paths and roads, which are unknown to us, would have to be surveyed. Thirdly, we might easily, seeing the number of the blacks, be surrounded and cut off from the boats, and then the boats' crews which we always employed in the landings, but who could not be depended upon in the use of their weapons, would have been

1 This is a very subjective way of putting it $1-$ Note by Heeres. 
in danger. If, on the other hand, we could make use of trained and proved soldiers (who are really necessary on such an expedition), we might make good reddings and scourings. ${ }^{1}$ Still, in spite of all these obstacles and difficulties, we have spared neither labour, trouble nor risk, with the means at our command, to inquire into everything, for our honour and reputation, and that nothing may pass unmarked, the following are the results of our investigations :-

“'The land between $13^{\circ}$ and $17^{\circ} 8^{\prime}$ is a dry and barren tract, without any fruit trees or anything that man could make use of. It is low and flat, without mountains or heights, overgrown in many places with scrub and stunted timber, with little fresh water and what there is must be collected in holes dug for the purpose. There is also an entire absence of capes or inlets, except for a few bights not sheltered from the sea winds. It extends mainly $\mathrm{N}$. by E. and S. by W., with clay- and sand-bottomed shoals, with numerous salt inlets extending into the interior, across which the natives ferry their women and children by means of dry logs or boughs of trees. The men are in general utter barbarians and built very much alike as to shape and features, pitch black and stark naked, with a braided net on head or neck for keeping their food in, the same consisting, so far as we could make out, of roots which they dig out of the earth, very evil-smelling. Their residences or dwelling-places appeared to us to be on the beaches during the easterly monsoons, as there we saw numerous huts made of hay. We also saw many dogs, herons and water curlews and other wild fowl, and also delicate fish, which may easily be caught with a seine net. They have absolutely no acquaintance with gold, silver, tin, iron, lead or copper, nor even with nutmegs, cloves or pepper, all of which we repeatedly showed them without their evincing any sign of recognising or setting any value on the same. From all of which, taken together with the rest of our observations, it may safely be concluded that they are poor and miserable creatures who prize most such things as iron and beads. Their weapons are shields, assegais and callaways, of the length of $\mathrm{I} \frac{\mathrm{x}}{2}$ fathoms, made of light wood and cane, some with fish-bones and others with human bones fastened to them. As we discovered, they are particularly expert in throwing them by means of a stick half a fathom in length, on which a hook is bound, so as to catch the upper part of the callaway or assegai."

The text of the diary continues:-

"In the morning of the 9th, the wind ESE., good weather : whereupon set sail, course NE. along the land, and after running 2 miles [8 minutes], anchored close to the shore in 9 fathoms [Pera Head.-R. L. J.]. I LANDED IN PERson, with IO

\footnotetext{
1 "Reddinge ende scheuringh," pickings of odds and ends. The old English verb "to redd" means to clean up. Stoffel's free rendering of the phrase is "we might have done a good deal of useful work." $-R$. L. J.
} 
musketeers, and found numerous FOOTPRINTS OF MEN AND TRACKS OF LARGE DOGs, going in a sOUTHERLY direction. We also found FRESH WATER FLOWING INTO THE SEA, and named this the WaterplaEts. The land is higher here than what we have seen to the south, and in front of the strand there are reefs, which are in $12^{\circ} 33^{\prime}$."

[Editorial Note.-The latitude of $12^{\circ} 33^{\prime}$ is, not 2 , but $8 \frac{\pi}{2}$ Dutch miles north of the anchorage at the Coen, de jure. It is evident from what follows that the midday ANCHORAGE of 9th May was still south of Albatross BAY, and the distance named (2 Dutch miles) would bring the "Pera" to what is now known as Pera Head, which is in $12^{\circ} 55^{\prime}$, according to the modern Lands Department map. In deciphering the manuscript, some transcriber, no doubt, mistook the figures 55 for 33 .

The latest issue (I908) of the 4 -mile Sheet $20 \mathrm{D}$ of the Department of Lands shows a small creek falling into the Gulf in $12^{\circ} 59^{\prime}$ S. lat. In this position, says Mr. N. HEY (in a letter dated 5 th February, I9I9), there is only, in wet weather, a SMALL RUNNEL OF FRESH WATER, which could not be called a creek. It is, I have no doubt, the "WATERPlaets" of 9th May, I623, regarding which Mr. J. T. EMbLey has given me the following additional particulars, in a letter dated Ioth August, I916: "The Waterplaets is at Pera Head. These headlands are about 80 feet high and consist of soft reddish and whitish sandstone. The red is most conspicuous, as being uppermost, and gives rise to the expression 'low reddish cliffs' as in the sea chart and land maps. After the wet season-April and May-small SOAKAGES OF FRESH WATER may be noticed oozing out from the base, and it is this which must have given rise to the "WATERPLAETS." "]

"In the afternoon," continues Carstenszoon, "wind SW., course as before. From the aforesaid watering-place to a high hook, or cape [Durfken Point.-R. L. J.], is a great bight [Albatross BAY.-R. L. J.] extending NE. by N. and SW. by S., 7 miles [28 minutes]. Anchored in the evening in $4 \frac{1}{2}$ fathoms."

[Editorial Note.-This night anchorage was in Albatross $\mathrm{BAY}$, and, judging by the course on which next day's journey had to be begun, so as to clear Duyfken Point, outside of the shoals which guard the mouths of the Embley and Mission Rivers. It is singular that Carstenszoon gave no name to the bay, nor to its two "horns," Pera Head and Duyfken Point. On 26th April, 1756, Lavienne Lodowijk van Asschens, in charge of the "Buijs," recognised the bay as that which TAsMan, in 1644 , had named VliegebaAiJ, and on 3Ist May, I756, Lieut. Jean Etienne Gonzal, commanding the "Rijder," called it Mosselbaaij. The name now current was that of the Queensland Government's steamer "Albatross," which used to patrol Torres Strait during the administration of the Hon. John Douglas.-R. L. J.] [SEE MAP B.]

"In the morning of the Ioth, wind ESE., steady weather, set sail, course WNW. [to clear Duyfken Point, after which the course, off the shore, would be N. by E.R. L. J.] At midday, the latitude $12^{\circ} 5^{\prime}$ [10 miles north of the Pennefather River.- 
R. L. J.], and I personally landed, with the skipper, and, as before, saw many footprints of men and tracks of dogs (going southwards). High duny land, with reefs in front of the sandy beach. When we were pulling back to the ship, the savages showed themselves, with their weapons; whereupon we landed again and threw them some pieces of iron, which they picked up, refusing, however, to come to parley with us; after which we re-embarked. [Apparently the 'Pera' lay at anchor in $12^{\circ} 5^{\prime} \mathrm{S}$. from noon of the roth till the following morning.-R. L. J.]

"In the morning of the IIth, the wind ESE., good weather; thereupon set sail, course NNE., along the land, and in the afternoon passed a LARGE INLET (which the men of the 'Duyfken,' in the year 1606, went into with the boat, and one man was killed by the missiles of the savages) and which lies in $11^{\circ} 48^{\prime}$, and is by us, in the new chart, entitled the Revier DE CARPEnTIER. [Although it is not distinctly stated, it is evident that the anchor was dropped here for the night.-R. L. J.]

"In the morning of the $12 t h$, the wind ESE., lovely weather, and here I personally rowed, with the skipper, to the shore, on which stood many Natives, quite 200 of them, making a violent noise and with their ARRows (pijlen) ready to throw, and evidently very distrustful, for, though pieces of iron and other things were thrown to them, they would not stop to parley, but tried every trick with the object of wounding and capturing one of our men. This compelled us to fire one or two shots to frighten them, one of them being hit in the breast and carried to the boat, while all the others retired into the sand dunes. In their wretched huts on the beach we found nothing but a four-edged assegai, two or three little stones, and some human bones, with which they make and scrape their weapons. We also found a quantity of resin and a piece of metal, which the wounded man had in his net, and which had probably been got from the 'Duyfken's' men. At last, there being nothing more to be done here, we turned back to go aboard the ship, the wounded man dying on the way."

[EDitorial Note.-We are now confronted with the most difficult problem raised by the narrative of the "Pera's" eventful voyage, viz., the identification of the "reviers" Batavia and Carpentier.

It will be readily conceded that the diary for I Ith May, 1623 , proves that the navigators of the "Pera" were familiar with the charts of the "Duyfken," which were undoubtedly then extant. They probably carried copies with them, and would naturally make them their daily study.

Our difficulties begin with the discovery of the "Chart by the Upper Steersman Arend Martensz(oon) DE LEEUw, who took part in the Voyage," in the State archives at the Hague. The chart has no date, but it may be taken for granted that it was compiled prior to I630, since in that year, Kepler and Eekerbrecht's map followed de Leeuw's in naming the Carpentier Revier the Batavia. It is not stated to what voyage reference is made in the title of de Leeuw's chart, but there can be no doubt that the "Pera's" voyage is indicated. The chart is reproduced in Remarkable Maps, II, 5, and (on a reduced scale) by Heeres (p. 46).

I offer the following as a fair and unbiassed paraphrase of the diary of IIth May, 1623:-

"In the morning of the IIth, we left the anchorage at $12^{\circ} 5^{\prime}$, and, with good weather and a favourable wind (ESE.), sailed NNE. along the land. Observed the sun at noon and made the latitude 
$\mathrm{II}^{\circ} 48^{\prime}$. North of this latitude, and in the afternoon, having passed a large inlet, which we identified as that where the 'Duyfken' had one of her men killed, and which we named the Revier de Carpentier (Carpentier Inlet), we dropped the anchor. We landed here next morning. ...."

The mouth of a river, now known as the SKardon, enters the Gulf in $11^{\circ} 45^{\prime}$, and everything points to this having been the inlet which Carstenszoon named the Carpentier.

It is very strange that the "Pera" should have passed, without remark, the entrance to PORT Musgrave, which is practically the estuary of the great river which Tasman was the first to notice in I644 and to which Asschens, in 1756, gave the name of Batavia, no doubt believing it to be de Leeuw's Batavia, that is to say, Carstenszoon's Carpentier. According to Mr. J. T. Embley, who is very familiar with the aspect of this portion of the coast, the entrance to Port Musgrave could hardly be missed by a ship passing in daylight and fine weather. Perhaps it was not unobserved by the officers of the "Pera," but the true explanation of their silence regarding it may lie in their anxiety to make northing, coupled with the fact that they were making good progress and the consideration that they passed the entrance too early in the day to be willing to stop. On the other hand, the identification, later in the day, of the inlet which had been the scene of the "Duyfken's" mishap formed a perfectly sound reason for a halt with the object of making observations on shore.

Returning to DE LEEUw's CHART : it bears, to my thinking, internal evidence of having been constructed-perhaps by request-some time after the conclusion of the voyage, and from memory, possibly with the aid of notes, by a man who had not, at the time, access to the ship's log or diary, or to the authentic "newly made chart" so often referred to therein. The following table shows, by means of parallel columns, how imperfect was de Leeuw's knowledge (or recollection) of the positions of the various inlets referred to in the log.

Approximate Latitudes (by Scale) on de Leeuw's Chart, compared with Latitudes given in the "Pera's" Log and confirmed by Modern Charting

R. Van Spult

R. Batavia (a river supposed by de Leeuw to enter Albatross Bay, but not mentioned in the $\log$ ) .

R. Carpentier (not mentioned by de Leeuw)

Watering-place (Pera Head).

R. Coen

R. Vereenichde (Mitchell River)
Watering-place (south of Angeram Mission Station)

R. Nassau

R. Staten (Accident Injet, Gilbert River) - $\quad 16^{\circ} 40^{\prime}$

R. Staten (Accident Inlet, Gilbert River) . . . $\quad 1^{\circ} 20-30^{\prime}$

\begin{tabular}{c|c}
$\begin{array}{c}\text { De Leeuw. } \\
11^{\circ} 50^{\prime} \mathrm{S} .\end{array}$ & $\begin{array}{c}\text { Correct. } \\
10^{\circ} 58^{\prime} \mathrm{S} .\end{array}$ \\
$12^{\circ} 34^{\prime}$ & - \\
- & $11^{\circ} 4^{\prime}$ \\
$13^{\circ} 5^{\prime}$ & $12^{\circ} 55^{\prime}$ \\
$13^{\circ} 35^{\prime}$ & $13^{\circ} 7^{\prime}$ \\
$14^{\circ} 50^{\prime}$ & $15^{\circ} 12^{\prime}$ \\
$15^{\circ} 46^{\prime}$ & $15^{\circ} 30^{\prime}$ \\
$16^{\circ} 40^{\prime}$ & $16^{\circ} 10^{\prime}$ \\
$17^{\circ} 20-30^{\prime}$ & $17^{\circ} 12^{\prime}$
\end{tabular}


The watering-place at Pera Head, north of the Coen River, to which de Leeuw assigned the latitude of $13^{\circ} 5^{\prime}$ (correctly, $12^{\circ} 55^{\prime}$ ) is one of the localities where de Leeuw and the "Pera's" $\log$ evidently mean the same thing. North of this watering-place de Leeuw shows a bay, at the head of which his supposed "Revier de Batavia" falls in. This bay (Albatross Bay) is now known to be entered by the Embley and Mission, both considerable rivers, and although de Leeuw may have been justified in conjecturing that at least one river would enter the bay, it is more than doubtful if he could see either the Embley or the Mission. In any case, he had no authority to name this hypothetical river, or any other.

The captain of the "Pera" had his authority very much curtailed by the "Full Council," and even Carstenszoon had to bow to its decisions. It is quite possible that de Leeuw's memory, when he made his sketch-chart, may have recalled a discussion in the Council in the course of which the name Batavia was suggested, but the log leaves no room for doubt that the name Carpentier was finally adopted for the inlet identified with the "Duyfken's" misfortune.

Nevertheless, de Leeuw "got the ear" of cartographers, so that the name of Batavia appeared on Dutch maps long before Asschens gave that name (in I756) to the river which enters the Gulf at Port Musgrave.-R. L. J.]

"Set sail at noon [12th May], wind SSW., course NNE., along the land, and having run on for 2 miles [ 8 minutes] came to anchor on the wind failing [say, $\mathrm{II}^{\circ} 4 \mathrm{O}^{\prime} \mathrm{S}$. lat.-R. L. J.].

"In the morning of the 13 th, the wind SW., good weather, set sail, course NE. by $\mathrm{N}$., in more than 7 fathoms and about 2 miles from the land. At noon, in latitude $11^{\circ} 16^{\prime}$, the wind E. In the evening, anchored in 2 fathoms, near an inlet (revier), which, in the chart, we have entitled the Revier Van Spult. [SeE Map A.] On the $14 t h$, sailed before daylight, wind SE., steady weather. From the 9 th of this month up to date, we have found the land of Nova Guinea to stretch NNE. to SSW., and from here onwards N. and S. Here [while the ship stood by under short sail] I, personally, rowed to the land, with the skipper and ro musketeers, and saw many human footprints and tracks of dogs (going southwards) and also a very fine fresh water river which runs out in to the sea, whence water could conveniently be taken by boats or pinnaces, and which lies in $10^{\circ} 50^{\prime}$ latitude, and is noted in the chart as DE Waterplaets (the Watering-place). The land is high and duny (sand dunes), with reefs in front of the sandy beach. Seeing that no service could be done, or profit made, here, we returned to the yacht (which was standing by with shortened sail)." [SEE Maps B and A.]

[Editorial Note.-There is no reason to question the correctness of the observation for latitude $\left(11^{\circ}{ }^{1} 6^{\prime}\right)$ made at noon on I3th May. The anchorage for that night, which was "near" an inlet from which fresh water was running out to sea, and which was named VAN Spult, is another matter. The "Pera" dropped her anchor in the evening of the 13 th, and sailed before daylight 
of the I 4 th, so that there was no opportunity for a solar observation.

The latitude attributed to the anchorage at the Van Spult Inlet must therefore have been more or less of a guess based upon dead reckoning. The guess made by the navigators was $10^{\circ} 50^{\prime}$. Carstenszoon must have overestimated the distance sailed in the afternoon of the 13 th. Had the "Pera" reached the latitude of $10^{\circ} 50^{\prime}$, Barn Island and Red Island could not have escaped observation, and indeed the high land of Prince of Wales Island must have appeared a much more striking object than the low-lying mainland. In view of what took place on the following day (14th May), the probability is that the observed inlet was where the modern chart shows a breach in the coast-line, in $10^{\circ} 59^{\prime}$. The Van Spult is, therefore, probably a mouth of the JARDINE River. The principal channel of that river (which has been carefully surveyed almost to its head), discharges into the Gulf in $10^{\circ} 54^{\prime}$, and the Jardine Brothers, in 1865 , found the tide to flow up it for about 6 miles, even in a very wet season. It is quite possible, however, that another mouth, that named the Van Spult, carries fresh water down to the beach. The point could easily be settled, even by a party on foot, as the inlet is, apparently, not more than ro miles west of Jardine's crossing of the river at his camp 87. After the landing party rejoined the "Pera" on 14th May, I623, the narrative continues as follows.R. L. J.]

"Towards evening [ $14^{t h} M a y$ ], we were about one mile from three little islands, of which the southmost was the largest [WoODY and WALLIS IsLands] and some 5 miles [ 20 minutes] to the north, by our estimate, was mountainous land [PrinCE of WaLES IsLAND], which, however, it was impossible to approach by reason of shoals; for in almost every direction in which we took soundings very shallow water was found, and we sailed for a long time over $5,4,3,2 \frac{1}{2}, 2$ and $1 \frac{1}{2}$ fathoms, or even less, and at last were obliged to anchor in $1 \frac{1}{2}$ fathoms, without knowing where to look for greater or less depths. After sunset, therefore, we sent out the boat to take soundings, and water deeper than 2, 3 and $4 \frac{1}{2}$ fathoms was found, to which, very well pleased, we brought the yacht, and anchored in 8 fathoms, thanking God Almighty for His unspeakable grace and mercy on this occasion, as on all others.

"In the morning of the I5th, the wind SE., good weather, thereupon set sail, course W., which took us into shallower water, such as $2,2 \frac{1}{2}$ and 3 fathoms; altered course to SW., where we had $3 \frac{1}{2}, 4,5$ and 6 fathoms, or more. Lost sight of the land, which, because of the shoals, reefs and banks, as well as of the easterly winds, it was not possible to reach and follow further. This was agreed to, and it was resolvedto avoid all the obvious dangers which would be encountered if we continued to coast the land any longer-to TURN BACK and, firstly to shape our course for the Vleermuis Eijlant. We therefore stood out to sea, westwards, in $9 \frac{1}{2}$ fathoms and upwards, and, keeping west, made 17 miles [ 68 minutes] in 24 hours, finding no bottom in 27 fathoms.

"Note. - That in our landings between $13^{\circ}$ and $11^{\circ}$, we only saw blacks or savages twice, and that they received us with even greater hostility than had the men further south ; also that they have some knowledge of muskets, of which, apparently, they had learned, to their great cost, from the men of the 'Duyfken,' who landed here in the year 1606. 


\section{VOYAGE OF THE “PERA" AND “AERNEM"}

". .... In the morning of the 22nd ... we turned our course westward. . . . About noon, we saw the island of ARU ahead of us. . . . The yacht 'Aernem,' which on the $27^{\text {th }}$ ultimo, being then in $17^{\circ}$, alongside of Nova Guinea, deliberately ran away from the 'Pera,' was not to be seen, nor was she heard of from the Aruese who came alongside us with their prows. . . .

"On 8th fune, in the evening, anchored before the castle of Aмвогna, having thus completed our voyage through the gracious providence of God, Who, we pray, will bestow on Their High Mightinesses the States-General, on His Excellency the Prince of Orange and on the Directors of the United East India Company, and especially on the Most Noble the Governor-General and his Governors, fortune and success in all their good undertakings.

Remaining"ever,

Their High Mightinesses', \&c., most obedient and affectionate Servant,

Jan Carstenszoon."

On the home voyage of the "Pera," monuments were erected at Aru and Queij, with inscriptions which have to be recorded here because of their significance as historical documents.

\section{AT ARU (SEE VAN DIJK, UNDER DATE 22ND MAY, 1623)}

"Anchored opposite the native village of Woodgier on the second of the northmost islands of the Aroe group, where they received a friendly welcome. The same day concluded with the Aroe chiefs a TREATY under which they accepted Dutch protection. A high column was erected bearing the inscription :-

" "In the year 1623 , on the Ist of February, there came here to Aroe the yachts "Pera" and "Arnbem," Commandeur Jan Carstensz., Koopleiden (Traders) Jan Bruwel and Pieter Lingtes, ${ }^{1}$ Skippers Jan Sluijs, Dirck Melisz., Stuurlieden (Mates) Arent Martensz. and Jan Jansz., dispatched under order and command of the Noble Lord General Jan Pietersen Coen, on behalf of their High Mightinesses the States-General, His Excellency the Prince of Orange and Messrs. the Directors of the United East India Company; and we have also on the 4 th day of the same taken possession of the island for the above-mentioned Highnesses. Likewise the Chiefs and People have placed themselves under the protection and rule of the aforesaid Lords and saluted the Princely flag." "

\section{AT QUEIJ (SEE VAN DIJK, UNDER DATE зотн MAY, 1623)}

"Reached Queij, in front of the native village of Waijer, whose inhabitants, as well as those of Laer and Ada, were informed of the protectorate of the Dutch. At Laer, a high column was erected, bearing the inscription :-

" "Anno 1623, the last day of May, here to Queij came the yacht "Pera," Commandeur Jan Carstensz., Coopman Pieter Lingtes, Schipper Jan Sluijs, Stierman Arent Martensz., by order and command of the Noble Lord General Jan Pietersen Coen, sent on behalf of the High Mighty Lords the States-General, His Excellency the Prince of Orange, \&c., and Messrs. the Directors of the United East India Company, and by us also on the said zoth the villages of Waijer, Laer and Ada were

1 Named Lintiens in the Diary.-R. L. J. 
taken possession of for the aforesaid personages and the Chiefs and People placed themselves under the protection and rule of the said Lords and saluted the Prince's flag." "'

The formality and quasi-legal phraseology of these inscriptions contrast strongly with the simplicity of the inscription on the board nailed up at the Staten River. 
THE VOYAGE OF THE “PERA” AND “AERNEM" (I623), continued

\section{THE “AERNEM"}

Careless Landing on New Guinea Coast. Skipper and Nine Men killed and some wounded by Natives. "Aernem's" Inferior Sailing Qualities. Her Desertion of the "Pera." Crosses Gulf of Carpentaria. Groote Island. Arnheim Land.

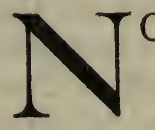

O reader of Carstenszoon's narrative can fail to observe that although the "Aernem" was inferior in sailing qualities to her consort, the "Pera," she was expected to keep up with her, and that her failure to do so was the cause of much friction between the officers of the two ships.

Before the expedition left the shores of New Guinea proper, and approximately in $4^{\circ} 20^{\prime}$ S. lat., the "Aernem" met with a DISASTER which is related by Carstenszoon under date I I th February, I623:-

"The same day the skipper of the yacht "Aernem," Dirck Melrszoon, without the knowledge of myself or of the supercargo or first mate of the said yacht, unadvisedly rowed to the open beach in the boat, with fifteen persons, officers and hands, with only four muskets, with the object of fishing. There was great disorder in landing, the men running off in different directions, and presently the BLACKs issued savagely from the bush and, to begin with, SEIZED an assistant named JAN Willens(ZOON) VAN DEN BRIEL, who was unarmed, and dragged him away from the others, and so forth, without our people having been able to resist or shoot. Next, with arrows, callaways and oars which they took out of the boat, they SLEW no less than NINE of our men and WOUNDED the remaining SEVEN (among them the SKIPPER, who was the first to run away), who by a miracle, and by means of the boat and a single oar, returned to the ship in a sorry plight, the skipper loudly lamenting his gross imprudence and begging forgiveness for the fault he had committed."

He died next day, and was succeeded by Willem Joosten van Coolsteerdt, second mate of the "Pera."

The return voyage had barely commenced when the "Aernem" once more lagged behind (27th April, 1623) before dark, and the "Pera" saw her no more. (SEE MAP H.) The latter was then at anchor off the coast of the Cape York Peninsula, in about $16^{\circ} 25^{\prime} \mathrm{S}$. lat. Carstenszoon, in his diary, accuses the "Aernem" of deliberate desertion because her men had no liking for the business, and he believed they desired to have " a good time" at Aru, where, apparently, the natives were kind. It is, indeed, more than likely 
that the "Aernem's" complement were heartily tired of the voyage, which brought them daily recrimination on account of the shortcomings of their vessel, for which they were not to blame. They had hardships enough, saw no chance of profit for themselves and were condemned to play the unenviable part of second fiddle. On the other hand, it is probable that the " jury" rudder was lost, in which case (the wind being SE. by E.), the ship would have to stand out to sea, and in course of time some other substitute for a rudder would have to be rigged up. At any rate, IsACK DE BRUNe, Governor of BAnda, reported to the Governor-General, Pieter De CARPentier, that on I4th May a ship was sighted, which proved to be the "Aernem," and that she had lost her rudder on the I 3 th.

No report of the "Aernem's" voyage is known to exist, and with her parting from the "Pera" she passes out of the region with which we are dealing. HeEres, who has thoroughly investigated the whole of the available documentary evidence, comes to the conclusion that the first land she saw was Groote EyLAND and that afterwards she skirted the north-western horn of the Gulf of Carpentaria, forming the northern portion (now known as ARNHEM LAND) of the "Northern Territory" of Australia. 


\section{CHAPTER IX}

\section{TASMAN'S VOYAGE OF 1644}

First to circumnavigate New Holland (1642-3). Touches Van Diemen's Land (Tasmania). Believes it to be Southern Extremity of New Holland. Coasts New Zealand. To Batavia, via North Coast of New Guinea, whici he believes to be joined to Australia. The i644 Expedition. Three Vessels leave Batavia. Sailing Orders. Satisfied that there is no Strait between New Guinea and New Holland. Report, if any, still undiscovered, but a Sketch-map shows that Tasman followed Coast-line from the "Dry Bight" (Torres Strait) round the Shores of Gulf of Carpentaria, past Arnheim Land and along the North and West Coast of Australia to the Tropic of Capricorn. A Poor Country, inhabited by Miserable but Malignant Savages. Tasman probably did not carry the "Pera" Diary or Charts. Had been furnished with an Inaccurate "Specially Prepared" Chart. Names New Inlets in Cape York Peninsula and observes Mouth of Port Musgrave Estuary. Names Prince Inlet (Pennefather River). Names Vliege Baij (Albatross Bay). Misidentifies the "Pera's" Coen and Nassau Inlets. Arnheim River (= Vanroox Creex ?). Misidentifies "Pera's" Staten Inlet. Names Van Diemen Inlet (Norman River), Van Der Lijn Inlet (Bynoe Mouth of Flinders River) and Caron Inlet (Mouth of Flinders RIVER).

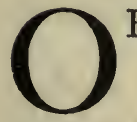

$\mathrm{F}$ all her gallant sailors there is none of whom Holland has more reason to be proud than of ABeL Janszoon TASMan. In many voyages of discovery he rendered signal services

to his country. Only two of these, however, come within the scope of our inquiry.

Prior to the first of these voyages, the western and a portion of the southern shores of Australia were already known, but the theory that the South Land formed part of a great antarctic continent had yet to be disproved. In 1642-3, Tasman demonstrated the INSULARITY of "New Holdand" by sailing round it, although at a great distance, with Batavia as his starting- and finishing-post. He touched Tasmania (named by him Van Diemen's Land) and rounded its southern end, believing it to be the southern limit of the South Land, now to be called New Holland. Thence he sailed eastward to New Zealand, which he coasted to the north. He returned to Batavia via the Friendly Islands, Fiji and the north coast of NEW GuINEA, which he believed to be the northmost part of New Holland. Tasman's journal is extant and relates, with painstaking industry, the minutest details of his remarkable voyage. 
The voyage which mainly concerns us is that of 1644 . The instructions ${ }^{1}$ of the Governor-General and Council of the Dutch East India Company were drawn up at Batavia on I3th January, 1644, and were signed by Antonie Van Diemen, Cornelis Van Der Lijn (Director-General), Joan Maetsuijker, Justus Schouten ("Councillor-Extraordinary to the present assembly"), Salomon Sweers, and Pieter Metschagh (Secretary).

The ships employed in the expedition were the yachts "Limmen" and "Zeemeeuw" and the galiot "Bracq," and their respective complements were :-

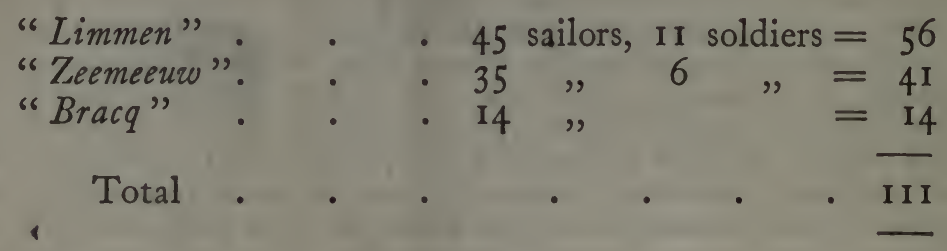

From the instructions and a list of members of the Full Council, we gather how each of the ships was officered :-

Limmen.-Commander and Skipper, Abel Janszoon Tasman. Assistant Skipper, Pilot-Major Francois Jacobszoon Visscher. Mate, Crin Hendrikszoon. Trader (Assistant Supercargo), Counsel and Secretary, Anthonio Blauw.

"Zeemeeurw." Skipper, Dirck Corneliszoon Haen. Supercargo, Isaac Gilesemans. Mate, Carsten Jeuraenszoon. Robel.

"Bracq." Skipper, Jasper Janszoon Koos. Mate, Cornelis

When matters concerning navigation were to be discussed in the Full Council, the second mates were to be called in. Councils of individual ships were to consist of the officers, to whom were to be added the Assistant Supercargoes or book-keepers and the masterboatswains. The minutes of the Full Council were to be made out in triplicate.

The fleet left Batavia on 3oth January, and returned to that port on Ioth August, I644.

The SaILING OrDERs began with a preamble recapitulating the achievements of previous navigators in the region to be visited, and to this narrative we are indebted, inter alia, in default of the "Duyfken's" journal and charts, for some of our scanty information regarding her disastrous pioneering voyage along the coast of the Cape York Peninsula.

The orders were first to go to Banda and there to take in water and firewood and to obtain such information regarding "New

1 Printed in Dalrymple's Collections concerning Papua, in Major's Early Voyages, in Heeres' Life of Tasman and (partly) in Heeres' Part borne by the Dutch, etc. 
Guinea " as could be supplied by the Vice-Governor, who, it was said, was likely to have a copy of CARSTEnszoon's JournaL of the "Pera" and "Aernem" expedition. This shows that, in I644, the journal was not obtainable in Batavia; and it may be assumed that the "Pera's" chart was also missing. Tasman, therefore, unless he succeeded in obtaining copies in Banda, must have started on his voyage of exploration without these documents which were so essential to his success in identifying the localities visited and charted by Carstenszoon.

After leaving Banda, Tasman was instructed to make for FALSE $\mathrm{C}_{\mathrm{APE}}$, on the New Guinea coast ; to follow the coast east to $9^{\circ} \mathrm{S}$. latitude; cautiously to clear the shoals (the so-called "Drooge Bocht," the entrance to Torres Strait); to anchor near the High Island (Prince of Wales Island) or the Speult River and to send the "Bracq" into the bight to make one more search for the alleged (and actual) passage. Having settled this point, he was to skirt the west coast of "New Guinea" southward to the FURTHEST KNOWN PoINT, about $17^{\circ} \mathrm{S}$. latitude. Thence he was to follow the coast and connect the coast-line charted by Carstenszoon with the "V VAN DIEMEN's LAND" discovered by himself and supposed to be the southern extremity of the "South Land." He was, however, to carry out only as much of this programme as time would permit; but, in any case, he was to be back in Batavia, via Sunda Strait, " by June or July."

The expedition, as we have seen, returned to Batavia on roth August, and we are justified in assuming that the instructions were obeyed, although the carrying out of the full programme was impossible. As a matter of fact, Tasman had only followed the Australian coast (already to some extent known) to the Tropic of Capricorn when the prescribed time-limit compelled him to make for Batavia. Considerable portions of the Australian coast west of where the "Pera" turned back had already, however, been discovered and more or less charted fron twenty-eight to twentyone years before; so that Tasman's achievement consisted of a demonstration of the conTINUITY OF THE LAND from the "Drooge Bocht" (Torres Strait) to the Tropic of Capricorn. His contributions to cartography were chiefly the southern and western shores of the GULF OF CARPENTARIA and the coast-line from Melville Island to the Tropic of Capricorn.

A clause in the instructions (perhaps mere routine) empowered Tasman to take possession of new discoveries and to enter into Treaties. There is nothing to show that either power was exercised. The tone of contemporary official references to the expedition gives the impression that the Dutch East India Company regarded it as having been only moderately successful and as having failed to add materially to the Company's assets. The presumption is that Tasman did not claim to have discovered any land of value or to 
have fallen in with any potentates with whom it was worth his while to conclude alliances.

Before leaving Batavia, Tasman was supplied with a SPECIALly PREPARED CHART, which, no doubt, showed all that was known of the south coast of New Guinea (as we know the island to-day) and the north, west and south coasts of Australia. There is reason to believe that, as regards previous exploration of the coast of the Cape York Peninsula, this chart was very imperfect.

In a report under date 23 rd December, 1644 , signed by Van Dieman, Van der Lijn, Sweers, Crooq and Van Alpen (President), representing the Governor and Council of the Dutch East India Company, and addressed to "The Noble, Worshipful, Provident and Very Discreet Gentlemen " (The Directors of the Company in Holland), it is stated that Tasman's expedition, after leaving Bantam on 29th February, I644, "followed the coast-line, but found No OPEN CHANNEL between the half-known Nova Guinea and the known land of Eendracht or Willem's River in $22 \frac{\pi}{2}^{\circ} \mathrm{S}$. latitude and $119^{\circ}$ longitude. ${ }^{1}$ They, however, found a large, spacious BAY OR GULF, as shown in the annexed CHART AND Journals. Nor did they make any profit by bartering, having only met with naked, beach-roaming wretches, destitute of rice and not possessed of any fruits worth mentioning, excessively poor and in many places of a very malignant nature, as Your Worships may in great detail gather from the Batavia Minutes, in which are recorded the courses kept and the incidents of the voyage, under date 4 th, $5^{\text {th }}$ and roth August last, at which time the said Tasman returned to our port through Sunda Strait, from the latitude and longitude aforesaid of the South Land (having continually sailed in shallow water along the coast). . . . This vast and hitherto unknown South Land has by the said Tasman been sailed round in two voyages and is computed to comprise 2,000 miles of land, as shown by the delineation of the Charts, which we subjoin for Your Worships' inspection."

Whatever became of Tasman's journal, it has nót come down to us. There is, however, a CHART, on the scale of $\mathbf{I ~ c m}$. to a degree of longitude, showing Tasman's routes in 1642-3 and I644, entitled "Company's New Netherlands. To the east the large Land of Nova Guinea forming one land with the first-known South Land, and all of it joined together, as may be seen from the dotted courseline of the Yachts 'Limmen' and 'Zeemeeuw' and the Galiot 'Bracq' anno 1644." A further inscription sars: "This Work has been put together out of divers Writings, together with Personal Observations by Abel Janszoon Tasman anno Domini I644." The chart shows a continuous New Guinea and Cape York Peninsula, with a shallow bight between. Professor Heeres,

1 Actually $\operatorname{II} 3^{\circ} \mathrm{E}$. The Dutch of this period reckoned longitude from the meridian of the Peak of Teneriffe, which is $16^{\circ} 4^{\prime}$ W. of Greenwich. 


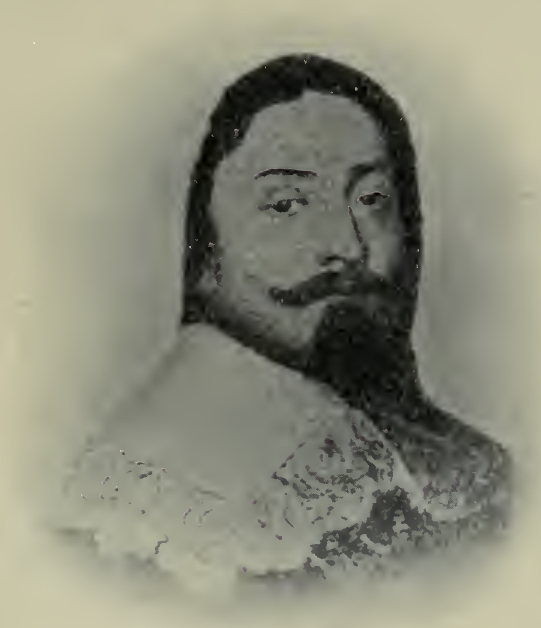

ABEL TASMAN, 166 . 


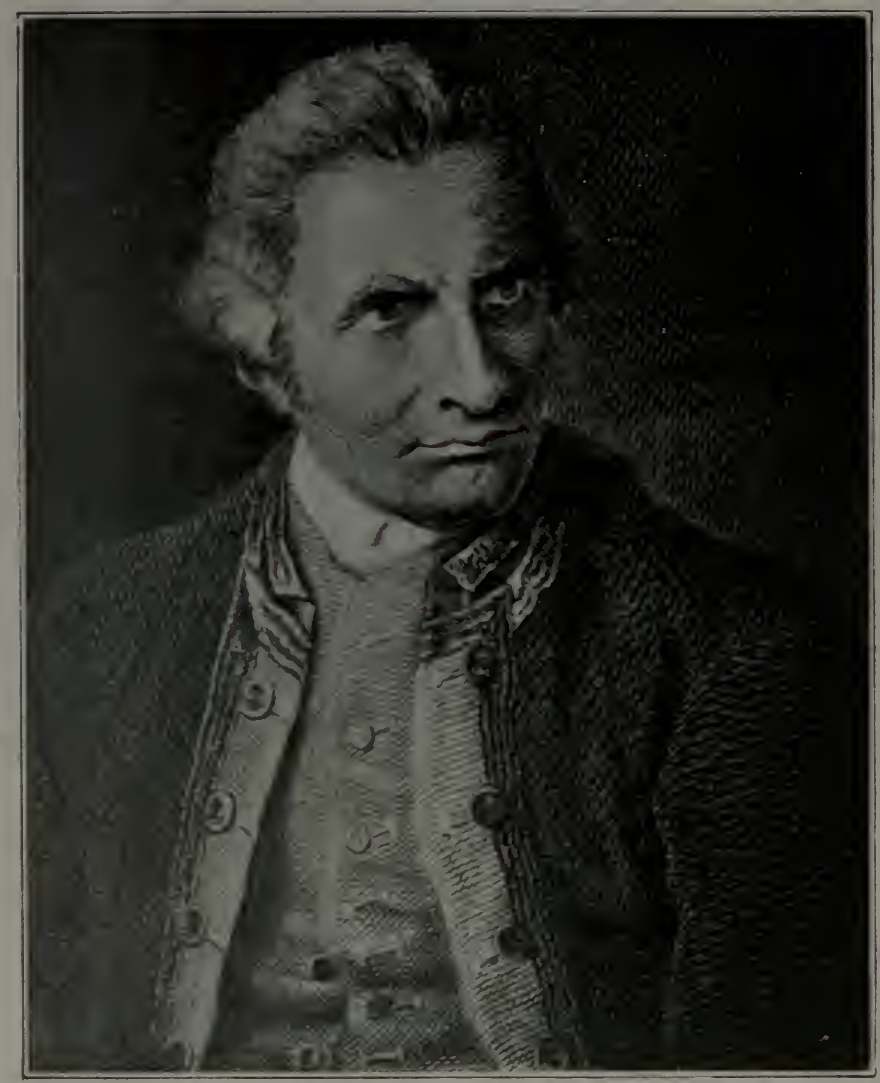

JAMES COOK, 1772 . 
in his great work, The Life of Tasman, ${ }^{1}$ describes it as having been "drawn up immediately after the (1644) expedition and under the eye of Tasman himself." It may, indeed, be a copy of the chart forwarded with the Report by the Governor-General and Council at Batavia to the Directors in Holland. It was reproduced by JAсов SWART in his Fournaal van de Reis nar bet Onbekende Zuidland in den Fare 1642 door Abel Fanszoon T asman (Amsterdam, I860), and HeEres, in his Life of Tasman gives a version of it, with the place-names and other inscriptions translated into English.

The names along the west coast of the Cape York Peninsula in the charts reproduced by Swart and Heeres are as in Column I of the table below, and the latitudes as in Columns II and III ; but the small scale of the map, together with a "personal equation" resulting from mechanical differences in drawing between the two maps, makes it impossible, in some cases, to be certain of the positions indicated within a few minutes of latitude.

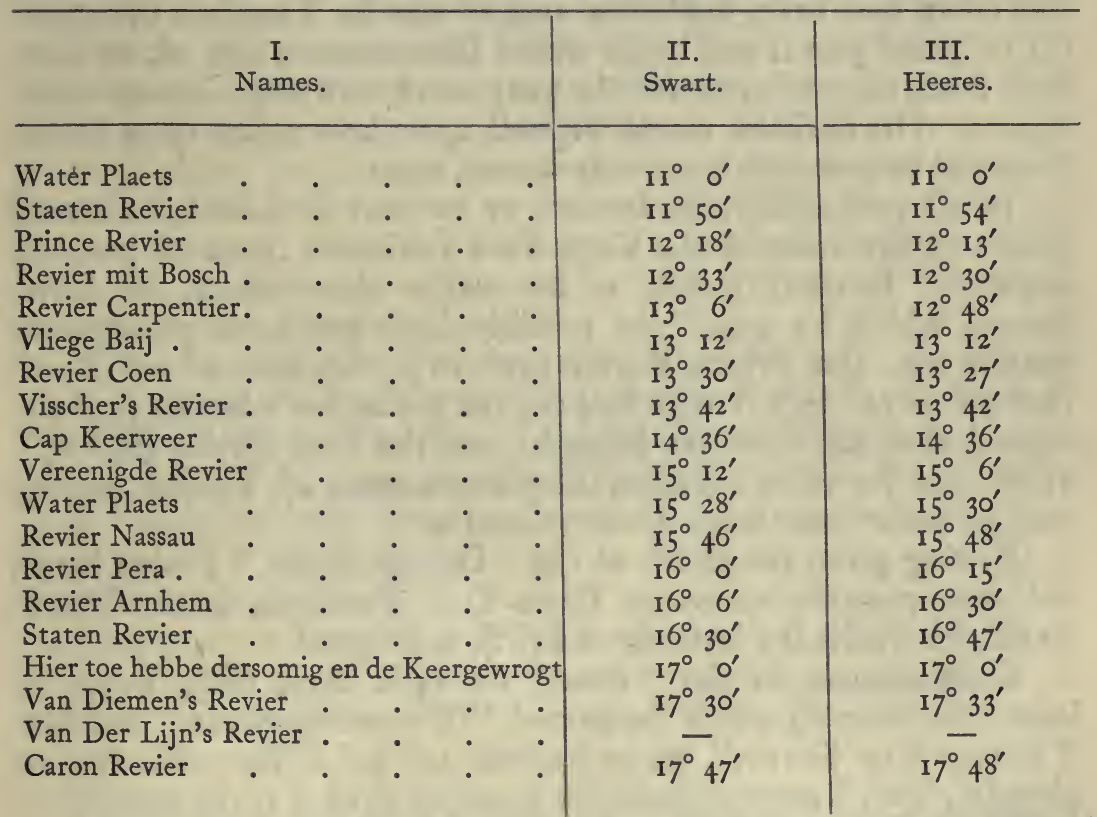

1 The full title is: Abel Janszoon Tasman's Journal of his Discovery of Van Diemen's Land and New Zealand in 1642, with Documents relating to his Exploration of Australia in 1644, being Photo-lithographic Fac-Similes of the Original Manuscript in the Colonial Archives of the Hague, with an English Translation and Fac-Similes of Original Maps : To which are added Life and Labours of Abel Janszoon Tasman, by J. E. Heeres, LL.D., Professor at the Dutch Colonial Institute, Delft, and Observations made with the Compass on Tasman's Voyage by Dr.W. Van Bemmelen, Assistant Director of the Royal Meteorological Institute, Utrecht. Amsterdam, 1898.

It is almost needless to say that the greater part of the facts quoted in this chapter relating to Tasman's voyage are borrowed from this exhaustive work, for which Professor Heeres is peculiarly qualified not only because of the exceptional opportunities enjoyed by him for obtaining access to the original documents, but also because of his critical and judicial mind. He is, however, not at all responsible for the views and comments herein. I may claim, perhaps, better opportunities for access to Australian documents and charts.-R. L. J. 
It would be of great assistance to know whether or not Tasman succeeded in getting Carstenszoon's diary and charts from the Vice-Governor at Banda. I am inclined to think that he left Banda without these important documents ${ }^{1}$ and had to rely entirely on the general chart with which he was furnished at Batavia. Had he been able to refer to the original report and chart, he would surely have adopted for the northmost "Wateringplace" at which he touched, Carstenszoon's name of "Van Spult Revier." The question arises, was the sketch-chart made by de Leeuw, mate of the "Pera," prepared for the guidance of Tasman ? I conclude that it could not have been, or Tasman would have used de Leeuw's name of "Batavia Revier" instead of Carstenszoon's "Carpentier."

The note at $17^{\circ} \mathrm{S}$. latitude, on Tasman's I 644 chart, which may be freely translated: "Some people have been as far as this," was, in all probability, of the nature of an instruction. To that point the coast had been explored, and it was in Tasman's discretion (I) to hurry past it and begin where Carstenszoon left off, or (2) to land from time to time for the purpose of verifying Carstenszoon's report. His decision would depend upon how much time he was prepared to spend on an already-known coast.

In all probability, he landed, or at least anchored, in several places on the coast of the Cape York Peninsula short of previous explorers' furthest south, as he makes observations, or leaves names, which he could not possibly have got from pre-existing charts, e.g., the Prince Revier ( $\left.12^{\circ} 12^{\prime}\right)$, the Revier mit Bosch $\left(12^{\circ} 30^{\prime}\right.$ or $\left.12^{\circ} 33^{\prime}\right)$, Vliege Baij ( $\left.13^{\circ} 12^{\prime}\right)$, Visscher's Revier $\left(13^{\circ} 42^{\prime}\right.$, named after his Assistant Skipper) and the Pera Revier ( $16^{\circ}$ I $5^{\prime}$ ). It remains for us to consider the places named by Tasman, one by one, in their order from north to south.

Having given the shoals of the "Drooge Bocht" a wide berth, the first position noted in Cape York Peninsula is the Water Plaets to which the latitude of $\mathrm{II}^{\circ} \mathrm{S}$. is assigned.

Carstenszoon, in the "Pera," on 14th May, 1623, noted an inlet (SeE MAP A) which he named "WATERing-PLACE" and also "Revier Van Spult," in, as he said, $10^{\circ} 50^{\prime} \mathrm{S}$. lat. For reasons already given, I have pointed out that this (which is the latitude of Red Island) is impossible, and that the Van Spult Inlet must be a mouth of the Jardine River, and in, or about, $10^{\circ} 59^{\prime} \mathrm{S}$. Carstenszoon having described it as an ideal watering-place, where fresh water could be taken up in buckets lowered from ships, Tasman was likely enough to have paid it a visit, especially if he needed water. If he really found and identified it, he was practically

1 My son, R. Lockhart Jack, suggests that if Tasman had a difficulty in obtaining the "Pera's" charts, he would endeavour to enlist and carry with him some of the "Pera's" old sailors, in the hope of getting from them assistance in the identification of Carstenszoon's reviers. - R. L. J. 
correct in placing it in $\mathbf{I I}^{\circ}$. But why did he not adopt Carstenszoon's name of "Van Spult"?

The next position noted by Tasman is the "Staeten Revier," in $\mathrm{II}^{\circ}{ }^{\circ} \mathrm{O}^{\prime}$ (Swart) or $\mathrm{II}^{\circ} 54^{\prime}$ (Heeres). (SeE MAP B.) Close to the coast and in either of these latitudes, Tasman would be looking into the mouth of Port Musgrave, the estuary common to the Batavia, Ducie and Dalhunty Rivers of modern maps. He had just passed (apparently without observing it) the river to which Carstenszoon gave the name of CARPentier (called the Skardon River in modern maps), and still believed that river to be a long way south; and this shows how inaccurate was the chart on which he had to rely for information as to his predecessor's discoveries. Having missed the real Carpentier and found another "revier" not very far to the south, he would almost certainly have called the latter the Batavia had he been in possession of either de Leeuw's chart (date uncertain, say 1623-30) or Kepler and Eekerbrecht's chart (1630), as de Leeuw had altered Carstenszoon's name of Carpentier to Batavia and Kepler and Eekerbrecht had copied from him. TAsman Did not, however, Call the inlet the Batavia, but, believing it to be new, called it the Staeten (States) Revier. Why he should have called it by that name is a mystery, seeing that (as proved by his subsequent erroneous identification of another Staeten Revier in $16^{\circ} 47^{\prime}$ ) Carstenszoon's Staten Revier was shown (although, incorrectly, to the north of lat. $17^{\circ}$ ) in the "specially prepared " map which he carried.

$\mathrm{UP}_{\mathrm{p}}$ to the date when Tasman passed Port Musgrave, the singular state of affairs was that no inlet had yet been named the Batavia, although the name even then stood on at least two charts. As a matter of fact, the name was first applied in 1756 to the principal river debouching into Port Musgrave by Van Asschens, the mate in command of the "Buijs," who, no doubt, was in possession of Kepler and Eekerbrecht's chart, if not of de Leeuw's. Thus Tasman was the first to notice the mouth of the Port Musgrave Estuary, but he gave it a name (Staeten) which cannot be accepted, and Van Asschens was the first to apply the name Batavia to the principal river discharging into the estuary.

Tasman's third position is in $12^{\circ} 18^{\prime}$ (Swart) or $12^{\circ} 13^{\prime}$ (Heeres), and is named the Prince Revier, probably in honour of Prince Frederik Henry, then Stadtholder of Holland. The only opening between $12^{\circ} 13^{\prime}$ and $12^{\circ} 18^{\prime}$ is the mouth $\left(12^{\circ} 14^{\prime}-12^{\circ} 15^{\prime}\right)$ of the Pennefather River, which has figured on maps for several decades as the "CoEN" River, from Flinders' erroneous identification with the "revier" to which Carstenszoon gave that name. Tasman had named the inlet in question the "PRINCE" more than two centuries before it was named the Pennefather.

Tasman's "Revier mit Bosch" (Wooded Inlet) is placed in $12^{\circ} 33^{\prime}$ by Swart and in $12^{\circ} 30^{\prime}$ by Heeres. On modern charts, 
the mouth of Pine or Nomenade CReEK is in $12^{\circ} 30^{\prime}$, but to reach it Tasman must have doubled sharply round DuYfKen PoInT, and it is very odd indeed that his 1644 chart gives no indication of this very prominent cape. The omission may be attributable to a desire to avoid overcrowding the chart with details.

If Tasman really sailed to the mouth of Pine Creek, he was then well inside of AlBatross Bay, and his next inlet, which he calls the "Revier Carpentier," is placed in a bay in $12^{\circ} 48^{\prime}$. In $12^{\circ} 40^{\prime}$, the Embley River discharges into Albatross Bay. Tasman's observation may be correct, but why should he have given a new name (Staeten Revier) to Carstenszoon's Carpentier Inlet? And why should he have identified as Carstenszoon's Carpentier an inlet 55 minutes to the south of it ? It is easier to believe that he was supplied with a very imperfect chart of Carstenszoon's voyage than that he was careless in his identifications. I conclude that he did not find Carstenszoon's diary and chart at Banda, as the Governor and Council at Batavia expected he would, and that the "special chart" supplied to him was imperfect and misleading.

Tasman next writes "Vliege BaIJ" (Fly Bay) on the coast in $13^{\circ}$ I $2^{\prime} \mathrm{S}$. Towards the latter end of the nineteenth century, this bay was labelled by the Hon. John Douglas (I am afraid unalterably) "Albatross Bay." It extends from Duyfken Point $\left(12^{\circ} 33^{\prime}\right.$ S.) to Pera Head ( $12^{\circ} 55^{\prime}$ S.), and receives the important, and to some extent navigable, Mission and Embley Rivers. Here, for the first time, Tasman's latitude will not square with modern charting, as, even if the latitude given by him is meant to be that where he left the bay behind him, he is wrong by 17 minutes too much south. In any case, his name of Fly Bay has priority, by more than two and a half centuries, over the de facto name Albatross Bay. The name probably records the fact that mosquitoes had forced themselves on Tasman's notice. The skipper of the "Buijs," in April, I756, recognised VliEgE BAIJ, although, a month later, the skipper of the "Rijder" named it Mossel BaiJ. (SEE MAP D.)

South of Albatross Bay, an inlet in $13^{\circ} 30^{\prime}$ (Swart) or $13^{\circ} 27^{\prime}$ (Heeres) was named the Revier Coen by Tasman, who evidently believed that he had identified the inlet (in $13^{\circ} 7^{\prime}$ ) so named by Carstenszoon.

The "Investigator" Chart by FuINDERS (I 802), corrected by the Admiralty surveyors up to 1896 , shows no break in the coast-line in the position ( $13^{\circ} 7^{\prime}$ S.) assigned to the Coen Revier by Carstenszoon in 1623; nor does the Lands Department map. In the chapter devoted to Missionary Exploration it is shown that the "Pera's" anchorage was in $13^{\circ} 7^{\prime}$ and that a boat's crew landed there, and a short walking distance to the north found a small inlet remarkable only for the presence of esculent herbs, and which was named the Coen. The Rev. N. Hey, of the Mapoon Mission, 
informs me that there is such a water-course in $13^{\circ} 4^{\prime} \mathrm{S}$. lat. Tasman was mistaken in his identification of the inlet in $13^{\circ} 27^{\prime}-$ $13^{\circ} 30^{\prime}$ with Carstenszoon's Coen, which is in $13^{\circ} 4^{\prime}$. Tasman's inlet is, in fact, in lat. $13^{\circ} 20^{\prime}-13^{\circ} 2 \mathrm{I}^{\prime}$, and is the mouth of the important river named the Archer by Jardine in 1865. Some 70 miles from its mouth, the Archer splits into two branches, and the southern and shorter has borne the name of the CoEN since 1876 , for the reason that the discoverers of a GOLDFIELD on its upper reaches believed it to be the head of the "Pera's" (i.e., Carstenszoon's) Coen. The Lands Department maps now call the river of the goldfield the "South Coen." Tasman's erroneous identification was probably due to the imperfection of the charts with which he had been supplied.

It would not surprise me if direct investigation were to prove the inlet in $13^{\circ} 27^{\prime}-30^{\prime}$ which Tasman mistook for the Coen to be a mouth of the Archer. Considering the "habit" of rivers on this coast, I should expect a river like the Archer to have several mouths. In fact, a sketch-map recently made by the Rev. A. Richter, and certified by the Rev. N. Hey, shows a mouth named the Dugaliy River in $13^{\circ} 33^{\prime}$. There are probably other inlets or mouths of the Archer between $13^{\circ} 33^{\prime}$ and $13^{\circ} 20^{\prime}$, where the only charted mouth is located, and in this case we need not even suppose an error of a few minutes of latitude on Tasman's part.

Next in order, in Tasman's I664 chart, is Visscher's Revier, in $13^{\circ} 42^{\prime}$. Here, again, no inlet appears on the most recent Admiralty charts or on the maps of the Lands Department. On the latter, the whole of the coast-line from the mouth of the Archer River to Cape Keerweer is a blank; but my charting (not very far to the east) of Jardine's route of the last days of I 864 , from his camp numbered 55 to that numbered 57 , shows that a group of considerable streams must find their way to the sea somewhere on this stretch of coast, unless they all go to feed the Archer River. It is, however, equally probable that, assuming Tasman's latitude to be correct, the inlet which he named in compliment to his Assistant-Skipper was a mouth of the Archer itself. So far, there is no reason for suspecting any serious error in Tasman's latitudes. The fact that he named what he believed to be a new "revier" in $13^{\circ} 42^{\prime}$ is strong evidence that he actually landed in or near that latitude.

The next locality noted on Tasman's chart is CAPE KeERweER (where the "Duyfken" turned back), which he places in $14^{\circ} 36^{\prime}$. In that latitude nothing like a cape appears in modern official sea charts or land maps. I suggest that his course here was too far out at sea to enable him to lay down this not very prominent cape from his own observation and that he copied it from the defective chart which he carried. (SEE MAP F.)

South of the real $\left(13^{\circ} 5^{8^{\prime}}\right)$ and the imaginary $\left(14^{\circ} 36^{\prime}\right)$ Cape 
Keerweer, Tasman's chart shows the "Vereenigde Revier" (the "main channel" of the Mitchell River), in $15^{\circ}$ I $2^{\prime}$ (Swart) or $15^{\circ} 6^{\prime}$ (Heeres). Modern charts place it in $15^{\circ} 9^{\prime}$. Did Tasman identify the inlet so named by Carstenszoon, or did he merely copy from the chart supplied to him ?

Next in order comes the "Water Plaets" in $15^{\circ} 30^{\prime}$, which agrees with Carstenszoon's data. I doubt if Tasman would have attempted to land here if he had had access to the text of Carstenszoon's diary, which shows that water was only to be collected by a tedious process and in trifling quantity. For this reason, I conclude that he did not land, and that he merely copied the note from the chart supplied to him. (SEE Map H.)

Tasman next places the Revier Nassau in $15^{\circ} 37^{\prime}$ (Swart) or $15^{\circ} 4^{\prime}$ (Heeres), instead of in $16^{\circ}$ IO' where it was placed by Carstenszoon, and where, according to modern maps, an unnamed creek runs into the sea. A large river, which modern maps name the Nassau, and which is one of the mouths of the Mitchell River, runs into the sea in latitude $15^{\circ} 54^{\prime}$, but it was unnoticed by Carstenszoon. It is more likely that Tasman copied the Revier Nassau from the imperfect chart supplied to him than that he was 33 or 22 minutes out in his own observation, so that I doubt if he really visited it. His supposed identification of Carstenszoon's Nassau was, unfortunately, accepted by FLINDERS (I802), and has, since then, passed into geography and literature, so that the error cannot now be corrected. It must, however, be understood that the "NASSAU" MOUTH of the Mitchell, as it appears on modern land maps, is not Carstenszoon's Nassau, and that the name is merely a complimentary one.

On an inlet in $16^{\circ}$ (Swart) or $16^{\circ} 15^{\prime}$ (Heeres), Tasman bestows the name of the Revier Pera. If the latitude ( $16^{\circ}$ ) scaled from Swart's version of Tasman's chart correctly conveys Tasman's meaning, this Pera Inlet must, according to the Lands Department map, be the "Tidal Mouth" of Leichhardt's "Rocky Creek." This mouth is navigable by small craft for four miles. It may, therefore, be conceded that Tasman landed at or rowed up the inlet which he named the Pera Revier.

South of the Pera inlet, and 5 minutes south of the mouth of the large river which modern maps (incorrectly, though irrevocably) name the Staaten River, Tasman places the Revier Arnhem in $16^{\circ} 30^{\prime}$. Modern land maps show that a water-course, known as VAN Rook CREEK, leaks out of the Einasleigh, a tributary of the Gilbert River, and falls into the Gulf in this latitude, only 6 miles south of the mouth of the Staaten River, de facto, after meandering across the coastal plain, in a general WNW. direction, for I 50 miles. Carstenszoon, in the diary of the "Pera's" voyage, made no mention of an inlet in this neighbourhood, where he was fuming over the desertion and supposed treachery of the "Aernem." 
I am inclined to believe that Tasman actually saw the inlet which he named the Arnhem, and that he named it in commemoration of the last appearance of that yacht on the "New Guinea " coast.

In an inlet in $16^{\circ} 47^{\prime}$ (Heeres), Tasman believed himself to have recognised Carstenszoon's Staten Revier. The modern land map shows a mouth of the Gilbert River falling into the Gulf in $16^{\circ} 45^{\prime}$, and it may be assumed that this is the inlet mistaken by Tasman for Carstenszoon's Staten Revier. There is, however, as is argued elsewhere, every ground for believing that CarsTenszoon's STATEN Revier was Accident InLet, another mouth of the Gilbert, in $17^{\circ} 3^{\prime}$. However, seeing that the note in the chart "specially prepared " for Tasman's use laid down $17^{\circ}$ as the limit of previous discovery, he was compelled to recognise, SHORT OF THAT LATITUDE, some inlet or other as that which was the "Pera's" and "Aernem's" furthest south, and which Carstenszoon named the Staten Revier. That note itself was incorrect, Carstenszoon's diary giving the latitude as $17^{\circ} 8^{\prime}$, while $17^{\circ} 13^{\prime}$ is probably more accurate. That Tasman accepted the authority of the note is an additional proof, if such were required, that he was not in possession of Carstenszoon's diary or chart.

The foregoing attempt to follow Tasman, with the assistance of modern charts, along the coast previously described by Carstenszoon leads to the conclusion that while he might very well, in following the instructions laid down for his guidance, have passed rapidly over the already-described region and commenced operations where Carstenszoon left off, he adopted the alternative course of spending a considerable amount of time in verifying Carstenszoon's information. That his success was indifferent is probably attributable to the imperfection of the chart with which he was supplied.

It must be remembered that we have not the chart which accompanied Tasman's instructions, and that there are good grounds for the belief that it gave only an imperfect, second-hand delineation of Carstenszoon's discoveries; that Tasman, apparently, was not furnished with Carstenszoon's diary or chart; and that we have not Tasman's account of his own voyage and have to rely on a small-scale chart on which he laid down his discoveries, identifications and observations. (SeE MAP M.)

Free at last, and with an absolutely untouched stretch of coast before him, I am inclined to think that Tasman found that he had already spent too much time in verifying Carstenszoon's data, and that he had to hurry over what should have been the most important part of his task. It may be truthfully said in excuse for him that the whole world presents but few stretches of coast less picturesque than that on which he was now entering. It may well be imagined that he was content, in the first place, by a cursory observation, to 
settle whether "New Guinea" (as he regarded it), or Cape York Peninsula (in reality), was continuous with Arnhem Land or whether a passage to the south lay between.

Presumably with the intention of making certain that he was now on an unexplored shore, Tasman made his first descent at $17^{\circ} 30^{\prime}$ (Swart) or $17^{\circ} 33^{\prime}$ (Heeres), where he named Van Diemen Inlet (Revier). Next, he named the Van Der Lijn and Caron INLETS, the latter in $17^{\circ} 47^{\prime}$.

FLINDERS, in 1802, in the "Investigator," believed he had identified Tasman's Van Diemen Inlet in the mouth of the Gilbert River $\left(16^{\circ} 57^{\prime}\right)$. All the attendant circumstances point to the incorrectness of this identification, but it has, nevertheless, been adopted without question in subsequent official maps. Firstly, there is the discrepancy between the latitudes of $16^{\circ} 57^{\prime}$ and $17^{\circ} 30^{\prime}$. Then it is precisely at his Van Diemen's Inlet that Tasman makes the trend of the coast-line change from S. by W. to W. by S. I see no reason for doubting that 'Tasman's latitude of $17^{\circ} 30^{\prime}$ was substantially correct, especially as it is here that his chart shows the abrupt change in the trend of the coast-line. There can be no reasonable doubt that Tasman's VAN Diemen InLET was the Mouth of the Norman River, now the port for the Croydon goldfield and a considerable area of pastoral country. Its latitude is $17^{\circ} 28^{\prime}$.

Tasman's three inlets, the Van Diemen, Van Der Lijn and Caron, are all, according to his chart, within 17 minutes of latitude. The position in which the name of the VAN DER LIJN is written appears to me to be purposely indefinite, as if it were designed to convey merely that the inlet is between the $V$ an Diemen and the Caron. I take it to be what is now mapped as the "Bynoe" mouth of the Flinders River.

The Caron Inlet is placed on Tasman's chart in $17^{\circ} 47^{\prime}$, and must be the principal moUth of THE Flinders itself. Here, however, Tasman's latitude is incorrect, according to modern charts, which place the mouth of the river in $17^{\circ} 36^{\prime}$, so that Tasman's position is II minutes inland. I am under the impression that Tasman had become rather indifferent as to his true position and had come to regard the continuity of the coast of the Cape York Peninsula with that of Arnhem Land as the problem of the moment.

It may be noted here that Flinders' chart of 1802 shows the Capron River coming from the east and falling into the Norman River at Normanton. Subsequent Lands Department maps have always given the name of the CARRon RIVER to this water-course, thus creating a mistaken impression that this was supposed to be Tasman's Caron.

From the Caron Inlet (Flinders River) Tasman passes beyond our ken. By following the coast he established the conTINUITY of the Cape York Peninsula (which he named Carpentaria) 
with Arnhem Land, and incidentally that instead of a passage to the south there was merely the Gulf of Carpentaria.

\section{SUMMARY}

The loss of Tasman's journal reduces us to conjecture and the weighing of probabilities when ve attempt to realise what it was that he accomplished, the groundwork or text of such speculations being the sketch-chart containing the names which he bestowed on certain inlets or capes.

So far as the Cape York Peninsula was concerned, he was apparently supplied with a very imperfect and misleading "SPECIALLY MADE" CHART of the voyage of his predecessor, Carstenszoon (in the "Pera"). He failed to procure the copies of Carstenszoon's journal and chart which it was expected he might pick up at Banda. Carstenszoon's journal, however, is available to us, although it was denied to him, so that we are in a position to judge how far he succeeded in identifying the inlets, etc., named by Carstenszoon.

The truth is that he was very unsuccessful; but this must be attributed entirely to the defects of the "specially made" chart and to no fault of his own.

He began his exploration of the Peninsula by rediscovering the "Pera's" "Watering-Place" in or near $\mathrm{II}^{\circ} \mathrm{S}$. lat., but did not give it the additional name of the "Revier Van SpUlt" which Carstenszoon had bestowed on it. He next made a very bad guess at the locality of Carstenszoon's Coen Revier, but either correctly identified or copied from his "specially made" chart (which seems to have been correct in this instance) Carstenszoon's Vereenigde Revier (the Mitchell River).

Carstenszoon's Nassau and Staten Reviers were incorrectly located by Tasman, the latter inlet being placed north instead of south of $17^{\circ}$, because the "specially made" chart had erroneously fixed that latitude as Carstenszoon's southern limit.

He was the first ${ }^{1}$ to notice Port Musgrave, which-probably misguided by the "specially made" chart-he seems to have taken at first for Carstenszoon's Staten Revier (before he realised that the latter was in the neighbourhood of $\left.17^{\circ}\right)$.

He next found a new inlet $\left(12^{\circ} 13^{\prime}-18^{\prime}\right)$ which he named the Prince Revier. The name never "caught on." For a good part of the nineteenth century this inlet was believed (incorrectly) to be Carstenszoon's Coen, and towards the end of that century was officially, and irrevocably, named the Pennefather.

He indicated a "Revier mit Bosch" just inside of Duyfken Point, where modern maps now show the mouth of PINE or record.

1 Unless he was anticipated by Janszoon, in the "Duyfken," of which there is no 
Nomenade CReek. To press Tasman's undoubtedly just claim to priority of nomenclature is not to be thought of, as it would only add one more to the too numerous family of "Scrubby" Creeks.

He was the first to give a name, VuIEge BaIj (Fly Bay) to what was afterwards named Mossel BaIJ, and, in recent times, AlBATROSS BAY, now unalterably fixed by usage and official recognition.

An inlet in this bay $\left(12^{\circ} 4^{\prime}\right)$ was named by Tasman the CARPENTIER, although its identification with the inlet so named by Carstenszoon would be absurd. This is one of the few remaining uncharted portions of the coast land, and if there should turn out to be an inlet of any importance in the locality indicated, I would suggest that it be named the TAsman.

In $13^{\circ} 27^{\prime}-30^{\prime}$, Tasman was the first to note a revier which he erroneously took for Carstenszoon's Coen, but which must have been one of the mouths of the great river named the Archer by Jardine in 1865 .

A new Revier, VIsscher's, was placed by Tasman in $13^{\circ} 42^{\prime}$. Should there prove to be such an inlet in this uncharted portion of the coast land, there is every reason why Tasman's name (Visscher) should be applied to it.

CAPE KeERweer (where the "Duyfken" turned back) is placed in an altogether wrong position. It is more than doubtful if Tasman saw it, and I believe he merely copied it from his incorrect "specially prepared" chart.

An inlet in $16^{\circ}$ was named the Revier Pera. This inlet, one of the mouths of LeIchHARDT's Rocky CREeK, is only designated a "TIDAL INLET" in the modern official map, and should have the name given to it by Tasman.

On Tasman's Revier ARnhem, long use and official recognition have irrevocably fixed the name of VAN ROOK CREEK.

In Tasman's three inlets named Van Diemen's, Van Der LiJn's and CARon's, there is no difficulty in recognising respectively (I) the mouth of the Norman River, (2) the "Bynoe" MOUTH of the Flinders River and (3) the "Flinders" MOUTH of the Flinders.

The name of the Van Der Lijn does not appear to have ever been adopted by modern maps, but Flinders was responsible for erroneous identifications of the Van Diemen and Caron, and, following him, the name Van Diemen still persists as applied to one of the mouths of the Gilbert River, in $16^{\circ} 5^{\prime}$. The sooner it is dropped the better. Nor could any useful purpose now be served by restoring Tasman's names for the three inlets, even if it were possible to overcome the weight of long-established private and official use of other names. 


\section{CHAPTER X}

\section{VOYAGES OF THE "BUIJS" AND “RIJDER" (1756) VAN ASSCHENS AND GONZAL}

Start from Batavia. Separated by Storm. "Buijs" makes Banda Harbour. Her Voyage resumed. Sights Pera Head, which is mistaken for the "Duyfken's" Cape Keerweer. Coasting northward. Tasman's Vliegebaij (now Albatross Bay) recognised. Asschen's Hoek named (now Duyfken Point). Batavia River named. Van Spult River recognised. Makes for the " Pera's" Watering-place. Boat and Crew lost. "Buijs" Waits and searches (without landing) till Shortage of Water compels the Survivors to make for Timor Laut, Tenimber Islands. Unjust Criticism by the Chief Cartographer at Batavia. "Rijder" reaches Frederick Henry Island. Prince of Wales and Booby Islands sighted. Landing on Prince of Wales Island and Exploration of Part of its Coast. Landing on Wednesday Island. Voyage resumed. Too far West. Land sighted South of Pennefather River. Visited by Natives in Canoes. Landing. Two Dingoes seen. Natives guide Party to Water. Then give a Corroborree. Arrack and Sugar given to Natives. Another Landing next Day with Intention of kidnapping Natives. Unsuccessful. Landing next Day. Natives made drunk. One wounded and dragged to Boat. General Encounter. "Rijder" anchors in Vliegebaij (Albatross Bay), which is named Mosselbaaij. Boat Party discovers Water at the "Pera's" Watering-place of 9th May, i623, Which is renamed Rijder's Watering-place. Wood and Water taken in. Southward Voyage resumed. Rijder's Hoek named. Landing. Brush with Natives. One captured. Sails for Arnheim Land. Timor reached.

are indebted to Professor Heeres' Commemoration Volume The Part of the Dutch in the Discovery of Australia for the text of a Summary, forwarded by GerRit de HaAn, Chief Cartographer at Batavia, to the Governor and Council of the Netherlands East India Company, of the LoGs OF THE "RIJDER" AND "BuIJs," the former commanded by Lieutenant Jean Etienne Gonzal and the latter by "Stuurman" (first mate) Lavienne Ludowijk van Asschens. The Dutch text is accompanied by an English translation by C. Stoffel, which, however, I have not always followed literally.

The two ships set out together from Batavia on 8th February, 1756, but parted company in a storm which was encountered off the Banda Islands. The "Buijs" took refuge in the port of Banda and remained there till Ist April. The "RIJDER," having ridden out the gale, continued her voyage alone.

1 Rijder, Ritter, Rider, person of equestrian rank, Knight. 


\section{THE "BUIJS" (ASSCHENS)}

Emerging from the friendly harbour of Banda on Ist April, the "Buijs" barquentine sailed to the east, and on 23rd April, while in latitude $12^{\circ} 5^{\prime}$ ' S., "sighted the Land of Carpentaria, recognising what has been named CAPE KEERweER." The anchor was dropped at sunset.

On 24 th April, the noon latitude was $12^{\circ} 54^{\prime}$. The anchor was dropped at sunset and bearings gave Cape Keerweer $8 \frac{1}{3}^{\circ} \mathrm{N}$. and "the inner hook near the river" (inlet) ENE. (SEE MAP D.)

Assuming the correctness of the noon observation of $12^{\circ} 54^{\prime}$ (and there is no reason to doubt it), the point of land was not Cape Keerweer, which is in $13^{\circ} 59^{\prime}$, but either False Pera Head or Pera Head itself-probably the former, the latter being the " inner hook." The reference to "the revier" (inlet) is obscure, but this may be the fault of the summary rather than of the log.

Under the mistaken impression that he had identified the Cape Keerweer of the "Duyfken's" voyage, Asschens resolved to steer to the north. In the forenoon of $25 \mathrm{th}$ April he cleared Pera Head. At noon he was in $12^{\circ} 42^{\prime}$ and he anchored at sunset.

Next morning the northerly course was resumed, and in the forenoon "a red point" was seen to form the northern horn of " a deep bay or bight" (now Albatross Bay) on which the "Buijs" had entered after clearing Pera Head. (SeE Map B.) The bay was recognised as that which Tasman had designated VliEgE BaIJ. The Point, which now bears the name of the "Duyfken," was charted as Asschens' Hoek, and by right of priority should be so called. The error, however, has so long been condoned by usage as to have become unalterable.

Leaving this point and keeping close to the land, the "Buijs" was in $12^{\circ} 16^{\prime}$ at noon. Smoke was observed on land, and even what appeared to be men and huts. The anchor was dropped at sunset in a position which may be conjectured to have been about $12^{\circ} 2^{\prime} \mathrm{S}$., a little south of the mouth of JANIE CREEK, between the Pennefather River (which Tasman had already named the Prince Revier) and Mapoon Mission Station.

Setting sail again at daybreak on $27 t h$ April, the land was found to fall away to the east. As a matter of fact, in coming from the south, the direction of the coast-line changes, about 7 minutes short of Mapoon, from N. by E. to NE. Before midday, Asschens was abreast of "a revier (inlet) with an island lying off its mouth." The inlet (which had been seen by Tasman) was designated by Asschens the Batavia, and by this name the largest river of the Peninsula, ending in Port Musgrave estuary in $\mathrm{II}^{\circ} 5^{6^{\prime} \mathrm{S}}$, is now known. It is true that the name of Batavia had already figured for some time on Dutch maps, but it was improperly applied (following de Leeuw) to the inlet which 
Carstenszoon had named the Carpentier River in 1623, and which is now known as the Skardon River.

The "Duyfken" had passed this inlet in 1606, and the "Aernem" (once) and the "Pera" (twice) in 1623, without observing it. The records of the "Duyfken's" voyage have been lost, and it may be conjectured that the "Buijs" either sailed closer to the land, or approached it in a better light, than the "Pera" or the "Aernem." The supposed island was, no doubt, a sandbank visible at low tide, 3 miles off the mouth of Port Musgrave. ${ }^{1}$

Without landing at the new river, the "Buijs" sailed on to the north. At noon on the 27 th, the latitude was roughly estimated at $\mathrm{II}^{\circ} 38^{\prime}$. Smoke was observed on the land, and apparently the mouth of Carstenszoon's Carpentier River was not seen. The "Buijs" anchored in the afternoon. At noon on the $28 \mathrm{tb}$ she was in $\mathrm{II}^{\circ} 29^{\prime}$. At noon on the $29 t h$ she was in $\mathrm{II}^{\circ} 3^{\prime}$. (SeE MAP A.) Two hours later, the anchor was dropped in 8 fathoms, the navigators believing themselves to be close to the Van Spult River named by Carstenszoon in 1623 . In this belief they were quite correct, the solar observation at noon on the 30 th giving $10^{\circ} 56^{\prime}$. They were, in fact, on the Inskip Banks or the "extensive sandy shoals" south of the Banks which are indicated by modern charts.

It had become necessary to take in water and firewood, both of which were running short. The charted Watering-place at the Van Spult River naturally suggested itself to Asschens, but the uncharted shoals called for prudent action. Accordingly, on $30 t h$ April, a boat with eight men was sent out to take soundings towards the land. The BOAT was lost sight of before nightfall and Was NEVER SEEN OR HEARD OF AGAIN. Whether it was wrecked among the shoals or the crew fell into the hands of the natives must remain a mystery. The "Buijs" waited for the boat till I 2 th May, when the scarcity of water and firewood compelled her to sail westward for TIMOR LAUT, ${ }^{2}$ which was reached on 2oth May. No attempt appears to have been made to search the land for the boat's crew, and it may have been that there were too few men left on the "Buijs" to furnish a landing party and risk its loss.

From the cartographer's covering letter, it appears that the sailing orders of the "Rijder" and "Buijs" enjoined some exploration of the interior, and Asschens probably intended to carry out this instruction when the overwhelming disaster overtook him.

1 Mr. J. T. Embley, who has sailed frequently along this coast, and seen it from probably the same distance as the "Buijs," writes me under date I8th July, I9r6: "The Batavia has a little island about three miles out from the mouth, but it is only a high sandbank covered at high tide. . . The mouth of the Batavia is plainly visible to any boat travelling from the north at a distance of 15 or 20 miles before you come to it. No boat could pass it in the daytime without seeing it."

2 The largest island of the Tenimber group, and now known as Yamdena. 
The cartographer's comment on Asschens is most severe, and, I think, unjust :-

"Of the proceedings of 'Stuurman' Lavienne Lodewijk Asschens (who had command of the barquentine ( $B u i j s^{\prime}$ '), the Undersigned can give no account deserving of consideration, while his reports or notes are so misleading that it is clear at the first glance that he can never have had any first-hand knowledge or ocular view of the matters referred to by him, seeing that he has hardly ever been nearer to the land than 3 miles off, at which distance, however, he pretends to have seen a river with an island before its mouth, as well as men, huts, etc.: all which seems to the Undersigned impossible on a flat land, such as this is. Nor has he made any landing on the said coast, although, contrary to Your Worships' orders, he had sailed along it from S. to N. for 40 miles before the misfortune of the loss of the boat befel, as Your Worships may gather from the annexed rough sketch of the coast sent in by him." 1

Asschens certainly began by mistaking Pera Head for Cape Keerweer, but, with the exception of this mistake, his description can easily be followed on, and agrees with, accurate modern charts. It must be remembered that his description is only known to us from a paraphrase of it made by a very unfavourably impressed (shall we say, prejudiced ?) official. He correctly identified Tasman's Vliege Baij (Albatross Bay) and gave the name of Asschen's Hoek to what is now called Duyfken Point. He noted the estuary now called Port Musgrave, which he named the Batavia Revier. Lastly, he correctly located himself abreast of the VAN SPULT RIVER before leaving Australia.

\section{THE “RIJDER" (GONZAL)}

After losing sight of her consort, the "Buijs," off Banda, on 26th March, 1756, and unaware that she had found shelter, the " RIJDER," having weathered the storm, continued her voyage, and reached FALSE CAPE, the westmost point of Frederick Henry Island, Papua, on 4th April. (See Map A.) "The high land of CarPENTARIA, known by the name of Hoog EijLAND," was sighted on roth April. This "high land" was, no doubt, Hammond and Prince of Wales Islands. A reef (the Gerard and Larpent Banks) was observed to extend from the high land nearly to a hitherto uncharted island, which was named RIJDER's IsLAND, and which must have been Booby Island. Possibly the ship's course lay between the reef and the island. In making cautiously for the coast, the "Rijder" apparently approached PRINCE OF WALES IsLAND near its north-western corner, where a first LANDING was made on I 7 th April. Only one NATIVE was seen, and he fled on the approach of the boat's crew, who noted bark huts, a bark canoe,

1 Heeres says: "I have not met with this chart."

2 Tasman, who was probably misled by the " specially prepared " chart with which he was provided, had named it the Staeten Revier, under the impression that it was the Staten Revier of Carstenszoon. 
fishing-lines, claws of animals used for fish-hooks, and spears barbed with bone. The description of the country could not possibly apply to any portion of the adjacent Cape York Peninsula. There were very rich soil, tall grasses, long straight timber and fine valleys with rills of fresh water. Several landings were subsequently made for the purpose of taking in water and firewood before the "Rijder" put out to sea again on 26th April. Her next recorded course was ENE., "following the trend of the coast," in 5, 6 or 7 fathoms. The coast-line of Prince of Wales Island, it is true, takes this direction from the north-western point of the island, but modern charts show that it would have been impossible to carry the depth of water indicated for any distance on an ENE. course. The presumption is that after an unsuccessful attempt on this impossible coast-line, the ship stood out to sea until she had cleared the Gerard and Larpent Banks and then followed the Prince of Wales Channel east-north-eastward, passing the north sides of GooD and Hammond Islands. The anchor was dropped on 28 th April in $10^{\circ} 30^{\prime} \mathrm{S}$. The only land in this latitude is WeDnesday IsLand. Here a party LANDED, but found only bark huts inhabited by natives, who fled into the woods. The ship's boat was beached and repaired. The "Rijder" herself lay at anchor till I 3 th May, to give the "Buijs" a chance of rejoining her.

Had Gonzal taken the "Rijder" east of Wednesday Island, he would have had a clear way into the Coral Sea and the Pacific Ocean, but he turned back on 13th May with the intention of following the coast to the south. He kept well out from the land, and, in fact, overdid it in his natural desire for sea-room, and it was not until 24th May that he again sighted LAND (south of the Pennefather River-Tasman's Prince Revier), in $12^{\circ} 18^{\prime} \mathrm{S}$. (SEe MAP B.) Drawing closer to the shore, he anchored on 25th May in $12^{\circ} 26^{\prime} \mathrm{S}$. (9 miles north of Duyfken Point).

"As they lay at anchor at about I or I $\frac{1}{2}$ miles distance from the shore, they saw two of the previously described canoes paddling up to the ship, each containing two men, who, when they had got near the ship, by signs and cries began to signify to our men that they wished them to come ashore. The following day, being the 26 th of May, our men went ashore at daybreak, and on landing found several persons there, who, however, all took to flight directly. They also saw two dogs, ${ }^{1}$ not unlike Bengal jackals. The persons who had fled shortly afterwards returned to them, when they found them armed with the assegays above described. They were accompanied by a number of womenfolk who were clothed with a sort of mat. The natives then all of them sat down on the beach near our men, who made signs to them that they were seeking fresh water, upon which the natives rose and signified their willingness to point out the places where water was obtainable. And so it happened that our men were taken along the beach for a short distance and conducted to a beautiful valley with fine trees. This seemed to be the home of the natives, as there were more women and children and also some places where they lived, consisting merely of shelters beneath the trees covered in with bark. The water which was found here welled up through artificial openings. They walked round and inspected the

1 They were thus the first white men to record having seen the DINGo. 
place and then returned to the strand, where they found the two canoes in which the natives had first visited the ship. While they sat on the beach, I 9 natives came up to them, having their bodies all besmeared with red, and held a frolic with a kind of song. ${ }^{1}$ Then they were treated to some arrack with sugar, and shortly afterwards they retired satisfied into the wood.

"In the morning of the $27 \mathrm{th}$, our men landed again, to see if they could not capture a man or two, but they did not succeed in doing so that day, because they were too late to entice the natives to the beach. Early in the morning of the $28 \mathrm{th}$ they landed again in order to execute their plan. On their arrival the natives came dancing and singing, sat down beside them and laid aside their so-called assegais or weapons and again indulged in drinking, under the influence of which two of them were seized, whereupon the others jumped up and set upon our people with their assegais, without, however, wounding anyone ; but the ship's clerk, who was trying to get hold of one of the savages, was slightly wounded by him in the hand. Then a shot was fired and one of the natives was wounded and the others fled into the bush. Our people then tried to drag to the boat the two men they had got hold of, but while they were being tied up one of them, by superhuman biting and tearing, managed to break loose and took to flight. Immediately thereafter, upwards of 50 natives came up, preparing to throw assegais, but a single volley put them to flight. Then our men took their one captive on board."

On 29th May, the "Rijder" dropped anchor at noon in $12^{\circ} 3 \mathrm{I}^{\prime}$ S., i.e., about 4 (English) miles north of Duyfken Point. She lay at anchor all the next day, and two canoes paddled out and inspected her from a distance of half a mile (Dutch). On the 3 Ist, she cleared DuYfKen Point, and at noon was in lat. I $2^{\circ} 44^{\prime}$ S. (SEe MAP D.) After contending with a contrary current, she anchored at sunset in Albatross Bay, which Gonzal named Mosselbaaij. Asschens had recognised it five weeks earlier as Tasman's Vliege BaiJ.

On ist fune, only a short distance was sailed in the forenoon, and an anchor was dropped in $12^{\circ} 5^{\prime} \mathrm{S}$. A boat was sent out the following day, and reported abundant water at or near the "PERA's" WATERING-PLACE of 9th May, 1623, where " the chart showed a fresh-water river." The "Rijder" moved on, on 3 rd Fune, to the position indicated, which was in $12^{\circ} 57^{\prime}$ S., between Pera HEAD and False Pera Head, and dropped her anchor. A stay of ten days was made here while water and firewood were taken in and the boat was repaired. "Water came rushing down the rocks, and there was also a fine pool where many birds of different sorts were seen." The place was named RiJDER's WaterplaeTs. The above description is not unlike that of the "Pera's" Waterplaets, but the two may be distinct, although they cannot be far apart. No natives were seen.

The voyage was resumed on 13 th fune. At noon the latitude was $13^{\circ} 2^{\prime} \mathrm{S}$. (the narrative gives $12^{\circ} 2^{\prime}$ S., evidently a clerical error). On the 14 th, it was $13^{\circ} 8^{\prime}$ at noon. "At the first glass of the dog-watch," the anchor was dropped, slightly to the south of the RiJder's Hoek. To this prominence, in $13^{\circ} \mathrm{IO}^{\prime}$, modern

1 This is the first record of white men having been entertained with a CORROBORREE. 


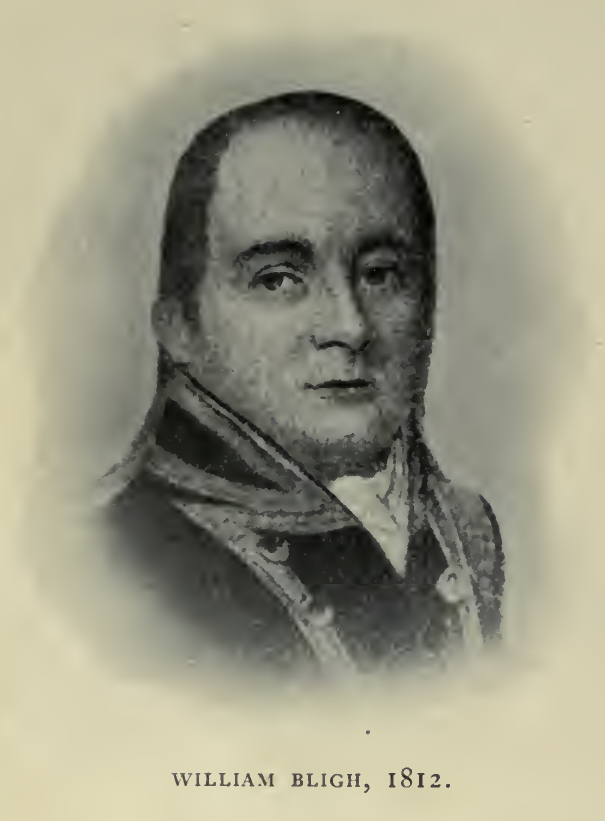




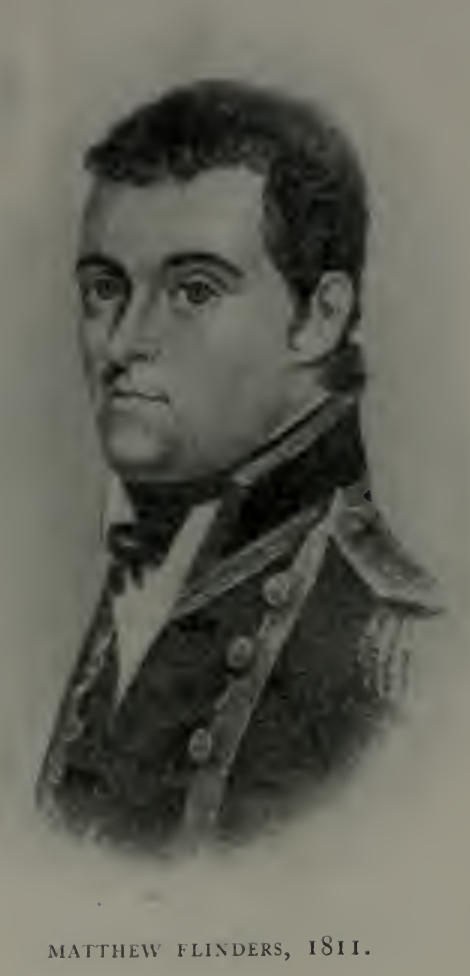


charts give no name. The latitude of the anchorage was made out to be $13^{\circ} \mathrm{S}$. at noon on the following day. I can only conclude that this was a faulty observation, as it is contradicted by the observations of the two preceding days, which agree with the contour of the coast-line. In the morning of the same day, a boat's crew landed, after having been met by two men in a canoe, who invited them to come ashore. Eleven men and five women met them on the beach, the men being armed with spears. The NaTIVEs tried to take off the hats of the visitors, which the latter resisted ; whereupon the natives threatened with their spears. A shot was fired and the crowd fled, with the exception of one youth, who was carried on board.

The sailors found a large pond of fresh water, and judged that the country, if cultivated, would prove fertile. It was remarked that the natives subsisted mainly on roots of trees, and wild fruits such as batatas or oubis, with a little fish, and that they seemed to have some knowledge of gold when some lumps of the metal were shown them. It is not stated on what occasion these observations were made. It cannot have been on the single interview above referred to.

On I6th fune, the course was set westward for Aernem's Land. On the 24 th, the "MAINLAND OF NEW Holland" was sighted, and the home journey was concluded via Timor and Rotti.

Inasmuch as her crew effected landings on Prince of Wales Island and at three different localities on the mainland, the "Rijder" added more to our knowledge of the interior and its inhabitants than the "Buijs," whose men were defeated on their only attempt at landing. The "Rijder" was the first (except, perhaps, the "Duyfken") to land a party in the neighbourhood of DuYFKEN Point and to explore the southern shore of Albatross Bay. The landing south of Pera Head confirmed the existence of the "Pera's" watering-place. The last landing on the Peninsula, at RijDer's Hoek, was made in a locality till then unvisited. After this landing, probably no white footprint marked the soil until, fourteen years later, Captain Cook landed on the eastern coast of the Peninsula. 


\section{CHAPTER XI}

\section{COOK IN “ENDEAVOUR" (I770)}

Transit of Venus observed at Tahiti. New Zealand visited and divided into two large Islands. East Coast of Australia struck near Cape Howe. Coast followed Northward. Landing at Botany Bay. Attempted Intercourse with Hostile Natives. Landing at Trinity Bay. Off Cape Tribulation. "Endeavour" on a Coral Reef. Beached in Endeavour Inlet (Cooktown), careened and repaired. Seten Weeks in Harbour. Short Inland Excursions. Exploration of Northern Coast and Islands. Intercourse with Natives fairly amicable, but their Acquisitive and Inquisitive Habits have to be carefully watched. Northward Voyage resumed. Landing at Lookout Point. Landing at Turtle, Eagle and Lizard Islands. Outside of Barrier Reef. Becalmed and drifting on the Reef. Inside the Reef again by Providential Channel. Northward Voyage Resumed. Round Cape York and Westward. Prince of Wales and Horn Islands. Insularity of New Guinea finally settled. Cook lands on Possession Island and takes Possession of New South Wales. Plants his Flag on an Auriferous Reef. Had he but known! Booby Island and Home. Endeavour Strait not the Passage used by Torres. Alexander Dalrymple a disappointed Candidate for the Command of the “Endeavour." His Great Services to Cartography. His Ideal Explorer. A Satirical Dedication.

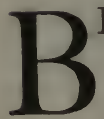

EYOND question, Lieutenant-Commander (by courtesy Captain) James Cook, R.N., ranks foremost among the navigators who helped to build up the British Empire. Among the services which he performed, the greatest of all were the discoveries which led to the acquisition of Australia.

The main incidents of his adventures in Australia are so well known that in the present volume it is necessary to do little more than to trace his connection with the Cape York Peninsula.

The great "First" Voyage commenced in 1768 and ended in 1771. Although Cook's original Log or Journal is still extant, it was only given to the world in its entirety by Captain Sir W. J. L. Wharton, R.N., in 1893 . The Editor remarks :-

"Strange it must appear that the account of the most celebrated and certainly, to the English nation, the most momentous voyage of discovery that has ever taken place-for it practically gave birth to the great Australian colonies-has never before been given to the world in the very words of its great leader. It has fallen out in this wise.

"After the return of the 'Endeavour,' it was decided that a full and comprehensive account of the voyage should be compiled. Cook's Journal dealt with matters from the point of view of the seaman, the explorer and the head of the expedition, responsible for life and for its general success. The Journals of Mr. Banks and Dr. Solander looked from the scientific side on all that presented itself to their enthusiastic observation. 
"What could be better than to combine these accounts and make up a complete narrative from them all ?

"The result, however, according to our nineteenth-century ideas, was not altogether happy. Dr. Hawkesworth, into whose hands the Journals were put, not only interspersed reflections of his own, but managed to impose his own ponderous style upon many of the extracts from the united Journals; and, moreover, as they were all jumbled together, the whole being put into Cook's mouth, it is impossible to know whether we are reading Cook, Banks, Solander or Hawkesworth himself."

Up to the present day, numerous accounts of the "Voyages," "Lives," etc., have been issued, and in many languages. They condense or expand with the greatest freedom, according to the views or objects of this or that author or editor.

More than fifty years ago, I picked up, at an Edinburgh bookstall, a Glasgow edition ${ }^{1}$ of Cook's Voyages, in three volumes, which may serve as an illustration of how Cook's narrative was dealt with and edited in such a fashion that Cook himself would hardly have recognised it. It is Hawkesworth, without the division into chapters, or the rubrics which preface the chapters. Portions, however, are omitted and again portions are added, the Journals of Cook, Banks and Solander, together with Kippis' Life of Cook, having been laid under contribution, while many philosophical observations were evidently contributed by the anonymous editor himself. No acknowledgment is ever made, but, even for statements or facts which at first appear to be new, justification can usually be found somewhere in one or other of the authentic documents. The editing, on the whole, is skilfully done, although Captain Cook is made to speak " in the first person singular," and reflections and observations are put into his mouth which he certainly would never have dreamed of making. What between Hawkesworth and the later editor, the plain tale of a sailor has assumed a mask compounded of pedantry and Calvinistic piety which forms a baffling disguise.

The primary object of the voyage which was commenced in I768 was the measurement of the sun's distance by means of an observation of the transit of Venus, a project which was urged by the Royal Society and warmly supported by King George III. This object having been accomplished, the expedition was to explore the South Seas.

The barque "Endeavour," of 370 tons, originally built as a collier, was selected as a suitable vessel and added to the Royal Navy. Her complement was ninety-five persons in all, inclusive of eleven who were civilians. Among the latter were Mr. (afterwards Sir) Joseph Banks, a naturalist with a leaning towards botany, who had been President of the Royal Society, Dr. Charles Solander, his Secretary and Assistant, Mr. Charles Green, Astronomer, and Messrs. Reynolds, Parkinson and Buchan, Artists. All of the

1 Captain Cook's Voyages, including Captain Furneaux's Journal. Glasgow, W. D. and A. Brownlie, $1807-8-9$. 
above-named, except Banks and Solander, died on the voyage. As Banks was merely a passenger, and therefore practically independent of Captain Cook, it would not have been surprising if friction had arisen. But he was plentifully endowed with judgment as well as with initiative and technical knowledge, and was able to render signal services during the voyage, and afterwards to help the Government with sage advice regarding the conduct of the newly acquired colony of New South Wales. Considering that the observations of Cook and Banks sometimes overlapped, and that their journals were written simultaneously, but independently, and that Cook, although self-taught, possessed no mean scientific knowledge, it is, indeed, much to the credit of both men that their intercourse was never marred by jealousy. The obvious explanation is that both were gentlemen in the finest sense of the word. It is, nevertheless, a fact that, reading between the lines of both of their journals, one can find here and there a trace of human weakness. The one can enjoy a joke which tells against the other.

The transit of Venus was duly and successfully observed at Tahiti, the locality selected for the purpose. Intimate relations were established with the natives of the islands during a residence of three months, and showed that an unsophisticated race had attained a measure of civilisation along ethical lines differing widely from those of Europe. New Zealand was next visited, and the information given by Tasman was greatly added to, the essential division of the land into two large islands being established.

Early in the year 1770, Cook set sail from New Zealand and struck the east coast of Australia near Cape Howe. Following the coast to the north, he made his first landing on 28th April at BotanY BaY, where he stayed till 6th May. Fresh water was taken on board and Banks and Solander revelled in new realms of natural history. Daily attempts were made to cultivate the friendship of the natives, who, unfortunately, proved hostile and suspicious, and on several occasions threw spears. It was observed that they used wimmeras.

Leaving Botany Bay, Cook followed the coast north and northwest, giving to the majority of the capes and bays the names which they now bear. His landings were few and brief, and were made chiefly in search of fresh water. His first landing at the base of Cape York Peninsula was at Trinity Bay, on ioth June. (SeE Map G.) It was at Cape Tribulation that his troubles began, on the night of that same day. In fine weather and clear moonlight, the ship stuck fast on a coral reef, and began to leak in an alarming manner. Ballast, six guns, and other material-over 50 tons - were jettisoned, and at length, by throwing out anchors, the "Endeavour" was warped into deep water. The leak was temporarily overcome by the process known as "fothering," i.e., a sail was passed below the keel and secured at both bulwarks and 
was pressed into the hole by which the water had been rushing into the ship. Then the pumps easily kept the water under control. In the nick of time, a harbour of refuge was found. On the I7th June, the "Endeavour" lay alongside a steep beach in ENDEAVOUR INLET, where, I03 years later, arose the town of Cooktown. (See Map E.) When the bottom could be examined, it was found that the biggest hole was plugged up by a stone which had been detached from the reef. Had this rock dropped out, the ship must inevitably have foundered.

While the ship was being repaired, the officers and passengers explored the land. They were in harbour till 4 th August. They made the acquaintance of the kangaroo, the opossum, the dingo, the flying fox, the snake, the turtle, the "alligator" and many birds. Banks collected a store of plants then new to science.

Tied, as they were, to the crippled ship, we cannot expect much information from Cook and his companions regarding the interior. Cook himself climbed Grassy Hill, south of the harbour, and probably also the jungle-clad hill now known as Mount Cook. What concerned him most was the question of a northward passage, and the outlook in this respect was disquieting. He also climbed one of the hills on the north side of the harbour, and another (Mount Saunders ?) 7 or 8 miles further north. Other members of the party rowed up the ENDEAVOUR RIVER to fresh water.

In Cook's mind, next to the safety of the ship, came the desire to cultivate the friendship of the Natives (the Indians, as it was then the fashion to call them) and observe their habits. The party had, however, been in the harbour for no less than three weeks before they "spoke" any of the inhabitants. On Ioth July, four men appeared on the north side of the estuary, engaged in spearing fish. Eventually, they paddled their outrigger canoe to the ship and entered into conversation "without expressing any fear or distrust." Small presents were given to the men, who came on board and remained for some time. Besides the spears which they carried, Cook noted the wimmera or throwing-stick. Daily visits followed and amicable relations were established and strengthened by gifts of iron, beads and food. It took the natives, however, only nine days of intercourse to learn how to presume upon the good nature of their hosts. On I9th July, a party of sixteen or seventeen came to the ship, the number including, for the first time, a few women. Scornfully rejecting biscuits, they demanded a turtle and attempted to take it by force. Foiled in this attempt, they leaped into the sea, climbed into their canoe and paddled for the shore. Cook and Banks got into a boat, with a crew, and were the first to land. As soon as the natives landed, they snatched a brand from beneath a kettle of pitch and set fire to the grass around the camp. The smith's forge was destroyed and a pig was burned to death. The natives then made for another 
spot, where sailors were engaged in washing and drying nets, and set fire to the grass. As matters had gone far enough, a musket loaded with small shot was discharged at one of the natives, "which drew blood at 40 yards," says Cook, and the natives fled. Then a ball was fired " across their bows," to convince them that they were not yet beyond the reach of punishment, whereupon the fugitives quickened their pace and were lost to sight. A few minutes later, they emerged from a wood, headed by an old man, made friendly advances, and were forgiven, and received presents, among which, by way of object-lesson, were musket bullets, the uses and effects of which were explained. If the trouble had occurred a few days earlier, Cook remarked, all his powder, which was then ashore, would have been lost.

Four days later, a member of the crew incautiously walked into a native camp, and found himself in the power of four "Indians," who, however, permitted him to depart in peace after having satisfied their curiosity regarding the texture of his clothing and skin and refused the knife which he offered them. They even took the trouble to set him right when he made for the ship in the wrong direction.

Such relations had been established before the "Endeavour" left the harbour that the crew knew most of their aboriginal visitors by name, and were able to distinguish strangers when these made their appearance. The tribe consisted, as far as Cook saw, of twelve men, seven women, one boy and one girl. He observed the native method of fire-raising by friction.

What "frightfulness" means in navigation can be fully appreciated by any passenger on a mail steamer who has the run of the chart-room on the bridge between Cooktown and Cape York. The narrow passage between the land and the Barrier Reef, charted, lighted, buoyed and beaconed though it now is, is crowded with reefs ready to punish remorselessly any deviation from the right path. That this path is negotiated daily in safety and comfort is due to the skill and the ceaseless watch of the officers. What must the passage have been when this was an unknown sea and the frail sailing craft depended on the caprice of light winds!

Cook put out to sea on 5th August. The "Master" had previously visited the "Three Islands" of the Low Woody GROUP. The "Endeavour" rounded CAPE BEDFORD and anchored off Lookout Point, where Cook himself LANDed. The lookout was very unsatisfactory, as the chance of getting away to the north seemed doubtful, and so the boats were called upon to scout. The Master landed on the Turtle IsLands to the north. Cook himself LANDED and passed a night on LIZARD ISLAND, and on his way back to the ship landed on EAGLE ISLAND.

The "Endeavour" left Lookout Point on r 3 th August and, passing on the north side of EAgLe and Lizard IsLands, found a 
way (Cook's Passage) through the reef due east of the Howick IsLAND. There was deep water (over I50 fathoms) outside of the reef and an open sea to the north-west, in which direction the course was set. At four in the morning of the $16 t h$, it was found that although the lead gave "no bottom" the ship was within a mile of a REEF on which the swell broke thunderously: there was hardly a breath of wind, and a strong current was driving the ship on the reef. After a fight with death lasting till late in the afternoon, a light breeze and a current combined to drive the ship through a narrow opening in the reef into a peaceful anchorage. The passage was appropriately named Providential Channel.

Cook was, no doubt, even better pleased to get inside the reef than he had been to get outside a few days before, and he resolved, as he said, "whatever the consequence might be, to keep the main land on board " for the rest of his northward voyage. He had to settle, once and for ever, the question "whether this country did or did not join to New Guinea." This question had been answered centuries before by Spaniards and Portuguese, but so well had these guarded the secret that the answer was unknown not only to the Dutch in 1606, 1623, 1644 and 1756, but also to the English in 1770.

Inside of the Barrier Reef, Cook again saw the mainland, at a point which he named Cape Weymouth. (See Map B.) On resuming his northward course, he saw and named Temple Bay and passed outside of the Forbes IsLands, which he named. $\mathrm{He}$ then rounded CAPE Grenvilite, which he named, leaving the SIR Charles Hardy and Cockburn Islands, which he named, on his right. Still keeping the mainland in sight and steering to the north-west, he passed outside of the islands which he named BIRD and Cairncross. He also named Newcastle Bay. (See Map A.) Arrived within sight of Mount Adolphus Island, he observed that the mainland receded to the west and altered his course to that direction. CAPE YoRK, the northmost horn of Australia, was passed and named. The high lands of Prince of Wales and Horn IsLands, which the earlier Dutch navigators had taken to be part of the mainland, were recognised as islands. The INsULARITY of New Guinea was at last settled beyond cavil.

Before bidding a last adieu to Australia, Cook landed on PosSESSION IsLAND and hoisted the ENGLISH FLAG on the highest point.

"Having satisfied myself," says Cook, "of the great probability of a passage, thro' which I intend going with the Ship, and therefore may land no more upon this Eastern coast of New Holland, and on the Western side I can make no new discovery, the honour of which belongs to the Dutch Navigators, but the Eastern Coast from the Lat. of $38^{\circ}$ down to this place, I am confident, was never seen or visited by any European before us; and notwithstanding I had in the Name of His Majesty taken possession of many places upon this Coast, I now once more hoisted English Colours, and in the Name of His Majesty King George the Third took possession of the whole Eastern coast from the above Lat. down to this place by the Name of New Wales, ${ }^{1}$

1 New South Wales in the "Admiralty" copy of the manuscript. 
together with all the Bays, Harbours, Rivers and Islands, situated upon the said Coast ; after which we fired 3 Volleys of small Arms, which were answer'd by the like number from the Ship."

It would have been more correct, dramatically, if the ceremony had been performed on the mainland, but the reason for the use of the island is sufficiently explained by the passage from Cook's diary above quoted.

On the summit of the highest hill in Possession IsLand, and therefore practically on the spot where Cook planted his flagstaff, a vein of AURIFEROUS QUARTZ was discovered by Mr. J. T. Embley in 1895 and worked by him and others for some years afterwards. ${ }^{1}$ It is safe to say that had the discovery been made by Captain Cook the development of Australia would have proceeded from north to south instead of from south to north. By what apparently trivial circumstances the currents of historical events may be directed into one channel or another!

Ten men were observed on a hill in Possession IsLand, and one of them appeared to have a BOW AND ARROws. Cook, however, confessed that the observation was of doubtful value, having been made with glasses and from a considerable distance. Subsequent observations have proved bows and arrows to be foreign to the mainland of Australia.

His task accomplished, Cook rounded the southern cape of Prince of Wales Island and set his course to the north-west. One more LANDING was made in Australian waters, at Booby IsLAND, on 23rd August, 1770. On his homeward voyage, he visited New Guinea, Timor, Java and the Cape of Good Hope, and reached Dover on I2th June, I77I. In after years, and far from Cape York Peninsula, he was fated to win further laurels and the crown of martyrdom.

The passage discovered by Cook is now known as Endeavour Strait, and is the southmost of the nine passages through the islands and reefs lying between Australia and New Guinea recognised as practicable by the modern cartographers of the Admiralty. The question of its identity with the passage through which Torres found his way in 1606 has already been discussed at some length, and there can be no reasonable doubt that Torres and Cook deserve the credit of having made genuine and DISTINCT DISCOVERIES, although the existence of a strait was known even before Torres.

Chiefly for the reason that the story of Cook is the best known of all the Australian explorers, it has been judged unnecessary to present to the reader any more than a brief account of his experiences in the Cape York Peninsula. This chapter may fitly close with the less known story, "in lighter vein," of how nearly another than Cook came to being in command of the "Endeavour."

Alexander Dalrymple, a younger brother of Sir John Dal1 See Chapter LXXXVII. 
rymple, Earl of Stair, the famous authority on the law of Scotland, was an enthusiastic and scientific geographer, and a shrewd and capable collector, critic and editor of Voyages. Many important documents came to light through his industrious researches. $\mathrm{He}$ had conducted marine surveys in the East Indies, and had been present at the capture of Manila by the British fleet in 1762 .

When the Royal Society initiated the project of a Transit of Venus expedition, Dalrymple was consulted as to the details and claimed to have actually selected the "Endeavour" as a suitable vessel. He was nominated as Observer of the transit and expected to be given command of the ship, and might have received it had not the conduct of the expedition been turned over to the Royal Navy. The Naval authorities could not possibly have sent out tars and marines under the command of a civilian. Dalrymple was of the merchant service, and the Admiralty put Lieutenant Cook in command.

This disappointment was never forgotten by Dalrymple during his long and useful after life. (He was born in 1737 and died in I 808.) The memory of his grievance undoubtedly lent a tinge of bitterness to his criticism of the explorers of his own time.

Commodore (afterwards Admiral) Byron, in H.M.S. "Dolpbin," made a voyage round the world (1764-6), in the course of which he devoted a good deal of attention to Patagonia.

In 1766, after Byron's return to England, CAPTAIN Wallis was sent out with the "Dolpbin" and Captain Cartaret with the "Swallow" to continue the discoveries made by Byron. The "Dolpbin" parted with the "Swallow" after passing the Straits of Magellan and subsequently visited Prince Rupert Island, Whitsun Island, Tahiti, etc., returning to Ingland in I768. In Tahiti the men of the "Dolpbin" made themselves much at home. The official account of the voyage may be read in Vol. III of $A$ Collection of Voyages round the World performed by Royal Autbority, London, 1790. A shorter History of Wallis and Cartaret's Voyage round the World (London, A. Wren and G. Hodges) hints at dalliance with the ladies, in passages such as these: "Port Royal, 5th July, I767. -The Captain was entertained by a lady of authority, whom he called his Queen." ... " 27th July.-The Queen parted from him with wild demonstrations of regret. This Island is represented by Captain Wallis as one of the most pleasant in the universe." It was owing to the representations of Wallis that Cook was directed to Port Royal as a favourable locality for the observation of the transit.

Dalrymple, while Cook was prosecuting his momentous first voyage, issued his admirable Historical Collection of the Several Voyages and Discoveries in the South Pacific Ocean, and seized the opportunity of expressing in a DEDICATION which is one of the curiosities of literature, his opinion of Byron, Wallis and another 
whom I cannot identify with confidence, and his admiration for an ideal discoverer.

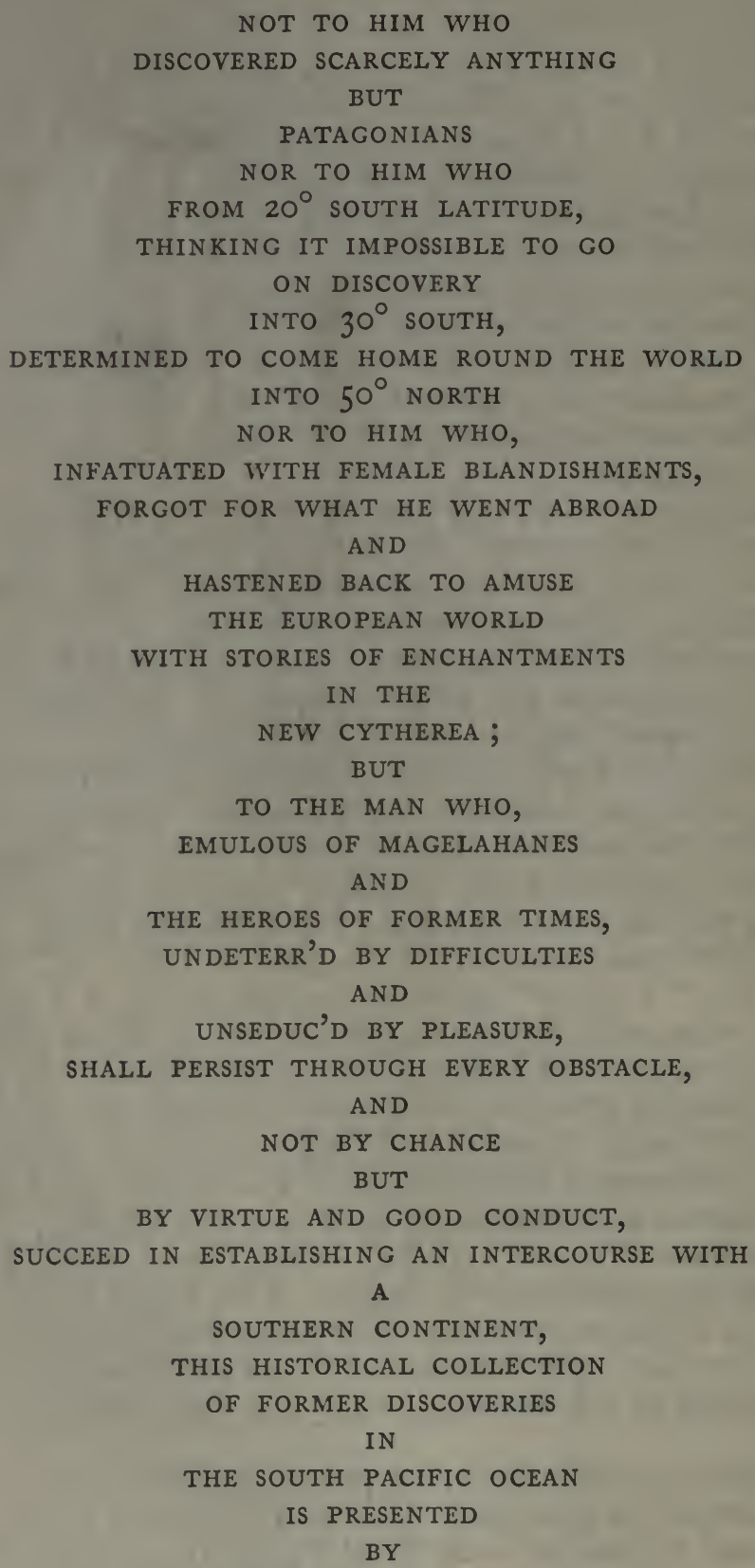


I am not prepared to admit the justice of the entemptuous allusions to Byron and Wallis. If the third person (mentioned second in order) was Quiros, which his alleged reluctance to go further than $20^{\circ}$ south renders probable, it must be remembered that Dalrymple, when he wrote in 1770 , was, like the rest of the world, very imperfectly informed as to the proceedings of Quiros. But whatever may have been the shortcomings of Quiros (?), Byron and Wallis, to whom the book was pointedly nот dedicated, the description of the ideal navigator, the man after Dalrymple's own heart, reads like a pen-portrait of Cook, who was even then, while Dalrymple wrote with his pen steeped in gall, making the great discoveries which the writer himself might have made if he had been given the opportunity. After Cook's return Dalrymple could not but admit the importance of his discoveries, but a tendency towards bitterness may still be traced in his inclinations to belittle the value of the passage between Australia and New Guinea and the assertion that its discovery had been forestalled by Torres. 


\section{CHAPTER XII}

\section{QUIROS, TORRES AND COOK AND THE VAUGONDY AND DALRYMPLE MAPS}

Insularity of New Guinea. Known to the Spanish and Portuguese. Denied by the Dutch. Proved by Torres, but Proof long withheld from Publicity. Demonstrated by Cook.

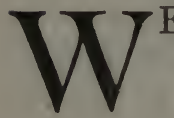

E have seen that, in 1606, Pedro Fernandez de Quiros found a harbour which he named Vera Cruz, on the east side of one of the islands of the New Hebrides group. Believing the land adjoining the harbour to be the east coast of the southern continent, he named the supposed continent La Australia del Espiritu Santo, and selected a site for its capital, which was to be called the New Jerusalem.

Admiral (i.e., Second-in-Command) LuIs dE Vaes Torres, who parted with Quiros at Vera Cruz, threw a justifiable doubt on Quiros' assumptions and sailed along the south coast of New Guinea. He thus demonstrated-though not for the first time-the SEPARAtion of New Guinea from Australia, a few months after the Dutch vessel the "Duyfken" had made a voyage along the southwest coast of New Guinea and the west coast of Cape York Peninsula, which voyage left, as far as the Dutch were concerned, the question of a strait unsettled. In 1623 , Carstenszoon, in the "Pera," decided that there was no strait, although the west coast of the Peninsula was indented with a shallow bight.

Carstenszoon's view as to the connection of New Guinea with Australia was held byROBERT DE VAUGONDY, one of the best-informed geographers of the eighteenth century, when he and his father, who was Geographer to the King of France, issued their magnificent Atlas Universel, containing a map (on a globular projection) dated 1752. The map also showed Tasmania as a part of Australia, and from Tasmania a "conjectural coast-line" ran north-eastward to include Vera Cruz and then west-north-westward to take in the north side of New Guinea, ${ }^{1}$ in accordance with Tasman's ideas on the conclusion of his voyage of $1642-3$.

Robert de Vaugondy issued another map (on Mercator's projection) in 1756 , "pour servir de la lecture de l'Histoire des Terres Australes." This, which is generally known as "Vaugondy's

1 This 1752 map is reproduced in Collingridge's work, p. 305, but transposed to a plane projection. 
Map," was on a scale of ' 15 inch to a degree. It is reproduced on a slightly smaller scale ('Iog inch to a degree) in Bartholomew and Cramp's Australasian School Atlas of $1915 .{ }^{1}$ It shows a very distinct expanse of water between New Guinea and Cape York Peninsula.

A comparison of Vaugondy's two maps, therefore, leads to the conclusion that between $175^{2}$ and 1756 the cartographer had become convinced of, or had strong reason to suspect, the existence of Torres Strait. What was the source of his information ? As the raison d'être of the second map was to help in the correct reading of President du Brosses' work, we naturally turn to that work for an explanation of the change in Vaugondy's views between $175^{2}$ and $175^{6}$; and, strange to say, the text only refers to the connection of New Guinea and the Southern Continent as doubtful. Perhaps something was known to Vaugondy of which du Brosses was ignorant. (SEE MAP A.)

In rediscovering Torres Strait in 1770 , Cook was, in one sense, merely settling a question which was still open to discussion, although he discovered a channel distinct from that used by Torres. Had he read Torres' report of 1607 there would have been no such question for him to settle. It is possible that Cook was aware of the conclusion arrived at by Vaugondy between $175^{2}$ and 1756 , without knowing the ground on which that conclusion was based.

In these circumstances, it would be well to know at what time the fact of Torres' passage through the strait (which he does not claim as a discovery at all) was given to the world, or "published."

In accordance with the custom and policy of Spain, the report would be kept a secret as long as possible. Likely enough, as it so happened that shortly after Torres' voyages Spain's interest in the South Sea diminished greatly, the report would soon be forgotten, "pigeon-holed" and lost sight of.

Alexander Dalrymple," an eminent British geographer (afterwards Hydrographer to the Admiralty), published in 1767 , an Account of the Discoveries in the South Pacifick Ocean previous to 1764. The chart accompanying the volume bears the date of October, 1767 , and shows Torres' route between New Guinea and New Holland, but the text makes no reference to Torres'adventures.

Dalrymple again, in 1770, issued the same map, with the date October, 1767, in his Collection of Voyages and Discoveries in the South Pacific Ocean. Although Volume I is correctly described as "being chiefly a literal translation from the Spanish Authors," it contains no reference to Torres' report.

1 The only omission from the reproduction is that of the legend "Carpentarie en I644 " applied to Cape York Peninsula, or perhaps more correctly to the whole of the land supposed to continue eastward to Vera Cruz.

2 Born 1737. See Biography in European Magazine for Nov., 1802. Mitchell Library, A $923,9 \mathrm{C}$. 
As early as I774, Dalrymple had claimed, in a letter to the editor of Cook's Voyages, that he had marked 'Torres' route on his map from information contained in Arias' Memorial, and that he had given a copy of that map to Mr. (afterwards Sir) Joseph Banks before the latter sailed with Cook in the "Endeavour" (i.e., before 27th May, 1768)." He therefore was quite justified in assuming that Cook's passage through the strait was "determined by" that information. It is reasonable to suppose that Cook took into consideration the probability of there being a passage, but that he considered it open to doubt as being based on maps only (Vaugondy's I756 map and Dalrymple's I767 map-probably then in manuscript - supplied by him to Banks).

It is clear that Dalrymple, although he had been in possession of 'Torres' Narrative since 1762 , had not yet seen, or at any rate had not yet translated, the narrative of Torres when he furnished Banks (prior to 27th May, I768) with a map showing Torres Strait. He himself states that the information which he had at that date was taken from Arias' Memorial.

I believe that 'TORRES' REPORT, written in I607, was, to begin with, kept secret by the Spanish Government, and was then pigeon-holed and forgotten. It need not, however, be supposed that Torres sent in his report, or narrative, without keeping a copy, and there is nothing in the narrative, as given by Dalrymple, to indicate that it was accompanied by a chart." A man who had a genuine grievance against his government, Torres probably (perhaps long after 1607) showed, or gave copies of the narrative and chart to people of importance whom he wished to interest. It is more than likely that he himself gave some high officer of the Dutch East India Company at Manila the copy of the narrative which was found by Alexander Dalrymple in the archives of the city when it was taken by the British in 1762 . It is probable that a copy of Prado's general chart had come into Vaugondy's hands between $175^{2}$ and 1756 , but if a copy of Torres' own narrative had come into Dalrymple's possession in 1762 , he had evidently not mastered its contents-perhaps had not reached it in the course of working through the translations-when he published his Collection of Voyages in 1770 .

Dr. Jean Luis Arias, acting as the mouthpiece of a Committee of priests, in a Memorial to King Philip III of Spain, exhorted the King to rise to a sense of the duties of his position and conquer the Southern Land, to the end that Christianity might be spread, and, above all, that Dutch and English heretics might be fore-

1 Collingridge, p. 200.

2 Three very accurate charts of localities on the south side of New Guinea, all of which are described as having been discovered by Torres, were made by Captain Prado, Torres' companion, but they only came to light about I778. Prado referred, in a letter dated 24 th December, I6r3, to a general chart of the Quiros-Torres Voyage, which has not yet been discovered. The report of Torres himself bears internal evidence of having been written at a time when he had not the charts of his voyage to refer to. 
stalled. Among the arguments employed are the achievements of early Spanish navigators (recounted at some length), including those of Torres.

Internal evidence dates this remarkable document between 1614 (referred to as the year of Quiros' death) and I62I (when Philip III died). The Memorial was published in Spanish in Edinburgh, and translated by Dalrymple, who printed it as an appendix to his Charts and Memoirs in I772.

After relating the parting of Quiros and Torres, in 1606, the memorialist goes on to say :-

"The Admiral Luis Vaes de Torres being left in the Bay, and most disconsolate for the loss of the 'Capitano' [Quiros' vessel] resolved to continue the discovery. . . . Finding himself in great straits in $2 \mathrm{I}^{\circ} \mathrm{S}$., to which high latitude he had persevered in sailing in about a SW. direction from the $15^{\circ}$ or $20^{\circ} \mathrm{S}$., in which lay the aforesaid Baia, he put back to the NW. and NE. up to $14^{\circ}$, in which he sighted a very extensive coast, which he took for that of New Guadalcanal. From thence he sailed westwards, having constantly on the right hand the coast of another very great land, which he continued coasting, according to his own reckoning, more than 600 leagues, having it still on the right hand (in which course may be understood to be comprehended New Guadalcanal and New Guinea). Along the same course he discovered a great diversity of islands. The whole country was very fertile and populous. $\mathrm{He}$ continued his voyage on to Bachan and Ternate, and from thence to Manila, which was the end of his discovery." 1

Had Arias and his colleagues themselves seen Torres' report they would not have had to conjecture, as they did (and rightly), that the land which lay on Torres' right hand included New Guinea, as Torres' report leaves no room for question on the point. They therefore must have obtained the information at second hand. The report was almost new-at the most not fourteen years old - and must have been zealously kept a secret if even priests powerful enough to lecture the King on his neglect of duty, with impunity, were denied a sight of it.

It was not 'Torres' report but Arias' summary of it which was known to Dalrymple in 1768 (although it may have been in his possession, but still untranslated), and we may believe that it had already come to the knowledge of Robert de Vaugondy between 1752 and 1756 .

Torres' report, or a copy of it, was discovered in the archives of Manila in 1762." It was first presented to English readers in a translation by Dalrymple in Captain James Burney's Discoveries in the South Sea, 1806, Part II, p. 467. The translation is

1 An English translation is given by R. H. Major in Early Voyages to Terra Australis. London, Hakluyt Soc., 1859. Another is printed in the same Society's Voyages of Quiros, 1904. A portion of it is given by Collingridge, p. 225.

${ }^{2}$ Flinders, Voyage to Terra Australis in 1801, 1802 and 1803 . London, 1814. In vol. i. p. Io, Flinders writes: "Torres, it should appear, took the precaution to lodge a copy of his letter in the Archives of Manila, for after that town was taken by the British forces in $1762, \mathrm{Mr}$. DALRYMPLE found out and drew from oblivion this interesting document of early discovery ; and . . . NAMED the passage TORRES STRAIT." 
reprinted in Collingridge, p. 229, where it is more accessible to the general reader. Captain Burney refers (p. 272) to the manuscript as follows :-

"Mr. Dalrymple has in his possession a copy of the Narrative written by de Torres, of which he has made an English translation. ... I have to acknowledge the being favoured with the use of this valuable manuscript."

Although Dalrymple had been in possession of a copy of the 'Torres' manuscript since 1762 , or shortly thereafter, he was unaware of its contents in 1768 , when he only knew as much of the doings of Torres as is related in the Arias Memorial.

According to Collingridge (p. 229), Quiros' original narrative is in the castle of Simancas, near Valladolid. ${ }^{1}$ The probability is that Dalrymple's copy was one of those promulgated by Quiros himself, and not the original, which had been filed in the archives of the State.

1 The documents in the castle were taken away by Napoleon and afterwards restored. Collingridge, p. 246. Except for this interruption, the archives of Castile and Leon have been preserved in this stronghold since 1563 . 


\section{CHAPTER XIII}

\section{BLIGH-VOYAGE OF “BOUNTY'S" LAUNCH, I789}

Mutiny of the " Bounty" at the Friendiy Islands. Bligh and Eighteen Others SET adrift in the Launch. Bligh makes for Timor, via New Holland. Scanty Provisions. Reaches Cape Direction. Coasts northward. Lioyd Bay. Restoration Island. Fair Cape. Carron Range. Cape Grenville. Landing on Sunday Island. Incipient Mutiny Quelled. Fish and Oysters. Bird, Hannibal and Bushy Islands. Boydong Cays. The Mainland. Names Pudding Pan Hill. Orford Ness. Escape River. Turtle Island. Wednesday Island. Through Prince of Wales Channel. Booby Island. Arrives at Timor, gets a Passage in a Dutch Vessel and reaches Plymouth. Who named Tuesday, Thursday and Friday Islands? Fate of the "Bounty" MutineERs.

ILLIAM BLIGH was born in Cornwall about 1753. He was Sailing Master of the "Resolution" in Captain Cook's Second Expedition. In 178I he took part in the naval action off the Dogger Bank, and next year fought under Howe at Gibraltar.

The story of the Mutiny of THE "Bounty" has been so often told that it need only be referred to here as the event which led to Bligh's acquaintance with the Cape York Peninsula and Torres Strait, which is our immediate concern. His memorable voyage in the "BounTY's" LAUNCH brings into prominence the characteristic faults and virtues of one who was at the same time a capable and courageous navigator and an insufferable master.

The story is told in two books issued by Bligh. The first may be referred to, by way of "short title," as the Narrative" and the second as the Voyage:" The Narrative was written and published with all possible speed as Bligh's vindication of his conduct, and commences with the departure of the ship from Otaheite on 4th April, 1789, reviews the incidents of the mutiny of 29th April, and ends with Bligh's arrival at Portsmouth on

${ }^{1}$ A Narrative of the Mutiny on board His Majesty's Ship "Bounty," and the Subsequent Voyage of Part of the Crew in the Ship's Boat, from Tofua, one of the Friendly Islands, to Timor, written by Lieutenant William Bligh. Illustrated with Charts. London, I79o.

2A Voyage to the South Seas, undertaken by command of His Majesty for the Purpose, of Conveying the Bread Fruit Tree to the West Indies, in His Majesty's Ship the "Bounty," commanded by Lieutenant William Bligh, including an Account of the Mutiny on board the said Ship, and the Subsequent Voyage of Part of the Crew, in the Ship's Boat, from Tofua, one of the Friendly Islands, to Timor, a Dutch Settlement in the East Indies: the Whole illustrated by Charts, etc., Published by Permission of the Lords Commissioners of the Admiralty. London, $\mathbf{1 7 9 2 .}$ 
I4th March, I790. The Voyage commences with the departure of the "Bounty" from Spithead on 23rd December, 1788, and includes a revised edition of the Narrative. (Admiralty Chart, No. 780.)

At Tofua, twenty-five of the mutineers took possession of the "Bounty" and forced Bligh and eighteen others, loyal to him, or at least obnoxious to the ringleaders, on board the ship's launch, and cast them adrift. The names of the men in the boat were :-

Lieut. William Bligh, Commander.

John Fryer, Master.

Thomas Ledward, Acting Surgeon.

David Nelson, Botanist.

William Peckover, Gunner.

William Cole, Boatswain.

William Purcell, Carpenter.

William Elphinston, Master's Mate.

Thomas Hayward, Midshipman.

John Mallet, Midshipman.

John Norton, Quartermaster.

Peter Linkletter, Quartermaster.

Laurence Lebogue, Sailmaker.

John Smith, Cook.

'Thomas Hall, Cook.

George Simpson, Quartermaster's Mate.

Robert Tinkler, Boy.

Robert Lamb, Butcher.

-. Samuel, Clerk.

Left in this plight, says Bligh :-

"My first determination was to seek a supply of breadfruit and water at Tofua, and afterwards to sail for Tonga Taboo, and there risk a solicitation to Poulaho, the king, to equip our boat and grant us a supply of water and provisions, so as to enable us to reach the East Indies."

A stock-taking of the provisions on board furnished a very brief inventory: "Bread, $150 \mathrm{lb}$.; Pork, $32 \mathrm{lb}$.; Wine, 6 bottles; Empty Barracoes, 4"-about nine days' rations on a most economical scale. Three days' foraging in TofuA produced only a few coco-nuts and plantains. On Ist May, thirty Natives were met with, and supplied a small quantity of food in exchange for buttons and beads. Next day, the crew, as they were getting into the boat, were stoned by 200 natives, John Norton being killed and every other man being more or less seriously injured. The idea of seeking aid from the king was abandoned. A fresh stock-taking showed that $\mathbf{1} 2 \mathrm{lb}$. of the pork and three bottles of wine had been consumed: the bread (150 lb.) was intact, and five quarts of rum were discovered. With this provision, the voyage to Timor, via New Holland, was commenced on the evening of 2nd May. The nights were cold; the sea was rough enough 
to enforce constant bailing; and there were frequent heavy rains, which at any rate enabled the unhappy men to catch drinking water. The rough weather continued till 26th May, and in all the twenty-four days the only addition to the food supply consisted of three small birds, two boobies and a noddy. As the boat approached Australia, birds became comparatively plentiful. On $28 t h$ May, the boat touched the Barrier REef, but a passage was found in $12^{\circ} 5^{\prime}$. The mainland of Australia was sighted, as well as an island, which Bligh named Direction Island. (See MAP C.)

This region is thus described by Bligh :-

"As we advanced within the reefs, the coast began to show itself very distinctly as a variety of high and low land, some parts of which were covered with wood. In our way towards the shore, we fell in with a point of a reef which is connected with that towards the sea [the shoals south of CHAPMAN IsLAND, which are almost connected with the 'Frederick Patches' to the east.-R. L. J.] and here we came to a grapnel, and tried to catch fish, but had no success. The Island Direction at this time lay about 4 miles to the W. by N. and appeared eligible for a resting-place, if for nothing more; but on our approaching to the nearest island [Ashton Rock ?-R. L. J.] it proved to be only a heap of stones, and its size too inconsiderable to shelter the boat. We therefore proceeded to the next [Rocky IsLand, I30 feet high, and presumably what Bligh named Direction Island, from the circumstance of its being where he picked up his bearings. -R. L. J.], which was close to it and towards the main. On the north-west side of this island, I found a bay, and a fine sandy point to land at. Our distance was about a quarter of a mile from a projecting part of the main [VILLIs Pornt ?--R. L. J.], which bore from SW. by S. to NNW. $\frac{3}{4} W$., we landed [presumably on the mainland south of Villis Point.-R. L. J.] to examine if there were any signs of the natives. .... We saw some old fireplaces, but nothing to make me apprehend that this would be an unsafe situation."

The tide was low, and by this time it was nearly dark. Oysters were found, and some of the party spent the night on shore.

Next morning (29th May), the boat passed what is now known as Cape Direction, and ran the chord of the arc of Lloyd Bay (20 miles), making for the furthest visible point of land, which proved on closer acquaintance to be an island. Bligh took its latitude at noon, $12^{\circ} 39^{\prime}\left(12^{\circ} 37^{\prime} \frac{1}{2}^{\prime}\right.$ really, but near enough for identification). (SEE MAP B.) The men dug and got water; found oysters in abundance ; made a fire with a magnifying glass; and indulged in a generous stew of oysters and palm tops. "This day," says Bligh, "being the anniversary of the restoration of King Charles II, and the name not being inapplicable to our present situation (for we were restored to fresh life and strength), I named this Restoration Island."

Being now, as he thought, in a land flowing with water and edibles, Bligh felt himself justified in distributing the remainder of the pork. Next morning (3oth May), after prayers, he resumed the voyage to the north. As the men bent to the oars, they saw, on the mainland, a crowd of NATIVEs, who were armed with spears 


\section{and wimmeras, and who invited them to come ashore; but the invitation was declined.}

"I directed my course," continues Bligh, "within two small islands [Blue Bell Rocks ?-R. L. J.] that lie to the N. [NNW.-R. L. J.] of Restoration Island, passing between them and the mainland towards Fair Cape [WeYmouth BAY, which extends from Restoration Island to Fair Cape.-R. L. J.] . . . . I was abreast of it [FAIR CAPE] by 8 o'clock. The coast we passed was high and woody [Carron Range.-R. L. J.]. As I could see no land beyond Fair Cape, I concluded that the coast inclined to the NW. and WNW. I therefore steered more towards the W.; but by II o'clock at night we met with low land which inclined to the NE.; and at 3 o'clock in the morning [Sunday, 3Ist May], I found that we were embayed [He had met with the promontory of CAPE Grenville, which is the northern limit of Temple Bay, the southern being Fair Cape.-R. L. J.], which obliged us to stand back for a short time to the southward."

\section{When daylight came (Sunday, 3ist May), it was found that} the aspect of the country had completely changed.

"There was now," says Bligh, " a low sandy coast, with very little verdure, or anything to indicate that it was at all habitable to a human being, except a few patches of small trees or brushwood [the heathy swamp land, interspersed with sandhills, between the Macmillan River and Temple Bay.-R. L. J.]. Many small islands [Cockburn IsLands.-R. L. J.] were in sight to the NE., about 6 miles distant. The east part of the main [CAPE Grenville.-R. L. J.] bore N., 4 miles, and Fair CAPE SSE., 5 or 6 leagues. I took the channel between the nearest island and the mainland [CAPE Grenville.-R. L. J.] which were all about a mile apart, leaving all the islands on the starboard side. Some of these were very pretty spots, covered with wood and well situated for fishing. Large shoals of fish were about us, but we could not catch any. In passing this strait, we saw another party of Indians, seven in number, running towards us, shouting and making signs for us to land. Some of them waved green branches of the bushes which were near them, as a token of friendship; but some of their other motions were less friendly. A little further off, we saw a larger party, who likewise came towards us. I therefore determined not to land, though I much wished to have had some intercourse with these people. Nevertheless, I laid the boat close to the rocks, and beckoned them to approach; but none of them would come within 200 yards of us. An island [SUnDAY IsLand] of a good height [ 157 feet] bore N. W., 4 miles from us, at which I resolved to land, and from thence to take a look at the coast. At this isle we arrived about 8 o'clock in the morning. The shore was rocky, but the water was smooth, and we landed without difficulty. I sent two parties out, one north and the other south, to seek for supplies, and others I ordered to stay by the boat. On this occasion, fatigue and weakness so far got the better of their sense of duty that some of the people expressed their discontent at having worked harder than their companions, and declared that they would rather be without their dinner than go in search of it. One person in particular went so far as to tell me, with a MUTinous Look, that he was as good a man as myself. It was not possible for me to judge where this might have an end, if not stopped in time; therefore, to prevent such disputes in future, I determined either to preserve my command or die in the attempt; and, seizing a cutlass, I ordered him to take hold of another and defend himself; on which he called out that I was going to kill him, and immediately made concessions. I did not allow this to interfere further with the harmony of the boat's crew, and everything became quiet."

The parties collected oysters and clams and a few small fish, and water enough for their requirements. Bligh himself climbed 
to the highest peak ( 57 feet), and named the scene of the disturbance SUNDAY IsLAND. On rejoining the boat, he steered NW. by N., in which direction he saw a small "key," alongside which he grappled at night. At dawn on the following day (Monday, Ist June), he landed, and named Lagoon KeY. This was the south-western of Cook's Bird Islands. He observed the shells and tracks of turtles, but the only edibles collected were clams and dolichos (beans). The ruins of a native dwelling were observed.

"After 8 o'clock, Mr. Samuel and Mr. Peckover went out to watch for turtle, and three men went to the east [north-east] key to endeavour to catch birds. All the others, complaining of being sick, took their rest, except Mr. Heywood [Hayward] and Mr. Elphinston, whom I directed to keep watch. About midnight, the bird party returned, with only 12 noddies, birds which I have already described to be about the size of pigeons; but if it had not been for the folly and obstinacy of one of the party, Robert Lamb, (This man, when he went to Java, acknowledged he had eaten nine birds raw after he separated from his two companions), who separated from the other two and disturbed the birds, they must have caught a great number. I was so much provoked at my plans being thus defeated that I gave the offender a good beating. I now [Tuesday, 2nd June] went in search of the turtling party, who had taken great pains, but without success."

The party embarked at dawn on Tuesday, 2nd Fune, and set a course $\mathrm{N}$. by $\mathrm{W}$. In about two leagues, the sea became very rough, from which Bligh inferred that he was opposite an open channel in the Barrier Reef. Beyond this there was a large shoal, ( $V$ Reef), on which were two sandy keys. Between these keys and two others, 4 miles to the west (Hannibal and Bushy IsLands), Bligh passed on his way northward. His journal continues :-

" Towards noon, I fell in with six other keys [Boydong Cays and HaLfway IsLand. - R. L. J.], most of which produced some small trees and brushwood. These formed a pleasing contrast with the mainland we had passed, which was full of sandhills, and the northmost land ... appeared like downs, sloping towards the sea. Nearly abreast of us was a flat-topped hill, which, on account of its shape, I called Puddrnc PAN Hill, ${ }^{1}$ and a little to the north were two other hills which we called THE PAPs, and here was a small tract of country without sand, the eastern part of which forms a cape [ORFord Ness. -R. L. J.], whence the coast inclines to the NW. by N." [SEE MAP A.]

At noon, Bligh observed the latitude of $1 \mathrm{I}^{\circ} \mathrm{I} 8^{\prime} \mathrm{S}$., the Cape bearing W., at an estimated distance of 10 miles. A few miles further, "five small keys bore W. [SW. ?], distant 4 miles. My course from the Lagoon Island had been N. $\frac{\mathbf{s}}{2}$ W., distance 30 miles."

This day the gunner's watch was lost, so that, as Bligh remarked, "sunrise, noon and sunset for the future were the only points of time accurately known."

1 The tragic events which followed Kennedy's mistaking a similar sandstone-capped hill, 50 miles to the south, for Pudding Pan Hill, are related in a subsequent chapter.R. L. J. 
"At 5 p.m.," continues Bligh, "steering to the NW., we passed a large and fair inlet [Escape River, in $10^{\circ} 5^{\prime}$.- R. L. J.], into which, I imagine, there is a safe and commercial entrance. It lies in lat. $\mathrm{II}^{\circ} \mathrm{S}$. About three leagues [miles ?-R. L. J.] to the north of this, is an island, at which we arrived about sunset, and took shelter for the night under a sandy point which was the only part we could land at. . . The island was covered with wood, but in other respects it was a lump of rock.

"Wednesday, 3rd fune.-We lay at grapnel till daylight. The main bore from SE. by S. to NNW. $\frac{1}{2}$ W., 3 leagues; and a mountainous island with a flat top [MounT Adolphus Island.-R. L. J.] N. by W., 4 or 5 leagues, between which and the mainland were several other islands. The spot we were at, which I call Turtle IsLand [He grappled to the island on Tuesday night, and therefore it would be his TuesDay IsLAN D. - R. L. J.], lies in latitude, by account, $10^{\circ} 52^{\prime} \mathrm{S}$. [say, $10^{\circ} 55^{\prime} \mathrm{S} .-\mathrm{R}$. L. J.]. Abreast of it, the coast has the appearance of a sandy desert, but improves about 3 leagues further to the northward, where it terminates in a point, near to which are many small islands. I sailed between these islands, where $I$ found no bottom at 12 fathoms [He did not take the Albany Pass, in which the greatest depth is II fathoms.R. L. J.], the high mountainous land with a flat top [Mount Adolphus Island.R. L. J.] and four rocks to the SE. of it, that I call the BROTHERs, being on my starboard hand. Soon after, an extensive opening appeared in the mainland [He evidently considered Prince of $W$ ales and other high islands to be part of the mainland.- R. L. J.], in which were a number of high islands. I called this the Bay of Islands. We continued steering to the NW. Several islands [ENDEAvour STrait, across which a chain of islands (including Cook's Possession Island), stretching westward from Peak Point, Cape York, to Rattlesnake Point, Prince of Wales Island.-R. L. J.] and keys were in sight to the northward. The most northerly island was mountainous, having on it a very high round hill ; and a smaller was remarkable for a single-peaked hill.

"The coast to the northward and westward of the Bay of Islands [HoRn and Prince of Wales Islands.-R. L. J.] is high and woody, and has a broken appearance, with many islands close to it, amongst which there are fine bays and convenient places for shipping. The northernmost of these islands I call WEDNESDAY IsLAND [Wednesday, 3rd June, 1789]. ${ }^{1}$ To the NW. of this, we fell in with a large reef [NoRTh-West REEF.-R. L. J.], which, I believe, joins a number of keys that were in sight from the NW. to the ENE. We therefore stood to the SW., half a league, when it was noon, and I had a good observation of the latitude in $10^{\circ} 3 \mathrm{I}^{\prime} \mathrm{S}$. Wednesday Island bore E. by S., 5 miles; the westmost land in sight [HAMMOND IsLAND.-R. L. J.], SW., 2 or 3 leagues; the islands to the northward from NW. by W. to NE. ; and the reef from W. to NE., distant I mile. I was now tolerably certain that we should be clear of New Holland in the afternoon.

"I know not how far this reef extends. It may be a continuation or a detached part of the range of shoals that surround the coast. I believe the mountainous islands [Prince of Wales IsLand.-R. L. J.] to be separate from the shoals, and have no doubt that near them may be found good passages for ships. But I rather recommend those who are to pass this strait from the eastward to take their direction from the coast of New Guinea. Yet I likewise think that a ship coming from the southward will find a fair strait in the latitude of $10^{\circ} \mathrm{S}$. . . .

"At 2 p.m., as we were steering towards the westernmost part of the land in sight, we fell in with some large sandbanks that run off from the coast. I therefore called this Shoal CAPE. We were obliged to steer to the northward again till we got round the shoals, when I directed my course to the west.

"At 4 o'clock, the westernmost of the islands to the northward bore N., 4 leagues ;

1 Bligh did not name Tuesday, Thursday or Friday Islands. $\mathrm{He}$ anchored on Tuesday at Turtle Island. After leaving Wednesday Island on Wednesday, 3rd June, he took the Prince of Wales Channel and reached Booby Island in the afternoon. The earliest reference to Thursday Island which has come under my notice is contained in Lieut. James Grant's Narrative of a Voyage of Discovery in the "Lady Nelson," 1801-2. London, 1803. 
Wednesday Island E. by N., 5 leagues; and Shoal Cape SE. by E., 2 leagues. A small island was seen bearing W., at which we arrived before dark, and found that it was only a rock, where boobies resort, for which reason I called it Bоову IsLand. Here terminated the rocks and shoals of the north part of New Holland, for, except Booby Island, no land was seen to the westward of south after 3 o'clock this afternoon.

"I find that Booby Island was seen by Captain Cook, and, by a remarkable coincidence of ideas, received from him the same name; but I cannot with certainty reconcile the situation of some parts of the coast that $I$ have seen to his survey. I ascribe this to the various forms in which land appears when seen from the different heights of a ship and a boat.

"The chart which I have given is by no means meant to supersede that made by Captain Cook, who had better opportunities than I had and was in every respect properly provided for surveying. The intention of mine is chiefly to render this narrative more intelligible, and to show in what manner the coast appeared to me from an open boat. I have but little doubt but that the opening which I have named the BAy of Islands is Endeavour Straits; and that our track was to the northward of Prince of Wales Isles. Perhaps, by those who may hereafter navigate these seas, more advantage may be derived from the possession of both our charts than from either of them singly."

Without landing on Bоoвy Istand, Bligh left it late on 3 rd fune. He reached Koepang, Timor, on 14th June, 1789, and having obtained a passage to Europe on a Dutch vessel, landed at Portsmouth on I4th March, I790. Nine of the mutineers found their way to Pitcairn Island, where they married native women and founded a colony, which is still in existence. The fate of the other sixteen is bound up with the voyage and wreck of the frigate "Pandora," to which a chapter must be devoted. 


\section{CHAPTER XIV}

\section{THE VOYAGE OF THE “PANDORA," I79r EDWARD EDWARDS}

"Pandora" sent to apprehend "Bounty" Mutineers. Arrests fourteen at Tahiti. Reaches Murray Islands. Wrecked at Pandora Entrance while searching for a Passage through Barrier Reef. Many drowned. Survivors take to Boats. Boats thread Barrier Reef and reach Queensland Coast near Orford Ness. Northward to Mount Adolphus Island. Skirmish with Natives. Westward. Horn Island. Wolves (Dingoes). Hunger and Thirst. Through Flinders Passage (between Horn and Wednesday Islands) and Prince of Wales Channel. Good Island. Timor. Passengers to Spithead. Trial and Punishment of Mutineers.

THE "Pandora," a frigate carrying I60 men and 24 guns, was commanded by CAPTAIN (afterwards Admiral) EDWARD EDWARds. Her commission was to capture and bring to punishment the mutineers who had seized the "Bounty," one of His Majesty's ships of war, and turned her Captain and his adherents adrift in an unvictualled open boat.

The fullest record of this voyage is the narrative of the Surgeon, George Hamilton. ${ }^{1}$ Next in importance as regards detail, though probably more reliable as to the navigation, are the Commander's Reports to the Admiralty, especially one dealing with the wreck on the Barrier Reef and the subsequent passage of the survivors, in four boats, through Torres Strait.2 Then a Chart of the Voyage, up to the date of the wreck, was constructed by Lieutenant Hayward, and was published in 1798 by Alexander Dalrymple. From the above materials, Flinders compiled a short account of the voyage for his introductory chapter of Terra Australis (I, XVI). On his own chart, he copied the route, as far as the wreck, from Dalrymple; but he frankly admitted that, as regards the boat voyage, the imperfection of the narrative had baffled his editorial capacity. No serious attempt to identify the route followed by the boats appears to have been made up to 1915, when Basil Thomson, ${ }^{3}$ formerly of the Colonial Service and

1 A Voyage Round the World in H.M. Frigate "Pandora," by George Hamilton, Surgeon, R.N. Berwick and London, 1793.

2 Report dated Batavia, 25th November, I791 ; endorsed " 29th May, 1792, from Amsterdam."

"Voyage of H.M.S. "Pandora," dispatched to arrest the Mutineers of the "Bounty": being the Narratives of Captain Edward Edwards, R.N., the Commander, and George Hamilton, the Surgeon. London, Francis Edwards, 1915. 
Acting Prime Minister of Tonga, reprinted and edited the narratives of the Commander and Surgeon.

The "Pandora" left Portsmouth in August, I790, and reached TAhiti on 23rd March, I79I. Here sixteen of the MUTINEERS had settled down, but two had already been killed by the natives. The fourteen remaining were arrested and confined on board the "Pandora." The frigate left Tahiti on 8th May, and after having made some search (without having any clue) for the "Bounty," continued her voyage, via Palmerston Island, Atafu, Samoa, the Friendly Islands and Tongatabu, Wallis Island, the Santa Cruz Islands and Indispensable Reefs, to the Great Barrier Reef. (Sez Map A.) The latter was met with on $26 t h$ August, ${ }^{1}$ in about $10^{\circ} \mathrm{S}$. lat. Steering westward, the Murray Istands were seen and named. The islands were found to be fringed by a reef, which forced the ship to take a southerly course, interrupted by many attempts to find a westerly passage. The last of these attempts was made on 29th August, late in the afternoon, when the ship grounded on the reef in about $\mathrm{II}^{\circ} 24^{\prime} \mathrm{S}$. lat. The spot is now charted as Pandora Entrance. The "Pandora" was hammered on the reef during the whole of the night, but at daylight next morning (3oth August) slipped over into deep water and sank. Thirty-one of the ship's company and four of the mutineers were drowned. Ninety-nine men answered the rollcall and found temporary refuge on a sandbank about four miles from the wreck. Very little could be saved and the party were almost destitute of provisions. It may be assumed, however, that the Captain saved his sextant and charts and that each of the boats carried a compass. A reference by Hamilton to the boat's position " at meridian" makes it probable that Lieutenant Larkin, on the "red yawl," had a sextant.

From this point it is necessary to compare the reports of the Commander and Surgeon, remembering always that the two witnesses were in different boats, which parted company for a time.

\section{CAPTAIN EDWARDS}

"On the Ist September, I79I, the BoATs were completed and were launched, and we put everything we had saved on board of them, and at half-past ten on the forenoon we embarked. .... We steered NW. by W. and WNW., within the reef. This channel through the reef is better than any hitherto known, besides the advantage it has of being situated further to the north, by which many difficulties would be avoided when within the reef. In the run from thence to the entrance of Endeavour Straits, there is a small white island or key on the larboard end of the channel, which lies in latitude $\mathrm{II}^{\circ} 23^{\prime} \mathrm{S}$. The sides are strong and irregular.

"On the $2 n d$ September, in the morning, saw land, which probably was the coast of NEW South WaLEs. The yawls were sent on shore to ground [sound ?] and look

1 I correct the dates from this point onward. Captain Edwards had lost a day in sailing round the world, but he did not make the correction till he reached Timor.R. L. J. 
out. They saw ['on entering a very fine bay,' according to Hamilton] a run of water, landed and filled their two barricois, which were the only vessels of consequence they had with them, [What follows is the narrative of Captain Edwards in the pinnace, the Surgeon, with the yawls, having taken a more southerly course, almost west, for the nearest land.-R. L. J.], and I steered for an island called by Lieutenant Bligh Mountainous Island [Mount Adolphus Island.-R .L. J.], and when JoINED BY THE BOATs ran into a bay of that island [on 3 rd September] . . ."

\section{SURGEON HAMILTON}

"Everything being ready on the following day, Ist September, at I2 o'clock [10.30 a.m., Captain], we embarked in our little squadron, each boat having been previously supplied with the latitude and longitude of the island of Timor, r, 100 miles from this place. Our order of sailing was as follows :-

"In the Pinnace.-Captain Edwards; Lt. Hayward; Mr. Rickards, Master's Mate; Mr. Packer, Gunner; Mr. Edmonds, Captain's Clerk; Three Prisoners; Sixteen Privates.

"In the Red Yawl.-Lt. Larkin; Mr. George Hamilton, Surgeon; Mr. Reynolds, Master's Mate; Mr. Matson, Midshipman; Two Prisoners; Eighteen Privates.

"In the Launch.-Lt. Corner; Mr. Gregory Bentham, Purser ; Mr. Montgomery, Carpenter; Mr. Bowling, Master's Mate; Mr. McKendrick, Midshipman; Two Prisoners; Twenty-four Privates.

"In the Blue Yawl.-Mr. George Passmore, Master; Mr. Cunningham, Boatswain; Mr. James Innes, Surgeon's Mate; Mr. Fenwick, Midshipman; Three Prisoners; Fifteen Privates.

"As soon as we embarked, we laid the oars upon the thwarts, which formed a platform, by which means we stowed two tiers of men. A pair of wooden scales was made in each boat, and a musket-ball weight of bread served to each man.

"At meridian, we saw a key, bounded with white craggy rocks. As the principal part of our subsistence was in the launch, it was necessary to keep together, both for our defence and support. We towed each other during the night and at daybreak cast off the tow-line.

"At 8 in the morning [2nd September] the red and blue yawls were sent ahead to sound and investigate the coast of New South Wales and to search for a wateringplace. The country had been described as very destitute of the article of water; but on entering a very fine bay [Orford Bay.-R. L. J.] we found most excellent water rushing from a spring at the very edge of the beach. Here we filled our bellies, a tea kettle and two quart pots. The pinnace and launch had gone too far ahead to observe any signal of our success, and immediately we set sail after them. The coast has a very barren aspect, and from the appearance of the soil and land, looks like a country abounding with minerals.

"As we passed round the bay [towards Usher Point, west of Gilmore Bank.R. L. J.] two canoes, with three black men in each, put off and paddled very hard to get near us. They stood up in the canoes, waved, and made signs for us to come to them. But as they were perfectly naked, had a very savage aspect, and having heard an indifferent account of the NATIVEs of that country, we judged it prudent to avoid them.

"In two hours we joined the pinnace and launch, which were lying to for us. At ro at night, we were alarmed with the dreadful cry of 'Breakers ahead.' We had got amongst a reef of rocks ; and in our present state, being worn out and fatigued, it is difficult to say how we got out of them, as the place was fraught with dangers all round. ... After running along, we came to an inhabited island, from which we promised ourselves a supply of water. [It was evidently daylight, and therefore 3 rd September.-R. L. J.] On our approach, the Natrves flocked down to the beach in crowds. . . . We made signals of distress to them for something to drink-which they understood; and on receiving some trifling presents .... they brought us a 
cag of good water, which we emptied in a minute, and then sent if back to be filled again. They, however, would not bring it the second time, but put it down on the beach and made signs to us to come on shore for it. This we declined, as we observed the women and children running and supplying the men with bows and arrows. In a few minutes, they let fly a shower of arrows amongst the thick of us. Luckily, we had not a man wounded; but an arrow fell between the Captain and Third Lieutenant and went through the boat's thwart and stuck in it. We immediately discharged a volley of muskets at them, which put them to flight. There were, however, none of them killed. We now abandoned all hopes of refreshment here. This island lies contiguous to Mountainous Island [Mount Adolphus Island.-R. L. J.]. It may be observed that the channel through the reef is better than any hitherto known. ${ }^{1}$ We ascertained the latitudes with the greatest accuracy and exactness."

The writer goes on to advise the Government to plant pines and coco-nut palms as landmarks.

\section{CAPTAIN EDWARDS}

"I steered for an island called by Lieutenant Bligh Mountainous Island, and when joined by the boats [2nd September] ran in to a bay of that island [3rd September, Mount Adolphus Island.-R. L. J.], where we saw indians on the beach. The water was shoal, and the Indians waded off to the boats. I gave them some presents and made them sensible that we were in want of water. They brought us a vessel filled with water, which had been given them for the purpose, and they returned to fill it again. They used many signs to signify they wished us to land, but we declined their invitation from motives of prudence.

"Just as a person was entering the water with the second vessel of water, an arrow was discharged at us by another person, which struck my boat on the quarter, and perceiving that they were collecting bows and arrows, a volley of small arms was fired at them, which put them to flight. I did not think proper to land and get water by force, as land was seen at that time in different directions, which by appearance was likely to produce that article, and which I flattered myself we might be able to procure without being drove to that extremity. I therefore ran close along the shore of this island and landed at different places at some distance from the former situation. I also landed at another island near it, which I called Plum Island [Thomson's footnote: 'TRee Island.' Possibly Little Adolphus Island.R. L. J.], from its producing a species of that fruit, but we were unsuccessful in finding the article we were in search of and in so much want of.

"In the evening [3rd September] we steered for the islands which we supposed were those called by Captain Cook the PRINCE of WALES IsLANDS, and before midnight came to a grapnel ... . near one of these islands, in a large sound formed by several of the surrounding islands, to several of which we gave names, and called the sound SANDwich Sound. ${ }^{2}$ It is fit for the reception of ships, having from 5 to 7 fathoms of water. There is plenty of wood on most of the islands, and by digging we found very good water [in the morning of 4 th September.-R. L. J.] on the flat part of a large island which I called I_Afory's IsLand [Basil Thomson's Note: Horn Island], situated on the larboard hand as we entered the sound from the eastward. We saw a burying-place and several wolves [Basil Thomson's Note: 'Dingoes'] near the watering-place, but we saw no natives. Here we filled our several vessels with water and made two canvas bags, in which we also put water, but with this assistance we had barely the means to take a gallon of water for each man in the boats. We sent

1 Evidently an interpolation, being practically a quotation from the Captain's log, which Mr. Hamilton probably saw at Batavia.-R. L. J.

2 Basil Thomson's Note: "Now called Prince of Wales Channel. It is the best channel through Torres Straits, and if Edwards' narrative had been published, his discovery would doubtless have been perpetuated in his name." 
our kettles on shore and made tea and portable broth, and a few oysters we picked off the rocks, with which we made a comfortable meal, indeed the only one which we had made since the day before we left the ship."

\section{SURGEON HAMILTON}

" 3 rd September.-We steered from these hostile savages to other islands in sight, and sent some armed men on shore... without success. This island we called Plumb Island, from its bearing an austere, astringent kind of fruit, resembling plumbs, but not fit to eat.

"In the evening, we steered for these islands which we supposed were called the Prince of Wales Islands, and about 2 o'clock in the morning [4th September. 'Before midnight,' says the Captain], came to anchor, with a grappling, alongside of an island, which we called Lafory's Island [Horn IsLand]. As the night was very dark, and this was the last land that could afford us relief, all hands went to sleep.

"The morning [ 4 th September] was ushered in with the howling of wolves, who had smelt us in the night. . . Lieutenant Corner and a party were sent at daylight to search again for water; and, as we approached, the wild beasts retired and filled the woods with their hideous growling."

Water was discovered on digging in a hollow. Signs of recent human presence were also observed.

"After having gorged our parched bodies with water till we were perfectly waterlogged, we began to feel the cravings of hunger-a new sensation of misery we had hitherto been strangers to, from the excess of thirst predominating. We found a harsh, austere, astringent fruit, resembling a plumb. ... We permitted the men to fill their bellies with them. There was also a small berry, of similar taste to the plumb. ... We carefully avoided shooting at any bird, lest the report... should alarm the natives, whom we had every reason to suspect were at no great distance. .... When every other thing was filled with water, the carpenter's boots were also filled. The water in them was first served out, on account of leakage.

"There is a large sound here, to which we gave the name of SANDwICH's Sound [now Flinders Passage], and commodious anchorage for shipping in the bay, to which we gave the name of WoLF's BAY, in which there is from 5 to 7 fathoms water all around. This is extremely well situated for a rendezvous in surveying Endeavour Straits ; and were a little colony settled here, a concatenation of Christian settlements would enchain the world and be useful to any unfortunate ship; . . . or should a rupture take place with South America, a great vein of commerce might find its way through this channel.

“ Hammond's Island lies NW. by W., Parker's Island [Wednesday Island ?] from $N$. and by W. to N. and by E., and an island seen to the north entrance NW. We supposed it to be an island called by Captain Bligh Mountainous Island [now BAN KS IsLAND.-R. L. J.], laid down in latitude $10^{\circ} 16^{\prime} \mathrm{S}$. [The island now charted as Hammond Island may or may not be the one so named on this occasion, as the above confused description does not tally with anything when the bearings are plotted on the modern chart. The name, however, has been perpetuated, but must be regarded as a 'complimentary' one.-R. L. J.]

"SANDwich's Sound is formed by Hammond's, Parker's and a cluster of small islands on the starboard hand at its eastern entrance. We also called a back land behind Hammond's Island and the other islands to the southward of it, Cornwallis LAND. The uppermost part of the mountain was separated from the main by a large gap. Under the gap, low land was seen; but whether that was a continuation of the main or not we could not determine. Near the centre of the sound is a small, dark-coloured, rocky island. [By a 'back land,' Hamilton probably meant a land 
behind the boats, and on this assumption his Cornwallis Land was probably Prince of Wales IsLand.-R. L. J.]

"This afternoon, at 3 o'clock, being the 4 th of September, our little squadron sailed again, and in the evening saw a high-peaked island lying NW., which we called HaWkesbury's IsLand [It rises to 560 feet]. The passage through the north entrance [i.e., between Flinders Passage and Prince of Wales Channel.-R. L. J.] is about 2 miles wide. After passing through it, saw a reef. As we approached it, we shallowed our water to 3 fathoms; but on hauling up more to the SW. we deepened it again to 6 fathoms. Saw several large turtle, but could not catch any.... After clearing the reef, stood to the westward. Mountainous Island [BAN KS IsLAND] bore N. $\frac{1}{2}$ E.; Captain Bligh's WEst IsLAND, which appears in three hummocks, NNW.; a rock [RED WALlis IsLAND] NW., at the SW. extreme of the mainland, S. and by E.; and the northernmost Cape of New South Wales SSE. [Not really Cape York, but the projecting hump of land west of the mouth of the Jardine River and south of Cook's Possession Island.-R. L. J.]; and to the extreme of the land in sight, the eastward E. $\frac{1}{2}$ N., a small distance from the nearest of the Prince of Wales Islands, we discovered another island, and which we called Christian's Island. Saw two hummocks [Duncan Islands, or Phipps and Spencer Islands.-R. L. J.] between Hawkesbury's Island and Mountainous Island; but could not be certain whether it was one or two islands.

"We now entered the great Indian Ocean, and had a voyage of 1,000 miles to undertake in our open boats. As soon as we cleared the land, we found a very heavy swell running, which threatened destruction to our little fleet; for should we have separated, we must inevitably perish for want of water, as we had not utensils to divide our slender stock. For our mutual preservation, we took each other in tow again."

\section{CAPTAIN EDWARDS}

"On the 4 th September, at half-past 3 in the afternoon, we stood out of the north entrance of the sound [i.e., out of Flinders Passage into Prince of Wales Channel. -R. L. J.]. Before 5, we saw a reef extending from the N. to the WNW., and which appeared to run in the latter direction, or more to the westward [NoRTH-West REEF]. On the edge of this reef, we had $3 \frac{3}{4}$ fathoms of water, and after hauling to the southwest we soon deepened our water to 5 fathoms. Besides Mountainous and West Islands, seen by Lieutenant Bligh, we saw several other islands between the north and the west, one of which I called Hawkesbury IsLand. . . .

"In the evening, we saw the Northernmost extremity of New South WaLes [really the hump of land west of the mouth of the Jardine River.-R. J. L.], which forms the south side of Endeavour Straits. At night the boats took each other in tow and we steered to the westward.

"It is unnecessary to retail our particular sufferings in the boats during our run to Timor, and it is sufficient to observe the company suffered more from heat and thirst than from hunger, and that our strength was greatly decreased. We fortunately had good weather."

Surgeon Hamilton states that "we ascertained the latitudes with the greatest accuracy and exactness," a claim which he would hardly have made on his own account, and which, it may be conjectured, he simply copied from the Captain's log, of which the latter evidently made only a short abstract for his reports to the Admiralty. Nor, I imagine, would the Captain himself have made such a claim unless he had been provided with a sextant. The Captain gives the position of Murray Islands as $9^{\circ} 57^{\prime} \mathrm{S}$. and $216^{\circ} 43^{\prime} \mathrm{W}=$ $143^{\circ} \mathrm{I} 7^{\prime} \mathrm{E}$. ; and the WRECK REEF is also given in his table, but the figures are left blank. The Surgeon gives the same position to the 
Murray Islands, and fills in the blank at the Wreck Reef with the figures $11^{\circ} 22^{\prime} \mathrm{S}$. and $216^{\circ} 22^{\prime} \mathrm{W} .=143^{\circ} 38^{\prime} \mathrm{E}$. The inference is that he copied from the Captain's log, and set down, without question, data regarding which the Captain himself had some doubt, so that he omitted them from his report.

After many attempts at plotting from Hamilton's data, on various hypotheses as to his meaning, I can no more make head or tail of the positions of the islands and other landmarks mentioned by him than could Flinders, although I had the advantage of more complete charts than were accessible to, or made by, Flinders. One hypothesis, suggested by the Surgeon's tale, which I tried by all possible tests, was that the boats went through Endeavour Strait; but this is flatly contradicted by the Captain's narrative. I am satisfied, therefore, that Basil Thomson is correct in supposing that the "Sound " referred to by both Captain and Surgeon was neither Endeavour Strait as a whole nor the passage between Entrance Island and Prince of Wales Island, but the strait between Horn and Wednesday Islands, now known as Flinders Passage. Edwards thus anticipated Flinders (in the "Cumberland") by twelve years. The island named LAFORY's was, no doubt, as suggested by Basil Thomson, Horn IsLAND, and the "wolves" which Edwards saw and Hamilton heard must have been Dingoes. This is the only mention of the dingo as an indigenous inhabitant of the Torres Strait Islands which I have met with.

Edwards, then, took the "Pandora's" boats through the Flinders PASSAGE, and was actually its discoverer, rounded the north end of Hammond Island, ${ }^{1}$ entered the Prince of Wales Channel and passed through its western half. The first to enter the Prince of Wales Channel was Gonzal, in the "Rijder," in 1756. Bligh, in the "Bounty's" launch, in 1789 , was the first to traverse it from end to end.

Endeavouring to maintain a westerly course through the Channel, Edwards encountered the "North-West ReEF," and was forced by it southwards, nearly to Good Island, before he found an open sea by which he could make westward for Timor.

On emerging from the strait, a last glimpse of Australian land was obtained, S. and by E. Both Edwards and Hamilton refer to this as the northernmost extremity of New South Wales, Edwards adding "which forms the south side of Endeavour Straits." The land visible from the observer's position could not have been Cape York, which would be shut out by the high Prince of Wales Island, and must have been the blunt promontory west of the MoUTH oF THE JARDINE RIVER.

The provisions with which the boats left the scene of the wreck were inventoried as " a small barrel of water, a keg of wine and some

1 He gave the name of Hammond to some island hereabouts, but his narrative does not make it clear that it was the island now known by this name. 
biscuit." The ship's cat was saved from the wreck. The scanty fare was supplemented by shellfish while the party sojourned among the Torres Strait islands.

The survivors got a passage from Koepang, in Trmor, to Batavia and thence to Europe. At the Cape of Good Hope, Edwards and his prisoners were transferred to H.M.S. "Gorgon." They arrived at Spithead on 19th June, 1792. The prisoners were tried by court martial, when six were condemned to death (18th September), and three were executed.

It is beyond the limits of our task to relate the whole story of the mutiny, one of the most tragic and romantic in modern history ; but the reader who desires to pursue the subject for its own inherent interest may refer to Sir John Barrow's little book, The Mutiny of the "Bounty" (the World's Classics, No. CXCV, 1914). 


\section{CHAPTER XV}

BLIGH, I788-92, continued

\section{SECOND VOYAGE THROUGH TORRES STRAIT WITH THE "PROVIDENCE" AND "ASSISTANT," 1792}

Bligh COMmissioned to CONVEy Breadfruit from Tahiti to West Indies. Flinders, a Junior Officer on the "Providence," the Historian of the Expedition. Lieutenant Portlock commanding the "Assistant." Bligh plans to keep close to New Guinea. The Portlock Reefs. Darnley Islands. "Assistant's" Boats attacked by Islanders in Canoes. Nepean Island. Darnley Islanders come out to barter. Iron In GReat Demand, Stephens' and Campbell Islands. Dalrymple Island. Natives barter Fruit and Ornaments for Iron. Dungeness Reef and Island. Warrior Regf and Island. The Channel (later, Basilisk Pass) through the Reef. Determined Attack by Islanders. Turtle-backed Island. Cap Island. Ban ks Island seen and named. Burke's Island. Mt. Cornwallis (Cornwallis Island). Turn-again and Jervis Islands. Orman Reef. Mulgrave Island. North Possession Island. Bligh takes possession of Torres Strait Islands. Jervis Island and Bligh Channel (previously used by Torres). Threatening Islanders. Shoal cleared. Bligh's Farewell. Sea-room enough. Timor. Promotion of Bligh and his Subsequent Naval Services. Bligh appointed Governor of New South Wales. A Stern Disciplinarian, but arrogant and brutal. His Attempt to stop the Rum Scandal in New South Wales. Arrested and deposed by the New South Wales Corps. Promotion to Vice-Admiral. Death. A French Appreciation of his Qualities.

AVING reached England after his perilous voyage in the open boat, following on the mutiny of the "Bounty," and written his Narrative, Bligh was given command of H.M.S. "Providence," and was accompanied by the brig “Assistant," under Lieutenant J. Nathaniel Portlock, in a second expedition having for its object the transference of breadfruit from Tahiti to the West Indies. He had thus another opportunity of traversing Torres Strait, and this time he succeeded in his mission. So far as is known, he wrote no report on this voyage, but he lodged his charts in the Admiralty Office. The only available record of the voyage is the journal kept by MATTHEW Flinders, who accompanied Bligh as a junior officer. (Terra Australis, Vol. I, pp. xix. et seq.). Bligh's charts, "with other authorities," were incorporated in Plate XIII of Flinders' Atlas, and the journal was sanctioned by Bligh, so that there is every reason for accepting it as authoritative. The expedition left 
England in 1791. The quotations which follow are from Flinders' Journal.

Having come to the conclusion, when he threaded Torres Strait in the open boat three years before, that ships attempting the passage from the east should keep in touch with the New Guinea coast, Bligh took the "Providence" and "Assistant" north of his former course. After passing south of the Louisiade Archipelago and the south-eastern part of New Guinea, he sighted the REEFS which he named after Captain Portuock on Ist September, I792. After seeking vainly for a passage to the south, he steered to the north till he had cleared the Portlock Reef, when he bore NW. and SSW. for the high land which he named Darnley Island, and anchored NE. of the island on 4th September, 1792. He might, had he known the soundings, have set a straight course SW. for Dalrymple Island, through what is now charted as "BLIGH ENTRANCE," but he did not, preferring to make for the landmark to which he gave the name of Darnley. (Ser Map A.)

" 5 th September, 1792.-Boats were again sent to sound the passage. Several large sailing canoes were seen, and the cutter making the signal for assistance, the pinnace was sent to her, well manned and armed. On the return of the boats in the afternoon, it appeared that of four canoes which used their efforts to get up to the cutter, one succeeded. There were in it 15 Indians . . . and they made signs which were interpreted to be amicable. These signs the officer imitated, but not thinking it prudent to go so near as to take a green coco-nut which was held up to him, he continued rowing for the ship. A man who was sitting upon the shed erected in the centre of the canoe then said something to those below, and immediately they began to string their bows. Two of them had already fitted arrows, when the officer judged it necessary to fire in his own defence. Six muskets were discharged, and the Indians fell flat into the bottom of the canoe, all except the man on the shed. The seventh musket was fired at him, and he fell also. During this time, the canoe dropped astern, and the three others having joined her, they all gave chase to the cutter, trying to cut her off from the ship; in which they would probably have succeeded had not the pinnace arrived at that juncture to their assistance. The Indians then hoisted their sails and steered for Darnley's Island.

"No boats could have been manœuvred better in working to windward than were these long canoes by the naked savages. Had the four been able to reach the cutter, it is difficult to say whether the superiority of our arms would have been equal to the great difference of numbers, considering the ferocity of these people and the skill with which they seemed to manage their weapons.

" 6 th September. - Two boats were sent ahead and the vessels followed them, between Canoe Key and the reef lying from it half a mile to the north. After running 12 miles beyond this narrow pass, they anchored in 13 fathoms, the latitude being $9^{\circ} 37^{\prime}$ and longitude $143^{\circ} 4 \mathrm{I}^{\prime}$ [east of 'Tobin Cay.-R. L. J.]. In the afternoon, they proceeded 5 miles further to the NNW., and Darnley's Island then bore S. $74-75^{\circ} \mathrm{E}$., 2 leagues. Except on the north side, this island appears to be surrounded with reefs and sandbanks to a considerable distance. In sailing for [from.-R. L. J.] Canoe Key, the vessels had left on the larboard hand a long chain of reefs and banks, at the north end of which were three low woody islands, the nearest of these, bearing S. $4 \mathrm{I}^{\circ} \mathrm{W} ., 2$ or 3 miles from the anchorage, was named Nepean IsLand. . . .

"This day, several canoes from Darnley Island came off to both vessels. On approaching, the Indians clapped upon their heads and exclaimed 'Whou! whou! whou !' repeatedly, with much vehemence; at the same time they held out arrows 
and other weapons, and asked for 'toree, toree,' by which they meant iron. . . . Their arms were bows, arrows and clubs, which they bartered for every kind of ironwork with eagerness, but appeared to set little value on anything else. . . .

"Their canoes are about 50 feet in length, and appear to have been hollowed out of a single tree. ... These vessels are low forward, but rise abaft, and being narrow are fitted with an outrigger on each side to keep them steady. A raft, of greater breadth than the canoe, extends over about half the length, and upon this is fixed a shed or hut, thatched with palm leaves. These people, in short, appeared to be dextrous sailors and formidable warriours, and to be as much at ease in the water as in their canoes.

" 7 th September. - The boats having found deep water round the north end of the three low islands, the vessels followed them, but anchored again soon after noon, in lat. $9^{\circ} 3 \mathrm{I}^{\prime}$ and long. $143^{\circ} 3 \mathrm{I}^{\prime}$, being sheltered by the two western IsLaNDs, named Stephens' and Campbell's, and the reefs which surround them. . . .

" 8th September.-The vessels steered westward. . . . No land or other obstruction had been seen in that quarter, but at Io o'clock they were forced to haul the wind to the southward, their course being impeded by reefs, upon one of which was PEARCE's SANDY KEY. At noon they had anchored in 15 fathoms under the lee of DaLRYMPLE's ISLAND, the westernmost before seen; but two other islands were then visible in the S. by W. ... The latitude here was $9^{\circ} 37^{\prime}$ and longitude $143^{\circ} 31^{\prime}-143^{\circ} 15^{\prime} \mathrm{E}$. In the afternoon, NATIVEs came out from the beach and exchanged ornaments and plums for iron. A moderate-sized dog, of a brown chestnut colour, was observed amongst the party."

9th September.-The ships still followed the boats, " between the cluster of islands to the southward and an extensive reef to the west. ${ }^{1}$... At noon, the lat. was $9^{\circ} 4^{\prime}$, long. $143^{\circ} 6^{\prime}$, and two other islands came in sight to the westward. Before $20^{\prime}$ clock, an extensive reef, partly dry, to which the name of Dungeness was given, made it necessary to heave to until the boats had time to sound; after which Captain Bligh bore away along the north side of the reef, and anchored a mile from it. . . . In this situation Dungeness IsLAND, which is low and woody, bore N. $64-87^{\circ} \mathrm{W}$., 3 miles, and a small sandy isle, named Warriour's IsLand, N. 6- ${ }^{\circ}$ W., 4 miles . . . . Besides these, there were other low isles, called the Six Sisters, in sight to the SE., and a long flat island, bearing S. $33-46^{\circ} \mathrm{W}$., over the dry Dungeness Reef. In the west also there were islands visible, at a greater distance, and much higher, than the others. The strait, instead of becoming clearer, seemed to be more and more embarrassed with dangers as the vessels proceeded westward. The latitude of this anchorage was $9^{\circ} 50 \frac{1}{2}^{\prime} \mathrm{S}$. and longitude $142^{\circ} 55^{\prime} \mathrm{E}$.

" Ioth September.- The boats sounded the channel [Basilisk Pass, so named in I871 by Captain Moresby, of the 'Basilisk.'-R. L. J.] to the north-west between Dungeness and Warriour's Islands, and finding sufficient water the vessels got under way at noon to follow them. There were many natives collected upon the shore of Dungeness Island, and several canoes from Warriour's Island were about the brig. Presently Captain Portlock made the signal for assistance, and there was a discharge of musketry and some guns from his vessel and from the boats. Canoes were also coming towards the 'Providence,' and when a musket was fired at the headmost, the natives set up a great shout and paddled forward in a body ; nor was musketry sufficient to make them desist. The second great gun, loaded with grape, was directed at the foremost of eight canoes, full of men, and the round shot, after raking the whole length, struck the high stern. The Indians leaped out and swam towards their companions, plunging constantly to avoid the musket-balls which showered thickly about them. The squadron then made off as fast as the people could paddle, but afterwards rallied at a greater distance, until a shot which passed over their heads made them disperse and give up all idea of any further attack.

"In passing the deserted canoe, one native was observed still sitting in it. The other canoes afterwards returned to him, and, with glasses, signals were perceived

1 Warrior Reef.-R. L. J. 
to be made by the Indians to their friends on Dungeness Island, expressive, as was thought, of grief and consternation.

"No arrows fell on board the 'Providence,' but three men were wounded in the 'Assistant,' and one of them afterwards died. The depth to which the arrows penetrated into the deck and sides of the brig was reported to be truly astonishing.

"The vessels passed between Dungeness and Warriour's Islands [Basilisk Pass.R. L. J.] . . . and anchored at 4 o'clock under the lee of Dungeness Istand and reef. The passage to the westward then appeared clearer, three high islands bearing from S. $60^{\circ} \mathrm{W}$., 3 leagues, to N. $76^{\circ} \mathrm{W}$., 5 leagues, forming the sole visible obstructions.

"IIth September. - ... Course WNW., and passed two islands, to which the descriptive names of TurtLe-BACKed IsLAND and The CAP were given, and soon, after noon, the vessels anchored in 7 fathoms. . . L Lat. $9^{\circ} 43^{\prime}$, long. $142^{\circ} 40^{\prime}$. . . Besides the islands above mentioned, there was in sight a mountainous land, to which the name of BANKs was given, bearing S. $43^{\circ} \mathrm{W}$., 12 or 13 leagues; also BuRKE's Island, S. $13^{\circ} \mathrm{W} ., 8$ or ro leagues, and Mount CoRnwallis, on another island, N. $29^{\circ} \mathrm{W}$., 6 or 8 leagues; and from behind this last, to N. $7^{\circ} \mathrm{W}$., there extended a level land, which was supposed to be a part of the coast of NEw GuinEA.

" 12 th September.-The vessels followed the boats to the westward reefs, ${ }^{1}$ and anchored before noon. Lat. $9^{\circ} 4 \mathrm{I}^{\prime} \mathrm{S}$., long. $142^{\circ} 24^{\prime} \mathrm{E}$. Two other islands were then in sight. A low one, named Turn-Again IsLand, bore N. $53^{\circ} \mathrm{W}$., about 4 leagues, and Jervis Island, which is rather high, S. $48^{\circ} \mathrm{W}$, 9 leagues. . .."

Here the ships lay at anchor for three days, the boats sounding, while a fresh gale blew from the south-east.

" 16 th September.-The vessels passed to windward of the southern [Orman.R. L. J.] reef, and steered south-westward, as it trended, ... . until half-past noon, when they anchored in lat. $10^{\circ} 3^{\prime}$ and long. $142^{\circ} 14^{\prime} .^{2}$ The sole direction in which the eye could range without being obstructed was that whence the vessels had come; everywhere else the view was arrested by rocks, banks and islands. The most extensive of these was BANKs IsLAND, extending from S. $14^{\circ} \mathrm{E}$. to $62^{\circ} \mathrm{W} ., 2$ or 3 leagues, with a little hill upon it, named Mount Augustus, which bore S. $14^{\circ} \mathrm{E}^{3}{ }^{3}$ Another large ISLAND, named MulgRAvE's, extended from behind the last to a cluster of rocks whose extreme bore W. $5^{\circ} \mathrm{N}$. The nearest land, bearing S. $24^{\circ} \mathrm{E}$., $1 \frac{1}{2}$ miles, was the north-westernmost of three small isles, and to this the Second-Lieutenant was sent for the purpose of taking possession of all the islands seen in the strait for His Britannic Majesty George III, with the ceremonies used on such occasions. The name bestowed upon the whole was Clarence Archipelago. [The name has not been adopted by cartographers. - R. L. J.]

"North Possession Island was found to be little else than a mass of rocks surrounded by a reef, but it was covered with a variety of trees and shrubs. Amongst them was a cluster of coco-nut trees, bearing a small but delicious fruit. . . . There did not appear to be any fixed inhabitants upon Possession Island, but from a fire which had been recently extinguished, and the shells and bones of turtle scattered about, it was supposed to have been visited not many days before. . . .

" I 7 th September. - The boats led to the westward, steering for a passage between Mulgrave's and Jervis' Islands; but seeing it full of rocks and shoals the vessels

1 Charted as the "Orman Reef, r8r6."

2 There is an error of 4 minutes in the longitude if the latitude and bearing to Mt. Augustus are right.-R. L. J.

s Note by Flinders: “This mountain, in lat. $10^{\circ} 12^{\prime}$ S., long. $142^{\circ} 13^{\prime}$ E., was seen by Captain Bligh from the 'Bounty's' launch, and marked in his chart (Voyage, \&c., p. 220). It appears to be the same island, indistinctly laid down by Captain Cook in lat. $\mathrm{IO}^{\circ} \mathrm{IO} \mathrm{O}^{\prime}$, long. $\mathrm{I} \mathrm{I}^{\circ} \mathrm{I}^{\prime}$, and is also one of those to which the term HoGE LANDT is applied in Thevenot's Chart of $1663 . "$ (The "little hill" is 1,3 Io feet high, according to modern charts.-R. L. J.). 
anchored a little within the entrance .... until the boats could sound ahead. The latitude here was $10^{\circ} 2^{\prime}$ and long. $142^{\circ} 3^{\prime} .^{1} \ldots$

"Whilst the boats were sounding, several Indians, in three canoes, were perceived making towards them, but on a swivel-shot being fired over their heads they retired to Mulgrave Island, on the south side of the passage.

"On the signal being made for good anchorage further on, the 'Assistant' led to the W. by S.; but on reaching the boats, the bottom was found much inferior to what had been imagined. The approach of night, however, obliged Bligh to anchor soon afterwards. ...

"In this situation, the vessels were so closely surrounded with rocks and reefs as scarcely to have swinging-room. The bottom was rocky. The wind blowing a fresh gale, and a tide running between 4 and 5 knots an hour. This anxious night was, however, passed without accident, and next morning,

" 18 th September, the route was continued through the passage, between reefs and rocks which, in some places, were not three-quarters of a mile asunder. . . .

"On clearing this dangerous pass, which Captain Bligh called Bligh's Farewell, " he anchored in 6 fathoms.... The latitude here was $10^{\circ} 5^{\prime}$, long. $141^{\circ} 56^{\prime}$. From north nearly round by the east to $\mathrm{S} .8^{\circ} \mathrm{E}$., there was a mass of islands, rocks and reefs, at various distances; but in the western half of the compass no danger was visible.

"Igth September.-The wind moderated, and the vessels steered W. by S. until noon. . . The latitude was then $10^{\circ} 8 \frac{1}{2}^{\prime} \mathrm{S}$., longitude by timekeeper $141^{\circ} 3 \mathrm{I}^{\prime} \mathrm{E}$., and no land was in sight; nor did anything more obstruct Captain Bligh and his associate in their route to the IsLAND TIMOR."

After his voyage in the "Bounty," Bligh was promoted to Commander and afterwards to Post Captain. In 1794, he was Captain of the 74-gun "Warrior," off Ushant. In 1797, he commanded the 64-gun "Director" at Camperdown and distinguished himself on the occasion of the mutiny at the Nore. On 2Ist May, I801, he commanded the 64-gun "Glatton" at Copenhagen, and was personally thanked by Nelson.

During the administration of John Hunter and Philip Gidley King as Governors of New South Wales, the colony had got somewhat out of hand, chiefly on account of the "rum"-currency, the usurpation of authority by the New South Wales Corps and questions arising out of the status of freed convicts. To the Government in England, it appeared that the only remedy lay in the appointment of a strict disciplinarian, and his whole career indicated that Bligh was such a man. He took up the reins in 1806 .

"Bligh's insistence on discipline," says Professor Scott, " "was indeed sufficiently stiff, but unfortunately he was also a quarrelsome, ill-tempered, coarse-speaking man. His manner of doing business with those who had to see him was repellent. He would, with no regard for the dignity of his position, pour forth a stream of personal abuse, loaded with dire threats; and if he felt angry with anyone he would blurt out his displeasure, no matter where he was-on the parade ground, in the street, in his own house, or in church. One who had experience of the Governor

1 More like $142^{\circ} 1 I^{\prime}$. At $142^{\circ} 3^{\prime}$, they would have been clear of all reefs and beyond the Farewell Islands. - R. L. J.

2 It is now charted as Bligh Channel. There are very strong grounds for believing that Torres passed through it in $1606 .-\mathrm{R}$. L. J.

\& A Short History of Australia, 1916, p. 66. 
in his tantrums wrote that he would not brook contradiction or protest; ' his features became distorted, he foamed at the mouth, stamped on the ground, and shook his fist at the person so presuming.' He was a law unto himself, and he said so. It can hardly be contended that Bligh's acts were more arbitrary than those of his predecessors, and he had the same refractory material to deal with; but his manner soon made him hated by those who came into personal contact with him, and at length brought about the mutiny by which he was deposed from office."

He was deposed and put under arrest on 26th January, I808, by the New South Wales Corps, whose officers administered the colony until the arrival of Governor Macquarie in December, I809. After his return to England, Bligh was promoted to the rank of RearAdmiral in I8II, and to that of Vice-Admiral in 1814, but he was never again entrusted with official responsibility. He died on 7th December, 1817 .

A foreign, and therefore presumably unbiassed, estimate of Bligh's character, that of the Surgeon-Major of the French warship "La Zièlée" " may be given here.

" He was a sea-wolf, a rude, brutal, intrepid, indefatigable man. He never slept, and could not bear that any of his crew should sleep. He was a poor eater, and he desired that his crew should diet themselves on his scale. All his words were words of wrath. All his orders were threats. All his threats were of the lash. The day comes when his crew revolt and lay hold of the shark that has no pity. 'Cease your cries!' say the mutinous sailors. 'We don't want to kill you, but we will not obey you. We will put the launch in the water, and you in it, with four sailors, all good swimmers. Then you can beat the waves with those hands that are always so ready to strike. Farewell, Bligh, and a good voyage. Here is the compass. Search for and find ...."

Such was the imaginary scene conjured up by the dramatic imagination of the Surgeon while his ship lay fast on a sandbank in the "Canal Mauvais," near Warrior Island and within a few miles of Bligh's track, and when it seemed more than likely that the crews of the "Astrolabe" and "Zèelée" might have to make for Timor in open boats, as Bligh had done forty-eight years before.

1 Voyage autourdu Monde del" "A strolabe" et de la "Zelele," sous les ordres du ContreAmiral Dumont D'Urville, 1837-40, par Elie Le Guillou. Paris, 1843. 


\section{CHAPTER XVI}

\section{THE “HORMUZEER" AND “CHESTERFIELD” (BAMPTON AND ALT)}

1793

From Norfolk Island. Murray Islands sighted. New Guinea sighted. Failure to pass between New Guinea and Louisiade Archipelago. Darnley Island. Natives approach in Canoes and barter Bows and Arrows for Knives, etc. Two Officers of the "Chesterfield " and a Passenger lost. "Hormuzerr's" Boat in search. Natives in Ambush. Treacherous Attack. Landing Party. Darnley and neighbouring Islands taken Possession of. Evidence of Murder of the Missing Men. Punishment. Stephens' Island. Hostile Natives. Campbell's Island. Bristow Island. Stephens' Island. News of Missing Men obtained from a Native. Six were killed and Four Wounded. The Wounded Men escape in Boat and reach Timor Laut, Tenimber Group. Dungeness and Warrior Islands. Ships go through Basilisk Pass. Gabba Island. Mount Cornwallis. Turn-again Island. Talbot Island. Deliverance Island. Through the "Pera's" "Dry Bight" and clear of Torres Strait.

" 7 HE last passage known to have been made through Torres Strait previously to the sailing of the "Investigator,'", says Flinders (Terra Australis, I, xix) "was by Messieurs William Bampton and Matthew Alt, Commanders of the ships 'Hormuzeer' and 'Chesterfield.' Their discoveries were made public in two charts by Mr. Dalrymple in 1798 and I799, and from them, and Captain Bampton's manuscript journal, the south coast of New Guinea and most of the reefs and islands near it are laid down in Plate XIII, after having been adjusted to the observations of Captain Bligh and those subsequently made by me in the 'Investigator' and 'Cumberland.'" Flinders then gives an abridgement of BAMPTON's Journal, which I further condense.

The "Hormuzeer" and "Chesterfield" sailed from Norfolk Island with the intention of passing through TORRES STRAIT by a route which the Commanders did not know to have been before attempted. (SEE MAP A.)

Late on $20 t h$ fune, I793, MUrRay Islands were seen, bearing NW. $\frac{1}{2} W$. The following day the course was changed to the north. At the point where the change was made, the latitude was $10^{\circ} 20^{\prime} \mathrm{S}$. and the longitude $144^{\circ} 50^{\prime} \mathrm{E}$., according to Flinders. It is doubtful whether it was the intention of the Commanders to attempt a 
passage via Murray Island; but if so, the Boot and Portlock Reefs no doubt forced them to alter their plans. At noon on the 22nd, they were in $8^{\circ} 48^{\prime}$ S., and land (NEW GuineA) was seen an hour later. An attempt was made to follow the New Guinea coast and to get away to the north between New Guinea and the Louisiade Archipelago.

No such passage, however, having been found, and following the coast of the Gulf of Papua having carried the ships too far east, it was determined once more to seek a passage through TORRES Strait. From $7^{\circ} 55^{\prime}$ S., ${ }^{1}$ therefore, the ships turned southward on 26 th fune. At dawn on ist fuly, Bligh's DaRnLeY IsLAND was in sight, bearing $W$. by $N$. $\frac{1}{2} \mathrm{~N}$., at an estimated distance of 5 leagues. Next day, the boats were employed in sounding, and NATIVEs from Darnley Island (to which the ships were near enough for coco-nut trees to be seen) approached in canoes and exchanged bows and arrows for knives, etc.

The following quotations are from Terra Australis (I, xxxiii et seq.).

" 3 rd Fuly.-Mr. Shaw, Chief Mate of the 'Chesterfeld,' Mr. Carter, and Captain Hill, of the New South Wales Corps, who was a passenger, went away armed, with five seamen, in a whaleboat, and were expected to return on the following day; but the 4 th, 5 th and 6 th passed, without any tidings of them. . .

" 7 th Fuly.-Two boats, manned and armed, under the command of Mr. Dell, Chief Mate of the 'Hormuzeer,' were sent in search of the whaleboat. On reaching the island, Mr. Dell heard conch-shells sounding in various parts, and saw eighty or ninety armed NaTives upon the shore. To the inquiries, by signs, after the missing boat, they answered that she was gone to the westward; but none of them would venture near; nor did they pay attention to a white handkerchief, which was held up, and had before been considered a signal of peace.

"As the boats proceeded on their search round the island, the natives followed along the shore, with increasing numbers. One man, who was rubbed with something blue, and appeared to be a chief, had a small axe in his hand, which was known, from the red helve, to have belonged to Mr. Shaw. On reaching the bay in the north-west side of the island, Mr. Dell remarked that the natives disappeared, all except about thirty, who were very anxious in persuading him to land. They brought down women, and made signs that the boat and people whom he sought were a little way up in the island. He, however, rowed onward, when the beach was immediately crowded with people who had been lying in ambush expecting him to land.

"After having gone entirely round the island and seen nothing of the objects of his research, Mr. Dell returned to the first cove, where a great number of natives armed with bows, arrows, clubs and lances, were assembled at the outskirt of the wood. By offering knives and other things, a few were induced to approach the boat, and the coxswain seized one of them by the hair and neck, with the intention of his being taken off to the ships to give an account of the missing boat and people. A shower of arrows instantly came out of the wood, and a firing was commenced, which killed one Indian and wounded some others. In the meantime, the coxswain found it impossible to keep the man, from his hair and body being greased, and the boat's crew was too much occupied to assist him.

" 8 th Fuly. - The two Commanders, having heard the report of Mr. Dell, proceeded

1 This latitude is only attainable at the very head of the Gulf of Papua, between longitudes $144^{\circ} \mathrm{E}$. (eastern mouth of Aird River) and $145^{\circ} \mathrm{I} 5^{\prime} \mathrm{E}$. (mouth of Alele River, New Guinea).-R. L. J. 
with the ships round the northern reefs and sandbanks to the bay on the north-west side of Darnley Island, which was named Treacherous Bay.

" 9 th $f$ uly.-In the afternoon they anchored,... the extremes of the island bearing E. $\frac{1}{2}$ N. to SW. by S., and the nearest part distant a quarter of a mile. A boat was sent on shore, and returned at sunset with a few coco-nuts, but without having seen any of the inhabitants.

" roth fuly.-An armed party of 44 men landed from the ships, under the command of Mr. Dell. After hoisting the Union Jack and taxing Possession of this and the neighbouring islands and coast of New Guinea in the name of His Majesty, they examined the huts, and found the greatcoats of Captain Hill, Mr. Carter and Mr. Shaw, with several other things which had belonged to them and to the boat's crew, so that no doubt was entertained of their having been MURDERED. In the evening, the party arrived from making the tour of the island, having burnt and destroyed 135 huts, 16 canoes measuring from 50 to 70 feet in length, and various plantations of sugar-cane. The natives appeared to have retired to the hills in the centre of the island, as not one of them could be discovered. . . The plantations of the natives, which were extensive and numerous in the plains, contained yams, sweet potatoes, plantains and sugar-canes, included within neat fences of bamboo, and coco-nut trees were very abundant, particularly near the habitations.

"The habitations of the Indians were generally placed at the heads of the small coves, and formed into villages of ten or twelve huts each. .... In each of the huts ... were suspended two or three human skulls, and several strings of hands, five or six on a string. These were hung round a wooden image, rudely carved into the representation of a man or of some bird. . . In one hut, containing much the greater number of skulls, a kind of gum was found burning before one of these images. ...

"The corpse of a man who had been shot we found disposed of in the following manner. Six stakes were driven into the ground about three feet from each other and six feet high. A platform of twigs was worked upon them at the height of about five feet, and upon this the body was laid, without covering; but the putrid state of the corpse did not allow of a close inspection.

"IIth July.-The 'Hormuzeer' stood north. In the afternoon both ships anchored off Stephens' Island. An armed party was immediately sent ashore to obtain intelligence, if possible, of the lost whaleboat. The NAtives were assembled in hostile array upon the hills, sounding their conches, but after lancing a few arrows they fled. Several were wounded by the shots fired in return, but they succeeded in escaping to a canoe at the back of the island and getting off, all except one boy, who was taken unhurt. In the huts which were burnt, several things were found, and amongst them a sheet of copper which belonged to the 'Chesterfield.'

"I 2 th Fuly.-Stephens' Island was traversed all over, and a spike nail, with the King's broad arrow upon it, was brought on board. [Note by Flinders: "It had probably been obtained from the crews of either the "Providence" or "Assistant," which had been anchored under Stephens' Island nine months before.']

"I 3 th fuly.-A boat was sent to CAMPBELL's IsLAND, but it did not contain either plantations, coco-nut trees or fixed habitations. ...

"In the afternoon, the ships proceeded to the westward, but, meeting with many reefs, they hauled more to the north, and discovered Bristow IsLand, lying close to the coast of New Guinea. Their attempts to find a passage here were fruitless, and, after incurring much danger, the 'Chesterfield' getting aground, they returned to their former anchorage in the evening of

" 2 Ist Fuly.-The banks, reefs and land seen during these eight days will be found marked in Plate XIII.

"Two canoes immediately came off from STEPHENs' IsLAND, and one of the natives remained on board the 'Hormuzeer' till 8 o'clock. He seemed to be without fear, and when inquiry was made after the lost boat and people, he pointed to a whaleboat and made signs that such a one had been at Darnley's Island, and that six of 
the people were killed. ${ }^{1}$ Many presents were made to this man, and he was clothed and sent ashore in one of the boats.

" 24 th Fuly.-Left in afternoon. Course W. Anchored at dusk, Campbell's Island bearing NE. by E. to E. by N.3. W.

" 25 th Fuly.-Course S. by W. $\frac{1}{2}$ W., 7 a.m. to 6 p.m., and anchored among small islands. Inhabitants seen on most of them, and two canoes visited the 'Chesterfield.'

" 26 th $\mathcal{F}$ uly.-Course W. Slow.

" 27 th Fuly.-Morning, anchored, Dungeness Island bearing W. by N. to NW. by W. $\frac{1}{2}$ N., 6 miles; Warriours' IsLand NNW. $\frac{1}{2}$ W., 8 miles. . . . Later in the day, passed between Dungeness and Warriours' Islands [BAsIllsk PAss, through which BuIGH had passed in the 'Providence' ten months previously.-R. L. J.], and anchored.

" 28 th Fuly.-Course W. Passed Turtle-backed Island, The Cap and The Brothers on one side and Nichol's KEY on the other. Upon The Cap (which he called Fire Island, not knowing it had already been named), he saw a volcano burning with great violence. [The observer was probably deceived by a bush fire. There is no active volcano on this island.-R. L. J.]

"At noon, The Brothers [Gabba Island.-R. L. J.], with The Cap and Turtlebacked Island behind, bore SE. by S. to S. $\frac{1}{2}$ E., 4 miles, and Mount Cornwallis 2 N. by E.tE.

" $29 t h \mathcal{h}$ uly. - Course NW. Noon latitude $9^{\circ} 42^{\prime}$ S. ${ }^{3}$ The Brothers bearing S. $64^{\circ}$ E., and Mount Cornwallis N. $38^{\circ} \mathrm{E}$., and Turn-again Island N. $35-58^{\circ} \mathrm{W}$.

" 3 oth fuly.-Boats sounding.

" 3 Ist Fuly.-Rounding TURn-Again Island. Noon lat. $9^{\circ} 32^{\prime}$, long. $140^{\circ} 58^{\prime}$.

"Ist August.-Going NW. in afternoon, the 'Chesterfield' grazed coral.

" 3 rd August.-Both ships made SSE. $\frac{3}{4} \mathrm{E}$. for TURN-Again Island for wood, water and refreshments, while the boats should explore for a passage through the reefs. Position of island given as $9^{\circ} 34^{\prime} \mathrm{S}$., $140^{\circ} 55^{\prime} \mathrm{E}$. Little ' refreshment' obtained; only small quantities of fish, crabs and shellfish. Bampton contrived an ingenious still for condensing water.

" 20tb August.-Course for three hours, NW.

" 2Ist August.-West. New Guinea coast visible. North-west end of a long island, which was named TALBOT IsLAND, bore N. by E. $\frac{1}{2} \mathrm{E} ., 9$ or 10 miles.

" 22nd August.- Steered W. from daylight. At 7 a.m., the 'Hormuzeer' grounded on a bank whence Talbot Island bore NNE. to ENE., in latitude $9^{\circ} 27^{\prime} \mathrm{S}$.

" 24 th August.-Got off the bank in morning. . . .

" 28 th August.-At noon, in $9^{\circ} 26 \frac{1}{2}^{\prime}$, an island was discovered, bearing SW. $\frac{3}{4} \mathrm{~S}$., 5 or 6 leagues, which eventually received the name of Deliverance Island.

" 29 th August.-Course W. At noon, Deliverance Island bore SSW. $\frac{1}{2}$ W., 9 or Io miles, and New Guineá NW. to N. by E. $\frac{1}{2} \mathrm{E} ., 4$ or 5 leagues. Lat. $9^{\circ} 25^{\prime} \mathrm{S}$. Anchored shortly after.

" 30 th August.-Noon, $9^{\circ} 2 \mathrm{I}^{\prime}$ S., Deliverance Island just in sight to SE. by S. Anchored in afternoon.

" 3 Ist A ugust.-Course SW., with extensive shoals on starboard. Noon latitude $9^{\circ} 27^{\prime}$, no land in sight. At sunset, no bottom at 40 fathoms. A swell coming from SSW. announced an open sea in that direction and that the dangers of Torres Strait were at length surmounted."

1 "Hill and four seamen were murdered by natives. Shaw and Carter were severely wounded, but with Ascott, the remaining seaman, they got into the boat, cut the grapnel rope and escaped. They were without provision or compass, and it being impossible to reach the ships, which lay 5 leagues to windward, they bore away to the west, through the strait, in the hope of reaching Timor. On the tenth day they reached Timor Laut." Note by Flinders. (Timor Laut, now known as Yamdena, is the largest island of the Tenimber group.-R. L. J.)

$2^{2}$ Mount Cornwallis is on DaUAN IsLand $\left(9^{\circ} 25^{\prime} \mathrm{S}\right.$. ; $142^{\circ} 32^{\prime} \mathrm{E}$.), off the coast of New Guinea, rising to 795 feet.-R. L. J.

Flinders remarks that these observations are all four to six minutes south of Bligh's positions. 
Captains Bampton and Alt succeeded in their main object of finding a new passage through the Coral Sea of Torres Strait. They even succeeded in traversing, from east to west, the dreaded "Drooge BoGHT" of the early Dutch navigators. In 1623 , the "Pera" and "Aernem," coming from the west and keeping slightly closer to the New Guinea coast, had been forced to return from about the longitude of $14 \mathrm{I}^{\circ} 5 \mathrm{O}^{\prime} \mathrm{E}$. 


\section{CHAPTER XVII}

\section{FLINDERS, I79I-I8I4}

\section{EARLY LIFE AND VOYAGE TO AUSTRALIA IN THE "INVESTIGATOR," I80I-2}

Enters Navy. The "Bellerophon." Joins the "Providence" under Bligh. Is the Historian of the "Breadfruit" Voyage. Rejoins the "Bellerophon." The Brest Naval Action. Midshipman on the "Reliance." Reaches Sydney with Governor Hunter. Friendship with Surgeon Bass of The "Reliance." Bass and Flinders explore South Coast in "Tom Thumb." Flinders in the "Reliance" to Cape of Good Hope, for Cattle to stock the Colony of New South Wales. Bass in a Whaleboat to Western Port. Ships "Francis" and "Eliza" dispatched to Wreck of "Sydney Cove" at Furneaux Islands. Total Loss of the "Eliza." Flinders on the "Francis." The Kent Islands. Flinders and Bass, in the "Norfolk," circumnavigate Tasmania. Flinders, in the "Norfolk," sails North to Moreton and Hervey Bays. Returns to England in the "Reliance." Given the Command of the "Investigator." His Marriage. Is refused Permission to take his Wife with him. Sails for Sydney. His Provisions for Food Supply and Sanitation. Round the Leeuwin. Coast from Leeuwin to Fowler's Bay already known. Flinders surveys Fowler's Bay. Cape Catastrophe. Boat's Crew drowned. Kangaroo Island. Spencer's Gulf explored and charted. Site of Adelaide. Eastward. Baudin, in the "Geographe," met in Encounter Bay. "Geographe" had come through Bass Strait. Exchange of Courtesies. Flinders to King Island and Cape Schanck. Enters Port Philitip, but the Discovery of the Site of Melbourne had already been made by Captain Grant in the "Lady Nelson." Arrives at Sydney. A clean Bill of Health. Temporary Peace with France. The "Naturaliste" and "Geographe" in Port JACKSON.

attempt to estimate the value of the contribution made by Matthew Flinders to the geography of Torres Strait and the Cape York Peninsula would be complete without a relation of the circumstances which led to his visiting that part of the world and the events which followed, and which put a tragic end to his career. The story is taken in the main from his own work on Terra Australis ${ }^{1}$ and the atlas issued with it; but there is an immense mass of other documents, both French and English, to be carefully considered. Indeed, in a biography brimful of touching human interest the chief difficulty of a writer

1 A Voyage to Terra Australis, undertaken for the Purpose of Completing the Discovery of that Vast Country, and prosecuted in the Years 1801, 1802 and 1803, in His Majesty"s Ship the "Investigator." 2 vols., 4to. London, G. and W. Nicol, Bookseller to His Majesty, I8r4. 
is to leave out enough to reduce it to reasonable proportions. In this difficult matter of condensation, I gratefully acknowledge my indebtedness to Professor Scott. ${ }^{1}$

Flinders was the son of a physician in Donington, Lincolnshire, where he was born on I6th March, I774. From his earliest youth, he developed an invincible inclination towards maritime pursuits. The patron so necessary in these days was opportunely found for him in Captain (afterwards Admiral) Sir Thomas Pasley, through whose influence he entered the Royal Navy in 1789 , and was rated as "Lieutenant's Servant" on the "Bellerophon" on 3Ist July, I790. In I79I, he joined the "Providence," under Captain William Bligh, on his second voyage for the transport of the breadfruit tree to the West Indies. This mission was successfully accomplished, the plants being delivered at their destination near the end of I793. By this time, Britain was at war with France. The only existing account of the voyage of the "Providence" and her tender, the "Assistant," is that given by Flinders in the introductory chapter of his great work.

On his arrival in England, Flinders (then nineteen years of age), eagerly embraced the opportunity of rejoining the "Belleropbon," and Admiral Pasley, who had received a good report on his conduct from Captain Bligh, made him his aide de camp. In the great battle off Brest, Pasley's active career was ended by the loss of a leg. Afterwards, although he received promotion and honours, he was only fit for administrative duties, and therefore Flinders left the "Bellerophon," after exactly five days' experience of naval warfare (28th May to Ist June, r794).

In 1788 , the British colony of New South WaLes was inaugurated by Captain Phillips, who sailed from England in the "Sirius," commanded by Captain John Hunter (who succeeded him in the governorship in I794). In March, I794, the "Reliance" and "Supply" were commissioned to convey Hunter to Sydney, and Flinders was a midshipman on the first-named vessel. Sydney was reached on 7 th September, I 795.

On the voyage out, a close friendship had sprung up between Flinders and George Bass, the Surgeon of the "Reliance." The two friends had no sooner landed than they concerted measures for the exploration of the coast of New South Wales. Having secured the best boat available, the "Tom Thumb," eight feet in length, they, and a boy, visited Botany Bay and the St. Georges River before the end of I795. In a second boat of the same name, they left Sydney on 25 th March, I 796, and explored the coast of the Illawarra district to the south and Port Hacking to the north, returning to Sydney on 2nd April.

A British protectorate of the Cape of Good Hope had by this

1 The Life of Captain Matthew Flinders, R.N. By Ernest Scott, Professor of History in the University of Melbourne. Sydney, I9I4. 
time been proclaimed, and the "Reliance," under Captain Waterhouse, with the "Supply," under Captain William Kent, made a voyage to the Cape and brought back cattle to stock the colony of New South Wales. The ships returned to Sydney on 26th June and 16 th May, 1797, respectively. ${ }^{1}$ Flinders was one of the officers of the "Reliance."

While Flinders was either confined to the neighbourhood of Sydney during the overhaul of the "Reliance" and "Supply," or engaged in their voyage to the Cape, Bass started on the memorable voyage which led to the discovery of Bass Strait. He set out from Sydney on 3 rd December, 1797 , in a WHALEBoat with six men. A month later, they found white men near Wilson's Promontory. These proved to be escaped convicts, marooned by the treachery of some of their companions, who made away with the

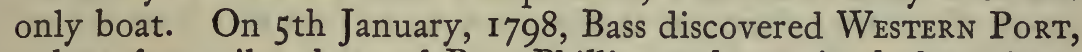
only a few miles short of Port Phillip, and remained there for a fortnight. The port is now a naval base for the Commonwealth fleet. Bass firmly (and correctly) believed that he had discovered a strait separating Tasmania from Australia ; but official admission or recognition of the fact was delayed until the strait had actually been sailed through.

Flinders had passed as lieutenant while at the Cape in 1797 ; On his'return to Sydney, it was reported that the "Sydney Cove"; had been wrecked at the Furneaux Islands (north-east of Tasmania), and the schooner "Francis" and sloop "Eliza" were dispatched from Sydney for the scene of the wreck on Ist February, I798. Governor Hunter permitted Flinders to embark on the "Francis," " to make such observations serviceable to geography and navigation as circumstances might afford." Unfortunately, the " Eliza" got separated from the "Francis," and was lost with all hands. The "Francis" returned to Sydney on 9th March. The net geographical result of the voyage was the addition to the map of the Kent group of islands, west of Tasmania.

Bass had returned to Sydney from his whaleboat voyage along 600 miles of the coast of New South Wales on 25th February. $\mathrm{He}$ and Flinders were eager to "pursue inquiry to the point of proof" regarding the separation of Tasmania from New South Wales, and Flinders desired to circumnavigate Tasmania. Before this object could be attained, however, Flinders, as an officer of the "Reliance," had to make a trip (May to July, I798) to Norfolk Island. On 7 th October, the Governor having put him in command of the sloop "Norfolk," he sailed with a crew of eight men, accompanied by Bass. They circumnavigated Tasmania and returned to Sydney on I 2th January, I799.

On 8th July, 1799, Flinders sailed for the north in the "Norfolk." $\mathrm{He}$ visited Moreton Bay, where he spent fifteen days, and Hervey

$$
1 \text { Terra Australis, I, civ. }
$$


Bay, returning to Sydney on 2oth August. He came to the conclusion that there were no important rivers on this stretch of the coast, having missed the Hunter, Clarence, Richmond and Brisbane.

Flinders sailed for England on 3rd March, 1800, in the "Reliance," under command of Captain Waterhouse, and arrived at Portsmouth on 26th August. He pressed the Admiralty for employment in the further exploration and survey of Australia, and through the influence of Sir JOSEPH BANKs was given the "Investigator," a sloop of 334 tons, built as a merchantman and originally known as the "Xenophon." He was promoted to the rank of commander, and took possession of his ship on 25 th January, I80I. The Admiralty was most liberal in "finding" the vessel, giving Banks carte blanche to furnish it according to his own and Flinders' ideas, and the assistants were well remunerated, according to the value of money at the time, as witness the sums placed against some of their names. Evidently, the expedition was a popular one. Under Flinders, the following were the officers :-

Ist Lieutenant, Robert Fowler.

2nd Lieutenant, Ward Flinders.

Midshipmen, 6, one of whom was John Franklin.

Botanist, Robert Brown ( $£_{420}$ per annum).

Landscape and Figure Draftsman, William Westall $\left(\varsigma_{3}+5\right)$.

Botanical Draftsman, Ferdinand Bauer $\left(£_{3} 15\right)$.

Gardener, Peter Good (£105).

Miner, John Allen ( 6 105).

Astronomer, John Crossley $\left(\oint_{42} 2\right)$. His health broke down, and he returned to England from the Cape of Good Hope, when Matthew Flinders and his brother, Ward, took over his duties.

The East India Company donated $£ 600$ for table-money for the officers and staff.

Britain was at war with France at this time, but in view of the purely scientific aims of the expedition Flinders was provided with a passport signed by the French Minister of Marine on behalf of the First Consul.

With this improvement in his position and prospects, Flinders Married, on I7th April, I80I, Miss Ann Chappell, ${ }^{1}$ whom he proposed to take with him, in spite of a regulation to the contrary. The regulation had, indeed, been frequently disregarded, but unfortunately for Flinders recent instances of flagrant abuses on the part of highly placed officers had just then forced the Admiralty to insist on implicit obedience. Even Sir Joseph Banks looked coldly upon what seemed like an attempt to smuggle a wife on board. In the end, Flinders had to yield and leave his bride behind. The separation was destined to last more than nine years, and the married lovers had less than four years of life together.

1 Scott, Life of Flinders, p. 164. 
Flinders sailed from Spithead on 18th July, I80I, and it is recorded that he raised discipline, sanitation and food supply to a pitch never before attained, even improving on the methods of Cook. The Australian coast, near CAPE LeEUwin, was sighted on 6th December, I80I.

From the Leeuwin to Fowler's Bay, the coast was already known.

"In I79I, Captain Grorge Vancouver, in the 'Cape Chatham,' sailed along it from Cape Leeuwin to King Georges Sound, which he discovered and named. . . . In I792, Bruny D'EnTrecasteaux, with the French ships 'Recherche' and 'Espérance,' searching for tidings of the lost 'Lapérouse,' followed the line of the shore more closely than Vancouver had done, and penetrated much further eastward, to $13 \mathrm{I}^{\circ} 38 \frac{1}{2}^{\prime}$, east of the present border-line of Western and South Australia. These navigators, with the Dutchman PIETER NuYTs, in the early part of the seventeenth century, and the Frenchman St. Alouara, who anchored near the Leeuwin in 1792, were the only Europeans known to have been upon any part of these southern coasts before the advent of Flinders; and the extent of the voyage of Nuyts is by no means clear." 1

Fowler's Bay was named and surveyed by Flinders, who now commenced to devote careful study to this part of the coast, seeing that it was new to geography. As an evidence of the minuteness of the survey, Scott compares the 240 names bestowed by Flinders on the South Australian and Tasmanian coasts with the I03 noted by Cook along the whole of the eastern coast of Australia.

Cape Catastrophe was rounded on 20th February, 1802, and the northward trend of the land east of the Cape revived for a time the old idea of the connection of the Bight with the Gulf of Carpentaria. The ominous name of the cape was conferred because on the 2Ist a boat, with the master of the "Investigator," John Thistle, a midshipman and six sailors, was upset while returning from the shore to the ship, and the whole party was lost.

Spencer's Gulf was explored and charted between 6th and 20th March, I802, and Kangaroo Island was also discovered. St. Vincent's Gulf was entered on 27th March, and the survey was finished on Ist April. Forty years later, the foundations of the city of Adelaide were laid at the foot of the Mount Lofty Range, on country which Flinders had described as "well clothed with forest timber" and "having a fertile appearance."

Kangaroo Island was left behind on 6th April. About half a degree to the east, on the 8th, Flinders met Baudin, in the "Geographe," in Encounter Bay. It appeared that the "Gíographe" had sailed through BAsS STRAIT and had been between Wilson's Promontory and Cape Otway from the 28th to the 3 Ist of March, thus narrowly missing the discovery of Port Phillip. Captain Nicolas Baudin, on the "Géographe," left Havre on 
I9th October, I80o, accompanied by Captain Hamelin, in the "Naturaliste," on a geographical and scientific expedition, and had passports not only from the Government of the First Consul of France but also from the British Government, although the two countries were at war. Early in the voyage, scurvy made dreadful havoc in both ships. The expedition reached (via Timor), in January, I802, the southern shores of Tasmania, in which island there was then no European settlement, and sojourned there till March. On 7th-8th March, the vessels were separated by a storm near the east end of Bass Strait. The "Naturaliste" spent some time in Western Port, which had already been discovered by Bass. Finally, Captain Hamelin took her to Sydney, with the object of soliciting aid from the Colonial Governor. In the meantime, Baudin had taken the "Géograpbe" westward through Bass Strait, and he was fortunate enough to meet the "Investigator" in Encounter Bay. Flinders advised and invited him to make for Sydney to refit and victual his ship. Baudin went on to King Island, where he turned back, and arrived at Sydney on 20th June, 1802.

Baudin had explored the coast from Cape Banks to Encounter Bay. From Cape Banks to Port Phillip, the discoverer was Captain Grant, of the "Lady Nelson," who sailed from the Cape of Good Hope eastward through Bass Strait (3rd-16th December, 1800).

From Cape Otway, Flinders went to King Island, the southern part of which had been discovered in 1799 by Captain John Reid, a sealer, and the northern part by Captain John Black, of the "Harbinger." Leaving King Island on 24th January, 1802, Flinders sighted Grant's Cape Schanck on the 26th. Thence, bearing west, to trace the land at the head of the Great Bight, he entered PorT PHILlip, which at first he took for Bass' Western Port. It did not take him long to satisfy himself that this was a mistake, and his natural conclusion was that in Port Phillip he had himself discovered a bay of no less importance than Western Port; but the discovery of Port Phillip had been anticipated by Lieutenant John Murray, who succeeded Captain Grant in the command of the "Lady Nelson." Flinders surveyed the bay, and ascended Arthur Seat, where he found himself with Port Phillip on the west and Western Port on the east.

On 9th May, 1802, Flinders entered Port Jackson, with something to be proud of - a clean bill of health-and reported himself to Governor King. In the harbour lay the "Naturaliste" (which had arrived on 24th April), and Flinders was able to inform Hamelin that his lost consort would make for Sydney also. As a matter of fact, Baudin brought the "Géographe" into the port on 2oth June, with every man on board sick.

The signing of a treaty of peace (which, unfortunately, proved 
EARLY LIFE AND VOYAGE TO AUSTRALIA I29 very temporary) between Britain and France had become known in Sydney a few days before the arrival of the "Géographe." There was, therefore, nothing to prevent the utmost kindness being extended to the distressed explorer; but it is pleasing to relate that, even while a state of war was supposed to prevail, the "Naturaliste" had been equally well treated. 


\title{
CHAPTER XVIII
}

\author{
FLINDERS, continued
}

\section{WITH THE “INVESTIGATOR," FROM SYDNEY TO THE GULF OF CARPENTARIA, I 802}

The "Investigator" and the " Lady Nelson" set out for Torres Strait. The "Lady Nelson " found unsuitable and sent back to Sydney. "Investigator" continues Voyage Northward. Port Curtis. Percy Islands. Pandora Entrance. Murray Islands. Barter with Natives. South-Westward. Halfway Island. Mount Adolphus Islands seen. Double Island. Wednesday Island. Through Prince of Wales Channel. Good Island named. Landing. Flinders observes Indications of Copper. Booby Island. Finders looks into Cook's Endeavour Strait, Which he misidentifies with the "Pera's" Van Spult Inlet. Southward. Wallis Island and Shoals. Westward out of Sight of Land. Southward and South-Eastward. Landfall. Skardon and Batavia Rivers. Landing. Natives. Mutual Suspicions. Opening (Tasman's Prince Inlet, later the Pennefather River) mistaken for "Pera's" Coen. Flinders' Imperfect Supply of Charts. Thevenot's Chart. Southward. Durfien Point. Albatross Bay (Tasman's Vliege Baaij). Location of Rivers entering the Bay. Southward. Pera Head seen and named. "Pera's" Coen Inlet passed unnoticed. Rijder's Hoek. Mouth of Archer River. The "Duyfien's" Cape Keerweer. Smokes on Shore. “Pera's" Vereenichde In lett (Mouth of Leichhardt's Mitchell River). Erroneous Identification of "Pera's" Nassau River. Misidentification, in $16^{\circ} 25^{\prime}$ S., of “Pera's" Staten River. Smithburn River, a Mouth of Leichhardt's Gilbert River, erroneously identified with the "Pera's" Staten Inlet (Stokes" Accident Inlet and the "Pera" and "Aernem's" "Furthest South"). Tasman's Caron Inlet misidentified. Tasman's Van Diemen Inlet is the Mouth of the Norman River. His Van der Lijn Inlet is the "Bynoe" Mouth of the Flinders River. His Caron Inlet is the Principal Mouth of the Flinders. Flinders mistook them all. His Mistakes accepted by Stokes and perpetuated. His own Charting is admirable, but his Comprehension of the Inlets mentioned by Carstenszoon and Tasman is erroneous. This is due to the Insufficiency of the Data in his Possession. The "Lady Nelson" again in Torres Strait on the Way to Port Essington.

$7 \mathrm{HE}$ "Investigator" having been repaired and refitted in Sydney Harbour and a new master (John Aken) having been appointed, it was decided, on consultation with Governor King, that she should proceed to explore Torres Strait and the eastern side of the Gulf of Carpentaria, accompanied by the "Lady Nelson" (Captain Murray).

Flinders accordingly left Sydney on 2Ist Fuly, I802, with the "Investigator" and "Lady Nelson." The latter-a 6o-ton brig- 
proved herself from the first to be an unsuitable ship, and merely a drag on the larger vessel, and was sent back on 18th October. In following the coast to the north, Flinders named (7th August) Port Curtis, now the port of Gladstone, and (28th September) the Percy Islands. (Admiralty Chart, No. 2759 A.) On $20 t h$ October, he got outside of the Barrier Reef ( $18^{\circ} 45^{\prime} \mathrm{S}$.; $148^{\circ}$ Io' E.) by the passage which now bears his own name. Nine days later, he came inside of the reef by a passage in $9^{\circ} 5^{\prime} \mathrm{S}$. and $144^{\circ} 45^{\prime}$ E., between Portlock and Boot Reefs, which he identified as the one used by Captain Edwards of the "Pandora" in I79I, and therefore named Pandora Entrance. " (SeE Map A.) The same night (29th October, I802), he was at anchor north of the largest of the MURray IsLands. He remarks," "I did not forget that the inhabitants of these islands had made an attack on the 'Providence' and 'Assistant,' ' nor that Mr. Bampton had some people cut off at Darnley Island in I793 (pp. xxxiv-xxxix). The marines were therefore kept under arms.... Bows and arrows were contained in all the canoes, but no intimation of hostility was manifested by the Indians." $\mathrm{He}$ bartered iron articles, including hatchets, for plantains, bows and arrows, etc., with forty or fifty islanders.

From Murray Island, Flinders picked his way cautiously among the reefs and low islets southward and westward towards Cape York. Late in the afternoon of $30 t h$ October, he anchored at the south end of the reef surrounding what he called HALFWAY IsLAND. This island is described as being barely a mile in circumference, only a few feet above the reach of spring tides, and covered with casuarina and other trees. Indications of the recent presence of "Indians" were observed.

On 3 Ist October, good progress was maintained to the southwest. At noon, the position was $10^{\circ} 26^{\prime} 45^{\prime \prime} \mathrm{S}$. and $142^{\circ} 39^{\frac{x^{\prime}}{2}} \mathrm{E}$., and from this position high land was seen bearing SSE. and at an estimated distance of 10 or 12 miles-almost certainly the Mount Adolphus Islands, the larger of which rises to 548 feet. By 2 p.m., the ship passed on the north side of Double IsLand and the course was altered to SW. by S., in which direction lay some rocky islets. These, however, when reached, afforded no shelter, and the ship wore round to the west until an anchorage was found on the north side of WEDNESDAY IsLAND ( $10^{\circ} 30^{\prime} \mathrm{S}$.; $142^{\circ}$ I $8 \frac{1}{2}^{\prime}$ E.), which had been named by Bligh.

On Ist November, the weather was too rough for landing or

1 Now on Admiralty charts as " Pandora Passage." Not to be confounded with the "Pandora Entrance" in Admiralty Chart, No. $2759 \mathrm{~A}$, in $11^{\circ} 25^{\prime} \mathrm{S}$. and $144^{\circ} \mathrm{E}$, where the "Pandora" was wrecked.

2 Terra Australis. Introduction, p. xxiv.

3 This attack was at Darnley Island, 30 miles north-west of Murray Island. The expression " these islands" evidently referred to the group. Flinders was the first to visit the Murray Islands (29th October, 1802), although they were seen and named by Edwards in August, I79I, a few days before the "Pandora" was wrecked. 
sailing. Some fires were seen on Hammond IsLand, but Wednesday Island showed no sign of habitation except for gigantic ant-hills which were at first taken for huts. On the following morning (2nd November), the course was shaped westward and west-southwestward, with Wednesday and Hammond Islands to the south and the North-West REEF on the north. This passage is now officially known as Prince of Wales Channel. (In modern charts the passage between Wednesday and Horn Islands, named Flinders PASSAGE, is that used by Flinders in his later voyage [1803] in the "Cumberland.")

Hammond Island was so named by Captain Edwards on his voyage in the boat of the wrecked "Pandora."

South-west of Hammond Island, Flinders distinguished another, which he named Good IsLAND, after the gardener of the expedition, and the anchor was dropped near its west end in the afternoon. Flinders landed with the botanists and took bearings, and remarked that "the stone is granite ... and ... porphyry, and in one place I found streaks of verdegrease, as if the cliffs above had contained copper ore." This is the earliest recorded indication of "MINERAL WEALTH" in Queensland territory. The adjacent Hammond Island, nearly a century later, was found to contain auriferous quartz associated with copper pyrites, and there can be no doubt that Flinders' observation on Good Island was correct and his deduction justifiable.

From Good Island, Bоову IsLand was visible, and the "Investigator" was therefore in the open sea west of Torres Strait.

The voyage was resumed on 3 rd November, with the immediate object of "getting in with the mainland south of the Prince of Wales Island." The course taken was mainly to the south-west between the LARPENT and GERARD Banks, and must have been a very hazardous one, from the shallow soundings shown on modern charts. Once clear of the shoals, the vessel's head was turned to the south, and at noon she was west of the WaLLis IsLands and between the RED and WALLIS BANks. Flinders wrote: ${ }^{1}$ "Between Cape Cornwall [southern point of Prince of Wales Island] and the low mainland ... is the opening called in the old Dutch chart Speult's River, but which Captain Cook, who sailed through it, named Endeavour Strait."

Some of the charts prior to Tasman's conveyed the idea that the Van Speult Revier was identical with the passage afterwards named Endeavour Strait, but Carstenszoon's diary (13th May, 1623) clearly points out that it was the (or a) mouth of a fresh-water river draining the land, and as such it was identified by Asschens in the "Buijs" in 1756 .

After clearing the WALLIS IsLANDS, further progress to the south was barred by the INSKIP BANKs, and the "Investigator" 
was forced to the west until the mainland was lost sight of. It was late in the day when the southerly course could be resumed, and at dusk the anchor was dropped in $\mathrm{II}^{\circ} 5^{\prime} \mathrm{S}$. and $\mathrm{I}_{4} \mathrm{I}^{\circ} 5 \mathrm{I}^{\prime} \mathrm{E}$.

From early morning till 3 p.m. next day ( 4 th November), the wind was unfavourable for an approach to the land, and the ship still headed to the south, the midday latitude being $\mathrm{II}^{\circ} 24{\frac{x^{\prime}}{2}}^{\mathrm{S}} \mathrm{S}$. and longitude $14 \mathrm{I}^{\circ} 46 \mathrm{x}^{\prime} \mathrm{E}$. (SEE MAP B.) A change of wind at $3 \mathrm{p} . \mathrm{m}$. enabled the course to be laid ESE.: the low-lying mainland soon afterwards came into view, and the anchor was dropped near the shore.

On 5 th November, the ship had gone but a little way south when the wind failed. At this point, Natrves could be seen grouped around a fire.

"At II, the sea breeze came in from W. by N., with dark, cloudy weather, and we steered forward, passing a sMaLI opening at one o'clock [where the 'Duyfken's' men landed in 1606, one of them being killed by the natives; where Carstenszoon landed in 1623 from the 'Pera', naming the inlet the Carpentaria Revier; the mouth of what is now known as the SKarDon RIVER, the name having been given by Jardine in 1865 to what may possibly have been one of its heads. - R. L. J.]." This opening was 4 or 5 miles south of where the natives had been seen. "A much LARGER OPENING came in sight at 2 , into which I hoped to get the ship; but the water was so shallow at 5 or 6 miles off that we were obliged to tack, and after making a second ineffectual attempt it became dark, and we anchored in 6 fathoms, fine dark mud, the centre of the opening bearing S. $37^{\circ} \mathrm{E}$., 3 leagues.

"The coast was low, as before, but the trees upon it were taller. The largest opening [Port Musgrave.-R. L. J.] is about two miles wide, leading in SE., but turning afterwards more east and apparently contracting its width [the mouth of the Dalmunty River, de facto, of modern maps, where it enters the Port Musgrave estuary.-R. L. J.]. Near the south-west point of the entrance [Cullen Point.R. L. J.], which projects a little from the general line of the shore, was a clump of trees higher than usual, presenting the first mark I had yet found for bearings. The latitude of this opening is $\mathrm{II}^{\circ} 55^{\prime}$, and agrees nearly with that of the BATAvia RivER in the old Dutch chart [i.e., in Thevenot's chart.-R. L. J.]; but the shoal which runs 6 miles out seemed to render it inaccessible to a ship." ${ }_{1}$ [What is now known as the Batavia River falls into the south-western corner of the Port Musgrave Estuary. Tasman anchored in 1644 off the mouth of Port Musgrave, and named it StaAten REviER, which is curious, as there was already a Staten Revier on the map, more than 5 degrees further south. - R. L. J.]

In the morning of $6 \mathrm{th}$ November, adverse weather conditions and the fear of the north-west monsoons forbade any further investigation of this important opening, at the mouth of which (on Cullen Point) now stands the headquarters and village of the Mapoon Aboriginal Mission. The "Investigator" therefore coasted to SSW., and anchored at sunset, about $12^{\circ} 12^{\prime} \mathrm{S}$.

" 7 th November.-At daylight " we again steered southward, but in two hours the wind died off and an anchor was dropped in 9 fathoms. There was a small opening at $\mathrm{E}^{\circ} 5^{\prime} \mathrm{S}$., about 3 miles; and the botanical gentlemen being desirous of seeing the productions of this part of the country, the whale-boat was lowered down and we went 
to explore the inlet. ... We had a good deal of difficulty to get in on account of the shoals, the channel among them being narrow and winding and not more than 9 to $\mathbf{I} 2$ feet deep. On the north side was a party of Natives, and Bongaree went on shore to them, naked and unarmed; but, although provided with spears, they retreated from him and all our endeavours to bring about an interview were unsuccessful. It was not safe for the gentlemen to botanise in presence of these suspicious people, and therefore we rowed a mile higher up, to a green-looking point on the same side and landed about noon. The depth thus far was 2 fathoms, and I could see $2 \frac{1}{2}$ miles further up the inlet to the ESE., where it turned more southward round a wooded point, and, from the strength of the tide, probably extended some miles into the country.

"While the botanists were making their examination and I walked along the shore to shoot some birds, several voices were heard in the wood, as of people advancing towards us. .... We rowed back to the first place, where the country was open, and the gentlemen botanised, whilst sentinels kept watch on the sandy hillocks. . . .

"Before quitting the shore, a hatchet was made fast to the branch of a tree and set up conspicuously near the water side. We had scarcely shoved off, when the party of Indians, sixteen in number, made their appearance and called to us; but when the boat's head was turned towards them they ran away. On the south side of the entrance were four other natives, who also ran at our approach. We therefore set up another hatchet for them, and returned back to the ship.

"These people were all naked; and in colour, as in everything else, seemed to have a perfect resemblance to the inhabitants of the east and south coasts of Terra Australis. In Torres Strait, bows and arrows are the offensive weapons; but here we saw spears only. Each man had several in his hand, and something which was supposed to be a throwing stick.

"This small opening appears to be the Coen River of the Dutch chart. Its latitude is $12^{\circ} \mathrm{I} 3^{\prime} \mathrm{S}$. ..."

Tasman was the first to chart this inlet (1644), and he named it Prince Revier. Flinders' suggested identification of it was a most unfortunate one, and was destined to give rise to much confusion in later years. He could not possibly have made the mistake had he been in possession of the diary of Carstenszoon's voyage in the "Pera," which distinctly places his Coen InLeT, where he landed on 8th May, 1623 , and kidnapped a native, in $13^{\circ} 7^{\prime}$ S., i.e., midway between the mouth of the Archer River and Pera Head, the southern horn of Albatross Bay. The fact is, Flinders had to rely on second-hand and generalised charts, such as Thevenot's, ${ }^{1}$ of which he gives a copy as an inset in his Chart Sheet 2, in the atlas issued with Terra Australis. When, in the process of land exploration, it became necessary to give names to rivers which rose in the ranges near the east coast of the Peninsula, but obviously flowed towards the Gulf, the natural tendency was to connect the new rivers with the few inlets, or reviers, which appeared on the map of the Gulf coast. Thus, when, in 1876, a goldfield was discovered in $13^{\circ} 55^{\prime} \mathrm{S}$. and $143^{\circ} 13^{\prime} \mathrm{E}$., on a river which flowed to the northwest, the discoverers believed themselves to be near the head of the

1 Melchisadech Thevenot. Divers Voyages Curieux. Fol. Paris, 1663-72. The source of Thevenot's information is left to conjecture. His chart summarises Tasman's discoveries, but as it agrees neither with the version of Tasman's chart published by Swart, nor with that published by Heeres, it was probably taken from some contemporary chart to which neither Swart nor Heeres had access. 
Dutch Coen River, whose position was very erroneously laid down on the map, on the authority of Flinders, in $12^{\circ} 13^{\prime} \mathrm{S}$. It would be impossible now to alter the name of the Coen GoldField, which has been sanctioned by half a century of usage, but the Department of Lands has begun to call the "COEN RIVER" of the goldfield the South Coen, in order to minimise the confusion.

About I88I, the inlet named by Tasman the Prince Revier, and erroneously identified by Flinders as Carstenszoon's Coen Revier, was renamed the Pennefather River. As the change took place during the administration of the Hon. John Douglas, who used, as Government Resident at Thursday Island, to patrol the pearl fisheries of the Gulf, it was probably made because he had realised the impossibility of the inlet being the real Coen, while at the same time he may have been unaware that it had already been named the Prince by Tasman.

When Flinders and "the botanical gentlemen" finally rowed out of the supposed Coen River (to which we may henceforth refer as the Pennefather) and rejoined the ship, at 3 p.m., he resumed his narrative :-

"We then steered south-westward along the shore, and soon after sunset anchored in Io fathoms nearly four miles from the land, which ... was still low and woody and fronted with a sandy beach." According to the chart, the anchorage was in $12^{\circ} 23^{\prime} \mathrm{S}$.

" $8 \mathrm{th}$ November, 1802.-Early in the morning we steered along the coast, with good soundings, between Io and 9 fathoms, muddy bottom. A SANDY PoINT, with two hillocks on it, ... was passed at Io o'clock; and, seeing a large bight [Albatross BAY.-R. L. J.] round it, we tacked to work up. ... This point is one of the very few remarkable projections to be found on this low coast, but it is not noticed in the Dutch chart. [It is, however (unknown to Flinders), very clearly referred to in Carstenszoon's diary of the voyage of the 'Pera' on I2th May, I623. - R. L. J.] There is little doubt, however, that it was seen in 1606 , in the yacht 'Duyfken,' the first vessel which discovered any part of Carpentaria; and, that the remembrance may not be lost, I gave the name of the vessel to the point. Our observations placed the south extreme of Duxfren Point in $12^{\circ} 35^{\prime} \mathrm{S}$. and $141^{\circ} 42^{\prime} \mathrm{E}$. [It had already been named Asschens Hozk by Asschens, Skipper of the 'Buijs,' who passed it on 26th April, 1756.-R. L. J.]

"On the sea breeze setting in at 2 o'clock, we steered into the bight until past 5, when, having no more water than $2 \frac{1}{2}$ fathoms, we tacked and stretched out. The bight extends II or I 2 miles back from the line of the coast, and there are THRER SMALL OPENINGS in it; but the shore being so low and in many places overrun with mangroves, these openings are probably no more than drains out of salt swamps or lagoons. The bearings when we tacked in $2 \frac{1}{2}$ fathoms were :-

“ [I] Duyfken Point, south extreme, distant 6 or 7 miles, N. $63^{\circ} \mathrm{W}$.

"[2] A small opening behind it, distant 5 or 6 miles, N. $23^{\circ} \mathrm{W}$.

“[3] A second opening, distant 4 miles, N. $64^{\circ} \mathrm{E}$.

"[4] A third, distant 3 miles, S. $78^{\circ}$ E."

These bearings, taken from the shoals off Urquhart Point, very accurately locate :-

[2] Pine or Nomenade Creek, referred to in Tasman's chart as a wooded inlet (" REVIER MIT BOSCH"). 
[3] Myall Creek, now known as the Mission River.

[4] The EMBLEY River, which is navigable for boats for a good many miles, and on which the Weipa Mission STATion now stands.

Having "reached out of the bight" at 8 p.m., a southward course was kept till 10.30, when the anchor was dropped, approximately in $12^{\circ} 45^{\prime} \mathrm{S}$. lat.

"Next morning" ( 9 th November), says Flinders,1 "I set the west extreme of Duyfken Point at N. $9^{\circ} \mathrm{E}$. and the furthest land in the opposite direction at S. $9^{\circ} \mathrm{E}$. [SEE MAP D.] This land forms the south side of the large bight, and besides projecting beyond the coast-line and being a little higher than usual, is remarkable for having some reddish cliffs in it and deep water near the shore. It is not noticed in the Dutch chart [referring to Thevenot's chart.-R. L. J.], but I called it PERA HEAD, to preserve the name of the second vessel which, in 1623 , sailed along this coast."

Modern maps give the name Pera Head to the northmost point of this blunt promontory, while its southern portion, where the " reddish cliffs " are marked on Flinders' chart, is distinguished as False Pera Head; on the other hand, Flinders, in his chart, applies the name of False Pera Head to a blunt projection about 14 miles south of Pera Head proper. It is to be noted that Flinders' False Pera Head is in $13^{\circ} 8^{\prime} \mathrm{S}$., practically where Gonzal, in the "Rijder," had placed RIJDER's Hoex in 1756.

It is fortunate that Flinders did not add a third name to the two which had already been given to the "bight" so carefully charted by him. TASMaN had named it Vliege BaIJ in 1644 , and as such it was recognised by Asschens, in the "Buijs," on 26 th April, 1756. On 31st May, 1756, Gonzal, in the "Rijder," had named it Mossel BaAij. Tasman's name of Vliege Bay has undoubtedly the right of priority, but usage has irrevocably fixed the name of Albatross Bay, bestowed upon it about I88I, after the small government steamer used for patrol purposes during the residency of the Hon. John Douglas.

The narrative of Flinders is resumed, after his sailing out of Albatross Bay on 9th November, 1802 :-

"Pera Head was passed at a distance of one mile and a half at noon, with 9 fathoms water; and the most projecting part of the cliff found to be in $12^{\circ} 5^{81^{\prime}} \mathrm{S}$. and $14 \mathrm{I}^{\circ} 4 \mathrm{O}^{\prime} \mathrm{E}$. The sea breeze had then set in, and we steered southward till past ro o'clock, when a decrease in the soundings to 3 fathoms obliged us to tack at a league from the land; and the wind being at south-west, we worked along the shore till ro in the evening, and then anchored in 6 fathoms, oozy bottom. At daylight (roth November), the land was seen to be 5 miles distant, equally low and sandy as before ; and a sMall opening in it, perhaps not accessible to boats, bore S. $79^{\circ} \mathrm{E}$. [mouth of Archer River.-R. L. J.]."

Between Pera Head and the anchorage of 9 th November, Flinders had unwittingly passed the inlet in $13^{\circ} 7^{\prime} \mathrm{S}$. where

1 Terra Australis, II, p. 129. 
Carstenszoon landed on 8th May, 1623, and which he named the Coen Revier. The unfortunate misidentification of this inlet with the "Coen River" of the goldfield has already been alluded to. Carstenszoon's latitude ( $13^{\circ} 7^{\prime}$ S.) places it north of the blunt projection which Gonzal named RIJDER's HoEk on I 3 th June, 1756, and which Flinders saw-obviously from a distance-and named False Pera Head (not what is called False Pera Head on modern charts). In Chapters LXXXV and LXXXIX it is shown that Carstenszoon's Coen Revier is the creek located by the missionaries about $13^{\circ} 4^{\prime} \mathrm{S}$.

"On getting under way again [1oth November]," continues Flinders, "we closed in with the shore and steered along it at the distance of 2 or 3 miles, in soundings from 3 to 7 fathoms, until noon. Our latitude was then $13^{\circ} 42^{\prime} 35^{\prime \prime}$, long. ${ }_{14} \mathrm{I}^{\circ} 32^{\prime}$, being nearly the position of CAPE KEERWEer, at which the yacht 'Duyfken' gave up her examination. I could see nothing like a cape here; but the southern extreme of the land, seen from the masthead, projects a little, and from respect to antiquity the Dutch name is there preserved [i.e., at $13^{\circ} 57^{\prime}$ S. - R. L. J.]. At 4 , we passed the southern extremity of CAPE KEERWEER, round which the coast falls back somewhat ; the water then became more shallow and did not admit of [the coast] being safely approached nearer than 4 miles. An opening is laid down here in the Dutch chart, called Vereenichde River, which certainly has no existence. [Evidently referring to Thevenot's map, which puts the Vereenichde River in $14^{\circ}$ and makes no mention of Cape Keerweer. Flinders does not deny the existence of the river, but merely states that it is not in the position assigned to it by the Dutch chart.-R. L. J.] All this afternoon the sea breeze was fresh and favourable, and by 8 o'clock, when we anchored in 5 fathoms [This would be about opposite the mouth of Jardine's Hersey Creek. - R. L. J.], the distance run from noon exceeded 40 miles. A fire was seen on the land about 4 miles off, and some smokes had been passed in the day; so that the country should seem to be at least as well peopled in this part of Carpentaria as further northward. The coast was, if possible, still lower than before; not a single hill had yet been seen; and the tops of the trees in the highest land had scarcely exceeded the height of the ship's masthead."

In coasting from the mouth of the Archer River southward to Cape Keerweer, Flinders failed to observe two inlets noted on Tasman's chart, in $13^{\circ} 27-30^{\prime}$ and $13^{\circ} 42^{\prime} \mathrm{S}$. The former was erroneously identified by Tasman with Carstenszoon's Coen and the latter was named by him Visscher's Revier. It would not surprise me if both inlets should turn out to be mouths of the Archer River. It would be surprising if a river of such importance as the Archer were almost the only one on the western coast of Carpentaria to have a single mouth. In fact, the Dugally River, located on a missionary sketch-map in $13^{\circ} 33^{\frac{x^{\prime}}{2}}$ S., is obviously a mouth of the Archer, and probably the same is true of Visscher's Revier.

Continuing his account of the voyage, Flinders writes (II, p. 130) :-

"II th November, I802.-The land wind came from NNE., and our course was pursued along the shore at the usual distance. At 8 o'clock, the depth decreased 
to $2 \frac{1}{2}$ fathoms and obliged us to steer off, though 5 miles from the land; and when fair soundings were obtained, the tops of the trees only were visible from the deck. [SEE MAP F.] At noon we had closed in again, the shore being distant 5 or 6 miles and the depth 6 fathoms, on a gravelly bottom. Our latitude was $14^{\circ} 5 I^{\prime} 5^{\prime \prime}$, long. $141^{\circ} 33^{\prime}$; the extremes seen from the deck bore N. $29^{\circ}$ to S. $26^{\circ} \mathrm{E}$., and a smoke was seen arising at S. $28^{\circ} \mathrm{E}$. The sea breeze came in from the south-westward, but the trending of the coast being nearly SSE., we lay along it until past 4 o'clock and then tacked off, in 3 fathoms. . . A A 8 in the evening, the breeze died away, and a stream anchor was dropped in 5 fathoms, mud and shells, 5 or 6 miles off the shore, where the latitude, from an observation of the moon, was $15^{\circ} 5^{\prime} \mathrm{S}$.

" 12th November, 1802.-At sunrise next morning, the ship was steering southward, with a land wind at east; and at 7 o'clock we passed an OPENING near which several NATives were collected. The entrance seemed to be a full mile in width, but a spit from the south side runs so far across that there is probably no access to it unless for rowing boats. Its latitude is $15^{\circ} 12^{\prime} \mathrm{S}$., corresponding with a bight in the Dutch chart to the south of the second waterplaets. [This, beyond question, was the Vereenichde Revier, afterwards named by Leichiardt the Mitchell River.-R.L.J.] ... Our course southward was continued at 2 or 3 miles from the shore. . . The latitude at noon was $15^{\circ} 25^{\prime} 20^{\prime \prime}$, and long. $141^{\circ} 32^{\prime}$. At I o'clock, we steered SSW., with the whaleboat ahead ... until 7 in the evening, when the stream anchor was dropped about 4 miles from the shore. [SEE MAP H.]

"I 3 th November, 1802.-We were again under way very soon after 5 o'clock, and at 6 , being then 4 miles from the land and steering SSW., a LAGoon was seen from the masthead over the front beach. It has doubtless some connection with the sea, either by a constant or a temporary opening, but none such could be perceived. The latitude, $15^{\circ} 53^{\prime}$, corresponds with that of NAssau REvier in the old chart; and from the examples already seen of the Dutch rivers here it seems probable that this lagoon was meant. [Subsequent cartographers have accepted Flinders' suggestion, which was, however, altogether a mistaken one. Carstenszoon gave the name of Nassau Revier to an inlet in $16^{\circ} 10^{\prime}$ S., where modern Lands Department charting places the mouth of an unnamed creek, near the head of which were LEIchHARDT's CAMPS of 2nd and 3 rd July, 1845. Thevenot's chart (perhaps reduced and generalised from Tasman's) places the Nassau about $16^{\circ}$.-R. L. J.]

"A few miles further south, the shoal water obliged me to run westward out of sight of land from the deck. [Thus Flinders missed the 'Tidal Arm' of Leich hardt's 'Rocky Creek,' which had already been named the Revier Pera by Tasman.R. L. J.] At noon, when the latitude was $16^{\circ} 24^{\prime} 29^{\prime \prime}$ and longitude $141^{\circ} 14 \frac{1}{2}^{\prime}$, trees were visible from the deck at N. $70^{\circ} \mathrm{E}$., and from thence to $\mathrm{S}$. $50^{\circ} \mathrm{E}$., the nearest part, whence a smoke arose, being distant 7 or 8 miles, and the depth of water 4 fathoms. The slight projection here is probably one of those marked in the old chart on each side of Staten River; but where the river can be found I know not."

This " nearest part" of the land, "whence a smoke arose," is identifiable, with the aid of Flinders' chart, about $16^{\circ} 25^{\prime}$, where, as a matter of fact, one of the mouths of a large river is placed by modern Lands Department maps. Flinders' identification of it, however, with the Staten Revier of the "Pera's" voyage is a very unhappy one, the latter (which was the "furthest south" of the "Pera" and "Aernem") being, in all probability, Accident InLet, one of the mouths of the Gilbert River, in latitude $17^{\circ} \mathrm{I} 3^{\prime} \mathrm{S}$. To do Flinders justice, the identification of an inlet which he did not even see was suggested by him in the most tentative way; but it was accepted by Stokes (I84I), Leichhardt (1845) and Jardine (1864), and the river has become 
for all time the StaAten River, de facto, though not de jure. It is noteworthy that Flinders, although his diary carefully gives the latitudes and his conjectures as to the identification of his inlets with "the Dutch chart" (Thevenot's), his own chart, "North Coast, Sheet 2," names no rivers or inlets south of Cape Keerweer. The inference is that although he indulged in conjectures his intention was to be careful not to commit himself.

Flinders continues his narrative of 13 th November:-

"The nearest approach made to the land in the afternoon was 5 or 6 miles, with 3 fathoms water. At dusk we anchored in 6 fathoms, mud, at 6 or 7 miles from the shore. [Flinders' chart gives the latitude of this anchorage as $16^{\circ} 4 \mathrm{I}^{\prime}$ S., i.e., just outside of the 'Pera's' anchorage of 26 th April, 1623.-R. L. J.]"

\section{The voyage was resumed at daylight on I4th November.}

"We steered," says Flinders, " a course nearly due south, which, as the coast then trended southward, brought us in with it. At noon, the latitude was $17^{\circ} 3^{\prime} 15^{\prime \prime}$, longitude $\mathrm{I}_{4} \mathrm{I}^{\circ} \mathrm{O}^{\prime}$ : a PROJECTING PART bore N. $59^{\circ} \mathrm{E}$., 3 or 4 miles. [SEE MAP M.] ... There appeared to be a sMall opening on the south side of this little projection, which corresponds in latitude to VAN Diemen's River in the old chart [Thevenot's.-R. L. J.], but across the entrance was an extensive flat, nearly dry, and would probably prevent even boats from getting in. If this place had any title to be called a river in $166_{4}$ [i.e., by Tasman.-R. L. J.], the coast must have undergone a great alteration since that time."

Tasman's chart, according to Swart's version, gives to his Van Diemen River the latitude of $17^{\circ} 30^{\prime}$, and it cannot therefore be doubted that Flinders was in error in supposing his "small opening" south of the "little projection"-where, in fact, one of the mouths of Leichhardt's GILBERT RIVER is pushing out delta-mud into the Gulf-to be the Van Diemen Inlet. The "small opening" must be the SMITHBURN River of modern Lands Department maps, which is one of the numerous mouths of the GILBERT.

"I $4_{\text {th }}$ November, continued.-In the afternoon, our course along shore was more westward ; and this, with the increasing shallowness of the water, made me apprehend that the Gulph would be found to terminate nearly as represented in the old charts, and disappoint the hopes formed of a strait or passage leading out at some other part of Terra Australis. - At 4 o'clock, after running more than an hour in $3 \frac{1}{2}$ fathoms, or less than 3 at high water, our distance from the shore was 5 miles, and a sMaLL opening then bore S. $14^{\circ} \mathrm{E}$., which seems to be the Caron River marked at the south-east extremity of the Gulph in the Dutch charts [i.e., in Thevenot's version of Tasman's chart. My impression is that Thevenot, in reducing Tasman's chart to an inconveniently small scale, found himself crowded towards the south-eastern corner of the Gulf and omitted some of Tasman's names.-R. L. J.], but," continues Flinders, "whatever it might have been in Tasman's time, no navigator would now think of attempting to enter it with a ship. The latitude is $17^{\circ} 26^{\prime}$ and longitude $140^{\circ} 52^{\prime} \mathrm{E}$. From 4 till 7 , our course was W. by S., close to the wind, the depths being mostly 3 fathoms and the land barely within sight from the masthead. We 
then stood off ; and the water being smooth, anchored on muddy ground in $4 \frac{1}{2}$ fathoms, which became $3 \frac{1}{2}$ at low water."

The position of this anchorage is not given on Flinders' own chart. The "small opening " in $17^{\circ} 26^{\prime}$, which Flinders thought might be Tasman's Caron River, was the mouth of the modern Norman River, which was named the Van Diemen Revier by TAsman in 1644. The precise position of the mouth, according to Captain John Lort Stokes' survey of $1844,,^{1}$ is $17^{\circ} 28^{\prime}$. Stokes suggests, by a dotted line entering the sea in $17^{\circ} 23^{\prime}$, the position of the Caron River, and in this position, according to the Lands Department Map, Sheet 19 A, there actually appears an insignificant water-course. But it is easier to believe that Flinders' position was two minutes too far north than that it was three minutes too far south, and the mouth of the Norman River, however little Flinders may have thought of its possibilities, is a genuine "opening" and is at the present day the port for Normanton and the Croydon goldfield. Granting that the modern Norman River is Tasman's Van Diemen (and there seems no room for doubt), his VAN Der Lijn's Revier was the "Bynoe" mouth of the Flinders River, and his Caron Revier was the principal mouth of the Flinders. Flinders' course after he saw (from a distance) the mouth of what he erroneously took for the Caron was too far from the land to permit of his seeing the Van der Lijn and Caron Inlets.

As Flinders, when he altered his course after passing the supposed Caron Inlet, passed out of the waters of the Cape York Peninsula, it is unnecessary for us to follow his further progress with critical minuteness. Some observations on the character of his work are, however, in place here.

From his earliest youth, Flinders had put before himself a lofty ideal, his constant endeavour, as he declared, being to do his work in such a manner that no one should have to come after him to correct it. Incidentally, it may be mentioned that he carried a chronometer, and his longitudes are reliable, which even Cook's were not. The chronometer was first adapted to navigation by James Harrison in $1735 .^{\circ}$ It had been officially tested on a voyage to Barbados in 1763 , when its efficiency was demonstrated, and it is odd that Cook was not furnished with one, and had to rely mainly on lunar observations for his longitudes. ${ }^{3}$ In a word, the accuracy of Flinders' own work along the western coast of the Cape York Peninsula was beyond praise. On the other hand, his interpretation of the work of previous

1 Admiralty Chart, No. 1807 .

2 See The Royal Observatory of Greenwich, by E. Walter Maunder, London, 1900. I am indebted to Mr. G. F. Dodwell, B.A., Government Astronomer, South Australia, for this reference.

3 Wharton's Captain Cook's Journal, p. xxvii. 
navigators was very faulty. For this, however, he could hardly be blamed, as his identifications were for the most part based on second-hand and erroneous data. He had not the advantage of access to the most important documents, viz., Carstenszoon's diary of the "Pera's" voyage and Tasman's chart of his second voyage, both of which came to light after his time. The onus of the confusion which has arisen lies rather with those cartographers who came after him and who treated his obviously tentative suggestions as authoritative statements.

The "Lady Nelson" was destined to make another appearance in Torres Strait. In 1824, with the double object of extending British commerce with the east and forestalling the suspected intention of the French to claim part of Australia, H.M.S. "Tamar," Captain James Gordon Bremer, was sent out from England to Sydney with instructions to establish a settlement in the vicinity of Melville Island. At Sydney, the "Tamar" was joined by the "Countess of Harcourt" and the "Lady Nelson," commissioned by the colonial authorities to assist in the conveyance of troops and stores.

The three ships sailed via Cape Grafton, Snapper Island, Cape Tribulation, Cape Flattery and the Howick Islands, passed Cape Melville and the Flinders Islands, and anchored off Cape Direction on I2th September, 1824. (See Maps C, B and E and Admiralty Chart, No. 2922.) Thence they sailed by Forbes Island and Bligh's Sunday Island to the Bird Islands ${ }^{1}$ (I 3 th September). (See Map B.) From the Bird group they sailed to Mount Adolphus IsLand, where they anchored on I4th September. (SeeMapA.) They had, in the course of the day, passed Turtle Island, where Bligh had been with the "Bounty's" launch on a Tuesday (which may therefore be considered his TuEsDay IsLAND, even if he did not name it so). On I 5 th September the "Tamar" and her consorts passed WEDNESDAY and THURSDAY IsLANDs, got into the open sea and, keeping a westerly course, crossed the mouth of the Gulf of Carpentaria, to anchor at Port Essington on 20th September.

So far as his journals and charts show, Bligh (1789) named only Sunday and Wednesday Islands. Lagoon Island, of the Bird group, and Turtle Island, off the mouth of the Escape River, were, respectively, the islands at which he touched on Monday and Tuesday. He named Wednesday Island because he passed it that day on his way to the open sea, but obviously he could not have named Thursday and Friday Islands. There is no Monday Island on modern charts, but there are Tuesday, Thursday and Friday IsLands (the Tuesday Island not being where Bligh was on Tuesday), and the question arises, who named the three last? As regards

1 Bligh had landed on Lagoon Island, one of the Bird group, on Monday, Ist June, 1789, and that may therefore be regarded as his Monday Island. 
Thursday Island, at least, the date of its naming is narrowed down by its mention by the Commander of the "Lady Nelson" to the period between I 789 and I824. The probability is that KING named Tuesday, Thursday and Friday Islands in 1818 , although the names do not appear on his charts.

Having completed her mission at Port Essington, the "Tamar" left for Mauritius and England on Ioth November, 1824, taking the "Countess of Harcourt" with her. The "Lady Nelson" was left behind, to make herself useful in the transport and provisioning services required by the new settlement. On 28 th February, 1825, she set out from the port to bring buffaloes from Timor. She fell into the hands of pirates and her men, with, apparently, only one exception, were murdered. Her wreck lay for many years on the rocks at Baba Island, one of the Serawatti group."

1 Narrative of a Voyage of Discovery in H.M. Ship "Lady Nelson," 1800-1802. By Lieutenant James Grant. London, 1803 .

The Logbooks of the "Lady Nelson," with the Journal of her First Commander, Lieutenant James Grant, R.N. By Ida Lee, F.R.G.S. (Mrs. Chas. Bruce Marriott). London, I9I5.

"An Historical Vessel, the 'Lady Nelson." By W. S. Campbell. Journ. Aust. Hist. Soc., Vol. III (1914), p. 483 .

"H.M.S. "Lady Nelson." " By W. C. Thomson. Trans. Roy. Geogr. Soc. Aust., Victorian Branch, Vol. XIX (I90I), p. 85. 


\section{CHAPTER XIX}

\section{FLINDERS, continued}

\section{“INVESTIGATOR'S" RETURN TO SYDNEY, I802-3}

Along South Coast of Gulf of Carpentaria. Sweers and Bentinck Islands. Investigator Roads. Overhaul and Repairs. The Ship rotten and dangerously unseaworthy. Mornington Island. Sir Edward Pellew Islands visited. Maria Island separated from Mainland. North Coast of Arnhem Land. Fleet of Malay Vessels collecting Bêche de Mer. Outbreak of Scurvy. Flinders sails for Timor. Sails from Timor to Sydney via the LeeUwin. The "I NVestigator" Broken up.

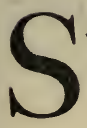

ATISFIED at last that he had really reached the "bottom" of the Gulf and that there was no passage between "New South Wales" and the "mainland of New Holland," and weary of the monotonous flats defended by wide shoals, Flinders turned the head of the "Investigator" to the northwest, in order to survey the western shores of the Gulf. On 22nd November, 1802, an anchorage was found in Investigator Roads, between SWEers and Bentinck Islands, and fears having arisen as to the condition of the ship, she was careened and examined by the carpenters. (SEE MAP M.) Their comprehensive report (26th November) may be summed up in a single line of Kipling. The ship was " just a pack of rotten planks puttied up with tar." With luck and fine weather she might hold together for six months. Flinders resolved to pursue his work until the monsoons abated, and then to make for Sydney by the west side of Australia, unless forced by rough weather to run for shelter to some port in the East Indies.

After such repairs had been made as were possible in the circumstances, Tasman's CAPE VAN Diemen was found to be an island, and named Mornington IsLand. Next the Sir Edward PELLEW group of ISLANDS was visited and named. Here were found traces of the former presence of MALAYs, in the shape of fragments of pottery, basket-work, rags, etc. The so-called CAPE Maria had to be called Maria Island. In Blue Mud Bay, the master's mate was fatally speared by natives. Melville Bay was discovered on 12 th February, 1803 .

On I7th February, the "Investigator" left the Gulf and steered west along the north coast of ARNHEM LAND. Here were met no 
fewer than sixty MaLAy vessels, in squadrons. Their business was to collect bêche de mer for sale to Chinese merchants at Timor.

Early in March, a severe outbreak of scuRvy reinforced the argument furnished by the rotten condition of the ship in favour of a speedy return to Sydney. Flinders therefore made for TIMor, which was reached by the end of March. His intention was to send Lieutenant Fowler home in any Europe-bound ship, with his reports and charts, and a scheme for completing the survey. No such ship offered itself, and the "Investigator" finally sailed for Sydney on 16th April, 1803. She touched at CAPE LeEuwin and the north-west cape of Tasmania, but otherwise gave the land a wide berth. SYDNEY was reached on 9 th Fune. Flinders was the first to circumnavigate Australia, although Tasman had previously demonstrated its insularity, but not its separation from Tasmania. The crew were in a very bad way with scurvy and dysentery, and Flinders himself was much debilitated. As for the "Investigator," she was in such a crazy condition that Flinders believed she must have foundered had she encountered a single gale between Timor and Sydney. She had done her last exploratory work, and was broken up at Deptford in $1810 .^{1}$

1 Terra Australis, II, p. 284. 


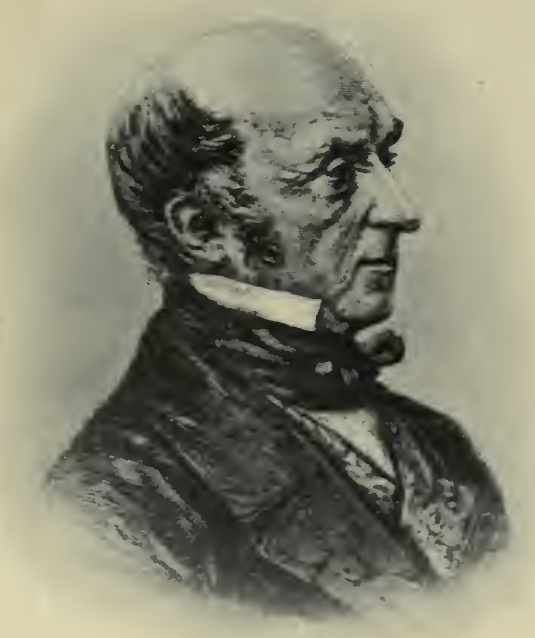

PHILLIP PARKER KING. 


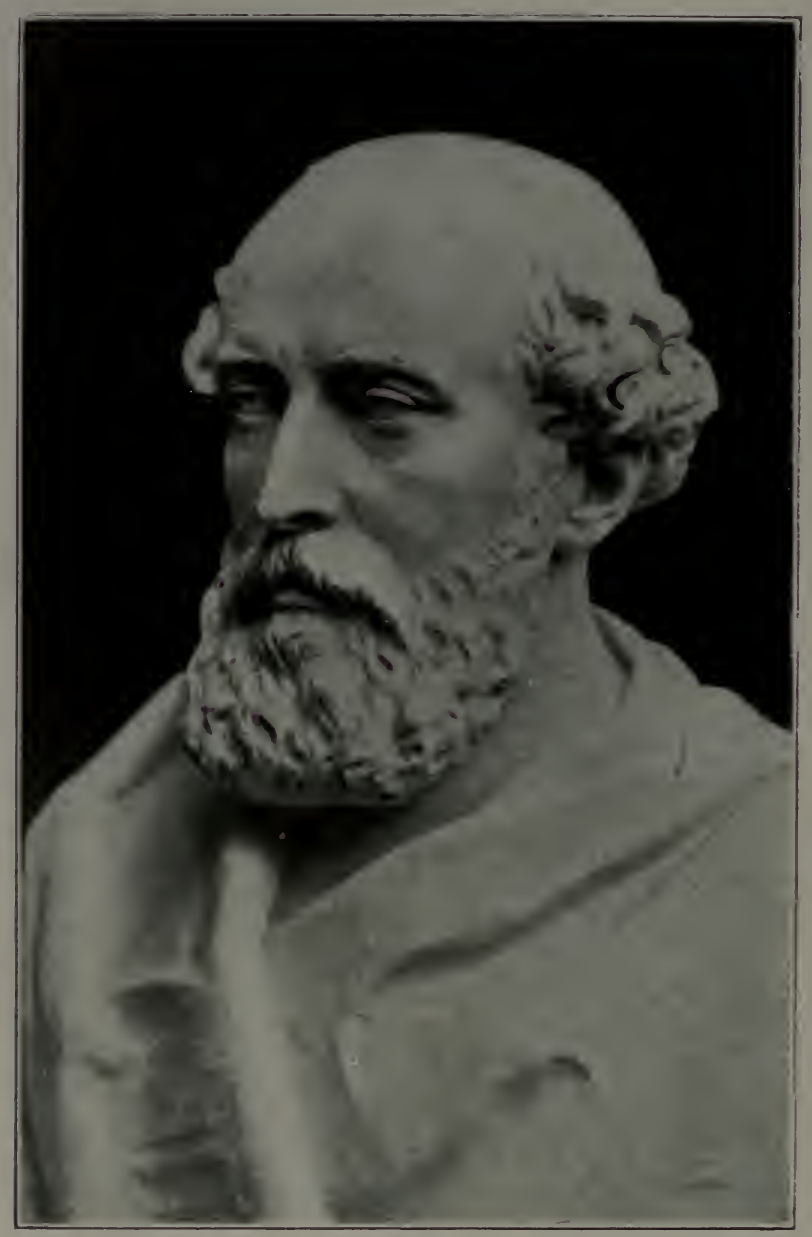

J. BEETE JUKES, I $\$$ 7O. 
CHAPTER XX

FLINDERS, continued

WITH THE "CUMBERLAND" TO TORRES STRAIT, 1803

CAPTIVITY AT MAURITIUS, I803-IO AND CLOSE OF HIS CAREER

Flinders on the "Porpoise" as a Passenger for England via Torres Strait. "Bridgewater" and "Cato" accompany "Porpolse." "Porpoise" and "Cato" stranded on Wreck Reef and deserted by the "Bridgewater." Three Lives lost. Ninety-four Men on a Sandbank. Flinders and the Captain of the "Cato" with Twelve Men reach Sydney in a Boat. Flinders given the Schooner "Cumberland." Sails for Sandbank in Company with the "Rolla" and "Francis." "Rolla" takes some of the Shipwrecked Men to Canton. "Francis" takes Others to Sydney. The "Cumberland" unseaworthy, but Flinders takes her through Torres Strait by the Cumberland Passage and Prince of Wales Channel, and towards Timor, via Booby Island and Arnheim Land. Calls at Koepang. No Facilities for Repairs. Leaves for Cape of Good Hope. Flinders, unaware that War between France and ENGLAND had bRoken oUt again, is COMPELled by Rough Weather to run into Port Louis, Mauritius. Frosty Reception by Governor De Caen. Suspected of Espionage. The Breach widens. Seven Years' Captivity. Flinders regains his Liberty on the Capture of Mauritius by the British. Return to England. Rejoins his lost Bride. Failing Health. Three Years writing his Great Work, "Terra Australis." His Death.

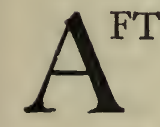

FTER consultation with Governor King, Flinders determined to go to England as a passenger by the "Porpoise," under command of Lieutenant Fowler, to lay his charts and journals before the Admiralty and to solicit the grant of another vessel to continue his investigations. Fowler's instructions were to go by Torres Strait " by the route Captain Flinders may indicate." The "Porpoise" left Sydney on roth August, I803, accompanied by the "Bridgewater," of the East India Company, and the "Cato," of London, both bound for Batavia."

On I7th August, the "Porpoise," which was in the lead, struck on Wreck Refr (22 $2^{\circ} I^{\prime}$ S., $155^{\circ}$ I $3^{\prime}$ E.) and the "Cato" immediately did the same. The "Bridgewater" weathered the reef and shamefully deserted her consorts. (She reached Bombay and left for London; after which she was never heard of again.)

Three lives were lost in the WRECK, but the remainder (ninety-

1 Terra Australis, II, p. 286. 
four in number) of the crews of the "Porpoise" and "Cato" got on a dry sandbank. They saved what they could from the stranded "Porpoise," including three months' provisions and sails to make tents, but the "Cato" had disappeared.

On 25th August, Flinders took three weeks' rations and left for Sydney, with Captain Park, of the "Cato," and twelve men, in a six-oared boat. "The men left on the sandbank did fairly well on the rations saved from the "Porpoise," supplemented by fish and turtle, and they built a boat of 32 feet keel, which was ready for launching early in October.

Flinders arrived in SyDNEY on 8 th September, his boat having rowed 700 miles in fourteen days, and reported the disaster to Governor King. It was planned that Captain Cummings, of the "Rolla," a 438-ton ship bound for Canton, should call at the reef and take some of the shipwrecked men to his destination, while the "Francis" was to bring the rest back to Sydney. Flinders was to take command of the "Cumberland," a 29-ton schooner, and sail her to England, with his charts and papers.

The flotilla left Port Jackson on 2 Ist September and reached the sandbank on 7 th October. Flinders selected to go with him on the "Cumberland" John Aken, late Master of the "Investigator," Edward Charrington, Boatswain, John Elder, Steward, and seven seamen; and, on IIth October the three ships sailed for their respective destinations. From the first, the "Cumberland" proved an unseaworthy craft. (SEE MAP A.) Flinders took her through Torres Strait, past Murray Island (see Inset Map on Plate 13, Terra Australis Atlas) on 22nd October, and thence, not far from his track in the "Investigator" a year earlier, but a little to the south, through what is now known as Cumberland Passage, and between Horn ${ }^{1}$ and Wednesday Islands (24th October), north of Hammond Island, and westward through Prince of Wales Channel, north of Booby Island, and westward, via Arnhem Land, towards Timor, which was reached on roth November.

Flinders had originally planned to call at Koepang, in Timor, Mauritius, the Cape of Good Hope, St. Helena and the Canaries; but by King's desire Mauritius was cut out of the programme. As it happened, there were no facilities for repairs at Koepang, and Flinders therefore left, with his ship unrepaired, for the Cape. Bad weather shortly afterwards compelled him, in spite of himself, to run to the Mauritius for shelter: moreover, he doubted if it would be safe to complete the voyage in the "Cumberland," and

1 Flinders did not actually give this name, but referred to " a hill forming something like two horns at the top." "This hill appeared to him to be on PRINCE OF WALES IsLAND itself, but as he approached it from the north-east he got a glimpse of a bight, which must have been the "BOAT PASSAGE" separating what is now called HORN IsLAND from Prince of Wales Island. Flinders, as well as Cook, passed north of ALBANY IsLAND, taking it for part of the mainland. 
hoped to sell her and get a passage to England by some other ship. He arrived at Port Louis, Mauritius, on 17 th December, 1803 . When he left Sydney, England had been at peace with France, but WAR, unknown to him, had broken out soon after between the two countries.

The Governor, or Captain-General, of the island was General DE CAEN, an old soldier, who had been, in fact, one of the most conspicuously heroic figures in the battle of Hohenlinden, and was violently anti-British; and Flinders was unfortunate enough to strike the wrong note with him from the first. In the prejudiced eyes of the Governor, he appeared, to begin with, as an impostor; next as a spy; and finally as an enemy who knew too much to be safely set free; and all the time as a person of arrogant and unconciliatory bearing, who demanded rights where he should have sued for favours. This was very far indeed from being the true character of Flinders; but he was wounded by the hostile reception he met with when he expected a sympathetic welcome and generous assistance. On the other hand, it was undeniable that his passport was three years old and was for the "Investigator" and not for the "Cumberland," and he should have made allowance for the fact that his mere presence at the Mauritius in a time of war would naturally raise a suspicion that he was not engaged in the investigation covered by his French passport. Although when Flinders left Sydney, Governor King had objected to his touching at the Mauritius, he had foreseen the possibility of the "Cumberland" being driven by stress of weather into French waters, and that, in such a case, the necessity would arise for an explanation of her presence there. Accordingly, he had provided Flinders with two letters addressed to General Magallon, Governor of the Mauritius (De Caen's predecessor), to be forwarded from the Cape, or by such opportunity as might offer itself. These letters, together with passports and commission, were actually sent ashore for the Governor's inspection when Flinders found himself obliged to seek shelter and assistance. The probability is that De Caen chose to regard them as personal and not official letters and declined to read them; or if he did read them, considered them irrelevant, and confined himself to the consideration of the passport and commission.

'The details of Flinders' CAPTIVITy on the island, which grew, as it did, out of a misunderstanding, are most distressing, but he received much kindness from civilians and from some of the French officers. His detention lasted till I3th June, 1810. Although, on Ist March, I806, Napoleon, then Emperor, ordered Flinders' release, the order did not reach Mauritius till July, 1807, and by that time De Caen considered that the circumstances had altered, and took the responsibility of disobeying the order, pending further instructions. Britain had, in fact, gained the mastery of the sea; 
had taken possession of the Cape of Good Hope ; and was threatening Mauritius. In June, 1809 , a British squadron was actually blockading the island. On I 5 th March, De Caen consented to the liberation of Flinders. On I 3 th June, Flinders had his sword returned to him and was liberated on parole. ${ }^{1}$ The blockading squadron being still outside the harbour, Flinders arranged for a passage in the "Otter" to the Cape, where he was delayed for six weeks. In August, I8ro, he embarked on the "Olympia" and he reached ENGLAND on 23 rd October. He lost no time in rejoining the wife he had left as a bride more than nine years before. The British captured Mauritius on 3rd December, r81o.

In spite of failing health, Flinders laboured for over three years on his narrative and charts, and his great work on Terra Australis was published in 1814 . The first copy of the book and atlas came to his hand on 18 th July, and he died on the r 9 th. His wife lived till I852, and he left a daughter, born Ist April, r812.

1 Terra A ustralis, II, p. $38 \mathrm{r}$. 
PHILLIP PARKER KING, IN THE “MERMAID," I8I9, AND IN THE "BATHURST," I82I

First Votage of "Mermaid." Survey of Australian Coast. A Weer in Endeavour Estuary. Cultivating the Natives. A Rupture and a Skirmish. Boat Navigation on Endeavour River. Chart. Sailing Northward. Cape Flinders and Flinders Islands. Islands near Cape Grentille. McArthur and Hannibal Islands named. Aground. Floated with Difficulty. Escape River named. Turns NW. between Albany and Mount Adolphus Islands. Through Prince of Wales Channel to Booby Island. Third Voyage of "Mermaid." Ten Days in Endeavour Estuary. Limited Inland Explorations. Tricky Natives. Landings on Lizard and Bligh's Sunday Islands. Cook's Track followed to Booby Island. Cape Wessel. Botany Bay. Ship Unfit for Further Service. Voyagr of the "Bathurst." Sails Northward accompanied by Merchant Vessels. Trinity Bay. Across Bathurst Bay. Landing. Surprise Attack by Natives. One Man wounded. Flinders Islands shown to be distinct from Mainland. Cave-drawings on Clack's Island. Strait between Albany Island and Mainland. By "Mermaid's" Track to Booby Island. To Cape Wessel and Sydney. King's New Charts. His Sailing Directions for the Inner Passage.

\section{$\S$ I. FIRST VOYAGE OF THE "MERMAID"}

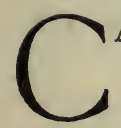

APTAIN, afterwards Admiral, Phillip Parker King, a son of Phillip Gidley King, who had been Governor of New South Wales from I800 to 1805 , left England in I8r9 in H.M.S. "Mermaid," on a surveying cruise along the Australian coast. ${ }^{1} \mathrm{He}$ was accompanied by Allan Cunningham as Botanist.

On 27th Fune, I8r9, the "Mermaid" anchored in the $\mathrm{E}_{\mathrm{N}}$ Deavour River. (See MAP E.) Amicable relations were maintained with the NATIVEs for nearly a week, but on 2 nd $\mathcal{F} u l y$ the aboriginal instincts of curiosity and acquisitiveness brought about a rupture. Some of the sailors were washing clothes, to which the natives took a violent fancy, going so far as to insist that one of the sailors should denude himself for their benefit. They threw a spear, and shots had to be fired over their heads before they would desist. Two days later, they attempted to decoy and ambush the white visitors.

On 8 th $f u l y$, a boat was rowed up the Endeavour River to

1 Narrative of a Survey of Intertropical and Western Coasts of Australia, I819-22, by Admiral Phillip P. King. London, 1827. 
the limit of boat navigation, about ro miles "as the crow flies," and this portion of the river was charted and soundings were taken." In this chart, the name "Mount Cook" appears for the first time.

The ship left the harbour on I I th fuly, and followed the coast to the north. After passing Cape Bedford and Cape Flattery, Lieut. Jeffreys named the Cole Group of Islands (off Murdoch Point), Cape Bowen' and Cape Ninian. On I 4 th fuly, the "Mermaid" passed CAPE Flinders, the northmost point of Stanley Island, Flinders Group ( $14^{\circ} 8^{\prime}$ S. ; I $44^{\circ} \mathrm{I} 4^{\prime}$ E.), where the wreck of the "Frederick" was seen. On $20 t h$ fuly, King named Haggerston and the Sir Everard Home Islands and Margaret BAY, all in the vicinity of Cape Grenville. (SEe MAP B.) Bligh had already crossed the mouth of Margaret Bay in the "Bounty's" launch, in 1789 .

On $24 t b$ fuly, the McArthur and Hannibal Islands were named." (SeE MAP A.) The same day the "Mermaid" grounded off the mouth of the ESCAPE RIvER and was got off with great difficulty. It is to this incident that the river owes its name, and not, as is generally supposed, to the attempted escape of Kennedy.

From the Escape River, King steered (25th fuly) NNW., altering his course to NW. between Albany and Mount Adolphus IsLands. Practically following the route taken by Bligh in the "Bounty"s" launch, he rounded the northern capes of WEDNESDAY and Hammond Islands. Thence, between Good Island and the North-West Reef (Prince of Wales Channel), he followed the track of Flinders, in the "Cumberland," to Booby IsLand. The long distance from the Escape River to Booby Island was covered in a single day. Crossing the Gulf of Carpentaria, Wessel's Island was reached on 28th fuly. (Admiralty Chart, No. 447.)

\section{§ 2. THIRD VOYAGE OF THE "MERMAID"}

The "Mermaid's" second voyage does not concern the present inquiry. On her third, she left Sydney on $14 t h$ Fune, I820, and anchored for the second time in the ENDEAvour RIver on $27 t h$ fuly. The previous watering-place was found to be dry. (SEE MAP E.) The party made observations and took in wood and water, and explored the land within a radius of 6 miles. The Natrves appeared inclined to be tricky : on one occasion, they approached furtively dragging spears with their toes.

The anchor was weighed on $5^{\text {th }}$ August, and on the following

1 Plan of Endeavour River, surveyed by Mr. J. S. Roe, Master Mate of H.M. cutter "Mermaid," 1819.

2 My notebook contains a sketch of Cape Bowen, taken from the steamer "Normanby" on 9th July, 1877 . The bare hillside shows three thick horizontal beds of sandstone, separated by soft beds, presumably of shales, and resting on what appear to be highly inclined schistose rocks.

3 King also named Hannibal Bay, but the name, for some reason, has been omitted from modern charts. 
day a party landed on the LIZARD IsLAND, where rough weather detained the ship till the $8 t h$. She touched on the $13 t h$ at Bligh's Sunday Island, off Cape Grenville, and on the $14 t h$ at Cairncross Island. (See Map A.) On 15th-16th fune, King followed Cook's track through Endeavour Strait to Booby Island. He passed Cape Wessel on 19th August, and reached Botany Bay on 4th December, i820. (Admiralty Chart, No. 447.)

\section{§3. VOYAGE OF THE "BATHURST"}

A survey of the "Mermaid" in Sydney showed her to be unfit for further sea service, and after consultation with Governor Macquarie the purchase of a 170-ton brig was effected. The ship was renamed the "Batburst." Her complement was 33 men, among whom were Allan Cunningham, Botanical Collector, Andrew Montgomery, Surgeon, and an aboriginal named Bardwell. The "Batburst" left Sydney on 26th May, I821, accompanied by the merchant ship "Dick," bound for Batavia. On r 7 th Fune, the merchant brig "San Antonio," from Sydney for Singapore, was overtaken at the largest of the FrankLAND IsLands ( $17^{\circ} 15^{\prime} \mathrm{S}$., opposite the mouth of the Mulgrave River), and she followed the "Batburst" and "Dick." (SEE MAP K.) The same night they anchored in TRINITY BAY, where they rode out a storm. (SEE MAP G.) On 20th fune, they were at Lizard IsLand, which, according to King, is granite. (SEE MAP E.) On 2Ist fune, they rounded CAPE MeLville and crossed Bathurst Bay, landing, 22nd Fune (at Bathurst Head?). Here the landing party was surprised and threatened by NaTIVEs, and one man was slightly wounded. Presumably, the Bay, the Head and the Bathurst Range were named on this occasion. This voyage showed that CAPE Flinders, till then believed to be a point of the mainland, was really the northern extremity of the chain of islands which prolongs Bathurst Head to the north for about Io miles, and, as King demonstrated the fact, it may be assumed that it was he who gave the islands the name of the Flinders Group which they still bear. Cook had no idea of the contour of this portion of the coast, as he was too far to the east to see it-in fact, outside of the Barrier Reef. Flinders was still further east, both in the "Investigator" and "Cumberland."

On 23rd fune, Cunningham observed aboriginal caveDRAWINGS on schistose rocks, underlying sandstone, on CLACK's IsLAND ( $144^{\circ} 15^{\prime} \mathrm{E}$., $14^{\circ} 5^{\prime} \mathrm{S}$.). They were executed in white on a ground of red ochre, and represented sharks, porpoises, turtles, lizards, tripang, starfish, clubs, canoes, water-gourds and quadrupeds.

The ships were detained by bad weather from 27 th $\mathcal{F}$ une to ist fuly, on which day they reached the opening between AlbanY and Mount Adolphus Islands. (See Map A.) Thence they 
followed the "Mermaid's" track of I8I8 to Booby Island, via Prince of Wales Channel. The "Batburst" left Booby IsLand, where she parted with the "Dick" and "San Antonio," on Ist fuly. CAPE WeSSEL was reached on $3 r d$ fuly, i821, and Sydney on 25 th April, 1822 .

The series of Admiralty Charts issued after King's surveys, bringing the charts of Cook and Flinders up to date, may be said to have set the hydrography of the Coral Sea on a firm foundation. There were, however, many shoals, reefs and other dangers still to be located before Torres Strait could be safely navigated by sailing vessels.

King was responsible for the "INNer PAssace" in the first issue of the Sailing Directions." Two notes from the "Directions" may be quoted here, with a view to their preservation :-

I. The "Lalla Rookb," passing eastward through Torres Strait in I82I, struck a reef "inside of" (i.e., east of) Booby IsLand. She was repaired at Port LiHou, on the south side of Prince of Wales Island, and concluded her voyage to Sydney outside of the Barrier Reef.

2. H.M.S. "Tamar" touched at Mount Adolphus IsLand in 1824 .

1 I have not seen this first edition, but it is reprinted in Complete Sailing Directions for the Various Passages to and through Torres Straits: Comprising the Inner Passage by the late Admiral King and the Outer Routes by Raine Island, and by the North-Eastern Entrance, by Captain Blackwood, R.N.: to which are added The Exact Positions of Outlying Islands, Reefs and other Dangers in the Outer Route of the Straits, as lately determined by Captain Denham, H.M.S. "Herald." 2nd Edition, Reading and Wellbank, Sydney, 1864 . 


\section{CHAPTER XXII}

\section{WRECK OF THE "CHARLES EATON," I834, AND SEARCH FOR SURVIVORS, 1836}

Wrecked on a Reef near Sir Charles Hardy Islands. Boatswain, Carpenter and Three Sailors take a Boat. All but One reach Timor Laut. TwentySIX LefT ON Wreck. IN Two Years News of Wreck Reaches Sydney. Raft with Nine Persons leaves Ship. All killed but Two Boys, who are taken to Aureed Island. A Second Raft, with Seventeen Persons, drifts to Boydong Cays. The Castaways invited by Natives to land. All killed in their Sleep except Two Boys. The Boys and the Heads of the Adults taken to Aureed Island. Two of the Four Boys taken to Marsland Island and later to Murray Island, Where they are Well treated. The "Isabella" From Sydney and the "Tigris" from India go in Search of Survivors. Two Boys rescued at Murray Island by the "Isabella." Exploitation of Torres Strait Islands by Papuans. Ethnological and Geographical Results of Voyages of "Isabella" and "Tigris." Captain Ashmore's Charts.

7 HE "Charles Eaton," a 313-ton barque, commanded by Captain G. F. Moore, left Sydney on 29th July, I834, for Canton, and was WRECKED on the Barrier Reef, near the Sir Charles Hardy Islands. (See Map B.) The only available boat was taken by George Pigott (Boatswain), Laurence Constantine (Carpenter), and three seamen, two of whom were William Frendall and Joseph Wright. The four above named, having sailed through Torres Strait, landed at Timor Laut after a run of only five days, the fifth man having died on the voyage. It was not till twelve months later that they were able to leave the island, and they eventually reached Amboyna and Batavia, whence the news of the wreck slowly travelled to Sydney.

The story told by these men was that on 15th August, 1834, the "Charles Eaton" "was making for an apparent opening in the reef near Sir Charles Hardy's Islands" (ENE. of Cape Grenville) when she grounded. "She fell broadside on, the sea making a clear breach over her. The longboat and one of the quarter boats were stove. The remaining boat was lowered and three seamen jumped into her. The Captain and officers determined to continue in the ship, as they thought the boat could not live. The rest of the crew and passengers went on the poop."

The Captain of the ship "Mangles" reported that he had seen, on an island in Torres Strait, a white boy who said he had been in 
the wreck of the "Charles Eaton." The Captain made an unsuccessful attempt to get the boy from the natives.

For the rescue of any of the crew or passengers who might still be alive among the natives, the Government of New South Wales fitted out their schooner the "Isabella," under command of Captain C. M. Lewis. The Captain's journal was edited by Captain Phillip Parker Kinc, R.N. ${ }^{1}$ Additional particulars are given by William EDWARD BRockett." The words "I shipped on the "Isabella" " are the only clue to the capacity in which Brockett was on board, but he was evidently an educated man, and was occasionally entrusted with difficult and delicate duties, so that it may be taken for granted that he was an officer.

The story has also been lucidly retold by Captain James $H$. Watson in the Scottish Australasian for September, I9I6.

The Hon. East India Company also sent their sloop "Tigris" (Captain Iggleston) from Bombay on the same quest. The two search ships, in fact, met at Double Island, Torres Strait.

In a very short time after striking the reef, the "Charles Eaton" became a hopeless wreck, but the upper part held together and gave a foothold for the greater number of the passengers and crew.

When she left Sydney, there were altogether thirty-one persons on the ship, including about a dozen passengers, among whom were Captain D'Oyley, H.E.I. Co.'s Artillery, his wife, two sons and a native Indian servant, Dr. Grant and George Armstrong, Barrister. Five left with the boat, leaving twenty-six on the wreck.

After the departure of the boat, as above related, the first raft was constructed, but it proved of insufficient capacity. The raft, therefore, carrying only nine persons, viz., Captain Lewis, Dr. Grant, Mr. Armstrong, Captain D'Oyley, his wife and two sons and native servant, with, probably, an officer or seaman, left the ship. Of the fate of this FIRST RAFT little is known with certainty. The only survivors were the two D'Oyley boys, who said that the ADULTs of the party had all been killed. The boys were taken in a canoe to an island, probably Aureed, and in all probability the heads of the adults were taken there at the same time. (SEE MAP A.) So at least we are justified in conjecturing from what happened to the occupants of the second raft.

Seven days after the first, a SECOND RAFT left the ship, carrying seventeen persons, including Mr. Clare (Chief Officer), W. Mayor (2nd Officer), John Ireland (Steward's Boy), a boy named Sexton,

1 A Voyage to Torres Straits in Search of the Survivors of the Ship "Charles Eaton," which was wrecked upon the Barrier Reef in the Month of August, 1834, in His Majesty's Colonial Schooner "Isabella," C. M. Lewis, Commander. Arranged from the Journal of the Commander by Authority of His Excellency Major-General Sir Richard Bourke, K.C.B., Governor of New South Wales, etc., etc., etc., by Phillip P. King, Captain R.N., F.R.S., etc. Sydney, 1837 .

2 Narrative of a Voyage from Sydney to Torres Straits in Search of the Survivors of the "Charles Eaton," in His Majesty's Colonial Schooner "Isabella," C. M. Lewis, Commander. By William Edward Brockett. Sydney, 1836, pp. 54. Illustrated. 
and thirteen others. These, after being two days and nights half-immersed in the sea, on a daily ration of two glasses of water and half a biscuit, drifted among a number of small islands. In the morning of the third day, they saw a canoe, carrying about a dozen natives, approaching. The natives were apparently unarmed, and appeared very friendly. Proposals that the castaways should land were acceded to, and they were taken in the canoe to "the island of Boydan." (See Map B, Boydong, lat. II $^{\circ} 30^{\prime}$ S., about 40 miles north-west of the Sir Charles Hardy Islands.)

On this island, where there was neither water nor food, the castaways lay defenceless, sleeping the sleep of utter exhaustion, when they were set upon and BEATEN TO DEATH, with the exception of IRELAND and Sexton, who for some reason were spared, although Ireland had a spear wound. Growing boys have obviously some potential value, even among savages. The heads of the murdered men were cut off and placed, together with Ireland and Sexton, in a canoe which proceeded to Aureed IsLand, where a party of natives were in temporary residence for the fishing season, and where they found the two D'OyLeY воYs, who had arrived before them. (See Map A.)

With the addition of the crew of the canoes from Boydong and their captives, and the murderers of the castaways of the first raft and their captives, there were now on this island about fifty persons. About two months after the arrival of Ireland and Sexton, the natives left the island in two parties. No. I PARTY took Ireland and the two-year-old D'Oyley boy, and No. 2 Party took Sexton and the elder D'Oyley boy, and both set out in their canoes, for destinations which were of course unknown to the captives.

The boys with No. 2 PARTY of savages were never heard of again. No. I PARTY, after cruising among islands for some weeks, reached Marsden Istand. ${ }^{1}$ To this island came, after a time, a native named Dappar and his wife, who took Ireland and the younger D'Oyley boy to their home on Murray Island, where they were kindly treated until their rescue by the "Isabella."

Ireland related that at BoyDong IsLAND the savages ate the eyes and cheeks of the murdered people, not, as he judged, for food, but with an idea that the act would increase their efficiency against enemies.

The "I sabella" left Sydney on 3 rd Fune, 1836 , and on the 9 th was " in the latitude of CATO'S REEF" ( $23^{\circ} 20^{\prime} \mathrm{S}$. and $155^{\circ} 35^{\prime}$ E.). (Admiralty Chart, No. 780.) Six days later, Captain Lewis saw floating wreckage, but did not suppose it to have come from the "Charles Eaton." On I7th Fune, the northmost reefs of the Eastern Fields (Admiralty Chart, No. 2759 A) were rounded

1 This island was probably named in honour of the Rev. Samuel Marsden, Rector of St. John's, Paramatta, who, in 1812 and for many years after, was unofficially regarded as "the head of the English Church in New South Wales." See J. P. McGuanne in Journ. Roy. A ust. Hist. Soc., Vol. V (1919). 
and a westward course was set for the "PANDORA PASSAGE" in the Barrier Reef (Admiralty Chart, No. 2422), which was cleared in lat. $9^{\circ} 58^{\prime} \mathrm{S}$. and long. $144^{\circ} 4^{\prime} 6^{\prime} \mathrm{E}$. on the $18 \mathrm{th}$, and before noon of that day the anchor was dropped off Murray Island. ${ }^{1}$

In the absence of all information, Captain Lewis' obvious course would have been to commence his search for survivors at the Sir Charles Hardy Islands, where the wreck took place. But the meeting of the captain of the "Mangles" with a white boy on an island in Torres Strait indicated that survivors might be searched for further to the north, and therefore MURRAY IsLAND was selected as the starting-point.

Natives of Murray Island came out in canoes and made known by signs that a white man was with them. This man, who proved to be JoHn IRELAND, two years older than when he shipped as Steward's Boy on the "Charles Eaton," was ultimately brought out to the "Isabella" and exchanged for tomahawks. Later on, WILliam, the younger of the D'OYLEY boys, was also produced and ransomed, the chief difficulty being his reluctance to part with his black foster-mother. He did not understand English, but spoke the Murray Island language fluently.

On 24 th Fune, the "Isabella's" launch was sent to WYER Island, south of Murray Island, where the men saw a string of HUMAN SKULLs in a hut. There was no reason to suppose that the skulls were those of white men, but they, no doubt, gave Captain Lewis a hint.

Four days later, the "Isabella" left for Darnley Island, steering north-west, but grounded on Canoe Key, where she was detained for a week. On the $5^{t h} \mathcal{F} u l y$, she sailed round the reefs east and north of DARNLEy ISLAND, and anchored on the north side of the island. The natives recognised the two boys. The island was searched for survivors of the wreck, but without avail. On 2Ist fuly, the low woody islands west of Darnley Island, viz., Stephen's and CAMPBell's, were searched, and also (by parties in the two whaleboats) islands lying to the windward, known by the native names of Masseed and CADDOW (presumably the two Yorke Islands designated on the modern chart Massik and Kodall). The inhabitants, who were apparently in a state of great alarm and anxious to get rid of their visitors, came down to the beach, offering gifts of coco-nuts, shells, etc. Ireland believed that they had skulls hidden in the bush, but they denied the imputation and fled.

On 25th Fuly, the "Isabella" anchored at AUreED IsLAND, which was carefully searched. No natives were met with, but in a hut there were found a great number of skuLLs, many of them having marks of violence, lashed with rope of European make to a

1 The route is plotted in ink, with notes in Captain Lewis' own handwriting, on a copy of Flinders' Chart, Pl. XIII of the Atlas to Terra Australis, in the Mitchell Library.

2 Such variations are only natural when Europeans spell foreign words phonetically. 
mask-like figure of turtle-shell. The skulls were taken possession of and carried to Sydney, where a sufficient numberwere pronounced to be of EUROPEAN ORIGIN to account for the majority of the shipwrecked people.

The object of the expedition had been attained, and the "Isabella" left Aureed on 26th fuly, on the home voyage, calling at Halfway, Mount Adolphus and Double Islands. While at Double Island, the "Isabella" was overtaken by the " Tigris." It appeared that the latter had sailed south-west from Murray Island by a new route, now known as the Tigris Passage, changed her course to north-west and rounded the north end of Halfway Island and followed on the track taken by the "I sabella" to Double Istand. The two ships left Double Island on 2nd August, passed through the Prince of Wales Channel, passed Booby Island on $3^{r d}$ August and reached Rafrles Bay, and ultimately Timor, where they parted, the "Isabella" for Sydney and the "Tigris" for India.

Although the geographical results of the "Isabella's" voyage were of no great importance, the voyage furnished ethnological data of considerable value. It gave, before the disturbing influence of a white invasion had had time to make itself seriously felt, a picture of the islands of the Coral Sea inhabited by a race of Papuan type, absolutely distinct from the Australian, who, while carrying their agricultural acquirements with them, had specialised in navigation and fishing, roaming from island to island in their canoes, fishing and turtle-hunting here and there at what their observation of winds, rains and currents had taught them were seasonable times for their pursuits, with, probably, only a limited enjoyment of home or head quarters. They worked the islands and fishing and hunting grounds on a carefully thought out plan, comparable to a scientific rotation of crops. As far as their opportunities permitted, they were HEAD-HUNTERS and SLAVERS. They penetrated by sea at least as far south as CAPE Grenville, and it is very singular indeed that they seem never to have attempted to seize or settle upon the mainland of Australia, and that they had communicated very few of their accomplishments to the inhabitants of the continent. So far as observation goes, slight or local infusions of Papuan blood into the Australian race are the only traces of their descents on the coast. It seems to me that the only possible explanation must be that they had not had time enough to make their mark on the Cape York Peninsula. In other words, it may not have been many centuries, or perhaps not even many generations, since they had begun their systematic exploitation of the Torres Strait islands and reefs. To all appearances, they had not had time, up to 1836 , to exhaust or seriously impoverish the fishing and hunting grounds which it was their custom to harry year after year. 
It is stated by Captain Watson ${ }^{1}$ that Captain Moore, of the "Charles Eaton," carried Captain Samuel Ashmore's charts, which I have been unable to find, although modern Admiralty charts locate several "dangers," etc., as having been "seen by Mr. Ashmore." According to Captain Watson, Ashmore was "a well-known master mariner of Sydney who, like Captain Thomas Beckford Simpson, of a decade or two later, never went a voyage without, on his return, giving his brother mariners and the public the benefit of what he learned by a careful study of the many problems which confronted the early navigators, of the dangers on the Australian coast."

1 Scottish Australasian, Sept., I916, p. 4957. 


\section{CHAPTER XXIII}

H.M.S. "BEAGLE," WICKHAM AND STOKES, I839-4I THE NORMAN RIVER AND NORMANTON, AND THE ALBERT RIVER AND BURKETOWN

"Beagle's" First Surveying Cruise. Sydney to Torres Strait. Endeavour Strait. Post Office on Booby Island.| Port Essington. Port Darwin. Point Pearce. Stokes Speared. Swan River. Infant City of Perth. Penal Settlement on Rottnest Island. Timor. Swan River. Albany. Adelaide. Sydney. "Beagle's" Second Surveying Cruise. Restoration IsLand CROWDED With Visitors from Torres Strait Islands. Boating UP supposed Van Diemen Inlet (a Mouth of the Gilbert River). Bountiful Island. Investigator Roads. Surveying and Sounding. Boat Parties sent out. Point Bailey. Point Parker. Proposed Transcontinental Railway to Point Parker (i88i). General Feilding's Expedition. The People's Patrimony. Sir Thomas McIlwraith's Government ousted. Progress of District delayed for a Generation. "Beagle" proceeds Eastward to Gore Point. Boat Parties exploring Shallow Coast South of Gulf of Carpentaria. Point Tarrant. Pascoe Inlet. Nicholson River. An "Important Inlet." Albert River. Twenty-seven Miles up an Inlet (a Mouth of Leichhardt River). Gun Accident to Lieutenant Gore. Inlet named Disaster Inlet. "Beagle" at Mouth of Flinders River (Tasman's Caron Inlet ?). Bynoe Mouth of Flinders (Tasman's Van der Lijn Inlet). Aboriginal Funeral Customs. Boat Party explores the "Important Inlet" (Albert River) for 40 miles. Plains of Promise. Stokes advises Explorers to start Inland from this Point. Site of Burketown. Important Mineral Fields easy of access. Boat Party explores Norman River (Tasman's Van Diemen Inlet). Site of Normanton, now Terminus of Railway from Croydon Goldfield. Smithburn River (a Mouth of Leichhardt's Gilbert River). Accident Inlet (another Mouth of Gilbert) is the "Pera's" "Furthest South" and Carstenszoon's Staten Inlet. Unfortunately, Stokes accepted Flinders' Guesses at the Identity of the Inlets named by the Dutch Navigators as Facts. "Beagle" coasts Peninsula Northward. Booby Island. Port Essington. Timor. Swan River. Adelaide. Sydney. Landsborough's Burke and Wills Search Expedition from Sitb of Future Normanton across Barkly Tableland to Camoweal. Pastoral Occupation progressing Northward. Captain Norman steams from Sweers Island and selects Site for Normanton Township and Custom House.

\section{THE "BEAGLE"}

\section{§ I. FIRST CAPE YORK SURVEYING VOYAGE, I839}

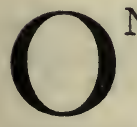
of the "Beagle" is told by Captain (afterwards Admiral)

N 29th May, I839, Commander John Clements Wickham left Sydney in H.M.S. "Beagle" to explore the northern part of the Australian continent. The story of this and the other Australian voyages 
J. Lort Stokes, who succeeded Wickham in the command in I 84 I. $^{1}$

An interesting link with the last important surveying voyage was found at Port Stephens, where Wickham and his officers were the guests of Captain Phillip Parker King, who was settled as Superintendent of the Australian Agricultural Company. This company, in about eighty years of usefulness, up to the present date has contributed greatly to the industrial progress of Australia. (See Map E.)

In crossing Princess Charlotte Bay, Wickham identified the "remarkable level-topped hill" called by Captain Cook, JanE's Tableland. (See Map B.)

At the northern extremity of Lloyd Bay, he surveyed Cook's Cape Weymouth and Bligh's Restoration Island, which he observed were of granite.

In Boydong IsLand, he recognised the scene of the massacre of the castaways on the second raft from the "Charles Eaton." (See Map A.)

Sailing, as Cook had done, between Reefs $Y$ and $Z$, and between the Brothers and Albany Islands, the "Beagle" was headed for Mount Adolphus Island, where (in Blackwood Bay) the anchor was dropped on 12th Fuly. From Mount Adolphus Island, she sailed west, past Possession Island, into Endeavour Strait. In this neighbourhood, channels about the Wallis Islands and Cape Cornwall (Prince of Wales Island) were surveyed. Wickham called the largest of the Prince of Wales Islands Cook Istand, but the name has not been adopted in official cartography."

A few days afterwards, the "Beagle" passed Bоoвy Island, on her way to Port Essington. Some particulars regarding this island recorded by Stokes are worthy of preservation. The island, he says, is 30 feet above sea-level and is composed of porphyry. The famous " POST OFFICE " was started in 1835 by Captain Hobson, of the "Rattlesnake" (afterwards Governor of New Zealand), who also erected a flagstaff on the island.

Wickham's observations and experiences during the rest of this voyage may be briefly alluded to.

Leaving PORT Essington on 4 th September, I839, he called at Port Darwin (I2tb September), and then he and Stokes explored the Victoria River in boats. (Admiralty Chart, No. 2759 A.) Afterwards, on landing at Point PeArce, near the mouth of that river, to correct his chronometers, Stokes was speared in the left

1 Discoveries in Australia, with an Account of the Coasts and Rivers Explored and Surveyed during the Voyage of H.M.S. "Beagle" in the Years 1837-43, by Command of the Lords Commissioners of the Admiralty. By Captain J. Lort Stokes, Commander, R.N. London, 1846 .

"The "group" name of Prince of Wales Islands has been dropped, and the largest island alone is now known as Prince of Wales Island, the others having received distinctive names, such as Wednesday, Hammond, Horn, and so on. 


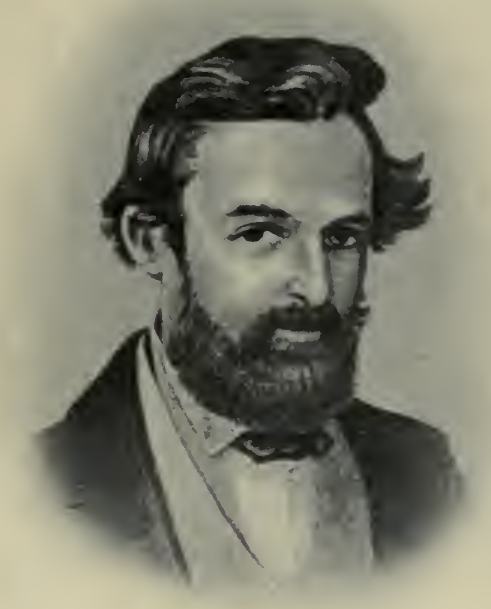

LUDIVIG LEICHHARDT, I $8 \uparrow+$. 


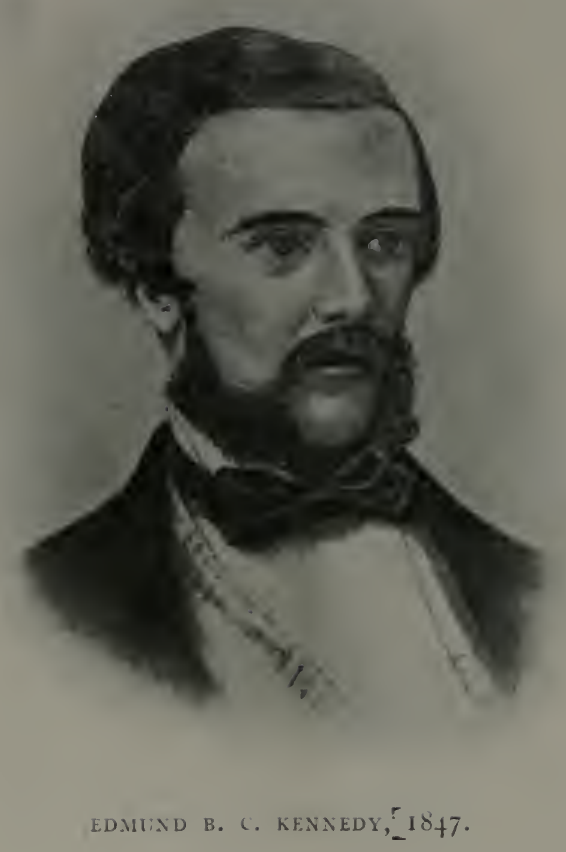


shoulder by NATIVEs from an ambush in a cliff. Having drawn out the spear, he ran, with the natives in pursuit, to safety in the arms of a party of sailors coming from the boat with instruments. By I 2 th December, he had recovered from the wound sufficiently to bear the motion of the vessel, which accordingly left Point Pearce for the Swan River settlement. Twelve days later, he was "just able to crawl on the poop." At the Swan River, he was interested in the shipping in Gage's Roads, which included some American whalers, and in the infant city of Perth. On 25th March, 1840, he visited the penal establishment for aborigines on RoTTNEST IsLAND. A surveying cruise to the north, along the western coast of Australia, commenced on 4 th April and ended at Trmor on 23rd July, I 840.

Timor was left behind about 9th August. The Swan River was revisited. The town of Albany was visited on 2nd and Adelaide on 27th November, and the "Beagle" returned to Sydney on 23 rd December.

\section{§ 2. SECOND CAPE YORK SURVEYING VOYAGE, I84I}

On 3 rd Fune, 1841, the "Beagle" again left Sydney for Torres Strait, this time in command of Captain Stokes, as Captain Wickham had not recovered from dysentery contracted at the Swan River. On anchoring on 19th Fune at Restoration IsLand, off Cape Weymouth (SEE MAP B), it was found that the island was temporarily occupied by a large party of BLACKs from Torres Strait, who had come in canoes. Some further surveying was done between Possession and Wallis Islands (see Map A), and Booby IsLAND was reached on $23 r d$ fune (SEE MAP H).

On 27th Fune, the "Beagle" lay off Bold Point ( $17^{\circ} \mathrm{S}$. ; $140^{\circ} 56^{\prime}$ E.), on the Cape York Peninsula. Two miles northnorth-east of the point, an inlet was observed, and, following Flinders, it was taken for Tasman's Van Diemen Inlet. It was explored in whale-boats by Messrs. Forsyth, Fitzmaurice and Tarrant up to fresh water, a distance of 27 miles by the windings, but not more than 10 in a direct east-south-easterly line. Natives were seen, but they displayed no hostility. This inlet is, in fact, as later exploration has proved, the largest of the many MouTHs of the Gilbert River.

Leaving Bold Point on 5th Fuly, the "Beagle" reached Bountiful Island ${ }^{1}$ ( $16^{\circ} 4 \mathrm{I}^{\prime} \mathrm{S}$.; $139^{\circ} 55^{\prime} \mathrm{E}$.), east of Mornington Island, the following day. On $8 t b$ Fuly, she dropped anchor in Investigator Roads, between Sweers and Bentinck Islands. (SeE Map M.) On the latter were found the well sunk by Flinders and a tree branded "Investigator." About a dozen NATIVEs were observed under Mount Inspection, but they displayed no hostility.

1 So named by Flinders on account of the abundance of turtles. 
Surveying and sounding in this neighbourhood occupied the time till 2 Ist July.

Two boats were sent out from Investigator Roads on 9th July, under Lieutenants Forsyth and Parker. They returned on the I 3 th with the report that they had passed to the south of Bentinck Island and landed at Point Bailey (see Map N), between which and the south end of Mornington Island were what were named the Forsyth Islands. At Point Bailey ( $139^{\circ} 4^{\prime}$ E. ; $16^{\circ} 55^{\prime} \mathrm{S}$.), a native well was observed. Ten and a half miles to the south-east was Point Parker, where, from a hillock 30 feet in height, there was a view of " a vast level."

[In 1881, Point Parker became "a name to conjure with," as it, or some place near it, was designated as the northern terminus of a "Transcontinental Railway" which, as an " all-Queensland " line, was to connect the existing railway from Brisbane to Charleville with the Gult of Carpentaria, and thus shorten the line of communication between Australia and England. The distinguishing feature of the undertaking was that, on the American model, the interior of the country was to be settled along the railway on a land-grant system, of which principle Sir Thomas McIlwraith's government approved. The railway was to be constructed by a British syndicate and handed over to the Government, the syndicate receiving as a consideration alternate blocks of land on both sides of it. There seemed no reason why the settlement of a large inland population should not have followed the realisation of such a scheme, as was the experience of America.

It was, however, too good an opportunity to be missed by the rising Labour Party, and the Government fell, on a cry, raised by Sir Samuel Griffith and his followers, of the danger involved in the " alienation of the people's patrimony." The immediate construction by the new Government, on borrowed money, of a railway to the Cloncurry copper-field was promised as an alternative. It was not, however, till the end of 1907 that Cloncurry was connected with Townsville by rail. The delay of twentysix years deprived the great majority of the pioneer discoverers of the copper-fields of the just reward of their struggles; there was no population settled on " alternate blocks"; and the Townsville railway does not answer the purpose of a "transcontinental " line, as it adds, for the produce of the mines, the circumnavigation of Australia to the distance from a European market.

Major-General the Hon. William Feilding was in charge of the Transcontinental Railway Expedition, and he traversed the country from Charleville to Point Parker in what proved to be an exceptionally hot and dry summer, and was consequently delayed beyond expectation. Acting under instructions from the Colonial Treasurer of Queensland, I rode from Townsville to Cloncurry (558 miles), where I arrived on 20th September, 188I. General Feilding only arrived on 7 th October, so that I had already had an opportunity of inspecting a portion of the mining district. After his arrival, while the main body of the expedition toiled on in the direction of Point Parker, I accompanied him and Ernest Henry, one of the leading pioneers, on excursions to outlying mining properties, which, of course, still lay idle from the want of facilities for transport. My reports were dated between I2th October, I88I, and Ist March, 1882.1 I parted with General Feilding on 9th October, 1881, at Gregory Downs and, after spending some further time in the mineral district, returned to Townsville by a route south of that by which I had travelled to Cloncurry.

It is evident, from the soundings given in modern charts, that the immediate

1 Six Reports on the Geological Features of Part of the District to be traversed by the Proposed Transcontinental Railway. By Robert L. Jack, Government Geologist. Brisbane, by Authority, 1885. Reissued, with Notes and Additions, as Bulletin No. 5 of the Geological Survey of Queensland, 1898. 


\section{SECOND CAPE YORK SURVEYING VOYAGE ${ }_{1} 6_{3}$}

neighbourhood of Point Parker, although admirably protected from the weather, does not afford the depth of water required by ocean-going steamers. A better site for a harbour would have to be looked for further west.-R. L. J.]

The "Beagle" left Investigator Roads on 2ist fuly, and at the same time Lieutenants Fitzmaurice and Pascoe set out in boats to examine a portion of the mainland which it was unsafe for the ship to approach too closely. The officers on the boats reported on 30 th July to Captain Stokes (who by this time had brought the ship to Flinders Inlet) the occurrence of a cape which was called Point Tarrant ( $139^{\circ} 31^{\prime}$ E. ; $17^{\circ} 24^{\prime}$ S.), and, 2 miles west of it, a "promising inlet," up which a boat was taken for about a league to the south-west. (SeE MAP M.) Ten miles south-east of Point Tarrant was a "large inlet," which was named the PAscoe INLET ( $17^{\circ} 30^{\prime}$ S.). [It is now known to be the mouth of the Nicholson River.--R. L. J.] Seven miles further in the same direction was an "important inlet," afterwards named the Albert River.

The "Beagle" herself, which had left Investigator Roads on 2ist $\mathcal{F} u l y$, anchored on the 24 th off Gore PoInT, on the mainland, where (in $139^{\circ} 56^{\prime} 30^{\prime \prime} \mathrm{E}$. ; $17^{\circ} 38^{\prime} \mathrm{S}$.) a sand-hill rises to a height of 40 feet. Between the sand-hill and a quoin-shaped ${ }^{1}$ clump of mangroves to the south-east, is an opening, which was explored in boats by Stokes and Gore for 27 miles by the windings ( 9 miles direct, to SW. $\frac{1}{2} W$.), up to " plains with open woodlands." It was named Disaster INLET, owing to a gun accident with injured the hand of Lieutenant Gore, who was shooting at white cockatoos. A pedestrian excursion for 6 miles S. $\frac{1}{2} E$. appears to have been devoid of interest or incident. There can be little doubt that Disaster Inlet is a mouth of the LEICHHARDT River.

On 26th Fuly, the "Beagle" went eastward, approaching the low "head" of the Gulf of Carpentaria as closely as the soundings permitted (about I3 geographical miles off), to Middle Point ( $140^{\circ} 12^{\prime}$ E.), 2 miles east of which is Morning InLeT.

On $28 t b \mathcal{F} u l y$, the ship anchored in about $140^{\circ} 35^{\prime} \mathrm{E}$.; $17^{\circ} 35^{\prime} \mathrm{S}$., off the mouth of a large inlet, which was named the FLINDERs River (which I believe to be Tasman's Caron Revier), and which was explored southward in a boat on the 29th and the morning of the 30 th to $17^{\circ} 5^{1} \frac{1}{2}^{\prime} \mathrm{S}$. Here the river split up into two branches, one of which came from the east and the other from the south. The former is now regarded as the "main " channel of the FLINDERS River, and, in fact, jains, or rather "leaves," the "Bynoe" Mouth of the river; while the latter is known as Armstrong CReEK. The reach below (north of) the conjoined Armstrong and Flinders was named Burial Reach, because an unburied aboriginal corpse was observed exposed in the fork of a tree.

1 A quoin is the wedge which used to be placed below the breech of a cannon to give the desired elevation. 
In the afternoon of the $30 t h$, Captain Stokes, accompanied by Lieutenant Gore and Messrs. Forsyth and Dring, took a boat back to the west to the "important inlet" noted by Fitzmaurice and Pascoe on 2Ist July. They followed it to the south-west for about 40 miles as the crow flies, and more than 50 by the windings, until the water had become quite fresh and the country had opened up into the "Plains of Promise" " (Ist August). It was named the Albert River. At Stokes" "furthest south" ( $\left.17^{\circ} 5^{8 \frac{T^{\prime}}{2}}\right)$, he was, in fact, nearing the southern limit of the coastal plain in which the mouths of the Nicholson, Gregory and LeichHardt Rivers anastomose. The party returned to the ship on 6th August. Stokes indulged in speculations on the facilities for INLAND EXPLORATION afforded by the landing at the Albert, opening up into country of the most inviting character. They were wise words, and if they had come under the eye of Kennedy/might have averted the disasters which overtook that unfortunate explorer in $\mathbf{I} 848$.

Up the Albert River, about half-way to Stokes' furthest point, now stands the town of BURKETOWN, which serves as the port for a large pastorally occupied area, as well as for the northern portion of the continuous mineral district extending from the heads of the Burke and Wills Creeks ( $21^{\circ} 30^{\prime} \mathrm{S}$.), through ClonCURRY COPPERFIELDS and the LAWN HILL SILVER-LEAD MINES.

While Captain Stokes was occupied as above mentioned, Lieutenant Fitzmaurice had been engaged in examining the coast of the Gulf between the mouth of the Flinders River and what was known to him as the Van Diemen Inlet of Tasman. Ten miles from the Flinders, he found the Bynoe InLET (Tasman's VAN DER Lijn Revier), another mouth of the same river. Seven miles further, there was another, which he did not name, in reality Tasman's Van Diemen Revier, but now known as the Norman River, on which stands Normanton, the sea outlet for a large pastoral country and the terminus of the railway to the CROYDON GOLDFIELD. From this inlet, the coast-line begins to trend only a few degrees to the east of north, and it continues so for 25 miles to the wrongly named Van Diemen Inlet ( $16^{\circ} 5^{8^{\prime}} \mathrm{S}$.). North of this, the coast-line trends north-north-east to the I6th parallel.

Thirteen miles south of the supposed Van Diemen Inlet (Smithburn River, a mouth of the Gilbert), " an opening of some magnitude " was observed ( $17^{\circ}$ I I' S.), with ponds of fresh water on its southern side. Two and 4 miles south of it were smaller openings (marked in the modern chart in $17^{\circ} 13^{\prime}$ and $17^{\circ} 15^{\frac{y^{\prime}}{2}} \mathrm{~S}$. .). The "opening of some magnitude" was named Accident INLET because "Mr. Fitzgerald had been seriously wounded in the ankle by the discharge of a gun, which had gone off within a few yards of it." He was, in fact, maimed for life.

1 This country is now all occupied as pastoral holdings: the part reached by the explorers is now Alice Vale No. 5 block on Bustard Plains run. 
Accident Inlet is the outlet of CRooked CReek, one of the mouths of the Gilbert River, and there is every reason to believe it to be the Staten Revier, the "Pera's" boat's " furthest south" in the year 1623 . Another opening was noted in $17^{\circ} 4^{\prime} \mathrm{S}$., and this is marked in modern charts "Southern Mouth of Gilbert R." It is certainly a mouth of the Gilbert, but Accident Inlet, which is another, is further south. This so-called "Southern Mouth" is named the Smithburn River in the maps of the Lands Department. (See Maps H, F, D, B and A.)

From the Smithburn mouth of the Gilbert River, after the wounded Lieutenant had been taken on board, the "Beagle" ran along the western coast of the Cape York Peninsula to BоовY IsLAND. In passing, a cursory examination was made of the North WaLlis Island (now Red Wallis IsLand), which is described as a conical hill of coarse sandstone, 70 feet in height-modern charts say 6o. A "grave" was seen, containing several skeletons covered with turtle-shells.

Booby Island was left on i7th August, i841. Cape Wessel was passed on the I8th, and Port Essington was reached on the 20th. Koepang (Timor) was visited. Touching at the Swan River and Adelaide, the "Beagle" returned to Sydney on 15 th March, I842. After a visit to Tasmania, she arrived in England on 3oth September, 1842 .

It is greatly to be regretted that Stokes accepted, without hesitation or investigation, Flinders' erroneous identifications of several of the "reviers," or inlets, named by the early Dutch navigators. In the case of Flinders, as we have already seen, the errors into which he fell were very pardonable, as he had not seen Carstenszoon's Journal of the voyage of the "Pera" (I623) and was only acquainted with the chart of Tasman's voyage of 1644 through the medium of Thevenot's by no means careful reduction. Tasman's chart, in fact, only became available through Jacob Swart's reproduction in $\mathbf{1} 860$. We have to remind ourselves that Flinders, although permitting himself to make guesses as to the identity of Carstenszoon's and Tasman's inlets, modestly omitted the names from his own chart. It would have been well if Stokes had imitated Flinders' caution, since he, no more than Flinders, could have seen Swart's version of Tasman's chart, and he was equally unacquainted with Carstenszoon's "Pera" journal which was first published by Van Dijk in 1859. The acceptance by Stokes as facts of what Flinders merely put forth as conjectures gave official authority for a number of errors which must for all time disfigure the maps, to the detriment of historical accuracy.

Taking the various inlets in their order from south to north, the corrections which should be made, but which have been rendered impossible by long official and private usage, may be traced, so as to distinguish between de facto and de jure names. 
I. The Finders River, first named by Stokes, may be accepted as a safe starting-point.

2. The Bynoe Inlet, so named by Stokes, is another mouth of the Flinders, but it had already been named by Tasman VAN DER LIjN's REVIER.

3. The Norman River, to which Stokes alluded only as " another inlet," and to which he attached so little importance that he gave it no name, and which Flinders had erroneously conjectured to be Tasman's Caron Revier, is Tasman's Van Diemen Revier. (The name of Van Diemen Revier is erroneously applied in modern charts to a mouth of the Gilbert River in $16^{\circ} 58^{\prime} \mathrm{S}$.)

4. Stokes' Accident Inlet (a mouth of the Gilbert River, continued inland as CROoKED CREEK) was the "furthest south" of the "Pera" and "Aernem" expedition in 1623 and was named the Staten Revier by Carstenszoon, who was on board the "Pera" and in command of the expedition.

5. The Smithburn River, or Smithburn Mouth of the GILBERT, was fortunately not named by Stokes, who merely refers to it as an "opening." (The modern chart, corrected to 1896 , calls it "Southern Mouth of Gilbert River," although Accident Inlet, another mouth, is still further south.)

For the reason that many of the names of the officers have been conferred on capes, islands and other geographical features of Torres Strait, the Gulf of Carpentaria and the neighbourhood of Cape York, the full list of the personnel of the "Beagle" is given below.

John Clements Wickham, Commander and Surveyor (1837-4r).

John B. Emery, Lieutenant.

Henry Eden, Lieutenant.

John Lort Stokes, Lieutenant and Assistant Surveyor (succeeded Wickham in I84I; afterwards Admiral).

Alex. B. Usborne, Master.

Benjamin Bynoe, Surgeon.

Thomas Tait, Assistant Surgeon.

John E. Dring, Clerk in Charge.

Benjamin F. Helpman, A. T. Freeze, Thomas T. Birch and L. R. Fitzmaurice, Mates (Fitzmaurice was appointed Assistant Surveyor when Stokes succeeded Wickham in the command).

William Tarrant, Master's Assistant.

Charles Keys, Clerk.

Thomas Sorrel, Boatswain.

John Weeks, Carpenter.

A corporal of marines and seven privates.

Forty seamen and boys.

The following changes took place during the voyages :-

May, I839.- Usborne invalided by wound. Tarrant acted as master until the position was filled by C. J. Parker in December, 1840 .

August, 1839.-Birch exchanged into the "Britomart" and was replaced by Pascoe. 
September, 1839.-Freeze exchanged into the "Pelorus" and was replaced by Forsyth.

December 7th, 1839.-Stokes speared at Point Pearce.

February, 1840.- Helpman entered Colonial service in Western Australia.

March, 1841.--Emery and Eden returned to England.

March, 1841.-Wickham invalided and Stokes took command.

March, I 841 .- Emery succeeded by Lieutenant Graham Gore (Gore's father was with Bligh and his grandfather with Cook).

\section{NORMANTON AND THE NORMAN RIVER}

\section{(See Map M.)}

In consequence of the disastrous issue of the Burke and Wills expedition, parties set out in different directions, in the year 186r, in search of traces or survivors, and two of these, Landsborough's and Frederick Walker's, reached the base of the Cape York Peninsula. Both parties had been carried north by the 200-ton brig "Firefly" (Captain Kirby). Walker's debarked at Rockhampton and Landsborough's at the Albert River. Landsborough established a depôt 20 miles up the river and commenced his land travelling on I7th October, I86r. He ran the Albert (SEE Maps $\mathrm{N}$ and $\mathrm{R}$ ) up to its head, either by the Gregory or O'Shanassy branch, crossed the BARKLY TABLeLAND and followed down the Herbert (now Georgina) River southward to $20^{\circ}$ S., i.e., to about the site of CAMOWEAL township, when the hostility of the natives compelled him to retrace his steps to his depôt on the Albert River, which he regained on 7 th December, to find that Walker had already been there. WALKER had gone westward from Rockhampton to the Barcoo River in long. $146^{\circ} \mathrm{E}$. and lat. $24^{\circ}$ S., and from this point had shaped his course to the north-west, running down the river which was afterwards called the Norman, and crossing the Flinders to the Albert. He had left the depôt on his return journey before Landsborough's arrival. ${ }^{1}$

By the end of 1869 , the northward march of pastoral occupation had brought it to the southern shores of the Gulf of Carpentaria, BURKETOWn had been established as a township on the Albert, and a custom house on Sweers Istand was supposed to meet the requirements of the Gulf and Straits. A small steamer named the "Black Diamond" (Captain Norman) left Sweers Island in February, I870, and landed 200 tons of cargo at the point where the Normanto custom house now stands. The new township and the river itself were named in honour of Captain Norman." Normanton is now the port for a considerable area of pastoral country, as well as for the Croydon goldfield, with which it is connected by a

1 Tracks of McKinlay and Party across A ustralia, by John Davis, one of the Expedition. Edited from Mr. Davis's Manuscript Journal. With an Introductory View of the Recent Australian Explorations of McDouall Stuart, Burke and Wills, Landsborough, etc., by William Westgarth. London, 1863 .

2 Captain William Campbell Thomson, "The Gulf of Carpentaria." Proc. Queensland Branch of Roy. Geogr. Soc. of A ustralasia, V, p. 26, 30th September, 1889. 
railway. The railway which links Cairns with the Etheridge goldfield will probably in the future be joined with that from Croydon to Normanton. The ultimate northern, or Gulf, terminus of the Townsville-Hughenden-Cloncurry-Mount Cuthbert railway will probably be at Burketown rather than at Normanton, as not only is the distance less (Burketown 152, Normanton I84 miles), but the tendency will be to keep the line as far as possible on the high and mineralised country extending through Mount Oxide and Lawn Hills.

I have already pointed out, when dealing with Flinders' conjectural identifications, that the "small opening in $17^{\circ} 26^{\prime} \mathrm{S}$." ( $17^{\circ} 28^{\prime} \mathrm{S}$., really), which he thought might be Tasman's Caron Revier, was much more likely to have been what Tasman named the Van Diemen Revier, and that this Van Diemen Inlet is the mouth of the modern Norman River. 


\section{CHAPTER XXIV}

\section{"L'ASTROLABE" AND “LA ZELEÈ" (1840)}

\section{DUMONT-D'URVILLE}

A French Scientific Expedition admirably equipped and carried out. Darnley Island. Changed and almost civilised. Bartering with Natives. Warrior Island. The "Mauvais Canal" through Reef. Aground. Ships floated and repaired. Inhabitants of Papuan Type. Their Water Supply Scheme. Bligh Channel cleared. Timor. The Napoleon Passage.

7 HIS admirably planned and equipped expedition left Toulon on 7 th September, 1837 , and returned to that port on 6th November, 1840. Its brilliant achievements and scientific reports ${ }^{1}$ form a valuable and permanent addition to the world's knowledge of south polar as well as of tropical regions. As usual, however, we confine ourselves to that portion of the work bearing on the region dealt with in this book.

The two vessels of the expedition, coming from New Zealand, sailed westward, to the north of the Portlock Rerfs and ANCHOR CAy, and dropped anchor in Treacherous Bay, Darnley Island, on 3Ist May, 1840. (SeE Map A.) A boat was sent ashore, and the NATIVES greeted their visitors with waving palm branches. They endeavoured to entice the sailors to accompany them inland, using women as decoys. This invitation having been declined, they displayed a desire for iron articles of all kinds, but indicated a preference for axes. They had, however, no eatables to offer in exchange, and would not take the hint when palm trees bearing fine coco-nuts were pointed out to them. When, after what the Surgeon called "an agreeable hour" had been spent ashore, and the visiting party turned back on the sound of the recall from the flagship, the natives were so friendly as to carry them to the boat and to repeat the word "to-morrow" again and again.

In 1886, the Hon. John Douglas described Darnley Island as the most important in the Strait, and as having a native popula-

1 Voyage au Pol Sud et dans L'Oceanie sur les Corvettes " L'A strolabe " et " La Zelée," 1837-40, sous le Commandement de $M$. J. Dumont-D'Urville, Capitaine de Vaisseau. Publié pár Ordonnance de Sa Majesté. Paris, 1846. ro Volumes and 2 Atlases.

Voyage autour du Monde de "L'A strolabe" et de "La Zelee," sous les Ordres du ContreA miral Dumont-D'Urville, I837-40, par Elie Le Guillou, Surgeon-Major de " La Zllée." Paris, 1843 .

2 The Islands of Torres Strait (with Map), by the Hon. John Douglas, F.R.G.S., Special Commissioner of British New Guinea, Ist April, s886. Proc. Queensland Branch of the Geogr. Soc. of Australasia, Vol. I, p. 70. 
tion estimated at 300 , besides fifty South Sea Islanders and three or four Europeans. Further evidences of progress were a police station and a mission station, with plantations of bananas, coco-nuts, sweet potatoes and bamboos.

On Ist Fune, the voyage was resumed, and the vessels passed StePhens' and DalRYMPLE IsLands, and made for the south end of the Warrior REEF. "On the right," says the Admiral, "was the Grand Reef, off which is the little Warrior IsLand, called Toun ${ }^{1}$ by the natives. I wished to anchor behind this little island and establish our second stage. I kept close to the reef on the starboard side, confident that it was completely charted. The blacks of Toud Island ran out on the reefs to watch us." The Surgeon puts it more elegantly: "We entered a calm channel, bordered with islets which looked like oases on the surface of the blue sea. There were shady dwellings beneath clumps of vegetation and coco-nut groves. The natives ran out on the reefs to see us pass and invited us to approach. We sailed confidently, being provided with the carefully constructed charts of the scientific King. . . . But here are two passages, one wide, free and open, and the other narrow, tortuous and bristling with reefs. The "Astrolabe" takes this one. There are shoals ahead. . . ."

Both vessels GROUNDED in the narrow channel, on which the name of Canal Mauvais was appropriately bestowed. They were, in fact, on the wrong side of Warrior Island. The channel on the south side, which Moresby named Basilisk Pass in 1871 , had already been used by Bligh ("Providence" and "Assistant") in I 792 and by BAmpton and Alt ("Hormuzeer" and "Chesterfield") in 1793 .

The ships, which had, unfortunately, grounded at high water, were very seriously-it seemed for a time hopelessly-in danger, and there was something maddening in the thought that the brave ships which had triumphantly come through the storms of the southern seas were cast away on a mud-bank in good daylight and fine weather, while the crews would have to make their way in boats to Timor. But by dint of superhuman exertions the ships were at last floated, the "Zèlée" on the 2 nd and the "Astrolabe" on the 4th June. Naturally, they had sustained considerable damage; and, while the necessary repairs were being effected, the way out of the passage was carefully surveyed and sounded.

The NAtives of the island were considered to be of New Guinea origin, as by their hair, their habits, and especially their custom of tattooing, they recalled the Papuans. They were entirely distinct from the Australian aborigines, and much more industrious and enterprising. They possessed about thirty very fine carved canoes or dugouts, and fishing was their daily avocation. Near the south end of the island were about a dozen huts. As there was no fresh

\footnotetext{
1 Tutre in modern charts.
} 
water, the natives had a system of collecting it in large clam-shells placed so as to catch the drip from pandanus trees when showers fell. Their weapons were of Papuan type, bows and arrows, and spears barbed with iron, and they had also iron hatchets. Their vocabulary included a few English words, and the conclusion was inevitable that they must have enjoyed frequent opportunities of intercourse with the English. A heap of bones and skulls of the dugong, observed at the north end of the island, was believed to be a depôt to be drawn upon, as required, for the decoration of graves.

On $8 t h$ and $9 t h$ Fune, the ships, piloted by the boats which had been engaged in sounding, cleared the Canal Mauvais. In the morning of roth June, Gueborar (Gabba, or "The Brothers") IsLaND was passed on the north, and, says D'Urville, "served as a guide-post towards Bligh's ExIT : then we saw the high summits of Banks, Mulgrave and Jervis Islands." In the afternoon, Passage Island (which marks the entrance to Napoleon Passage) was left behind and the anchor was dropped south of the Jervis REEF, which stretches east and west between Jervis and Mulgrave Islands. The next day was spent in soundings to assure a safe passage through Bligh Channel. The passage of the channel was made on I2th fune, and a week later TIMOR was in sight. BLIGH took the "Providence" and "Assistant" through the channel which bears his name in 1792 , and there is every reason to believe that he had been anticipated by TORRes in 1606 .

Jervis Island was named by Bligh in 1792 and surveyed by Moresby in the "Basilisk" in I873, but I have been unable to ascertain who discovered the channel now charted as "NAPOLEON Passage (1859)," a few miles north of Bligh Passage and between Jervis Island and Jervis Reef. The name suggests a French explorer, while the "Hamelin Boulders" in the middle of the passage are reminiscent of Captain Hamelin, of the "Naturaliste," whom Flinders met in Sydney in $\mathbf{1 8 0 2}$. Captain James H. Watson informs me that he has seen a reference in the Shipping Gazette to the passage (apparently by the Prince of Wales Channel) through Torres Strait of a British ship called the "Napoleon III" in July, I856. It is quite possible that the same vessel may have revisited the Strait three years later and discovered a new passage, but I have failed to find any record of the occurrence. 


\section{CHAPTER XXV}

\section{BLACKWOOD AND YULE, 1843-5}

\section{H.M.SS. “FLY,” “ BRAMBLE ” AND “ PRINCE GEORGE ” AND THE PINNACE "MIDGE"}

The Naturalist, J. Beete Jukes, the Historian of the Cruise. Blackwood's Additions to "Sailing Directions" of Torres Strait. Jukes" Work a Geological Classic. First Cruise of "Fly" and "Bramble," Sydnet to Torres Strait. Hinchinbroox Channel explored. Tully River. Dallachy and Wreck Creeks. Gould Ieland. "Friendly" Natives attack Boat's Crew. Jukes and Party stoned North of Rockingham Bay. Landing in Endeavour Harbour. Barometrical Observations on Lizard Island. Outer Edge of Barrier Regf. Landing near Cape Melville. Natives guide Party to Water and afterwards attack them. Survey of Cape Melville, the Barrier Reef and the Inner Passage. "Bramble" goes to Cape Direction. Ascent of Mount Direction by Boat Party. Attack by Natives. A Sailor rilled. "Bramble” rejoins "Fly" in Wreck Bay. Sir Charles Hardy Islands. Raine Island. A Crowded Breeding-place for Birds. Murray Island. Islanders eager to trade. Coco-nut Plantations. Wednesday Island. Booby Island. Port Essington, Timor, Swan River and Tasmania. "Fly's" Second Torres Strait Cruise, with "Bramble" and "Prince George." Raine Istand. Erection of Beacon. The Great Detached Reef. Surveying Endeavour Strait. "Flyy" and "Bramble" visit Port Essington and Sourabaya. Their Return to Torres Strait. Booby Island Depôm. Passage between Albany Island and Mainland. Darnley Island. Trade and Friendly Intercourse with Natives. Murray Island. Natives Civilised and Friendiy. Trade. "Bramble" surveys Part of Outer Edge of Barrier Reef and returns to Sydney. "Fly" and "Prince George" to New Guinea. Fresh Water at Sea. Fly River. Attack on Boat Party by War Canoes. "Midge" charting Coast. “Midge” and Gig separated from "Fly" and "Prince George." Boats reach Port Essington via Booby Island. "Fly" returns to Darnley Island to interest Natives in Search for Missing Boats. Natives engaged in Civil War. Blackwood and Evans assaulted. Civil War ends in Tournament. Honour is satisfied. "Fly" joins "Prince George" at Bramble Cay. The "Prince George" to Aird River, New Guinea. Sharp Fight. "Prince Grorge" sent to Booby Island. Log found in Booby Island Post Office gives News of Missing Boats. "Fly" returns to Darnley Island. Gentle Peace. "Fly" sails via Warrior Island to Evans Bay, Cape York. Jukes contrasts Australian Natives with Islanders. "Fly" to Booby Island. Joins "Prince George." Ships reach Port Essington. Two Shipwrecked Crews relieved. "Prince George" to Singapore. "Fly" to Sydney. Jukes recommends Establishment at Cape York. F. P. Blackwood (Sailing Master, F. J. Evans; Mate, D. Aird), was commissioned by the Admiralty to continue the SURVEYING WORK on the coast of Australia which had been commenced by FLINDERS and carried on by KING, WicKHAM 
and Stokes. She was accompanied by the tender "Bramble," LiruTENANT C. B. YULE, and the pinnace, which was named the "Midge," did useful service in the minutice of the surveying operations. Blackwood devoted himself heart and soul to the work, but he was a parsimonious writer. He has left us a short "Abstract of the Voyage," "which is little more than an itinerary, and incomplete at that. The Admiralty charts, as revised and corrected by him, and his "Chart of Endeavour Strait," and Notes in "Sailing Directions," "were apparently his only published contributions to the hydrography of Torres Strait. Fortunately, there was, among the scientific staff, a naturalist, J. BEETE JuKES, whose account of the voyage not only took its place at once as a geological classic, but abounded in that human interest which gives to a book of travel a permanent value apart from its geographical and scientific data. It is to this work, ${ }^{3}$ therefore, that we must turn for the greater number of the incidents and observations which made the voyages of the "Fly" memorable. Jukes joined the Geological Survey of Great Britain on his return from Australia, and was subsequently appointed Director of theGeological Survey of Ireland and Professor of Geology in the University of Dublin.

\section{§I. FIRST VOYAGE FROM SYDNEY AND CRUISE IN TORRES STRAIT, 1843 (SEe MAP K.)}

Between 19th May and Ist fune, 1843, the "Fly" and "Bramble" lay in Rockingham Bay, off Gould Island. The passage between "Mount Hinchinbrook" and the mainland, which had been "suspected" by King, was explored by Lieutenant Shadwell, Mr. Porcher and Jukes.

On the mainland, Blackwood explored " a fresh-water stream of considerable size," in the north-western portion of Rockingham Bay, probably the Tully River. Two others, traced by Lieutenant Ince, Mr. Pym and Jukes, through jungles till they became streamlets of no importance, were probably DaLLACHY and WRECK CREEKS.

The Natives of Gould Island commenced by being very friendly, and soon fell into the habit of paddling up to the ships for long talks, punctuated by the occasional receipt of trifling presents. Such

1 Printed as an Appendix by Jukes.

2 Complete Sailing Directions for the Various Passages to and through Torres Straits, comprising the Inner Passage by the late Admiral King, and the Outer Routes by Raine Island, and by the North-Eastern Entrance, by Captain Blackwood, R.N., to which are added the Exact Positions of Outlying Islands, Reefs and other Dangers in the Outer Route to the Straits, as lately determined by Captain Denham, H.M.S. "Herald." Second Edition. Reading \& Wellbank, Sydney, 1864.j atis

${ }^{3}$ Narrative of the Surveying Voyage of H.M.S. "Fly," commanded by Captain F. P. Blackwood, R.N., in Torres Strait, New Guinea and other Islands of the Eastern Archipelago, during the Years $1842-1846$. By J. Beete Jukes, M.A., F.G.S., Naturalist to the Expedition. London, 1847. 
confidence did they inspire that boats' crews would sometimes "neglect" to take their firearms when they went ashore. On 3 Ist May, one crew netted a good haul of fish, which they shared with the natives. Greatly to their surprise, they were assailed shortly afterwards with SPEARS AND sTONES. Mr. Weekes, the boatswain, was struck by a stone, which laid him off duty for a week. One of the men happened to have an uncharged fowling-piece, and after some search a ball was found on the bottom of the boat, and with this one of the foremost of the blacks was wounded, whereupon the attack was abandoned.

On another occasion, Jukes, Ince and Pym, when on a creek on the north side of Rockingham Bay, were sToNeD by some forty or fifty blacks, and replied with small shot. One of the blacks was slightly wounded.

On $4^{\text {th }}$ June, Jukes and others landed in Endeavour Harbour, but found no trace of the visit of Captain Cook, nor even of Captain King. (SEE MAP E.)

On $5^{\text {th }}$ June, Jukes, with Evans and others, climbed the hill on Lizard IsLand to make barometrical observations. They camped on the summit for the night and took a series of bearings in the morning. They made the altitude nearly 1,200 feet. While they descended, a party of NATIVEs, five men and some women and children, were seen below them. After they joined the ship, the voyage to the north was resumed.

From 7 th to 17 th Fune, the "Fly" was engaged in surveying the outer edge of the BARrier ReEF between Lizard Island and Cape Melville.

On I 7 th June, Blackwood, Mackay and Jukes landed 2 miles south of CAPE Melville and Jukes observed that the formation was granite. Some NAtives approached, and after mutual laying down of arms, guided the visitors to water. At sunset, the latter boarded the boat which was waiting for them. They then discharged their guns into the sea-with what object does not appear, unless they meant to "impress" the natives, who were observing them from some cliffs about 200 yards distant. It may be conjectured that the natives took this to mean that, having "shot their bolt," the visitors were at their mercy. At all events, the stowing away of the guns in the lockers was the signal for the discharge of two SPEARs, which fell close to the boat. The arms were got out again, and Jukes, having loaded one barrel with ball and the other with shot, fired at trees in the vicinity of the blacks, alarming the blacks sufficiently to put them to flight. A confiscated spear was found to be barbed with an iron nail and two sting-ray spines.

For some time after this incident, the "Fly" was "in and out" of the Barrier ReEF near Cape Melville. Jukes himself was not on board, and Blackwood is silent, but the expression "in and out" may be taken to mean that the inner passage and the landward side 
of the Barrier Reef, from the Pipon Islands and Melanie Rock south-westward, were surveyed on this occasion.

Lieutenant Yule was dispatched with the "Bramble" from Cape Melville, to measure the difference in latitude between that cape and CAPE Direction, and Jukes was a passenger. Evidently the "Bramble" took the passage inside the reef, as Night Istand is mentioned as having been seen before CAPE DIRECTION was reached on 24th fune. (See MAP C.) At daybreak on the 25 th, two natives were observed near the anchorage fishing from a large outriggerdugout. Following on a brief parley, some amicable bartering of spears, etc., for bottles, biscuits and ribbons took place. After breakfast, two boats were rowed ashore with a party comprising Lieutenant Yule, Dr. McLatchie, Messrs. Pollard and Sweatman, Jukes and nine seamen. The landing-place was probably near Villis Point, where Bligh had landed in I 789 from the "Bounty's" launch. A few men were left in the boats, and the rest of the party ascended Mount Direction, where they made a series of observations. The hill was of granite and 490 feet high. The two blacks who had been fishing reached the hill-top shortly after the whites, and were presently joined by a third. To keep them in good humour and prevent them disturbing Yule and the observing party, Jukes and McLatchie engaged their attention by dancing and "daffing." When the serious business was finished and the descent had begun, the blacks shouted and signalled to others below, who replied, and the whites began to suspect that they were being betrayed into an ambush. The suspicion was justified when they reached the bottom of the hill and made for the boats, and a crowd of natives concealed in the bushes assailed their flank and rear with a flight of sPEARs. Yule, at this time, was limping painfully in the rear (being crippled with rheumatism), and was followed by a sailor named Bayley, who carried the artificialhorizon box. Jukes happened to look back just in time to see a tall savage discharge a spear from a wimmera and transfix BAYLEY, who DIED of the wound three days later. The post mortem showed that the spear had passed from behind between the heads of two ribs and the spine, splintering the bones, and then penetrated the left lobe of the lungs all but an eighth of an inch. The spear was barbed with a three-inch bone, wrought to an acute spindleshape, and this barb remained in the body when the spear was withdrawn.

Some random shooting into the scrub followed this act of treachery, but no good could be done, and it would have been mere folly to follow the natives into the jungle.

The "Bramble" which had left the "Fly" at Cape Melville about a week before the end of June, rejoined her in Wreck Bay ( $143^{\circ} 5^{\prime}$ E.; $12^{\circ}{ }^{\prime} 0^{\prime}$ S.). (Admiralty Chart, No. 2920.)

There is nothing in the narratives of Jukes or Blackwell to 
indicate the route taken by either the "Fly" from Cape Melville or the "Bramble" from Cape Direction. It may be considered the most probable conjecture that both ships got outside of the Barrier Reef, the "Fly" by the Melville Passage, due north of Cape Melville (4-mile Sheet $20 \mathrm{C}$ ), and the "Bramble" by "Bligh's Boat Entrance" ( $15^{\circ} 52^{\prime}$ S.), east of Cape Direction. In Wreck Bay, which is an indentation in the outer edge of the Barrier Reef, there were seen (between 26th Fune and I 2 th $\mathrm{Fuly}$ ), the wrecks of the "Ferguson" (I840) and "Martha Ridgway", (184I). Three vessels were met on their way to pass through Torres Strait. Two of these, the "Winscales" and the "Fobn Wrenwick," carried sheep, potatoes and ale, and a bargain was made for fresh provisions, which were badly needed, scuRvy having broken out on board; and it may be added, the fresh food acted like a charm. (See Sheet B and Admiralty Chart, No. 2920.)

From Wreck Bay, and probably by the line of soundings shown on the chart extending north-westward from the MARTHA RIDGWAY ReEF, the flotilla made for the Sir Charles Hardy Islands, which were visited on 12tb fuly. (SEE MAP B.) Jukes describes them as composed of a brown siliceous rock, like a flinty slate passing into porphyry, the northmost island rising to 280 feet (modern charts give 320 feet). Thence the route lay by the Pollard Channel, south of the Cockburn Reef.

Jukes and Aird, in the "Midge," arrived at CAPE Grenville on I $8 t b \mathcal{F} u l y$ and ascended the eminence which modern charts name Highgate Hill (249 feet. Jukes gives it as 400). The rock was of the same character as that of the Sir Charles Hardy Islands, and the view comprised a "barren sandy country with low, scrubcovered hills." In fact, this was the dreary stretch of scrubby sand-dunes through which the Macmillan River finds its way into Margaret Bay.

Probably the "Fly" and her consorts next rounded CockBURN REEF and surveyed the eastward "course recommended" of the charts, by the "North Channel" to Raine Island. (Admiralty Chart, No. 2354.)

RaINe IsLand was visited on $29 t h$ fuly, and Blackwood and Jukes spent the night on it. It is described as an oval rim of coral, enclosing a sandbank which rises a few feet above the sea. As a breeding-place for birds it can have few rivals. It was hardly possible to walk or lie down without stepping on a bird or an egg. "The whole island," says Jukes, "stank like a foul hen-roost, and we were covered with bird-lice and ticks. After sleeping in the sand, we dined upon young boobies and frigate-birds' and terns' eggs."

On Ist August, the ships anchored in Pandora Entrance (where the "Pandora" was wrecked in I79I). On the $3 r d$, 4 th and 5 th, they skirted the outside of the BARRIER REEF to the north- 
ward. On the $5 t h$, they entered the reef by a small opening in $10^{\circ} \mathrm{I}^{\prime} \mathrm{S}$., and reached Murray Island the same day. (See Map A.) The highest point of the large island was estimated at 700 feet (modern charts make it 750). Many huts were observed and the INHABITANTS were numerous and eager to trade. In fact, they were so numerous and so hearty in their manners, when Blackwood landed on the 6 th, accompanied by Jukes and Melville (artist) and exchanged iron for coco-nuts, turtle-shell and bows and arrows, that he feared his men might be hustled, with an undesirable collision as the probable result. Jukes observed that the whole of the lower portion of the island, and even a good part of the hill slopes, were covered with a continuous plantation of coco-NUTS.

Murray Island was left behind on the $7 t h$, and the survey was extended to Mount Adolphus Island (i $t h$ ). Jukes climbed Mount Adolphus ( 5 I 8 feet) and observed that this and the whole of the York Islands (meaning, apparently, Mount Adolphus and the smaller islands in the vicinity) were composed of porphyry.

On 14th August, I 843 , the ships passed north of WEDNESDAY IsLAND and hove to off BOOBY IsLAND for a visit to the "POST OFFICE." The log-book and a bag of beef and some biscuits were observed. The "Fly" then sailed to Port Essington, Timor, the Swan River and Tasmania.

\section{§2. SECOND VOYAGE FROM SYDNEY AND CRUISE IN TORRES STRAIT, $1844-5$}

The "Fly" left Sydney on 22nd March, 1844, accompanied by the "Bramble" (Lieutenant Yule) and a small revenue cutter named the "Prince George," and sailed direct to Raine IsLand, where a party under command of LieUtenant InCE landed on 27th May. (Admiralty Chart, No. 2354.) Their primary business was the erection of a BEACON on the island to mark what was believed to be a safe passage through the Barrier Reef for ships coming from the east. A tank and some necessary timber were obtained from the wreck of the "Martha Ridgway," but other building material had to be cut or quarried from various islands or the mainland. The work was not completed until the middle of September.

As there was no anchorage close to Raine Island, the "Fly" lay about twelve miles to the south-west, under the shelter of the "GREAT Detached Reef," while the smaller vessels were fetching and carrying for the party camped on the site of the beacon. The "Fly" herself had to keep in touch with, and serve as a base for, the party operating on the island, but she managed, with the assistance of the "Prince George," to put in a good deal of surveying and sounding between Raine Island and Endeavour Strait. From 8th August to 25th September, the "Bramble" (Lieutenant Yule) 
was surveying Endeavour Strait. ${ }^{1}$ (See Map A.) On 2 Ist September, the "Fly" left Endeavour Strait for Port Essington and Sourabaya, Java, where she arrived on I9th October, 1844 , to be joined, shortly afterwards, by the "Bramble" and "Prince George."

The "Fly" and "Bramble" returned to Torres Strait on roth February, 1845. At Bоову Island, they left provisions for possible future shipwrecked people-fortunately for themselves, as it turned out. They were engaged up to I th April in surveying the central and north-eastern parts of Torres Strait. During this time they laid down the "track recommended" from the north-eastern end of the Barrier Reef to Endeavour Strait. Lieutenant (afterwards Commander) Shadwell, of the "Fly," made a series of magnetical observations. Shadwell Point, near Somerset, was named after him. Yule, in the "Bramble," surveyed the passage between the mainland and Albany Island and named it Port Albany.2

From 28th Marcb to Ist April, the ships lay off the west side of Darnley or Erroob Island, and the officers and men spent a good part of the time on shore. They sedulously cultivated a good understanding with the NATIVEs, and came to regard some of them as personal friends. Among these were two individuals named MAmmoos and SEEWAi, who were leaders rather by virtue of their strength of character than by right of any hereditary or electoral chieftainship. It was observed by Jukes that товАссо was cultivated and smoked, and he puzzled himself over the question of whether the plant and the custom had been introduced by early Portuguese, Spanish or Dutch visitors. He saw carved wooden figures, and was of opinion that they had no religious significance, but represented the filling up of idle time, or perhaps the instinctive expression of artistic feeling. The barter of iron articles, chiefly axes and knives, for coco-nuts and turtle-shell went on briskly. Jukes made the observation that Darnley and Murray IsLands were of volCANIC origin, while the islands extending from Cape York to Mount CoRnwallis were composed of granite or old metamorphic rocks. Dr. Muirhead and Lieutenant Risk s were among the persons who landed on Darnley Island.

On II $t h A$ pril, the ships anchored off Murray Island and the NATIVEs gave Blackwood and Jukes a hospitable and even effusive welcome. During the whole of their stay (till 1 5 th April), the most friendly relations were maintained between the islanders and the ships' companies. Bartering was carried on with zest, the islanders frequently visiting the ships in their canoes. It was noted

1 I gather the impression that Blackwood intended to apply the name "Endeavour Strait " to the whole of Torres Strait.

${ }_{2}^{2}$ MacGillivray's Voyage of the "Rattlesnake," I, I32. MacGillivray erroneously gives the year as 1846 instead of 1845 .

8 RIsk PoINT, on the mainland, opposite the Hannibal Islands, was probably named after him. 
that the shore was lined with a continuous row of huts, each enclosed in a courtyard of ten to twenty yards square, fenced with bamboo. The interiors were neat and clean. The natural products most in request were yams, plantains and coco-nuts, which seemed to be parted with reluctantly; on the other hand, the market was, perhaps, overstocked with bows and arrows. Many of the houses contained skuLLs, on which the tenants did not appear to set much value. One skull was sold for a fig of tobacco.

Blackwood and Jukes visited the smaller islands of the group, Dowar and Wyer, in the "Midge." Darnley Island is composed of a lava-form hornblendic trap rock, with volcanic sandstone and conglomerate. WYER and DoWAR are composed of volcanic sandstone and conglomerate, dipping at high angles quaquaversally, i.e., from the centre towards the circumference of the islands. There is an igneous rock also in the centre of the coral ring known as Bramble Cay.

On 19th April, Lieutenant Yule left with the "Bramble" for Sydney, against the prevailing wind of the season. Shewas successful, although Jukes remarks that the feat had only twice been attempted before, first in the "Zenobia" by Captain Lihou," and second by Captain McKenzie in the "Heroine" (1845). On this southward voyage, the "Bramble" surveyed the outside of the BARRIER REEF from Lizard Island to $16^{\circ} 40^{\prime} \mathrm{S}$. (south of 'Trinity Opening). (See Maps E and G and Admiralty Chart No. 2759 A.)

The "Fly" and "Prince George" finally left Murray Island for New Guinea on 2 Ist April. (SEe MAP A.) On the 25th, they anchored off the WARRIOR REEF, the eastern outline of which had already been surveyed by the "Bramble." Thence they made northward for BRISTOW IsLAND and the adjacent portion of the New Guinea coast, into which the Fly River discharges its waters. The sea-water was found to be barely salt ro miles out from the shore.

Blackwood and Ince explored, with the "Fly's" gig (29th April to Ist May), the FLY River, which was 5 miles wide at its mouth. They found a depth of 4 fathoms, and the water quite drinkable. They were not, however, allowed to go far without opposition. A landing had been made on the north, or left, bank of the river, when something like 500 men rushed at them from the woods, and they retreated. They were no sooner in the boat than a hot pursuit was commenced by four WAR CANOEs, each containing forty men. At nightfall the party in the gig shook off their pursuers, and at midnight they reached the "Prince George" and safety.

The water was too shallow for the "Fly" and "Prince George", and on 2nd May it was planned to outline the coast with the 1 After whom is named Port LiHov, Prince of Wales Island (Admiralty Chart.
No. 2354). 
"Midge," under Mr. Pym, and the second gig, under Mr. Harvey. Mr. Millery is also mentioned as being in the gig as a volunteer. Besides those named, there were twelve seamen. Dirty weather set in and the boats and ships lost sight of one another. Captain Blackwood's plans were upset and an earnest search for the boats took the place of the projected survey.

On 6th May, the "Fly" anchored at Bramble CAY, and on 6th and $7 t h$ she sailed northward towards Aird's Hill.

No trace of the MISSING BOATs having rewarded the search, it was resolved to return to DARNLEY IsLAND and enlist the services of some of the friendly natives, to "explain" matters to the New Guineans, and accordingly the anchor was dropped in Treacherous BAY on 24 th May.

The island (which Jukes estimated to contain no more than 100 men of military age) was in a ferment, and something like civil war was in progress. When, after a time, the position began to get clearer to Blackwood and Jukes, the trouble appeared to resolve itself into a trial of strength between Mammoos and Seewai and their respective partisans-a sort of tournament, in fact. The islanders had seen and heard nothing of the missing boats, and had no time for other people's affairs, and so turned deaf ears to the proposal that either leader should withdraw himself from the business in hand. Specifically and emphatically did they object to visit "DowDEE" (their name for the nearest portion of New Guinea), whose people they feared and hated.

In such a condition of affairs, the atmosphere is electric, and it is not surprising that in a few days the strangers, hitherto treated as friends, were subjected to an unprovoked assault. Blackwood and Evans had been ashore taking a meridian observation, and when they returned to their boat five ARRows were discharged at them, and muskets had to be fired in return. Happily, there were no casualties on either side.

At last the contending parties of natives met and "had it out" with bows and arrows. There were only light wounds on either side. Apparently somebody's, or everybody's, honour was satisfied, and the affair was over, obviously to the great relief of all concerned.

The peace, however, did nothing to overcome the reluctance of the islanders to go to "Dowdee," and after promises had been made and broken again and again, the idea of obtaining help from Darnley Island had to be abandoned.

The "Fly" left Darnley Island on 27th May and joined the "Prince George" at Bramble Cay.

On 29th May, Blackwood and Jukes went on board the "Prince George," and sailed to a point 24 miles north of $8^{\circ} \mathrm{S}$. latitude, and up a large inlet (AIRD RIVER) in $7^{\circ} 50^{\prime} \mathrm{S}$., where they had a sharp encounter with the New Guinea men, ten or twelve of whom were shot, some, it was supposed, being killed. 
It would be going too far outside the scope of this work to detail the further adventures of the "Fly" and "Prince George" in New Guinea. The point that chiefly concerns us is that nothing was heard or seen of the missing boats.

The "Prince George" was sent, on 2nd Fune, direct to Bоову IsLAND, where she found, in the "post office," an account of the adventures of the boats.

On 3 rd Fune, the "Fly" once more cast anchor in Treacherous Bay, Darnley Island, and this time gentle peace was smiling on the land. Nevertheless, the islanders did not disguise their satisfaction when they heard that their white friends had been obliged to shoot some of the detested Dowdeeans.

There were on the island a good many visitors from Tutte (Warrior) and Damood (Damuth or Dalrymple) Islands, and these reported that the MISSING BOATs had passed by their islands peaceably and safely.

On $4^{t h}$ Fune, the "Fly" left Darnley Island, ran rapidly round Attagor (Attagoy or Stephen's Island), and between Damood (Dalrymple) and Tutre (Warrior Island), and anchored under Dove IsLAND $\left(10^{\circ} \mathrm{S}\right.$; ; $143^{\circ} 2^{\prime} \mathrm{E}$.). On the following day she was in Evans BAY, CAPE YoRK, where the 6 th, 7 th and $8 t h$ were employed in watering. The presence of five Australian natives gave Jukes an opportunity of contrasting the physical characteristics of this race with those of the natives of the islands, who are of Papuan type. Briefly, his observations may be stated thus :-

Skin.-Australians, sooty black. Islanders, reddish or yellowish brown.

Hair.-Australians, uniformly fine, and either straight or waved in broad, open curls. Islanders, tufted on head and body: on the head frizzled when short, and forming hard pipe-ringlets when long.

Jukes says of the Australians :-

"Houseless and homeless, without gardens or any kind of cultivation, destitute of the coco-nut, the bamboo, the plantain or the yam, as of almost all useful vegetables, they pass their lives either in the search for food or in listless indolence. Instead of associating with us on something like terms of equality, bartering with us, teaching us their words and learning some of ours, laughing, joking and engaging in sports, like our Erroobian friends, these Australians sat listlessly looking on, standing where we told them, fetching anything or doing anything we ordered them, with great docility indeed, but with a complete want of interest or curiosity. In our endeavours to get words from them, they merely repeated our sounds or imitated our gestures." 1

In the vegetation of the two regions, there was a line of demarca-

$1 \mathrm{My}$ own experience corroborates these remarks. In spite of many more opportunities for learning the Aboriginal language, or languages, than Jukes enjoyed, I was completely baffled by the attitude which he so well describes. All attempts that I made to " exchange words," although my object was quite well understood to begin with, met with the invariable routine of amusement as at a game, a tired feeling, brain-fag, sulks and insubordination.- R. I. J. 
tion equally clear. On the mainland, gum trees extended to Cape York and the immediately adjoining islands, with jungle-foliage only in gullies. On the northern islands of the strait, there were no gum trees, and the woods were dense and umbrageous, and often matted into thickets, with coco-nuts, plantains, bamboos, etc. "It was evident," says Jukes, "that in crossing Torres Strait we were passing from the Australian centre of life, so to speak, into that of the Indian Archipelago, or, more strictly, perhaps, of the Moluccas."

Having replenished the water supply at Evans Bay, the "Fly" sailed to Bоову IsLAND, where she found the "Prince George," whose men had learned through the "post office" all about the movements of the LOST BOATS. It appeared that the boats, unable to sight the ships or to make Bramble Cay, the length of their stay being determined by the amount of the provisions carried, had made for Booby Island, where, fortunately, the provisions left by the "Fly" in February were still available. Their men had got water at PORT Linou, Prince of Wales Island, and then taken on the "Midge" to Port Essington.

The "Fly" and "Prince George" arrived at Port Essington on 12 th Fune, I845. There they found the crews and passengers of the "Hyderabad" and "Coringa Packet," which had been WRECKED, the former in the Cumberland Passage, near Murray Island, and the latter on outside reefs in $17^{\circ} \mathrm{S}$. and $150^{\circ} \mathrm{E}$. The "Prince George" conveyed some of the men to Singapore and the "Fly" took the rest to SYDNEY, where she arrived on 25 th September, 1845. There, orders were waiting, requiring the "Fly" to return to England, while the survey was to be continued by Yule in the "Bramble," with a tender to be commanded by Master (now Lieutenant) Aird. The "Castlereagh" was subsequently purchased in Sydney for this purpose, but was found unsuitable and was resold. The "Bramble" was paid off in Sydney, but on the arrival of the "Rattlesnake" to replace the "Fly," was recommissioned to act as her tender and again put under the command of Lieutenant Yule. ${ }^{1}$

In reviewing the voyage of the "Fly," Jukes strongly urged the establishment of a POST AT CAPE YORK similar to that at Port Essington. He foreshadowed the changes soon to be brought about by steam navigation, citing Captain McKenzie's article in the Nautical Magazine for February, 1847, in support of his views, and insisted on the necessity for coaling stations. He predicted for such a settlement that it would speedily become " another Singapore."

1 MacGillivray's Voyage of the "Rattlesnake," I, p. 43. 


\section{LEICHHARDT'S OVERLAND EXPEDITION FROM BRISBANE TO PORT ESSINGTON, I844-5}

\section{BRISBANE TO THE LYND RIVER}

Leichhardt's Previous History. The Overland Expedition. Start from Brisbane. Personnel and Equipment. Mobilise at Jimbour. Itinerary from Jimbour to the Head of the Lynd.

$\mathrm{F}^{\mathrm{on}}$

OR a brief hour, as the southern cross appears to a watcher in the north, Dr. Ludwig Leichinard, the first land explorer to reach the Cape York Peninsula from the south, rises above our horizon.

Leichhardt was born in Trebatch, Lübben, Prussia, in 1813. Owing to the accidental omission of his name from the military rolls, he found himself, on arriving at the age of manhood, free to indulge the passion for travel which had been born with him. $\mathrm{He}$ reached Sydney in $\mathbf{1 8 4 2}$, and as soon as he had attained sufficient prominence to be noticed, was posted in his native country as a deserter. At a later date, in recognition of his services to science, the King of Prussia was graciously pleased to remove the stigma from his name by granting him a free pardon. He might prove a useful instrument for peaceful penetration.

For a little over two years, Leichhardt occupied himself in BOTANICAL AND GEOLOGICAL TRAVELS, in the course of which he went as far north as Moreton Bay (Brisbane).

Apart from the mysterious circumstances surrounding his death, Leichhardt's fame rests on his successful TRAVERSE OF THE Australian continent from Moreton Bay to Port Essington, the early settlement in Coburg Peninsula, in the north of Arnheim Land, which has since been superseded by Port Darwin.

Leichhardt Left Sydney on I3th August, 1844, accompanied by James Calvert, John Roper, John Murphy (aged i6), William Phillips (a "prisoner of the Crown") and "Harry Brown," an aboriginal of the Newcastle tribe.

In Brisbane, there were added to the party, Pemberton Hodgson, a botanist; John Gilbert, who had been collecting for Gould, the Naturalist; CALEB, an American negro; and Charley, an aboriginal from Bathurst.

The expedition was mobilised at Jimbour, on the Darling Downs, and finally left that station on Ist October, I844. 
The scientific EQUIPMENT consisted of a sextant and mercurial horizon; a chronometer; a compass; and Arrowsmith's Map of New Holland. The TRANSPORT animals were seventeen horses and sixteen bullocks.

A SPRING CART formed part of the initial train, but was evidently not meant to go far : as a matter of fact, it was abandoned after a few days.

Leichhardt's original idea was to LIVE almost entirely on GAME, as far as meat was concerned. This was, however, soon found to be impracticable, and as it was necessary to reduce the number of the party, Hodgson and CALEB LEFT on 3 rd November to return to Jimbour, the main camp being then on the heads of the Dawson RIVER.

The ItINerary of the expedition from Darling Downs to the heads of the rivers falling into the Gulf of Carpentaria need only be briefly summarised, as only the latter portion of the journey comes within the region forming the subject of this work.

From Jimbour station, north of Dalby, ${ }^{1}$ to near Miles, ${ }^{1}$ the plain on the southern side of the Bunya Bunya Range was followed. The range was crossed north of Miles and the heads of the Dawson RIVER were successively crossed on a course which was at first nearly west and gradually swung round to the north. The Comet River was next run down from its head to its junction with the Mackenzie. After the high ground forming the Peak Range had been traversed, a descent was made into the valley of the Isaacs River, in the latitude of Broad Sound. The IsAacs was then run up to its head, at a gap in the Denham Range, leading to the head of the SutTor River; and the Suttor was followed down to the Burdekin. (SeE Map Q.) The Burdekin valley was next followed up, past Sellheim railway station on the Townsville to Charters Towers line, Dalrymple and the Valley of Lagoons, and the DIvide between the waters of the Pacific and the Gulf of Carpentaria was cleared north of Mount Lang. (See Maps O, P AND K.)

1 The route is more easily followed by the introduction of names of places which did not exist in Leichhardt's time than it would be if only his own place-names were given. 


\section{CHAPTER XXVII}

\section{LEICHHARDT'S OVERLAND EXPEDITION, I844-5, continued}

\section{THE LYND VALLEY}

Across the Divide. The Lynd River discovered. Telegraph Line. Camp 23rd May, 1845. Geological Observations. Camps 25th and 26th May. Oaks and Mulindie. Rob's Range. Threatening Natives. Camp 27th May. Lunar Observations for Longitude. Lyndbrook Railway Station. Camp 3ist May. Fossilbrook. Camp ist June. Fulford Creek. Camp 2nd June. Natives. Camps 3rd and 4th June. Kirchner Range. Camps 5th and 6th June. Natives. Horizontal Sandstone. Tate River. Camps 7th, 8th and 9th June. Leicester. Lygon. Camp roth June. The Lynd, after traversing Mountainous Country, enters on Flats. Camps itth and izth June. Sandstone and Conglomerate. Massie Creek. Camp i3th June. Box-tree Flats. Native Huts. Camps i4th and i5th June. Last of the Lynd River. Age of the Horizontal Sandstone. PermoCarboniferous? Daintree's Desert Sandstone. Mount Mulligan. Probable Extension of Artesian Water Area. Fauna of the I.ynd Valley.

(SEE MAP K.)

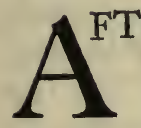

ER spending some time in an attempt to get on western waters, Leichhardt succeeded in crossing the DIviding RANGE and dropped down on the river to which he gave the name of LYND, and which he ultimately followed down to the north-west till it joined the Mitchell River.

Leichhardt's narrative of this portion of his travels shows some carelessness as regards the direction and the distances travelled daily. It may be assumed that, as he knew that he was following a river with a general north-westerly course, he trusted to the establishment of his position from time to time by observations for latitude, but as a matter of fact such observations were not always possible or convenient. The best that can now be done is to assume the correctness of the latitudes given and trust to hints in the narrative for the position of intermediate camps. Arrowsmith's map, however, gives additional information on many points, and, as it was " laid down from Leichhardt's original map," such information is of material assistance.

The gap by which Leichhardt crossed the DIVIDING RANGE on 23rd May, 1845, appears to have been that which now takes the TELEGRAPH LINE from Junction Creek to Mount Garnet. From this gap he reached the LYND in about 6 miles. The rock passed over was mainly granite. CAMP, 23RD MAY. Lat. $17^{\circ} 5^{8^{\prime}} \mathrm{S}$. 
25th May.-Eight miles down the river WNW. Granite and pegmatite. CAMP 25TH MAY. This camp was probably about the mark LL 7 of the modern survey.

26th May.-This day's journey was mainly in granite country, although basalt was met with towards the end of the stage. Very rough and mountainous. Probably covered 8 miles to WSW. down the river. CAMP 26TH MAY must have been about the western boundary-line of Glenfinlas block, St. Ronan's run.

27 th May.-Low rocky ranges. Course of river mainly NW. Basalt reappeared on the banks of the river below " a range of rugged little peaks" (RoB's RANGE?) and "extended for some distance, now filling the flats with its rough and cellular blocks and pebbles and again forming small hillocks of black bare rock." CAMP 27th May. "The latitude is given as $17^{\circ} 44^{\prime} 40^{\prime \prime}$, which is probably a clerical error, and should read $17^{\circ} 54^{\prime} 40^{\prime \prime}$, and on this assumption the camp would be about the modern bench mark L, XIX. This day some Natives, men, women and children, were met with. "The men poised their spears and shook their waddies to frighten us," says Leichhardt, "but when, notwithstanding their menaces, we approached them, they left all their goods and, with their weapons only, hurried up the rocks with wonderful agility."

A halt of three days was made at this camp while a bullock was killed and the beef dried, the last of the salt having already been used. A series of LUNAR OBSERVATIONS enabled Leichhardt to calculate the longitude of the camp as $143^{\circ} 30^{\prime}$. It may be that by a clerical error "I 43 " has been substituted for "I44," as the error is practically one degree; but if Leichhardt really meant $143^{\circ} 30^{\prime}$ his longitudes must be taken with caution. Arrowsmith charts the camp at $144^{\circ}$, which is impossible.

The expedition moved on down the river on 3Ist May, the country being granitic except for small outbreaks of basalt. The distance travelled is not mentioned, nor the direction, but the latter must have been NW. and the former about I4 miles. CAMP 3 Ist May was probably on the site of the "LYNDBROOK" station on the modern Chillagoe-Etheridge Railway.

On Ist Fune, 8 miles down the river to NW. took the party to the infall of Fossilbrook. CAmP ist fune. Lat. $17^{\circ} 45^{\prime} 50^{\prime \prime} \mathrm{S}$., at Bench Mark LF.

2nd fune.-Seven and a half miles WNW. down the river, in porphyry and granite. CAMP 2 nd June. Opposite mouth of HacketT's (Fulford) Creek.

$3^{\text {rd }}$ Fune.-Seven miles NW. down the river, in porphyry and granite, but had to leave the river in some places and cross porphyry hills. Saw a family of natives, who fled. Camp 3 rd June. Talc schist near the camp.

4th June.-Travelling so rough that the party was compelled 
to leave the river. Regained the river after covering about 8 miles, gaining about 5 miles to NW. Camp in lat. $17^{\circ} 34^{\prime} 17^{\prime \prime}$.

5 th fune. - The party travelled about 9 miles west, on the chord of an arc formed by a northward detour of the river. A range north of the river was named Kirchner Range. (The 4-mile map names one of its peaks Mount Valentine.) The rocks observed during the day's journey were granite, syenite, permatite and hornblende rock. С $\mathrm{C}_{\mathrm{MMP}} 5$ th fune. On bank of river, near bench mark L 95.

6th fune.-Nine miles west. Porphyry rocks, "composing hills of an almost conical form." CAMP $6 t h$ fune. Lat. $17^{\circ} 39^{\prime} 47^{\prime \prime} \mathrm{S}$. Opposite bench mark L 87.

7 th Fune.-Travelled about 9 miles down the river, NW. Porphyry for the first 4 miles, and then sandstone rocks appeared in the distance on the left. As the party progressed, the sandstone approached the river, until they were forced to travel in its bed. CAMP 7 th Fune. About a mile short of the mouth of the river which Hann afterwards named the TATE. Passed a camp of NATIVES.

8th Fune.-Travelled about 9 miles NW. Open country, although the sandstone ranges approached the river in many places. CAMP 8th Fune. About 2 miles below bench mark L 7 I.

9th fune.-Ten miles down the river NNW. Box-tree flats interrupted by " abrupt barren craggy hills composed of sandstone, which seemed to rest on layers of argillaceous rock." CAMP 9th fune. Near the division between Torwood and Torwood No. I pastoral blocks.

roth Fune.-Five miles NNW. down the river, over similar country. САMP Ioth fune. Lat. $17^{\circ} 9^{\prime} 17^{\prime \prime}$. At bench mark L 54 .

I $t$ th fune.-Travelled 8 miles a few degrees west of north, the river opening up into fine flats. CAMP i ith fune. About 6 miles below bench mark L 50 . (See MAP G.)

I2th Fune.-Travelled 9 miles NNW. CAMP I 2 th fune. Lat. $16^{\circ} 55^{\prime}$ S. (SEE MAP H.)

I 3 th fune.-Travelled 9 miles NNW. on " a coarse conglomerate of broken pieces of quartz, either white or coloured with oxide of iron." Leichhardt remarks of this conglomerate that " it greatly resembles the rock of Wybong Hills on the Upper Hunter." CAMP I 3 th Fune. About 2 miles south of MAssie CREEK.

I th fune.-Travelled 9 miles N. by W. over extensive box-tree flats. Saw a two-storey Native hut or gunyah. Camp i 4 th $\mathcal{f}$ une. Lat. $16^{\circ} 38^{\prime} \mathrm{S}$.

I 5 th f une.-Travelled $9 \frac{1}{2}$ miles $N$. by W. down the river, over similar country. CAMP I 5 th Fune. Lat. $16^{\circ} 30^{\prime} \mathrm{S}$.

This was the LAST CAMP ON THE LYND. It will be observed that a sandstone, apparently resting on argillaceous strata, and 
associated with a conglomerate bearing a resemblance to certain rocks on the Upper Hunter, was met with from 7 th to I 5 th June. I have been accustomed to regard this and similar sandstones, occurring in tablelands in this district, as belonging to DAINTREE's Desert Sandstone formation (Upper Cretaceous), but in view of its proximity to "TAYloR's Carboniferous RANGe" and the relation of the latter to Mount Mulligan, it is at least as likely to prove to be Permo-Carboniferous. (See postea, under "Hann's Expedition.")

Beneath this horizontally-bedded sandstone, or at least a portion of it, there is reason to believe that the Lower CRETACeous sedimentary rocks (which, in this region, are the principal source of ARTESIAN WATER) will be found. The probability is that the fossiliferous strata of the Walsh River and Elizabeth Creek (vide, Taylor, in Hann's Expedition) are continued BENEATH THE NEWER SANDSTONES OF THE LOWER LYND till they join the great artesian basin of western Queensland.

All the way down the Lynd, GAME was abundant, and the presence of animals not destined for "the pot" was noted by the leader of the expedition. Among these were scrub turkey, bower bird, black cockatoo, kite, crow, duck, teal, white crane, native companion, pike, perch, sawfish (roth June), kangaroo, wallaby, opossum, bandicoot and dingo. 


\section{CHAPTER XXVIII}

\section{LEICHHARDT'S OVERLAND EXPEDITION, I844-5, continued}

Leichhardt the first to Chart Interior of the Peninsula. Rhrography of the Staaten, de facto, and the Mitchell. The Coastal Plajn. Anastomosis of Lynd, Staaten, de facto, and Mitchell Rivers. The Lynd falls into the Mitchell. Highbury Lagoon. Flour exhausted. Camp i6th June, 1845. Crocodiles. Camp igth June. Lagoons. Camp 20th June. Palms. Natives. Gamboola and Dunbar Stations. Camp 2ist June. Mitcheli Grass and Sheep Country. Camp 22Nd June. Swamps. Bed of the Mitchell River. Camp 23rd June. Plain Creex runs out of Mitchell and joins Dunbar Creek. Dunbar Creek runs out of Mitchell. LeichHARDT FOLLOWS FLiNDERS IN INCORRECTLY IDENTIFYING IT AS THE DUTCH "Nassau River." The River named the Staaten in Modern Maps is the Dutch Nassau River. The Dutch "Staten Revier" is one of the Mouths of the Gilbert River. Camp 24th June. Rivers overflowing and anastomosing in the Plains. "China's Sorrow," the Hoang Ho, a Parallel. Leichhardt Creek. Camp 25th June. Too far North. Westward to clear Gulf of Carpentaria. London Creek. Dunbar and Kalka Stations. Camp 26th June. Dunbar Creek not the Nassau. Threatening Attitude of Natives, who drive the Cattle. Camp 27th June. Down Dunbar Creek. Camp 28th June. Later Contributions to the Geography of the Mitcheli. Delta. The Jardine Brothers. J. T. Emblex. Church of England Mission. New Mouths of the River.

\section{(See Map H.)}

$\mathbf{I}^{1}$

$\mathrm{T}$ is easy to follow Leichhardt's footsteps down the Mitchell with the aid of modern maps. It must not, however, be forgotten that seventy years ago Leichhardt was traversing an absolutely uncharted new land, and that his were the first contributions to the charting which now delineates the topography of the interior of the Cape York Peninsula.

Before tracing Leichhardt's progress north and west of the mouth of the Lynd, it is necessary to consider the RHEOGRAPHY OF the Nassau, de jure, and Mitchell Rivers, as it is now understood.

Travelling from south to north, the three rivers, the NAssaU, de jure (the StaAten, de facto), the Lynd and the Mitchell, are perfectly distinct, but long before they reach the Gulf of Carpentaria they have entered a coastal plain which is common to them all, and have lost their identity by linking one with another in a complex system of anastomosis.

For about 25 miles of its lower course, before joining the Mitchell, the LYND begins to leak through numerous channels into the Staaten, de facto. Then the Mitcheld, nearly as far down as 
the mouth of the Palmer, sends similar leakages to the STAaten, de facto. Below the Palmer, the Mitchell, now only a little more than a degree of longitude from the sea, begins to spread out a FAN OF MOUTHs, which, however, do not keep independent courses but form a bewildering network of anastomosing channels. It is difficult at all times for a traveller to be certain which is the "main channel " of such a river, and it must be that, if not from year to year, at least from century to century, floods alter the channels in such a manner that their comparative importance undergoes radical alterations.

Leichhardt himself did not actually see the junction of THE Lynd with the Mitchell when he camped about 2 miles south of it on I 5 th Fune, I845. Had he realised, at the time, the importance of the Mitchell, he would not have been content to take, as he did, his information about it from his followers. Roper, Brown and Charley described the river at the junction as having a very broad sandy bed, quite bare of vegetation, and, meandering through the sand, a small stream which here and there expanded into large water-holes.

The expedition moved on $16 t h$ fune WNW. down the Mitchell for an estimated distance of 9 miles. The camp was on Highbury LAGoon, on the left bank of the river (long afterwards a Native Police Reserve).

A delay of two days was made at this camp while a bullock was killed and the meat cured. The flour had been finished three weeks before.

On I9th Fune, a stage of about 8 miles was made to the NW., down the Mitchell. The CAMP, beside a deep lagoon on the left bank, was in lat. $16^{\circ} 22^{\prime} 16^{\prime \prime} \mathrm{S}$., and must have been about bench mark ro M. Here Leichhardt noticed the tracks of CROCODILES.

20th Fune.-Ten miles NW. down the Mitchell, past some fine LAGOoNs. Camp at bench mark 2oM.

2ist June.-Nine miles NW. down the Mitchell, past more fine lagoons. The CAMP, in lat. $16^{\circ} 9^{\prime} 4 \mathrm{I}^{\prime \prime} \mathrm{S}$., was on "a small creek, scarcely a mile from the river, from which John Murphy and Brown brought the leaves of the first PALM TREES we had seen on the waters of the Gulf. They belonged to the genus Corypha." This creek runs into the left bank of the river near bench mark $30 \mathrm{M}$. Natives were observed collecting the seeds of water-lilies for food.

From the Lynd to the camp of 2 Ist June, Leichhardt's course is now followed by the road connecting Gamboola with Dunbar cattle station.

22nd Fune.-Twelve miles NW. down the Mitchell. Passed a very long lagoon and noted the superior quality of the grass now known as Mitchell GRAss, which is the most appreciated of all on the "sheep country" of the western interior of Queensland. The 
CAMP, in lat. $16^{\circ} 3^{\prime} \mathrm{II}^{\prime \prime} \mathrm{S}$., was on a swamp or sedgy lagoon near bench mark L.

23rd Fune.-Eight or 9 miles NW. down the Mitchell, passing a great number of dry swamps. The CAMP was in lat. $16^{\circ} 0^{\prime} 26^{\prime \prime}$, about the bench mark R 100 . The river is thus described: "Its banks were covered with a rather open vine brush. Palm trees became numerous and grew 40 or 50 feet high, with a thick trunk swelling in the middle and tapering upwards and downwards. Sarcocephalus, the clustered fig tree, and the drooping tea tree were also present as usual. The bed of the river, an immense sheet of sand, was full a mile and a half broad, but the stream itself did not exceed 30 yards in width." In the course of this day's journey, the infall of the Palmer River was passed, but was not observed.

24th June.-Nine miles W. by N., to lat. I $5^{\circ} 59^{\prime} 30^{\prime \prime}$ S., the CAMP being on Plain CreEk. This creek leaks out of the left bank of the Mitchell and falls into Dunbar Creek, which itself leaks out of the Mitchell. Leichhardt, referring to it, remarks that "a chain of water-holes, fringed with mangrove myrtle, changed into a creek which had no connection with the river, but was probably one of the heads of the Nassau."

This erroneous conjecture has been followed by all subsequent cartographers, and the creek named DunBAR CREEK where it issues from the river, is designated the Nassau River further to the west. It SHOULd BE NAMED THE DUNBAR THROUghout.

The inlet which the Dutch navigators named the NASSAU REVIER is the river which hugs the parallel of $16^{\circ} 30^{\prime} \mathrm{S}$. lat. westward from the meridian of $142^{\circ} 35^{\prime} \mathrm{E}$. long., and which is erroneously named the Staaten on modern maps. The true Staten Revier of the Dutch is one of the mouths of the Gilbert River, probably Accident Inlet.

$25 t h$ Fune.- Travelled ro miles NW., but did not follow the river, which made large windings to the north. The track lay " over a well-grassed forest land and several CREEKS, WHICH, ALTHOUGH RISING NEAR THE RIVER, APPEARED TO HAVE NO COMMUNICATION WITH IT." The plains, says Leichhardt, "rose slightly towards the river, forming a remarkable watershed, perhaps between the Nassau (i.e., Dunbar Creek) and the Mitchell."”

Leichhardt was, in fact, puzzled by a phenomenon which is well known to travellers in lands where large rivers deploy upon flat country. The beds of such rivers tend to silt up, and the deposits left by periodical floods raise the banks until they become the highest land of the neighbourhood. The best known instance is that of "China's Sorrow," the Hoanc Ho, whose channel has to be laboriously cleared out from time to time as a precaution against the inundation of the " netherlands."

The CAMP of $25^{t h}$ June was in $15^{\circ} 21^{\prime} 26^{\prime \prime} \mathrm{S}$. lat., on an anabranch now known as LeICHHARDT CREEK. 
Here Leichhardt determined to LEAve the Mitchell, which was carrying him too far north, his intention being to round the southern end of the Gulf.

26 th Fune.-Seven miles almost due west, passing a number of fine long reedy water-holes. The CAMP, in lat. $15^{\circ} 52^{\prime} 38^{\prime \prime} \mathrm{S}$., was on London CREeK, and on the road which now connects DunBar and KALKa stations. ${ }^{2}$

27 th fune.-Eight miles WSW. to a CAMP on a lagoon parallel to a dry creek, "which," says Leichhardt, " must belong to the Nassau, as its latitude was $15^{\circ} 55^{\prime} 8^{\prime \prime} . "$ This is the water-course which, as has already been pointed out, ought to be called DunBar CREEK.

The smoke of NATIVES' FIRES was seen on the plains in every direction, and in all probability the fires were gathering signals.

After the party had arrived in camp, Leichhardt relates that "whilst Charley and Brown were in search of game, they observed a NATIVE sneaking up to our bullocks, evidently with the intention of driving them towards a party of his black companions, who, with POISED SPEARS, were waiting to receive them. Upon detecting this manœuvre, Charley and his companion hurried forward to prevent their being driven away, when the natives gave the alarm, and all took to their heels, with the exception of a lame fellow, who endeavoured to persuade his friends to stand fight. Charley, however, fired his gun, which had the intended effect of frightening them, for they deserted their camp, which was 300 yards from ours, in a great hurry, leaving, among other articles, a small net full of potatoes [yams ?] which Charley afterwards picked up. The gins had previously retired; a proof that mischief was intended."

28 th Fune.-Crossing DunBAR CREEK (which Leichhardt erroneously believed to be the Nassau), the party travelled 9 miles west, over " a most beautifully varied country, of plains, of forest land, and chains of lagoons. The camp was on a chain of shallow lagoons, connected by a hollow."

\section{THE DELTA OF THE MITCHELL (See Maps H and F.)}

It is convenient, in this place, to conclude the description of the Lower Mitchell, as it is now known.

It has already been pointed out how Leichhardt, in 1845 , followed down the river which he had named the Mitchell, while it was still a distinct watercourse and ran in its own valley, and how, having entered on the delta, he ran down Dunbar Creek, one of the mouths of the Mitchell, which (following Flinders) he erroneously identified with Carstenszoon's Nassau Revier. The error has since been confirmed by long usage, and Dunbar CREEK, de jure, has become the NAssau River, de facto.

1 Assuming the correctness of the modern map, Leichhardt's positions from 20 th to 25 th June are all about 4 miles too far south. 
The JaRdine BRothers' traverse of the delta of the Mitchell in I864 was further west than Leichhardt's. Keeping a northerly course, they crossed Dunbar CREek (the Nassau River, de facto) and were the first to wander among the anastomosing channels intersecting the delta. They next crossed the Scrutton River, which comes out of Magnificent Creek and runs into the Dunbar, and Magnificent Creex (named by them Arbour Creek), which comes out of the Mitchell proper and runs into the "South Mouth" of the river. Lastly, they followed the Mitchell proper northwestward to lat. $15^{\circ} \mathrm{ro}^{\prime}$ S., where the "North Mitchell " leaks out of the mouth which is named the "Main Channel."

Most of the mouths of the Mitchell (below the infall of the Palmer) were surveyed by J. T. Embley in 1886-7.

It was the part of the Church of England Mission to the Aborigines to make the latest addition to our knowledge of the delta. I am indebted to the Rev. John Jones, of the Australian Board of Missions, for a pamphlet entitled "Mitchell River Aboriginal Mission," printed in Thursday Island, undated, but evidently issued after IIth July, 1905, as it contains excerpts from Bishop White's diary of that date. A map attached to the pamphlet shows that KilpatricK CREEK has been traced northwestward to its junction with the "South Mitchell," while another creek, to the west, runs NNW. and joins Kilpatrick Creek. On this creek, which may be referred to as Bosworth CREEK, is located “Old" Bosworth (Cattle) Station (lat. $15^{\circ} 30^{\prime}$ S.), as well as the site of a new mission station, to be named YEREMUNDO. West of Magnificent Creek, a chain of fine fresh-water lagoons extends from east to west, and on the banks of the lagoons are first the out-mission-station DAPHNE, and then the head station Trubanaman. Below the head station the lagoons merge into a winding salt-water inlet, opening into the Gulf in lat. $\mathrm{II}^{\circ} 25^{\prime} \mathrm{S}$. Two out-stations of the mission, Koongalara and Angeram, are situated on this salt-water inlet, the former about a mile west of the head station and the latter on the sea coast. A few miles south of the Trubanaman Creek and lagoons, ToPsY CREEK commences in the east, also as a chain of fresh-water lagoons, and further west becomes a salt-water inlet, which falls into Trubanaman Creek. Bishop White, in his diary, expresses the belief that both Trubanaman and Topsy Creeks leak out of Magnificent Creek, and I have no doubt that he is right.

The Mission, for which a reserve of about 500 square miles has been set apart, was initiated in 1902, and evidently exercises a civilising influence on the natives, but I am unable to assign the credit due to individual missionaries for their part in the exploration of this exceptionally interesting geographical region. 


\section{CHAPTER XXIX}

\section{LEICHHARDT'S OVERLAND EXPEDITION, 1844-5, continued}

28th June, 1845. Attacked by Natives. Gilbert killed. Roper and Calvert WOUNDEd. Journey (WestWard and SouthWARd) RESUmed, IST July. Leichhardt's own Summary of Results. Salt Water, 7th July. CRoss Nassau River. Cross Van. Diemen River, 9th July. Gilbert River, i2th July. Norman River, 14th July. Caron River, 17th July. Beame's Brook. Nicholson River. Round South End of Gulf of Carpentaria. Reach Port Essington, 17th December. Return to Sydney. Leichhardt's Second Expedition. An Attempt to cross the Continent to the Swan River Settlement. Inadequate Preparations. Leaves Jimbour, 7th December, 1846. Turns back from Peak Range. Reaches Condamine River, 6th July, 1847. Third Expedition, to connect his Lines with Sir Thomas Mitchell's at Roma. Return to Jimbour, September, 1847. Fourth Expedition, from the Condamine towards the Swan River Settlement. Starts March, 1848. Mystery of the Fate of Leichiardt and his Party. Leichhardt's Personal Character.

\section{T Leichhardt's camp on 28th June, I845, a terrible disaster overtook his party. (SEE MAP H.)}

"After dinner," says Leichhardt, "Messrs. Roper and Calvert retired to their tent, and Mr. Gilbert, John Murphy and the aboriginal Brown were platting palm leaves to make a hat. Gilbert then retired with John to the tent. This was about seven o'clock, and I stretched myself upon the ground as usual, at a little distance from the fire, and fell into a dose, from which I was suddenly roused by a loud noise and a call for help from Calvert and Roper. NATrves had suddenly ATTACKed Us. They had doubtless watched our movements during the afternoon and marked the position of the different tents; and as soon as it was dark sneaked upon us and threw a shower of spears at the tents of Calvert, Roper and Gilbert, and a few at that of Phillips, and also one or two towards the fire.

"Charley and Brown called for caps, which I hastened to find, and as soon as they were provided they discharged their guns into the crowd of the natives, who instantly fled, leaving Roper and Calvert pierced with several spears and severely beaten by their waddies. Several of these spears were barbed and could not be extracted without difficulty. I had to force one of them through the arm of Roper, to break off the barb; and to cut another out of the groin of Mr. Calvert. John Murphy had succeeded in getting out of the tent and concealing himself behind a tree, whence he fired at the natives, and severely wounded one of them before Brown had discharged his gun."

GILBERT was KILLED outright. ${ }^{1}$ On coming out of his tent,

1 Macgillivray, who was Naturalist on the "Rattlesnake," wrote in September, I849:-

"I am convinced that some at least of the collisions which have taken place in Australia between the first European visitors and the natives of any given district have originated in causes of offence brought on by the indiscretion of one or more of the party and revenged on others who were innocent. As a memorable instance I may give that which happened during Leichhardt's overland journey to Port Essington, when his 
he handed a gun and ammunition to the aboriginal Charley, and then dropped dead. "The spear," says Leichhardt, " had entered the chest between the clavicle and the neck; but made so small a wound that for some time I was unable to detect it."

"Mr. Roper had received two or three spear wounds on the scalp of his head: one spear had passed through his left arm, another into his cheek below the jugal bone, and penetrated the orbit, and injured the optic nerve, and another in his loins, besides a heavy blow on the shoulder. Mr. CALVERT had received several severe blows from a waddi; one on the nose, which had crushed the nasal bones; one on the elbow, and another on the back of his hand; besides which, a barbed spear had entered his groin, and another into his knee. As may be readily imagined, both suffered great pain and were scarcely able to move."

Both the wounded men recovered rapidly. Calvert was able to resume his duties by 2 Ist July.

The JOURNEY WAS RESUMED on ist $\mathcal{F}$ uly, and SALT WATER was met with on the 5th, in an inlet from the Gulf of Carpentaria. It is of interest, before going further, to quote Leichhardt's own summing-up of his progress to this point. He remarks, with satisfaction :-

"We had now discovered a line of communication by land between the eastern coast of Australia and the Gulf of Carpentaria. We had travelled along never-failing and, for the greater part, running waters; and over an excellent country, available, almost in its whole extent, for pastoral purposes."

On 7 th $\mathcal{F} u l y$, the party forded a salt-water river, in $16^{\circ} 30^{\prime} \mathrm{S}$. lat., which Leichhardt (erroneously, following Flinders, who followed Tasman) supposed to be the "Pera's" Staten Revier, but which, it is now clear, must have been the "Pera's" Nassau Revier. It would be impossible to restore the original name, and long use has indelibly stamped the river as the Stanten, de facto.

On $9 t h$ Fuly, the explorers camped on what Arrowsmith's map ${ }^{1}$ called the Van Diemen River. This, according to modern maps, is the Smithburn mouth of THE Gilbert, erroneously identified by Flinders as Tasman's Van Diemen River. On the 12th, I3 miles to the south-west, they crossed a small river which Leichhardt named the Gilbert. (SeE Mar M.) This appears to have been Crooked CReex (ending in Accident Inlet), below the modern

camp was attacked one evening and Mr. Gilbert lost his life. Long afterwards, the undoubted cause of this apparently unaccountable attack transpired, in the acknowledgment, while intoxicated, by one of the persons concerned, that a gross outrage had been committed upon an aboriginal woman a day or two previously by the two blacks belonging to the expedition." (Voyage of the "Rattlesnake," I, 31 3.)

Macgillivray, who was a man of sound and temperate judgment, and who had more than once been confronted with the aboriginal problem in its most practical form, must be respectfully heard, and it may be presumed that he had satisfied himself of the truth of the story, although, as he tells it, it certainly would not pass for legal evidence in a court of justice.

1 A ustralia, from Surveys made by Order of the British Government combined with those of D'Entrecasteaux, Baudin, Freicinet, etc., etc., by John Arrowsmith, 1838. Evidently the map by which Leichhardt travelled. 
Midlothian Station. It is the southmost mouth of the Gilbert, and there are the strongest grounds for the belief that it was the "furthest south" of the "Pera" and "Aernem," named by Carstenszoon the Staten Revier.

On 18th July, Leichhardt camped in $17^{\circ} 41^{\prime} 5^{\prime \prime}$, probably east of the modern township of Normanton. There does not appear to have been anything distinctive enough about the Norman RIver, in this region, to call for a name. It was simply that the party had to go a long way round to the east and south to avoid mangrove swamps. On the $17 t h$, presumably because he was near the latitude $\left(16^{\circ} 23^{\prime}\right)$ of the inlet which Flinders had mistaken for Tasman's Caron Revier, he reckoned he had identified "Caron River (Corner Inlet)." Possibly it was Brannigan Creek.

It may be said here that I have made painful and conscientious attempts to follow Leichhardt round the southern end of the Gulf by the aid of his diary and Arrowsmith's illustrative map, and I warn those who may essay the task in future that "that way madness lies." Leichhardt did not give sufficient data for the identification of his positions on the modern map, whereas Arrowsmith, with only the coast-line to guide him, must have had even a harder task than was mine. I have come to the deliberate conclusion that all charting of this portion of Leichhardt's journey is worthless. His latitudes must be wrong. Perhaps his sextant was out of order. He must have been very careless about distances and bearings.

We find him camped on 6 th August in what he calls lat. $17^{\circ} 57^{\prime} \mathrm{S}$., on a river which, he says, "I am inclined to think is the AlbERT of Captain Stokes and the Maetsuyker of the Dutch navigators." Sir (then Mr.) Augustus Gregory noted (in I 856) the obvious mistake and named the river the LEICHHARDT.

On I8th August, Leichhardt struck a large river which must have been the real Albert, and had to follow it up 4 or 5 miles to the south-west before he could find a crossing. A running creek was found falling into its left bank, and was named BEAME's Brook, after Walter Beames, of Sydney. (SeE MAP N.)

Leaving Beame's Brook on a north-westerly course, a river, which Leichhardt named the Nicholson, after Henry Alleyne Nicholson, of Bristol, was crossed within two miles. Pursuing this, or a slightly more northerly course, the 138 th meridian of east longitude was passed. This line now divides the State of Queensland from the Northern Territory.

Leichhardt's journey across the southern end of the Gulf of Carpentaria was marked by few noteworthy incidents. His assiduity in making botanical and geological observations had full play, and his success in "shooting for the pot" gave him no reason for complaint as regards diet, emus, pigeons and cockatoos being abundant. 
It is not within the scope of our subject to follow the fortunes of the expedition from the Gulf to Port Essington, which was reached on 17th December, I845. At the small settlement, the party were entertained for a month by the Commandant, Captain Macarthur. The schooner "Heroine," Captain Mackenzie, conveyed the party, via Torres Strait and the inner passage, to SyDnEy, where they arrived on 29th March, and were accorded an enthusiastic welcome.

LeichHardt's Second Expedition had for its object the crossing of the continent from Brisbane to the "Swan River Settlement" (now Perth). Having collected funds and made other necessary preparations, he lefF Melbourne in September, 1846. The expedition was, like the first, mobilised at Jimbour, which was left on 7 th December. The party comprised LeichHardt, Daniel Bunce (Botanist and Naturalist), John F. Mann (Draftsman), Hovenden Hely, James Perry (Saddler), Henry Boecking (Cook), Turnbull (Assistant Storekeeper) and Wommai (or Jimmy) and "HARRY Brown" (both aboriginals).

The progress of this second expedition is mainly to be followed in Bunce's "Notes from Travels with Dr. Leichhardt" and Mann's "Eight Months with Dr. Leichhardt." 1 Both men had grievances against their leader, and refused to follow him in his subsequent campaigns. This circumstance may have coloured their narratives, but even allowing for such colouring, there seems to be strong grounds for the belief that Leichhardt's PREPARATIONS for a two-years' trip were INADEQUATE beyond all reason or prudence. There was hardly any MEDicine CHEsT, and as for Food, Bunce states :-

"The quantity of FLour taken was just sufficient to admit of a daily allowance of $3 \frac{1}{2}$ OUNCEs to each man for a period of 8 MonTHs, by which time it was supposed they would have become sufficiently abstemious in their habits to enable them to dispense with that staff of life during the remainder of their journey, which it was expected would terminate in TWO YEARS from that period."

It is not to be wondered at that the expedition was a fiasco.

By slow marches, interrupted by long periods of camping in different places, the expedition wound its way to the NORTH-NORTHWEsT. The route of the previous "overland expedition" was followed for the most part, the chief exception being that the head waters of the DAwson were crossed a little further to the east and the Expedition Range was crossed from east to west into the valley of the Comet River.

EVERYTHing WENT WRONG From the START. Much time was lost in SEARCHING FOR HORSES, mules, cattle, sheep and goats, which

1 See also Ernest Favenc's History of A ustralian Exploration, Sydney, 1888, p. 165, and Rev. J. E. Tenison-Woods' History of the Discovery and Exploration of A ustralia, London, 1865, Vol. II, p. I47. 
continually strayed. A heavy WET SEASON set in, and the march along alluvial flats on which mud was drying in the sun brought MALARIAL FEVER in its train. By the end of March, 1847 , the whole stock of FLOUR had soured. Parties of the sick had to be left here and there, the main body having to wait for them to catch up. The individual members of the expedition grumbled and discussed the advisability of retreat, and the leader, himself sick, lost his nerve and displayed the most embarrassing vacillation.

Bunce's statement that the expedition set out on a two-and-ahalf years' trip, with only a starvation allowance of flour for eight months, if true, shows that the leader was rash to the point of criminality. On the other hand, if his followers were aware of the state of affairs from the start (and in handling the loads daily they must have learned the facts in a few days at most), their only course, as sensible men, would have been to refuse to embark on an expedition foredoomed to failure.

On 22nd June, I 847, LEICHHARDT TURNED BACK from a point on the eastern side of the PEAK RANGe in lat. $22^{\circ} 50^{\prime} \mathrm{S}$. (approx.). This was the point from which he had originally planned to strike west for the Swan River, but the hopelessness of the task had become obvious, and the inevitable had to be accepted.

Chauvel's station on the Condamine River, at that time the furthest outpost of civilisation, was reached on 6th $\mathcal{F} u l y, 1847$, and the party was broken up.

Here Leichhardt heard of the successful termination of Sir Thomas Mitchell's expedition, and on 9 th August he set out from Henry Stuart Russell's station, on what may be called his

Third Expedition, accompanied by F. N. Isaacs, James Perry, Daniel Bunce and Wommai (Jimmy), the aboriginal. No difficulty was experienced in reaching and identifying Mitchell's Fitzroy Downs and Grafton Range. The route traversed by Leichhardt, indeed, offered no natural obstacles (except black soil in wet seasons) and is now served by the Western Railway. Leichhardt joined lines with Mitchell at Mount Abundance, near Roma, where smiling vineyards now gratify the eye of the tourist.

Leichhardt returned to Jimbour about I4th September, and shortly afterwards went to SyDNEY. His journal of this Third Expedition is given in an Appendix to Bunce's Travels with Dr. Leichbardt, and is also to be found, as edited by the Rev. W. B. Clarke, in Waugh's Australian Almanac for i860. The latter, it may be pointed out, is an instance of the extraordinary media chosen by Clarke for the publication of his writings, which were valuable at the time, and have now become of historical as well as scientific importance. It may well be doubted whether any human being is in possession of Clarke's Omnia Opera, and the fact that somebody vaguely recollected having somewhere seen something written by Clarke is, no doubt, responsible for the 
luxuriant growth of unverifiable legend which has gathered around his statements and opinions.

Leichhardt's Fourth, and last, Expedition set out from "Birrell's Station on the Condamine" in March, i848. Its only record is contained in a short letter, dated 3 rd April, from "Macpherson's Station on the Cogoon," ${ }^{1}$ in which he states that he had travelled to that station, via Mount ABundance, in eleven days. The rest is silence.

The party consisted of Leichnardt, Bozcking, Classen, Hentig, Stuart, Kelly, and two black boys. Boecking, who had been cook on the second expedition, was the only white man who had been with Leichhardt before. BunCE makes the significant statement that he and other members of the second expedition had agreed to join the fourth on certain conditions to which Leichhardt had agreed at the conclusion of the second expedition, but which he repudiated on his return from Sydney. We can only conjecture that the disputed stipulations referred, inter alia, to food, medicines and remuneration. Bunce's words regarding the "stipulations" are: "They were such as we humbly conceived to be of the greatest importance to the success of the expedition."

From the mass of documents relating to Leichhardt's preparations, I carry away the impression that he was short of funds, and that what appeared mean and parsimonious to the men who were prepared to share his adventures and privations, may have been forced upon him by pecuniary considerations, added to, of course, by his desire to TRAVEL LIGHT, and TRUST TO LUCK for game and vegetable foods. It appears also, according to Bunce, that Leichhardt held some faddist theory that men could train themselves to dispense with farinaceous food.

As on his second expedition, LEICHHARDT's GOAL on his fourth and last was the Swan River Settrement(Perth, Western Australia). $\mathrm{He}$ is known to have entertained theories as to the northward extension of the supposed "Great Australian Desert," which would naturally lead him to the north of a direct westerly course. Many conjectures have been made regarding his route, some even supposing that he would make for the Gulf of Carpentaria before turning to the south-west. Several search parties tried to solve the mystery of his fate; none of them, however, met with any success, except, perhaps, Mr. (afterwards Sir) Augustus GrEGory's, who, in April, 1858, discovered traces of what may have been ONE OF LEICHHARDT's CAMPS on the upper waters of the BARCOO RIVER between the modern townships of Tambo and Blackall, and, perhaps, Duncan Macintyre of Glengower's.

Macintyre, who had made a journey down the Flinders to the Gulf of Carpentaria towards the end of the year 1864, reported on

1 Now better known as Muckadilla Creek. It runs south-eastward from Muckadilla railway station and falls into the Balonne River about fifty miles south of Roma. 
his return that he had seen two trees marked $L$ on the western bank of the Flinders in about $20^{\circ} \mathrm{S}$. lat. (SEE MAP R.) It would be natural to suppose that the marks were Landsborough's, made in 1862 , but the growth of bark over the incised letters appeared to be of considerably greater age than two years, and besides there were no numbers, whereas it was Landsborough's custom to mark his camps with consecutive numbers as well as initials. On these grounds it was argued that the marked trees indicated camps of Leichhardt on his last journey. Two old horses picked up by Macintyre on the Dugald River (which he named) about roo miles west of the marked trees, he also supposed to have been Leichhardt's. The ladies of Melbourne raised a sum of money and sent Macintyre back to the locality in $186_{5}$, but no further traces of Leichhardt were discovered. On this occasion, Duncan Macintyre observed a tract of fine land on Julia Creek, where, later, his brother, Donald, took up Dalgonally Station. (See Proc. Roy. Geogr. Soc., Vol. IX, p. 303, quoting letter to the Editor of the Melbourne Age of 24th December, 1864, signed by Drs. Ferd. von Mueller and David Wilkie, and The Empty North, by John Norman Macintyre. Sydney, Penfold, 1920.)

It will never be known whether Leichhardt and his party were killed by natives, or whether they fell before one of the other furies of the waste whose dread names are Famine, Thirst, Flood and Fire.

In the cities of the south, Leichhardt was noted for a charming and ingratiating manner, and this served him in good stead while he was soliciting financial aid for his schemes of exploration. $\mathrm{He}$ desired above all things to win the honour of a British Knighthood, and this ambition was probably never lost sight of when he cultivated the friendship and support of influential colonists. The conspicuous success of his "Overland" expedition, and afterwards the tragedy of his mysterious disappearance from the face of the earth, stimulated the enthusiasm of a generous public to a high appreciation of the amiable and admirable qualities he had displayed.

The success of the "Overland" expedition was due in a great measure more to the luck of an exceptionally favourable season than to the perfection of his plans. His other expeditions were no less ill-planned, and they confronted him with obstacles which he was incompetent to overcome.

Out in the field with his men, and faced with difficulties which foresight and resource on his part should have averted or minimised, he would not have been recognised as the suave and tactful courtier known to Sydney Society. The coarse bully lecturing his followers and comparing himself to a general leading an army had forgotten that he had taken advantage of the mistakè of a registrar to evade the military service which was the law of his own land. He was callous to the sufferings of the fever-stricken members of the party, who were unable to keep up with his pace. He made agreements 
which he refused to fulfil. He carried secret stores of dainties on which he luxuriated while his followers were on the brink of starvation. In the middle of the nineteenth century he was a living proof that the Prussian spirit, as the world came to know it in 1914-18, was no new thing.

It is painful to write such words of a man who did unquestionable service to Australia, and I am conscious that my opinions may be supposed to be tinged with the bitterness engendered by the Great War. As a matter of fact, these opinions were formed on the whole mass of documentary evidence before the war broke out, and I am unable to place the easy-going rule of saying nothing but pleasant things of the dead above the duty devolving on the historian to write the unvarnished truth. It may be added that my conclusions had been arrived at before my reading on the subject had taken me as far as Ernest Favenc's History of Australian Exploration. ${ }^{1}$ After reading that writer's illuminating remarks, it will be understood that I make no claim to originality for my estimate of Leichhardt's personal character.

1 Sydney, Turner \& Henderson, 1888. 


\section{CHAPTER XXX \\ KENNEDY'S EXPEDITION, 1848 \\ THE EAST COAST AND THE COAST RANGE}

Kennedy leaves Sydney in “Tam O'Shanter," convoyed by H.M.S. “Rattlesnake." Lands at Tam O’Shanter Point, Rockingham Bay. Arrangement for meeting Ship in Princess Charlotte Bay. Equipment, including Carts and a Flock of Sheep. Personnel. Thirteen Persons. "Rattlesnake" assists in Debarkation (24th and 25th May, 1848). Thomas Huxley. Mountains and Scrubs to the North. Try Southward. Hull, Tully and Murray Rivers and Dallachy, Wreck and Meunga Creeks crossed. Natives occasionally assist. The Shepherd deserts and joins Natives, but is recovered. Carts and Sheep cause Delay and Trouble. Southward to near Site of Cardwell. Attacked by Natives, who are repulsed, with Loss (4th July). Westward up Meunga and Kennedy Creeks. NorthWestward. Scrubby Mountains. Carts abandoned (i4th July). Overdriven and Hungry Sheep and Horses. Hewing a Way through Scrub and up Mountains. Rain. Scrub Leeches. Summit of Range between Tully and Herbert Rivers (9th August).

$\mathrm{E}$

DMUND BESLEY COURT KENNEDY had been second in command of Sir Thomas Mitchell's expedition, which left Buree on 15 th December, 1845 , and which penetrated to the Darling River, Balonne, St. George and the Maranoa

River. In 1847 , he led an expedition with the object of tracing the course of the Barcoo, when he followed the river into South Australia till it ran out into marshes.

In I 848 , he was appointed by the Government of New South Wales to the leadership of an expedition designed TO EXPLORE the coast country FROM Rockingham BAY (I $8^{\circ}$ S. lat.) TO CAPE YoRK. The successes of Mitchell and Leichhardt had roused him to emulate their exploits and to plan an expedition on a more ambitious scale than the one which he had already concluded. $\mathrm{He}$ carried a copy of Leichhardt's Overland Expedition, then fresh from the press. No doubt it was his daily study, and Leichhardt's methods his model. The influence of the book is very distinctly traceable in the nature of his preparations and equipment-which proved singularly inapplicable to the country he was to travel over. He and his party left Sydney in the "Tam O'Shanter" barque, on 29th April, I848, convoyed by H.M.S. "Rattlesnake." The "Rattlesnake's" voyages extended to New Guinea and the Louisiade Archipelago, although she set out from Sydney with the 
specific object of surveying the "Inner Passage," viz., that between the eastern side of Cape York Peninsula and the Barrier Reef. ${ }^{1}$

The ship was also to carry Kennedy's party to Rockingham Bay and assist in their debarkation and start. 'The two vessels anchored on $23 r d$ May under the lea of the westmost of the Family Islands group, and the debarkation was accomplished on the two following days. The "Rattlesnake" carried a distinguished group of naturalists, among whom was Thomas Huxley, Assistant Surgeon. Huxley accompanied Kennedy, before the "Rattlesnake" sailed, on an excursion made by the explorer "for the purpose of searching a way out from the low swampy district of Rockingham Bay," and contributed a drawing, reproduced in the Narrative of the Voyage, of a scene entitled "Cutting through the Scrub." Kennedy is represented hacking at vines with a tomahawk, and is followed by a man carrying a gun. Both men lead spirited and gaily-caparisoned horses. MacGillivray remarks :-

"I last saw poor Kennedy on the evening before he broke up his camp: he was then in high spirits and confident of success. The party, of 13 men and 28 horses (with carts, a flock of sheep for food, etc.), appeared to be furnished with every requisite for their intended journey, and the arrangements and appointments seemed to me to be perfect. Nor did I, despite the forebodings of others, argue anything but a successful result to an undertaking, the blame of which was afterwards attempted to be thrown upon those who had planned it." "

We learn from the Narrative of the Voyage that Kennedy's original plan was to explore first to the east of the dividing range ; to meet a vessel ${ }^{3}$ which was to wait at Cape York with supplies; and then to make his way southward by the west coast to the southeast corner of the Gulf of Carpentaria, and make his way back, as might be found convenient, to the nearest settlement. It was a gigantic undertaking, and its success obviously depended upon the endurance of the horses, regarding which bushmen of experience might well have entertained serious forebodings.

It appears also that H.M.S. "Bramble" was to be in Princess Charlotte Bay in the beginning of August," and Kennedy expected to obtain supplies from her. He arrived, however, too late, and abandoned the attempt to reach the coast on 13 th October, in the belief that the "Bramble" must have left the rendezvous.

Kennedy was provided with a SEXTANT and must also have carried a CHRONOMETER, ${ }^{5}$ as, in the few instances where the latitude is given and the still fewer instances where the longitude is recorded, the figures are as accurate as could be expected in the circumstances.

1 Narrative of the Voyage of H.M.S. "Rattlesnake," commanded by the late Captain Owen Stanley, R.N., F.R.S., etc., during the Years 1846-50. By John MacGillivray, F.R.G.S., Naturalist to the Expedition. London, T. and W. Boone, 1852.

2 With all due respect to MacGillivray's high attainments in his own line of study, the value of his opinion on a question of bush equipment may be doubted.

3 The "Rattlesnake" herself, according to Carron.

- Carron's Narrative, quoted in "Rattlesnake," Vol. II, p. 203.

"The search party from the "Freak" found " part of a key belonging to a chrono. meter" on the site of the Pascoe camp on 3rd May, I849. 
He may have given these readings to Carron at the request of the latter, or Carron may have assisted in the observations and noted the results.

The leader kept a DIARY, which was LOST, or lost all but a few unimportant scraps. Carron kept a private diary, but that portion of it which would have been of geographical value, bringing the travels of the party to his last camp at the mouth of the Pascoe River, was lost, and it was only from an abstract of it that he reconstructed his narrative.

Practically, the only record of the ill-fated expedition is con. tained in an octavo booklet entitled :-

"Narrative of an Expedition undertaken under the Direction of the late Mr. Assistant Surveyor, E. B. Kennedy, for the Exploration of the Country lying between Rockingham Bay and Cape York: By William Carron, one of the Survivors of the Expedition ";

to which are added :-

(I) "The Statement of the Aboriginal Native JACKEY-JACKEY, who accompanied Mr. Kennedy";

(2) "The Statement of Dr. VAlLACK and Captain Dobson, who rescued the Survivors of the Expedition"; and

(3) "The Statement of CAPTAIN Simpson, of the 'Freak,' who proceeded in search of Mr. Kennedy's Papers, etc."

The booklet was printed in Sydney in 1849 by Kemp \& Fairfax. It is now almost inaccessible to the public, the only copy for sale in Sydney being priced at three guineas. It has, however, been substantially incorporated in the Voyage of the "Rattlesnake," and an examination of the copy in the Mitchell Library enables me to point out the omissions from the reprint.

I. The Statement of Captain Dobson, of the "Ariel," is omitted entirely.

2. In Captain Simpson's Statement, the portion of the diary relating to the voyage from the Percy Islands to the Claremont Islands is omitted.

3. In "Rattlesnake," II, p. 263, after the words "pick them up," the following passage seems to have been inadvertently left out :-

"At 2 p.m., the tide commenced ebbing, the schooner got under way and worked down towards the 'Freak.' At half-past 6 p.m., the tide being down, the schooner anchored about I mile to the northward of us, while I returned on board."

Besides Carron's Narrative, some facts have been gleaned from documents in the Parliamentary Library of New South Wales, to which I obtained access through the courtesy of Mr. Charles Walsh, Parliamentary Librarian. Chief among these are :-

(a) A notice of the arrival at Sydney, on 5 th March, 1849, of the schooner "Ariel"; printed, together with an interview with the Survivors, in the Sydney Morning Herald of 6th March, 1849. 
(b) Report of an Investigation conducted by Captains Innes and Brown at the Instance of the Government, held at the Water Police Court on 6th March, I849, reported in Sydney Morning Herald of the day following.

(c) Official Announcement by the Colonial Secretary of the Deaths and Disasters, 9th March, 1849. Govt. Gazette, Vol. XXV, I849, p. 394.

(d) Dispatch, dated Ist October, I849, by Earl Grey to Sir Charles Fitzroy, Governor of New South Wales, acknowledging the receipt of Papers forwarded by

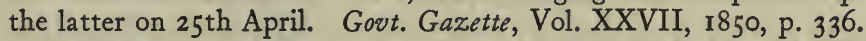

(e) Debate, I7th July, 1849 (reported in Sydney Morning Herald of 18 th) on Mr.Darvell's Motion to erect a Tablet to the Memoryof Kennedyin St. James' Church, Sydney.

Having carefully perused all the available material, I propose, in the pages which follow, to tell the story as it appears to me, in the light of modern maps. In other words, an attempt is made to ascertain where Kennedy was from day to day and to compare my conclusions with the ideas held by Carron or Jackey-Jackey as to his whereabouts. It must be remembered that although Kennedy was an expert surveyor, and no doubt had provided himself with "blanks" constructed from the then existing Admiralty charts, and plotted his work on these blanks, this material, there is every reason to believe, has been irretrievably lost, as has also his journal.

Kennedy's party consisted, besides the Leader, of William Carron, Botanist; Thomas Wall, Naturalist; C. Niblet, Storekeeper; James Luff, ${ }^{1}$ Edward Taylor and William Costigan, Carters; Edward Carpenter, Shepherd; William Goddard, Thomas Mitchell, ${ }^{2}$ John Douglas and Denis Dunn, Labourers; and JACKEY-JACKEY, an aboriginal from the Hunter River; thirteen persons in all. Kennedy seems to have had no misgivings about the unlucky number ! There were also 28 horses, I00 sheep, three kangaroo dogs and one sheep-dog. One ton of flour, $600 \mathrm{lb}$. of sugar, $90 \mathrm{lb}$. of tea, $22 \mathrm{lb}$. of gunpowder, $-130 \mathrm{lb}$. of shot, a quarter-cask of ammunition, 588 feet of tether rope, 40 hobble chains and straps, boxes and paper, etc., for preserving specimens, firearms, cloaks, blankets, tomahawks, horse-shoes, cooking utensils, four tents and a canvas sheep-fold constituted the chief items of the load, and there were, besides, 24 pack saddles and harness for nine draught horses. The greater part of the load was to be carried in ONE HEAVY SQUARE CART and TWO SPRING CARTS, while each man had a horse to ride and a spare horse in reserve. Some of the stores, which it was not expected would be required before the arrival of the expedition at Cape York, were repacked and sent on board the "Rattlesnake" on 3oth May. After a good deal of rehearsal and experiment, A START was made on 5 th $\mathcal{F}$ une, with seven pack-horses and three carts, carrying 2I cwt., drawn by nine horses. (SEE MAP K.)

1 Luff had been with Kennedy in 1847 , when he traced the course of the Barcoo.

2 The Mural Tablet in St. James' Church, Sydney, has "J. Mitchell." 
The large party, with its equipment, was LANDED AT TAM O'Shanter Point on 24 th and 25 th May, I848. The tents were pitched in the form of a square, with the SHEEP-FOLD in the centre, about 200 yards from the beach and near a fresh-water creek. One HORSE Was DROWNED in landing.

A party of Natives approached (24th May) and watched the landing of the sheep with curiosity, and without displaying hostility.

KENNEDY and three others rode out to examine the country in advance of the main party, leaving on $30 t h$ May and returning to the camp on 3 rd June, HuXLEY accompanying him part of the way. Kennedy came to the conclusion that a get-away to the north or north-west was impossible because of swamps and dense scrubs. Had he gone further north, the coast range coming down close to the sea would have formed an insuperable barrier to his progress. If he had left the sheep and carts behind and landed at Port Douglas he might have got away by the now-existing road; but of course he knew nothing of the country before him. Again, had he landed at Cardwell, I 8 miles south of 'Tam O'Shanter Point, and made a road up a comparatively easy spur of the coast range, as George Elphinstone Dalrymple did in 1864, he might have carried his expedition to a successful issue.

It was most unfortunate that, before parting with the " $\mathcal{T}$ am O'Shanter" and "Rattlesnake," Kennedy did not make a reconnaissance to the south. As it was, he started on 5 th Fune, with an outfit of CARTS and SHEEP, to penetrate a country equally unsuitable for the carriage of the one and the feeding of the other.

The caravan had only gone two miles south when it met with a large tidal river, which was then named the Mackay on the Admiralty charts, but which has since been named the Hull River. A boat lent by the "Rattlesnake" assisted in carrying the stores and some of the sheep across, while the horses and the remainder of the sheep swam. The Natives assembled in great numbers to watch the landing, but gave no trouble. Kennedy himself CAMPED, in the dark, on the south side (right bank) of the river, whilst Carron and five others recrossed for fresh water, with which they filled their kegs, returning to Kennedy's camp at midnight.

On 6th June, Lieutenant Simpson, of the "Rattlesnake," left to rejoin the ship, and the exploring party thereafter saw no more white faces. Carron does not explain how the carts were got across the river, but says that early in the morning they loaded the carts and pack-horses and travelled for 3 miles inland, when they met with impassable swamps and returned to the beach and resumed their southward course. In 2 miles (say 3) they reached, about dusk, a second tidal river, larger than the first, the Tully (subsequently named after the Commissioner of Crown Lands, who took part in Dalrymple's expedition in I864), and CAMPED on its left, or northern, bank. 
In the morning of 7 th $\mathcal{F}$ une, a RAFT or punt was improvised by covering the body of one of the carts with a tarpaulin, its buoyancy enhanced by air-filled kegs and water-bags; and the tether-ropes having been tied together and made fast on both banks, the punt was pulled from bank to bank. Most of the things were thus got across during the day, and the party CAMPED, some on the right and some on the left bank of the river.

8th Fune.-The remaining baggage was transported across the river. The horses also were taken across, not without difficulty. Nothing is said about the sheep, which probably were ferried in the punt. The party camped on the right bank of the river, near the beach.

9th Fune.-With the exception of Kennedy, Jackey-Jackey and three others, the party remained in camp, where they were visited by a great number of NATIVEs, who evinced no hostility.

Ioth fune.-Kennedy and his companions returned to the camp at night, having found nothing but swamps and no practicable inland route for the carts.

II th June.-After about 4 miles of travelling southward along the beach, the party came to another river, the MurRay, and CAMPED. Near the river, they explored an untenanted native camp, noting a shield, four wooden two-handed swords, fishinglines, fish-hooks made of shells, cooking ovens of a now well-known type, consisting of excavations nearly filled with stones, and gourds for holding water.

I 2 th Fune.-Taylor having failed, owing to the strength of the ebbing tide, to swim across with a rope, some NATIVEs who had been observed fishing from canoes were induced to take the rope across and make it fast on the right bank, receiving a tomahawk for the service. It was Io o'clock before the last of the baggage had been punted across, by moonlight. The horses were led across a quarter of a mile above the ferry, the operation being watched with interest by several natives, who afterwards visited the camp and were presented with fish-hooks. It may be assumed that the party CAMPED at night on the southern, or right, bank of the river, and that the carts were got across somehow on the following day, but Carron says nothing about these matters.

I 3 th Fune.-In the morning Carpenter, the shepherd, was MISsING, and was ascertained to have taken with him a damper weighing I I lb., Io $\mathrm{lb}$. of sugar and $2 \mathrm{lb}$. of tea. He was Found, after much searching, next day, in the act of sharing the damper with a party of NaTIVEs. He expressed contrition, but, according to Carron, "throughout the expedition he was of very little service, being, in fact, little better than an idiot." Carpenter died at the Pascoe camp on 26th November. It is well known that many Australian shepherds of the old days went mad as a natural consequence of their lonely life. If Carpenter had really been 
recruited from that class, it is more than likely that his mind was unhinged by the new style of shepherding, with its attendant difficulties, to which he had been introduced.

Carron mentions that on the I4th an Alligator rose to the surface of the water close to the camp and appeared to have his eyes on the sheep. The unhappy sheep were further disturbed by a pack of dogs belonging to the natives.

On 15 th $\mathcal{J}$ une, the party progressed 3 miles inland, and camped on the edge of some fresh-water swamps. On this and the following day, Kennedy, with a small party, endeavoured, without success, to find a way through the swamps. The camp was broken up on I 7 th $\mathcal{F}$ une, and a stage of 5 miles was made along the edge of the swamp, the cart-wheels often sinking to the axles in the rotten ground.

The next day, Sunday, I8th Fune, was observed as a day of rest, the Leader reading prayers at eleven.

I 9 th-22nd Fune.-Kennedy and five others explored unsuccessfully for a way out of the swamps, and the Leader made up his mind to return to the beach. There was heavy rain from the night of the rgth to the night of the 22nd. Two of the horses left at the main camp were found bogged, and were extricated. Parties of NATIVEs, as many as 80 or 100 , came and surveyed the main camp from a distance.

23rd June.-The expedition moved on southward by the beach, and presently crossed a small tidal river (DALLACHY CREEK?), on a sand-bar near its mouth. Turning inland for a short distance, they camped on the north, or left, bank of "a small river" (WRECK CREEK) south of the last. Kennedy and five men spent the next day (24th June) looking for a way out of the swamps, but without success.

On 25 th Fune, they accomplished 5 or 6 miles southward, near the beach, the ground being rotten and sandy.

On 26 th Fune, after a little distance southward along the beach, another "small river" was met with, which Carron thought might be the same they had left the day before (WRECK CREEK), but which must have been Meunga CREEK, 2 miles north of the modern town of CARDWELl. In crossing this creek, the carts sunk into the mud, and had to be unloaded, the goods being carried ashore. In this operation, a number of NATIves, who had by this time learned to address some of the party by name, assisted. One or two were detected in petty acts of theft. The camp was made on a grassy rise, after cutting through half a mile of mangroves.

On 27 th $\mathcal{F}$ une, a progress of 5 miles was made inland (west), the country rising gradually and becoming dryer. Probably the night's Camp was on Meunga Creek, where it turns south. On the $28 \mathrm{th}$, a road had to be cut for 3 miles west, through a 


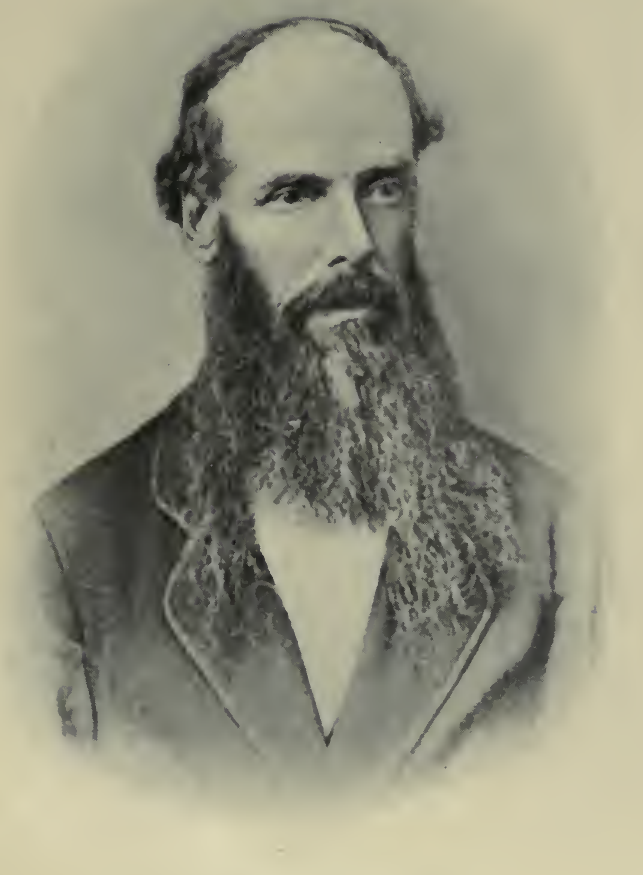

WILLIAM CARRON, I870. 


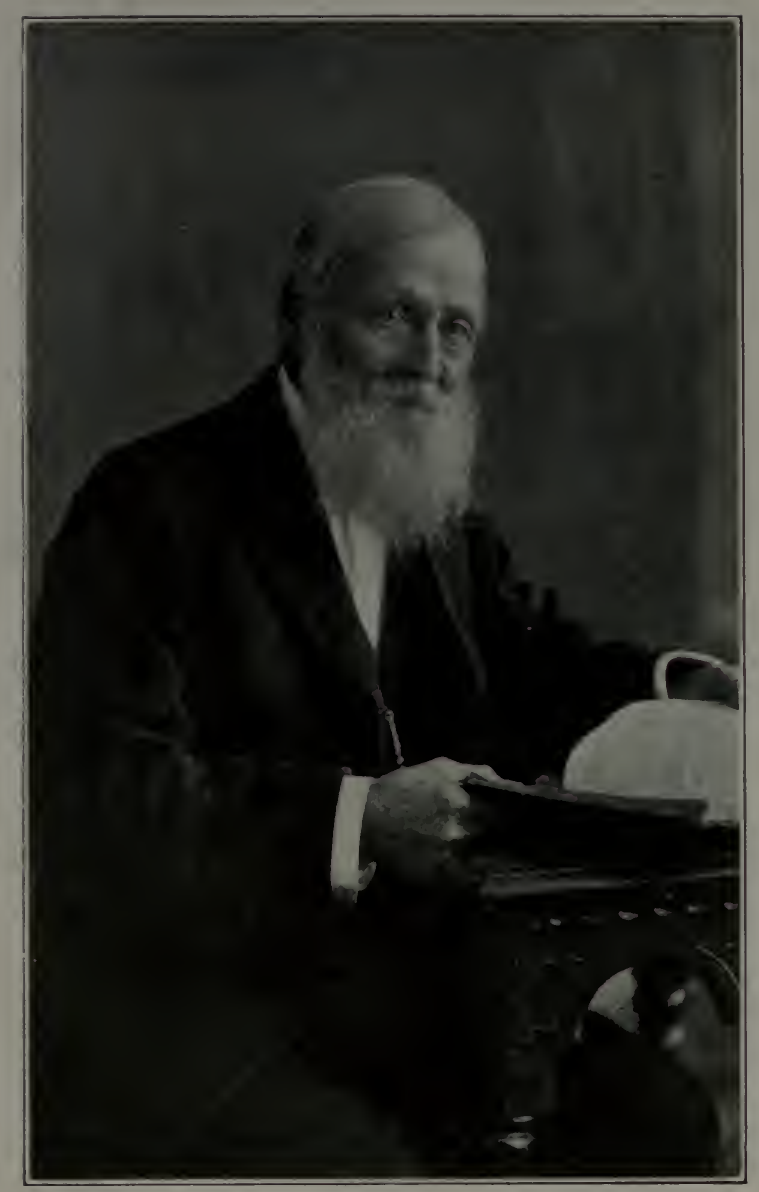

SIR ALGUSTLS c. GREGURY, I 898. 
thick scrub, after which a CAMP was made in open forest country. LuFF and Douglas were very ill with Ague.

From 29th Fune to Ist Fuly, Kennedy and three others, leaving the main camp, explored 40 miles of country, having, as they believed, at last found the WAY out. A fresh start was to have been made on Monday, 3rd July, but was delayed by the continued ILLNESS of LUfF and Douglas. The HoRses were GETTING WEAK and the SHEEP were FALLING AWAY, and for this reason four days more were spent at the camp. On $4^{t h} \mathcal{F} u l y$, Kennedy and three others, roaming "some distance from the camp," were ATTACKED BY NATIVEs. "One spear was actually thrown, when Mr. Kennedy, fearing for the safety of his party, ordered his men to FIRE upon them. Four of the natives fell, but Mr. Kennedy could not ascertain whether more than one was killed, as the other three were immediately carried off into the scrub."

On 6 th fuly the camp was broken up and the WESTWARD MARCH was resumed. Early in the day two creeks were met with, running to the north-east. The second was crossed with difficulty, the CARTs having to be lowered into its bed with ropes and pulleys. The camp was made on the north, or left, bank, in hilly open forest country, with a high range visible to the west.

On 7 th $\mathrm{f} u l y$, small progress was made, owing to fallen timber which impeded the carts. The evening Camp was made on a creek with a large sandy bed. This was, no doubt, what is now called KenNedy CREeK, one of the heads of Meunga Creek.

$8 t h$ Fuly.-Cutting scrub on north side of Kennedy Creek. Small progress. CAMPED in open forest country with large boulders of granite.

9th fuly (Sunday).- - Rest and prayers.

Ioth to $\mathrm{I}$ th Fuly.-Travelling at an estimated rate of 3 to 5 miles per day (probably less), cutting SCRUB and crossing many small creeks. I am convinced that they must have taken an ENE. course till they had rounded Mount Carruchan (2,810 feet), as they could never have got the CARTS across the spur of the range connecting that mountain with Mount Alma (3,300 feet). These four days' travelling probably brought them to DEEP CREEK or Dundonald Creek, tributaries of the Murray River. On the I $t h$ the party was visited by a small tribe of Natives, "who appeared very friendly and did not stop long."

On I4th Fuly, in crossing country which had the appearance of being frequently inundated, ONE OF THE CARTS BROKE DOWN and had to be left behind. A start had been made early in the morning, and at dusk THE OTHER TWO CARTS STUCK FAST at the crossing of a small creek and some of the horses got bogged. It was only two hours short of midnight when the loads were carried to a dry CAMP.

This experience finally convinced Kennedy that the CARTS were a useless impediment, and he admitted that they had to be LEFT 
BEHIND. While it is impossible to withhold our admiration for the tenacity of purpose with which he clung to his original plan, it is to be deplored that he was not convinced of its hopelessness till forty days of incessant work and worry had taken the heart out of man and beast. Certainly the horses never recovered from the strain which had been put upon them at the beginning of the journey.

The 15 th and 17 th fuly were devoted to rearranging the load for transport on pack-saddles, a crosscut saw, pickaxes and various other articles being left behind; among them Carron specially lamented his specimen-box. Sunday the 16 th was given to rest and prayers.

On $18 t b \mathcal{F} u l y$, the company set out in the new order, "rejoicing," says Carron, "to have got rid of one great impediment to our progress." He adds : "The BLAcks regarded us with curious interest as we proceeded on our way, forming a train of twenty-six horses, followed by the sheep, and Mitchell occasionally sounding a horn he had brought with him." Little wonder that the blacks were impressed by this outburst of innocent merriment! But for the absence of a score or so of banners, it might have been a Chinese procession. Carron records that the SHEEP had by this time grown very thin and poor. "They had, however, become so habituated to following the horses that they cost us very little trouble in driving them." Thus is the wind tempered to the shorn lamb! On this day, after travelling about 6 miles (presumably NNW.) through open forest land, the party camped near a creek on the edge of a thick scrub.

For four days, from the 19 th to the $22 n d$ fuly, the march was continued over mountainous country, with numerous belts of SCRUB, which had to be cut. Considering the sheep, the scrub, the steep gullies and the inevitable windings, the rate of progress may be estimated at 3 miles per day. Sunday, the $23 r d$, was devoted to REST AND PRAYERS.

On $24^{t h}$ fuly, similar country was passed through, with occasional patches of open forest, and the CAMP was pitched by a creek running to the north. One HORSE, which had fallen lame, was shot. This would leave twenty-five. A tribe of friendly Natives visited the camp. The creek was found to be one of two branches of a river running to the south-east, the other running east, possibly BeAr Creek and Davidson Creek, affluents of the Tully River.

25 th Fuly. - The party went up the creek (NW.) for 3 miles, having much scrub to cut, and crossed the creek; here several horses fell among granite boulders. Unable to get out of the scrub before dark, the party CAMPED and the horses were tied up for the night. The next day is not accounted for by Carron. Probably it was spent in hacking through the scrub for a short distance. 
$27 t b$ fuly.-The greater part of the day was occupied in cutting scrub and little progress was made. Eventually the creek was recrossed and a path was cut to the top of a high hill on which there was grass for the horses. Here the party spent the night, the horses being tethered lest they should fall down the steep bank of the creek. A high granite range lay ahead.

28 th Fuly.-No sooner had the HORSEs been untethered than one of them fell down 30 feet and was KILled (twenty-four left). The party cut through the scrub down the hill to the foot of the range, and camped.

$29 t b$ Fuly.-Kennedy was out exploring the range, which was densely scrubby. The following day being Sunday was spent in the usual manner. On Monday, Kennedy took out Jackey-Jackey and four others, clearing a way up the mountain through the scrub, a task which occupied them till Wednesday, 2nd August.

On $3^{\text {rd }}$ August, the party climbed a spur of the range by the cleared track. One horse was unable to do his part and was tied up to a tree and left behind, the party going on a little further and CAMPING in the scrub. Next morning (4th August), the whole of the horses, including the weak one, and the sheep, were driven back to grass by Carron, Mitchell and Dunn, who camped beside them. At the main camp, Niblet and three others remained to watch over the stores, while Kennedy, Jackey-Jackey and four others formed an advance party cutting scrub. The main camp was on the creek by which the party had camped on 24 th July.

On 6th August, the party camping with the horses and sheep were visited by seven or eight NATIvEs, who ran away on seeing Carron shoot a bird which had opportunely perched on a neighbouring tree.

Carron left his camp on $7 t h$ August with the sheep and horses, widening and improving the partially cleared track made by the advance party, whom they overtook on the 9th. At Carron's camp on the night of the 8th, great difficulty was experienced in lighting a fire, everything having been saturated with rain, and he and his companions were copiously bled by LEEches. I may say that I have had a similar experience on the coast range further north, and that the annoyance is something frightful. Carron left one horse, which was too weak to travel, at his camp on the morning of the 7 th, thus reducing the number to twenty-three. 


\section{CHAPTER XXXI}

\section{KENNEDY'S EXPEDITION, 1848, continued \\ FROM THE COAST RANGE TO THE PALMER}

Tributaries of Herbert River. Herbert Valiey. Storekeeper's Defalcations. His Duties added to those of the Botanist (Carron). Drastic Rationing. Witd River (Head of Herbert). Nettre Creex. Horses dying. Horsefiesh eaten. Across Watershed of Peninsula. Site of Future Glen Linedali Tin Mines. Emu Creek. Walsh River. Tin Mines of the Future. Friendiy Natives. Goddard temporarily lost. The Future Wolfram Camp. Down Hodgrinson Valley. Mitchell River (2nd September, I848). Kennedy believes it will take him to Princess Charlotte Bay. Down the River. Too far West. Strikes North-West. Natives and their Food. Palmer River crossed at Site of Future Palmerville. Demonstration by Hostile Natives. Natives burn Grass and throw Spears and are repulsed.

\section{(See Map K.)}

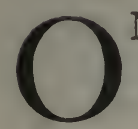

N $9^{t h}$ August, the united party reached the summit of THE COAST RANGE, which Kennedy estimated to be over 2,000 feet above sea-level, and CAMPED on the western side of a small river, which must have been BLUNDER CREEK, a tributary of the Herbert River, which falls into the south end of Rockingham Bay. (See I6-mile MaP of QueEnstand, or, Preferably, the i6-mile Inset in Sketch Map of the Walsh and Tinaroo Mineral Field, i904: No. i8i of Geological Survey Publications.)

Sixty-six days of toil and hardship had brought the explorers into the Herbert valley, their actual start for the north having been preceded by a long and arduous journey in the opposite direction. Kennedy was, at this furthest south, 2 miles from the site of Cardwell and within a few miles of the point where, had he only known, he might have ascended the range by DALRYMPLE's GAP and then made his way with ease up the Herbert valley to the point which he had at length reached with so much difficulty.

On Ioth August, Blunder Creek was crossed and the party camped on the right bank, lat. $17^{\circ} 48^{\prime} \mathrm{S}$. long.; $145^{\circ} 20^{\prime} \mathrm{E}$. The horses swam across and the sheep followed them "like dogs." A deep channel between two rocks was bridged with three trees, over which the men carried the stores. "Niblet, who had been very UNWELL for three or four days, was taken much worse to-day."

Consideration for the horses kept the party in camp on the IIth. Five miles of uneven open forest country were covered on the I 2 th, and the party CAMPED by a chain of rocky water-holes, which must 
have been near the left, or southern, bank of QuAmber CReEK (?). The $13 t h$, being Sunday, was given to rest and prayers.

Next day (14th August) it was found that Niblet, the storekeeper, had been APPROPRIATING sTORES for himself and making false returns. Kennedy thereupon gave the charge of this department to Carron and a weekly ration was directed to be weighed out for the future. The FLOUR was found to have been reduced to 700 LB. Having started with $2,240 \mathrm{lb}$. on 5 th June, about twothirds had been consumed in 70 days, or at the rate of about II $8 \mathrm{lb}$. per man, which works out at about $\mathrm{I} \cdot 7 \mathrm{lb}$. per man per day. The future RATION was fixed at $50 \mathrm{lb}$. per week for the thirteen men; equal to a little over half a pound per man per day. In addition, there were to be served out weekly for the thirteen men : I $2 \mathrm{lb}$. of sugar and $2 \frac{3}{4} \mathrm{lb}$. of tea; and, as before, a sheep was to be killed every second day. Starting with roo sheep, 35 would be eaten in the 70 days, and allowing 5 more for losses, there would now be about 60 left.

The journey was resumed on 15th August, scrub having to be cut nearly all day, and the party camped "by the side of a fine Casuarina creek coming from the north-east." There can be no doubt that this was the Wild River, the head of the Herbert. The CAMP was probably about 4 miles above the modern WoodLeigh cattle station and 20 miles below the tin-mining township of HERBERTON, which is now connected by RAILwAY with the port of Cairns, in Trinity Bay. One more Horse was ABANDONED, leaving twenty-two.

I6th August. - No reference is made by Carron to the crossing of the Wild River, and the presumption is that it was forded without difficulty, as it may be in many places. (Mulligan must have crossed KenNEDY's TRACK here on 8th June, 1875.) This day's stage, to the north-west probably, ended near the head of NETTLE CREEK, a tributary of the Wild River and a prolific source of stream tin in later years. One HORSE, too weak to travel further, was KILLED (leaving twenty-one) and what flesh was on him was EATEN in two days, and the SAVING OF ONE SHEEP for future consumption was effected. On the following day ( $17 t h)$, only a short stage had been made when the party camped out of consideration for the horses, there being rugged and broken country to the north-west. This country, although the explorers were not aware of it-or at any rate Carron was not-was the DIVIDE BETWEen the rivers falling eastward into the Pacific and westward into the Gulf of Carpentaria. The night's CAMP must have been a little north of the modern tin-mining township of Coolgarra and not far from the present TELEGRAPH LINE and road from Coolgarra to Herberton.

On 18th August, the march was continued ACross THE DIVIDE and 4 miles north-west till a camp was found "by the side of a fine river, with steep reedy banks lined with large casuarinas and 
flooded-gum trees, and abundance of grass in the valley." The march was difficult, one HORSE falling into a gully, to DIE next day, thus leaving only twenty. The position of this CAMP is given as $17^{\circ} 30^{\prime} \mathrm{S}$. and $145^{\circ} 12^{\prime} \mathrm{E}$., and if this is correct the camp would be down the valley a little below the Glen Linedale tin mines, Glen Linedale being one of the heads of EMU CREEK, which falls into the Walsh River.

A halt on Saturday, 19th August, was substituted for the usual Sunday halt, and the journey was resumed on the $20 t h$. The expedition moved on to the north-west during that and the three following days, camping on the $23 r d$ by " a creek running to the westward, with rather a broad bed and steep banks of strong clay." The country traversed during the four days, in the valley of Emu Creek, was undulating forest land, with red ant-hills, up to Io feet in height, on the sandy flats. About midway between the CAMPs of the $18 t h$ and $23 r d$, the expedition's track is now crossed by the Chillagoe Railway east of Lappa Lappa Junction. The district traversed between these two points is now thickly studded with tin, copper and silver mines. The creek on which the Camp was pitched on 23 rd August was the Walsh River, about three miles below the mouth of Eureka Creek.

When the party approached the camp, about a score of NATIVEs made a friendly visit and were presented with fish-hooks and a tin plate.

The camp having been pitched, Goddard and Jackey-Jackey went out to shoot wallabies for the pot. They parted at a hill, which they agreed to round in different directions, and meet. GodDARD, however, got LosT and did not reach the camp till late next day, after the party had searched anxiously for him. Only a short stage to the north-west was made that day (24th August), owing to the late start. The march was probably continued northward on the 25 th and $26 t h$. Carron does not give the direction in which the party travelled; but it was probably north, as they wished to go in that direction, and that it was possible to do so was proved by Mulligan in 1874 (6th to 9th September). Carron mentions only that three or four of the party suffered severely from eating figs. It is now known that these native figs can be made more wholesome by a period of burial, this method being practised by the blacks. (Mulirgan's camp of 8th September, I874, west of Wolfram Camp, was probably on Kennedy's footsteps of 25th August, 1848.)

27th August (Sunday).-Prayers at eleven. Carron refers to the "poor condition of the horses," saying that the wool from slaughtered sheep was carefully saved to stuff saddles.

28th August.-During this day's (presumably northward) march, a HORSE, too weak to travel, was SHOT, and the meat saved for consumption. (This left nineteen.) Only a short distance was 
covered, and the CAMP was pitched on a small creek, which I assume to be Mount Mulligan Creek, draining the south-eastern end of Mount Mulligan and falling into the Hodgkinson River. (SEE MAP G.)

Another weak HORSE was ABANDONED before a start was made on 29th August, leaving eighteen. The party CAMPED at night on the Hodgkinson River, which was not running, but had large water-holes.

On the $30 t h$ and 3 Ist August and ist September, the party followed the Hodgkinson down the valley to the north-west, with much difficulty, owing to the roughness of the country, the depth of the gullies and the density of the scrub on the hills. On 2nd September, they left the river at a bend-probably about 6 miles short of its junction with the Mitchell, and in about 5 miles to the north-west CAMped on the Mitchell River itself. They had been under the impression that the Hodgkinson would lead them to Princess Charlotte Bay. ${ }^{1}$

On Sunday, 3rd September, prayers were read as usual, and some of the party hunted for food, bagging an emu, a kangaroo and some fish.

For six days (4th to $9^{t h}$ September), the party followed the Mitchell to west-north-west, sometimes in its bed and sometimes over hill-tops, being under the impression that the river would lead them to Princess Charlotte Bay. Kennedy's mountain BAROMETER Was BROKEN, so that altitudes, for the future, could only be guessed at. The CAMP of 9 th September was on the river, probably about the I $44^{\text {th }}$ meridian, where it is now crossed by the TELEGRAPH LINE between the Walsh and Palmerville stations (HANN's CAMPS I 6 and $48, \mathrm{I} 873$ ).

There is no evidence in Carron's narrative that Kennedy identified this river with Leichhardt's Mitchell, and, of course, Kennedy was many leagues higher up the river than Leichhardt had been. The mere fact that he expected it to lead him to Princess Charlotte Bay proves that he considered it a different river.

Kennedy must by this time have been convinced that he had gone far enough west if he was to strike Princess Charlotte Bay, where the relief ship was awaiting him. On 5 th September, while they were travelling down the Mitchell, Carron says: "We were now in the vicinity of CAPE Tribulation." Possibly Kennedy may have told him they were near the latitude of that cape, but they must then have been at least 80 miles west of it. The Leader now (Ioth August) altered his course from NW. to N.: in fact, he took the route which HaN followed in 1872 and Mulligan in 1873 , and which is now followed by the TELEGRAPH LINE from the Walsh to the Palmer.

1 Muliigan's journey of 2nd and 3rd September, 1874, practically covered the same ground as KENNEDY's of 28 th August to 2nd September, 1848 . 
The Ioth September was a Sunday, and although the party was on the march, there were " prayers as usual at eleven o'clock.", Exactly twelve hours later, three SPEARS were thrown into the camp, and were answered by a few sHots fired in the dark, but no casualties appear to have resulted on either side.

From the IIth to the I $4^{t h}$ September, the course was north, over " rotten," but fairly level, country, partly liable to inundation and occasionally with small grass-covered hillocks, among which the failing horses continually stumbled and fell. A camp was surprised and the NATIVEs having fled in alarm, a half-cooked chestnut cake and some pandanus fruit were taken away, fish-hooks being left in compensation. The pandanus did not prove satisfactory because of its laxative properties and its tendency to produce violent headache. It might have been better, after all, to have eaten the fish-hooks and left the pandanus to the natives. On the I5th, the party crossed the Palmer River and camped on its right, or northern, bank, opposite the site of the future PALMERvilLE. The Hodgkinson, Walsh and Palmer are, of course, designated by names bestowed long after Kennedy's day. By what name he distinguished them will never be known.

After the camp had been pitched, a party caught a few fish in the river. Towards evening, six or eight NATIves threatened the camp, shipping their SPEARS in throwing-sticks (wimmeras). An endeavour to convince the intruders that hostility was not intended was construed into an indication of fear and the advance was continued, whereupon the white men FIRED. No one was hurt, and the invaders retired, but only to go and attack the fishing party. Here again they met a determined defence, and they only fled after they had been fired on.

The party remained in camp on the following day ( 16 th Septem$b e r)$, when they were again ATTACKED, this time by 12 or I 4 NATIVEs, armed with spears and boomerangs.

"Their bodies were painted," says Carron, "with a yellowish earth, which, with their warlike gestures, made them look very ferocious. The grass in the position they had taken up was very long and very dry, quite up to the edge of the gully; they set it on fire in three or four places, and the wind blowing from them to us, it burned very rapidly. Thinking we should be frightened by this display, they followed the fire with their spears shipped, making a most hideous noise, and with the most savage gestures. Knowing the fire could not reach us, as there was nothing to burn on our side of the gully, we drew up towards them with our firearms prepared. They approached near enough to throw three spears into our camp, one of which went quite through one of our tents. No one was hurt, but a few of our party fired at them; we could not tell whether any were wounded, as they disappeared almost immediately. We kept three on watch this night for fear of the natives."

It does not appear that Kennedy or any of his party prospected the Palmer, or had any suspicion of the presence of GOLD, which was to be so amply demonstrated by the subsequent explorations of Hann and Mulligan. 


\section{CHAPTER XXXII}

\section{KENNEDY'S EXPEDITION, I848, continued}

\section{FROM THE PALMER TO THE PASCOE}

Leate the Palmer, I7th September, 1848. On "Conglomerate" Tableland. On Pacific (Princess Charlotte Bay) Waters. Heads of Kennedy River. The Belief that Kennedy ran this River down to the Ocean is erroneous. Wangow Creek, 22Nd and 23rd September. Jack's Track crosses Kennedy's. Great Heat. The "Conglomerate" Range. Down Warner River. Salt Water. Lost Sheep. Horseflesh, a Little Flour and a Litrle Game. Natives burning Grass on Plains. Men and Horses exhausted. Jane's Tableland seen. Saltwater Creex (6th October). Native Camp inspected. Stone Ovens, Nets and Bottle-glass. Annie River. Natives follow and throw Spears and are driven back. Natives visit Camp and fetch Water. Mangroves on Shore of Princess Charlotte Bay. Useless to force a Way to the Bay, as the "Bramble" must have left. Further Losses among HORSES, WHICH ARE CHIEFLY DRIVEN ON FOR FOOD. BAGGAGE LIGHTENED. Stewart River. Northward on Eastern Side of Future Rocky River Goldfield. Track of a Hurricane. Up Nisbet Valley. Men despairing. Three ill. Alarming shortness of Rations. Ascending scrubby Western Slopes of McIllwraith Range. Jack's Camps 25 and 26 near Kennedy's Track. A Man too lame to walk. Tents burned to lighten Load. Scrubby Mountains. Head of Pascoe River, running Southward. Jackey-Jackey shoots a Cassowary. Horses killed for Food. Scarcity of Grass. Breadless for lack of Water. Northward through Janet Range. Camp (itth November) on Tidal Water near Mouth of Pascoe River. Carron and Jackey-Jackey walk to Beach. Last Sheep killed. Camp moved East to Barrett Hill. Nine Horses left out of Twenty-seven. Provisions almost exhausted. Dash to Cape York planned. Carron and Seven Men to be left in Camp. Kennedy, Costigan, Dunn, Luff and Jackey-Jackey to make the Dash. Kennedy hopes to bring Relief by Water in I4 Days. Division of Horses and Rations.

\section{(See Map G.)}

TROM the I7th to 2Ist September, inclusive, the course is given by Carron as north-west; more probably it was north-west to begin with, and then veered round to the west until a gap was found in the "Conglomerate RANGe," which bounds the Palmer valley on the north-likely enough the same gap which was subsequently made use of by "MACMIllan's ROAD," and then the north-western course was resumed, to be changed to a northern as soon as the nature of the ground permitted. "There was," says Carron, "occasionally fair travelling over stiff soil intersected by many creeks, most of 
them dry, but we were everywhere able to find water at intervals of a few miles. We passed over some ironstone ridges and rocky hills covered with Callitris, Cocblospermum and Sterculia."

After clearing the gap and getting on the "Conglomerate" tableland, Kennedy was on PAcific WATERs, and must have crossed the heads (here no more than rivulets) of the river to which his name was afterwards given, and which is popularly believed to have been followed by him northward to Princess Charlotte Bay. That this idea is erroneous is evident when we consider that his course was nearly north, while the Kennedy River presently turns sharply to the north-east. A few miles to the north would take him out of the catchment area of the Kennedy. It should therefore be understood that the KENNEDY River was NAMED in HONOUR OF KENNEDY, but was not, as is supposed, traced by him from its head to the ocean. (SEE MAP E.)

On 22nd September, the explorers "crossed a creek running eastward" and CAMPED. This was, in all probability, WANGow CREEK. The CAMP of 23 rd September was on the same creek, at a point where it ran temporarily south-west. My first camp on my second Cape York Peninsula expedition must have been close to this camp of Kennedy's.

Kennedy crossed to the right bank of the creek next morning, and as the creek was running south-west, he supposed it to be an affluent of the Palmer (Carron, p. 193). He had not yet grasped the idea that he was now at last on Princess Charlotte Bay WATERS. By this time the heat had become intense, noonday shade temperatures of 95 to 100 degrees Fahr. being recorded, and this must have added greatly to the distress of the surviving horses.

The description of the country traversed (northward) on the $24^{t h}$ and $25^{t h}$ is that which is typical of the sandstone tablelands in these latitudes.

On the morning of $25 \mathrm{th}$ September, three HORSES were MISSING, and four men were left behind to search for them, while the rest of the party moved on. At night, a CAMP was made on a large water-hole. One of the four men came in, stating that the other three had halted for the night. Carron, by Kennedy's instructions, went back and led them (and presumably also the lost horses) to the camp in the dark. The best KANGAROO DOG failed to reach this camp, having been overpowered by the heat. He crawled into the camp of the 28 th, 30 miles on, but DIED next day.

On 26 th September, Kennedy's camp was fixed "in a sandy, creek where the country seemed to fall slightly to the north-east." Kennedy was still under the impression that the waters he was meeting with ran into the Mitchell, via the Palmer, and "still hoped to find a river running into Princess Charlotte Bay." As a matter of fact, he had been on such rivers for several days without 
being aware of it ; but the valleys on sandstone tablelands are not, as a rule, separated by "ranges." The "sandy creek" of the CAMP of $26 t \bar{b}$ September was the "STATION CREeK" of modern maps, about 5 miles south of Mulirigan's ROUTE (1875), between his 8oth and 8Ist camps, and which he (Mulligan) named the WARNER RIVER.

In this place it becomes necessary to refer once more to the comedy of errors arising out of the multiplication of "Kennedy" Rivers and Creeks. The river which Kennedy is supposed to have followed down towards Princess Charlotte Bay is placed in Carron's sketch map on the I44th meridian of east latitude, and this was, of course, the only river in these parts then known to geographers. In what is practically the same map, attached to A. J. Richardson's Overland Expedition from Port Denison to Cape York under the Command of $F$. and $A$. Jardine, Esqrs., in 1865, this river appears as the "Kennedy River." It was not known, even at that date, that quite a number of rivers run northward into Princess Charlotte Bay, their mouths anastomosing when they reach the coastal plain. From east to west, these now appear on the maps as the Laura River, Normanby River, Kennedy Creek, Kennedy River, North Kennedy River and Hann River. The first of the "Kennedy" group, viz., Kennedy Creek, might advantageously be renamed. The Kennedy River, long known as such by the thousands who have come and gone between Cooktown and the Palmer, and the largest of the group, should retain the name of the revered explorer who was the first to reach Princess Charlotte Bay by land. To the whole of the so-called North Kennedy, the name of Therrimburi Creek, which is borne by its upper reach, should be applied. It was BETWEen TherRimburi Creek and the Hann River (named by Mulligan) that KenNedy TRAVELLED northward in 1848 .

On 27 th September, the party travelled over sandy ridges and marshy flats subject to inundation. The CAMP was made at a rocky creek containing very little water, probably the WARNER River (Station CREEK), where it takes an easterly course before falling into the so-called "North Kennedy River" (Therrimburi Creek). The salt Water came up the creek to the camp, but fresh water was obtained in a lagoon.

For the next two days (28th and $29 t h$ September), a halt was necessitated by the STRAYING of the SHEEP.

The sHeEP are only once again referred to in Carron's narrative, viz., on I Ith November, when the last was killed at the Pascoe camp, and it may be surmised that the majority were finally LOST here, as the party evidently subsisted for the rest of the way to the Pascoe mainly on horseflesh, a little flour and what game they could shoot. When we last took stock of the sheep, on I4th August, 60 were left of the original 100. Since that date, reckoning 
the consumption at one in two days, and balancing losses while travelling by economies made possible by the capture of game, there should have been 38 left on 27 th September.

Two NaTives were seen, carrying spears, on 28 th September.

On $30 t h$ September, the expedition moved on for 5 or 6 miles to the west, across a plain, when, finding a dry lagoon where a supply of water was expected, they RETURNED to the camp on Station Creek. Nothing is said of the Sheep, but the poor animals must have been about equally unfortunate whether they had to be left where there was no water or were driven Io or 12 miles back in the summer heat.

The Ist of October, being Sunday, was spent in rest and prayer. Next day (2nd October), the party again crossed the plain westward, the NATIVES BURNING THE GRASS behind them, so that they were glad to hurry on to a patch which had already been burned. They must have reached water, probably in the HANN RIVER, about the place where I crossed it on 4 th September, I879. One horse, too weak to travel, was bled, and his blood was mixed with flour and made into a pudding. The HORSE DIED next day, and his flesh was prepared for food. This left seventeen horses alive. The STRENGTH OF THE MEN WAS DECLINING, and it is sad to record that their morals also had been sapped by privation and toil, so that, to guard against selfish peculation, it became necessary to watch the horseflesh when it was drying in the sun.

When the march to the north-west was resumed on 4 th October, JANE'S TABLELAND ${ }^{1}$ was in sight. It appears in Arrowsmith's map, issued in 1838. I saw this tableland on $4^{\text {th }}$ September, I879. It is impossible, from Carron's journal, to account satisfactorily for the whole of the 4 th, 5 th and 6 th October (1848), but on the afternoon of the 6 th the CAMP was pitched near " a salt-water creek," which is probably that now shown on the maps as "SAltwater Creek," and which was known as such to the diggers who rushed the "Coen" in I878. My track from the Hann River to Saltwater Creek, on 4th September, 1879, probably coincided with Kennedy's.

Near the explorers' camp of 6th October, a Native camp was inspected in the absence of its owners. There were seven or eight conical huts built of saplings and lined inside with woven strips of bamboo and covered outside with palm leaves. It was obviously a camp designed to keep out rain in the wet season. In the huts were stone ovens, fishing-nets and pieces of вотTLEGLASS.

On $7 t h, 8 t h$ and $9 t h$ October, the march was continued NNW. to " a river running into Princess Charlotte Bay, in lat. $14^{\circ} 30^{\prime} \mathrm{S}$. and long. I $43^{\circ} 5^{\prime} 6^{\prime}$," which must have been the AnNIE RIVER, if the latitude is correct. The longitude given is evidently about

1 This conspicuous table was probably named by King, in the "Bathurst," in I821. 
Io minutes too far east, as the river was crossed I 2 or I4 miles from the sea, where the water was only brackish.

During the midday halt on Ioth October, the party were visited by a large number of NATIVEs, including women, who had been collecting the fruit of the nondah. When the march was resumed, says Carron, "the natives followed us at some distance, continually THROWING SPEARS after us for some time: one was thrown into the thigh of a horse, but, fortunately, not being barbed, was taken out, and the horse was not much injured. We then rode after them in two or three directions, and FIRED at them, when they left us, and we saw no more of them."

On the IIth, when halting in a place where there was no water, the travellers were visited by NATIVEs, who, in exchange for fish-hooks, brought water in bark vessels, and left quietly.

I am unable to place Kennedy's camps between the 9 th and 2oth of October, but it is evident that he must have travelled north-north-west and kept as close to the west coast of Princess Charlotte $\mathrm{BAY}_{\mathrm{y}}$ as the mangroves and salt-water creeks and swamps permitted. In all probability, from the ANNIE to the STEwarT River, his route was near-perhaps a little west of-that followed by William Hann on his "home" trip, 5th to 8th September, I872, between his camps Nos. 32 and 35. (SEE MAP C.)

On I3th October, a last unsuccessful attempt was made to penetrate the mangroves to the beach. It may be surmised that this was somewhere near the latitude of the Rattlesnake Reefs. H.M.S. "Bramble" was to have been in Princess Charlotte Bay in the beginning of August, and Kennedy was satisfied that the ship must have come and gone, and that relief was no longer to be expected.

On the 15th (Sunday), there were "prayers as usual at II o'clock," and the sugar was finished. Next day (I6th) a horse which fell into a rocky water-hole was killed and his flesh was dried in the sun. This left sixteen horses, for the most part too exhausted to carry loads, and the horses were now driven on chiefly for food. One tent and other useless articles of baggage were left behind.

- In the four days, I6th to $20 t h$ October, the march continued across the creeks which drain the eastern side of the McIlwraith RANGE, including the valleys of the Rocky River, Scrubby Creek and Chester River, which now form the Rocky River Goldfield. It is noted on the I9th that " several of our horses were now quite unable to carry anything but the saddle." On the following day the party " passed over a piece of stiff ground about two miles in extent, which appeared to have been the scene of a devastating HURRICANE. The ground was covered with fallen timber, which rendered it very difficult to cross. The wind must have swept from the south-west to the north-east, and from the appearance of the saplings which were growing from the stumps of some of 
the trees which had been broken, this terrific storm appeared to have taken place about two years ago. Not a tree had been left standing. . . . Many of the trees in the middle of the fallen timber measured two feet in diameter. Some were torn up by the roots, and the trunks of others were snapped off at various heights from the ground." It is interesting to compare this description with that of the cyclone-swept clearing seen by me on 2oth February, 1880.

Kennedy's camp of $20 t h$ October was in $13^{\circ} 35^{\prime} \mathrm{S}$. lat., which was probably in the valley between the McIlwraith and Macrossan Ranges, south of the mouth of the Nisbet River. It is safe to assume that Kennedy followed this valley, which not only affords an easy passage to the north, but is practically the only one.

On the 22nd October, only a short stage was made, three of the party, Douglas, Taylor and Costigan, who were suffering from diarrhœa, being compelled to ride, in spite of the weakness of the horses. The flour was found to be reduced to $200 \mathrm{lb}$. In 70 days which had passed since it was weighed at $700 \mathrm{lb}$., the I 3 men had consumed $500 \mathrm{lb}$., or at the rate of $0.55 \mathrm{lb}$. per man per day, so that they must have kept strictly to the ration fixed on 14 th August. The three sick men "complained despairingly to $\mathrm{Mr}$. Kennedy that they should NEVER BE ABLE TO REACH CAPE YORK"and they never did. The travelling this day is briefly described as "between the hills," which makes it almost certain that the party was between the McIlwraith and Macrossan Ranges, and now ascending the valley of the Nisbet River. The blacks were burning the grass to the south.

In the six following days, $23 r d$ to 28 th October, the expedition travelled over " a rocky mountainous country, interspersed with deep gullies and creeks, fringed with belts of scrub." Kennedy must have got up on the eastern slopes of the McIlwraith Range, crossing Swallow, Cherry, Surprise and Greyhound Creeks. Had he but known, he might have found an ideal natural road by running the Nisbet River to its head and crossing into the Lockhart Valley by an almost imperceptible gap.

In all probability, when I was attacked on 9 th January, I880, and my horse was killed by the blacks, I was standing on Kennedy's footsteps. I probably also followed his track on I8th January, I880, between my Camps 25 and 26. Dickie, Dick and Sheffield's " home" track, as far as it went NNW. from Cherry Creek, in I9ro, was probably also Kennedy's.

29th October. - This was Sunday and there were "prayers at eleven o'clock" and three wallabies were shot to eke out the scanty food supply. The party remained in camp, and the horses must have needed rest.

$30 t b$ October.- L Luff was too lame to walk. Here the two last of the round tents were burned to lighten the load and enable Luff 
to ride. The party had left Rockingham Bay with a $6 \mathrm{ft}$. by $8 \mathrm{ft}$. tent for Kennedy and two large tents and a small round one for the others.

It is doubtful, from the wording of Carron's narrative, whether the party left camp on the Ist and 2nd November. One more horse was killed, leaving fifteen.

Very little progress was made on 3 rd November, the party having had to cut through scrub intersected by deep gullies and rocky hills. In the afternoon they reached "a small river, with very uneven rocky bottom, running southerly," with a rapid current swollen by a recent rainfall. There can be no doubt that this was the upper portion of the PASCOE RIver, the only stream with a southerly fall in these parts. (Here I crossed his track, in 1880, between my Camps $3 \mathrm{I}$ and 32, and again between Camps 32 and 33.) The Pascoe, it may be remarked, has a singular course. Rising in the centre of the Janet Range, it first runs south-south-east and south for 14 miles, then west for 20 miles, due north for 16 miles, north-east for 17 miles, and finally east for 10 miles, when it falls into Weymouth Bay.

On reaching the Pascoe, five of the horses, including the one carrying Carron's botanical SPECIMENS AND SEEDs, fell in crossing the river, but the specimens were recovered. The night's camp was in a thick bamboo scrub by the side of the river, the HORSEs being TIED TO TREES.

On the $4^{t h}$ November, the camp was not moved. Jackey-Jackey climbed a hill and saw grass ahead, and shot a cassowary. Mr. Wall failed to preserve the skin " properly." Greater misfortunes were to follow.

While admiring the persistency with which the botanist and naturalist kept their object before them, one cannot help wondering whether they had not lost all sense of proportion. To load even a single horse with specimens at the same time that they were daily throwing away the necessaries of life seems a questionable proceeding.

On $5^{\text {th }}$ November, the camp was moved to the hill from which Jackey-Jackey had seen the grass, and another horse was killed, leaving fourteen. A halt was made at this hill on 6 th November, and two more horses were killed, leaving twelve. The condition of the remaining horses, which had, apparently, not eaten for four days, may be imagined.

On 7 th and 8 th November, travelling over "very rough rocky ground, intersected with gullies and belts of scrub, the head of the PAsCOE ${ }^{1}$ was reached.

On 9 th November, starting without breakfast, having had no

1 This river was afterwards named in honour of Lieutenant Pascoe, the officer in

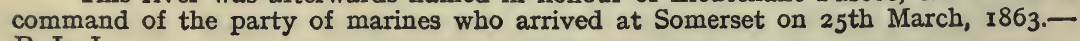
R. L. J. 
water to bake with, the party got over a gap and into a creek running to the north. They must have threaded their way among the peaks afterwards named South PAP, North PAP, Mount Dobson and Mount Nelson-probably west of the "Paps" and east of the "Mounts." They ran the creek down, and in the evening found water in its bed and camped. (SEE MAP B.)

On roth November, the expedition moved about three miles northward down the valley of the creek and camped near a spot where a great number of pandanus trees were growing. On the I $t h$, a further progress of 2 or 3 miles was made to the north; the creek was crossed where it turned eastward and showed the influence of the tide; and the party camped. This day the LAST SHEEP-presumably the only one that had reached the campWaS KILLED.

The camp was visited by several Natives, who conducted themselves peaceably, having been gratified by presents of a tin plate and fish-hooks and impressed by the shooting of fourteen or fifteen hawks. One of the dogs killed a puppy belonging to the natives, and the puppy was eaten by Dunn, Luff, Costigan and Goddard.

On Sunday, I 2 th November, there were "prayers at eleven." Carron and Jackey-Jackey walked to the beach in the hope of finding a supply of salt, but were disappointed.

On I 3 th November, the camp was shifted to a more suitable position on the right or southern bank of the creek, at the foot of a high bare hill. The hill was evidently what appears in the Admiralty Chart of 1897 as BARRETT Hill, the camp being at the northern end of the hill. Carron gives its latitude as $12^{\circ} 35^{\prime} \mathrm{S}$., but it is really $12^{\circ} 3 \mathrm{I}^{\prime}$.

Kennedy was constitutionally averse to admitting his defeat and hard to convince; but he had at last been satisfied by the unanswerable logic of facts that it was impossible to complete the journey as he had originally planned. He now made preparations for a DASH TO CAPE YORK, from which he hoped to bring speedy relief to the party left in charge of Carron at the depôt on the Pascoe River, near its outfall into Weymouth Bay.

A short distance below the depôt, the creek which had been followed down from 9 th November becomes a tidal inlet and joins the Pascoe River. The river itself is little more than a mile north of the camp of the IIth. North of the river, a range of mountains extends north-westward, by Fair Cape to Temple Bay. To this I gave the name of the CARron RANGe (see my Diary of IIth February, I880). According to the Admiralty Chart of I897, individual peaks of the range are now named WALL HiLL, HuXLEY Hill, Stanley Hill, Kennedy Hill (the highest point, I,440 feet) and Carron Hill ( 1,380 feet). ${ }^{2}$ South of the river mouth lies

1 Names given by the officers of the surveying ships "Paluma" and "Dart," 1890-8. See the chapters on Minutiæ of Marine Surveys. 


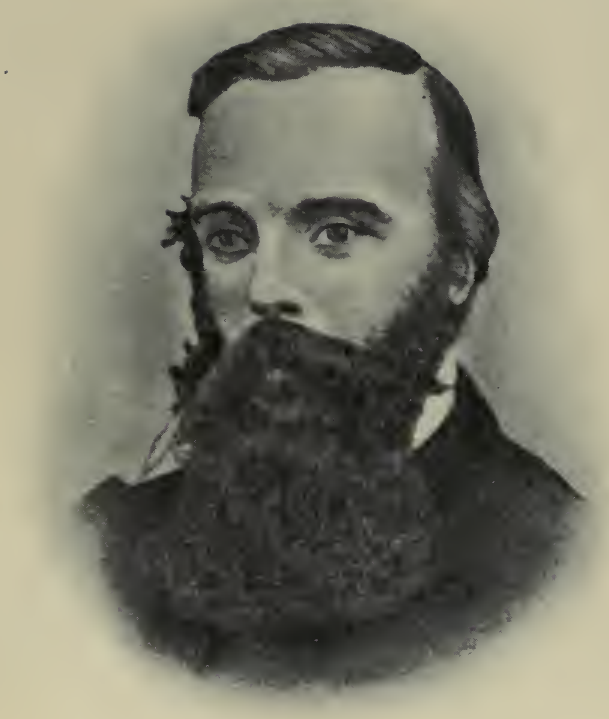

ROBERT O'HARA BURKE, I 860 . 


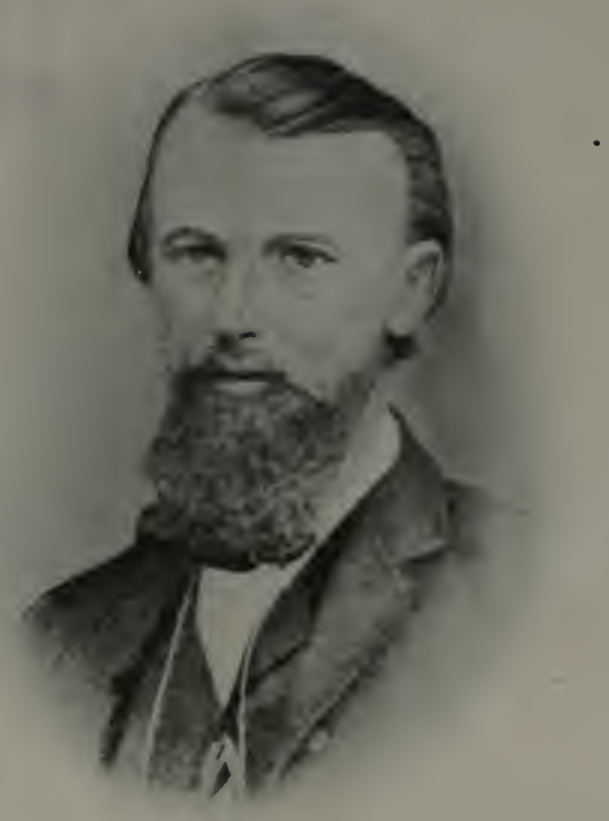

WILLIAM J. WILES, I 860. 
the mountain mass which I named the JANET RANGE in $\mathbf{I} 880$. Individual points now appear on the chart, including SImpson Hill at the mouth of the Pascoe, Barrett Hill (on the north end of which was Carron's depot), the Round Back Hrlus, near Cape Weymouth, Mount Tozer (the highest point, I,953 feet), the "South" and "North" Paps, Mount Dobson, Mount Nelson and the Goddard Hills. ${ }^{1}$ The names commemorate Kennedy's expedition, the voyage of the relief ship "Ariel" (I848), the voyage of the "Rattlesnake" and the administration of two Premiers of Queensland, Sir Horace Tozer and Sir Hugh Nelson.

Kennedy and Carron took stock of the PROvisions remaining on I 3 th November, which consisted of $46 \mathrm{lb}$. of flour, $75 \mathrm{lb}$. of dried horseflesh and I lb. of tea. The consumption of flour since stock was taken on $23 \mathrm{rd}$ October had been at the rate of $0.7 \mathrm{lb}$. per man per day.

The twenty-seven HORSEs with which the expedition set out from Rockingham Bay had now been reduced to NINE. There were, apparently, twelve on 6th November, so that three are unaccounted for. They either died in the passage of the Janet Range, or Carron omitted to mention some deaths or losses when they took place.

KENNEDY TOOK with him SEVEN of the HORSES, the $75 \mathrm{lb}$. of HORSEFLESH, I $8 \mathrm{lb}$. of FLOUR and half a pound of TEA. CARRON and his party were left with $28 \mathrm{lb}$. of FLOUR, half a pound of TEA and two HORSEs, which were to be killed for food as occasion required. $\mathrm{He}$ was instructed to make his provisions last for six weeks. Besides Carron, the party left at the depôt consisted of Wall, Niblet, Taylor, Carpenter, Goddard, Mitchell and Douglas. Those eight men were to wait in camp for the relief which Kennedy hoped to bring them by water in fourteen days at the earliest. Kennedy expected to meet H.M.S. "Bramble" at Port Albany and to have a party sent out at once to Weymouth Bay by sea.

Mr. Archibald Meston in his Report on the Aboriginals of Queensland, ${ }^{2}$ states that in 1896 he mustered the blacks of the district surrounding Moreton Telegraph Station, and adds : "One old fellow remembered Kennedy's expedition of 1848 and all the fatal circumstances of the last sad days. He said Kennedy had been shooting blacks all along his track."

If that old black really saw the Kennedy expedition forty-eight years before he told the story, there can be no doubt that he exaggerated grossly. Carron records only two instances (I6th September and Ioth October, I 848) when Kennedy's party used firearms in self-defence. If there was any foundation for the

\footnotetext{
1 Names given by the officers of the surveying ships "Paluma" and "Dart," 1890-8. See the chapters on Minutiæ of Marine Surveys.

2 Report on the Aboriginals of Queensland, by Archibald Meston, Special Commission under Instructions from the Queensland Government, Brisbane. By Authority, I896.
} 
"old fellow's" story, he was probably confounding the Kennedy with the Jardine expeditions. Supposing him to have been ten years old in 1848, he would be fifty-eight when Meston interviewed him, and at fifty-eight an Australian aborigine is in his dotage. The accuracy of such a person's recollection of dates, figures or names would be open to grave doubt. 


\section{CHAPTER XXXIII}

\section{KENNEDY'S EXPEDITION, 1848, continued}

\section{THE FORLORN HOPE. FROM THE PASCOE TO CAPE YORK}

Kennedy and Party, with Seven Horses, leave Pascoe Camp, i3th November, 1848. His Journals lost. Jackey-Jackey's Account of the 40 DaYs' Journey. Flour soon exhausted. Dried Horseflesh and Nonda Fruit. Luff lame. Costigan accidentally shot. The Three White Men left at what Kennedy mistook for Bligh's Pudding-Pan Hill. A Horse killed and the Flesh divided. A Live Horse left with the Three Men for Food. Kennedy and Jackey-Jackey continue Northward Journey. Horse bogged in Swamp. (Entering on the "Wet Desert"?) Kennedy bogged. Kennedy ill. Jackey-Jackey carries him from Camp to Camp, hides him from the Blacks and scouts for Food. Past the Real Pudding-Pan Hill. Jardine River? Scrubs and Bogs. Jackey-Jackey bogged, with his Horse on him. Kennedy saves him. The Horse dies. Henderson River? Mouth of Escape River. Albany Island in sight. Up Escape River. Numerous Blacks, who pretend Friendship. A Sleepless Night. Blacks appear in Force at Dawn. They dog the Two Men all Day and at Dusk spear Kennedy, who dies, and wound Jackey-Jackey. They also spear the Last Two Horses. JackeyJackey buries KenNedy and steals aWAy, evading the Enemy. Struggles on, starving and dazed. Reaches Port Albany (23rd December, 1848). SeEs the "Ariel" and is taken on Board.

ENNEDY, accompanied by Costigan, Dunn, Luff and Jackey-Jackey, Left the Pascoe Depot on I 3 th November, 1848. On 22nd December, JACKEY-JACKEY, the sole survivor of the party, having been forty days on the journey, arrived at CAPE York and he was taken on board the "Ariel" on the following morning. The "Ariel" sailed the same evening bent on relief, and Dr. Adoniah VAllack, who was on board, committed JACKEY-JACKEY'S DEPOSITION to writing. This deposition is a document of the utmost value, not only because it is almost the only record of Kennedy's last journey, but also because it throws light on the aboriginal mind and its limitations. I have myself on many occasions been under the necessity of eliciting information from aboriginals, and my experience is that a very short course of interrogation is sufficient to confuse and give them brain-fag, which generally ends in sulks, so that it is difficult or impossible to obtain from them a consecutive tale. Jackey-Jackey's "Statement" is a marked instance of this limitation, and it is evident that Dr. Vallack, tactful as he was, gave up the attempt to pin the hero of the tale down to dates. Moreover, the poor fellow was DIs- 
TRACTED, WEAK from wounds and fatigue, and STARVING, and was probably unconscious for a considerable part of the eventful forty days; and thus could not be expected to take note of the divisions of time in such a manner as to satisfy either a Justice of the Peace or an historian.

As the "Statement," for what it is worth, must form the text from which any conclusions whatever regarding the last days of Kennedy's career must be drawn, it is given below in its entirety; but I have added my conjectures as to dates in notes within the text and appended explanatory footnotes.

\title{
STATEMENT OF JACKEY-JACKEY
}

\author{
MADE BY HIM ON BOARD THE “ARIEL," AND WRITTEN \\ DOWN BY DR. VALLACK
}

(SEe MAP B)

I staRted with Mr. Kennedy from Weymouth Bay for Cape York, on the $13^{\text {th }}$ November, 1848, accompanied by Costigan, Dunn, and Luff, leaving eight men at the camp, at Weymouth Bay. We went on till we came to a RIVER $^{1}$ which empties itself into Weymouth Bay. A little further north we crossed the river [ 13 th November]; next morning a lot of Natives camped on the other side of the river. Mr. Kennedy and the rest of us went on a VERY HIGH HILL ${ }^{2}$ and came to a flat on the other side and camped there [ 14 th November]; I went on a good way next day [I5th November]; a HORSE FELL down a creek; the FLOUR we took with us LASTED THREE DAYS; we had much trouble in getting the horse out of the creek; we went on, and came out, and camped [16th November] on the ridges; we had no WATER. Next morning went on and LUFF was taken ILL with a very bad knee; we left him behind, and Dunn went back again and brought him on [17th November]; Luff was riding a horse named Fiddler; then we went on and camped at a little creek $^{3}$ [1 18 th November]; the flour being out this day we commenced EATING HORSEFLESH, which Carron gave us when we left Weymouth Bay; as we went on we came on a small river, ${ }^{4}$ and saw no blacks there; as we proceeded we gathered NONDAs, and lived upon them and the meat; we stopped at a little creek ${ }^{5}$ and it came on raining, and Costigan shoт HIMSELF ${ }^{\circ}$; in putting his saddle under the tarpaulin a string caught the trigger and the ball went in under the right arm and came out at his back under the shoulder; we went on this morning all of us, and stopped at another creek in the evening [19th November], and the next morning ${ }^{7}$ we KILLED A HORSE named Browney, smoked him that night [20th November], and went on next day, taking as much of the horse as we could with us, and went on about a mile and then turned back again to where we killed the horse, because Costigan was very bad and in much pain; we went back again because there was no water; then Mr. Kennedy and I had dinner there and went on in the afternoon [2Ist November], leaving Dunn, Costigan and Luff at the creek. This was at Pudding-Pan Hill,

1 Pascoe River.-R. L. J.

2 A spur of the Carron Range.-R. L. J.

- Glennie Creek.

- MacMillan River, near my Camp 44 of 21 st February, I880.-R. L. J.

- The creek falling into the left bank of the Macmillan opposite my 43 rd Camp.R. I. J.

- A reporter elicited from Jackey-Jackey that " it was on a Sunday morning Costigan shot himself" (Sydney Morning Herald, 6th March, 1849). Jackey-Jackey was not likely to be mistaken on this point, as Kennedy's custom was to differentiate Sunday from week-days. The date would therefore be the 19th, the first Sunday after the departure from Weymouth Bay.

? "Next morning," i.e., the morning after the accident.-R. L. J 
near Shelburne Bay. Mr. Kennedy called it Pudding-Pan Hill. ${ }^{1}$ We left some horse meat with the three men at Pudding-Pan Hill and carried some with us on a pack-horse. Mr. Kennedy wanted to make great haste when he left this place, in order to get the doctor to go down to the men that were ill. This was about three weeks after leaving Weymouth Bay. ${ }^{2}$ ONE HORSE was LEFT with the three men at Pudding-Pan Hill, and we (Kennedy and myself) took with us THREE HORses. ${ }^{3}$ The three men were to remain there until Mr. Kennedy and myself had gone to and returned from Cape York for them. Mr. Kennedy told Luff and Dunn when he left them, if Costigan died they were to come along the beach till they saw the ship, and then to fire a gun; he told them he would not be long away, so it was not likely they would move from there for some time. They stopped to take care of the man that was shot; we (me and Mr. Kennedy) KILLED A HORSE for them before we came away. Having LEFT THESE THREE MEN, we camped that night [21st November] where there was no water ${ }^{4}$; next morning Mr. Kennedy and me went on with the FOUR HORSEs ${ }^{5}$ : two pack-horses and two saddle-horses; ONE HORSE got BOGGED in a swamp. We tried to get him out all day, but could not; we LEFT HIM there, ${ }^{6}$ and camped at another creek ${ }^{7}$ [22nd November]. The next day Mr. Kennedy and I went on again, and passed up a ridge very scrubby and had to turn back again, and went along gulleys to get clear of the creek and scrub. ${ }^{8}$ Now it rained and we camped ${ }^{9}$ [23rd
[ November]; there were plenty of BLAcks here, but we did not see them, but plenty of fresh tracks, and camps, and smoke. ${ }^{10}$ Next morning we went on and camped at

1 It is clear, from subsequent events, that Kennedy was mistaken in his position and believed that he was at the Pudding-Pan Hill of the Charts (named by Bligh) when he was actually 50 miles south of it. As far as appearance goes, any one of the numerous fragmentary Desert Sandstone tablelands might be supposed to bear a fanciful resemblance to an inverted " pudding-pan." All the known circumstances are in favour of Kennedy's so-called Pudding-Pan Hill being west of Cape Grenville. The probability is that it was the "Sandstone Table" sketched by me on 25 th February, 1880, in $\mathrm{I}^{\circ} \mathrm{I}^{\prime} \mathrm{S}$. lat. and $142^{\circ} 34^{\prime} \mathrm{E}$. long. Jackey-Jackey's petulant remark: “ Mr. Kennedy called it Pudding-Pan Hill " was evidently his reply to cross-examination when the spot where the men had been left had become the question of the hour in the minds of the officers of the relief ship.

2 Jackey-Jackey has accounted for only nine days. They probably seemed like three weeks to him, and his arithmetic was defective.

3 Jackey-Jackey breaking down under the strain of prolonged cross-interrogation and his memory and arithmetic hazy. He states on the 2 Ist-no doubt correctlythat he and Kennedy left the so-called Pudding-Pan Hill with two pack-horses and two saddle-horses.

${ }^{4}$ Say near Middle Peak, $\mathrm{II}^{\circ}{ }^{\circ} 6^{\prime} \mathrm{S}$. lat., $\mathrm{r}_{42^{\circ}}{ }^{\circ} 2^{\prime} \mathrm{E}$. long.

5 They left the Pascoe with seven horses. One was killed on rgth November, one live horse and one which was killed for food were left with the party at the so-called Pudding-Pan Hill on 20th. Four were now left to go on with Kennedy.

6 This leaves three horses alive.

7 Say $\mathrm{II}^{\circ} 47^{\prime} \mathrm{S}$. lat. and $\mathrm{I}_{42^{\circ}} 5^{\circ} \mathrm{E}$. long.

- The description of this country, with its bogs and scrub, corresponds with that of the country where my own party were in great difficulties from the same cause (involving starvation for the horses) between Camps 51 and 55, rst-6th March, 1880, and where the Jardine Brothers had experienced similar difficulties between their Camps $7 \mathrm{I}$ and 77 , i th-23rd January, r865. The "ridge very scrubby" may have been the same on which Jardine's $74^{\text {th }}$ and $75^{\text {th }}$ Camps and my 5ist, $54^{\text {th }}$ and $55^{\text {th }}$ were situated.

This camp was probably west of Helby Hill, near Jardine's 77 th and my 5 and Camp. The "gulleys" to which the travellers doubled back " to get clear of the creek and scrub " were probably heads of my "Captain Billy's" and "Camisade" Creeks.

${ }_{10}$ The Herald reporter obtained a significant addition to Jackey-Jackey's story (Sydney Morning Herald, 6th March, 1849): “ Mr. Kennedy once got into a bog, after leaving Pudding-Pan Hill, up to his shoulder, and was 'like a pig in the mud,' Jackey says. He lifted him out. . . After Jackey had taken Mr. Kennedy out of the bog between Shelburne Bay and Escape River, they SPELLED FOR SEVERAL DAYS, he was so ill, and Jackey says he carried him often on his back-not far; only half a mile at a time. . Sometimes Jackey carried Mr. Kennedy from place to place when he was ill, out of the way of the blacks, and, as he terms it, "planted "him." It may be conjectured that this "spell" of several days took place at the camp of 23 rd November. We may suppose that perhaps for three days (24th, 25th and 26th) Jackey-Jackey was busy collecting food, evading the blacks, and from time to time carrying his enfeebled master to new hiding-places. 
another creek ${ }^{1}$ [ $27 t b$ November], and on the following morning we continued going on, and camped in the evening close to a scrub ${ }^{2}[28$ th November]; it rained in the night. Next day we went on in the scrub, but could Not Get Through. I cut and cleared away, and it was near sundown before we got through the scrub-there we camped [29th November]. [SEE MAP A.] It was heavy RAIN next morning, and we went on in the rain; then I changed horses and rode a black colt, to spell the other, and rode him all day, and in the afternoon we got on clear ground, and the HORSE FELL down, me and all; the horse lay upon my right hip. Here Mr. Kennedy got off his horse and moved my horse from my thigh; we stopped there that night [30th November], and could not get the horse up; we looked to him in the morning and he was DEAD $;^{3}$ we left him there. We had some horse meat left to eat, and went on that day and crossed a LITTLE RIVER and camped ${ }^{4}$ [Ist December]. The next day we went a good way; Mr. Kennedy told me to go up a tree to see a sandy hill somewhere; I went up a tree, and saw a sandy hill a little way down from Port Albany. That day we camped near a swamp ${ }^{5}$ [2nd December]; it was a very rainy day. The next morning we went on, and Mr. Kennedy told me we should get round to Port Albany in a day; we travelled on all day till twelve o'clock (noon), and then we saw Port Albany; then he said: "There is Port Albany, Jackey-a ship is there-you see that island there," pointing to Albany Island; this was when we were at the mouth of Escape River. ${ }^{-~ W e ~ s t o p p e d ~ t h e r e ~ a ~ l i t t l e ~ w h i l e ; ~ a l l ~ t h e ~ M E a t ~ w a s ~ G O N E ; ~ I ~ t r i e d ~ t o ~ g e t ~ s o m e ~}$ fish, but could not; we went on in the afternoon half a mile ALONG THE RIVER-SIDE, ? and met a good lot of BLACKs, and we camped [3rd December]; the blacks all cried out "Powad powad," and rubbed their bellies; and we thought they were friendly, and Mr. Kennedy gave them fish-hooks all round; everyone asked me if I had anything to give away, and I said "No," and Mr. Kennedy said, "Give them your knife, Jackey" ; this fellow on board was the man I gave the knife to; I am sure of it ; I know him well; the black that was shot in the canoe was the most active in urging all the others on to spear Mr. Kennedy; I GAvE THE MAN ON BOARD MY KNIFE ${ }^{8}$; we went on this day, ${ }^{\circ}$ and I looked behind, and they were getting up their spears, and ran all round the camp which we had left; I told Mr. Kennedy that very likely those black fellows would follow us, and he said, "No, Jackey, those blacks are very friendly" ; I said to him, "I know these black fellows well, they too much speak"; we went on some 2 or 3 miles and camped [ 4 th December]; I and Mr. Kennedy watched them that night, taking it in turns every hour all night; by-and-by I saw the black fellows; it was a MOONLIGHT NIGHT; and I walked up to Mr. Kennedy and said to him, "There is plenty of black fellows now"; this was in the middle of the night ; Mr. Kennedy told me to get my gun ready; the blacks did not know where we slept, as we did not make a fire; we both sat up all night; after this, daylight came [5th December], and I fetched the horses and saddled them; then we went on a good way up the river, and then we sat down a little while, and we saw three BLACK FELLows coming along our track, and they saw us, and one fellow ran back as hard as he could run, and fetched up plenty more, like a flock of sheep almost ; I told Mr. Kennedy to put the saddles on the Two HORses and go on, and the blacks came up, and they FOLLOWED US ALL THE DAY; all along it was raining, and I now told him to leave the horses and come on without them, that the horses made too much track.

1 Possibly on the Jardine River, west of False Orford Ness.

2 Say west of Orford Ness, having passed the real Pudding-Pan Hill.

3 This leaves only two horses.

4 Probably Henderson Creek, from the right bank to the left.

- A mangrove swamp near the mouth of Henderson Creek.

- The Escape River was named by Captain King, R.N., on 24th July, 1819. See Narrative of a Survey of the Tropical and Western Coasts of Australia, I818-1822. Murray, 1827.

7 Kennedy came to the mouth of the Escape River and ran up the right bank because he could not cross, precisely as I did on I8th and I9th March, I 880 .

8 The question of the identity of this man was discussed later on, during the voyage of the "Ariel."

"Jackey-Jackey evidently meant " next day," $4_{\text {th }}$ December. 
Mr. Kennedy was too weak, and would not leave the horses. We went on this day till towards evening [5th December]; raining hard, and the blacks followed us all the day, some behind, some planted before; in fact, BLACKS ALL-AROUND following us. Now we went on into a little bit of a scrub, and I told Mr. Kennedy to look behind always; sometimes he would do so, and sometimes he would not look behind to look out for the blacks. Then a good many black fellows came behind in the scrub, and threw plenty of spears, and hIT Mr. KenNEDy in the back first. Mr. Kennedy said to me, "Oh! Jackey-Jackey! shoot 'em, shoot 'em." Then I pulled out my gun and fired, and hit one fellow all over the face with buck shot; he tumbled down, and got up again and again, and wheeled right round, and two black fellows picked him up and carried him away. They went away then a little way, and came back again, THROWING SPEARS all around, more than they did before; very large spears. I pulled out the spear at once from Mr. Kennedy's back, and cut out the jag with Mr. Kennedy's knife; then Mr. Kennedy got his gun and snapped, but the gun would not go off. The blacks sneaked all along by the trees, and speared Mr. Kennedy again in the right leg, above the knee a little, and I GOT SPEARED over the eye, and the blacks were now throwing their spears all ways, never giving over, and shortly again speared Mr. Kennedy in the right side; there were large jags to the spears, and I cut them out and put them into my pocket. At the same time we got speared, the HORSES GOT SPEARED too; and jumped and bucked all about, and got into the swamp. I now told Mr. Kennedy to sit down, while I looked after the saddle-bags, which I did; and when I came back again, I saw blacks along with Mr. Kennedy; I then asked him if he saw the blacks with him; he was STUPID WITH THE SPEAR wOUNDS, and said "No"; then I asked where was his watch. I saw the blacks taking away watch and hat as I was returning to Mr. Kennedy; then I carried Mr. Kennedy into the scrub ; he said, "Don't carry me a good way"; then Mr. Kennedy looked this way, very bad (Jackey rolling his eyes). I said to him, "Don't look far away," as I thought he would be frightened ; I asked him often, "Are you well now," and he said, "I don't care for the spear wound in my leg, Jackey, but for the other two spear wounds in my side and back," and said, "I am bad inside, Jackey." I told him black fellow always die when he got spear in there (the back); he said, "I am out of wind, Jackey"; and I asked him, "Mr. Kennedy, are you going to leave me ?" and he said, "Yes, my boy, I am going to leave you"; he said, "I am very bad, Jackey; you TAKE THE BOоKs, Jackey, to the Captain, BUT NOT THE BIG onEs, ${ }^{1}$ the Governor will give anything for them." I then tied up the papers; he then said, "Jackey, give me paper and I will write"; I gave him paper and pencil and he tried to write, and he then fell back and died ${ }^{2}$ [ 5 th December, dusk]; and I caught him as he fell back and held him, and I then turned round myself and cried; I was crying a good while until I got well ; that was about an hour, and then I BURIED HIM ; I digged up the ground with a tomahawk, and covered him over with logs, then grass, and my shirt and trousers.

That night I left him near dark; I would go through the scrub, and the BLAcks THREW SPEARS at me, a good many, and I went back again into the scrub; then I went down the creek which runs into Escape River, and I walked along the water in the creek very easy, with my head only above water, to avoid the blacks, and get out of their way; in this way I went half a mile; then I got out of the creek, and got clear of them, and walked on all night nearly, and slept in the bush without a fire; I went on next morning and felt very bad, and I spelled for two days [6tb and 7 th December]; I lived upon nothing but salt water; next day I went on and camped I mile away from where I left [8th December, camp], and ate one of the pandanus fruits;

1 There were two or more books, larger than the others, to which Kennedy attached great importance even in his dying moments. It may be taken for certain that they were the diary of the whole trip from Rockingham Bay. It is impossible to conjecture the nature of the smaller books.

2 The deplorable events of this day, culminating in Kennedy's death, took place on the right bank of the Escape River, the ground which I covered on Igth March, I880, between Camps 62 and 63 . 
next morning I went on 2 miles, and sat down there, and I wanted to spell a little there, and go on; but when I tried to get up, I could not, but fell down again very tired and cramped, and I spelled here two days [camp]; then I went on again I mile, and got nothing to eat but one nonda [camp]; and I went on that day ${ }^{1}$ and camped [camp], and on again next morning, about half a mile, and sat down where there was good water, and remained all day [camp]. On the following morning, I went a good way, went round a great swamp and mangroves, and got a good way by sundown [camp]; the next morning I went and saw a very large track of black fellows ; I went clear of the track and of swamp or sandy ground; then I came to a VERY LARGE RIVER ${ }^{2}$; and a large lagoon; plenty of ALLIGATORS in the lagoon, about 10 miles from Port Albany. I now got into the ridges by sundown, and went up a tree and saw Albany Island [camp]; then next morning at four o'clock 3 I went on as hard as I could go all the way down, over fine clear ground, fine ironbark timber, and plenty of good grass; I went on round the point (this was towards Cape York north of Albany Island) and went on and FOLLOWED A CREEK DOwn, and went on top of the hill, and SAW CAPE YORK ; and I knew it was Cape York, because the sand did not go on further ; I sat down then a good while; I said to myself, "This is Port Albany, I believe inside somewhere"; Mr. Kennedy also told me that the ship was inside, close up to the mainland; I went on a little way, and SAW THE SHIP and boat; I met close up here two black gins and a good many piccaninnies; one said to me "Powad, powad " ; then I asked her for eggs; she gave me turtle's eggs, and I gave her a burning-glass; she pointed to the ship which I had seen before; I was very frightened of seeing the black men all along here, and when I was on the rock cooeying, and murry murry glad when the boat came for me [8 a.m., 23 rd December, 1848].

1 Next day.

2 The head of Kennedy Inlet, now called Jackey-Jackey Creek. Here JackeyJackey secreted the papers and books entrusted to him by Kennedy on ist December. They were recovered in a very damaged condition, by the Chief Officer of the "Freak," whom Jackey-Jackey led to the spot on II th May, I849.

${ }_{3}$ This must have been 23 rd December, although by the most liberal reckoning of the Camps mentioned by Jackey-Jackey it would only be the 15th. Eight days are thus unaccounted for. Hungry, thirsty and utterly exhausted as the narrator of the tale was, as is evident from his creeping on at the rate of a mile or half a mile in a day, his periods of sleep and insensibility were, no doubt, longer than he knew, and as he scarcely knew, at times, what he was doing, his memory was not to be relied on-at least since his and Kennedy's arrival at the Escape River.

4 Peace. 


\title{
CHAPTER XXXIV
}

\section{KENNEDY'S EXPEDITION, I848, continued}

\author{
VOYAGE OF THE “ARIEL"
}

\section{TRACES OF KENNEDY AND THE “ PUDDING-PAN HILL ” PARTY}

Captain Dobson takes "Ariel" in search of Survivors of Expedition, 24Th December, I848. Jackey-Jackey on Board. Dr. Vallack elicits Story of Forlorn Hope from Jackey-Jackey. Natives in Canoe near Gilmore Bank. ONe boards "Ariel," is ReCOgnised by JaCKey-Jackey as ONE of Kennedy's Murderers, and is detained. One of the Blacks spears Barrett and is shot. Evidence that Kennedy's Body had been exhumed. Voyage Southward resumed. Bligh's Pudding-Pan Hill passed. Hannibal Bay. Camisade Creek. Shelburne Bay. Jackey-Jackey recognises Kennedy's "Pudding-Pan Hill." Landings. Canoe found containing Part of a Cloak belonging to the Three Men left at Supposed Pudding-Pan Hill. Unable to reach this Hill. Must push on for Pascoe Camp. "Ariel " reaches Mouth of Pascoe. Carron and Goddard rescued and taken on BOARD.

7 HE Schooner "Ariel" (72 tons), ${ }^{1}$ under the command of Captain Dobson, having on board Dr. Adoniah Vallack and BARRETT, who were to join Kennedy's party, was chartered by the Government of New South Wales to await Kennedy's arrival and supply him with provisions for the return journey. The ship left Sydney on 2nd October, I848, and reached Port Albany on the $27 t h$ of the same month. Although the period for which she had been chartered had expired, she was still waiting when JACKEY-JACKEY ARRIVED on 23 rd December with the news of the fate of the expedition.

The story of the rescue of the survivors is contained in (I) a Statement by Captain Dobson, printed with Carron's Narrative but not reprinted in the Voyage of the "Rattlesnake," (2) a STATEMENT BY DR. VALLACK, printed with Carron's Narrative and reprinted in the "Rattlesnake," (3) a few Notes By Dr. John MacGillivray in the Voyage of the "Rattlesnake." Captain Dobson's Statement is short and bald and he evidently delegated to Dr. Vallack the task of writing the history of his voyage.

JACKEY-JACKEY was seen from the ship about 8 a.m. on

1 Number of hands not stated. One of the crew was named Parker and another is referred to by Dr. Vallack as "Thomas" and "Tom," but it is not clear whether this was a christian name or a surname. 
23rd December, "first standing, then walking very lame, then sitting down on a rock." When taken on board he became faint and had to be revived with wine. He carried the mark of a spear wound on his forehead. (SEE MAP A.)

The "Ariel," after losing the remainder of the day in an attempt to increase the supply of beef, got away on $24 t h$ December. Dr. VALLACK spent that day in eliciting the information already given in JACKeY-JACKeY's "STATEMENT." The deponent could not be kept too long under the strain of examination and Dr. Vallack humoured him "by changing the subject now and then by speaking of his comrades at Jerry's Plains." The anchorage for the night was 5 miles south of Shadwell Point, opposite the mouth of HENDERSON CREEK.

A dead calm the following morning (25th December) made it useless to weigh anchor till about 10 o'clock, when a light breeze sprang up. Shortly afterwards, a CANOE was met with-probably about 2 miles north of the Gilmore Bank-and the native crew were interrogated. One native was allowed to come on board, and Jackey-Jackey, who had been stationed in the foretop, recognised the NATIVES as those WHO HAD SPEARED KENNEDY, the one who had come on board being the one to whom Jackey-Jackey had given his knife at Kennedy's request. The native was therefore forcibly detained, and it was observed that his arm was decorated with part of a bridle and a piece of a tendon of a horse round his arm. The other blacks in the meantime had jumped into the sea and the long-boat was put out to examine the deserted canoe for other relics. Observing the boat, the natives re-entered the canoe and paddled for the shore. The boat, however, overtook the canoe, when all the blacks again sprang overboard, with the exception of one, who SPEARED BARRETT in the arm, and was himself shot. The boat returned to the ship towing the canoe, in which lay the dying native. A portion of a spear, an inch in length, was extracted by Dr. Vallack from Barrett's arm on I3th February.

There were found in the canoe "the leg part of a pair of trousers, three spears, a piece of iron of a saddle, hooks and lines, etc.," and a piece of moleskin was taken off the captive native's leg and identified by Jackey-Jackey as part of his own trousers which he had tied round KENNEDY's head before burying the body. Jackey concluded, and, no doubt, correctly, that the BoDY had been eXhumed. (See Map B.)

With a favouring and refreshing breeze the ship resumed her course, and shortly afterwards Jackey-Jackey pointed out from the foretop, a Hill which he said was like Pudding-Pan Hill. This was the real "PUdDing-PAN Hill " of the chart, but the absence of certain surroundings which Jackey-Jackey had noted soon convinced him that it was NOT THE HILL TO WHICH KENNEDY HAD erroneously GIVEN THAT NAME. On his vehement insistence, the 
"Ariel" kept on its course to the south and anchored at nightfall " in the centre of Hannibal Bay, Risk Point ahead."

There is no Hannibal Bay in the chart from which I made my travelling "blank" in 1869 , nor in that of 1894 , but the double bay extending north from the latitude of the Hannibal Islands to False Orford Ness was so named in the older charts which, presumably, were carried by Kennedy and Captain Dobson in 1848 . Risk Point, although not named in the chart which I used in 1879, nor in later issues, must have appeared in the charts carried by Kennedy and Captain Dobson in 1848, and is located from bearings taken by Captain Simpson as $11^{\circ} 35^{\prime} 30^{\prime \prime} \mathrm{S}$. The probability is that the anchorage of $25 \mathrm{th}$ December was off the mouth of CAMISADE CREEK, where, thirty-one years later, the blacks attacked my own party.

While approaching the anchorage in the afternoon of 25 th December, Dr. Vallack saw about forty natives on the shore.

On 26th December, the "Ariel" struck a reef within a few minutes of weighing anchor, but got off without damage. She ANCHORED in the afternoon in SHELBURNe BAY in sight of a HILL which Jackey-Jackey identified by surrounding landmarks as the locality where Costigan, Dunn and LufF had BEen LEFT on 2oth November (Costigan having been mortally wounded by an accidental gunshot) and which Kennedy erroneously supposed to be the "Pudding-Pan Hill" of the chart. Captain Dobson saw two NATIVEs on the shore WEARING what he took to be either CLOAKS OR BLUE SHIRTS.

It is unfortunate, considering how important it was to locate the last resting-place of Costigan, Dunn and Luff, that Captain Dobson did not record the latitude of his landing, which he might easily have done from the chart in the absence of an observation.

At daybreak of $27 t h$ December a party consisting of CAPTAIN Dobson, Dr. Vallack, Barrett, a sailor named Tom and JaCKeyJACKey landed on the coast, the last named acting as guide. From a careful consideration of every expression made use of by Dr. Vallack, the probability is that the boat, which was left in charge of two of the "hands," touched first at Double Point. A CANoe was found here, containing part of a cloak which Jackey-Jackey said belonged to the men left behind on the 2oth November. The party then "trudged through dense scrub inland for about an hour." Considering the density of the scrub, that Barrett had a spear wound, and that Jackey-Jackey had by no means recovered his "condition," probably not more than 2 miles were covered. The direction of the march is not stated, although " inland" may be taken to be south-west, or at right angles to the coast-line. Jackey-Jackey then declared that they were not going far enough south and might as well get away in that direction from a new point of departure on the coast which would be easier to reach by 
the boat. Returning to the boat, it was decided, before again going inland, to visit a point, probably "White Point," about 4 miles distant, and at " the southernmost part of the bay," where fires had been seen in the morning, as well as on the previous night. No camp, however, was seen, but only the remains of a bush fire. Jackey-Jackey then pointed out a place, about three miles distant and "more in the central part of the bay," as the spot where the next landing should be made. Jackey-Jackey, who was weak and lame and had to rest from time to time, led the party westward for a distance estimated at 6 miles, but which was probably less. $\mathrm{He}$ then climbed a tree, from which he reported that he could see Kennedy's supposed " Pudding-Pan Hill," but it was still a long way off, and as the party had left early in the morning without food, under the impression that only a short walk was before them, they went back to the boat and rejoined the ship. The men waiting in the boat reported having seen from 50 to IOO NATIves on the beach.

Concluding, as there was every reason to do, that Costigan, Dunn and Luff must have long ago been dead; and seeing that Jackey-Jackey had collapsed and was no longer capable of acting as a guide through the bush; and, above all, mindful of their duty to the men still possibly alive at the Pascoe Camp, it was resolved to spend no more time in investigating the circumstances attending the death of the "Pudding-Pan Hill" party.

The "Ariel" accordingly left Shelburne Bay next morning, 28th December, dropping her anchor at night between the " $\mathrm{M}$ ", ReeF and Young Island.

On the 29th, the anchor was dropped at the mouth of the Pascoe River in Weymouth Bay, and on the following day the last SURVIVORS OF KENNEDY'S EXPEDITION found rest and succour on board the "Ariel." 


\title{
CHAPTER XXXV
}

\section{KENNEDY'S EXPEDITION, I848, continued}

\author{
VOYAGE OF THE "FREAK"
}

\section{SEARCH FOR RELICS OF KENNEDY AND THE “PUDDING-PAN} HILL" PARTY

Position of Costigan, Dunn and Luff's Camp. "Freak's" Boat Coasting Shelburne Bay Northward. Landing. Canoe found, containing Holster recognised by Jackey-Jackey. Boat rejoins "Freak" near Orford Ness. Ship "Coquette" overtaken. Boat Party land 2 Miles up Escape River. Scenes of Kennedy's Death and Burial searched. Convincing Relics found. Whale-boat Party led by Jackey-Jackey to Place where he had hidden Kennedy's Papers. Charts and Notebooks found, but apparently almost destroyed. Larger Notebooks, Which PRobably CONTAINed KenNedy's Diary, Not Found.

\section{THE " FREAK"}

B EFORE relating the story of the rescue of the two survivors of the Pascoe Camp, the last efforts made to discover traces of Costigan, Dunn and Luff, and of Kennedy himself, have to be recorded.

The brig "Freak," Captain T. Beckford Simpson, Chief Officer, Macnate, was chartered by the Government of New South Wales " to call (on her way to Port Essington) at Shelburne Bay and Escape River, to ascertain-if possible - the fate of the three men left at the former place, and recover the papers of Mr. Kennedy secreted by Jackey-Jackey." JACKEY-JACKEY was on board, together with two other natives of his own tribe. Captain Simpson's Private Log of the voyage, which appeared in Carron's book, and was reprinted in the Voyage of the "Rattlesnake," gives the only available account of what was done.

In the afternoon of $4^{\text {th }}$ May, 1849, the "Freak" anchored near Round Point, the eastern horn of Shelburne Bay. (See Map B.) The importance of the exact position of the anchorage was fully realised by the Captain, who took careful bearings from three distinct landmarks which were then, and are now, laid down on the chart.

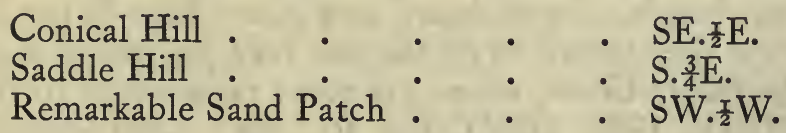

Unfortunately these bearings, when plotted on the chart, FIX No POSITION; the inference being that the landmarks had only 
been sketched from a surveying vessel, and were therefore valueless for Captain Simpson's purpose. Had he contented himself with giving the bearing of Round Point and marking the approximate latitude and longitude, as taken from the chart, the position of the anchorage and of what Jackey-Jackey pointed out as KENNEDY's SUPPOSED "PUDdING-PAN HiLL" would have been tolerably certain. From the anchorage the bearing of that hill is given as W. $\frac{x}{4} \mathrm{~N}$. Whether we assume the anchorage to have been "in 6 fathoms water" (as stated) on the bearings given from Conical Hill, or on those given from Saddle Hill, W. $\frac{1}{4}$. would place the supposed Pudding-Pan Hill NorTh of where the "Ariel's" boat party first landed on 27 th December, I 848 ; and where that party tried, guided by Jackey-Jackey, to get away soutH. The presumption is that, seen from a point of view new to him, Jackey-Jackey pointed out the Wrong HILL to Captain Simpson. For a mistake of this kind, Jackey-Jackey might very well be excused, as my own travels showed the neighbourhood to be full of little detached sandstone tablelands, any one of which might be fancifully likened to an inverted pudding-pan. The balance of probability is in favour of Costigan, DUNN and LUfF's LAST CAMP and KeNNEDY's supposed "Pudding-PAN Hill" being in the positions I have assigned to them.

From daylight to 8 p.m. on the following day ( 5 th May), the whale-boat of the "Freak," manned by the Second Officer, four seamen, Jackey-Jackey and his two aboriginal companions, skirted the coast of Shelburne Bay and the Pacific from Round Point to a point nearly opposite Helby Hill, landing at three places, as detailed in the Officer's short report :-

"I kept close along the beach all day, LANDED three times; first near the Creek where the 'Ariel's' boat [first] landed. Saw no indications there of Europeans. I landed again some distance further on, where I saw a NATIvE CAMP and a CANOE. In the latter I found a leathern pistol-holster, marked 34, which Jackey recognised as belonging to the party. Three Natives were seen by Jackey, who, on perceiving the boat, ran into the bush. At the third place I landed I saw no indication of men. I was close to the beach all along, and occasionally fired a musket."

The holster found in the canoe could only have been one belonging to the unfortunate Costigan, Dunn and LufF Party, but whether they died a natural death or were killed by the natives can never be known.

The "Freak" was anchored about a mile from the shore, at a place from which the Hannibal IsLANDs bore SE. by E. $\frac{1}{2} E$., when she took the boat's crew on board at 8 p.m. Risk Point lay S. $\mathrm{z} E$. Risk Point is thus shown to be the not very prominent cape north of Captain Billy's Creek, where my party came down to the beach on 9th March, I880, near Camp 56. As related elsewhere, we travelled that day northward along the beach to Camp 57, where the natives gave us a camisade. 
While waiting for the boat, the men on the "Freak" saw a CANOE and five NATives on the beach. Early next morning ( $6 \mathrm{th}$ May), the boat, manned as before, started to continue the exploraation of the beach northward, LANDING first where the canoe and natives had been seen. In the evening, the boat was picked up at Tern Island, near the mouth of the Escape River, having covered 48 miles, and the Officer reported :-

"I ran along close to the shore all day. I LANDED a little to the southward of OrFord Ness.1 We met about thirty NATIVEs on the beach, who came up to us without hesitation, and appeared very friendly; they shook hands with all of us, and brought us water. Jackey at first thought he recognised the native who escaped from the 'Ariel' among them; he got a little excited and wanted to shoot him; when he approached nearer he was satisfied he was not the same individual. ${ }^{2}$ At another place where I landed I found part of the lower mast of a vessel about 400 tons, and pieces of WRECK ; saw no natives or indication of them on the beach."

Next day (7th May) Captain Simpson boarded the schooner "Coquette," which was lying at anchor. The "Coquette," Captain ELLiotT, we learn from the Voyage of the "Rattlesnake," had been sent from Sydney to AWAIT the arrival of KENNEDY's ExPEDITION at Port Albany, the period for which the "Ariel" had been chartered for that purpose having expired. She was, when the "Freak" came up with her, trying to recover four anchors lost shortly before by the ship " Lord Auckland," from Hobarton, when the latter was aground on " $X$ " Reef. Captain Elliott had heard from the "Sea Nymph," from Hobart Town, of the fate of Kennedy's expedition and was about to sail for Sydney. He had seen a NATIVE at Port Albany who had, apparently, been wounded in the FACE WITH LARGE SHOT, and as he exactly answered the description given by Jackey, there is little room for doubt that he was the individual mentioned in the Statement of the latter as having been wounded with buck-shot on Ist December, I848.

Captain Elliott lent two men and himself joined Captain Simpson's boating party which set out next morning (8th May) at daylight. With this reinforcement, two boats were manned, " thus making a most formidable party," says Captain Simpson.

At the mouth of the Escape RIVER, the little bay west of Sharp Peak was pointed out by Jackey-Jackey as the place where KENNEDY and he first met hostile natives. (See Map A.) The party landed about 12 miles up the inlet at the first place where the left bank

1 Near the REAL "PuDDING-PAN Hill," not the hill so named by Kennedy.

2 The NATIVE in question was reported missing while the "Aviel" was at anchor on the night of $\mathrm{x}$ th January between Cape Bedford and Turtle Reef, near Cooktown. The night was dark and stormy and sharks were seen in the morning. It is doubtful whether the native ever reached land, and if he did there were about 400 miles to walk to Orford Ness, through hostile tribes. Even supposing him to have escaped death at sea he could hardly have covered the distance on foot in four months, delayed, as he must have been, by the necessity for procuring food daily.-R. L. J.

3 His right, as the Captain reckoned. 
was free of mangroves. This, Jackey-Jackey said, was WHERE HE ADVISED KENNEDY on the day when he was killed TO LEAVE THE HORSES, and swim the river, here about 30 yards wide. Jackey pointed out the tree where he TIED THE HORSES while they searched unsuccessfully for oysters, having had NOTHING TO EAT that day.

Three or four miles further up the stream, which had narrowed considerably and was overhung with mangroves, the fresh water was reached and a LANDING was made at a clear spot on the left or western bank. Near this was " an extensive PLAIN, with numerous large ant-hills on it, which JACKEY knew as the place he had CROSSED the day Mr. Kennedy was killed."

"We walked," says Captain Simpson, " some distance across a swamp, still following the course of the creek. We traced the creek for nearly a mile, looking out for a crossingplace, when JACKEY pointed out on the other side the place where he had SECRETED THE SADDLE-BAGS. At length we came to a tree which had fallen and formed a kind of bridge, over which we passed with difficulty, and returned to the place where Jackey said the saddle-bags were planted. Jackey then showed us the place where 'horse tumble down creek' after being speared. Some horse-dung was found on the top of the bank close to this place, which confirmed Jackey's statement. He then took us a few yards into the scrub to look for the saddle-bags, and told us to look about for a broken twig growing over a thick bush. The place was found, but THE SADDLE-BAGs WERE GONE. On searching under the bush among the leaves, the horizon glass of a sextant was found-a strong proof that Jackey had hit upon the right place.

" Jackey then took us through a dense scrub for some distance, when we came on open swampy ground about half a mile wide. On the opposite side there was more scrub, close to which there were three large ant-hills. Jackey took us up to the centre one, five yards from which poor KENNEDY FELL. Against this ant-hill Jackey placed him when he went after the saddle-bags. Jackey told us to look about for broken SPEARS; some pieces were found. He then took us to a place about sixty yards from the ant-hill, wHERE HE PUT Mr. KENNEDY, who then told him not to carry him far. About a quarter of a mile from this place, towards the creek, Jackey pointed out a clear space of ground, near an angle of a very small running stream of fresh water, close to three young pandanus trees, as the place where the unfortunate gentleman DIED. Jackey had taken him here to wash his wounds and stop the blood. It was here, when poor Kennedy found he was dying, that he gave Jackey instructions about the PAPERs, when Jackey said, 'Why do you talk so: You are not going to leave me ?'

"JACKEY then led the way to a dense tree-tea scrub, distant about three or four hundred yards, where he had CARRIED THE BODY AND BURIED IT. When we came to the edge of the scrub, Jackey was at a loss where to enter, as he said when he was carrying the corpse he did not look behind-all the objects in front being nearly alike he did not get a good mark. Into the midst of the scrub we went, divided ourselves and searched in every direction, but cOULD NOT FIND THE PLACE. Jackey had not made the spot too conspicuous; fearing the blacks might find it, he had only bent down two twigs across each other. The scrub was not very extensive but exceedingly thick. I placed the party (eleven in number) five yards asunder and traversed it this way in all directions, but without success. I then took Jackey to the plain where the poor gentleman died, and told him to go towards the scrub in the same manner he did when he was carrying the corpse, and not to look back, which he did, telling me the manner in which he carried it and where he shifted it from one shoulder to another. In this manner he entered the scrub, and I have no doubt he took us very near the exact place where the body was buried. We sounded the ground all round with our ramrods, but without success. After taking another good look we reluctantly gave up the search, as the night was rapidly approaching, and returned to the boats." 
Near the scrub where Kennedy was buried, the party searched for, and found, a prismatic compass which Jackey-Jackey told them he had left there. In another place he had left a sextant, which was not found. The trough of an ARTIFICIAL HORIzON and a bottle of QUICKSILVER were, however, found near the spot where the sextant had been left.

Captain Simpson was of opinion that Kennedy's body had not been exhumed and that the small mound must have been levelled by rains. As for Jackey-Jackey's idea that the moleskin rag found in the canoe (see Dr. Vallack's Statement, 25th December, 1848) was the one he had bound round Kennedy's head, he admitted that the saddle-bags which the natives certainly carried away, contained trousers exactly similar to those from which he tore the rag.

"Jackey-Jackey," adds Captain Simpson, "was very quiet, but felt, and felt deeply, during the day. When pointing out the spot where Mr. Kennedy died, I saw tears in his eyes, and no one could be more indefatigable in searching for the remains. His feelings against the natives were bitter, and had any of them made their appearance at the time, I could hardly have prevented him from shooting them."

The party regained the boat, got clear of the intricate navigation of the inlet before dark and CAMPED on the beach near PoINT ShadWell at II p.m.

At daybreak on $9 t b M a y$, they rowed to the beach of the inlet west of Sharp Point, where some natives had been seen launching a canoe the previous morning. They found only a CANOE and a CAMP which the natives had abandoned. One of Jackey's aboriginal comrades got a glimpse of a native disappearing into the bush. In the camp was a small piece of red cLOTH identified by Jackey as part of Kennedy's cloak, and a piece of painted canvas. The canoe was destroyed.

The BOATS REJOINED THE SHIP at Io a.m. At half-past twelve, the "Freak" and "Coquette" LEFT THE Escape River, to anchor at night on the north side of Albany IsLand.

On II $t h$ May, Jackey-Jackey and his two aboriginal companions were taken in the whaleboat by Mr. Macnate, Chief Officer of the "Freak," up KENNEDY INLET for an estimated distance of I I miles and landed at a point where the channel had narrowed to 40 feet. From this spot, Jackey-Jackey led across country for about 2 miles straight to the place where he had secreted the PAPERS entrusted to him by Kennedy on 5 th December, 1848 . The papers had been taken out of the hollow log in which they had been hidden, and had been saturated with water and much damaged. They consisted of a ROLL OF CHARTS and sOme MEMORANDUM BOOKs, including one in which Jackey-Jackey had drawn sketches. ${ }^{1}$

1 Captain Simpson, on 15 th May, I849, wrote a letter to Captain Owen Stanley, R.N., Commander of H.M.S. "Rattlesnake," which was communicated by the latter to the 
A PAIR OF COMPASSES which Jackey-Jackey expected to find was missing. The blacks probably carried away the compasses, which would make excellent barbs for spears, and left the papers, for which they had no use. Captain Simpson observed in his report that he feared the papers were " nearly destroyed," but thought the charts might be deciphered, with care. This was, apparently, never done, though the charts were carefully packed and sent to Sydney.

It is evident that the memorandum books and time book referred to in the letter quoted in the footnote were distinct from the " big ones," to which Kennedy attached supreme importance, and which probably contained his full journal.

WHERE ARE THE CHARTS AND BOOKS? Unless they can be recovered, we now know all that can ever be known of the gallant but unfortunate Kennedy.

Secretary of the Royal Geographical Society, and read at a meeting of the Society on

27 th January, 1851 :place found where Jackey had concealed the SMALL PAPERS in a hollow log, but a rat or some animal had pulled them out where they had been exposed to the weather, and were quite saturated with water. They consisted of a ROLL OF CHARTS, ON WHicH HIS TRACK WAS LAID DOWN ; these, with care, may possibly be deciphered: I am sure if you had them you could do it. There were some MEMORANDUM BOOKs, much defaced, and also a TIME воOK. I have sent everything carefully packed, to Sydney." It is evident that Captain Simpson was of opinion that the roll of charts on which Kennedy's route was laid down was, though damaged, not incapable of being deciphered if placed in competent hands. 


\section{CHAPTER XXXVI}

\section{KENNEDY'S EXPEDITION, I848, continued}

\section{CARRON'S PARTY AT THE PASCOE RIVER}

Departure of Kennedy's Forlorn Hope, i3th November, 1848. The Eight Men left behind. Harrowing Sufferings from Starvation and Sickness and the Hostility of the Natives. Dying one after another. The "Bramble" seen going South. Frantic Attempts to attract her Attention. She sails on (2nd December). Last Hope gone with her. Despatr. Treachery and Mockery of Natives. Threatened Attack in Overwhelming Numbers. All the Party dead but Two. Rescue by Captain Dobson and the "Ariel's" CRew, led by Jackey-Jackey (30th December), at the Moment when an Attack by the Natives was about to begin. Carron and Goddard, the only Survivors, Wasted to Skeletons, helped to the "Ariel." Carron's Journal since Kennedy's Departure and an Abstract of Carron's Journal from Rockingham Bay to the Pascoe the Only Records saved. "Ariel's" Arrival at Sydney, 5Th March, 1849. Carron's Last Two Camps visited by "Freak's" Officers, 3Rd May, 1849. Remains of Wall and Niblet found, and buried in Albany Island. Character of Kennedy. Pious, Amiable, Capable and Persistent. Jackey-Jackey's Heroism, Devotion to Kennedy and Mastery in Bushcraft. Official Investigation in Sydney. Carron writes a Narrative expanded from the Abstract of his Diary. Memorial Tablet in St. James' Church, Sydney. Carron's Death in 1876.

\section{(See MaP B.)}

T $\mathrm{T}$ now becomes necessary to resume the consideration of Carron's Narrative, for his account of the party left under his charge on the I 3 th November, I848, when Kennedy set out on his ill-fated journey to Cape York to obtain relief.

The party camped near the mouth of the Pascoe consisted of eight individuals, viz., CARron, Wall, Niblet, TAYlor, Carpenter, Goddard, Mitchell and Douglas. They had been told by Kennedy that in the most favourable circumstances they might expect relief in fourteen days, but were instructed to make their provisions last for six weeks. These Provisions consisted of $28 \mathrm{lb}$. of flour, $\frac{\mathrm{r}}{2} \mathrm{lb}$. of tea, and two horses, which were to be killed for food as required.

The men left behind were, as may well be believed, weak and weary, and settled down in their last camp with " a sort of sluggish indifference" and without the stimulus of hope.

One horse was killed on the I4th and the other on the 27 th November, and the last of the FLOUR was FINISHED on the $4^{\text {th }}$ 
December, and what little horseflesh remained was almost unfit to eat. A midday shade temperature of $110^{\circ} \mathrm{F}$. prevailed. The RAINS set in on the 27 th and continued for three days, and the heat and humidity, together with the absence of salt, made it difficult to preserve the meat, some of which was eaten in a putrid condition. The men were now face to face with starvation, twenty-one days after they had settled in camp. The flour had been consumed at the rate of less than a quarter of a pound per man per day, so that evidently an economical regimen had been submitted to.

Douglas DIED on the I6th and TAYLOR on the 2oth November, and they were buried side by side. Carpenter died on the 26 th and was buried in the bed of the creek, the survivors being too weak to carry the body to the resting-place of his companions. In all three cases, however, Carron read the burial service. Carron says that Carpenter " did not suffer very acutely on the approach of death, but the animal energies were destroyed, and they withered away one after another, without pain or struggle."

The stores of the party included a fair amount of ammunition, but it had to be used with economy in view of the requirements of defence. There were plenty of fish-hooks, but the eager anglers never got so much as a bite. A small bag of shell-fish was brought up from the beach by Carron and Goddard on the 4th December, and another on the 7 th by Carron and Mitchell, but after the latter date none of the party had sufficient strength for such work. A few small pigeons, a heron and a small wallaby fell to the guns, up to the 29th December, but these were far below the food requirements of the men. The kangaroo dog was killed on the 2 ist December and furnished two days' food for the survivors, then four in number. The sheep-dog was only saved from the same fate by the arrival of the rescue party.

There was at first a disposition to TRUST TO THE NATIVES FOR FOOD. The men were afraid to leave the camp and for the most part were unable to go far from it. Some natives came to the camp, on the I6th November, bringing " a few small pieces of fish, old and hardly eatable." Two days later they returned, this time with women, and "brought some fish, but it was such as they would not eat themselves; also a kind of paste, made of different kinds of leaves and roots, mixed with the inside of the roasted mangrove seeds, all pounded up together, then heated over a fire in a large shell. Although we did not much like the taste of the paste, and it was very full of sand, we ate some of it as a vegetable."

There can be no doubt that the visits of the natives under a pretence of offering food, which was always in such quantities and of such a quality as to suggest a spirit of mockery, were prompted by a desire to spy on the camp and ascertain the defensive capacity of its inhabitants.

On Igth November FIFTY OR SIXTY ARMED MEN came up and made 
a HOSTILE DEMONSTRATION, but retired on a show of resistance being made. This being Sunday, prayers were read as usual.

On 2 Ist November (the day after the second death in the party)

" about sixty Natives," as Carron relates, "came to the camp, well armed with spears, and pieces of fish, which they held up to us, to entice us to come to them. We took no notice, however, of their invitations, but preparing our firearms, we turned out. They were now cLosing ROUND Us in all directions, many of them with their spears in their throwing-sticks, ready for use-pointing them to their own necks and sides, and showing us by their postures how we should writhe with pain when they struck us. Then they would change their tactics and again endeavour to persuade us that they meant us no harm, but they would not lay down their spears. Some of them seemed inclined to go away, but others appeared determined to attack us. After keeping us standing for about an hour, ELEVEN SPEARS were THROWN AT Us. Three of my party then fired, slightly wounding one of them, when they all immediately ran away as fast as they could. Some of them, however, remained hovering in sight for some time after. Three of the spears that were thrown fell short of us, the rest passing very close, but fortunately no one was hurt. The three spears which passed us were barbed with bone, and were very heavy."

On 26th November (the day of the third man's death), the NATIVES RETURNED, bringing a few small fish, and leaving their spears at a distance. Apprehensive of a trap, however, the besieged refused to accept the fish. It is noteworthy that the two visits in force occurred each time after the death of one of the party, of which the hovering natives were evidently aware.

By the end of November the distress of the survivors reached such a pitch that they ate the hide of the last horse. The hide of the horse killed previously had been given to the dogs.

The LOWEST DEPTHS OF MISERY were sounded by the unhappy men on the 2 nd December, the day after Kennedy's death. H.M.S. "Bramble" had been seen on the previous day sailing southward, having waited at Cape York till the limit of time specified in her instructions had been exceeded and she was relieved by the "Ariel." Still on the look out for Kennedy's expedition, the "Bramble" actually lowered a boat the following morning, as if with intent to land a party. Failing, however, to see the signals made by the men on shore, the schooner CONTINUED ON HER SOUTHWARD VOYAGE, and the sufferers were apparently left to their fate. The events of these two days are best related in Carron's own tragic words :-

" Ist December.-The wind was blowing strong from the south-east this morning. On going up the hill in the afternoon, I saw a schooner from the northward beating to the southward. I supposed her to be the 'Bramble,' as it was about the time Mr. Kennedy had given me expectation of being relieved by water, and I afterwards found I was right in this supposition.

"I naturally concluded she had come for us ; and full of hope and joy I immediately hoisted a FLAG on a staff we had previously erected on a part of the hill where it could be seen from any part of the bay. We placed a ball above the flag to put the crew on their guard against the natives. We then collected a quantity of wood, and at dusk lighted a FIRE, and kept it burning till about half-past seven or eight o'clock. 
I then fired off three ROCKETS one after the other, at intervals of about twenty minutes. I also took a large PIsTou up the hill, and stood for some time firing it as quickly as I could load it, thinking they might perhaps see the flash of that, if they had not seen the rockets.

" 2 nd December.-Early this morning I was up, straining my eyes to catch a view of the bay, and at length saw the schooner standing in to the shore, and during the forenoon a BOAT was LOWERED. I now made quite certain they were coming for us, and thinking they might come up the creek in the boat for some distance, I hastened down the hill and began to pack up a few things, determined to keep them waiting for our luggage no longer than I could help. I looked anxiously for them all the afternoon, wondering much at their delay in coming, until at last I went up the hill, just in time to see the SCHOONER PASSING THE BAY. I cannot describe the feeling of despair and desolation which I, in common with the rest of our party, experienced as we gazed on the vessel as she fast faded from our view. On the very BRINK OF STARVATION AND DEATH-death in the lone wilderness, peopled only with the savage denizens of the forest, who even then were thirsting for our blood-HOPE, sure and certain hope, had for one brief moment gladdened our hearts with the consoling assurance that, after our many trials and protracted sufferings, we were again about to find comfort and safety. But the bright expectancy FADED; and although we strove to persuade ourselves that the vessel was not the 'Bramble,' our hearts sunk within us in deep despondency."

The remainder of the story of the camp cannot be better told than in Carron's own words, on which it is impossible to improve, and which I only abridge in a few places where incidents have already been related.

" 9 th December.-The NATIVES visited us this morning and brought with them a few pieces of turtle's entrails and a few nondas. I gave them an old shirt and a knife, the latter being highly prized by them. GODDARD had a fit of AGUE to-day, followed by FEVER.

" roth December.-We all of us had fits of AGUE this morning, and none of us could get up till the afternoon, when, being Sunday, I read prayers.

"II $t$ b December.-The NATIves came this morning, and brought us a little vegetable paste, and some pieces of turtle's entrails, with some shark's liver. The latter was fresh, but one could not eat it, as it all melted into a yellowish oil when boiled for a few minutes. I gave them a few fish-hooks, but found it very difficult to get them to leave the camp.

"I 3 th December.-This morning Mitchell, was found DEAD by the side of the creek, with his feet in the water. He must have gone down at night to get water, but too much exhausted to perform his task, had sat down and died there. None of us being strong enough to dig a grave for him, we sewed the body in a blanket, with a few stones to sink it, and then put it into the brackish water.

" 15 th December.-The thermometer fell this morning and was broken. It was raining heavily all day, and two bags of my seeds and several other little things were washed out of the tent by the water which ran down the hill. We were all very ill and weak.

"I 6 th December.-It was raining this morning, and we remained in the tent. Hearing one of our dogs barking, however, I went out and saw several NATIVEs with pieces of fish and turtle, which I took from them, when they left us. The natives also brought us some roasted nymphoea roots, which they call 'dillii.'

"During the last few days we shot seven pigeons. Wall and Goddard used to go into the scrub and sit beneath a tree, to which they used to come for berries to feed their young, and, watching their opportunity, shoot them.

"2I st December. - Our KANGAROO DOG being very weak, and unable to catch anything, 
we KILLED and lived on him for two days. There was very little flesh on his bones, but our dried meat was so bad that we very much enjoyed the remains of our old companion, and drank the water in which we boiled him.

" 24 th December.-The NATIves took a tin case from Wall whilst he was talking to them, he not being able to resist them. My legs had swelled very much, and I was able to walk but a very short distance.

" 26 th December. - The Natives brought in a few pieces of fish and turtle, but both were almost rotten. They also gave us a blue-tongued lizard, which I opened, and took out eleven young ones, which we roasted and ate. There was nothing but scales on the old one, except in its tail.

"We always divided whatever we got from the natives, be it what it might; but they brought us very little that was eatable. I could easily perceive that their pretended good feeling towards us was assumed for the sake of fulfilling their own designs upon us. Although they tried to make us believe they were doing all in their power to benefit us, THEIR OBJECT was to obtain an opportunity of coming upon us by surprise and DEstroying us. They had at many times seen the fatal effect of our firearms, and I believe that it was only the dread of these that prevented them from falling upon us at once and murdering us. . . . It would be almost impossible for any class of men to excel these fellows in the scheming and versatile cunNING with which they strove to DISGUISE THEIR MEDITATED TREACHERY. In fine weather I always had our firearms standing out for them to see, and once or twice every night I fired off a pistol to let them know we were on the look out by night as well as by day.

" 28 th December.-Niblet and Wall both DIED this morning. Niblet was quite dead when I got up, and Wall, though alive, was unable to speak. They were neither of them up the day previous. I had been talking with them both, endeavouring to encourage them to hope on to the last; but sickness, privation and fatigue had overcome them, and they abandoned themselves to a calm and listless despair. We had got two pigeons the day before, which in the evening were boiled and divided between us, as well as the water they were boiled in. Niblet had eaten his pigeon and drank the water, but Wall had only drunk the water and eaten part of his half pigeon.

"About eleven o'clock as many as FIFTY NATIVEs, armed with spears, and some of them painted with a yellowish earth, made their appearance in the vicinity of our camp. There were natives of several sTRANGE TRIBES amongst them. They were well aware that neither Niblet nor Wall was able to resist them, if they did not know they were dead. They also knew that we were very weak, although I always endeavoured as much as possible to keep that fact from them. This morning, when I made signs to them to lay down their spears, they paid no attention, with the exception of two, who had been in the habit of coming very frequently to the camp. These two came running up quite close to us, without their spears, and endeavoured to persuade one of us to go across a small dry creek for a fish which another of the rascals was holding up to tempt us. They tried various methods to draw our attention from the rest, who were trailing their spears along the ground with their feet, closing gradually round us, and running from tree to tree, to hide their spears behind them. Others lay on their backs on the long grass, and were working their way towards us, unnoticed as they supposed. GODDARD AND MYsELF stood with our guns in readiness and our pistols by our sides for about two hours, when I fell from excessive weakness. When I got up we thought it best to send them away at once, or stand our chance of being speared in the attempt, both of us being unable to stand any longer. We presented our guns at the two by our side, making signs to them to send the others away, or we would shoot them immediately. This they did, and they ran off in all directions, without a spear being thrown or a shot fired.

"As the evening came on, there came with it the painful task of removing the bodies of our unfortunate companions who had died in the morning. We had not strength to make the smallest hole in the ground as a grave; but after great exertion we succeeded in removing the bodies to a small patch of phyllanthus scrub, about four feet high, and eighty yards from the tent. We then laid them side by side and 
covered them with a few small branches; and this was all the burial we were enabled to give them.

" 29 th December.-Goddard went into the scrub and shot three pigeons. We ate one at night, and the others we reserved till next day. Our bowels were greatly relaxed, which was partly stayed by eating a few nondas, which we got occasionally.

"The six weeks having expired which Mr. Kennedy had led me to expect would be the longest period we should have to wait, I now began to fear the rainy season had set in, and filled the creeks to the northward, so that his party had been unable to cross them, or that some untoward accident had happened, which prevented us being relieved.

"I did not quite despair, but I knew we COULD NOT LIVE LONG. OUR SHOT Was ALMOST CONSUMED, not having more than eight or ten charges left, and although we had plenty of ball, we were too weak to attempt to form any plan to make shot. Our sole remaining companion, the sheep-dog, I intended to kill in a day or two; but he would not last long, as he was nothing but skin and bone.

" 30 th December.-Early this morning we ate the two pigeons left yesterday and boiled each a quart of tea from the leaves we had left ; but we had not had any fresh tea to put into the pot for a long time. Goddard then went into the bush, to try to get another pigeon or two, and if the natives made their appearance I was to fire a pistol to recall him to the camp. After he had gone I saw Natives coming towards the camp, and I immediately fired a pistol ; but before Goddard could return they came in to the camp and handed me a piece of paper very much dirtied and torn. I was sure, from the first, by their manner, that there was A VESSEL IN THE BAY. The paper was a note From Captain Dobson, of the schooner 'Ariel,' but it was so dirtied and torn that I could only read part of it.

"For a minute or two I was almost senseless with the joy which the hope of our deliverance inspired. I made the natives a few presents, and gave them a note to Captain Dobson, which I made them easily understand I wanted them to take to that gentleman. I was in hopes they would have gone, but I soon found they had other intentions. A great many NATIVEs were coming from all quarters well ARMED WITH SPEARs. I had given a shirt to the one who had brought the note and put it on him; but I saw him throw down the note and pull off the shirt, and picking up his spear he joined the rest, who were preparing to attack us. We were expecting every minute to be attacked and murdered by these savages, our newly awakcned hope already beginning to fail, when we saw Captain Dobson and Dr. Vallack, accompanied by JACKEY and a man named BARRETT (who had been wounded a few days before in the arm by a barbed spear), approaching towards us, across the creek. I and my companion, who was preserved with me, must ever be grateful for the prompt courage with which these persons, at the risk of their own lives, came to our assistance, through the scrub and mangroves, a distance of about three miles, surrounded as they were all the way by a large number of armed natives."

The strange conduct of THE natives in first bringing Captain Dobson's letter and then refusing to carry the answer was probably caused by an imperfect comprehension of the means of communication. In any case, they, no doubt, thought the Captain's letter would furnish one more PRETEXT FOR A VISIT TO THE CAMP. Understanding, from the directions accompanying the reply, that the besieged knew that relief was coming, they prepared to ANNIHILATE THE SURVIVORS before they could be reinforced by the addition of the new-comers. CARRON's NARRATIVE approaches the end :-

"I WAS REDUCED ALMOST TO A SKELETON. The elbow bone of my right arm was through the skin, as also the bone of my right hip. My legs were also swollen to an 
enormous size. GODDARD WALKED TO THE BOAT, but I COULD NOT DO so without the assistance of Captain Dobson and Dr. Vallack, and I had to be carried altogether a part of the distance. The others, Jackey and Barrett, kept a look out for the blacks.

"We were UNABLE TO BRING MANY THINGs from the camp. The principal were the firearms and one parcel of my seeds, which I managed to keep dry, containing eightyseven species. All my specimens were left behind, which I regretted, for, though much injured, the collection contained specimens of very beautiful trees, shrubs, and orchideæ. I could also only secure an ABSTRACT OF MY JouRnAL, except that portion of it from I 3 th November to 3 oth December, which I have in full. MY original Journal, with a botanical work which had been kindly lent me by a friend in Sydney for the expedition, WAS LEFT BEHIND. We got safely on board the 'Ariel,' and, after a very long passage, arrived in SYDNEY.

"I am confident that no man could have done more for the safety of the party than was done by $M_{R}$. KENNEDY, nor could any man have exerted himself more than he in the distressing circumstances of our perilous journey. He walked by far the greater part of the distance, giving his one horse for the use of the weak men and the general use of the expedition. I never rode but two hours all through the journey, and that was on two successive days when we were in the vicinity of Cape Sidmouth and I was suffering from bad feet.

"The unfortunate DEATH OF OUR brave and generous LEADER, deeply and extensively as I know it to have been lamented, can have no more sincere mourner than myself.

"The tale of his sufferings and those of his party has already been read and sympathised over by hundreds, and it would ill become me to add anything to the artless narrative of the faithful and true-hearted JACKEY, who having tended his last moments and closed his eyes, was the first, and perhaps the most disinterested, bewailer of his unhappy fate."

It may be remarked that Carron's narrative gives very few geological notes. Probably if Kennedy's diary had been preserved it would have added much to our geological knowledge. CAPTAIN DoBson concludes his brief "Statement" by saying :-

"We then pursued our way to Weymouth Bay and rescued Mr. Carron and GoDDARD. We brought with us what Instruments we could from the camp-they were not many, as Mr. Carron was hardly in a state to tell me what was there. I should have returned to the camp at Weymouth Bay to save everything, but for the hostility of The NATIVEs, who surrounded us in great numbers, and, as soon as we had left the camp, rifled it."

Some further particulars of the closing scene of the tragedy are given by Dr. VALLACK.

On 29th December, 1848, the "Ariel" anchored in Weymouth Bay. The afternoon was wet and squally, and the day was too far spent for a landing party to reach Carron's Camp and return to the schooner. An anxious look out for a flagstaff or signals, of which nothing was seen, led to a gloomy foreboding that all had been lost. At daylight, next morning, the $30 t h$, the "Ariel " shifted to a distance of about half a mile from the land. No sooner had she dropped anchor than FIVE CANOES were seen, paddling towards them from among the mangroves, five to ten natives in each. From the foremost canoe came shouts of "ferraman" and "white man" 
and the natives pointed towards the hill which had already been indicated by Jackey. Doubts as to the reality of the friendliness of the natives were allayed by the presence of some women and children in the canoes. Captain Dobson wrote a note to Carron, which was given to one of the natives, who was instructed by gestures to take it to the camp. A boat followed the canoes and Captain Dobson, Barrett, DR. VAllack and Jackey-Jackey LANDED among the mangroves. Having at length cleared the swamp, the party followed up a creek, for about 2 miles, when JackeyJackey exclaimed, "See, two white fellows sit down and camp." The natives, who had been " DEMonstrating," must have withDRAWN on the approach of the boat party. "On the other side of the hill," says Dr. Vallack, "not two hundred yards from us, were Two MEN sitting down, looking towards us, the tent and fire immediately behind them; and on coming up to them, two of the most pitiable creatures imaginable were sitting down. One had sufficient strength to get up; the other appeared to be like a man in the very last stage of consumption. Alas! alas! they Were THE ONLY TWO LEFT of the eight, the remainder having died from starvation."

Dr. Vallack continues :-

"Whilst here we were considering what was best to be done, when NATIVEs in great numbers were descried watching our movements. Jackey said, "Doctor," calling me aside, "now I tell you exactly what to do. You see these black fellows over there" (and in pointing to them I saw a great number, some 800 yards away, peeping from behind trees), "you leave him tent, everything, altogether, there, and get the two white fellows down to the boat quick." Jackey was exceedingly energetic, and grave as well. "Get away as quick as possible" was resounded by all, but what was to be done? Two MEN ALMOST DEAD to walk 2 or 3 miles! We looked over the tent, asked Carron for what important things there were, and each laid hold of what appeared to be of most value, the Captain taking two sextants, other parties, firearms, etc., etc. "Come along," again and again Jackey called out, and the Captain too, whilst they were half-way down the creek, and Barrett and I loaded ourselves. I took a case of seeds, some PAPERS of CARron's, a double gun and pistols, which, together with my own double gun and brace of pistols, thermometer ${ }^{1}$ and my pockets full of powder and shot, was as much as I could manage. Seeing Carron could NOT GET ALONG, I told him to put his hands on my shoulders, and in this way he managed to walk down, as far or nearly through the mangrove swamp, towards the water's edge, when he could not in that way get any further, and BARRETT, with his disabled arm, CARRIED hIM down to the edge of the water. Goddard, the other survivor, who was JUST ABLE TO WALK down, spoke and looked exceedingly feeble. They were brought on board at noon, and attended to according to my instructions. Carron's legs were dreadfully swollen, about three times their natural size, from œedema. In the afternoon both reviving and thanking God for their deliverance. I was for some time afraid of Carron. At ro p.m., they are both doing well, and I trust will be enabled to tell us their tale, which will render it unnecessary for me to write it down here. I told the Captain to proceed direct on to Sydney, Jackey, Carron and Goddard and the Captain stating it would be running too great a risk to go to recover anything from the tent. Moreover, with so small a party as the Captain, Jackey and myself (BARRETT really being UNFIT to go, and the SAILORS all REFUSING to

1 The broken one. - R. L. J. 
go), I consider the Captain deserves considerable credit for his action throughout in exerting himself to rescue the survivors."

The "Ariel" accordingly LefT Weymouth BAY on the following day, 3 I st December, 1848 , and reached SYDNEY on 5 th March, I 849 . The tidings of the disastrous conclusion of Kennedy's expedition having reached Sydney, the brig "Freak," as already stated, was chartered by the Government of New South Wales to make a FURTHER SEARCH for Kennedy's papers and for traces of the parties left at Kennedy's so-called "Pudding-Pan Hill" and the Pascoe. An account of the discovery of a few of KenNEDY's PAPERs between the Escape River, where he died, and Cape York, and of the unsuccessful attempt to reach the scene of the DEATH OF THE THREE men at "Pudding-Pan Hill" has already been given.

The "Freak's" whaleboat, on 3 rd May, 1849, landed in Weymouth Bay a party which included Captain Simpson of the "Freak," Captain Sampson of the "Harbinger" (who volunteered), JACKEY-JACKEY and two of his aboriginal comrades. The landing and the overhaul of CARRON's CAMP were made under very difficult circumstances owing to torrential rain and the threatening aspect of the natives. At the landing-place were found part of a BLANKET, part of a TARPAULIN, a piece of CANVAS and a small TIN DISH. Three outrigger CANOEs were also met with and in these some pieces of IRON were observed. These articles, Captain Simpson concluded, came from the PILLAGE of Carron's last camp. A tree was found with the carved letters "K. LXXX." This, Jackey-Jackey said, was the camp of the I I th November, I 848 (the last but one). This would indicate that it was KenNEDY's 80TH CAMP.

Of the LAST CaMp, to which Carron's Party removed on the 13th November, the day on which Kennedy left for Cape York, Captain Simpson writes :-

"This spot was strewed with portions of Books, all of a religious or scientific character. Found no MANUSCRIPTs. Parts of harness, leather belts, pieces of cedar boxes in leather covers, were also found ; one or two tins for carrying water, a camp stool and part of a table, and piece of a tent-pole; the bones, skull, and part of the feathers of birds, etc.; SPECIMENS of natural history, all DESTROYED. I observed the bones of a HORSE and the skull of a DOG. A piece of torn calico with a portion of a CHART adhering to it was picked up; I thought I could make out the words "River Mitchell" on it. I found, among the pieces of books, a portion of Leichhardt's Journey Overland.

"It was some time before I could find the remains of WALL aND Niblet, who were the last men that died, and had not been buried, the survivors being too weak. I placed myself at the camp and looked about for the likeliest place to which a corpse would be taken under the circumstances. I went down into a small gully, about sixty yards from the camp. Under some small bushes, in about two feet of water, I found THEIR BONEs, two skulls and some of the larger bones, the smaller ones having most probably been washed away by the flood. The bones were carefully collected and taken on board. From the position in which these bones were found, agreeing 
with the description given me by Mr. Carron, I feel confident that they are the remains of Wall and Niblet."

The remains of Wall and Niblet were carried on by the "Freak" to Albany Island, where, on the top of the highest hill at the southern end of the island, they were INTERRED on the I 3 th May, I849. A tombstone was erected on the spot by Captain Owen Stanley, of H.M.S. "Rattlesnake," who himself died in March, I 850.

There is abundant evidence that CARRON's LAST CAMP was pitched, not on Simpson's Hill, at the mouth of the Pascoe, but on Barrett's Hill, two or three miles to the west, near the tributary of the Pascoe River, which the expedition followed down on the 9 th, Ioth and IIth November, I848. In this position, the camp, flagstaff and signals cannot have been sufficiently conspicuous to attract attention from the sea. Had it been placed on Simpson's Hill it must have been visible from the "Bramble" when that ship sailed to the south on the 3 rd December, to the heartrending disappointment of the despairing watchers on the land, and the lives of Mitchell, Wall and Niblet would probably have been saved. It must not, however, be forgotten that Carron's party did not know whether relief was to come by land or sea, and therefore the position of their last camp may have been the result of a compromise. It is also impossible to say whether they judged the site chosen to have strategical advantages for defence against the savages. Lastly, it is only too likely that the weak and dispirited men had not energy enough to look for a better site and move the camp.

The touching narratives of the survivors and rescuers give a very clear insight into KENNEDY's CHARACTER. Unquestionably brave, he was always scrupulously fair and considerate towards his enemies. His plan of operations had been most carefully thought out, but with its cumber of carts and sheep it proved absolutely inapplicable to the country to be traversed; it is not too much to say that the plan would have been rejected with horror by any man knowing the country, as I for one came to know it later, and as, of course, Kennedy could not have conceived it when he set forth full of confidence in the perfection of his arrangements. Nevertheless, a more reasonable leader would have realised the impossibility of the task under the conditions much earlier than Kennedy did, and would have remodelled his equipment, as he did at last, after men and horses had had all the heart worked out of them before the journey could have been said to have begun. He and nine others paid, in full measure, the penalty of an admirable perseverance which had degenerated into obstinacy.

The persistence displayed by Kennedy, the inability to bow before the forces of Nature and admit defeat, were closely allied to the piety which distinguished him above other explorers. The heartfelt prayers which ascended from his moving tents every 
Sunday morning-sometimes under circumstances which would have driven other men to work rather than to pray-were persisted in to the very last, although they seem almost invariably to have been followed by some new disaster. Kennedy had the spirit which drew from Job in his agony the defiant cry: "Though He slay me, yet will I trust in Him, but I will maintain mine own ways." $\mathrm{He}$ was revered and loved by all who shared with him the hardships of the terrible journey.

\section{REQUIESCAT IN PACE!}

A sufficient reason why no serious attempt has hitherto been made to garner the geographical results of Kennedy's expedition is to be found in the fact that the task was practically impossible until the progress of settlement had brought with it the production of land maps on which his course could be traced.

CarRoN and WaLl merit the highest commendation for the fidelity with which they persisted in their scientific duties, even when everything pointed to their efforts being made in vain. Carron has furnished in his (which is the only) record of the Kennedy expedition, a narrative as thrilling as that of Daniel Defoe, and with the additional advantage of being true in every line.

Perhaps, after all, the hero of the tale is the aboriginal JACKEYJACKEY. The laurel wreath due to the first explorer to reach Cape York by land would have been justly placed on his black brow. The unavoidable limitations imposed on him by his ancestry have already been pointed out, but

"Though tawny was his hide,

He was white, clear white, inside,"

and in courage, prudence, resourcefulness and loyalty he could not have been surpassed by the whitest of men.

The "Ariel" arrived in SyDNEY on 5th March, 1849. A reporter of the Sydney Morning Herald at once interviewed the survivors of the expedition and the officers of the schooner. The report gives an abstract of Jackey-Jackey's narrative, as taken down by Dr. Vallack, and some further particulars which account for a portion of the time spent on the forlorn hope between the Pascoe and Cape York. These have already been embodied in notes appended to Jackey-Jackey's " Statement."

Jackey-Jackey now said that thirteen days elapsed between KENNEDY'S DEATH and his own arrival at Cape York. On a critical consideration of the statement, read in the light of other evidence, I conclude that only ten out of the eighteen days are accounted for. I have no doubt that Jackey-Jackey crawled along in a dazed condition and was too far gone to take an accurate account of time. He added that he had taken three spears out of Kennedy's body. 
If the guns and powder had not been damaged by the constant rain, he believed that Kennedy would have got through.

An official investigation, ordered by the Attorney-General, was held on 6th March at the Water Police Court by Captains Innes and Browne.

CARRON put in his diary of the period during which he was in charge of the party left at the mouth of the Pascoe. The subsequently published booklet gives the substance of the diary put into narrative form, together with the previous part of the journey from Rockingham Bay to the Pascoe, which was compiled from an abstract of his private diary.

GoDDARD's examination added nothing to Carron's narrative, but he gave instances of Kennedy's consideration for the subordinate members of his party.

Dr. VALLACK put in the Statement of Jackey-Jackey which he had taken on board the "Ariel" and gave an account of the voyage of the "Ariel" to Shelburne Bay and Weymouth Bay, and the doings on shore in these localities, but added practically nothing to the "Statement" included in the booklet.

The evidence was handed to the Attorney-General, who submitted it to the Government.

On 9th March, the Colonial Secretary, the Hon. E. Deas Thomson, officially announced the fate of the expedition in the Government Gazette. The announcement pays a high tribute to Kennedy and Carron and generously recognises the devoted services of Jackey-Jackey. It contains also the statement that " it is hoped from the documents which have been preserved, a narrative of the expedition may be compiled for publication at a future date."

On 25th April, 1849, the Governor, Sir Charles Fitzroy, transmitted the PAPERS relating to the expedition to Earl Grey, who replied :-

"Sir,

“Downing Street, ist October, I 849.

"I have to acknowledge the receipt of your despatch No. 55 , of the $25^{\text {th }}$ of April last, with the PAPERs which accompanied it, containing an account of the exploratory expedition undertaken by Mr. Assistant Surveyor Kennedy, and of the investigation which had taken place into the circumstances connected with the death of that gentleman and others of his party.

"I have read the melancholy narrative contained in these documents with much regret, and it has given me deep concern to observe the loss of life which has resulted from the undertaking. I avail myself, however, of the earliest opportunity of expressing to you the sense which I entertain of the courage and enterprise shown by every individual belonging to the party, by whom, notwithstanding so calamitous an issue, much appears to have been achieved; and I especially appreciate the intrepid zeal and energy by which their leader would seem to have been distinguished.

"I have, \&c.,

"GREY.

"Governor Sir Charles A. Fitzroy." 
On 17th July, I849, on the motion of Mr. Darvall, a sum of $f_{1} 100$ was placed on the Supplementary Estimates for the erection of a memorial tablet in St. James' Church, Sydney. The vote was carried on a division by twenty-one votes to four. In the course of the debate, the Colonial Secretary (the Hon. E. Deas Thomson) said :-

"A NARRATIVE BY ONE OF THE SURVIVoRS WOULD SHORTLY BE PUBLISHED, and advantage had been taken of the departure of a vessel to Torres Straits to send down Mr. Kennedy's faithful companion Jackey-Jackey, in the hope of recovering the Journal of the former. The Journal had not been found, but A CASE HAD BEEN DISCOVERED, somewhat affected by damp, in which were many vaLUABLE MAPS, delineating the route pursued by Mr. Kennedy and the general features of the country through which he passed. THESE DOcumenTs, he was happy to inform the House, wOULD SUPPLY A GOOD DEAL OF INFORMATION at present wanting, and would serve as a material guide to any person attempting the same route."

The principal objector was Mr. Robert Lowe, afterwards Lord Sherbrooke. His arguments were: (I), that " the expedition was a most ill-advised one, and was commenced by the Government on its own responsibility, without consulting the Council" ; and, (2), that the expense should be defrayed by private subscription rather than be taken from the public purse.

The mural tablet in St. James' Church is of white marble. A bas-relief representing Kennedy lying under a palm tree and supported by his faithful Squire, with armed savages in the distance, is followed by the inscription:

\section{This TABLET}

Erected by the Executive Government pursuant to a Vote of the Legislative Council of New South Wales in testimony of the respect and gratitude of the inhabitants of the Colony commemorates the active services and early death of

\section{EDMUND BESLEY COURT KENNEDY}

who, after having completed the Survey of the River Victoria, was chosen by the Government to conduct the

\section{FIRST EXPLORATION OF YORK PENINSULA,}

where, after the most patient and persevering exertions, to overcome the physical difficulties of the country, and the destructive effects of consequent disease, by which the expedition, originally consisting of thirteen persons, was reduced to three, he was slain by the Aborigines in the vicinity of Escape River on the 13th December, A.D. 1848.1

Falling a sacrifice, in the 3 Ist year of his age, to the Cause of Science, the Advancement of the Colony and the Interests of Humanity.

1 My reading of Jackey-Jackey's statement renders the date more probably 5 th December. The writer of the inscription had no better evidence to guide him than that which is before me.-R. L. J. 
Flebile Principium melior Fortuna sequatur.

The Persons who perished by disease were:

$\begin{array}{ll}\text { Thomas Wall (Naturalist) } & \text { W. Costigan } \\ \text { C. Niblet } & \text { E. Carpenter } \\ \text { James Luff } & \text { J. Mitchell } \\ \text { E. Taylor } & \text { J. Douglas }\end{array}$

The Survivors are

\section{Requiescat in pace.}

William Carron (Botanist)
and
Jackey-Jackey, $\quad$ William Goddard

an Aboriginal of Merton District, who was Mr. Kennedy's sole companion in his conflict with the savages, and, though himself wounded, tended his Leader with a Courage and Devotion worthy of Remembrance, supporting him in his last moments and making his grave on the spot where he fell.

A few biographical notes on Carron's career are furnished by Mr. J.H.Maiden, C.M.G., in his "Records of Australian Botanists" (Fourn. Roy. Soc., N. S. Wales, XLII, 1908). Carron was born in Norfolk, England, on 18th December, 1823, and arrived in Sydney in 1843 , in charge of plants for one of the Macleays. He was a Licensed Surveyor when he joined Kennedy's expedition. After the expedition he was engaged for some time in collecting plants. [Documents in the Mitchell Library show that he was appointed Sub-Collector of Customs at Eden, New South Wales, in I856.R. L. J.] He was on the staff of the Botanic Gardens, Sydney, as a Collector, from Ist September, 1866, to 3ist December, I875, when he left to take up the position of Forester on the Clarence River. He died at Grafton on 25th February, 1876.

The portrait herewith is reproduced, by permission, from $\mathrm{Mr}$. Maiden's " Records." 


\section{CHAPTER XXXVII}

\section{H.M.SS. "RATTLESNAKE " AND "BRAMBLE," I847-50 \\ STANLEY AND YULE}

First Northern Cruise. MacGillivray and Huxleyy, Naturalists. Ships leave Sydney, IIth October, I847. Upstart Bay, ioth December. Return to Sydney. Second Northern Cruise. Ships leave Sydney, 29th April, r848, convoying "Tam O'Shanter," with Kennedy's Expedition. Debarkation of Expedition at Rockingham Bay, 23rd-24th May. "Bramble" to meet Kennedy in Princess Charlotte Bay in First Week of August. "Rattlesnake" goes North. Trinity Bay. Mount Peter Botte named. Lizard Island. Cape Melville. Pipon Islands. "Bramble" arrives from Princess Charlotte Bay. Kennedy not there. Boat Party attacked by Natives in Bathurst Bay. Both Ships to Pelican Island. "Bramble" sent to chart Princess Charlotte Bay. "Rattlesnake" to Bligh's Sunday Island. Rejoined by "Bramble," 29th September. Both Ships to Evans Bay, through Albany Passage. Influx of Mount Adolphus Islanders to Evans Bay. Stanley recommends Settlement on Albany Island. "Ariel," with Reinforcements and Provisions for Kennedy, arrives 27th October. Kennedy late. "Ariel" left to wait for him. Arrival of Jackey-Jackey, sole Survivor of Kennedy's "Dash to Cape York." "Rattlesnake" and "Bramble" leave, 2nd November. Through Prince of Wales Channel to Booby Island. "Rattlesnake" to Port Essington and Sydney (24th January, 1849). "Bramble" left at Booby Island to survey in Endeavour Strait and Inner Passage. Passed (Ist and 2nd December, I848) close to Mouth of Pascoe, without seeing Carron's Signals. Third Northern Cruise. "Rattlesnake" and "Bramble" meet in Moreton Bay. To New Guinea. Leave for Cape York. Together to Marsden Island. "Bramble" sent to Booby Island. "Rattlesnake" arrives at Evans Bay, ist October, 1849, and is rejoined by "Bramble." White Woman claims Protection. Her Remarkable Story. Shipwreck and Life among Natives. A White Usurper on Mulgrave Island. MacGillivray's Views on the Breeding of Islanders and Cape York Natives. Crews witness Tournament and Corrobboree. "Younger Brotherhood" With Individual Members of Shooting Parties. Mew River, Muddy Bay. "Rattlesnake" starts North, 3rd December, 1849. The Three Sisters, Coco-nut, Dove, Arden, Keats, Rennel and Marsden Islands. Darnley Island (6th December). Barter. Mummy. To New Guinea. Survey of Louisiade Archipelago. To Sydney (5th February, 1850). Death of Captain Owen Stanley (izth March). "Rattlesnake" returns to England, with Marines from the abandoned Port Essington Station.

\section{§ I. FIRST NORTHERN CRUISE}

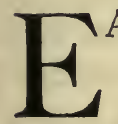

ARLY in the year I845, the Admiralty determined to replace the "Fly" by the "Rattlesnake," but his formal instructions were not handed to the Commander, Captain Owen Stanley, until the eve of his departure from England, towards the close of the following year. 
It was intended that the "Rattlesnake" (28 guns) should be accompanied by the "Bramble," under Lieutenant C. B. Yule, and the "Castlereagh," under Lieutenant Aird. A survey, however, proved the "Castlereagh" to be unfit for the service, and she was left behind. The complement of the "Rattlesnake," when she commenced her northern work, was 154 officers and men, and that of the "Bramble" 36. A decked boat, named the "Asp," followed the expedition, and appears when conducting independent operations to have usually been in charge of Lieutenant Dayman. John MacGillivray was Naturalist and a younger naturalist was Thomas Huxley, who was destined to attain world-wide fame as a biologist. Owing to the illness and death of the Commander of the expedition, which took place before the work was completed, it is not to his pen, but to MacGillivray's that we owe the narrative of the voyage, ${ }^{1}$ and from Huxley's brush came the spirited drawings which illustrate the text.

The "Rattlesnake" left Plymouth on IIth December, I 846 , and reached SyDNEY on I6th Fuly, I847. On IIth October, she, with the "Bramble," set out for Port Curtis and the north, anchoring in UPsTART BAY (between the sites of Bowen and Townsville, two towns not as yet founded) on roth December, I847. (SEE MAP O.) They returned to SyDNEY on I 4 th Fanuary, 1848 .

\section{§2. SECOND NORTHERN CRUISE}

The second northern cruise began at Sydney on 29th April, 1848. Up to that date, with the exception of Leichhardt's brief appearance on the base of the triangular area of the Cape York Peninsula, in 1845 , the exploration of the Peninsula had penetrated only in a few places for a few miles from the coast, and had been entirely the work of maritime pioneers. The time had now arrived for the opening up of the interior, and Kennedy's ambitious scheme for an overland journey from Rockingham Bay to Cape York was about to be carried out. The "Rattlesnake" and "Bramble," therefore, had the honour of convoying the barque "Tam O'Shanter," with KenNeDY's EXPEDition on board, to Rockingham BAy, the scene of its initial operations. (SEE MAP K.)

On $23 r d$ and 24 th May, I848, the sailors assisted Kennedy with the debarkation of his men, horses, sheep and stores, and immediately thereafter began their own labours to complete the survey of the INNER PASSAGE to the north. It was arranged that the "Bramble" was to be in Princess Charlotte Bay during the first week of August, to wait for Kennedy and to assist him in any way possible. (SEE MAP E.) We have already seen how

1 Narrative of the Voyage of H.M.S. "Rattlesnake," commanded by the late Captain Owen Stanley, R.N., F.R.S., etc., during the Years 1846-1850. By John MacGillivray, F.R.G.S., Naturalist to the Expedition. Published under the Sanction of the Lords Commissioners of the Admiralty. London, 1852. 
Kennedy was unable to keep the appointment, arrived only on 9th October, and did not think it worth while to force his way through the mangroves and swamps of the coastal plain to the bay, from which the "Bramble" must long ago have sailed away. (SEE MAP G.)

The "Rattlesnake" was in Trinity BAY (the site of the future

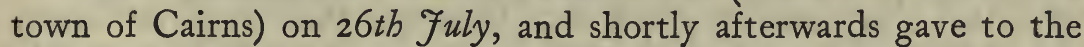
mountain behind Cook's Cape Tribulation the name of Peter Bотте, from a fancied resemblance to the mountain of that name in the Mauritius. A fortnight (3Ist July to I4th August) was spent at Lizard Island. (See Map E.) Cape Melville was reached on 2ist August and the Pipon IsLands on the following day. Here the "Rattlesnake" was joined by the "Bramble" and Yule reported that he had waited ten days in Princess Charlotte Bay without seeing anything of Kennedy. While the "Rattlesnake" lay off CAPE Melville, a watering party was attacked by NATIVES on a small stream "inside of the cape" (i.e., in Bathurst Bay, to the west), but no casualties took place. (SEE MAP C.)

From the Pipon Islands to Pelican Island ( $143^{\circ} 50^{\prime} \mathrm{E}$; I $3^{\circ} 55^{\prime}$ S.), which was reached on 28 th August, the course of the "Rattlesnake" and "Bramble" was probably across Bathurst Bay, through Rattlesnake Channel (between Denham Island and Bathurst Head), across Princess Charlotte Bay, and west of the Beabey Patches and Stainer Island. ${ }^{1}$

From Pelican Island, the "Bramble" was dispatched to the south, to fill in details of the survey to the head of Princess Charlotte Bay. The "Rattlesnake" anchored at No. 5 ClareMONT Island ( $143^{\circ} 43^{\prime} \mathrm{E} . ; \mathrm{I} 3^{\circ} 39^{\prime} \mathrm{S}$.), now charted as Fife IsLand, on 3 Ist August, and at Night Island ( $143^{\circ} 35^{\prime}$ E.; $10^{\circ} \mathrm{I}^{\prime} \mathrm{S}$.) on 8 th September. (SeE MAP B.)

On 29th September, the "Rattlesnake" arrived at Bligh's Sunday IsLand, where she was rejoined by the "Bramble." The two ships were at Cairncross Istand on 3 rd October, and at the northern entrance of Port Albany (Albany Passage) on 7 th October. (See Map A.) On the 8th, they went on to Evans Bay, where they took in water, after having cleared out the wells dug by the "Fly."

"While the ship, ['Rattlesnake'] remained at Cape York, the 'Bramble,' 'Asp,' pinnace and our second cutter were engaged in the survey of Endeavour Strait and the Prince of Wales CHANNEL, which they finished before they left, thus completing the survey of the IN NER RouTe between Dunk and Booby Islands" ("Rattlesnake," I, p. I22). Among the surveys made by Yule in the "Bramble" was that of Albany Passage. Yule named

1 Named after F. G. Beabey, Boatswain (1899), and C. E. Stainer, Lieutenant (1898), H.M.S. "Dart." 
Port Albany ("Rattlesnake," I, p. I32). The pinnace was sent to Bоову IsLAND and found letters.

About the same time that the "Rattlesnake" arrived at Cape York, five canoes arrived from Mount Adolphus Island, temporarily increasing the population of Evans Bay to about $150 \mathrm{men}$, women and children. They visited the ship and were friendly and well treated. They only stayed a few days, and then dispersed along the coast to the south. Stanley considered Cape York a suitable locality for a military post, such as was then contemplated, as Port Essington was not answering the purpose for which it had been founded. In Evans Bay, water was obtainable only in wells, and he judged a small sandy bay on Albany Island to be preferable. MacGillivray noted the occurrence of porphyry in the vicinity of Cape York and of sandstone cliffs, 30 feet high, on Albany ISLAND.

It had been "arranged" that KENNEDY should be at Cape York by the beginning of October, but such arrangements are liable to be overruled by unforeseen circumstances. The schooner "Ariel," Captain Dobson, sent from Sydney, with Dr. Adoniah Vallack and another man as reinforcements, and with sheep and other provisions for Kennedy, arrived at Cape York on 27th October.

The "Rattlesnake" or the "Bramble" was constantly on the look out for the expected arrival of the land party till 2nd November, when this duty was delegated to the "Ariel." It was not till 23rd December that Kennedy's aboriginal "boy" JACKEY-JACKEY, sole survivor of the forlorn hope which had attempted a "dash", to Cape York (Kennedy and his three white companions having perished), more than half dead, hailed the "Ariel" from the shore. It has already been related how Captain Dobson took Jackey-Jackey on board the "Ariel" and sailed promptly to the relief of the main body of the expedition marooned in WEYMOUTH BAY and rescued the two survivors, CARron and Goddard, on 3oth December.

The "Rattlesnake" and "Bramble" left Evans Bay on 2nd November and reached BOOBY IsLAND on the 4 th, having passed through Prince of WALES Channel. The "Rattlesnake" arrived at PoRT Essington on 9 th November, 1848, and at Sydney on 24 th January, I 849 .

The "Bramble" was left at Booby Island with instructions to finish some work in Endeavour Strait and the Inner Passage, and was then to proceed to Sydney. She passed Weymouth BAY on Ist and 2 nd December, full in sight of the party dying of sickness and starvation and frantically making signals of distress. (SEE MAP B.) Carron has described with a glowing pen the elation arising from the certainty of being snatched from the very jaws of death and the subsequent agony of despair when their hopes were dashed to the ground. 
Granting that one of the possibilities of the situation was that the exploring party had been lost, and that another was that they had been compelled to abandon their intention of making for Cape York, there still remained a third, viz., that they had made for the coast in the hope of signalling the ship which had been ordered to meet them at Cape York on her return voyage, or of being picked up by some other vessel. Yule had, no doubt, technically obeyed orders when he waited in Princess Charlotte Bay and at Cape York for Kennedy, who did not keep his appointment; but he might have been expected not to have lost sight of the third possibility, and to have kept a look out as he passed southward within sight of the coast. He may, indeed, have done so, and I have already pointed out that Carron's flagstaff was not planted in the most commanding position. It must also be admitted that on the afternoon of Ist January the declining sun in the look out's eyes may have prevented him seeing the signal flag as he scanned the shore, and that the noise of the pistol shots might not carry far, as "the wind was blowing strong from the south-east" ; but the fires and rockets might have attracted attention during the night. At the judicial investigation held in Sydney on 6th March, I 849 (the day after the arrival of the "Ariel" with the survivors), Lieutenant Yule was not called upon to give evidence, as he would almost certainly have been had he been on the spot. His account of the "Bramble's" traverse of Weymouth Bay might have been of material value as a commentary on Carron's narrative. The "Rattlesnake" was in Sydney from 24th January to 8th May, I849, and MacGillivray makes no mention of the arrival of the "Bramble," which probably came no further south than Moreton Bay, where she was joined by the "Rattlesnake" on I7th May.

\section{§3. THIRD NORTHERN CRUISE}

The "Rattlesnake," which left SyDNey on 8th May, picked up the "Bramble" in Moreton Bay nine days later. On 26th May, the two ships sailed for the Louisiade Archipelago and New Guinea. On 27th September, they left New Guinea for Cape York to meet a vessel which was to bring them supplies from Sydney. Next day they anchored off Bramble Cay. (See Map A.) By Stephens' and Campbell's Islands, they went to Marsden IsLAND, where they anchored on 29th September. Here the "Bramble" left the "Rattlesnake," to call at the Bоoвy IsLand post office. The "Rattlesnake," sailing via ARDEN and CocoNUT Islands, reached Evans Bay, Cape York, on ist October, and was rejoined by the "Bramble." Yule reported that the boats of an American whaler lost on the Alert Reef, outside the Barrier, had arrived at Booby Island, and their crews had been saved from starvation by the provisions deposited there. 
During the stay of the "Rattlesnake" at Cape York, a remarkable incident took place. On I6th October, a WHITE woman claimed the protection of a boat's crew who had landed on the beach. She was Barbara Thomson, a native of Aberdeen, who had immigrated with her parents to New South Wales, where she had married. Some four and a half years ago, she had embarked with her husband in the cutter "America," bent on the salvage of oil from a whaler wrecked on the Bampton Shoal. The guide, a member of the shipwrecked crew, failed to discover the wreck, whereupon recrimination and quarrelling ensued. Two men were accidentally drowned and a third was left on a small uninhabited island. Then the "America" made for Torres Strait and was wrecked on "the eastern Prince of Wales Island" (Entrance Island ?). The only two men then on the ship (one of them Barbara's husband ?) were drowned in the attempt to swim ashore ; but the woman was rescued by the natives, one of whom, named Boroto, took her to wife; and she also enjoyed the protection of a person of importance in the tribe, who lived in Muralug (Prince of Wales Island), and who recognised her as the re-embodied spirit of his deceased daughter, who had been named Gi'Om, which name was conferred on her.

A year ago, the people of the island had heard of the visit of "two war canoes"-no doubt the "Rattlesnake" and "Bramble" -to Cape York. Recently, when the smoke-telegraph conveyed the news of the return of the two ships, Gi'Om had persuaded her hosts, chiefly by hints of great rewards, to take her to Cape York. Once safely on board the "Rattlesnake," and in spite of objections and threats on the part of her black friends (who seemed to have become genuinely attached to her), she elected to return to Sydney, where she was ultimately restored to her parents.

Gi'Om had much to tell of a whITE MaN, with a name which sounded like Wini, who had lived with the Badu (Mulgrave Island) tribe for many years. This man had once visited Prince of Wales Island in the hope of inducing Gi'Om to "share his fortunes." From the fact of his not understanding English and having to converse with her in the native language, she took him to be a foreigner.

"He had," says MacGillivray, " reached Mulgrave Island in a boat, after having, by his own account, killed his companions, some three or four in number. In course of time, he became the most important person in the tribe, having gained an ascendancy by procuring the death of his principal enemies and intimidating others; which led to the establishment of his fame as a warrior, and he became in consequence the possessor of several wives and canoes and some property in land, the cultivation of which last he pays great attention to. Wini's character appears from the accounts I have heard-for others corroborated part of Gi'Om's statement-to be a compound of villainy and cunning, in addition to the ferocity and headlong passions of a thorough savage. It strikes me that he must have been a runaway convict, probably from Norfolk Island. It is fortunate that his sphere of mischief is so limited, for a more 
dangerous ruffian could not easily be found. As matters stand at present, it is probable that not only during his life but for years afterwards, every European who falls into the hands of the Badu people will meet with certain death."

Lieutenant J. Sweatman, of the "Bramble," connected the advent of Wini on Mulgrave Island with the murder of a boat's crew belonging to a Sydney bêche de mer and tortoise-shell vessel, who, in June, 1846, landed on Mulgrave Island to barter, but rowed off to a sandbank on the appearance of suspicious symptoms among the natives. Four men were killed on the sandbank, while two others, who were in the boat, apparently escaped. "In my opinion," observes MacGillivray, "Wini's arrival on Mulgrave Island probably took place long before the murder of the boat's crew. More, I think, than three years and a half must have been required for him to have acquired the influence, reputation and property referred to by $\mathrm{Gi}^{\prime} \mathrm{Om}$; and this supposition accords with her phrase of "many years." "

Only two years ago, i.e., before 1849 , adds MacGillivray, two men and a boy, who had reached BANKS IsLAND in a boat, were murdered by the natives. MacGillivray remarks that the natives of DaRnley IsLand, which is more frequently visited by ships than Banks Island, are safe to deal with, and that the Murray IsLanders treat distressed strangers with kindness.

MacGillivray's observations led him to the conclusion that the Cape York natives were of mixed Australian and Papuan blood. The Prince of Wales Islanders look down upon them and are justified in regarding them as inferiors. Bows and arrows are in use on the islands, but not on the mainland, where also there is no true chieftainship. I may point out that observations prior to MacGillivray's leave it doubtful whether, even in the islands, there is chieftainship, or anything more than the temporary ascendancy of individuals showing unusual strength of character. Nor am I certain that a deliberate preference for wimmeras and spears to bows and arrows is in itself a proof of mental inferiority. On the other hand, the superiority of the islanders in cultivation, in industry and in land and marine architecture, is beyond question.

During a stay of nine weeks in the neighbourhood of Cape York, the men of the "Rattlesnake" had good opportunities for observing the natives of the "Land's End" of the Australian continent, with whom they kept up friendly relations. They were interested spectators of a FIGHT or tournament, of fifteen warriors on each side, which resolved itself into duels with spears between individual combatants. When shooting parties left the ship, each sportsman was assisted by a favoured black individual who had been selected as associate, or botaiga (younger brother), and there was keen competition for this honour.

A native DANCE, of about 150 performers, was got up for the entertainment of the visitors; but it proved, according 
to MacGillivray, " a very poor affair," and broke up in disorder because of the distribution of biscuits having been entrusted to one of the women.

A fine fresh-water stream was discovered running into Muddy Bay, and was named the MEw River. As there was some good land on its banks, MacGillivray considered this a good site for a SETTLEMENT, Port Essington having by this time been abandoned.

On 3rd December, I 849, the "Rattlesnake" left Cape York and anchored at ERNEST IsLAND, 27 minutes to the north. The island is composed of syenite, rises to a height of 751 feet and contains a village of 150 inhabitants.

Sue IsLand $\left(142^{\circ} 50^{\prime} \mathrm{E} . ; 10^{\circ} 12^{\prime} \mathrm{S}\right.$.) is the central of the "Three Sisters" Group, Poll Island lying to the south and Bet Island to the north. The group is about 21 minutes east of Ernest Island. Sue Island, which is composed of coral sand, has a village of sixty inhabitants and a coco-nut plantation. Seven men paddled out to the "Rattlesnake" in a canoe and bartered tortoise-shell for tobacco. The men " differed in no material respect" from the natives of Prince of Wales and Darnley Islands. The "Rattlesnake " anchored for the night of the 7 th off the west end of the reef which runs east and west (chiefly east) of BET IsLAND.

On 8th December, the "Rattlesnake" sailed ENE. between Coco-nut and Dove Islands and anchored at ARden Island to the NE. A party landed on $8 t b$ December, but found no natives in residence. She then proceeded to KEATs IsLand, where she anchored, having passed RENNEL and MARSDEN IsLANDS on the right. The following day she anchored north of Darnley IsLAND, where, on the IIth, I2th and I 3 th, the usual bartering took place in the villages. In addition to coco-nuts, sago palms and mangoes were noted among the cultivated trees. The MUMMY of a child was offered for sale, and over this deal friction arose, which at one time threatened to develop into serious trouble. Huxley was allowed to enter a hut and sketch its interior and contents.

On I 4 th December, the "Rattlesnake" proceeded to Bramble $\mathrm{CAY}_{\mathrm{AY}}$, where some of the party landed, collecting turtles' and birds' eggs. The booby was present in great numbers.

On 19th December, the "Rattlesnake" left Bramble Cay for Cape Possession, New Guinea ( $146^{\circ} 20^{\prime}$ E. ; $8^{\circ} 38^{\prime}$ S.), and, two days later, was at anchor in the lee of the Paiwara Islands, where she lay for a week while Yule, in the "Bramble," surveyed between Cape Direction and Redscar Bay, New Guinea. (Admiralty Chart, No. $275^{8}$ A.) Observations were made (for the second time) to ascertain the height of Mount OWen Stanley (13,205 feet).

On 6 th Fanuary, 1850 , the Duchateau Islands ( $152^{\circ} 25^{\prime} \mathrm{E}$.; I I $^{\circ} 25^{\prime}$ S.) were reached, and the survey of the Louisiade ArchiPELAGO was entered upon. 
The "Rattlesnake" left the Duchateau Islands on 8th January, and reached Sydney on 5th February, 1850. Captain Owen STANLEY DIED there on I 3 th March, while apparently convalescing from an illness contracted during the last cruise, and Lieutenant Yule succeeded to the command.

The "Bramble" was left in Sydney when, on 2nd May, the "Rattlesnake" left for England, with, it may be noted, the greater number of the marines from the abandoned station of Port Essington on board. The voyage to England was made by the north end of New Zealand and round Cape Horn, and ended at Chatham on 9th November, 1850. 
CHAPTER XXXVIII

THE NORTH AUSTRALIAN EXPLORING EXPEDITION, $1855-6$

\section{GREGORY}

British Government forms Party to explore Interior. Eighteen Persons, including Leader (A. C. Gregory) and Ferdinand Mueller. Landing of Party near Port Essington (ist September, 1855). Depôts on Victoria River. Natives attempt to burn the Party out. To Roper River. A Camp of Leichhardt's? Natives attempt to rob a Camp. Leichhardt's McArthur River. Future Quennsland Border, 21st August, 1856. Nicholson River followed down to East. Albert River crossed. Eastward to Crooky Creek. South-South-Eastward. Names Leichhardt River and crosses it near Future Floraville Station. Attack by Natives checked (4th September). Eastward to Flinders River (9th September). Eastward to Norman River (itth September). River followed up to SSE. a Few Miles. Eastward to Belmore Creek (50 Miles below Future Croydon Goldfield). Down Clarina Creek. Westward to Sitr of Future Hayden Railway Station. Northward across Creen Creek (i5th September). Scarcity of Water. Nortiward to Wills and Walker Creeks. Walker Creex a Leakage from Gilbert River and falls into Norman River. NorthWestward to Smithburn Branch of Gilbert River. The Branch followed up to its Leakage from the Gilbert. South-Westward up Gilbert River. Site of Future Miranda Downs Station (23rd September). Confluence of Einasleich and Gilbert Rivers. Gilbert River still followed up SouthWestward. Camp near Site of Future Gilbert Telegraph Office. Auriferous and Cupriferous Country. Turning near the Future Cumberland Township, the Gilbert River is Followed up Southward (29th September) to Junction of Robertson River. Up Robertson River (SE. and NE). Newcastle Range crossed. Copperfield River crossed North of Future Kidston Township. North-Eastward. Einasleigh River crossed (i2th October) South of Future Carpentaria Downs Station. Eastward. Across Watershed of Peninsula. Down the Dry River to the Burdekin (i6th October). Down Burdekin River to its Junction with Belyando River (2ist October). Miclere Creek. Gregory Creek. Mackenzie River. Arrives at Connor and Fitz's Station, Dawson River (22nd November). Via Rannes, Nanango and Caboolture to Brisbane (i6th December, i 856). Gregory's Very Accurate Charting.

$\mathrm{N} 1854$, at the instigation of the Royal Geographical Society, the British Government, although at the time much preoccupied with the Crimean war, organised an expedition designed " to lay open, if favoured with success, more of the interior of the great Australian Continent than the many energetic but partial attempts hitherto made have succeeded in developing." A sum of $£ 5,000$ was voted and it was understood that more 
would be provided if necessary. The command was given to Mr. (afterwards Sir) Augustus Charles Gregory, then Assistant Surveyor, Western Australia. The full party was thus composed:-

Commander: A. C. Gregory.

Assistant Commander: H. C. Gregory.

Geologist: J. S. Wilson.

Artist and Storekeeper: J. Baines.

Surgeon and Naturalist: J. R. Elsey.

Botanist: Ferdinand von' Mueller (afterwards Baron and Sir

Ferdinand).

Collector and Preserver: J. Flood.

Overseer: G. Phibbs.

Stockmen, छc.: C. Humphries, R. Bowman, C. Dean, J. Melville,

W. Dawson, W. Shewell, W. Selby, S. Macdonald, H. Richards, J. Fahey.

The proceedings of the expedition are summarised in a British Parliamentary Paper, ${ }^{1}$ while the Diary is given in a Collection of Mr. Gregory's Journals published by the Queensland Government."

The expedition was conveyed to the scene of its land operations by the barque "Monarch" and the schooner "Tom Tough," which left Sydney on 18th July, Brisbane on 12th August and Port Albany on 27th August, 1855. After passing through EnDEAvour Strait, Port Essington was reached on Ist September. The horses were landed at Point Pearce. The "Monarch" went on to Singapore while the "Tom Tough" was sent up the VIctoria RIVER to establish a depôt at the highest convenient point.

After preliminary rides, during which the McAdam Range was crossed and the Fitzmaurice River was reached, the land party left Point Pearce on 6th October. The Victoria River was reached on 17 th October, but it was not until the 2oth that Elsey and two men were found camped at a spring, and they told that the schooner had grounded lower down the river (below Mosquito Flat). With infinite labour the damaged ship was brought up the river to a point in $15^{\circ} 39^{\prime} 43^{\prime \prime}$, near Steep Head, where a depôt was established. Further reconnaissances connected the explorer's route with the points named during the voyage of the "Beagle."

Finally, a party consisting of A. C. and H. C. Gregory, Baines, Mueller, Flood, Phibbs, Bowman, Dean and Fahey started out, on 3 rd Fanuary, 1856, to the south-west to carry out the main purpose of the expedition in the exploration of new country. A second depôt was established in $17^{\circ} 43^{\prime} \mathrm{S}$. (approx. longitude

1 Papers relating to an Expedition recently undertaken for the purpose of Exploring the Western Portion of Australia. Presented to both Houses of Parliament, London, 1857.

2ख Journals of Australian Explorations by Augustus Charles Gregory, C.M.G., F.R.G.S., etc., and Francis Thomas Gregory. Brisbane Government Printer, 1884. 
$130^{\circ} 30^{\prime}$ E.) and a party of four (the two Gregorys, Mueller and Dean) continued the journey. A river, which was named the STURT, was followed to the SW. to $20^{\circ} 16^{\prime} 22^{\prime \prime}$, where it entered a dry salt lake (6th March). The party then made for the (second) DEPÓT CAMP, which was reached on 28th March. The party there, in charge of Baines, had been "somewhat annoyed " by frequent attempts on the party by the NATIves to burn them out. The principal DEPÔT CAMP near Steep Head was reached on 6th May. Elsey was in charge, Wilson having gone down the river to where the "Tom Tough" was still undergoing repairs. One member of the crew had died. All was quiet at the depôt. The natives had been respectful to the full party, but isolated units or small parties had at different times been threatened.

The journey on which Gregory crossed and recrossed the southern base of the Cape York Peninsula started From the DEPÔT CAMP On 21 st Fune, 1856, and the party comprised, besides the leader, H. C. Gregory, Elsey, Mueller, Bowman, Dean and Melville. They had thirty-four horses and five months' provisions. The general course followed was E. by N. as far as Leich hardt's ROPER River ( $14^{\circ} 50^{\prime} 56^{\prime \prime}$ S. lat. ; approx. E. long. I $33^{\circ} 40^{\prime}$ ), and thence south-eastward, parallel to the Limmen Bight-Bentinck Islands shore of the Gulf of Carpentaria to the meridian of $138^{\circ} \mathrm{E}$., which three years later was to become the dividing line between Queensland and the Northern Territory. ${ }^{1}$

In running down what was named ELSEY CREEK, a tributary of the Roper, the remains of a hut were noted. This was taken to be one of Leichhardt's camps on his last journey. On 19th July NATIVES were detected in the act of breaking into the camp and had to be scared away by a charge of shot. Two horses died from poison on the 2 Ist.

On $4^{\text {th }}$ August, Gregory identified Leichhardt's McArthur River, although he must have been still considerably south of Leichhardt's course of 1845 .

On rgth August, the expedition struck the waters of the Nicholson River, which were followed for more than a week to the east. On the 2 rst the 138th meridian was passed and the future territory of Queensland was entered. (SEE MAP N.) On $30 t h$ August, the river was found to bend from east to north and it was left behind, the party continuing to follow an easterly course, and after crossing a large tributary, now known as the GREGORY River, camped for the night on the left bank of the BARKLY' RIVER.

The Queensland portion of the Nicholson River was surveyed by Twisden Bedford in 1882 . Run-surveys made in 1889 by

1 This meridian line was run in $1885-6$ by the South Australian Surveyors Messrs. Poeppel and Carruthers.

2 Gregory spells the name " Barclay," but it was given in honour of Sir Henry Barkly, Governor of Victoria. 
J. T. Embley connected the Nicholson River with Lawn Hill Creek. (See Map M.)

Gregory was now in touch with the "Beagle" (I84I) and LeICHHARDT (1845), for the Barkly had only to be followed down a short distance when it received Leichhardt's BEAME's BRooK, ${ }^{2}$ shortly below which it widened into what Stokes called the Hope Reach of the "Beagle's" Albert River. Beame's Brook is in reality one of the channels of the Barkly or Albert River and, as it happens, the only one which carries running water through all but the most prolonged droughts. On the banks of the Hope Reach, certain marks on trees were understood to denote the presence, in the month of March, 1856, of a boat party sent up the Albert by Lieutenant Chirnmo, of H.M. steamer "Torch."

It had been arranged that the "Tom Tough" should await the land party on the Albert River, but she had evidently failed to make the rendezvous in time, and Gregory left instructions which it was expected would be found by Baines.

It appeared that, having reached Soerabaya, the "Tom Tough" was overhauled and pronounced to be in need of extensive repairs before she would be fit for a voyage to the Gulf of Carpentaria. She was therefore left behind, while another schooner, the "Messenger," was chartered for the service. The latter reached the Albert on I Ith November, and found Gregory's letters. She then sailed for Sydney by the west coast.

From the right bank of the Albert River below Beame's Brook, Gregory steered (3rd September) eastward for about Io miles over box flats and grassy plains to HARRIS $C_{\text {REEK, which he followed }}$ to the NE. for a few miles until he had satisfied himself that it was one of the heads of the "SAltwater Arm" of the Albert. (Here he was 8 miles SE. of the modern township of Burketown.) Then turning SSE., he crossed CROOKY CREEK, here running north, and another head of the Saltwater Arm. On the same course, he camped for the night at "Millar's Waterhole," on Millar CREEK, by far the longest tributary of the Saltwater Arm. The telegraph line from Burketown to Normanton, via Floraville, now crosses Millar Creek at the water-hole. The names Harris, Crooky and Millar designate the three branches of the SouthWestern Arm on modern maps, but there is nothing in the diary or report to indicate that they were bestowed by Gregory.

The following day (4th February) brought the party by a course still to the SE., to the bank of a large river which Leichhardt, who had crossed it about 12 miles lower, i.e., down stream, had mistaken for the Albert, but which Gregory now named the LEICHHARDT. Its course is to the north and it falls into the Gulf only 2 miles east of the Albert, the mouths of the rivers being interlaced by the Landsborough Inlet. Gregory's camp of 4 th

1 Beame's Brook Hotel of modern times is near the junction. 
September must have been at or very near the modern FLoravilLE STATION. It was visited in the evening by a party of nine armed BLACKS, who seemed at first inclined to be hostile, but eventually retired. On the following morning, however, they returned, reinforced to the number of nineteen, and rushed the party, when it was about to make a start, with poised spears, "but just as their leader was in the act of throwing a spear," says Gregory, "he received a charge of small shot. This checked them, and we charged them on horseback, and with a few shots from our revolvers put them to flight, except one man, who climbed a tree, where we left him."

Without notable incidents, the expedition, travelling eastward, crossed Punchbowl and " $M$ " Creeks, heads of Morning Inlet, "L" and Armstrong Creeks, tributaries of the Flinders, and reached the Flinders on 9 th September $\left(18^{\circ} 8^{\prime} 4^{\prime \prime}\right.$ ). Still keeping an easterly course, the camp of the Ioth September was on BRown Creek, a tributary of the Norman River. The Norman River itself was crossed next day and followed up, on its right bank, to SSE. to the camp in $18^{\circ} 18^{\prime} 5^{\prime \prime}$. (SEE MAP L.)

On the I 3 th September, they steered ENE., through box flats for five or six hours, and must have crossed BELMORE CREEKprobably not recognisable-some 50 miles below (west of) the present Croydon Goldfield. The course was then altered to the north till a dry creek in a rocky channel was met with, falling to the west, and this was followed down till 6.1 5 p.m. when a waterless camp was made. This was, no doubt, Clarina Creek. Next day water was found some distance down the creek, in $17^{\circ} 59^{\prime} 26^{\prime \prime}$, and the camp was shifted. This was probably about a mile south of the HAYDEN Station on the present NormantonCroydon Railway.

On I 5 th September, a course of N. $10^{\circ}$ E. (mag.) brought the party in six hours to "a small water-hole in a sandy creek, 15 yards wide," in $17^{\circ} 46^{\prime} 11^{\prime \prime}$. This must have been the CARron River (= CreEN CREEK), some 35 miles below (WNW. of) the "Creen Creek" Telegraph Office of the "seventies."

On the $16 t h$, on a general NNE. course, the party travelled to what must have been WiLLS CREEK, and then followed the creek down to the west in search of water. The camp had been made in $17^{\circ} 34^{\prime} 5^{\prime \prime}$, before water was found in a hole half a mile lower down. A day's halt was made for the sake of the horses.

On 18 th September, a day's march to North $10^{\circ}$ East (mag.) brought them to a fine lagoon on the bank of WALKER CREEK, in $17^{\circ} 21^{\prime} 20^{\prime \prime}$, about 36 miles below (west of) where the creek leaks out of the Gilbert River. Walker Creek is one of the mouths of the Gilbert, and falls into the Norman River a few miles before the latter reaches the Gulf. Two days were spent here in refreshing the horses, with the exception of one unfortunate which was killed 
for meat, the flesh being sun-dried. The ration of flour was reduced to three-quarters of a pound per day.

Three hours, on the 2Ist, on a NE. course, brought the explorers to the SMITHBURN BRANCH, or mouth, of Leichhardt's GILBERT RIVER. The branch was then followed up for some I2 miles and the camp was pitched on the southern or left bank of the GILBERT's main channel, in $17^{\circ} 18^{\prime} 5^{\prime \prime} \mathrm{S}$., just above where the "branch" leaks out of it.

The left bank of the Gilbert River was then followed up to ESE. The camp of 22nd September was above the outfall of Walker Creek. On the 23rd, east of where Miranda Downs Old Station was afterwards built, and west of the Bobby Towns Lagoon, the confluence of the EinAsLeigh River with the Gilbert was passed unobserved, and the left bank of the GILBERT was followed on a south-easterly course to a camp in $17^{\circ} 36^{\prime} \mathrm{S}$.

Gregory and his party crossed to the right bank of the river next day, and followed its south-easterly course, camping on 27 th September in $18^{\circ} 15^{\prime} 2 \mathrm{I}^{\prime \prime}$, near what is nоw Совв \& Co.'s "TоNкs" Stage. The night before, they had camped near the present GilberT Telegraph and Post Office. ${ }^{1}$ A belt of auriferous and cupriferous country was afterwards discovered to extend eastward from the Gilbert Telegraph Station, through the Cumberland and Etheridge.

Above "Tonks," the Gilbert River first comes from the east for about 12 miles, and then from the south. The party rounded this bend and camped on the right, or eastern bank, on $29 t h$ September in $18^{\circ} 25^{\prime} 33^{\prime \prime}$, about 4 miles above the junction of Macdonald Creek.

Some distance east of the river, but for the most part keeping it in sight, the party followed it up to the south on $29 t h$ and $30 t b$ September and Ist October, passing through what was afterwards known as the Green Hills Goldfield. (See Map P.) On the Ist October, the camp was in $18^{\circ} 40^{\prime} 29^{\prime \prime}$, on the right bank of a river which Gregory understood to be still the Gilbert, but he had in reality left the river about 2 miles back and was on the branch now known as the RoberTson River. After reconnaissances, an east-south-east course was taken and the camp on $4^{t h}$ October was in $18^{\circ} 47^{\prime} 54^{\prime \prime}$ on the left, or south-eastern bank of the Robertson River west of Mount Helpman. On the 5 th the camp was moved 3 miles ENE. up the river, and the three following days were spent in reconnaissances, while a fourth was lost owing to the straying of horses.

On Ioth and IIth October, the course of the march was to the east. The camp of the roth appears to have been between Bowman's Springs and the bend of the Robertson River, which here runs to the north. On the II $t h$, the "Newcastle Range"-by which Gregory appears to have understood the dividing ridge

1 Not "Gilberton," which is much further up the river. 
between the Robertson and the Einasleigh-was crossed, and the camp was made in $18^{\circ} 45^{\prime} 53^{\prime \prime} \mathrm{S}$., within a two hours' march (say 5 miles) of the Copperfield River.

On $12 t h$ October, after steering E. $30^{\circ} \mathrm{N}$. for an hour and threequarters, a creek coming from the south was crossed. It had a sandy bed 100 yards wide, but only a few pools of shallow water. [It must have been the Copperfieid River, about 12 miles below (north of) Kidston, the township of the modern OAKs Goldfield. -R. L. J.] On the same course, over basaltic country, another water-course was met with in the afternoon and the camp was pitched in $18^{\circ} 38^{\prime} 12^{\prime \prime}$ on a water-hole 70 yards wide. [This must have been the Einasleigh River.-R. L. J.]

Gregory believed the two rivers met with on this day's march to be tributaries of Leichhardt's LYND RIVER. As a matter of fact, they unite some 15 miles north of Gregory's track at the modern copper-mining township of Einasleigh, and the united stream, under the name of the EinasLeigh River, falls into the GilBerT about I70 miles lower. The Lynd has its source in the range which divides the Gulf and Pacific waters about 60 miles N.E. of Gregory's camp of I 2 th October.

This misconception persisted for some time after the establishment of Carpentaria Downs station on the Einasleigh, which was believed, even by the owner of the station, to be the Lynd. The Jardine Brothers first, in 1864 , settled the distinctness of the two rivers.

The progress made by Gregory on 13 th and 14 th October was to the east, mainly in basaltic country traversed by small tributaries of the Einasleigh draining to the SW. The camp of the I 4 th was on one of these, in granite country, in lat. $4 \mathrm{I}^{\circ} 38^{\prime} \mathrm{S}$. and long. $144^{\circ} 33^{\prime} 15^{\prime \prime} \mathrm{E}$.

On I 5 th October, the so-called "Great Dividing Range" was crossed early in the day, and at I.I 5 P.m. the camp was pitched, in $18^{\circ} 49^{\prime} 13^{\prime \prime}$, on a small tributary of the DRY RIVER, which falls into the Burdekin River. Following the Dry River to the SE., Leichhardt's Burdekin River was reached early next day, and the camp was made at 2 p.m. on its right, or western, bank in $18^{\circ} 57^{\prime} 4^{\prime \prime}$, about 9 miles above the present Greenvale head station. It must have been near the site of that station of the future that Gregory, on $I 7 t h$ October, noted trees which had been cut with iron axes and a bullock-bone, and judged these to be traces of LEICHHARDT's CAMP of 26 th April, I 845 .

As Gregory was now retracing Leichhardt's tracks, it is unnecessary to follow his progress minutely, but a few details may be noted. (SEE MaP Q.)

Still following the Burdekin down, Gregory observed, on 2rst October, in $19^{\circ} 16^{\prime} 22^{\prime \prime}$, that the BLACKs used throwing-sticks (wimmeras) to propel their spears. On 27 th October, he crossed 


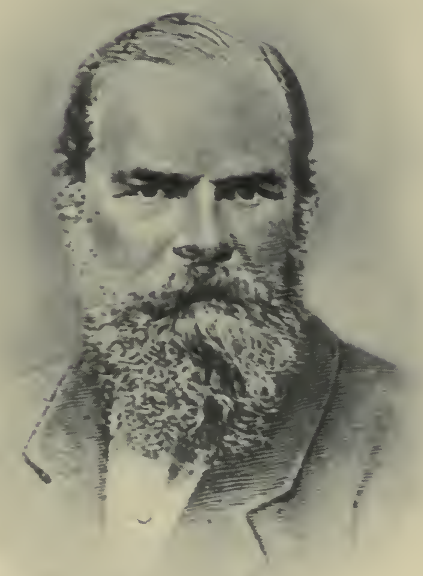

IVILLIAM LANDSBorough, I 870. 


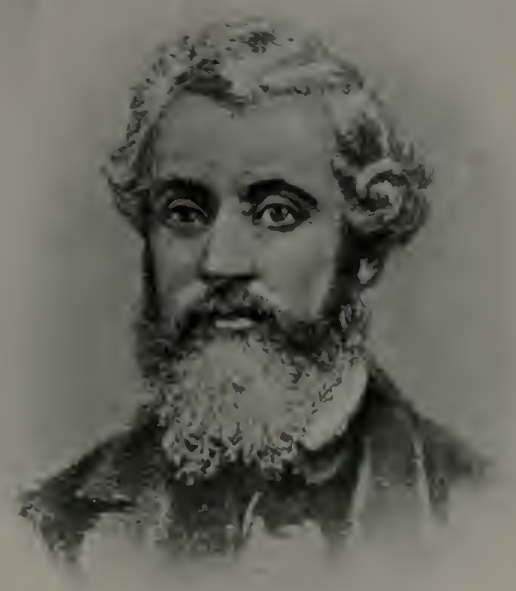

JOHX MUKINLAY, I 870. 
the Broughton River, south-east of Charters Towers, and camped at the mouth of GLADSTONE CREEK.

He followed the Burdekin to the SE., to its junction with the Suttor River, which comes from the south. He then followed up the Suttor to the south as far as lat. $21^{\circ} 22^{\prime} 43^{\prime \prime}$, where he placed his camp of 3 rd November.

Six miles south of this camp, the stream now known as the Suttor, branches off to the east. Gregory, however, followed southward on what is undoubtedly the more important watercourse, the Belyando, which he believed to be the Suttor. Ten miles above the Suttor, the Belyando is joined by another creek, which Gregory followed up to E. and SE., still in the belief that he was on the Suttor. This appears on modern maps as "Mistake CREEK," the name being apparently a sarcastic reference to Gregory's natural-and justifiable-mistake. A branch of this creek goes off to the SE. 45 miles above its junction with the Belyando, and is named Miclere Creek. Gregory camped on Miclere Creek on 8 th November, in lat. $22^{\circ} 26^{\prime} 16^{\prime \prime}$. Two days later he camped west of Blair Athol, on what is now known as Gregory CreEk, which runs WNW. into Mistake Creek.

Leichhardt's Mackenzie River was reached on 15 th November. (QueEnsland I6-Mile Map.) On the I7th, below the junction of the Comet and Mackenzie Rivers, one of Leichhardt's CAMPS on his second journey was identified. On the 22nd, the party arrived at Connor and Fitz's Station on the Dawson River (23 $5^{\prime}$ ' $5^{\prime \prime}$ S.). Thence, via Rannes (Hay's Station), Rawabelle, Boondooma, Tabinga, Nanango, Colinton, Kilcoy, Durundur and Caboolture. BRIsBane was reached on 16 th December, 1856.

Gregory did not travel by dead reckoning and rarely gave even his own estimate of the distance covered. But his carefully taken latitudes and occasional lunar observations for longitude are thoroughly reliable, and enable us to lay down the position of his nightly camps with confidence on modern maps. Kennedy was also an expert surveyor and may have been no less accurate on his Cape York Peninsula trip, but his records perished with him.

In addition to the charting of his route, Gregory made careful petrographical notes on the journey which we have followed, and these, so far as the Peninsula part is concerned, I have added to the map along his line of travel.

Gregory's expedition (March-July, 1858) in search of Leichhardt did not touch the Cape York Peninsula. 


\section{CHAPTER XXXIX}

\section{THE BURKE AND WILLS EXPEDITION, I860-61}

Flush Times in Victoria. A "Thorough" Inland Expedition planned. Police Inspector Burke, Leader, William J. Wills, Astronomical and Meteorological Observer. Eighteen Men leave Melbourne with Camels, Horses, Drays and 21 Tons of Provisions. Depôt at Fort Wills, Cooper's Creex. Tired of Waiting for Full Equipment, Burke makes a "Dash" for Gulf of Carpentaria, with Wills, King and Gray. Northward, 6th December, 1860. Up Diamantina River. Across Watershed and down Cloncurry River to its Junction with Flinders. Down the Flinders to the Gulf between Bynoz Mouth and Norman River, itith Frbruary, I86i. They mistake the Flinders for Stoxes' Albert River. Back to Site of Future Cloncurry Township. Selwy Range. O'Hara's Gap. Down Burke River. Site of Future Boulia Township. Death of Gray, i7th April. Burke, Wills and King reach Fort Wills in the Afternoon of 2 ist April. Party in Charge had left at Noon, leaving letter for Burke. Hopeless to overtake them. A Week in Camp. Death of Camels. Starvation. Living on Alms given by Natives. Attempt to go Westward to Eyre's Mount Hopeless frustrated. Search for and Preparation of Food (Nardoo) takes all the Time. No Progress. Death of Burke and Wills. King meEts Natives, who support him till he is rescued by Howitt's Search Party, i5th September. Death of Four Members of other Sections of the Expedition.

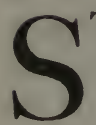

TRICTLY speaking, the famous "Burke and Wills Expedition" has no place in a history of the Cape York Peninsula. At its "furthest north" it merely touched one of the angles of the Peninsula, but its disastrous finish was the signal for the dispatch of a number of search parties, three of which were destined to add something to our knowledge of the region under review. ${ }^{1}$

1 Burke's Diary.

Tracks of McKinlay and Party across A ustralia, by John Davis, one of the Expedition. Edited from Mr. Davis's Manuscript Journal: With an Introductory View of the Recent Australian Explorations of McDouall Stuart, Burke and Wills, Landsborough, etc., by William Westgarth. London, 1863 .

$A$ History of the Discovery and Exploration of Australia, by the Rev. Julian E. Tenison Woods. London, 1865. 1888 .

The History of A ustralian Exploration from 1788 to 1888 , by Ernest Favenc. Sydney,

Stories of Australian Exploration, by Charles R. Long, M.A. Melbourne, 1903. Revised Edition, 1913.

A Short History of A ustralia, by Professor Ernest Scott. London, r9i6.

Anniversary Address of the President of the Royal Society of Victoria (Sir Frederick McCoy), 25th April, 1864.

G. Phillips, "The Victorian Exploring Expedition, 1860-6r." Queensland Geogr. Iournal, Vol. XXIII, 1908. 
The sixth and seventh decades of the nineteenth century were " flush" times in the new colony of Victoria, for the output of the goldfields had flooded it with prosperity. A period of lavish, extravagant and whimsical private spending suggested that the Colony should do something worthy of itself in its collective capacity, and a proposal for a thorough exploration of the interior of Australia by a strong party equipped as no previous party had ever been was enthusiastically taken up. A sum of $\oint_{1} 12,000$ was found in Victoria for the expedition itself, and it has been calculated that, including the relief expeditions, at least $£ .50,000$ was expended. An ideal leader seemed to have been found in Robert O'Hara Burke, a popular Inspector of Police. With him was associated William JoHn Wills, at first as astronomical and meteorological observer, but he soon became second in command. There were in all eighteen men when the expedition left Melbourne in August, I 860 , with at least 20 camels, numerous horses and drays and 21 tons of provisions.

A depôt, Fort Wills, Camp 65, was made on Cooper's Creek on the Queensland side of the South Australian border line, and here Burke and half the party waited for some time for the arrival of the other half, with the greater part of the stores. Burke soon grew tired of waiting and, having determined to make a dash for the Gulf of Carpentaria, left Fort Wills on 16 th December, 1860, accompanied by Wills, King and Gray, taking two horses, six camels and three months' provisions. On a course a little east of north, he struck the Diamantina, which he named and followed up, and then crossed the almost imperceptible watershed between that river and the Cloncurry, which latter river was struck at the site of the future Cloncurry township. (SEE MAP R.)

The Cloncurry (which Burke named after Lord Cloncurry) was traced down to the north till it fell into the Flinders, and the Flinders was then followed down till it debouched on the coastal plain and led the party of four almost to the sea. (See MAP M.) By this time it was the middle of February, I86I, and four of the camels had died and the stock of provisions had diminished to such an extent that a single exhausted pack-horse could easily carry it. King and Gray were therefore left behind on 9th February while Burke and Wills pushed on through the mangroves. They did not actually see the blue water of the Gulf, but they saw the salt water rushing through the tortuous passages in the mangrove swamps with the rise and fall of the tides. The camp (No. IIg, lat. $17^{\circ} 53^{\prime}$, according to Wills' Diary) where King and Gray were left behind has been identified by means of marked trees on the right bank of the Bynoe Arm (or mouth) of the Flinders, about 5 miles below where it leaks out of the river. Burke and Wills probably reached (I Ith February, i86i) a point between the Bynoe Mouth of the Flinders and the mouth of the Norman River. From the 
time when they struck the Cloncurry they had entertained the belief that that river and the Flinders were Stokes' AlberT River. As it happened, the mistake mattered nothing to them, but it meant a great deal to those who went out in search of them later on.

Burke and Wills having rejoined King and Gray (12th February), no time was lost in facing southward towards the depôt on Cooper's Creek. The party apparently retraced their steps past the site of the future township of Cloncurry (where they had first struck the river), and then followed the river up to the infall of the MALBoN River, after which it would be natural for them to shorten the way by taking the chord of the arc described on the outward journey in following up the Diamantina. (SEE MAP R.) Keeping on a southerly course and crossing the SELWYN RANGE by O'Hara's Gap, they struck a river falling to the south and now known as the Burke River. Following this river they passed the site of the future Boul.IA township (in Sheet $12 \mathrm{~A}$ ).

Three of the party reached the Fort Wills Depôt late on 2ist April, 1861. The fourth, Charles Gray, had succumbed, on the way, to fatigue and hunger on the 17 th. The day's delay caused by his obsequies had tragic consequences for the three survivors.

William Brahe and three other men had been left in charge of the depôt to await ( $I$ ) the arrival of the second half of the full expedition (with stores) and (2) the return of Burke and his companions from their ill-advised dash to the Gulf. Neither event, although long overdue, having taken place, and his own stores having been dangerously depleted, he left the camp at noon on the very day of Burke's arrival, having first buried a note to that effect, which was found by Burke. He also left some provisions.

Emaciated and footsore as Burke and his companions now were, they judged that they could not hope for success in chasing a party mounted on animals which presumably were fresh and in good condition. One is inevitably reminded of the agonising moment when Kennedy's party, left to starve and die at the mouth of the Pascoe, saw and failed to attract the attention of the rescue ship.

Burke, Wills and John King spent altogether about a week at the depôt, while in one false start one of the two camels died. Another false start was made and each man carried a bundle, in addition to a pack carried by the last camel; but they had not gone far when the camel knocked up and they had to return to the camp. Their plan had been to go down Cooper's Creek for some distance and strike west for Eyre's Mount Hopeless. The camel was shot and the meat sun-dried, and for a few days the men depended for food mainly on the alms given them by a tribe of friendly natives, who ultimately left them to their own resources. They then tried to live as the blacks did, but the time spent in finding and preparing nardoo to support life left them no time for 
progress towards their goal. Wills, unable to travel, was left behind, while Burke and King went back to the depôt in search of the natives. BURKE DIED next morning, and King returned to where Wills had been left, and found him also DEAD. BRAHE's PARTY, all this time, had not been far away. In fact, had the Gulf party waited at the depôt till 8th May, they would have been found by Brahe and Wright who, after they had effected a junction, visited the depôt together on that date. Strange to say, Brahe and Wright observed no trace of the Gulf party's recent occupation of the camp, and they themselves left no trace by which King, who returned a few days later, could gather that they had been on the spot.

Before it was too late, KING again fell in with the blacks, who supported him for nearly three months, until he was RESCUED by A. W. Howitr's search party on 15 th September.

One of Brahe's party, named Patton, died at the depôt. WRIGHT's PARTY, which was to have brought on the bulk of the provisions to the depôt, but failed to do so, was delayed by an outbreak of scurvy and the death of three of its members, Messrs. Stone and Purcell and Dr. Beckler.

In some respects the story of Burke and Wills is strikingly parallel to that of Kennedy. Both expeditions were marked by the high courage of their leaders, by their many mistakes in judgment, by the hamper of over-equipment, by the frequency of harrowing delays and disappointments, leading to fatal results, and by sufferings beyond the capacity of the human frame. But they differed widely as regards the attitude observed by the aboriginal NATIVEs. The northern tribes dogged Kennedy's footsteps day after day, malignantly watching for signs of exhaustion which would give them the opportunity to attack with impunity. On the other hand, the tribe into whose hands Burke, Wills and King fell, treated their guests with what was nothing short of philanthropy, considering their own limited means.

It has already been pointed out, in the case of the survivors of the "Maria," that even two neighbouring tribes might act on diametrically opposite principles. In one case there was barbarous murder, and in the other, help unceasing and unselfish. 
CHAPTER XL

\section{BURKE AND WILLS SEARCH PARTIES IN QUEENSLAND}

\section{LANDSBOROUGH, WALKER AND McKINLEY, I86I-2}

Search Parties leave before Success of Howitt's Party is known in Melbourne or Adelaide. Landsborough reaches Albert River by Sea. Depôt established at the Future Burketown. First Expedition leaves Depôt, 17th October, 1861. To Head of O'Shanassy River. Across Barkly Tableland to Site of Future Camooweal Township. Threatening Natives. Landsborough's Return. Beame's Brook. Walker's Tracks observed. Reaches Depôt, igth January, 1862. Second Expedition. South-Eastward. Crosses Leichhardt River above Tidal Waters, i4th February. SouthEastward up Alexandra River. To Flinders River near Donnor's Hill. Up River past Site of Future Richmond and Hughenden Townships. Observes Walker's Tracks in Walker Creek. Southward down Towerhill Creex and Thomson River. Warrego River. Williams' Station on Darling River. Discovery of Much Good Country. Race for Country follows.

Ernest Henry. Occupation of Hughenden Station. Discovery of Cloncurry Mineral Field. Attention redrawn to Stokes' "Plains of Promise." J. G. Macdonald starts, 3ist August, 1864, from Carpentaria Dowins, Einasleigh River, for Albert River. Macdonald traverses Future Etheridge and Gilbert Goldfields South-Westward to Gilbert River. Follows River down Northward to Site of Future Cumberland Township, and North-Westward to Site of Future Strathmore Station. Westward to Norman River near Site of Future Glenore Railway Station. Westward across Flinders River. South-Westward across Leichhardt River to Gregory River. Down Gregory and Albert Rivers to near Burketown (30th September, 1864). South-Eastward to Leichhardt River and selects Floraville as Site of Station to command "Plains of Promise." Return to Carpentaria Downs (22nd October, 1864). Takes out Cattle to stock Floraville.

Walker's Search Expedition leaves Nogoa River, i5th September, I86i. Emerald Downs. Barcoo River. Barcaldine. Aramac. Muttaburra. Cameron Downs. Afton Downs. Names Stawell and Woolgar Rivers. Northward down Norman River. Westward to Flinders River (near Future Milgarra Station). Observes Horse and Camel Tracks of Burke and Wills Expedition. Westward to Leichhardt River. Encounter with Natives. Sailors' Effects found in Native Camp. Sound of a Gun down the River. Gregory's Tracks observed. Buried Letter from Captain Norman directs Walker to Depôt (Site of Future Burketown). Walker reaches Depôt, 7th December, I86i, and meets Norman. Stores replenished. Hastens back to Flinders River. Runs Burke and Wills' Track down the River (Northward) to their Camp 119. Reaches Port Denison 5th MAY, 1862.

McKinlay's South Australian Search Expedition. Leaves Adelaide, i6th August, 186r. Finds Gray's Remains. Encounter with Natives. Hodgkin- 
son (Second-in-Command) sent to Blanche Water Station, S.A. Returns with News of Rescue of King by Howitt. McKinlay visits Graves of Wills and Burke. Determines to look for their Tracks in the North. Up Diamantina River. Up Hamilton River. Crosses Selwyn Range. Down McKinlay River to its Junction with Cloncurry River (3Oth April). Down Cloncurry River. Crosses and Names Dugald River. NorthWesterly to Gregory's Leichhardt River. Down River to the Gulf (Albert Inlet). Satisfied that Burke and Wills had not reached the Gulf here. Provisions diminishing. Makes for Port Denison. SouthEastward to Finders River. On Divide between Belmore Creek and Gilbert River. Subsequent Discovery of Gold at Croydon. Gregory Range. Up Gilbert River. Up Percy River to its Head. North-Easterly to near Site of Future Carpentaria Downs Station. Across Watershed. Down Dry River and Burdekin River. Last Camel killed and eaten. Loss of Horses. Bury "all but the Clothes they stood in." Harvey and Somers' Station on Bowen River (2nd August, i862). Strathmore. Native Police Camp. Arrive at Bowen. Leave by Sea for Rockhampton (i 7 th August, 1862). Founding of Bowen, 1861. Jimmy Morrill, a Shipwrecked Sailor, Sixteen Years among Blacks.

$7 \mathrm{HE}$ Brahe and Wright sections of Burke's expedition, having effected a junction and visited Fort Wills (8th May, I86I), hastened back to civilisation. Their reports reached Melbourne in the end of June, and steps were at once taken to send out various parties in search of the missing men. The most successful was that led by A. W. Howitr, which rescued the only survivor, KING (I 5 th September), and found the bodies of Wills and BuRKe. There was no occasion for this party to extend their search in the direction of the Cape York Peninsula.

\section{LANDSBOROUGH}

Moved by the Royal Society of Victoria, the Victorian Government, with the assistance of the Queensland Government, dispatched the "Firefly," a 200-ton brig, Captain Kirby, conveying William Landsborough and his party, who were to land at the Gulf of Carpentaria, and commence a search for Burke and his men. Unfortunately the brig was severely damaged at the Sir Charles Hardy Islands, but she was refitted and ultimately taken (with twenty-five horses) to the Albert River by Commander Norman of H.M. Colonial Steamship "Victoria," where the hulk was utilised as a depôt. ${ }^{1}$

1 Extracts from "Report of W. Landsborough, in Command of the Queensland Burke Relief Expedition, to Captain Norman, with reference to the Albert River. Sweers Island, 8th October, 186r." Proc. Roy. Geogr. Soc., Vol. XXXIII, p. 79.

Journal, "Landsborough's Expedition from Carpentaria to Victoria," ibid. p. 97.

G. Phillips, "The Victorian Exploring Expedition, I860-I," Queensland Geogr. Journ., Vol. XXIII, I908.

Dispatch from Governor Sir H. Barkly to the Duke of Newcastle, 2Ist August, 1862. Quoted in Proc. Roy. Geogr. Soc., London, Vol. XXXIII, p. I50.

C. Bourne, Journal of Landsborough's Expedition from Carpentaria in Search of Burke and Wills, Melbourne, 1862. 
The "Victoria" anchored on Ist October, 186I, 28 miles up the Albert River (20 miles in a straight line), where the water, although influenced by tides, was fresh. Landsborough recommended as a site for the proposed depôt to be formed of the "Firefly" hulk the vicinity of "a narrow mere which I called Wood's Lake," i.e., the site of the future township of Burketown. (SEE MAP M.) The report in which this recommendation is made was addressed to Captain Norman and is dated Sweers Island, 8th October. After that date, the "Victoria" must have come on to the Albert INLET, and established the depôt. Landsborough finally set out from the depôt on I 7 th October. As Burke had reported that he followed the Albert River to the sea, Landsborough's first task was to run that river up. He found its main feeder to be the GREGORY RIVER, which, with its important branch, the O'Shanassy, he traced to SSW., almost to the source of the latter, naturally without seeing any trace of Burke, who had mistaken a mouth of the Flinders for the Albert. (SEE MAPS N AND R.) He then crossed the Barkly Tableland to the south and followed down the Herbert (now Grorgina) River to $20^{\circ}$ I I' I $5^{\prime \prime}$ S. (27th December, I86I), i.e., to a few miles south of the present CAMOOWEAL township, where the threatening attitude of the NATIVES made it advisable, considering the numerical weakness of his party, to turn back. He named the Gregory and O'Shanassy Rivers, and the Seymour and Thornton Rivers, tributaries of the latter, the BarkLy Tableland and the Herbert (now Georgina) River.

On passing BEAME'S BROoK on his return journey from this "First Expedition," he observed (18th January, 1862) the tracks of an exploring party making for the depôt on the Albert. (These must have been WaLKER's TRACKs.) He reached the depôt early next day. (SEE MAP M.)

On what is called his "Second Expedition," Landsborough left the Firefly Hulk Depôt on 8th February, i 862. Crossing the LeichHardt River on I4th February, at a ford formed by a basaltic ledge, just above the influence of the tide, in latitude $18^{\circ}$ I0' $30^{\prime \prime} \mathrm{S}$. (where is now Floraville Telegraph Station), he struck out to the south-east and passed Donnor's Hill on the Cloncurry River-close enough to note that it was composed of sandstone and conglomerate-and reached the FLINDERS RIVER on I 9 th February. (SeE MAP R.) This course would take him up the valley of the AleXANDRA RIVER, a tributary of the Leichhardt, for about 40 miles and up the valley of its tributary, Collier $C_{R E E K}$, for some 16 miles, and then for a few miles across the watershed between the Alexandra and the Cloncurry Rivers. He then followed up the Flinders (SSE.) via Fort Bowen, Mount Brown, Mount Littrle, Hervey Downs, O'Connell Creek (near the modern township and railway station of Richmond), Sloane Creek, 
Walker Creek and Jardine Creek, to all of which places he gave their names. (SeE MAP Q.) Between Walker Creek and the Jardine he passed the site of the modern town of Hughenden. On 8th March, on O'Connell CREex, he saw CatTle tracks, and on WALKER CREEK he discovered TRACKs which he (no doubt correctly) believed to be those of Walker's Party. From the Jardine Valley he crossed the low WATERSHED BETWEen the GulF of Carpentaria and the Great Australian Bight and passed southward to Coxon CREEK, one of the heads of the Thomson River. Coxon Creek led him to Towerhill Creek, which he followed southward, apparently to its junction with Cornish and Landsborough Creeks, which unite with Towerhill Creek and form the Thomson River. From the Thomson River he crossed country to the south-east to the WARREGo RIVER, which he followed down to Williams' station on the DARLING (2Ist May, 1862).

As regards the primary object of his travels, the evidence procured by Landsborough was of a purely negative character, but perhaps more than any explorer of these regions he had the good fortune to demonstrate the existence of an enormous extent of first-rate PASTORAL COUNTRY.

The steamer "Victoria" was back in Moreton Bay on 14th March, 1862.

A sequel to Landsborough's expedition was the race for the magnificent pastoral country described by him. One of the first starters was ERnest Henry, of Mount McConnell station, near the junction of the Belyando with the Burdekin River. He had been, as a member of one of George Elphinstone Dalrymple's expeditions, among the earliest to follow up Leichhardt's discoveries in that region. In his early youth he had served as a subaltern officer in the Crimean War. Along with a companion named Devlin, he pushed through the spinifex country between the Cape and Flinders Rivers. Descending to the Jardine Valley, he followed the Flinders down to a point which he selected as the site for a new station, on which he bestowed the name of Hughenden, the Tudor manor house in Buckinghamshire owned by his grandfather, and known to fame in later days as the residence of Benjamin Disraeli. ${ }^{1}$ The name in due course passed on to the town which grew up near the station. Not long after the foundation of the station, Henry drifted westward and discovered the mineral riches of Cloncurry. He died at Epping, near Sydney, on 26th March, 1919.

Another of the immediate effects of Landsborough's expedition was the settlement of the fine "country" on the ALBERT RIVER, or Inlet. First observed by Sтокеs in 184I, the importance of this district was emphasised by LANDSBOROUGH in a manner which ensured attention. The leader in this new enterprise was Јонм 2 "Early Carpentaria," by " Pioneer." The World's News, 5th May, 1906. 
Graham Macdonald, who was already known in other districts as an enthusiastic explorer. When Landsborough's report became known, Macdonald started at once for the "Albert." He was then resident at Carpentaria Downs station, as Managing Partner of the firm of Towns and Black, of which Mr. (afterwards Sir) John Robertson was a member. ${ }^{1}$ This station had just been taken up, and was supposed to be on LeICHHARDT's LYND RIVER, but shortly afterwards Jardine proved it to be a tributary of the Gilbert and named it the Einasleigh. Macdonald's was the "old" station, not the one which now appears on maps " and which I saw in course of erection by the Brothers Barker in 1886.3 The "old" station (which was Jardine's starting-point in 1864) is about II miles to the north, down the Einasleigh.

Macdonald gives the position of the old station, from information supplied to him by A. J. Richardson, the surveyor attached to Jardine's expedition, as $18^{\circ} 37^{\prime} 10^{\prime \prime} \mathrm{S}$. and $144^{\circ} 3^{\prime} 30^{\prime \prime} \mathrm{E}$., and Richardson himself in his Journal ' gives the same figures, with the addition that the longitude was the mean of seven sets of lunar observations, and the latitude the mean of several northern and southern observations. The latitude is correct, according to modern mapping, but the longitude is about 8 miles too far west. (SEE MAP P.)

From the "old" station, then, which was at the time the "furthest north" of settlement, and which he left on 3ist August, r864, Macdonald struck south-west and saw the Robertson River (which he named) at the apex of its V-shaped bend to NW. and NE. Continuing to the south-west, he cut the Gilbert River, which he followed northward to the (future) Cumberland Goldfield. (See Maps Q and L.) The names Macdonald Town and MACDONALD CREEK are reminiscent of this trip, although they were bestowed by later comers. From the Cumberland, Macdonald followed the river on its westward and north-westward course to about opposite the modern STRATHMORE station, when, having headed the Carron (or Charron ?) River, he turned to the west. After crossing the Carron River, which falls into the Norman River, he crossed the latter at GLENORE, where the modern railway from Normanton to the Croydon Goldfield now crosses it. (SEE MAP M.) After crossing the FLINDERS River, he turned more to the south (almost to SW.) and, practically on the line now taken by the telegraph poles, struck the LeichHardt River in about $18^{\circ} 14^{\prime}$ S. latitude. Thence he went westward to the Gregory River, which-under the names of the Barkly and the Albert-he followed down north-

1 G. Phillips, Queensland Geogr. Journ., Vol. XXIII.

2 See 6-mile Sketch Map of the Croydon and Etheridge Goldfields, 1911, Publication No. 230 of Geological Survey.

seol. Observations in the North of Queensland, I886-7, by R. L. Jack, Govt. Geologist. Brisbane, by Authority, 1887 (p. 3).

t 3 oth February, I864, Journ. Roy. Geogr. Soc., London, Vol. XXXVI, p. 2 I. 
ward, almost, if not quite, to the site of BURKETOWN (30th September). Thence he returned (SE. by E. $\frac{1}{2} \mathrm{E}$.) to his former crossing of the Leichhardt, where he fixed upon the site of a head station, to be called Floraville, designed to command the greater part of what Stokes had designated the Plains of Promise nearly a quarter of a century before.

His return track to Carpentaria Downs was almost the same as his outward track; indeed, he generally camped at his old camps. On arriving, however, at the RoberTson RIVER, he ran the river up to its head. (Gregory had already run it up for some distance in 1856 , although he had not given it a name.) Macdonald arrived at Carpentaria Downs on 22nd October, 1864.

Very shortly afterwards he took cattle along his tracks to stock the new Floraville station. In May, I865, he chartered the " Fackmel Packet" for the conveyance of supplies to Burketown.

Mr. Macdonald, who afterwards was a Police Magistrate, died in Brisbane in 1918.

\section{WALKER, I861-2}

Frederick WaLker, an officer of Native Police, with troopers and a few white men, among whom were Haughton, Rodney and Macalister, was sent to search for Burke or his tracks on a traverse from the east coast of Queensland to the Gulf of Carpentaria. He came north by the "Firefly," which also carried Landsborough's party, and landed at Rockhampton, ${ }^{1}$ from which he travelled westward to "Mr. Macintosh's station on the Nogoa." The station was left behind on I 5 th September, I86I. Passing Emerald Downs on the 2oth, Walker reached Dismal Creek, a tributary of the BARCOo RIVER, at the intersection of the 146th meridian and 24th parallel, i.e., between the modern townships of BLAcKaLL and JeRicho. On $30 t$ October, after having, apparently, travelled via Barcaldine, Aramac, Muttaburra, Cameron Downs and Afton Downs, he reached (at his Camp 30) and named the Stawell River, which he then followed up about 12 miles northward to its junction with the Woolgar. (See Map Q.) Crossing the river (to which he gave its name), he struck out north-west, and on Ioth November (Camp 36) cut a river, running north-west, which might be either the "Bynoe" or the Norman. (SeE MaP R.) Modern charting proves that it was the latter. He followed

1 " Journal of Mr. Walker from the day he left Macintosh's Station on the Nogoa to that of his arrival at the Albert River, Gulf of Carpentaria," Journ. Roy. Geogr. Soc., London, Vol. XXXIII, p. 133.

Ernest Favenc, History of A istralian Exploration, Sydney, 1888, p. 396.

John Davis, edited by William Westgarth, Tracks of McKinlay and Party across A ustralia. London, 1863 .

Governor Sir H. Barkly, Dispatch from, to the Duke of Newcastle, 2 Ist August, 1862, in Journ. Roy. Geogr. Soc., London, Vol. XXXIII, p. I50.

G. Phillips, "The Victorian Exploring Expedition, I860-I," Queensland Geogr. Journ., Vol. XXIII, 1908. 
this river down for $\mathbf{I} 20$ miles and left it, near his Camp 48, on 25th November. (See Map M.) His 45th Camp (2 Ist November) was opposite the site of the modern Vena Park Station.

West of Camp 48, he struck the Flinders River (25th November, Camp 49) about 3 miles north of Gregory's camp of 9 th September, I856, and 6 miles north of the modern Milgarra station, but had to follow up the right bank of the river to the south for a couple of miles above Milgarra before he found a convenient crossing. On the bank of the river he found CAMEL AND HORSE TRACKS, making down stream, which could only have been made by BuRKE's expedition.

Keeping a course of west by north from the Flinders, almost on Gregory's track, he crossed Armstrong, "L," Goat and "M" CREEKS, camping on the latter (28th November, Camp 52) near the Geary Hills. He recognised this as very good pastoral COUNTRY.

On Ist December, salt water was met with on LAGoon CREeK, a tributary of the Leichhardt, and after a considerable southward detour the LeIchHARDT River itself was reached. But it was "salt"as brine." Followed up to SSE. for 8 miles it was still salt, but fresh water was found in a small creek (Camp 55, Ist December, 186r). Here the NATIves made a threatening attack. Few details are given, but it is stated that " their (the blacks") right wing, which was the strongest, got over the river and were off, but the centre and left wing suffered a heavy loss." Near the camp, a camp of the natives was found to contain a sailor's jumper and an empty brandy bottle.

Steering NNW., Walker's Camp 56 (2nd December) was on Millar's CREEK, close to Gregory's of 3rd September, 1856. A course of NNW. brought him next day (Camp 57) to the Albert (Barkly or Gregory) River, where the water was slightly salt and influenced by the tides. After the camp had been made snug, the sound of a GUN was heard down the river.

Near this camp, on the 4 th, a tree marked by GREGoRY (1856) was found, and also a buried bottle containing a letter from CAPTAIN Norman, dated 29th November, stating that the "Victoria's" depôt was 12 miles down the river (i.e., on the site of the modern town of BURKeTOWN). Walker crossed the BARKLY River and BEAME's BRook, and on 7th December, 186I, "shook hands with Captain Norman."

6- At the depôt, Walker was supplied with the rations and stores necessary to replenish his equipment, and eagerly addressed himself to the task of taking up BURKE's TRACKS from the point where he had seen them on the Flinders. He hastened back to the Flinders, no doubt, avoiding the difficulties which had delayed him on his outward course, and succeeded in tracking Burke to " two or three camps," i.e., probably to his Camp II9, when he 
had to give it up, owing to the obliteration of the hoof-marks by rain. His exact course from this point to Port Denison, which he reached on $5^{t h} M a y$, cannot be traced, as his journal, as printed by the Royal Geographical Society, ends with his meeting with Captain Norman. Westgarth's map in "McKinlay's Tracks" sketchily indicates Walker's homeward route, and if the sketch is correct, Walker's route must have been partly up the Lynd (and it is difficult to imagine what could have taken him there) and on, via Bowen, to Rockhampton. On the other hand, Landsborough saw TRACKs which there was every reason to believe to be WALKER'S on what he named WALKER'S CREEK, between Richmond and Hughenden, so that the probability is that Walker ran up the Flinders and struck eastward for Port Denison, crossing the heads of the Thomson and Cape Rivers, and the Belyando and Bowen Rivers on his way to Port Denison.

Walker's correspondence with Captain Norman shows that his first intention was to make for Adelaide via Eyre Creek on the conclusion of his task of tracking the hoof-marks of the camels. Seeing where he left the camel track, he probably argued that Burke and Wills must have made good their return to Fort Cooper, and he was probably influenced by considerations of his own chances of not finding water on Eyre Creek in deciding in favour of the Port Denison route.

\section{McKINLAY}

John McKinlay was born at Sandbank, on the Clyde, in 1819, and settled in Australia when still a young man. McKinlay's party (officially known as the South Australian Burke Relief Expedition) was composed of W. O. Hodgkinson (second in command), afterwards Minister for Mines, Queensland; John Davis; Robert Poole; Middleton (camel driver); E. Palmer (bullock driver); Bell and Wylde; and Frank, an aboriginal. It left Adelaide on $16 \mathrm{tb}$ August, 186I. The work of the expedition had already been done by Howitt, although the news had not yet reached Adelaide. On 2oth October, McKinlay found human remains $\left(27^{\circ} 15^{\prime} \mathrm{S}\right.$. ; $140^{\circ} \mathrm{E}$.), which must have been those of Gray, although, misled by cock-and-bull stories told by the blacks in circumstantial detail, he regarded them as evidence of the massacre of the whole of Burke's party, followed by a cannibal orgy. He had a rather serious encounter with the NATIVEs three days later. Hodgkinson was shortly afterwards sent back on a mission to Blanche Water Station, in South Australia, and on his return, in about five weeks,

1 " Diary of Mr. J. McKinlay, Leader of the Burke Relief Expedition fitted out by the Government of South Australia," Proc. Roy. Geogr. Soc., Vol. XXXIII, p. 13.

Tracks of McKinlay and Party across A ustralia, by John Davis, edited by William Westgarth. London, 1862.

Anniversary Address of the President of the Roy. Soc. Victoria (Sir Fredk. McCoy). 25th April, 1864. 
brought the news of Howitt's rescue of King. McKinlay next found Howitt's camp and visited the graves of Wills and Burke.

Leaving the region which had already yielded up its story, McKinlay determined to get on the track of Burke further north. According to his diary he ran up the "Mueller River" (the Diamantina) to its head ( $22^{\circ} 40^{\prime} \mathrm{S}$. lat., $8 \mathrm{th}$ April, 1862). It is now understood that he actually came up the Hamilton River, east of Boulia, crossed the SELwyn Range by "McKinlay's GAP," and ran for some distance northward down the "MCKinlaY River." (SEE MAP R.) He probably followed the McKinlay (which, lower down, is called the Gilliat) down to its junction with the Cloncurry (3oth April), which latter river here, and here only, runs, as described by him, from west to east, its general course being from south to north. Twenty-five miles below the junction, viz., at Caroline Creek, the CloncurRy River approaches the Flinders River (which lies east of it), and for the next 32 miles of their northerly course the two rivers are seldom as much as 4 miles apart. In fact, now that the rivers have deployed on the coastal plains, the usual " anastomosis" has commenced, and from the Cloncurry eastward, high floods would connect that river with channels running into the Flinders, the Saxby and the Norman Rivers.

Keeping the left, or western, bank of the Cloncurry River, McKinlay crossed and named the Dugald River (2nd May, i862). He had been practically on Burke and Wills' track since he struck the Cloncurry, but observed no trace of the lost expedition. By the time he crossed the Dugald, however, he must have been fully convinced that the river he was following, lead where it might, was not taking him to the Albert Inlet, although Burke and Wills had believed they were on the Albert when they reached the sea 72 miles east of that inlet. He, therefore, steered north-west from the Dugald River and, on $6 t b$ May, struck Gregory's LeichHardt River in $18^{\circ} 55^{\prime} \mathrm{S}$. lat. ( 7 miles below the modern LORRAINe cattle station). He then followed the Gregory down to the north (past the modern Augustus Downs station) to the sea (Camp 6o, I 8tb-21st May, I862). (See Map M.) This camp was probably between the ALBERT INLET and LANDSBOROUGH INLET, the latter of which connects the Albert with the Leichhardt. In spite of the mistake which he was now aware Burke must have made, McKinlay had to visit the Albert Inlet, where he might chance to meet the parties which were to come by sea and commence the search from the Gulf. He saw a tree which had marked Landsborough's Camp 5 in February, 1862.

He had now proved that the Albert was not the river which Burke and Wills had followed to the sea : the ship which had conveyed Landsborough's expedition had already left the inlet. His provisions were diminishing to danger-point; he knew that the 
lost men had been found, and there was no further reason why he should linger. Therefore, as his rations would not suffice to carry him back to Adelaide, he made for Port Denison, then the northmost known harbour on the east coast.

Retracing his steps up the Leichhardt, he crossed to the right bank about 6 miles north of the site of the present Floravilue Telegraph Office. Thence, on an eastward course, differing little from Gregory's (1856) and Walker's (December, I86I), he came, on 5 th fune (Camp I 2), to a large, broad creek, or mass of creeks, or river-the Flinders. His I4th Camp (7th-IIth fune) was on the Norman River (which he named), opposite Gregory's camp of roth September, 1856, and Walker's camp (No. 48) of 24th November, 186r. From the Flinders, he travelled, mainly E. by S., crossing the range (sandstone on-granite) dividing tributaries of Belmore Creek from tributaries of the Gilbert River. (SER MAP L.)

[The modern Croydon township is on Belmore Creek, about Io miles north of McKinlay's track, and is the centre of the goldfield which was opened in January, I886, in consequence of the discovery of payable gold by W. C. Brown, the owner of Croydon Downs cattle station, and the brothers $\mathrm{T}$. and R. Aldridge. In 1887 , the population was about $\left.6,000 .^{1}\right]$

The range which McKinlay crossed south-east of Croydon was named by him the Gregory RANGE. It has since proved fairly rich in reef GOLD and stream TIN. McKinlay was under the erroneous impression that the waters draining the south-western side of the range represented the principal head of the Flinders. Turning to the south-east, he struck the Gilbert River, which he provisionally called Stuart Creek, being unaware of the name it already bore. He followed the Gilbert to the south-east till the Percy River fell in, and traced the latter north-eastward to its source (Percyville, now a gold and copper-mining centre). (See MaP P.) From the head of the Percy River, McKinlay appears to have kept the same north-easterly course, crossing the CoPPERFIELD RIVER near the modern mining township of KIDSTON, and the Einasleigh River south of the now "old" (but then nonexistent) Carpentaria Downs station. Then, crossing the "Great Dividing Range" (here unimportant) between the Gulf and Pacific Waters, he got on the head of the DRY RIver, and followed it, and the BURDEKIN River, into which it flows, down to the junction of the BELYANDO RIVER, practically on Gregory's tracks. (See Maps O and Q.) All the way down the Burdekin, dray tracks

1 Geological Observations in the North of Queensland, 1886-7. By Robert L. Jack, Government Geologist. Brisbane. By Authority, 1887 .

Report on the Croydon Goldfield. By William H. Rands, Assistant Government Geologist. Brisbane. By Authority, 1896.

Some Croydon Gold Mines. By B. Dunstan, Acting Government Geologist. Brisbane.

By Authority, 1905. 
were seen, but no settlers were met with. The last of the CAmels was killed for food on 3 Ist July and the horses were by this time reduced to nineteen. This day he and his party buried " everything but the clothes they stood in."

On 2nd August, 1862, McKinlay reached civilisation at Harvey and Somers' station on the Bowen River (a tributary of the Burdekin). Five miles further they reached Strathmore station, where Messrs. Sellheim ${ }^{1}$ and Toussaint, the owners, entertained them hospitably for a week. Near the station was a camp of NATIVE POLICE, under a white sergeant. Troopers were sent back for the valuables buried on the Burdekin.

The party embarked at Port Denison on I7th August, r862, in the "Ben Bolt" (80 tons), Captain Tom McEwin, for RockHAMPTON.

Incidentally, it may be mentioned that Port Denison was discovered by the "Burdekin Mouth" party in 1860, and Bowen was founded in 1861 .

Westgarth refers to the discovery of JIMMY MORRILL about six months after McKinlay's arrival at Port Denison. Morrill was the sole survivor of twenty-one men who left the wrecked "Peruvian" in 1846 and landed from a raft on the north side of Cape Cleveland, in which neighbourhood he lived among the blacks for the next sixteen years. Morrill's experiences form the subject of a pamphlet written by himself, and of considerable ethnological value. (Fames Morrill. A Sketch of a Residence among the Aboriginals of North Queensland for Seventeen Years. Brisbane, Courier Office, 1863, 8vo, pp. 24.)

1 P. F. Sellheim, afterwards a Police Magistrate and Goldfield Warden, and UnderSecretary for Mines. 


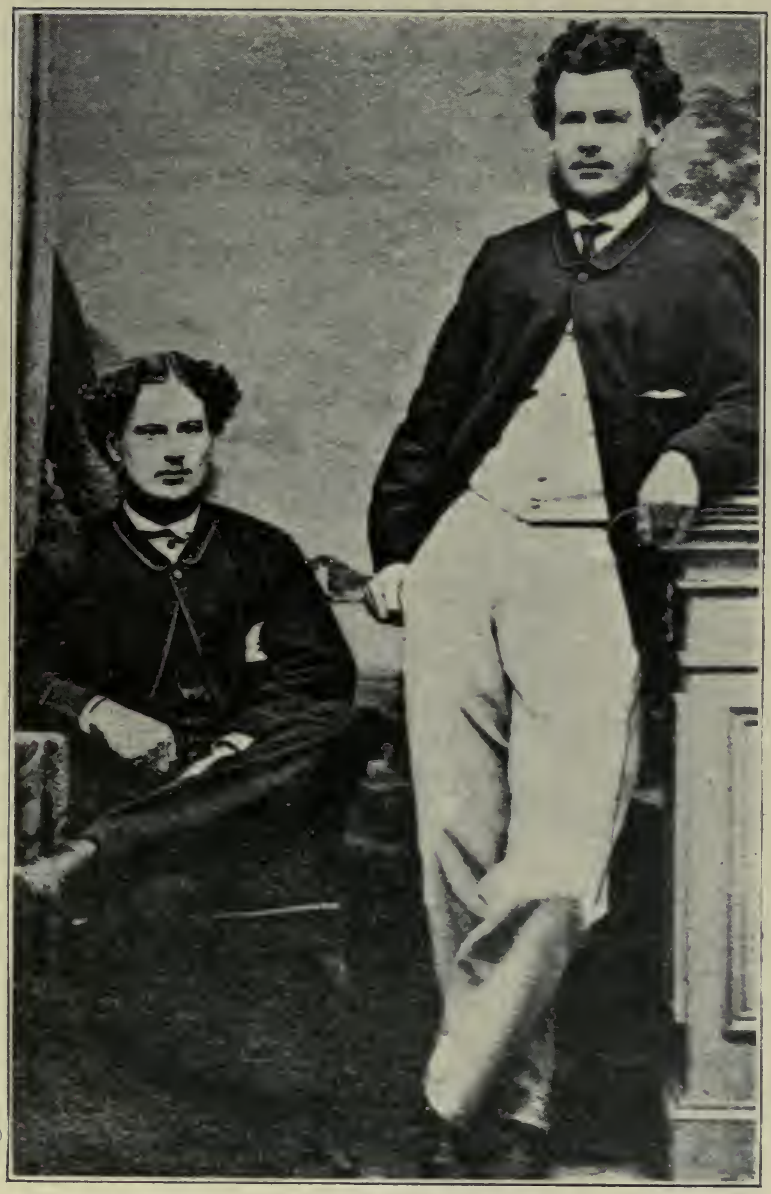

FRANK (left ) AND ALICK JARDINE (right), I 867. 


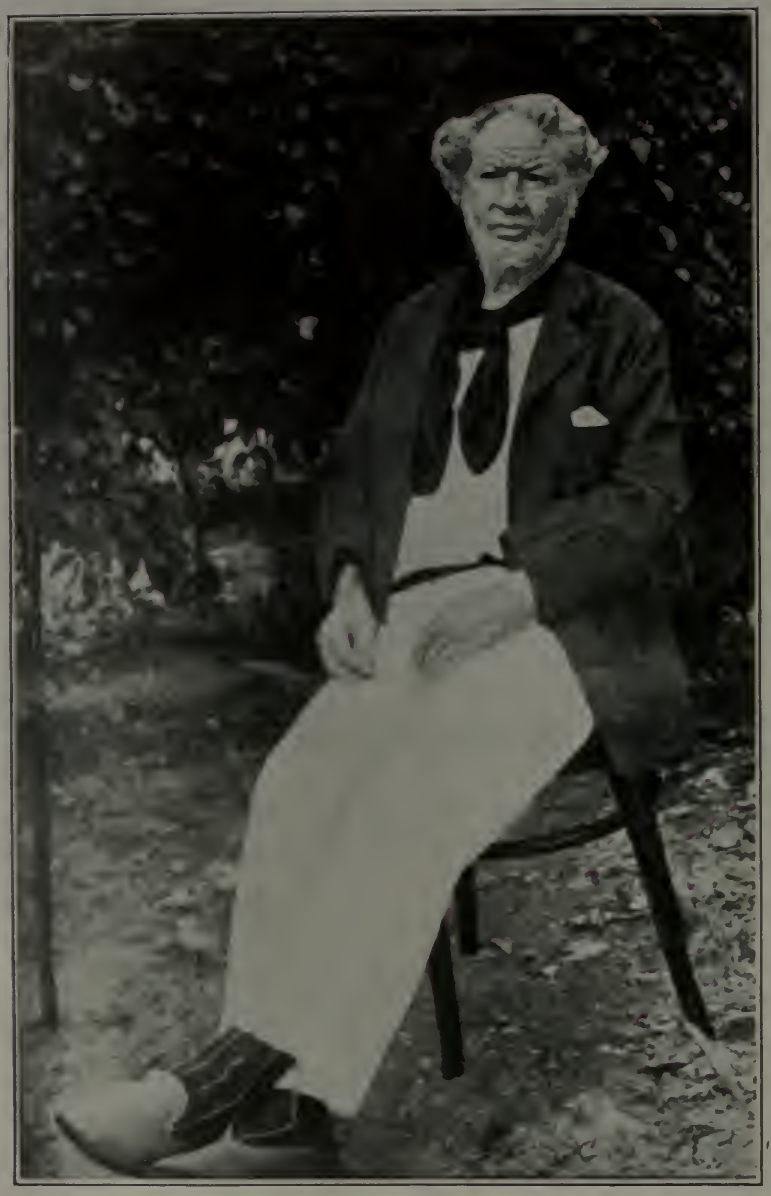

FRANK JARDINE, I9I7. 
THE JOURNEY OF FRANK AND ALEXANDER JARDINE (1864-5) FROM ROCKHAMPTON TO SOMERSET

\section{CARPENTARIA DOWNS VIA EINASLEIGH RIVER TO THE MOUTH OF THE ETHERIDGE RIVER}

Progress of Settrement of Queensland up to 1864. Somerset. Names of Members of the Expedition. Cattle and Horses to stock a Station. Equipment. Camp at J. G. Macdonald's Carpentaria Downs Station, which was supposed to be on Leichiardt's Lynd River. Alick's Reconnaissance down the River, which is named the Einasleigh. His return to Carpentaria Downs. A. J. Richardson, Surveyor. His Narrative and Map. F. J. Byrrley edits the Brothers' Diary. Expedition leaves Carpentaria Downs. Down Einasleigh River to Infall of Etheridge River. Camp 13. Cannibalism. Summary of Itinerary. Einasleigh River falls into Gilbert River. The Dutch Staten Revier, de jure, is one of the Mouths of the Gilbert River.

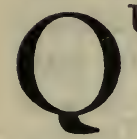

UEENSLAND was separated from New South Wales in I859. The Governor of the new colony, Sir George BOwEN, on his return from a voyage to the northern ports, recommended Somerset, Cape York, as the site of a settlement, "on account of its geographical importance, as harbour of refuge, coaling station and entrepôt for the trade of Torres Strait and the North Pacific." Mr. John Jardine, then Police Magistrate and Gold Commissioner at Rockhampton, was placed in charge of the new settlement as " Government Resident" and a detachment of marines was landed in 1863 .

Gradually as it became evident that the prevailing industries of the new settlement were destined to be chiefly maritime, Thursday IsLand, off the mainland of Cape York, became the chief depôt for the ships engaged in the search for pearls, pearl-shell and bêche de mer and the seat of Government was eventually transferred to the island.

Shortly after his installation, Mr. Jardine foresaw the necessity for a regular supply of FRESH MEAT to the new settlement, and proposed to the Government to send his two sons, Frank (22) and Alick (20) overland with a herd of cattle to form a station from which it might be supplied. The proposal was agreed to and the Government instructed a surveyor to accompany the expedition.

With all the advantages of health and youth, and above all, of training from their childhood in the bushmanship which Australia requires and bestows, the two brothers were unusually well qualified 
to lead such an expedition as that on which they were about to embark. For them no glamour of romance shone in the far north to lure them to adventure. Their object was strictly business. Their attitude towards the natives was from the first fair and considerate, but on the other hand they were determined to "stand no nonsense." The lessons unintentionally taught by Leichhardt and Kennedy had not been thrown away upon the young explorers. They chose their line of advance with a view to its capacity for the support of travelling cattle.

In the sixteen years that had elapsed since Kennedy had set out from Rockingham Bay, the settlement of northern Queensland had made rapid strides. Ports had been opened at MAckay, Bowen, CARDWEll and Somerset, and pastoral occupation was approaching the Gulf of Carpentaria. The whole of the CAPE York Peninsula, however, was still unoccupied except for the settlement at its extreme northern point, and the BROTHERS JARDINE were destined to be the FIRST TO TRAVERSE IT from end to end. The ill-starred KENNEDY, as we have already seen, almost succeeded, but laid down his life within a few miles of the goal.

The younger brother, Alick, led a party of ten, with thirty-one horses, overland from Rockhampton (I4th May, 1864) to Bowen (17th June). Six more Horses were added when the elder brother, Frank, joined the party at Bowen on I6th July and five more belonging to Mr. Richardson, the Surveyor, brought the total up to forty-two. The CATTLE were collected at Bowen, and, as opportunity offered, between Bowen and Carpentaria Downs. The latter station, which had recently been taken up by J. G. Macdonald, was at that time the NORTHMOsT dwelling-place along the Jardines' route, and they selected it as the spot where their expedition was to be finally mobilised.

The PARTY which left Carpentaria Downs included: Frank Lascelles Jardine; Alick Jardine; Archibald J. Richardson (Surveyor); C. Scrutton; R. N. Binney; A. Cowderoy and four black boys named Eulah, Peter, Sambo and Barney; ten persons in all. They carried " provisions estimated to last, with care, four months." The main item was $1,200 \mathrm{lb}$. of flour. The "mob" of cattle numbered about 250 head of bullocks and cows.

The Carpentaria Downs station of these days was the "old" STATION, now shown in the 16-mile map in $18^{\circ} 37^{\prime} 10^{\prime \prime} \mathrm{S}$. lat., while the modern station, of which I saw the beginnings in $\mathbf{I} 886$, is also shown on the map in $18^{\circ} 44^{\prime}$. (SEE MAP P.) It was situated on the right, or eastern, bank of the EINASLEIGH River which was then believed to be Leichhardt's "LYND." A station higher up the valley, to the south, still retains the latter name.

While waiting for his brother at Carpentaria Downs, Alick JARDINE set out on 3 rd September to reconnoitre the route to be followed by the expedition down the supposed Lynd River. He 
was accompanied by HARRY BODE (who was on the look out for cattle country), his own black boy "Eulah" and Mr. Bode's black boy. It may be mentioned that I met Mr. Bode in I 879 when he was residing near Bowen. Alick JARdine traced the river for I 80 miles, to north-west and west, and from the fact that it had not joined Leichhardt's Mitchell River, and other circumstances, he satisfied himself that it was NoT THE LYND, and the name "Einasleigh" was conferred on it. No adventure marked the outward journey. On the return two parties of Natives were met with, but they displayed no hostility. The party RETURNED, on 2 Ist September, to Carpentaria Downs, where they remained till the arrival of Frank Jardine, with the cattle, on 6th October.

The JaRDine BRothers kept DiARIEs which were afterwards edited by Frederick J. Byerley, Staff Surveyor, Rockhampton, a gentleman whom I afterwards knew, and who was gifted with literary talents which made the task a congenial one. Byerley's amplification of the diaries, under the title of Narrative of the Overland Expedition of the Messrs. Fardine from Rockbampton to Gape York, Northern Queensland, was published in Brisbane by $\mathrm{J}$. W. Buxton in 1867 .

RICHARDSON also kept a DIARY and charted the route travelled, and a paper by him, entitled $A n$ Overland Expedition from Port Denison to Cape York under the Command of $F$. and A. Fardine, Esqrs., was read before the Royal Geographical Society of London on 27 th November, 1865 . The paper was accompanied by a MAP on the scale of 40 miles to an inch showing the route followed by the main expedition. As he always accompanied the main caravan, he had no first-hand information to give regarding the numerous and important reconnaissances of the brothers.

BYERLEY's publication also includes a MAP (on a 38-mile scale), which is practically Richardson's, with the addition, however, of KENNEDY's route and with the omission of the Lynd River (of Leichhardt's charting). Regarding KENNEDY's route, as charted by Byerley, it may be observed that it differs considerably from the route as I have charted it, by the aid of surveys which were nonexistent in Byerley's time.

The expedition finally left Carpentaria Downs on in $t h$ October. It is only possible to give a short summary of the incidents and observations made by the travellers until they come within the region which is more immediately the subject of this review. (SER MAP K.)

Between the IIth and 22nd October, the caravan had covered I20 miles down the Einasleigh Valley, the last camp (No. 13) being near the right bank of the river about 5 miles above the point where the Etheridge River, coming from the south, falls into the Einasleigh. (SEE MAP L.) In this portion of their course, except for the last day and a half, the travellers found 
exceedingly rough country, their choice of evils often being between barren ridges and a river bed hemmed in by basaltic cliffs or flowing over high bars of granite; both horses and cattle suffered severely and the cows began to calve.

The BLACKs gave no actual trouble, although they had to be carefully guarded against. About fifty of them, "painted and fully armed," dogged the heels of the party on 15th and 16th October from Cawana Swamp to opposite Barney's Nob. Another "mob" was surprised on the I8th and decamped with their weapons, which included spears and a large stone axe. On the following day, near the lower junction of the anabranch named Parallel Creek, human remains were seen roasting on a fire. "Whether this was the body of an enemy cooked for food or of a friend disposed of after the manner of their last rites must," says Frank, "remain a mystery until the country and its denizens become better known." On the 2Ist, two blacks were seen spearing fish. It was judged advisable that the CATTLE AND the majority of the HORSES should REST AND FEED at Camp I3 while the brothers reconnoitred the proposed course. The valley had now become more open and it was surmised that a way might be found to the north, whereas the Einasleigh was now bearing them steadily westward. It is now known that the EinASLEIGH falls in to the right bank of the Gilbert River about 50 miles west of the Jardines' Camp 13. To one of the mouths of the Gilbert, Accident Inlet, Jan Carstenszoon, on the Dutch ship "Pera," gave the name of the Staten River on 24th April, I623.

The following is a brief summary of the ITINERARY of the expedition from Carpentaria Downs "Old Station" to the mouth of the Etheridge River, as read in the light of modern maps :-

I $t$ th October, I 864.-Down Einasleigh River, NW. Byerley says 20 miles, Richardson 19. Distance by map, 14 miles. (SEE Maps P And K.)

At 5 miles passed Mount Eulah (now called Mount Harry), Camp No. I, a mile N. of junction of Copperfield River, near Einasleigh Copper Mine and Einasleigh Station on the modern RAILWAY from Chillagoe to the Etheridge. Richardson gives LATITUDE of camp as $18^{\circ} 23^{\prime} 59^{\prime \prime}$, which is 7 miles too far north.

I2th October. - Shifted to CAMP 2, I I miles down the EinasLEIGH. (SeE Map K.)

1 . I 3 th October. - Travelled NNW. down the Einasleigh. Passed the Mount Alder gold diggings of the future. Passed lagoon now known as "JARDine's LAGoon," CAMP 3, on a small dry creek (Lighthouse CReek ?). Distance travelled II miles (B.), IO miles (R.)

I 4 th October. - Travelled I I miles NNW. down the Einasleigh. CAmp 4 on junction of Canal Creek with the river. The creek is described as "deep, sandy and dry, 80 yards wide, coming from 
ENE., its banks steep, and lined with immense Melaleuca trees"; " also," says Byerley, quoting Jardine, "some magnificent Leichhardt trees." The only creek that would answer to this description is the one now called Junction CreEk, in which case the distance travelled is understated by 5 miles, and the camp is on the site of the modern Amby Cattle Station opposite the Einasleigh Hot SPRINGS.

I 5 th October.-Travelled 8 miles NNW., a mile or two from the right bank of the Einasleigh. CAMP 5 is among the hills called by the Brothers the JörgenSEN RANGe and the western edge of a swamp which they called Cawana Swamp. Richardson gives the LATITUDE as $18^{\circ} 2^{\prime} 7^{\prime \prime}$, which may be taken as correct.

I6th October.-Travelled NW. : I I miles (R.), Io miles (B.): winding through the JörGensen RANGE. CAMP 6, at the point where Warroul Creek falls into Parallel CReek, which here leaves the Einasleigh River as an anabranch, to fall in again 22 miles lower. Warroul Creek has got into the maps as ElizabETH CREEK, and was identified by W. Hann in 1872 as the creek on which Mount Surprise Cattle Station was situated. Mount Surprise is now a station on the Chillagoe-Etheridge Railway.

I7th October.-PARALLel CREeK is separated from the Einasleigh River by a high ridge of Basalt. Travelled WNW. down Parallel Creek 8 miles (B.), $7 \frac{1}{2}$ miles (R.). CAMP 8 was in bed of creek (Byerley calls it Camp 8, although really Camp 7, and his numbering is followed with the object of facilitating reference to his narrative).

I8th October.-WNW., down Parallel CReek, which had now become a gorge. IOT miles (R.), Io miles (B.). CAMP 9.

Igth October. -W. by N. 8 miles. Midway, the lower confluence of Paralled CReek with the Einasleigh was passed. Camp IO on an alluvial flat on right bank of river. The LATITUDE given by Richardson ( $17^{\circ} 45^{\prime} 40^{\prime \prime} \mathrm{S}$.) is about right. (SEE MAP L.)

2oth October. -WNW., i I miles down the Einasleigh. At 6 miles crossed the mouth of GALAA CREEK (now on the map as Martin CReeK) and got out of the stony country. From 7 to I I miles, low sandstone ridges. Flood-MARKS 30 feet above river. CAMP II.

2ist October.-WNW., II miles down the river. Good travelling. Desert sandstone tablelands to north and (according to modern maps) also to south. CAMP I2.

22nd October.-W., Io miles down the river. Camp 13, on a creek which was named CoORoORA CREEK, but does not appear on modern maps, was half a mile north of the river and about 5 miles east of the point where the ETHERIDGe River falls into the southern, or left, bank of the Einasleigh. Richardson gave the LATITUDE as $17^{\circ} 34^{\prime} 32^{\prime \prime}$, which must be nearly correct, and estimated, after plotting his route, that the CAMP was 18 or 20 miles SSW. of Leichhardt's Lynd River. The actual distance is about 
53 miles, but the inaccuracy of Leichhardt's charting was mainly responsible for the miscalculation.

Had the Brothers Jardine followed their Einasleigh River a few miles further they would have seen it Joined BY THE Etheridge. Fifty miles west of the confluence, the conjoined stream meets the river which Leichhardt named the GILBERT, and this name is retained till the river waters discharge into the Gulf nearly a hundred miles west. The Einasleigh has actually a longer course than the Gilbert, but historical considerations have determined that the Gilbert be regarded as the main stream and the Einasleigh as a tributary. ACcident InLET, one of the many MOUTHS OF THE GILBERT (in $17^{\circ} 13^{\prime}$ S. lat.) was the "furthest south" of the "Pera" and "Aernem," and was consequently named the Staten Revier by Carstenszoon in 1623 . 


\section{CHAPTER XLII}

\section{THE JARDINE BROTHERS' EXPEDITION, 1864-5, continued}

\section{FROM THE EINASLEIGH RIVER TO THE MOUTH OF THE STATEN RIVER (DE FACTO)}

Was the Einasleigh the Lynd? Reconnaissance by the Brothers. Majormitchelling. Ophthalmia. Was Byerley Creex the Lynd? Progress of the Main Expedition. Disastrous Fire and Loss of Rations, etc. Losses of Horses and Cattre. Reconnaissance down Cockburn Creek and Nassau River (de facto) to Maramie Creek. Interlacing Mouths of Great Rivers faliing into Gulf of Carpentaria. Back to the Main Expedition, now camped on Cockburn Creek. Fighting with Natives. Down Cockburn Creek and the Nassau River (de facto). Camps 22 to 26. Scorpions and Mosquitoes. Camps 27 to 35. Death of Stallion from Snake Bite or Poison Plant. "Lynd" Question Settled. The True Position of the Nassau River of the Early Dutch Navigators.

$7 \mathrm{HE}$ Brothers, according to their diary, accompanied by Eulah, left Camp I3, on the Einasleigh, on 24 th October, I864, and after majormitchelling ${ }^{1}$ to the north, northeast and north-west, returned on the $27 t h$, having failed to find the Lynd River. (See Map L.) They had made about 40 miles of northing and had struck the creek which they named Byerley Creek (now mapped as the Red River) and another which they named MAROo N CREEK, and which appears in modern maps as the head of the Staten River. ${ }^{2}$ This Staten River, de facto, and which will, no doubt, be so called for all time, is de jure, the Nassau, one of its mouths ( $17^{\circ} 24^{\prime} \mathrm{S}$. lat.) having been named the Nassau Revier by Jan Carstenszoon on 26th April, I623. Byerley CReeK, or Red River, is a tributary of the Staten River, de facto.

Had the Brothers struck north-east from their Ioth or IIth Camp, on the Einasleigh, they would have reached LeichHARDT's Lynd River in less than 30 miles. Beyond Camp II, the chance was lost, as the courses of the two rivers diverge, the Einasleigh to the west and the Lynd to north-north-west.

1 This expressive verb, indicative of a method of exploration favoured by Major (afterwards Sir Thomas) Mitchell, was in common use among Australian bushmen in the "seventies," when I first made their acquaintance.-R. L. J.

2 Carstenszoon spelt the name Staten, which spelling, except in quotations, I retain. In modern Dutch, the double " $a$ " is correct, but in 1623 spelling was no more fixed in Holland than it was in England. 
The Staten River, de facto, north of the Einasleigh, flows mainly west, while the Lynd runs to north-north-west, and is east of the heads of the Staten, de facto.

On their way back to Camp I3, the reconnoitring party blazed a track to guide the party witlı the cattle to Byerley Creek.

After their return to Camp 13, the Brothers discussed the situation with Richardson, who contended that the EINAsLeIGH RIVER, which they had by this time traced for 50 miles, could be no other than the LYND. It is unfortunate that a question of this sort should have been discussed with heat; but so it was. The Brothers lost confidence in the Surveyor, who, on his part, performed his duties in a half-hearted and perfunctory manner and, as it were, under protest, for the remainder of the journey.

On the $29 t h$, the Brothers, accompanied by Eulah, set out on a further reconnaissance to the north. Having crossed BYERLEY CREEK (the Red River of modern maps), they gave the name of MAROon CREEK to what is now known to be the head of the Staten River, de facto (the Nassau River, de jure). Further north, they came on a creek running, like their Maroon Creek, to the north-west, and named it Cockburn CReEk. (SeE MAP H.) The latter is a tributary, or head, of the Staten, de facto, as is also Byerley Creek, which, before it falls into the Staten River, de facto, bears the names of Red River and Wyaaba Creek in parts of its course.

The reconnoitring party penetrated northward, as far as can be made out, to about $16^{\circ} 35^{\prime} \mathrm{S}$. lat. (approximate longitude $143^{\circ} 5^{\prime}$ E.), having for some distance been travelling almost parallel with the long-sought-for LYND. They TURNED BACK about 15 miles south of the Mitchell, and on 3 rd November reached the lagoons on Byerlexy CReEK (the Red River, de facto), to which the body of the expedition had by this time moved, in two stages, making this their CAMP 15. (SEE MAP L.) The majority of the men who had been with the cattle were now suffering from OPHTHALMia. The shade temperature was $90^{\circ}$ at daylight and $103^{\circ}$ at noon.

On $4^{\text {th }}$ November, Byerley Creek, now admitted not to be the Lynd, was crossed within half a mile north of Camp I5. CAMP I6 was about $4 \frac{1}{2}$ miles further north, on what was named BELLE CREEK.

On 5 th November, the Brothers, accompanied by BINNEY, EULAH and BARNEY, went ahead with the cattle and having marked a line of trees for 15 miles to the north, camped for the night, with the cattle, at Maroon Creek (head of the Staten River, de facto), in which there was no water. Some of the horses had been missing when the cattle left Camp 16. These having at length been collected, Richardson, Scrutton and Cowderoy 
brought them along, but were too late in the day to overtake the cattle. (SeE MAP H.) While they were unpacking and preparing camp (a dry camp, No. 17, some distance south of the Staten, de facto), the GRASS TOOK FIRE, with the result that $420 \mathrm{lb}$. of flour, almost all the tea, Ioo lb. of rice, jam, apples and currants, a box of cartridges and caps, 2 tents, I pack-saddle, 22 pack-bags, I4 surcingles, I 2 leather girths, 30 ring pack-straps, 2 bridles, 2 pairs of blankets, clothing and needles, awls, twine, etc., were destroyed. The most heroic exertions were required to save the rest of the stores. Scrutton is said to have snatched some of the powder canisters from the fire with the solder melting on the outside.

While waiting at Maroon Creex (Staten River, de facto) for the party to whom this misfortune occurred, the BROTHERS and their three companions had an anxious and trying time. At their camp, only a trifling amount of water had been obtained by digging, not enough even for their own horses. They could not go back to look for the men left behind, whose delay they could not understand. They had to go forward and find water for the cattle.

On the 6 th, the Brothers marked a line, while their companions drove the cattle to CocKBURN CREEK, where they camped (CAMP I8); and still the men did not arrive with the horses and packs. They remained the two following days at Camp I8, still awaiting the two parties left behind, and came near starvation. They succeeded, however, in killing three small "opossums" on the 7th and in shooting a calf on the 8th. On the latter day, twenty or thirty of the cattle were found to be missing, and "Maroon," a stallion designed for stud purposes, died of PoIson or SNAKE-BITE. On the $9 t h$, Alick went back and met the rear party.

On Ioth and inth November, the Brothers and Eulah followed

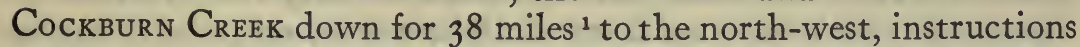
having been left for the rest of the party to follow with the cattle and pack-horses. On the I 2 th, about 9 miles further on the same course, they found two sandy water-courses, which they supposed to be the heads of the Mitchell, but which must have been branches of the Staten River (de facto). Then, striking out to north by west, they crossed 16 miles of barren inundable country to Maramie Creek, so named, in the aboriginal language, because of the abundance of fresh-water crabs.

On the $13 t h$, the Brothers followed Maramie CREeK down for 25 miles to WSW. Nothing but a waste of tea tree and spinifex was to be seen, and it was evident that this was no country for travelling cattle.

On I 4 th November, the Brothers struck south and came on "what they supposed to be the Mitchell, which was afterwards ascertained to be the Staten of the Dutch navigators, or one of its

1 Modern mapping shows that the distances must have been over-estimated. 
heads" (Byerley, p. 19). As already mentioned, the river is the "Staten," de facto and not de jure.

Here the NATIVES for the first time evinced a threatening disposition. Running the river up from the point where they had struck it ( 8 miles below the junction of Cockburn Creek), the little party of explorers was followed for 3 miles by a noisy crowd of armed blacks. "Getting tired of this noisy pursuit, which might at any moment end in a shower of spears, the Brothers turned on reaching a patch of open ground, determined that some of their pursuers should not pass it. This movement caused them to pause, and seeming to think better of their original intention, they ceased to annoy or follow the little party, which pursued its way for 5 miles further, when they camped in the bed of the stream."

The character of the country to which the Jardines had now penetrated had entirely changed. The littoral of the southern end and eastern side of the Gulf of Carpentaria is a network of salt-water inlets, which if nothing were known of their hinterland, might be supposed to be the delta of a single gigantic river. The inlets, however, prove to be the ANASTOMOSING MOUTHS of a great number of rivers which take their rise in the high ground to the south and east. Any one of the rivers may be followed down with confidence till it enters the deltal plain, whereupon it splits up into anabranches, which sooner or later coalesce with similar anabranches of other rivers. On the other hand, a traveller who attempted to follow any inlet of the sea up to its head, would find himself, within the deltal area, in a maze of anabranches. With no fingerpost to guide him, he might, for example, turn to the right and find himself on the Norman, or to the left and find himself on the Gilbert. Moreover, any two travellers crossing the NETWORK OF DELTAL ANABRANCHES, say from south to north, on parallel courses a few miles apart, would form quite different ideas as to what were "main streams" and what were mere "tributaries." An anabranch might in one place contain a long deep water-hole, and a few miles distant be only a barely distinguishable hollow. It may be stated that the mouths of the Nicholson, Gregory, Albert, Leichhardt, Flinders, Norman, Gilbert, Staten, de facto, Dunbar, Mitchell, Coleman, Holroyd and Archer Rivers anastomose.

For this reason, the rivers named by the Jardine Brothers, who kept as much as possible on the upper edge of the delta out of consideration for their cattle, are difficult of identification, even with the aid of modern maps.

On $5^{\text {th }}$ November, the Brothers and Eulah moved up and found the main Camp (Camp 18) settled on CockBurn Creek about 25 miles above its confluence with the Staten, de facto. Richardson gives the latitude of the camp as $16^{\circ} 46^{\prime} 5^{\prime \prime} \mathrm{S}$.

On the I6th, the now UNITED EXPEDITION followed CockBURN 
CREeK down (NW. by W.) for about II miles and camped (CAMP 23). ${ }^{1}$

On the $17 t h$, a further move of 5 miles was made to where Cockburn Creek falls into the Staten River (de facto), which the Brothers took for the Staten and Richardson for the Lynd. CAmp 24 was 6 miles down the river below the junction. At this camp SCRUTTON "was bitten in two or three places by a SCORPION, without, however, any very severe effects." The camp of the $18 t h$, No. 25, was about 8 miles further down the river. The next camp, No. 26 , was made on the I9th, I I miles further down.

On the 20th, 9 miles further west, ${ }^{2}$ the party having been compelled to camp early in the afternoon owing to a deluge of rain (CAMP 27), was ATTACKed by about a score of Natives and there were some narrow escapes, one spear passing between Cowderoy's legs. Two shots in reply, although they missed their aim, dispersed the assailants.

2 Ist November, I864. - The camp was shifted 3 miles to the west, to a spot where there was some grass and plenty of water (СамP 28). Thirteen of the horses were missing in the morning and were not found till the 27th. The BLACKs had been among them and had scattered them all over the country, and they were "wild as hawks" and had broken their hobbles.

On the 22nd, as Frank Jardine was riding out alone looking for good travelling for the cattle, he was ATTACKED by NATIVEs, who threw half a dozen spears at him. When he had shot three of the natives, the remainder (about nine) fled, leaving their weapons behind. The black boy Sambo was assailed by three natives who, after a boastful harangue, threw spears. The pinch of starvation now began to threaten and stern restrictions were imposed! on the consumption of rations. Kites hovered around the camp in myriads and grew so bold as to snatch the meat cooking on the fire.

Camp 28, where the party was compelled to stay for seven days, was a very undesirable residence. Mosquitoes, sandflies and gadflies tormented the explorers, who had worries enough on their minds. The final misfortune was the loss, on the night of the 26th November, of fifteen cattle owing to the carelessness of the man in charge, who slept on his watch. Only seven of the cattle were recovered.

Finally, when a start was made on the 27 th, one of the horses was missing and had to be left behind. Frank Jardine rode on, on the north side of the river, ahead of the party, looking for good travelling and a suitable camp. Nine miles down the river he

1 The numbers of the camps are as given by the Brothers. Richardson gives none, except in his map. The expedition was usually split up into two or three parties which camped at different places.

2 Distances obviously much exaggerated, probably owing to windings of the river and difficulties. 
passed a number of NATIVES, who seemed indifferent to his presence, but 2 miles further on he met seven more and a spear flew past, within six inches of his face. He shot one of his assailants. Shortly afterwards, he crossed to the other side of the river and met the other members of the party, who had also been attacked by the natives in force. They had killed or wounded several of their assailants. The distance travelled down the river (westward) was estimated by Richardson at 8 miles. CAMP 29 (infall of Emu Creek from the south).

Camp 30 (28th November) was 9 miles further down the river. The poverty of the country travelled and its obvious liability to be inundated gave rise to much misgiving, as the wet season was now drawing nigh.

On $29 t h$ and $30 t h$ November, CAMPs 31 and 32 marked stages of 9 and II miles respectively down the river. ${ }^{1}$ Camp 32 was within a quarter of a mile of the left bank of MARAmIE CREEK, near its junction with the Staten River (de facto).

Camp 33, ro miles down the river, was made on ist December. This day two parties of BLACKS were seen FISHING in the river with four-pronged spears and also lines and hooks, the latter made of wood barbed with bone.

On 2 nd and 3 rd December, the expedition moved on to CAMPs 34 AND 35, over stages of 10 and 6 miles respectively. At the last-named camp, the river had become a SALT-WATER ESTUARY, and the hope that it would turn to the north and lead them in the desired direction was finally abandoned by the Brothers. On the 4 th, the camp was moved 2 miles WNW. to good feed close to the mangroves. CAMP 36 (Leichhardt's Camp of 5 th July, 1845).

The long-drawn dispute between the Brothers Jardine and Richardson over the identification of the river which they had followed to the west since Cockburn Creek fell into it, was now brought to an end. It was admitted by Richardson that its course lay altogether west of the Lynd and that Leichhardt's Mitchell River was still to the north. It was, in fact, a new and distinct river. The Brothers proposed to name it the "Ferguson " after Sir George Ferguson Bowen, first Governor of Queensland (there was already a "Bowen" river), although they erroneously believed it to be identical with the Staten River of the Dutch navigators. For the last mistake the Jardines were not responsible, as the Admiralty charts of their day placed the Staten where the mouth of the "Ferguson" really is, as do the charts still in use. The name "Ferguson" never was adopted, and officially in the maps of the Lands Department, the river is still known as the Staaten. It falls into the Gulf where the Nassau Revier was placed by the Dutch

1 Distances uniformly over-estimated, as proved by comparison with the total distance between the mouths of Cockburn and Maramie Creeks. 
EINASLEIGH RIVER TO STATEN RIVER 3OI in i623. The Dutch Staten Revier is Accident Inlet, one of the mouths of the Gilbert. Modern Lands Department maps, following Flinders' chart, confirmed by King, erroneously place the Dutch Nassau Revier in $15^{\circ} 55^{\prime} \mathrm{S}$. latitude, the inlet in that position (on which is the "Nassau Landing" for Lochnagar and Dunbar cattle stations) being DUNBAR CREEK, one of the many mouths of the Mitchell River. 


\section{CHAPTER XLIII}

\section{THE JARDINE BROTHERS' EXPEDITION, continued}

\section{STATEN RIVER, DE FACTO, TO JARDINE RIVER}

Leave the Staten, de facto. Shark's Flesh. Inundable Country. Camp 38. Hostile Natives. Loss of Horses. Horses mad from Thirst. Loss of "Indispensables." Sickness. Leichhardt's "Rocky Creek." Camp 39. Dunbar Creek. Camp 40. Anastomosing of River Mouths in a Common Delta. Artesian Water a Probability. Group of Modern Stations. Conflict with Natives. Leichhardt's Mitchell River. Camps 42 and 43. Poison Plants. "Battle of the Mitchell." Aboriginal Tactics. Camp 47. Beginning of Wet Season. Camp 48. Heavy Rain and No Water for the Cattle. Balourgah Creek. Camp 51. Edward River. Coleman River. Hersey Creek. Camp 52. Holroyd River. Thalia Creek. Camp 54. Vereenichde River. The "Duyfken's" Voyage (i606). Conflict with Natives, who disperse Cattle. Some Cattle lost. Kendall River. Sinclair Creex. Camps 56 and 57. Patch of Good Country. Kinloch Creek. The Desert Sandstone. South Coen River. Archer River. Good Country. Camp 58. Tributaries of Watson River. Camp 62. Merluna Downs. Myall Creek. Mission River. Camp 63. Cox Creek. Batavia River. Camp 64. True Position of Coen River. The Dutch Landing (1623). Gold in Batavia River. Camp 65. Cattrle Bogged. Camp 66. Nimrod Creek. Horses drowned. Camp 67. Horses poisoned. "Black Thursday." Camps 68 and 69. Last Conflict with Natives. Light Jobs for the Day of Rest. Modern Seuatting Runs. Carpentier Revier (i606). The Cape York Telegraph Survey. Misidentification of Jardine's Creeks. Dismounted and Footsore. Palm Creek. Camp 70. Dalhunty Creek. Richardson Range. Gigantic Anthills. Skardon River. "Most Abominable Country." The Blasted Heath. Starving Horses and Cattle. Horseflesh. Camp 73. Shelburne Bay sichted. Camp 74. Intersections of Kennedy's and Jack's Tracks. Cabbage-tree Hats. Camisade Creek. Camp 77. Backbone of Peninsula. Camp 78. Confronting the Escape River Problem.

HE meagre diet of the camps at the mouth of the Staten River, defacto, was varied by the addition of shark's flesh, which was jerked (sun-dried), together with the flesh of a bullock which was killed.

The position of the party was now very serious. The HORSES were leg-weary and emaciated, and both they and the CATTLE were falling off owing to the insufficiency of food and were rapidly diminishing in numbers. Trying to progress to the north the party had been forced to march further and further to the west till they reached the mangrove swamps of the Gulf littoral. In the flat country where they now found themselves, ominous FLOOD MARKS 
on the trees proclaimed that at any moment the water might rise above the heads of the travellers. (SEE MAP H.) At least one large river, the Mitchell, was known to cross their path to the north. And the WET SEASON might set in to-morrow, if reliance could be placed upon what was then known of meteorological conditions in Northern Queensland. The supply of farinaceous FOOD was already limited and had been seriously diminished by fire. Finally, the hostility and treachery of the ABORIGINAL INHABITANTS had to be taken into consideration. The Brothers must have marvelled day by day, as every explorer of these regions has done, why the blacks did not compass their death by the simple expedient of killing their horses when the latter strayed from the camps in search of grass. Thanks only to the limited intelligence of the natives, this method of warfare does not appear to have suggested itself.

It is probable enough that the Brothers themselves, their black boys and some of the white men, might, if the blacks had let them alone, with their skill in bushmanship, have contrived to subsist for a time on the natural products of the country even if they had lost all the cattle and horses, as well as their rations. But the savages would certainly have waited for the time when relaxed watchfulness, hunger and fatigue would make them an easy prey, as in the case of Kennedy.

Everything pointed emphatically to the necessity for an immediate CHANGE OF COURSE to the north, with a leaning to the east, to escape from a country subject to periodical, and now imminent, INUNDATION.

With much rejoicing, the whole expedition turned their backs on their Camp 36, on the Staten River, de facto, on 5 th December, 1864, and after crossing sand flats and sandy ridges covered with tea tree, camped in a dry swamp (CAMP 37 ), say 10 miles $^{1}$ from Camp 36. This camp must have been very near LeichHardT's CAMP of 4 th July, 1845 , in $16^{\circ} 15^{\prime} 11^{\prime \prime}$ S. lat. A little slimy green water was, however, found about $2 \frac{1}{2}$ miles to north-north-west.

Next morning (6th December), half the HORSEs were MISSING, and the camp was shifted to the green water (CAMP 38). After having been packed for this short journey, a very useful MULE slipped away and got lost, carrying with him a load of "indispensable " articles. He only got ten minutes' start, but he travelled faster than a black boy could track his footprints.

The Brothers found nine of the horses at Camp 35 and camped there for the night, without food or blankets, and with myriads of mosquitoes for company. They returned to $\mathrm{C}_{\mathrm{amp}} 38$ next day ( 7 th December), to learn that five of the horses and the MULE were still MIsSING, Sambo and Binney having searched for them in vain.

1 F. Jardine says I3: Richardson I2. Both continually over-estimate distances made, though perhaps not distances covered. At Camps 35,36 and 37 , the Jardines must have been on or near Leichhardt's track of 6 th and 7 th July, 1845 . 
Sambo had been two days without food or water, and was DELIRIous, but when sufficiently recovered to speak, he stated that he had followed the mule's tracks to the back of Camp 35, when he was obliged to return.

On $8 t h$ December, Alick Jardine and Sambo set out in the direction of Camp 35. They found four of the five lost horses, one of them, named "Lucifer," at Camp 35, quite mad (it was supposed from drinking salt water.)

On resuming the search next morning (9th December), Alick and Sambo met Eulah and Barney, who had also seen the MAD HORSE. Sambo and Barney were sent after the mule, and Alick and Eulah came in sight of "Lucifer," but only succeeded in knocking up their mounts in pursuit of him. They then returned to Camp 38, with the recovered horses.

In the meantime ( 8 th December), Frank Jardine had been out 18 miles to the north of Camp 38, hoping to find water on the desired route, but without success, and the prospect of driving the cattle over dry country was disheartening. On Ioth December, Frank Jardine and Eulah rode westward from Camp 38 for 6 miles, when they found themselves on extensive marine plains and downs. After I9 miles more, mainly south (and probably over the site of the modern cattle-station named Mentana) they came on "Lucifer's" track and found the place where he had been drinking salt water and lying down. They followed the tracks for fifteen miles and camped without water.

From daylight on the following day (I t th December), Frank and Eulah followed the tracks, mostly on foot, leading their horses, and were thus led, at sundown, to Camp 33, on the Staten, de facto. Here, for the first time since they left Camp 38, they found water. It was brackish, but it satisfied a two days' thirst. While they were trying to catch something to eat, the elusive "Lucifer" was seen, but he galloped away at once. Frank mounted his horse and, heading the mad animal, drove him back to Eulah's horse, "but to no purpose, for he galloped past without taking the least notice of him, and as it was now dark they had to let him go." "Lucifer " was again tracked next day (12th) and was found at noon 13 miles off. He was white with perspiration, and it was surmised that he had galloped the whole distance. He was, besides, still quite mad, and Frank made up his mind to leave him behind. The remaining HORSE, "Deceiver," was found shortly afterwards-DEAD, whereupon the tired and hungry men made their way back to CAMP 38 .

"Lucifer" and "Deceiver," says Byerley, were the two best riding horses, and the MULE the best pack-animal. His own loss was aggravated by his carrying his pack with him. This carried most of the odd ARTICLES that were hitherto DEEMED INDISPENSABLE, but which henceforth they had perforce to dispense with. One pack contained all that remained of the tea, currants and raisins 
saved from the fire and two pairs of boots-the only ones the Brothers had; and the other was filled with oddments, such as files, gimlets, ragstone, steel, weighing maching, awls, tomahawks, American axes, shoeing tools and a number of things that they could not do without ; but perhaps the most important loss was that of the spade, to which they had many times been indebted for water. The losses also included the mallet and chisel with which the successive numbers of the camps had hitherto been cut on trees.

Alick had spent a day (I ith December) in searching for Water, and was rewarded by finding it in a creek 8 miles north-north-west of Camp 38. One day's march in the right direction was thus secured.

During the detention at Camp 38, Richardson determined the variation of the compass to be 4 degrees east (misprinted " 40 degrees" in Byerley). Previously he had been allowing 6 degrees.

To the other considerations which so urgently dictated a forward movement, was now added the ILLNESS of SCRUTTON and CowDEROY, brought on by drinking the impure water of Camp 38 .

The party fared forth on $\mathbf{1} 3$ th December, and in 8 miles reached the place where water was known. Alick, however, riding ahead of the main body, had come on water four miles further on, in what was probably LeICHHARDT's "RocKY CREEK," and the cattle were brought on. A disappointment ensued when the water turned out, although covered with nymphea, to be salt. Good water was luckily found a mile up the creek to the east (CAMP 39). At this camp a fine barramundi was caught and six whistling ducks were shot.

With the intention of striking the Mitchell about the head of the tide, the course was altered next day (I 4 th December) to north-east. Water was passed at 5 miles and 9 miles from Camp 39, and CAMP 40 was pitched on a well-watered creek at I4 miles (Dunbar CREEK). Richardson gives the latitude of the camp as $15^{\circ} 56^{\prime} 31^{\prime \prime} \mathrm{S}$.

The position assigned to Camp 40 is on what is called the "NASSAU RIVER" in the 4-mile map (I9I0) and in the "Tenure Map" (December, I9II). As has already been pointed out, the RIVER so CALLED BY Carstenszoon, in I623, is that WHich THE Jardine Brothers followed down from Camp 24 to Camp 36. Modern maps show that the water-course ( $15^{\circ} 53^{\prime}$ S. lat.), erroneously named the Nassau River (the NASSAU, DE FACTO), IS ONE OF THE MOUTHS of The Mitchell River, which leaves the main stream at BURKE's LAgoon, near Dunbar cattle station, and is there known as Dunbar Creek. Camp 40 may, therefore, be placed with confidence on Dunbar Creek. Between their 38 th and 39th camps, the Brothers must have crossed the (apparently insignificant) water-course which, some Io miles to the west, becomes the Revier Nassau ( $16^{\circ}$ Io' S. lat.) and which Carstenszoon, of the "Pera," named on 29th April, 
I623. It is now too late to give effect to the claim of this STATEN RIVER, DE JURE, for recognition.

On I5th December, a stage of 22 miles was made to the north-east, over better country than had been met with for some time, part of it being SANDSTONE RIDGES rising above the level of the inundable land. Four or five miles from Camp 40, a creek was passed falling to the west, which the Brothers proposed to call Arbour Creek, but which does not appear on Richardson's map, or on Byerley's. At 19 miles a halt was made at a dry swamp, which now appears on the maps as the "Scrutron River," running out of the main stream of the Mitchell below Dunbar Creek and joining Dunbar Creek (the Nassau River, de facto), midway between Camp 40 and the Gulf. Eulah, having been sent ahead, found a good site for a camp 3 miles further, and the caravan pushed on to it (CAMP 4I). "It was," says Byerley, "well worth the extra fatigue to the stock. They were rewarded by an excellent camp, plenty of green GRAss, open country, and WATER, which was alike acceptable to men and beasts. The creek received the name of EULAH CREEK, in honour of the discoverer." It was not, however, so named in Richardson's map or Byerley's, and is called "Magnificent CReEK" in modern maps.

Probably the Jardine Brothers passed through this country in an unusually bad season, and it was lucky for them. Had they not been ready to perish from THIRST in crossing the inundable country they would have run a serious risk of DROWNING.

Yet it is evident from the subsequent course of occupation that the country traversed by the interlacing and anastomosing MouTHS of The Mitchell River is not worthless, as it seemed to its first explorers. In good seasons at least, the coastal plains afford abundant FOOD FOR STOCK, and the Brothers' experience of 15 th December indicates the existence of ELEVATED SANDSTONE PLATEAUX to which stock may retreat in times of flood. Moreover, there is almost a certainty that the ARTESIAN WATER area of Normanton is prolonged in that direction, although the coastal alluvium makes it impossible to see the outcrop of the basal beds of the Lower Cretaceous strata. The area in question, according to modern maps, now contains cattle stations at Old and New Mentana, Dunbar, Kalka, Lochnagar, Rutland Plains and Koolata, as well as the Mission Station of Trebanaman. (See Map F.)

From Camp 4I to Camp 42, the company travelled about 6 miles north-eastward on $16 t b$ December. The two Brothers, riding ahead, had barely gone a mile when they were confronted by a party of NATIVES, who jeered and brandished spears. A stand was made and eight or nine fell to the rifle fire, whereupon the remainder retired. CAMP 42 was on an anabranch of the Mitchell. RIVER, running NNW., " its bed in some parts densely timbered, the foliage rich and luxuriant: in others there are fine sheets of 
excellent water. Leichhardt's melaleuca, fan-leaved palm and fig trees, some of the latter bearing ripe fruit, also vines and tropical trees unknown to me" (Richardson, p. 33).

On I 7 th December, about 7 miles were travelled to northwest, among the channels of the Mitchell. One of these, about midway, was taken to be the "MAIN STREAM." It is described thus by Richardson: "Bed 500 yards wide, sandy, and two channels, some water, not running, banks low, and flood marks above them; the foliage of the trees on both sides is very dense and rich in various shades of green. The latter part of our journey bore some resemblance to a deserted garden, which had contained many choice plants and trees, acacia, bauhinia, Leichhardt, and fan-leaved palm, the latter numerous, also cedar." Game was plentiful, including wallabies, native companions, duck, and Torres Strait pigeons. CAMP 43 was on a flooded gum flat. Here one of the cows died from the effects of some POISONOUS PLANT.

The story of the 18 th December is given in Byerley's words (p. 35), which cannot be abridged or paraphrased :

" I 8 th December. - The river was followed down to-day for 9 miles through a complete network of anabranches, gullies, and vine scrubs to another branch, which may be called the true stream. It was 30 yards wide, deep, and running strongly. Here the party had to camp for about 3 hours, whilst the Brothers searched for a good crossing. The cattle and pack-horses were crossed in safety, but some of the pack-bags got wetted in the passage. They were travelled another mile over to a sandstone bar, crossing another deep sheet of water that had been previously found. This stream had been explored in search of a ford for 4 miles further up but without success. It continued of the same width and appeared to do so much further. This day, Sunday, was marked by the severest conflict the travellers had yet had with the natives, one which may well be dignified by the name of the 'Battle of the Mrtchell.' On arriving at the running stream before mentioned, whilst the cattle halted, the Brothers and Eulah, taking axes with them to clear the scrub, went down to find a safe crossing. At about a mile and a half they came on to a number of blacks fishing: these immediately crossed to the other side, but on their return, swam across again in numbers, armed with large bundles of spears and some nullahs, and met them. The horsemen, seeing they were in for another row, now cantered forward towards the camp, determined this time to give their assailants a severe lesson. This was interpreted into a flight by the savages, who set up a yell, and redoubled their pursuit, sending in the spears thick and fast. These now coming much too close to be pleasant (for some of them were thrown a hundred yards), the three turned suddenly on their pursuers, and galloping up to them, poured in a volley, the report of which brought down their companions from the camp, when the skirmish became general. The natives at first stood up courageously, but either by accident or through fear, despair or stupidity, they got huddled in a heap, in, and at the margin of the water, when ten carbines poured volley after volley into them from all directions, killing and wounding with every shot with very little return, nearly all their spears having been expended in the pursuit of the horsemen. About thirty being killed, the leader thought it prudent to hold his hand, and let the rest escape. Many more must have been wounded and probably drowned, for fifty-nine rounds were counted as discharged. On the return of the party to the cattle an incident occurred which nearly cost one of them his life. One of the routed natives, probably burning with revengeful and impotent hate, got into the water under the river bank, and waited for the returning party, 
and as they passed threw a spear at Scrutton, before anyone was aware of his proximity. The audacious savage had much better have left it alone, for he paid for his temerity with his life. Although the travellers came off providentially without hurt, there were many narrow escapes, for which some of them might thank their good fortune. At the commencement of the fight, as Alexander Jardine was levelling his carbine, a spear struck the ground between his feet, causing him to drop his muzzle, and lodge the bullet in the ground a few yards in front of him. His next shot told more successfully. There were other equally close shaves, but providentially not a scratch. This is one of the few instances in which the savages of Queensland have been known to stand up in fight with white men, and on this occasion they showed no sign of surprise or fear at the report and effect of fire-arms, but it is probable that they will long remember the 'Battle of the Mitchell' (Camp XLIV). Course NNW. Distance 7 miles."

The camp was probably on the Alice River, about 3 miles west of the modern Koolatah Station.

The TACTICS OF THE ABORIGINES consist mainly of ambUSCADES AND HARASSMENT OF THE REAR of travelling parties. It is rarely, as Byerley observes, that they venture to stand up in bodies to fight.

The Mitchell River was followed down to the north-west on I9th, 20th and 2Ist December, CAMPS 45, 46 AND 47 , representing stages of I3, II and $9 \frac{1}{2}$ miles. The head of the SALT WATER was found between Camps 45 and 46 . Heavy RaIN fell on 2oth and 2Ist.

At sunset on the $2 \mathrm{Ist}$ it was discovered that the BLAcKs were "sTALKING" the party at the camp, under cover of screens of boughs. The Brothers, Scrutton and the four black boys mounted and PURSUED THE NATIVES for a couple of miles, driving them at last into the scrub, but using no fire-arms. At the conclusion of the chase, two dozen abandoned spears were collected along the line of retreat.

The Mitchell River ${ }^{1}$ was finally LefT Behind on $22 n d$ December and the camp was pitched 15 miles to the north (lat. $15^{\circ} 2^{\prime}$ IO" S.) " at a puddle without a blade of grass" (CAMP 48):

In the locality attributed to Camp 48 , the modern map (Sheet $20 \mathrm{~B})$ sketches a water-course about to fall into the Gulf, and obviously suggests that this water-course is the Coleman River. Mr. Embley informs me that he is not responsible for the sketch or the suggestion, and that he only traced the Coleman down (westward) to a point 30 miles east of the coast. He believes, in fact, that flood waters of the Coleman flow southward into the Mitchell by courses indistinguishable in normal dry weather.

The following day (23rd December) there was hEavy RaIN. "Twelve miles of wretched country were traversed, white sandy undulating ground, clothed with shrubs and underwood in the

1 The river was surveyed for the Department of Lands by Mr. J. T. Embley, in April, 1887 .

${ }_{2}^{2}$ If the latitude is correct, the distance must have been greatly over-estimated. 
place of grass, and the CAMP pitched on a low stringybark ridge, WITHOUT WATER, for in this flat sandy country the ground absorbs the rain as soon as it falls. The horses had to be watched again to-night, for there was not a blade of grass to be got. A small quantity of water was found in a creek about a mile and a half ahead. Late in the evening the horses and water-bags were taken to it, and sufficient water brought back for the use of the camp" (CAMP 49).

On 24th December the journey was continued 7 miles to the north and $\mathrm{C}_{\mathrm{amp}} 50$ was pitched on a ridge timbered with bloodwood and stringybark. The grass was poor, but it was better than none (CAMP 50). This camp cannot have been far south of the EDWARD RIver surveyed by Mr. J. T. Embley in 1885. That river runs westward between the Coleman and HolRoyd Rivers and very likely is to be connected with one or other or both.

25th December.-The RaIN which had set in the night before, continued to fall heavily during the whole of Christmas Day. In spite of this, 15 miles were gained to the north. At 7 miles, was a creek in which some swamp mahogany trees (balourgah) were growing. The creek at 15 miles was named "CHRIsTMAs CREEK." It ran in a rocky bottom and was well watered, and blue grass was plentiful on its banks (CAMP 5I). In the course of his traverse in I 885, Mr. Embley sketched Balourgah and Christmas Creeks as joining-or rather parting - a few miles above (east of) the Brothers' line of march and as being probably mouths of the Edward River to the south, while Christmas Creek is joined just above the Brothers' crossing by a water-course which emanates from the Holroyd River to the north. Thus mouths of the Edward and Coleman Rivers appear to be confluent.

$26 t h$ December.-The rain still continued but was not heavy enough to prevent travelling, and a further stage was made to the north and the night's camp was made on HERSEY CREEK, "a splendid sheet of water in a rocky creek, 80 yards wide and very long" (CAMP 52). According to the Brothers, the distance travelled this day was I 3 miles and according to Richardson I2 miles, whereas their maps agree in showing the distance between Christmas and Hersey Creeks to be not more than 5 miles. Perhaps the name Hersey Creek should be applied to another mouth of the Holroyd River, 9 miles north of that to which the name is attached on modern maps. The matter could probably be settled satisfactorily by some one on the spot who might be able to identify the long water-hole among the rocks. It is not in any case a matter of great importance, and the de facto may be accepted as the de jure.

On $27 t h$ December, the party made a northing of ro miles to a small creek with water for the men and horses but not enough 
for the cattle (CAMP 53). This may have been the other mouth of the Holroyd River above referred to.

28 th December. - The cattle satisfied their thirst 5 miles north of Camp 53, at a fine sheet of water in the river which the Brothers named Holroyd CREEK. The river is described as having a sandstone bed with several channels. Two miles further north was another similar stream which was named Dunsmuir CReEK. Both streams are channels of the HoLroyd River which was surveyed in September, I885, by Mr. Embley. The upper reaches of this river were named the Lukin River in 1875 by Mulligan. The river rises far to the east in the Hamilton Goldfield.

Four miles north of the Holroyd River (inundable box flats), Thalia Creek, a salt-water inlet, was met with. On following the creek up to the east for a mile and a half, CAMP 54 was pitched on a lotus lagoon, where the water was only slightly brackish.

The party had hardly settled down in Camp 54 and were digging trenches and making such other preparations as they could for an impending thunderstorm, when the BLACK воч who had been tailing the cattle, came in with the report that he had been PURSUED BY NATIVES, who were now engaged in "RUNNING" THE HORSES. The Brothers and Scrutton rushed out and found the horses flying about in all directions, while a party of natives waited for the men. "When the distance had been reduced to 60 yards, SPEARS began to fly and were answered by Terry BREECH-LOADERS. The blacks (some of whom were observed to be unusually tall) ultimately retired, having paid for their gratuitous attack by the loss of some of their companions" (Byerley, p. 40). "The THUNDERSTORM nOw broke with great violence, and the frightened CATTLE STAMPEDED from the camp. The rain continued to fall heavily until midnight."

There is a very unsatisfactory discrepancy between the narratives of Frank Jardine and Richardson concerning the proceedings of 29th, 30th and 3Ist December. I am inclined to follow Richardson, as his sole business was to chart the progress of the main caravan, while the Brothers Jardine went "majormitchelling" in search of country which would be safe in a time of floods, and perhaps their notes were not very intelligible to their editor, Byerley.

From Thalia CReEK (Camp 54) it appears that Richardson and the cattle on 29 th December travelled ENE. for about 4 miles, when a TIDAL RIVER, 40 yards wide, was met with. (SEE MAP D.) Frank Jardine, on a NNE. course, had struck it further west, where he estimated the width of the stream at Ioo yards. The river was followed up by Richardson, the pack-horses and the cattle for $\mathrm{I} \frac{\mathrm{r}}{2}$ miles before it could be forded. In the next $5 \frac{x}{2}$ miles, on the ENE. course, the inundable tea-tree flats began to be varied by low ridges covered with bloodwood. CAMP 55 was pitched beside a tea-tree swamp. Heavy rain fell at night. 
Thalia CReeK and the "TIDAl River," I take it, must be mouths, perhaps the most important mouths, of the Kendall River, de facto, which was run down by Mr. Embley in February, I886, as far west as the I42nd meridian of east longitude. This Kendall River, de facto, according to Mr. Embley, is the most considerable water-course in the district, but I am of opinion that he was mistaken in identifying it with the water-course to which Jardine gave the name of KENDALL CREEK.

Ten head of CATTLE had been Missing when Frank Jardine left Camp 54, and as they had not been recovered, he determined on his return to Camp 55, to wait there while they were searched for. The search proved fruitless, and " as it would have been madness to have remained longer in such dangerous country," the cattle were finally left behind. "The country," says Byerley, "was all alike, and they were satisfied beyond doubt that it must be ONE SEA DURING THE RAINS." On the night of the $30 t h$, the camp was visited by a rain-and-wind STORM of unusual severity.

On 3 Ist December, the distance travelled from Camp 55 was estimated at 12 miles on a general course of ENE. $\frac{1}{2} \mathrm{E}$. Two miles from Camp 55, a CREEK was met with, 50 yards wide, with steep banks and water 3 feet deep. (QueEnsland 4-mile Map, SheET 20 D.) It was named Kendall CReEK, ${ }^{1}$ after a friend of Richardson's, although Frank Jardine seems to have considered it identical with a creek further to the west which he had seen the day before, and which he named the Macleod.

Richardson's Kendall Creek was followed up for 3 miles to the east before it could be forded, and the journey could be continued on the desired course of NNE. $\frac{1}{2} \mathrm{E}$.

As plotted from Richardson's narrative, his Kendall Creek practically coincides with what appears on the modern map as "Sinclair Creek, G 52-4." This Sinclair Creek, de facto, has apparently been named on a mistaken identification with the creek so named by Jardine (Sinclair CReEK, de jure), which is further north.

The remainder of the journey of 3 Ist December $(5$ miles NNE. $\frac{1}{2}$ E.) was on bloodwood and stringybark forest country alternating with tea-tree flats. The latter were now bogs, owing to the rains. CAMP 56 was on the left, or southern, bank of the Kendall, de jure (Sinclair, de facto).

What must be called the Kendall River, de facto (see southeast corner of Sheet $20 \mathrm{D}$ and north side of Sheet $20 \mathrm{~B}$ of Queensland 4-mile Map), has been surveyed by Mr. Embley, in 1886 , as far down as the western boundaries of "Dunning" and "Lockton" runs $\left(142^{\circ} \mathrm{E}\right.$. long.). From this point, the supposed seaward course

1 In 1879-80 I believed the "Coen" (South Coen) of the Goldfield to be the head of what Richardson had named Kendall Creek. In this I was mistaken, as the South Coen has since been ascertained to be a tributary of the Archer River. 
of the river is indicated in the modern 4-mile map by a dotted line running about 12 miles towards Cape Keerweer (WNW.). Mr. Embley informs me that this conjecture is not his. It is more than likely that Jardine's Thalia Creek, Tidal Inlet, Macleod Creek and Kendall Creek (Kendall Creek, de jure = Sinclair Creek, de facto) reach the Gulf between the Holroyd River and CAPE KEERWEer, where the "men of the "Duyfken" " turned back in 1606, and where the "men of the "Pera." "landed on 5th May, 1623 , and were attacked by the natives.

Ist Fanuary, 1865. - The Kendall, de jure, i.e., what the Brothers called Kendall Creek and the modern map names Sinclair Creek, was crossed a mile above their Camp 56 and a course of NE. $\frac{1}{2} N$. was pursued through bloodwood and stringybark forest on ridges of red sand resulting from the decomposition of sandstone. Twelve miles on this course took the party to CAMP 57, on the small and canal-like NEW YEAR CREEK coming from the NE. and running S. by E. Four miles short of the camp another water-course was named SinClaIr CREEK. It looks as if the two creeks were one and the same. A heavy rain set in during the afternoon and lasted till midnight.

Sheet $20 \mathrm{D}$ of the 4 -mile map shows an isolated east and west line 5 miles long, marked "Sinclair CReEK, G 52-4," about 7 miles south-west of Camp 56 (which camp the information to be gleaned from the Jardine and Richardson diaries places approximately in $14^{\circ} \mathrm{I}^{\prime} \mathrm{S}$. and $142^{\circ} \mathrm{E}$.). A creek in the position indicated in the 4 -mile map, although it may be called the SincLaIR, DE FACTO, would, in my opinion, in all probability be what Jardine, or, rather, Richardson, named "Kendall CREEK." What the Jardine Brothers named "Sinclair Creek" (Sinclair CREEK, DE JURE) lies to the north of Camp 56.

On 2nd January, the stage was I 5 miles to NNE. over country described by Frank Jardine as "an extensive plateau, sloping away to the eastward, terminating abruptly in a perpendicular wall, overlooking the valley on the head of which the party camped." [Evidently a sandstone tableland.-R. L. J.] He adds that the country covered on this and the previous day "would make a FINE CATTLE RUN, being watered at every 6 or 7 miles by running creeks, besides a large swamp." CAMP 58 , in $13^{\circ} 46^{\prime} 46^{\prime \prime}$, was pitched near the head of a small creek running NNE.

$3^{r}$ d Fanuary. - The creek was followed down to NNE. for $3^{\frac{1}{2}}$ miles till it fell into a larger creek, running WSW., which was named the "KINLOCH," after John Kinloch, Mathematical Master of Sydney College. At 7 and 12 miles from Camp 58, small, deep, running creeks were crossed, the first by an improvised bridge. Four miles beyond the second of these creeks, CAMP 59 was pitched. Its latitude is given as $13^{\circ} 35^{\prime} 54^{\prime \prime}$. The country traversed this day consisted of sandstone ridges, timbered with 
bloodwood and stringybark, with occasional ironbarks, zamias, pines and grasstrees; in fact, the usual features of the DESERT SANDSTONE TABLELANDS. The small creeks had a fringe of banksias with a few "mahogany" trees. The escape of the party from the inundable coast land must have been a source of profound satisfaction. There was a heavy storm of rain and thunder at night.

In consequence of the rain, the country traversed on the following day (4th fanuary) was boggy. The travellers soon got on a river and its anabranches. CAMP 60 was on one of the anabranches, the total distance covered in the day being 6 miles. Frank Jardine proposed to call this water-course "MicketeeBOOMULGEIAI" ("the place where the lightning struck"). Fortunately the name has not stuck, to be a terror to future students of the gentle art of orthography. It is, in fact, the river on which, 90 miles higher up, is the centre of the GOLDFIELD which its discoverers called the "Cовn." It is nот, however, the Dutch Coen, but a tributary of the Archer River. The name "Coen" has been too long in use to be changed, but the Lands Department has begun to call the river of the goldfield the "Soutr CoEn" to distinguish it from the Coen proper.

On 5th fanuary, the party travelled, in the rain, I4 miles $\mathrm{N}$. by E., crossing at 5 miles a large river 200 yards wide, and dry, in spite of the rains, which was named the ArCHER RIVER, and two of its anabranches. The valley of this river is described by Frank Jardine as "of great richness and beauty, and the BEST COUNTRY FOR CATTLE seen north of Broadsound." "The banks," he continues, " are fringed by a thick belt of vine scrub, containing very many Leichhardt trees and other handsome trees and shrubs of great luxuriance and growth " (Byerley, p. 43).

Of the Archer River, Richardson (p. 38) says: "I believe this river to be the same as that one NAMED at its mouth the COEN ву тне Dutch." The discoverers of the goldfield to the south-east named it, as well as the river on which it occurred, the CoEn, following Richardson's suggestion; but their river is in reality only a tributary of the Archer and neither river is the Coen of the Dutch. The inlet named "Coen Revier" by Jan Carstenszoon on 8th May, 1623 , is about 17 miles north of the mouth of the Archer.

CAMP 6I was pitched on a small water-hole in a water-course running SSE.

$6 t h$ Fanuary was a toilsome day for the horses, but 16 miles were gained to the north, through undulating country with open box forest and some ironbark, bloodwood, acacia, sterculia and pandanus. The ground was "rotten" from the rains, and yet the WATER-COURSES were TOO SANDY TO RETAIN WATER. A "RANGE" was sighted 5 or 6 miles to the east-the escarpment of a fragmentary sandstone tableland. The day's march was a 
little to the west of the Divide between the Archer and Watson Rivers, and across the heads of Merkunga and Gumbol Creeks, tributaries of the Watson. CAMP 62 was on a little clay water-hole with barely water enough for the men.

On $7 t h$ fanuary, the stage was 15 miles, across " numerous small water-courses similar to those of yesterday." "It was strange," remarks Frank Jardine, " to see the horses bogging leg-deep during a thunderstorm and in five minutes after unable to get a drink of water." The course lay across LAGOON CREEK, the principal head of the Watson River (about Io miles west of the modern Merluna Downs cattle station, which has recently been "nationalised" by the State Government), and SAY CREEK, a similar tributary of the Watson, to the heads of MYaLL CREEK, which enters Albatross Bay under the name of the Mission River. CAMP 63 was on a small deep creek falling to NNW., but without much water. Scrub turkeys, wonga wongas and Torres Strait pigeons were seen.

The next day's journey ( $8 t h$ Fanuary) added 18 miles of northing between Myall and Cox CReEKs, both here running northward, the former to turn to the west and become the Mission River ${ }^{1}$ and the latter to fall into the Batavia River, which runs to the north-west and discharges into the Gulf. For the first I5 miles there was "good undulating forest country, timbered chiefly with box and apple-gum and a few ironbarks, and intersected with numerous canal-like creeks running north-west. The last 3 miles was wretchedly bad, being similar to the tea-tree country of the Staaten" (de facto). "The whole country between the Archer and Staaten is without water, save immediately after rain sufficiently heavy to set the creeks running." CAMP 64 (lat. $12^{\circ} 38^{\prime} 2^{\prime \prime} \mathrm{S}$.) was on a small shallow tea-tree water-pan. (SEE MAP B.) The night was marked by heavy rain and high wind. Two of the horses were knocked up.

On $9^{t h}$ fanuary, a distance of 16 miles was accomplished to the north. A little more than half-way, a large RIVER was crossed 20 miles west of the modern Moreton Telegraph Station. The Brothers believed this to be the Dutch Conn, but Richardson identified it correctly as the Batavia River.

A digression becomes necessary at this point.

It is distinctly stated in Carstenszoon's Diary of the Voyage of the "Pera" that " the Coen Revier is in $13^{\circ} 7^{\prime}$ latitude," but a careful reading of the narrative shows that that was the latitude of the anchorage of 7 th May, 1623. A boat party landed next morning, and followed northward the footprints of men and dogs, which led them to a "revier" notable only for the fact that esculent herbs-a great prize for scurvy-haunted sailors-grew on its banks. They spent some time in walking, in collecting

1 The Mission River was surveyed by Mr. Embley in 1897. 
herbs and finally in a skirmish with the natives when they returned to the boat; and they were alongside the "Pera" at midday. The "Coen," therefore, cannot be many miles north of the boatlanding. Now it so happens that, in quite recent years, members of the Mapoon Mission to Aborigines have located a small INLET IN I $3^{\circ} 4^{\prime}$ N. LAT. (between Pera Head and the mouth of the Archer), and I consider it practically demonstrated that this is CARsTEnszoon's Coen Revier. Unfortunately, Flinders, in 1802, made a bad guess, and suggested that an inlet, now known as the PENNEFATHER River, in $12^{\circ} 13^{\prime}$ S. lat., was " probably the Coen R. of the old charts," and the suggestion having been accepted without question, much confusion has arisen. The subject of the true location of the Coen is discussed in detail in Chapters VII, LXXXV, and LXXXIX.

The Batavia River, as seen by Richardson, is described by him as " running NW. by W., I 20 yards broad, sandy bed, 30 feet deep; water very clear and good, running about 2 feet deep." Crocodiles were seen in it by the Brothers Jardine. The head of the river is in $13^{\circ} \mathrm{II}^{\prime} \mathrm{S}$. lat. and $143^{\circ} \mathrm{I} 7^{\prime} \mathrm{E}$. long. Plutoville, the centre of the "Batavia Gold Rush," is about I3 miles west of its source. Below this, the river, to the north-west, cuts its way through the Desert SANDSTONE formation, and for a considerable distance divides the sandstone shelves named by me in 1880 the "Sir William Thomson Range" and the "Geikie Range."

The Jardines' CAmp 65 was on a tea-tree swamp north of the river.

On Ioth fanuary, the progress made was only $2 \frac{\pi}{2}$ miles to NNE. The greater part of the journey was on ridges timbered with bloodwood and stringybark. The trouble began at a watercourse running north-west, with the water knee-deep and the gently sloping banks very boggy. The CATTLE SANK IN THE MUD. Four refused to face it and had to be let go. Thirty or forty stuck fast and the greater part of the day was spent in hauling them out with ropes. Five had to be abandoned when only their backs and heads were out of the slough. The horses came through the ordeal better, but their saddles and loads had to be carried by the men. At Camp 66, which was, of course, pitched on the nearest piece of sound ground, the remainder of the day was spent in drying the arms and loads and in jerking the beef of one of the bogged bullocks. Heavy Rain fell at night.

A stage of from 2 to 3 miles was the total result of next day's toil (I Ith Fanuary).

"After having travelled with the greatest difficulty for 2 miles over execrable country, so boggy as to be barely possible to traverse, their progress," says Byerley (p. 45), "was stopped by a creek 25 yards wide, flooded 'bank and bank' and running like a mill sluice. This was the River Batavia [a mistake : it was a tributary of Nimrod CREEK, which falls into the right bank of the Batavia.-R. L. J.]. The usual 
formidable fringe of viNE SCRUB covered the margin and approaches, and had to be cut through before the cattle could cross. In addition, a large melaleuca which leant over the stream, was felled across it, by means of which (by tying a rope above it as a leading-line) they were enabled to carry over the packs, saddles, stores, etc., on their heads. The CATTLE, ACCUstomed TO swimming, took the water in splendid style, ONE, however, getting entangled and DROWNED. With the HORSEs they were not so fortunate, for though a headstall was put on each, with a rope attached to the bit, to haul them across, the rapidity of the current swept away Two of them into a tangle of vines in the middle of the stream, under which they were carried and DROWNED, despite the exertions of four or five of the party to pull them across by the rope. Their efforts to save them nearly cost their own lives, and A. Jardine chronicles receiving a 'nasty crack' on the head from a log in attempting to disentangle his own horse, 'Jack,' from the vines. The other, 'Blokus,' was a Government horse, belonging to Mr. Richardson. Both were useful horses and a great loss to the party, but only the forerunner of much greater ones. The creek at last crossed, the party attempted to push forward on the other side; but after travelling a mile leading the horses, slushing through bog and swamp, under a heavy rain, they were obliged to turn back and encamp on some high ground on the banks of the creek, about half a mile above the crossing, where there was a little good grass. Several of their horses were left behind, one more in particular, 'Nell Gwynne,' being too weak to travel." [CAMP 67.]

This camp (Camp 67) was in the centre of what is now a "Police Reserve" of about 840 square miles.

I 2 th fanuary.-The HORSES left bogged on the previous day were got out, but FIVE DIED from eating some POISONOUS HERB, and one was missing and was supposed to have been drowned. BlindNESS was one of the effects of the poison. The remaining horses were confined in an improvised yard. Owing to the loss of so many transport animals, only one man, Binny, tailing the cattle, could now be allowed to ride. Horseshoes and other articles were buried in a "cache." The day was marked "BLACK Thursday" in the Leader's diary, and the entry closed with the words " Nil desperandum."

The HORSES were now reduced to TWENTY-ONE, and these the poorest and worst, another of the malignant peculiarities of the poison being that it attacks the animals which are in the best condition-presumably because they eat more heartily.

"With stout hearts and naked legs," the Brothers Jardine, Binney, Scrutton and the four black boys set out on 13 th Fanuary to face what further trials might be ahead of them, for by this time their wardrobes had been reduced to shirt and belt. A stage of Io miles NE. by N. was made with the utmost difficulty during the day. The country was composed of ridges of red soil, divided by boggy black soil flats covered with tea tree. "The CATTLE floundered and BOGGED at every hundred yards, and even the spare unladen horses had to be pulled out. The latter were at length so completely knocked up that it was necessary to leave some of them at one side of the swamp, the party carrying their pack and loads about a quarter of a mile on to a dry ridge on the 
other. Here they camped, and, tired as they were, they were obliged to keep a vigilant watch, as, to add to their many annoyances, the NATives had been following them all day." (CAMP 68.)

On the $\mathrm{I} 3^{\text {th }}$ and $\mathrm{I} 4$ th there had been no rain. By the morning of the $\mathrm{I} 4 \mathrm{th}$, the swamp behind camp 68 had been so much dried that the horses were got across without any great difficulty. During the remainder of that day, however, in crossing the teatree flats between the red-soil ridges, the HORSES again and again BROKE THROUGH THE CRUST and the packs had to be unloaded and carried by the men. Two more HORSES DIED during the day from the effects of the Porson, leaving only nineteen. The camp was made a little after midday (CAMP 69). RaIN, the heaviest the party had yet experienced, began shortly afterwards and lasted for three hours. In the midst of preparations for the protection of the stores from the deluge, some fifteen or twenty unarmed NATives came up to the camp and were CHASED AWAY.

"They were soon back again, however," says Byerley (p. 48), "with large bundles of SPEARs barbed with fish-bones, but not before the party had had time to prepare for them. The rifles were dry and loaded. Frank Jardine here owns to a feeling of savage delight at the prospect of having a 'shine' with these wretched savages who, without provocation, hung on their footsteps, dogging them like hawks all through the thickest of their troubles, watching, with cowardly patience, for a favourable moment to attack them at a disadvantage. Even then, however, he would not be the aggressor, but allowed them to come within sixty yards and ship their sPEARs in the WIMMERAs before they were fired upon. The two foremost men fell to the only two shots that were discharged, and their companions at once broke and fled; nor was the advantage followed up, as the travellers were careful to husband their ammunition, and their caps were running short. This, however, was the LAST ocCAsIon on which the party was molested, their sable adversaries having, probably, at last learned that they were worth letting alone, and never again showing themselves."

The 15 th of Fanuary, "being Sunday," was observed as a day of rest, which was much needed by men and beasts. If the party did not travel, neither were they guilty of "profaning the day by idleness." Useful employment was found in SPREADING OUT THE CONTENTS OF THE BAGS TO DRY, everything having become mouldy from the damp, and in PICKING OUT PANDANUS THORNS from one another's feet and legs. Heavy rain fell during the night and three inches of water ran through the tents.

Very wisely, Richardson made no attempt to chart the ROUTE BETWEen the BataVia River and THE HEAd of the JaRdine, i.e., from Camp 67 to $\mathrm{Camp}_{\mathrm{am}}$ 78, and the reason is obvious. The expedition was boring through scrubs, unable to see any distance ahead, floundering through bogs or winding about to avoid them, and, in short, until the Pacific was sighted and a bearing was taken to Cape Grenville, did not know where it was. The latitude could not be ascertained, for black clouds blotted out the stars by night. Moreover, the flooded state of the country made it impossible to 
judge of the relative "values" of water-courses, a "creek of the fourth magnitude" being indistinguishable from a "river."

In these circumstances, with the aid of the charts now existing, I am obliged to attempt to HARMONISE THE NARRATIVE of the explorers WITH THE TOPOGRAPHY of the district, as the latter is now understood. I take it for granted that the water-courses laid down on modern maps actually exist and are in the positions assigned to them. The survey incidental to the construction of the Cape York Telegraph line (Cooktown to Cape York) in 1884-7 gives firm data for the intersections of the line by numerous creeks. The country is now partly taken up in pastoral "runs" and partly reserved for the aborigines or the police. In I885-6 and I $895-7$, Mr. Embley traversed and surveyed most of the important creeks and rivers as well as the boundaries of reserves and pastoral leases within the region now under consideration.

On the western or Gulf side of the peninsula, between I I $45^{\prime}$ and $12^{\circ} 5^{\prime}$ of south latitude, modern maps, viz., the Admiralty Chart, the 4-mile map (Sheet 2I A), the I 2-mile "Tenure Map" and the I6-mile map of Queensland, show a GROUP of RIVERS named in their order from north to south, the SKARDON, DALHUNTY and Ducie. A critical examination of the narratives of the Jardine Expedition leads to the conclusion that the so-called DaLHunty (the Dalhunty River, de facto) is the river to which the Brothers gave the name of the SKardon; that the Jardines' DalHunty is the so-called South Alice CReer, a tributary of the North Alice, which falls into the Ducie; and that the so-called SKardon, with its head east of the $\mathrm{McD}$ onnell station of the Cape York Telegraph line, falls into the Gulf in $\mathrm{II}^{\circ} 45^{\prime}$ south latitude, at the inlet where a boat's crew from the "Pera" landed on I2th May, I623, which Carstenszoon (who obviously followed the "Duyfken's" chart) then identified as the "CARPentier Revier," "which the men of the 'Duiffken,' anno I606, went up with a boat, and one of them was killed by the projectiles of the savages" (Heeres, p. 42). It would, however, be impossible to substitute the original name of the "Carpentier," bestowed 3 I4 years ago, for the de facto name of "Skardon," which has been confirmed by thirty-three years of usage. The de facto name of "Skardon" was unalterably fixed by the telegraph surveyors in 1887. Mr. Embley informs me that the river at the McDonnell Telegraph Station has a large deep channel and carries a large volume of water in flood times.

The mistake by which the Carpentier River, de jure, became fixed as the Skardon River, de facto, made it necessary to find another water-course to bear the Jardines' name of "Dalhunty," and accordingly the river (falling into Port Musgrave) which was the Jardines' Skardon, DE JURE, became the Dalhunty, DE Facto.

With these observations, we return to the NARRATIVES OF THE EXPLORERS. 
On the 16 th of Fanuary, $\mathrm{I} 865$, it is stated that the FEET AND LEGS of the men had been CUT IN PIECES by the thorny vines. [From my own experience in the same district I can testify that such WOUNDS are more or less POISONED and are difficult to heal.R. L. J.] With considerable reluctance, but driven by necessity, the men packed up and RESUMED THEIR JOURNEY. It had rained in the morning, but the weather cleared as the day went on. Five miles from Camp 69, the party descended gradually into a valley and crossed, "the horses bogging a little; a smaller stream of excellent water running to the west. A little further on a deeper creek, but sandy and firm, water also running knee-deep in the same direction." Richardson, from whom the above quotation is taken, conjectured that the last creek mentioned was one of the heads of the Batavia River. It was, in fact, the "RoCKY CREeK" of the subsequent Telegraph survey, and if he had crossed it twenty-two years later he might have seen the telegraph wire above his head. Unhappily no such infallible guide to Cape York cheered the foot-sore wanderers.

Rocky Creek, according to the Telegraph survey, is one of the heads of what appears on the modern 4-mile map as the Ducie River. Five or six miles ${ }^{1}$ further, the Palm CREek of the Telegraph survey was crossed, and at $15^{\frac{1}{2}}$ miles from Camp 69, the party camped (CAMP 70) on the north, or right, bank of a creek which the Brothers named the DaLhunTY. It is described as "ten yards wide; water knee-deep and running slowly to the westward : banks steep." This DaLhunty River, DE JURE, has unalterably become the South Alice CReEK, de facto.

The PALM CREeK of the Telegraph survey, according to Mr. Embley (in a recent letter to me) where it crosses the line, "has a big channel and carries a large volume of flood water."

Shortly after the construction of the telegraph line, in which Frank Jardine took part, he changed the name of Palm Creek to the Ducie River, in honour of the Earl of Ducie. He ran the river down westward for some 20 miles, where he established Bertie Haugh Station (named for his own son). He found that 20 miles further west, the river ran into Port Musgrave, the common estuary of the Dalhunty (de facto) and the Ducie and Batavia Rivers.

On this day's march (16th January, I865), Richardson refers for the first time for many months to something resembling a range. "They walked," he says, "over some high ridges, or one might almost say LOW RANGES; there does not appear to be a distinct range, merely a succession of gradually ascending ridges, which are not well grassed." They were now, in fact, getting on to the sandstone shelf which lies west of my "Sir William Thomson

1 Distances over-estimated, for a reason which it is easy to understand, viz., the " difficulty" equation. 
Range" and which forms the divide between the waters of the Gulf of Carpentaria and the Pacific Ocean. This divide, or watershed, the Brothers named the Richardson RanGE.

One more of the horses died in the course of the day from the effects of the POISON PLANT eaten at Camp 67.

On I7th Fanuary, "the country was similar to that of yesterday, save that the RIDGES were HIGHER AND MORE STONY." The ascent commenced at Camp 70 and the summit was reached in $4^{\frac{1}{2}}$ miles. ANT-HILls of bright red earth were noted by Richardson as reaching the height of 25 to 30 feet. At 2 and 10 miles from Camp 70, creeks were crossed, running west, probably to join the North Alice CReEK ${ }^{1}$ of the Telegraph survey. CAmp 7I was pitched on the right bank of a creek (with vine scrub and Seaforthia palms) I $5^{\frac{1}{2}}$ miles north of Camp 70, which was named SKardon CREEK. This creek crosses the telegraph line a few miles further west and discharges into Port Musgrave. It was erroneously identified by the telegraph surveyors as the Jardines' "Dalhunty" and the error has been imported into official maps subsequent to 1887 . It must remain the DALHUNTY, DE FACTO, although it is the SKaRDON, DE JURE.

The two last of the "good" HORSES DIED at this camp from the porson eaten at Camp 67 . The forty-two with which they had set out were now reduced to fifteen of the "culls."

A general course of N. by E. was kept on I 8 th fanuary and 12 miles were believed to have been accomplished. Applying the "correction for difficulty," the distance works out at about 4 miles of northing.

"The march to-day," says Byerley (p. 50), "is described as being through the MOST ABOMINABLE COUNTRY that can well be imagined, being a continuation of loose white sandy ridges thickly covered with LOw BUsH from 3 to 8 feet in height, broom, fern, grasstree, pandanus and 'five-corner' bushes being thickly matted together with PRICKLY VINE. Not a tree relieved the monotony of this waste, and, what was worse, NOT A BLADE OF GRASs was seen for miles. Several DEEP CREEKs were crossed, all running strongly with clear pellucid water to W. and NW. The timber, when it occurred,was bloodwood, stringy-and iron-bark on the ridges, banksia, grevillia and several kinds of teatrees in the gullies, which were honeycombed and boggy. Two new kinds of Palm were seen. The bush, which seems to be what Kennedy alluded to as " HEATH," could only be got through by leading a horse ahead, the others following slowly behind him, the cattle then following in their track. A straight course was impossible, as all the boggy creeks and gullies had to be run up to their heads before they could be crossed. . . . The packs were continually being knocked off the horses, occasioning great delay.... Some black perch were caught in one of the creeks and scrub turkeys were seen. Poor 'Nel Gwynne's' foal knocked up to-day, after having kept up bravely since the mare's death. Nothing remained therefore but to kill him. The party being without meat, and it being impossible to stop in such a country to kill a beast, part of his flesh was dressed and carried on, which was a grateful addition to the food, and although two or three at first refused to eat of it, the craving of hunger soon made them forget their repugnance to HORSEFLEsH.

1 Named after Frank Jardine's daughter. 
At night the horses had to be short-hobbled, and a watch kept over them. The weather kept fine, raising the hopes of the Leader of getting in before the rains." (CAMP 72.)

A clear night permitted of a star being taken, and the latitude of the camp is given as $11^{\circ} 46^{\prime} 36^{\prime \prime} \mathrm{S}$. This I take to be about $3^{\prime} 30^{\prime \prime}$ too far south.

I9th Famuary.-In similar "ABominable country," boggy creeks had to be headed, and capsized horses had to be set on their feet again and again, and only about 8 miles of northing were gained. CAMP 73 was on the head of a small creek running to the east, and the watershed of the Peninsula had been crossed at last. Late in the afternoon, after the camp had been pitched, the Brothers saw Shelburne BAY from trees which they had climbed in search of the honeycomb of the native bee.

20th Fanuary.-After having pushed on for 2 miles northward through brushwood and scrub, the travellers were confronted with a dense PINE-AND-Vine scrub. After some delay, a Native track was found and followed through the scrub for 2 miles further, when it was found that the tangle of scrub and vine ropes was more than the cattle could face. The native track was therefore retraced, and half a mile was made to the east, to a point whence Shelburne Bay was distinctly visible. Thence a stony spur of the range was followed down and the party camped on a small creek running east. (САMP 74.) The total distance covered was estimated at 9 miles, and the actual northing at a mile and a half. Quoting from the Leader's diary, Byerley observes that the tracks of NATives were very numerous on this day's journey, " and it was evident by the neat cutting of the marks on the trees that they were provided with good IRON TOMAHAWKs. Many TURKEYS' NESTS were found, but the eggs only benefited the stronger stomachs of the party, having young ones in them in most cases."

From a point near Camp 74, Richardson got a prismatic compass bearing of $117^{\circ}$ to $C_{A P E}$ GRENville and thus determined the position of the camp with some approach to accuracy. [My camp 5I (Ist March, I 880), must have been practically on the same spot. -R. L. J.]

It is a coincidence, although, considering the nature of the country, by no means a "remarkable" one, that in this region the THREE PARTIES which were making for Cape York, Kennedy's (by this time reduced to himself and a black boy), the Jardines' and my own, each HAD TO DOUBLE BACK and search for a new opening.

From their 74th almost to their 76 th Camps, the track of the Brothers was east of mine, and west of Kennedy's, mine being on the western and the Jardines' and Kennedy's on the eastern side of the watershed. Kennedy's and mine could not have been more than 2 miles apart. 
2ist fanuary.-The SCRUB was so dense that more than seven hours were spent in cutting 8 miles through it to the NNE. It was described by the Brothers as "FEARFULLY DIFFicult." "The cattle occasionally got their horns entangled in the vines and had to be cut loose. One cow got furious at being thus arrested, and when extricated galloped straight away and was no more seen. . . . A great variety of PALMs were seen in the scrubs, which were covered with fruit and berries, but only the 'Seafortbia,' the most graceful of the family, the Caryota urens, remarkable for its star-shaped fronds, and the more common Corypha, of which the Colonial straw hats are made, ${ }^{1}$ were known to the travellers." Four deep and narrow creeks were crossed, running generally east, says Richardson. The Brothers say, seven creeks, running westward. There can be no doubt that as regards the direction of the flow Richardson was in the right, as they were on the coastward side of the watershed. They must have crossed KENNEDY'S TRACK, between his camps of 21st and 22nd November, I848. CAMP 75 was probably on, or not far from, my "CAPTAin Billy Creek." Its latitude is given by Byerley as $11^{\circ} 37^{\prime} 46^{\prime \prime} \mathrm{S}$., which I take to be $3 \frac{1}{2}$ miles too far south. The fact that Richardson (who made the observations) does not record the latitude suggests that he himself doubted its accuracy.

22nd Fanuary.-The same class of country prevailed, with even a more marked ABSENCE OF GRASS. The distance travelled was estimated at Io miles, but the actual northing can hardly have been more than half. Four or five creeks were crossed, all running east. CAMP 76 was among open brushwood near one of them, which was probably CAMISADE CREEK, at the mouth of which (my Camp 57) the blacks made a nocturnal attack on my party in 1880 . Heavy RAIN set in before Camp 76 was reached and continued till midnight.

23 rd fanuary. - The rain fell steadily all day long. The course was altered to NNW., and for some distance was on the DIVIDE between the Pacific ( 5 miles to the east) and the Gulf (48 miles to the west). The distance traversed was estimated at $9 \frac{1}{2}$ miles, and was probably about 6 . CAMP 77 was on a teatree water-course in forest country, with GRASs enough for the camp. It cannot have been more than 2 miles west of my Camp 52 .

24 th Fanuary.-Two miles from Camp 77 a stream was struck, running north, with a clear bed 30 yards wide. The right bank was followed for $3 \frac{1}{2}$ miles through heath and brushwood, a track having to be cut for the passage of the horses and cattle. A heavy thunderstorm then caused the creek to rise rapidly and bar further progress. CAMP 78. Rain fell at intervals till midnight. This

1 The "Cabbage Tree Palm." The hats are woven by solitary bushmen, and being indestructible and highly valued as a protection from the sun, command fancy prices, up to $£ 5$. 
camp cannot have been more than 2 miles west of MY CAMP 53, from which I DOUBLED BACK to the south, on 4th March, I880, To AVoID the death of all my horses from staRvation.

The Brothers and Richardson agreed that this stream must be the EsCAPE RIVER to which reference has so often been made, and this theory, lightly formed, as it seems to me, and adhered to with an amazing obstinacy, was destined to lead to the most serious consequences. It is now known that the Escape River, which was named by Captain King, R.N., on 24th July, 1819, and where Kennedy met his death in 1848 , "heads" not more than 13 miles south of the point where it enters the Pacific 16 miles from Somerset, whereas Camp 78 was at least 31 miles south of the outlet. Acting on the theory they had adopted, the idea of the Brothers was to get on the left bank of the river to avoid the swamps which Jackey-Jackey's narrative had shown to exist near the mouth of the Escape. 


\section{THE JARDINE BROTHERS' EXPEDITION, continued}

\section{THE JARDINE RIVER AND THE PROBLEM OF THE ESCAPE RIVER}

Cross to Left Bank of the Mysterious River. Heath and Brushwood. Floods.

Camp 79. McHenry River. Swimming. Depót at Camp 82. ReconnaisSAnce Down the Mysterious River by the Brothers, who conclude that it falls into Gulf. Their Return to tire Depôt. Shortage of Flour. Second Reconnaissance. A Raft. Swimming. Mouth of the Real Escape River. Newcastle Bay. On Kennedy's Tracks. The Mysterious River at Camp 82 cannot be the Escape. Unsuccessful Attempts to cross the Escape. Wanderings between the Escape and the East Coast. The Mysterious River must be the Escape after all. Floods and Heavy Travelling. Exhausted Horses. Return to Depôt. Flour exhausted. Water and Jerked Beef only. Horses reduced to Thirteen. Fresh Start of the Expedition, Down the Mysterious River to the West in search of "the Bend." Camps 83 and 84. Eliot River. Camp 85. Difficulties in Bogs. Swimming. Camp 86. No Breakfast. Light Jobs for Sunday. Solution of the Problem. The Mysterious River is not the Escape and falls into Endeavour Strait near Carstenszoon's Van Sfult River (i623). The Mysterious River named the "Deception," the "Fergusson," and finally the "Jardine." Camp 87.

\section{(See MaP B.)}

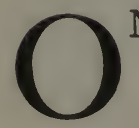

$\mathrm{N}$ 25th Fanuary, 1865, the party CROSSED THE SUPPOSED Escape River and travelled N. I $6^{\circ} \mathrm{W}$. down its left side for Io miles, the rain falling heavily almost all day. The country was " of the usual character, heath and brushwood." "A delay of a couple of hours occurred in consequence of a thunderstorm flooding a narrow gutter that might be hopped over. It was not until this subsided that the horses and cattle could be made to face it, the poor brutes having been so frightened with bogs and water that the horses had to be led over the smallest of them." CAMP 79 was in "a miserable hole" in the middle of the brush.

The RIVER which the expedition now followed down proved to be an ENTIRELY UNKNOWN one, to which the name of the JARDINE was subsequently given. The great mistake was made of regarding it as King's Escape River and believing that by keeping on its left bank a deep crossing and formidable swamps would be avoided.

On 26 th Fanuary, the river (subsequently named the JARDINE) was traced for 10 miles a little to the north of west, and the rain 
fell heavily all day, as well as during the night following. CAMP 80 , at the end of this stage, was pitched on the right bank of a river, which was named the McHenry, coming from the south, and of a volume equal to that of the Jardine itself. This river probably takes its rise near the 74th Camp.

On 27th Fanuary, the party crossed to the left bank of the McHenry. "This was accomplished in safety, CATTLE AND HORSES TAKING THE WATER LIKE DOGS, the greater difficulty being in getting over the packs, saddles and stores, which had to be carried on the heads of the swimmers of the party, and this necessary part of a bushman's education was not common to all." RaIN fell steadily the greater part of the day. The day's journey was estimated at 5 miles; the country slightly improving, with a little grass on the banks of the Jardine. CAMP 8I.

28th Fanuary.-Following the JARDINE, with its " endlessly recurring water-courses, each with its eternal fringe of thick vine scrub," was soon found to be intolerable, and a course was shaped to the west. The intention was to run the river (supposed to be the Escape) down to the head of the tide and to leave the cattle to recruit while the Brothers found a practicable way to Somerset. The westward excursion proved a failure, and " far from improving the travelling, made it worse, as they got into a maze of scrub, heath and swamp, through which they had to thread their course. They had therefore to make their way back to the river." The total distance travelled was estimated at I 2 miles. I reckon that it must have been more, and that CAMP 82 , on the bank of the river, was about 9 miles NNE. of Camp 8I. The rain poured all day long.

In the last portion of its course, the river seemed to be making at last as if it would really become the Escape. This hope, however, was to prove illusory.

CAMP 82 was established as a depôt and resting-place for the main body of the party and the animals, while the Brothers went out to reconnoitre. Packs, saddles and stores were found to be for the most part completely rotted from the constant wet. (SEE MAP A.)

The eXCURSion of the Brothers, who were accompanied by EulaH, occupied the 30 th and 3 Ist January and the Ist February, and the reconnoitring party returned to the main camp (82) early in the morning of 2 nd February.

They found that it was IMPOSSIBLE TO GET AWAY FROM THE RIVER, as they no sooner got out of sight of it than they became entangled in thick brush and teatree swamps without a blade of GRASS. Following the windings of the river for a distance which they estimated at $3 \mathbf{I}$ miles; they struck a large creek which they named the Eliot, coming from the south. The course of this river has since been determined by the CAPE York Telegraph SuRveY. It rises in $1 I^{\circ} 30^{\prime} \mathrm{S}$. lat. and the telegraph line now 
follows its left bank to N. $10^{\circ} \mathrm{W}$., and it falls into the left bank of the Jardine River in $\mathrm{II}^{\circ} 9^{\prime} \mathrm{S}$. According to the modern 4 -mile map, the junction of the Eliot with the Jardine is about 16 miles a little north of west of Camp 82. After wading across the Eliot, their saddles and packs on their heads, and the water up to their necks, the explorers FOLLOWED THE JARDINE for 14 miles further, until they were satisfied that the Jardine River must shortly fall into the Gulf, and could not by any possibility be the Escape. Rain was falling for the greater part of the three days they were out.

On their return to $\mathrm{CAMP}_{\mathrm{A}} 82$, the Brothers found an unaccountable DEFICIENCY of $30 \mathrm{lb}$. in the now very scanty supply of FLOUR. Byerley, who records the incident with hearty disgust, remarks that similar instances of non-communal meanness had blotted the records of the followers of Burke and Wills and of Kennedy.

It was now determined that the Brothers should cross THE JARDine River and make another attempt to reach Somerset or the mouth of the real Escape River. The RaIN being almost continuous, the Jardine was still high and the 3 rd and 4 th February were consumed in experiments to find a practicable crossing. All their labour had only resulted in their finding themselves hopelessly on the WRONG SIDE of a RIVER which was NOT THE ESCAPE, whatever it was.

A raft was constructed by stretching a hide over a framework of dead nondah, the only timber light enough for the purpose-and it was scarce. On this the saddles, rations, etc., were floated across the Jardine on 5 th February. Byerley's account of the passage is as follows :-

\footnotetext{
"The river having sunk considerably during the night, the crossing was commenced this morning, despite the downpour of RAIN, which lasted all day without a break. The stream was I 30 yards wide, the banks fringed with scrub and the current still running rapidly. It required, therefore, strong and expert swimmers to get the horses across, the method being as follows: One of the party went in first, with a line made fast to the bit of the horse's bridle, and another followed, holding on by his tail by way of rudder. Now as a horse can swim faster than a man, and is, of course, heavier in the water, the leader has no easy task, even if his horse swim honestly for the opposite bank, but should he turn or boggle at all, man and line are alike powerless; the use of the rudder, therefore, will be seen. When the leader reaches the opposite bank, he has to scramble up nimbly, or he may have the horse on him, and, arrived there, be in readiness with the line to assist him should he get entangled in the saplings and vines which fringe the banks. It will be remembered that in crossing the Batavia [Nimrod Creek.-R. L. J.] on the IIth January, two horses were drowned, in spite of every care and precaution. Here, however, they were fortunate enough to cross their four horses without accident, Mr. Scrutton, old Eulah and the black boys doing good service, being all excellent swimmers. The saddles and rations were then floated over in the raft, and the advance party (тнE Brothers and EULAH) CAMPED ON THE NORTH SIDE, leaving the remainder of the party and cattle in charge of Mr. Scrutton."
} 


\section{JARDINE RIVER AND ESCAPE RIVER}

"Even now," continued Byerley, "Frank Jardine was uncertain as to what stream they were on, and still LEANED TO THE BELIEF THAT IT WAS THE ESCAPE." "The necessity for reaching their journey's end was becoming urgent, for their tea and sugar were exhausted."

On this, their Second Excursion undertaken with the object of finding a way to the north, the Brothers and Eulah spent four days (6th to 9 th February). Leaving the Jardine opposite Camp 82, they rode NNE. and at 15 miles found themselves on "a line of high ridges forming a saddle-range." This was the WATERSHED of the Peninsula, probably a little east of my Camp 64. From this range they obtained a view of the PAcific OcEan and could distinguish a few small islands, probably ARNOLD and Sinclair and possibly Milman Islands. They could not, however, see clearly because of the drizzling rain. Now turning N. by E, ${ }^{1}$ they got, at an estimated distance of 5 miles [say 9.- R. L. J.] from the watershed, on a white hill [Sharp PEAK ?-R, L. J.] from which they looked on Newcastle Bay, which was about half a mile off. Then they skirted the coast for 3 miles to the west, and CAMPED. This westward stretch of coast was evidently that opposite the south end of TurTle Island. Their camp of this night (6th February) must have been in the immediate vicinity of KENNEDY's FIRST CAMP ON THE ESCAPE.

The following morning ( 7 th February) they came on what they correctly surmised to be the MOUTH OF THE VERITABLE EsCAPE RivER. It was three-quarters of a mile in width and running rapidly "from the NW." The flow, as given, is probably a clerical error in Frank Jardine's notes. The adjoining country was "villainous" with boggy swamps, brushwood and scrub.

For three days ( $7 t h, 8 t h$ and $9 t h$ February) the Brothers erred and strayed over the western side of the little peninsula almost encircled by the Escape River and the Pacific Ocean. Again and again they tried in vain to CROSS THE EsCAPE, the mosquitoes and the bogs and scrubs of the VILLAINOUS COUNTRY combining to reduce the horses to the last stage of debility.

It is impossible to chart these wanderings from the bearings and distances given. The Brothers met the same difficulties which had made a pothook of KENNEDY's RouTE seventeen years before. Even eighteen years later, in spite of having the experiences of my two predecessors to warn me, I HAD TO " HEAD" THE EsCAPE, after trying to cross it.

Frank Jardine had come round again to the belief, which he had persisted in almost against the evidences of his senses, THAT the JaRdine River was only the head of the Escape, his theory

1 It is doubtful whether the Brothers carried, or used, a pocket compass. They would trust, like bushmen, to taking their bearings from the sun, which, in such weather, would be a poor guide. 
being, that if he had only followed the Jardine down a few miles beyond his. "furthest west " of Ist February, he would have found the river doubling back to the east coast. He had, he imagined, proved that there was no way for the cattle across the EsCAPE, and made up his mind that the only thing to be done was to drive them down the (Jardine). river and get them round its supposed elbow.

It is not for a moment suggested that the Leader of the expedition was "bushed" during his wanderings in the little peninsula east of the Escape River. If proof were needed, it would be found in the fact that, having turned back on the Ioth, he found himself on the IIth on the right bank of the Jardine River, opposite Camp 82. This, however, was due rather to the mysterious instinct of locality known as bushmanship than to steering a course.

By the time they reached the camp their horses were incapable of a greater pace than a mile and a half an hour with the assistance of their now dismounted riders. They were left on the right bank of the river, while the Brothers and Eulah swam across to the camp. A very heavy thunderstorm had flooded the little creeks during the last part of the day's journey. It was found that another of the HORSES had DIED at the camp from exhaustion.

RichaRdson agreed with the Brothers. His diary of IIth February says : "There is no doubt that the river near which we are encamped is the EsCAPE, and our best plan is to follow it until it bends to the eastward." Richardson's sextant had already become an object of suspicion. On overhauling it at Camp 82 he found that it had been injured by the rough travelling, and it could not be corrected for some time, as the sun was invisible (and so presumably were the stars), "both days and nights being now rainy-not heavy rain, but continuous." He comforted himself with the thought that after all the error in latitude could not be more than fifteen miles! By 5 th February, however, he had got the instrument into some sort of adjustment and gave the latitude as $11^{\circ} 1 I^{\prime}$. $30^{\prime \prime}$.

On I th February, when the Brothers returned to the camp, it was found that II lb. of FLOUR was all that remained of the provisions. Henceforth the menu was restricted to JERKED BEEF AND WATER, with the addition of as much game as could be caught.

Owing to preparations for the journey, the necessity for rest to the horses and the temporary loss of some cattle, it was not till I 4 th February that a start was made. That day another HORSE had to be ABANDONED, leaving the party with only thirteen. CAMP 83 was pitched II miles down the river, perhaps 7 miles NW. More of the luggage was left behind; all that now remained consisted of jerked meat, ammunition, tents and personal swags.

Although the expedition followed the footsteps of the Brothers on their first reconnaissance, it was found that taking the CATTLE over the sodden ground was a very different matter from travelling 
in light marching order. On 15 th February, no less than three hours were consumed in crossing one of the boggy gullies. The horses had to be unpacked, and half of them had to be pulled across with ropes. From Camp 83 to $\mathrm{CAmP}_{\mathrm{Am}} 84,8$ miles east of the Eliot River, the distance was estimated at II miles.

I6th February.-The Eliot River was crossed; it was 30 yards wide and 5 feet deep, with sandstone outcrops. The horses had to be relieved of their loads. Two miles further, CAMP 85 was pitched on the river bank after Io miles had been accomplished. The camp must have been where the TELEGRAPH LINE now crosses the Jardine.

I 7 th February.-CAmp 86 was on the right bank of a large creek falling into the Jardine, 8 miles down the latter from Camp 85, and 2 miles beyond the Brothers' camp of Ist February.

18th February.-The creek at Camp 86 was crossed in the morning, cattle, horses and men having to swim, the men carrying the saddles and loads on their heads. The course of the Jardine River had now become NORTHWARD, and for a short time the travellers were elated by the conviction that they were about to round the elusive and mythical "BEND TO THE EAST," which had by this time become an article of faith with them. The ro miles of this day's march are described as " poorly grassed stringybark ridges" for the first mile, and then "the country resumed its old character of swamp, brushwood and low scrubby banks, flooded for 4 or 5 feet, the overflow filling swamps running parallel, and about 300 or 400 yards distant from the river." After CAMP 87 had been fixed, a suspicion arose that the river was within the influences of the tide, a rise and fall of 6 inches being perceptible, although, owing to the floods, the water was fresh.

Richardson made the latitude of the camp $10^{\circ} 5^{\prime} 6^{\prime} 4^{\prime \prime}$ S., which is nearly correct:

A halt was made at this spot earlier than would otherwise have been the case, because the party had started without breakfast, having NOTHING TO EAT, and it had become necessary to kill a calf.

The 19th February, "being Sunday," was, according to Byerley, "chiefly devoted to rest," the slight exception being the cutting up, jerking and smoking of the meat, a bark hut having to be erected for the smoking process.

20 th February. - Heavy RAIN fell from 2 a.m. till after the party resumed their journey. It was found that the JARDINE RIVER again took a WESTWARD COURSE, and after following it in this direction for 6 miles [say 4.-R. L. J.] the procession was brought to a standstill by a creek coming from the south, fringed with mangroves, the banks showing a TIDAL RISE AND FALL of 3 feet. The Brothers and Eulah crossed the creek and Alick and Eulah climbed a tree, from which they saw the MOUTH OF THE Jardine River some 2 miles distant, and also Prince of Wales and Barn 
IsLANDS. The rain poured down heavily and $\mathrm{C}_{\mathrm{AMP}} 88$ was pitched on the eastern, or right, bank of the creek.

The PROBlem WAS SOLVED! And the solution was a disgusting anti-climax. The rIVER WAS NOT THE Escape, and it lay, an apparently insurmountable barrier, between the explorers and their goal, where the father anxiously awaited the sons, who were nOW LESS THAN 30 MILES SOUTH-WEST OF SOMERSET.

Six miles south-west of the mouth of the river an indentation in the coast-line of the Endeavour Straits may be the " waterplaets" (watering-place) marked on the chart by JAN CARSTENszoon on I3th May, 1623, when he and ten musketeers landed from the "Pera" and found " a very fine FRESH-WATER RIVER, flowing into the sea, whence fresh water can easily be obtained by means of boats or pinnaces." This inlet was named the Revier van Spult, and there can be no doubt that it is a MOUTH OF THE JARDINE RIVER. The fresh water at the landing was probably due to floods. It is strange that Carstenszoon's diary never once mentions any meteorological conditions except winds.

On the NEW RIVER, the Brothers proposed to bestow the name of the Deception, but subsequently the Governor of Queensland, Sir George Bowen, gave orders that it should be charted, and named it the JARDine River. No name could have been more appropriate. The Brothers had indeed made the river their own. They had discovered it, followed it down from its head to the salt water during twelve toilsome and costly marches and investigated its surroundings. In time alone it had cost them a month, and was yet to cost some weeks more before the remnant of the cattle was delivered at Somerset. 


\section{CHAPTER XLV}

\section{THE JARDINE BROTHERS' EXPEDITION, continued}

Reconnaissance by the Brothers and Eulah. Swimming the Jardine River. A

Raft. Stopped by Flooded Creex (Cowal Creek). Wild Grapes. Swimming

Cowal Creek. Suspension Bridge. On Jackey-Jackey's Footsteps. Meeting with Friendly Natives. Dug-out Canoes. Guided to Somerset. Marked Tree Line Missed. The Van Spult River.

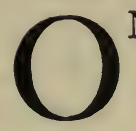

$\mathrm{N}$ 22nd February, 1865, the whole party retraced their steps to Camp 87. (SeE Map A.) A day (23rd February) was spent in killing a calf and drying the meat and in the construction of a RAFT like the one employed at Camp 82. The rain was falling heavily and the Jardine River was rising fast.

On 24th February, the Brothers and Eulah started on a THIRD EXCURSION OR RECONNAISSANCE IN SEARCH OF SOMERSET. HEAvy RAIN fell during the whole of the day and a COLD WIND nipped the wet and half-clad travellers more severely than they had a right to expect midway between the equator and the Tropic of Capricorn. By this time, however, they had learned the natives' trick of protecting themselves from the elements and the mosquitoes by SMEARING THEIR BODIES WITH FAT.

Opposite Camp 87, the Jardine River had to be crossed. The HORSES SWAM gallantly and the RAFT rode well on the flood, but the transit took the whole of the day, the party camping on the right bank of the JARDINE.

Next day (25th February) the travellers were arrested only 2 miles from the river by Cowal C REEK, which was in high flood, at least half a mile wide, running strongly, and, in short, IM PASSABLE. Three nights $(25 t h, 26 t h$ and $27 t h)$ were spent on the LEFT BANK OF THE CowaL, and the days were occupied in trying to find a crossing and hunting for something to supplement the ration of dried veal. The only success in the latter direction was the discovery of the oblate "WILD GRAPEs," which Alick said were "very good to eat, but they take all the skin off the tongue and lips." My own experience is that a very few of these "grapes" may be eaten with impunity when dead ripe.

On 28 th February, the creek had fallen sufficiently to be crossed. There was a rapid current 15 yards wide which the MEN AND HORSES SWAM ACROSs, the saddles, etc., being transported by a sUSPENSION BRIDGE improvised out of tent ropes. On the right bank of the 
river, the travelling improved at once to good sound stringybark ridges intersected by only a few broad teatree gullies. The party accomplished ro miles and CAMPED. In the evening, Frank and Eulah climbed trees and SAW NeWCAstLe BAY, "on the south-east of the bight on which they were now camped." This is puzzling, but it appears as if the Brothers had steered about 5 degrees north of east from Cowal Creek, crossing my (then non-existent) track midway between my Camps 69 and 70 , and that their camp on 28th February was on JACKEY-JACKEY's TRACK near the head of KENNEDY INLET.

The Ist March was a wet day. The party started early in the morning, and, probably heading a little to the west of north, in JACKEY-JACKEY'S FOOTSTEPS, "over a great deal of low scrub and brushwood," at 3 o'clock met a party of NATives. It may be assumed that they were now in the vicinity of my 7 Ist Camp. The NATIVES proved to be FRIENDLY and, moreover, were posted up in the names of some of the party, excitedly shouting "Alico, Franco, Dzocko [Jock], Johnny, Toby, tobacco and other English words" and pointing in the direction of SoMERSET, which they named "Kaieeby." It may be imagined how lovely seemed the "kindly dark faces" and how sweetly mellifluous sounded " English words" spoken by black lips!

Guided by their new friends, the party travelled about 7 miles (presumably ENE.), skilfully piloted through the scrubs and between the swamps, and reached " a shallow SALT-WATER CREEK that empties itself into a northern inlet of Newcastle Bay," where a large body of NATIVEs was met. These blacks were without arms, but later in the day they presented the white men-in token of friendship, as was supposed-with a number of spears and wimmeras which had been concealed among the mangroves. The party thus reinforced went on for 2 miles further to their main camp, where three large "dug-out" CANOEs lay at their moorings. Here the whites CAMPED and watched, still not sufficiently off their guard to feel secure against treachery, while the natives kept up a noisy corroborree till the "small hours" of the morning.

On 2nd March, the Brothers were up and away at daylight, in spite of a downpour of rain, the blacks guiding them to and along the coast, and they REACHED Somerset at noon. Father and sons met at last after five months of anxiety on one side and heroic effort on the other.

JoHN JARDine had realised, before he had been long resident in Somerset that the intricate nature of the country must render the approach from the south a matter of difficulty, especially in a wet season. With the object of guiding his sons to the settlement, he had, therefore, MARKED A LINE OF TREES, about 30 miles in length, south-westward to the head of the Kennedy (Jackey-Jackey Creek) [That would be about 2 miles south of my Camp 68.-R. L. J.] 
From that point, the line went west for Io miles to the Gulf coast [which would be on the parallel of II $^{\circ} 5^{\prime} \mathrm{S}$. lat., crossing the JARDine River, and in all probability also the VAN SPULt, and passing close to the Brothers' Camp 86.-R. L. J.]. The line was not observed, however, having probably been hidden by a rapid growth of scrub. 


\section{CHAPTER XLVI}

\section{THE JARDINE BROTHERS' EXPEDITION, continued}

Fresh Horses procured. Return of the Brothers to Camp 87. Natives enjoy a Gargantuan Meal. Whole Party leaves Camp 87. Swimming Jardine River. A Raft. Cowderoy narrowly escapes Drowning. Camp 89. Swimming Cowal Creek. Another Horse dropped. Camp 90. Telegraph Line. Cutring Scrub at Wimmerah Creek. More Cattle lost. Three Horses exhausted. Camp 9i. Cattle reach Camp 92 at Vallack Point, the Site selected for a Cattle Station. The "Might Have Been." Hostility of Natives. Geographical Results of the Expedition. Photographs. Death of Frank Jardine, 1919. His Diary. Fate of Eulah.

$7 \mathrm{HE} 2 n d, 3^{r d}$ and 4 th March, I 865 , were spent in getting five fresh horses across the Strait from Albany Island and in selecting a SITE FOR THE CATTLE STATION. (SeE Map A.) The spot chosen was at Vallack Point, 3 miles south of Somerset.

On 5th March, the two Brothers left Somerset for Camp 87, with black guides to show them the best track. They were also accompanied by a younger brother, John, "the "Jock" whose name, as pronounced by the friendly natives on the Ist March, sounded like "Dzocko." The guides led for some time by the line of marked trees to the SW. which was " a fair road for the cattle" and only presented a few light belts of scrub. The first night was spent where the Brothers had camped with the tribe on Ist March, which was 17 miles from Somerset by the new track. Next day (6th Marcb) the Brothers took the lead and in 22 miles reached the JaRDINE RIVER nearly opposite CAMP 87 . The river was still high and had been even higher during their absence. It was too late in the day for the party to cross, but two of the black guides swam over and returned with a large supply of beef. This was welcome enough to the whites, but to the native guides, who had never before seen cattle or fresh beef, it was nothing less than a revelation. The feast the blacks indulged in was a Gargantuan MEAL which filled the Brothers with awe.

The whole party swam across to CAMP 87 next morning ( 7 th $M a r(b)$, and were confronted with the familiar tale of missing horses and cattle. One of the horses had died. A beast was killed and with its hide a RAFT was constructed, having a carrying capacity of $400 \mathrm{lb}$.

1 Afterwards the owner of Aberfoyle Station, near Hughenden. 
Three of the CATTLE were still missing and were LEFT BEHIND when the expedition finally CROSSED THE JARDINE on 9 th March. CowDERoY, who was unable to swim, was taken across holding on by the raft, which was upset, and he NARROWLY ESCAPED DROWNING. The passage had been completed in safety by four o'clock and the party camped on the right bank. CAMP 89 .

Ioth March.-The distance covered to the NE. was estimated at II miles. Cowal Creer had to be swum early in the day. A HORSE, too much exhausted to travel further, had to be LEFT BEHIND. CAMP 90 must have been close to my Camp 7I.

It may be remarked here that between Cowal Creek and Camp 90, the Brothers' line of march is now crossed by the TELEGRAPH LINE, which goes nearly due north to Endeavour Strait, and then follows the beach north-eastward to Cape York. Probably the beach offers much better travelling than was found by the Jardine Brothers or myself.

I I th March.-The LINE OF TREES marked by Mr. John Jardine, Senior, was followed for 10 miles. A long detention took place at a scrub on Wimmerah CREEK, and here thirty head of CATTLE were Lost. Camp 9I was pitched on the north side of Chippagynya LAKE. THREE HORSES KNOCKED UP.

The following day (12th March) was spent in the recovery of twenty-five of the thirty cattle lost at Wimmerah Creek. The camp was not moved.

On 13th March, the whole party arrived at Vallack Point, CAMP 92, in about 8 miles. About midway they were met at LAKE BORONTO by Mr. John Jardine, Senior.

Thus ended the long march of the pioneers. Nearly five months had elapsed since they left Carpentaria Downs, the furthest outpost of civilisation, and the main body had covered about 900 miles, irrespective of several hundreds of miles traversed by the Brothers, singly or together, prospecting for "good travelling" for the cattle.

It is very easy-and very cheap-to speculate on " the might have been," and yet the temptation to do so is irresistible.

An actual economy of time would probably have been effected by the Brothers if they had made two separate trips. Had they left the cattle behind, chosen a suitable season, and travelled in light marching order, I have no hesitation in saying, knowing the men as I did, that they could have "romped through," marking a practicable route for the cattle as they went, in a couple of months. They could then have led the cattle to their destination without distress. As it was, the difficulties that met them at every step, and the consequent delays, were due almost entirely to the dragging weight of the helpless tail of cattle; and the cattle had to be knocked about hither and thither while a way was found for them.

The expedition cannot have been much of a commercial success, 
owing to the loss of three-fourths of the horses (including all that were of value) and at least a fifth of the cattle.

The Brothers have been criticised for their treatment of the BLACKs, and their tale shows that about fifty of the latter fell. Still it must not be forgotten that the hostility and treachery of the blacks was entirely unprovoked. These natives dogged the steps of the travellers, and threatened their lives day by day. There can be no doubt that had the Brothers betrayed any weakness, they would have shared Kennedy's fate.

I incline to the belief, founded on personal contact with the AUSTRALIAN ABORIGINES, that their MURDEROUS PROPENSITIES have no higher motive than MERE SPORTSMANSHIP. Their instinct is to ambush and kill their game, and to a race of cannibals human strangers are big game, and nothing more.

On the other hand, it is just possible that traditions of the descent of white men or Malays on the shores of the Cape York Peninsula may have been handed down among the natives for hundreds of years; at all events since the earliest landing of the Dutchman, or the perhaps still earlier landing of Spaniards and Portuguese, and that the intrusion of foreigners was synonymous in their minds with surprise, slaughter and kidnapping. Even in that case the question of "Who began it ?" may be raised. Unless the savages of three centuries ago were of milder manners than their descendants of to-day, I believe that they would have been tempted beyond their strength if ever they saw strangers at their mercy.

The contribution of the Jardine Brothers to a knowledge of the geography of the Cape York Peninsula was of immensely greater value than that of Leichhardt or Kennedy. The former only touched on a corner of the Peninsula and the journal of the latter perished with him. We owe to the Brothers our first real knowledge of the western interior of the Peninsula. I esteem it a privilege to have traced their steps, with the aid of modern maps, over a country which in their time was an uncharted waste.

Alick JARDine is now resident in London. In 1863 , the Brothers were awarded the Murchison grant of the Royal Geographical Society in recognition of their services of twenty-one years previously. Two interesting PHOTOGRAPHS are reproduced in this volume. The first is from Byerley's frontispiece, and shows Frank (sitting) and Alick (standing), and apparently dates from I 867. The second is from the Queenslander of Ioth February, 1917, and is a recent portrait of FRANK. The latter settled at Somerset on his arrival with the cattle in 1865 , and after the transfer of the government offices to Thursday Island made the old residency his home, or rather headquarters. After his father's return to the south, Frank was Acting Resident many times during the intervals between the periods when his father's successors held the office. For some years, his pastoral interests occupied his attention, but in 


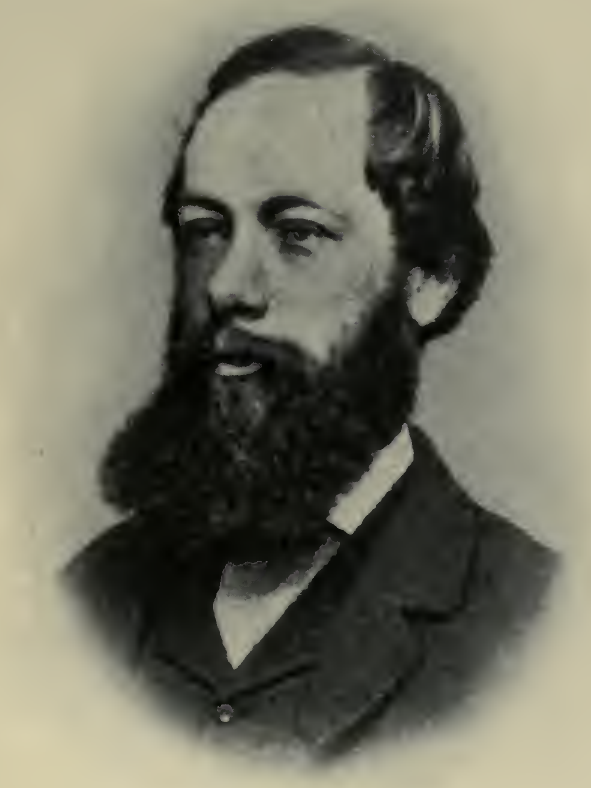

RICHARD DAINTREE, I 87 I. 


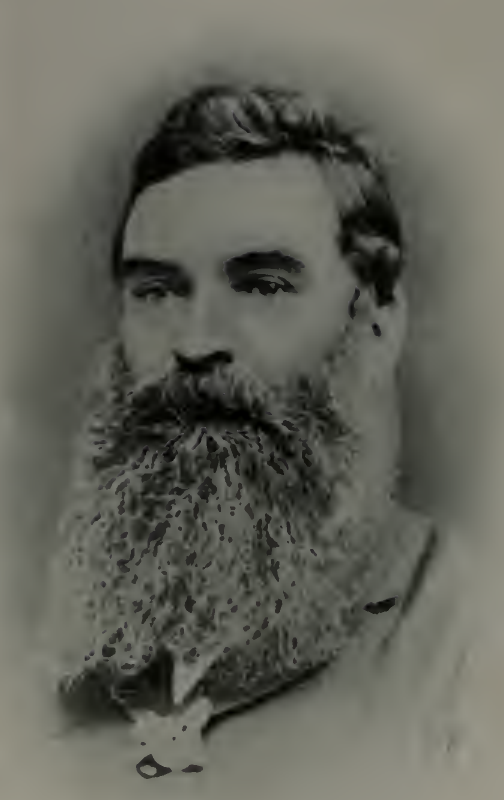

WILLIAM HANV, I 873 . 
course of time he directed his activities, with the assistance of his elder son, chiefly to pearl-shelling among the islands of the Coral Sea. He DIED at Somerset on 18 th March, 1919, after a short illness, having retained his vigour almost to the last. It is said that he kept a DIARY, covering the whole of his northern life. It is to be hoped that this diary will be given to the public. It should be an historical record such as very few men have had the opportunity of compiling.

EuLAH, one of the black boys who came with the Brothers to Somerset in 1865 , settled down there with Frank. He was a member of a party of white men and friendly blacks who were surprised and KILLED by the NATIVEs in a hut at Vallack Point a few years later. ${ }^{2}$ I 897.

1 A. Meston, "A Tour in North Queensland," Queenslander, I6th-30th January, 


\section{CHAPTER XLVII}

\section{SOMERSET AND ITS BACKGROUND}

Booby Island Refuge and Post Office. Voluntary Contributions by Passing Ships. Depredations on Booby Island by Prince of Wales Islanders and others. Wholesale Murder of Ships' Crews. The “Charles Eaton" Wreck and Massacre. New Settlement at Torres Strait proposed. Somerset selected as Site. Founded 1863-4. Garrison of Marines. John Jardine first Government Resident. His Successors. Somerset superseded by Thursday Island, 1879. Advantages of Somerset. Good Scrub Lands. Utingu Coco-nut Plantation. Cattle Stations at Vallack Point and Bertie Haugh. Stockmen murdered by Blacks at Vallack Point. Bruce and Roe, Pearl-shellers, murdered by their Aboriginal Crew. Bruce's Brother, with Native Troopers, follow supposed Murderers to Ducie River. Bruce and a Constable keep Boat. Troopers land and fire Guns all the Way to Bertie Haugh. Natives appear at Station. Troopers return Overland to Cape York and report the Two White Men rilled. The Whites return and report Landing Party exterminated. The Mapoon Mission and the Ducie River Natives. Cattre Stations at Lockerbie, Galloway, Thornbury, York Downs, Merluna, Pine Tree Creex, Rokeby and Langi. Murders of Pioneers. Somerset and Bêche de Mer and Pearlshell Industries. Roko Island. Dayman Island Leper Station. Natives and White Employers. Early Senile Debility among Natives. Frank Jardine's Diary of Residence in and about Somerset, 1865-19I9. ITs Publication desirable.

$$
\text { (See Maps A and B.) }
$$

MOR the history of Somerset, I have drawn, among others, from the following sources:-

(I) Sir George Bowen's Report, 1862.

(2) Report by J. Jardine, First Resident Magistrate, Ist March, 1865, in Appendix to Narrative of the Overland Expedition of the Messrs. Fardine from Rockhampton to Cape York, edited by Chas. Byerley. Brisbane, $186 \%$.

(3) Report by J. Jardine on the Overland Journey of the Messrs. Jardine to the Port Albany Settlement. Ist May, 1865, ibid., p. 86.

(4) Report of Dr. Haran, Surgeon, R.N., with the First Detachment of Marines landed at Somerset. 22nd May, I865, ibid., p. 88.

(5) Dr. A. Rattray, "Notes on the Geology of Cape York Peninsula," Queensland Fourn. Geol. Soc., 1869, XXV, p. 297.

(6) Dr. A. Rattray, "Notes on the Physical Geography, Climate, etc., of Somerset," Proc. Roy. Geogr. Soc., 1886, XII, p. 313.

(7) Pugh's Almanac, "Official Lists and Diary of Events."

(8) Willmett's North Queensland Almanac.

(9) Im Australischen Busch. Reise-erlebnisse und Beobacbtungen eines Naturforschers in Australien, Richard Semon, Professor in Jena. Leipzig, 1896. 
(10) A series of Articles written by M. W. Shanahan for the Queenslander newspaper, 17th April to 2nd October, 1897, entitled "With the Cape York Prospecting Party; being an Account of a Trip from Cape York to the Carron Range, with Various Peninsular Sidelights."

(II) Official Reports and Articles in Queenslander by Archibald Meston.

(12) Past and Present of Thursday Island and Torres Strait, by the Hon. John Douglas. Outridge, Brisbane, I900.

In the first half of the nineteenth century, Bоoвy IsLAND was known to seafaring men as a refuge, house of call, post office and club.

In those days, when two ships met on the ocean, it was the custom for each to record the date, the latitude and longitude, and the name, port of origin and destination of the other. On reaching port, each reported these particulars for the information of owners and friends. The event was analogous to a social call in polite society. In certain conventionally agreed upon localities, such as Booby Island, a letter-box and visitors' book were kept. In the former, letters were left to be taken up and "favoured" by the next passing ship, and in the latter, such particulars were written as the skipper might wish to communicate. The arrangement was advantageous to all concerned, inasmuch as ships which had never actually met might be deemed to have "spoken " one another.

Apart, however, from the advantage derived from the opportunity afforded a ship of reporting its presence at a comparatively frequented island on a given date, the necessity for HARBOURS OF REFUGE grew with the increasing traffic in dangerous and practically uncharted seas. A ship in distress could make for such a harbour with a fair chance of meeting other ships or finding provisions. Hence it became the custom for ships calling at such harbours to leave what stores they could spare. It was something like paying a premium of insurance. A ship might leave her surplus stores at some harbour marking a stage in a prosperous voyage, while later on the lives of her own crew might be saved by finding something to eat at that or another harbour of refuge.

Booby IsLAND ${ }^{1}$ served its purpose for a time; but at length the Prince of Wales and other ISLANDERS came to know of the existence of stores of undefended valuables and got into the habit of making periodical RAIDs, when they looted what suited them and destroyed what they had no use for. Contributions to the stores naturally ceased when it became evident that they would benefit murderous savages instead of distressed mariners. There followed a period when Castaway CREwS were MURdered wholesale on the Peninsula and the Islands. A particularly atrocious case was the massacre of the entire castaway crew ( 23 men) of the "Cbarles Eaton," wrecked near the Sir Charles Hardy Islands, off Cape Grenville.

For the remedy of this intolerable state of affairs, SIR GEORGE

1 There is now a lighthouse on Booby Island, and another on Proudfoot Shoal $\left(141^{\circ} 28^{\prime} \mathrm{E}\right.$. : $10^{\circ} 3 \mathrm{I}^{\prime} \mathrm{S}$.). 
Bowen, the first Governor of the new colony of Queensland, PROPOSED, on his arrival at Brisbane on 23rd October, I862, from a voyage of investigation with H.M.S. "Pioneer" (in the course of which, by the way, he found the stores on Booby Island " in good condition "), the establishment of a SETTLEMENT (to be named after the Duke of Somerset) on Albany Island, "on account of its geographical importance, as harbour of refuge, coaling station and entrepôt for the trade of Torres Straits and the North Pacific." 1 The approval of the Imperial and the Queensland Governments was given at once, and Mr. John Jardine, who was then Police Magistrate and Gold Commissioner at Rockhampton, was appointed Government Resident and sent, in 1863 , to establish the new settlement. He decided on a site on the mainland opposite the island.

Somerset, besides the uses pointed out by Sir George Bowen, was also to be a sanatorium "for the people who were just then rushing to the Gulf country to take up land," and in this respect was to supersede the establishment on Sweer's Island (east of the larger Bentinck Island).

The Queensland Government contributed $£ 5,000$ and the IMPERIal Government $£ 7,000$, besides sending a detachment of twenty-five marines under command of Lieutenant Pascoe, and accompanied by Dr. T. J. HARAN as Medical Officer, who landed on $25_{\text {th }}$ March, I863.

The official "Foundation" of the settlement took place on 2I st August, I864, when H.M.S. "Salamander," Captain the Hon. J. Carnegie, visited it on behalf of the Imperial Government. For some time, the "Salamander," and afterwards the "Virago," made three trips per annum from Sydney to Somerset for the provisioning and protection of the settlement.

The IMPERIAL BUILDINGs consisted of barracks and hospital, which were mainly erected by the marines. They have long ago disappeared, and their site is covered with scrub. The Colonial BUILDINGs (which included a custom house) were on the site occupied by Frank Jardine's residence until his death in March, 1919.

The necessity for the establishment may be gauged from the record of the year I866, during which forty men, being the CREwS OF THREE WRECKED SHIPS, were taken south by the "Salamander." Regarding other years, no records are available, but I have seen frequent references by travellers (e.g., James Dick) to meetings with shipwrecked mariners waiting at Somerset for ships to take them off.

JoHN JARDINE, the first Resident, held the office till the end of

1 At this time, the only habitation in the neighbourhood was the beche de mer station belonging to Captain Edwards, of the "Blue Bell," situated at Frederick Point (the north-western cape of Albany Island). Its buildings comprised a stone curing-house and a store. (Douglas, Past and Present of Thursday Island and Torres Strait, p. 9.) 
I 865, when he returned to his magisterial duties at Rockhampton. He was succeeded by

Captain Henry G. Simpson, R.N., who was still in office at the end of 1866. His appointment was for three years, but before the end of his time he left on sick leave, and did not return. The office was vacant at the end of 1867 .

The appointment was held by FranK JARDINE in 1868 and I869. In the latter year he discovered that the CREW of the "Sperwer," seventeen in number, had been MURDERED by the natives of Prince of Wales Island, and avenged the murder.

FrANK JARDINE held the office from 1870 to 1873 . He was succeeded by

Captain Charles Beddhame, of the East India Company. When he left on sick leave (say, 1874), he was replaced by

George Elphinstone Dalrymple. The conspicuous part played by Dalrymple in 1873 in the exploration of the eastern rivers and harbours between the Herbert and the Endeavour and in the opening of Cooktown after the discovery of the Palmer goldfield is described in another chapter. $\mathrm{He}$ also took up the Valley of Lagoons in the Burdekin valley and discovered a practicable road from the station to Rockingham Bay. He did not hold the office of Resident long, having contracted a fever at Somerset and died on his way south. His successor was

C. D’Oyley H. Aplin, who had been Government Geologist for Southern Queensland in 1868-9. He had been, in 1849, a guest on the "Freak" brig, when she searched for relics of the party left at the Pascoe River by Kennedy. The bones of two of the party, Wall and Niblet, having been recovered, were interred on Albany Island, Aplin reading the funeral service. ${ }^{1}$ He himself died at Somerset, and was buried beside the lost explorers.

Frank JARDINE again temporarily held the office until the appointment of

H. M. Chester, formerly of the Indian Navy, who was Resident from about I 876 to 1879 , when Somerset was closed on the oPENING of a new setTlement at Thursday Island. I saw him first on 7th July, 1877, when the "Normanby," the steamer by which I had come from Singapore, lay off Somerset in quarantine. He and $D_{R}$. Salter came alongside in a boat and arranged for the burial, on Albany Island, of a lady, Madame de la Forest, who had died on board. I saw him next at Thursday Island on 5th April, I 880 .

Hugh Milman, R.N., was the next Resident at Thursday

1 Vide, Shanahan, in "Sidelights." Queenslander, 25th September, 1897. "The Private Log of T. Beckford Simpson," Master of the Brig "Freak," as printed in Carron's Narrative of the Voyage of the "Rattlesnake," makes no mention of Aplin, but contains the following passage (I 3 th May, 1849) : "Pulled to the south end of Albany Island, and ... dug a grave and interred the remains of the unfortunate individuals Thomas Wall and Charles Niblet, reading the funeral service over them." It may be mentioned that the "Freak" was wrecked on the Barrier Reef early in the " seventies." 
Island, and was succeeded in 1885 by the Hon. John Douglas, who had been Premier of Queensland in 1877 .

"I have often thought," says Douglas, "that a good deal was lost to us when we left Somerset and the mainland. We abandoned with it the chance of occupying some twenty or thirty thousand acres of fine RICH SCRUB SOIL .... and we abandoned also the chance of a RAILWAY which might have pushed through the Peninsula and made our starting-point for the East, for India, China and even the Old Country. ${ }^{1}$

It must be admitted that much of the scrub in the vicinity of Somerset covers poor soil ; but Douglas's estimate of 20,000 to 30,000 acres (say, 31 to 47 square miles) of available good scrub land is probably a cautious one. The abandonment of the settlement on the mainland has undoubtedly retarded the occupation of whatever area of such soil there may be for over a quarter of a century. A commencement has been made at last by $\mathrm{Mr}_{\mathrm{r}}$. John McLaren, who, in partnership with Mr. J. W. Graham, started Utingu Plantation (960 acres), near the old Paterson Telegraph Station, in October, I9I I, clearing the scrub with the assistance of native labour. The greater part of the clearing is planted with coco-nuts, but maize, bananas, pine-apples, sweet potatoes, etc., are very much at home, and grow practically "without cultivation."

After Utingu was started, Mr. Frank Jardine planted coco-nut trees on an area at SOMERSET itself, and several thousands were also planted on Possession IsLand. Shanahan records that on his visit to Lockerbie (25th July, I896), he found corn (maize), pineapples, bananas and paupaus growing at the station.

The CATTLE overlanded by Frank and Alick Jardine were first camped on a station at Vallack Point. Writing on I Ith August, I 896 , Shanahan asserts that the scrubs between the Jardine River and Somerset contained several thousands of WILD CATTLE, descended presumably from stragglers of the overland mob, as well as many wild PIGs. Vallack Point station was not continuously occupied except during a few years after 1865 , but it was occasionally camped in by parties mustering cattle. One of these parties, consisting of white and black stockmen (among whom was EULAH, who had accompanied the Brothers Jardine on their overland expedition), Was ANNIHILATED BY THE NATIVES. On a previous occasion (August or September, I868), the blacks had rushed the station and carried away the whole of the stores, arms and ammunition, which, however, were afterwards recovered. ${ }^{3}$

Frank Jardine's first out-station was Bertie HaUGH, on the

1 Past and Present of Thursday Island and Torres Strait. Outridge, Brisbane, 1900.

2 A. Meston, "A Tour in North Queensland." Queenslander, 16th, 23rd and 3oth January, 1897. These articles are a "popular" supplement to Mr. Meston's official Report on the Aborigines of Queensland. Brisbane: By Authority, 1896.

8 Brisbane Courier, September, 1868. 
Ducie River. The river and "country" were discovered by him during the construction of the telegraph line in 1886-7. The station was named after his son, who, it may be mentioned, served with distinction in the European War of 1914-18.

An incident of the early days of this station may be abridged from Shanahan's "Sidelights."

"The manager, Harry Price, a South Sea Islander, with three others, heard, one morning in 1893 , what seemed to be a murderous FusILADE. In preparing for defence they loaded up the whole of their firearms, consisting of some fifty RIFLES AND MUSKETS and a r2-inch SWIVEL GUN, and ranged them inside the LOOPHOLED BUILDING. Presently they were approached by twelve native troopers in a state of nervous blue funk, who had been responsible for the firing.

"Two men named Charles Bruce and Sam Roe had been pearling or bêche-demer-ing in Torres Straits, and had been brutally MURDERED by their aboriginal crew, presumably on Orman Reef, the murderers getting away to their own country on the Ducie River. Senior Constable Conroy, of Thursday Island, with twelve native TROOPER, and accompanied by R. BRUCE, the murdered man's brother, were sent out to arrest the murderers. While their boat was going up the DUCIE the BLACKS THREW SPEARS at them from both banks of the river.

"The TROOPERS LANDED at seven o'clock next morning, the constable and Bruce remaining in charge of the boat. For two hours the white men listened to the sound of an almost continuous firing, and concluded that the troopers were engaged in a serious conflict with the natives-while, in fact, the troopers were making their way to the station. As the firing ceased, and the troopers did not return, the white men came, as the afternoon wore on, to the conclusion that the troopers had been overpowered. Then a strong force of natives appeared on the bank, boastfully asserting that the troopers had been annihilated, and holding up two "captured" guns in confirmation of their tale (the guns were afterwards believed to have belonged to the murdered men Bruce and Roe.) Satisfied that they could do no good, they set sail for Thursday Island, whence was telegraphed the false news that a detachment of native police had been annihilated on the Ducie River."

"What actually happened," says Shanahan, "was that the troopers marched straight to the station, without even seeing a native, but firing almost all their ammunition with the object of keeping the natives at a distance. One native came up to the station after the arrival of the troopers, and in this individual the troopers recognised, they alleged, one of the men 'wanted' for the murder. The troopers fired twelve shots at the native, who ran away uninjured, to return shortly with a large crowd armed with spears. The troopers (by this time, presumably, without ammunition) retreated to Cape York, Ioo miles distant, where they reported their belief that Conroy and Bruce had been killed."

The murder of Bruce and Roe, and the events which followed, as above related, for a time brought the newly established MAPOoN Mission Station into popular disfavour. In Thursday Island, the mere fact that the murderers, who belonged to the Ducie tribe, had returned to their haunts was construed into evidence that the missionaries on the coast were harbouring and encouraging them in their evil courses.

The story, as told by the missionaries, ${ }^{1}$ takes quite a different complexion. It appears that the murder of Bruce and Roe took place at the Skardon River, de facto. Nicholas Hey, one of the

1 The Miracle of Mapoon, p. I40. 
missionaries, heard of it, and reported to Thursday Island that it had occurred at the Skardon River. Charles Bruce had recruited his crew from the neighbourhood of Bertie Haugh station, having previously told JAMES G. WARD, one of the missionaries, that he " had done with the rascally Batavia River boys," and hinted that these had not improved under missionary influences. "Within six weeks," says the author of The Miracle of Mapoon, "this crew, uncontaminated by missionary influences, murdered him."

The murderers beached Bruce and Roe's cutter and waited to consume the provisions on board before going further. Some Skardon natives, who had been invited to participate in the feast, then took the cutter, which they professed to have "found," to Thursday Island in the expectation of obtaining a reward.

When the news of the murder reached Thursday Island, Mr. Douglas sent a police party to arrest the murderers, but gave them orders not to shoot. The party went out and returned, "without having effected anything."

Next came R. Bruce, the brother of Charles. He was a Justice of the Peace, and obtained the assistance of a POLICE CONSTABLE and the seven ${ }^{1}$ Skardon natives, who, on their arrival at Thursday Island, were "enlisted by the Justice and the constable." " Having reached Mapoon Mission Station in a cutter, R. Bruce, professing the belief that his brother might not be dead, and that he desired to search for the runaway crew and learn from them if his brother had been landed on some island, borrowed the mission whale-boat, into which the constable and troopers were transferred. The whale-boat was returned some days later, but the missionaries had already heard of the landing and the firing of guns. R. Bruce and the constable then returned to Thursday Island and reported their belief that the landing party had been wiped out by the natives.

Mr. Douglas's official REPorts, it is said, exonerated the missionaries from all blame. My own impression, after a dispassionate consideration of the story, as told from two different points of view, is that R. Bruce's expedition was undertaken with a punitive object, which was frustrated by the cunning of the Skardon natives, who had been enlisted as troopers for the occasion. Having been landed, with arms in their hands, and without any white witnesses, they began to fire their rifles as soon as they were out of sight, partly to impress the men in the whale-boat (who, of course, heard the firing) and partly to warn the local inhabitants, with whom they had no wish to come into collision.

It is certain that an avowed punitive expedition, with a constable and native troopers, would not have been sanctioned by $\mathrm{Mr}$. Douglas, and it is at the same time very difficult to believe that

1 Shanahan says twelve.

The Miracle of Mapoon, p. 146. 
such an expedition could have got away from Thursday Island without his knowledge. Either the true object of the expedition was not disclosed or the police acted independently of the Government Resident-which latter is most unlikely.

Another murder, that of a man named NicholLs, was reported in November of the same year (1893). He had shipped a crew of nine natives from the mission station, and they threw him overboard. The report that he was dead fortunately turned out to be incorrect. Nine natives were arrested at the mission, one for the Skardon murder and eight for the Nicholls affair. Four were discharged on a preliminary examination at Thursday Island and five were sent to Cooktown.

Frank Jardine, who at first located his cattle at VAllack Point in I 865 and next took up Bertie HaUgh in I887, afterwards started two out-stations, Lockerbie, on Laradunya Creek, and GALLoway, on Black Gin Creek, about 5 miles south-west of Lockerbie and 4 from Red Island. Shanahan, who visited LOCKERBie on 25 th July, I 896 , records that "within the last three or four years" (1892-3) the wild blacks and the native police boys (presumably he means ex-troopers) had been killing the cattle. In I 896, Frank Jardine "spent most of his time there." Galloway is used by the Torres Straits Butchering Co. as a mustering-place for the cattle which come from the Coen country to be killed and shipped at Red Island Point for the supply of Thursday Island.

In I89I, J. T. Embley formed Thornbury station, on Black Gin Creek, near the telegraph crossing. The original "Occupation Licence" was at RED IsLAND Point, where the bullocks were killed and dressed and shipped to the Thursday Island REFrigerating works of the Torres Straits Fresh Food and Ice Co. ${ }^{1}$

Lachlan KenNedy, an old Palmer and Coen digger, found cattle "country" on Myall Creek, and on this country York Downs station was established about 1885. Later, J. T. Embley acquired an interest in the property, which is now a State-owned cattle run." Myall Creek is the head of the Mission River, which discharges into Albatross Bay (SheEt 21 A). About I 895, Embley discovered a river, which now bears his name, by which he could bring supplies by boat from the bay to a landing only 9 miles from York Downs. ' The Weipa Mission Station was afterwards established on the EMbley River, which is navigated by the mission cutter. When the missionaries and Mr. Embley first met in I895, the latter had already suffered from the depredations of the natives among his cattle and had been forced to take stern measures in self-defence, and he welcomed the project of a mission settlement."

1 Letter from J. T. E., 25th November, 1915.

2 Letters from J. T. E., I 3 th and 26th June, 1915.

3 Albatross Bay and the Embley and Hey Rivers. F. C. Urquhart. Proc. Roy. Soc. Queensland, XII (1896), p. 42.

- The Miracle of Mapoon, p. 198. 
Twenty-five miles south-east of York Downs, a cattle station named Merluna was founded about I 888 by the Brothers Watson, one of whom (Edwin) was afterwards KILLED BY THE BLACKS. The station is on LAGOoN CREEK, one of the heads of the WATson RIver and about 9 miles east of the Jardine Brothers' track of 1865. Aurukun Mission Station was established in 1904 near the mouth of the river.

Pine Tree Creek station, near Mein Telegraph Station, was opened by Patrick Fox in 1887, while the telegraph line was under construction.

Rokeby cattle station, on the South Coen River, was taken up by the Brothers John and Charles Massy in I884. Charles Was KILLED BY THE BLACKS shortly afterwards.

LANGI cattle station, on the ARCHER River, was taken up by A. W. KNotr in 1883 .

The twenty-five Marines landed at Somerset in 1863 were WITHDRAWN in 1866, from which time till the seat of the Resident was transferred to Thursday Island, in 1879, a force of Queensland POLICE, generally numbering four to seven white men and four to eight native troopers, was maintained at the Residency. The EARLY DAYS OF SOMERSET were far from peaceful. Meston records that five of the MARINES were SPEARED, one of them, while performing sentry duty, being simultaneously wounded both before and behind. "James Howard was SPEARED at Newcastle Bay and brought in to Somerset with spear-points stuck all over him." 1 The massacre, at Vallack Point, has already been referred to.

Willmett's Almanac for $\mathbf{1} 867$ has a note to the effect that " the London Missionary Society has of late years made Somerset the point of departure for their proselytising expeditions to New Guinea." Shanahan mentions the abandonment of this mission, which he characterises as a failure.

Professor Semon, of Jena, who visited Torres Strait in I895, says: "On the mainland, near Cape York, stands a squatting and pearl-fishing station, Somerset, belonging to Mr. Jardine, one of the oldest and most celebrated settlers of North Queensland. Passing steamers observe the custom of saluting his house with one gun."

Shanahan asserts that the natives of Cape York POIsON THEIR SPEARS by dipping them into corpses." It is more than doubtful if the custom is indigenous, although this trick of "frightfulness" may have been learned in recent years from the Papuans.

Until the transfer of the Residency to Thursday Island, SomerSET was the base of the pearl-shelling and bêche de mer shipping, except for a short time when Roko, a small island between Posses-

1 A. Meston, "A Tour in North Queensland." Queenslander, I6th and 23rd January, 1897.

2 "Sidelights." Queenslander, 2nd October, 1897. 
sion Island and the mainland, was the base. In these days there was a LePER station on Dayman IsLand, south of Possession Island. ${ }^{1}$

I am tempted to add a few words on the subject of NaTive "BOYS" IN THE EMPLOYMENT OF WHITE MEN. On many occasions I have been impressively cautioned by miners and others never to trust police or missionary boys, who not only had the inborn treacherous instincts of their race, but were dangerous because they "knew too much." I have had no experience of ex-missionary boys, but I have had several ex-troopers in my employment. These I found capable enough, but, as a rule, unwilling to work their best. My impression is that without the semi-military discipline of the barracks and the incentive of competition with their fellows, they are apt to become lazy and to give themselves airs. There is also the undoubted fact that they are dangerous from their familiarity with the weak points in the white man's armour. This danger would probably be even more marked in the case of boys who had mixed with white ships' crews. With this class of boys I have not come in contact, unless I did so in the case of Captain Billy of Camisade Creek. Lastly, I have observed again and again that senile debility sets in, at least as regards the intellectual powers, among Australian aborigines at a very early age.

When the complete tale of Somerset comes to be written, it must of necessity form one of the most striking chapters in the history of the founding of the British dominions overseas. Fortunately, as has been pointed out in the preceding chapter, the material exists in the diary, covering a period of over half a century, left by the late Frank Jardine. It is to be hoped that the diary will be edited and published without delay.

1 Letter from J. McLaren, Utingu, 23rd November, I9I 5. 


\section{CHAPTER XLVIII}

\section{DAINTREE, 1863-7I}

Daintree on Geological Survey of Victoria, 1854-6 and 1858-64. Visits Queensland, 1863. Prospecting around Maryvale. Discovery of Gold on Broken River, Burdekin Valley. Partnership with William Hann in Maryvale Station, 1864. Paper by Rev. W. B. Clarke on "The Auriferous and Metalliferous Districts of North Queensland," 1867, based on Daintree's Notes. Daintree's Discovery of "Lynd " Copper Mine, Einasleigh River. Rich, but not payable under Then-existing Conditions. Modern Railway Facilities. Appointed Government Geologist for North Queensland, i868. Report on Cape River Gold Diggings. Leads Prospectors to Scene of his Gold Discoveries on Gilbert and Percy Rivers, 1869. Gilberton Township established, 1869. Gold on Delany Creex and Etheridge River. Discontinuance of Geological Survey. Reports on Ravenswood, Mount Wyatt and Cape River Goldfields, 1870. Collecting Specimens for London Exhibition, 1870 . To London with Mineral Exhibits, 1871. Appointed Agent-General. "Notes on the Geology of the Colony of Queensland," 1872. A Geological Classic, with First Grological Map of Queensland. Failing Health. Death, 1878.

$\mathbf{R}$

ICHARD DAINTREE ${ }^{1}$ was born in Huntingdonshire in 1831 , and came to Victoria in 1852 , and resided in that Colony till 1864 . From 1854 to 1856 , and again from 1858 to 1864 , he was a member of Selwyn's Geological Survey of Victoria.

In 1863 he visited Queensland, and spent some time in exploring and prospecting, from Maryvale, a tributary of the Clarke River, one of the principal heads of the Burdekin River. His observations were printed in the $Y_{\text {eoman }}$ (29th August, 1863), and contained

1 Map of Croydon and Etheridge Goldfields, I9Ir. Geological Survey Publication, No. 230. The "Lynd" (now the "Einasleigh" ") Copper Mine is the Mineral Area, "No. 55. Etheridge Goldfield " shown on this map.

"On the Auriferous and Metalliferous Districts of Northern Queensland," by the Rev. W. B. Clarke, read 9th September, 1867 (a "Communication" of Daintree's information, dated 23rd July, 1867). Trans. Roy. Soc. New South Wales, Vol. I, p. 42.

" Report by Richard Daintree on the Cape River Diggings, and the latest Mineral Discoveries in Northern Queensland," dated October, 1868. Leg. Ass. Papers, Session 1868-9.

" Report by Mr. Richard Daintree, Govt. Geologist, Northern Queensland, on Gold Discoveries in the Gilbert Ranges." Dated Forty-one Mile Creek, Gilbert Ranges, 7th April, 1869. Leg. Ass. Papers for 1869, Vol. II.

"Progress Report by Mr. Richard Daintree, Govt. Geologist, Northern Districts." Dated Gilbert Ranges, 2oth April, 1869. Leg. Ass. Papers for 1869.

"Report on the Gilbert Ranges Goldfields by Richard Daintree, Govt. Geologist, Northern Queensland." Dated Maryvale, 18th June, 1869. Leg. Ass. Papers for 1869.

"General Report on the Northern District by Richard Daintree." Dated Maryvale, 2nd February, 1870. Leg. Ass. Papers for 1870.

"Report by Mr. Richard Daintree, late Govt. Geologist, North Queensland, on the 
references to the discovery by himself of gold on the Broken River, Burdekin Valley.

In 1864 he entered into partnership in Maryvale cattle station with William Hann, and making the station his headquarters, extended his geological observations to the north and north-west. (See Maps Q, O, P, K and L.)

In the three years that followed, he appears to have visited the Flinders and Gulf country, and probably the Cook district. But he was such an impersonal writer that it is impossible to construct a satisfactory itinerary from his description of localities, and it is equally impossible to distinguish between his own observations and those made by somebody else. As he was a geologist of keen insight, his own observations would be worthy of the highest respect, while the hearsay evidence of an unnamed "somebody else" might or might not deserve consideration.

On 23rd July, 1867 , he wrote from Maryvale to the Rev. W. B. Clarke, sending his notes with permission to the latter to use them at his discretion. The result was a paper read by Clarke on 9th September, 1867, on "The Auriferous and Metalliferous Districts of North Queensland" before the Royal Society of New South Wales. The paper refers to the discovery of COPPER at Cloncurry by Ernest Henry, the discovery by Daintree of COPPER at the "LYND" MINE at the junction of the Einasleigh and Copperfield Rivers, and of GoLD at the head of the GILBERT RIVER.

It may be said here that Daintree "selected" and made a freehold of the " Lynd " Copper Mine, and, with his partner Hann, worked it in a desultory fashion for a few years. The low price of copper and the high cost of everything else, including carriage to the nearest port, soon brought about the inevitable consequence, although the ore was exceedingly rich. It was not till I 898 that the extension of railway facilities enabled the mine to be reopened under sounder economic conditions-and by that time it was not the pioneers who were to reap the benefit.

Ravenswood, Mount Wyatt and Cape River Goldfields, etc." Dated Maryvale, 29th August, 1870. Leg. Ass. Papers for 1870.

Queensland, Australia: Its Territory, Climate and Products, Agricultural, Pastoral and Mineral, etc., etc., with Map of Mineral Areas, by Richard Daintree, Agent-General, London. No date; but probably 1873.

"Notes on the Geology of the Colony of Queensland by Richard Daintree, Esq., F.G.S. With Geol. Map and an Appendix containing Descriptions of the Fossils by Robert Etheridge, Esq., F.R.S., F.G.S., and W. Carruthers, Esq., F.R.S., F.G.S." Read 24th April, 1872. Quart. Journ. Geol. Soc., Vol. XXVIII, 1872.

"Geology of Queensland, as Represented at London Exhibition, 1871." Leg. Ass.

\section{Papers for 1872 .}

Handbook for Immigrants to Queensland, by Richard Daintree. London, 1875 .

" Richard Daintree, C.M.G., F.G.S., An Obituary," by Robert Etheridge, Junior. Geol. Mag. for 1878, p. 429.

Heaton's A ustralian Dictionary and Men of the Time. Sydney, 1879, p. 50.

1 Now known as the "Einasleigh" Copper Mine. Although Carpentaria Downs station had by this time been established on the Upper Einasleigh, the river was still believed to be Leichhardt's Lynd River. 
In May, I868, Daintree was appointed Government Geologist for the Northern Division of Queensland, and C. D'Oyley $\mathrm{H}$. Aplin for the Southern.

Daintree's first official report was dated October, r868, and was descriptive of the CAPE River Gold Diggings, of which geological maps, on the Victorian model, were given.

In March, 1869, he led a party of prospectors from Mitton's Oak Park Station on the Copperfield River, and with their assistance blazed a track to the scene of his gold discoveries in the Gilbert Ranges. He left the prospectors on payable (alluvial) gold near the junction of the "Forty-one Mile Creek" with the Gilbert River, while his own party went on and found further payable gold in a tributary of the Gilbert to which he gave the name of the Percy River. His report is dated 7th April, r869.

His "Progress Report," dated 20th April, r869, has a map in which the locality of the new discoveries is given with relation to already known places, such as Oak Park and Carpentaria Downs, and Cave and Agate CReeks, tributaries of the Robertson River, are named for the first time and are indicated as gold-bearing. By this time there were 200 diggers on the ground, and Daintree recommended a site for a township (which was shortly afterwards established and named Gilberton.

From the Gilbert, he went to the new gold diggings on DeLANY CREeK and the head of the ETHERIDGe River, ${ }^{1}$ and then returned to Maryvale, his home and headquarters, where he wrote his report, dated 18th June, 1869, "On the Gilbert Ranges Goldfields." The report was accompanied by a geological map of the district visited.

It must have been something of a surprise for the competent geologist and altruistic citizen who had just handed over his own gold discoveries to the public, to find awaiting him on his return home an official intimation that after the conclusion of the current financial year (3oth June), the estimates would make no provision for the Geological Survey. The precise political significance of this action is still a mystery to me, since it is evident that Daintree had not lost the confidence of the Government, who employed him for the remainder of his life and eventually advanced him to practically the highest non-political position within its gift, the Agent-Generalship of the Colony (he was the last non-political Agent-General). Aplin retired at once from the service and took up commercial pursuits (tin-mining and tin-buying at Stanthorpe).

After completing a geological survey of Peak Downs, Mount

1 Named, as I am informed by Mr. Alfred Foot, after Donald Etheridge, who, in 1864 , took cattle from Carpentaria Downs down the valley of the Etheridge to stock $R$. Town \& Co.'s newly acquired station, Miranda Downs, on the Gilbert River (Queensland 4-mile Map, Sheet 18 B). 
Wheeler, etc., in the south ("Progress Report on a Portion of the Rockhampton Mining District"), Daintree wrote his "General Report on the Northern District," dated Maryvale, 2nd February, 1870, being a sketch of the geological features designed to make up for the want of the complete geological map which he had hoped to issue. In this report he claims to have made discoveries of economic importance as follows:-

(I) "Eighteen months before a digger had prospected the Cape Range, I had indicated the area of the present Cape diggings as a future goldfield."

(2) "It is now more than three years since I pointed out that auriferous tracts would be found to extend from the heads of the Gilbert, by way of Kirchner's Range, towards the Endeavour River."

On 29th August, 1870, he wrote "Report by Mr. Richard Daintree, late Government Geologist, North Queensland, on the Ravenswood, Mount Wyatt and Cape River Goldfields, etc." This was the record of a tour embracing the above-named places, and also the Bowen River Coalfield, the tour having had for its primary object the collection of specimens for the London Exhibition. In 1871 , he went to London in charge of the mineral exhibits. On the close of the Exhibition, he was appointed AgentGeneral for the Colony of Queensland. Early in his incumbency of this office he wrote a handbook entitled Queensland, Australia: Its Territory, Climate and Products, Agricultural, Pastoral and Mineral, etc., etc. (no date). Besides profuse illustrations, this handbook contains a "Map showing Mineral Areas," and it also shows "Mount Daintree" (named by Hann), and sketches Hann's "Northern Exploration" route. The latter shows the date of publication to be about 1873 , because during that year the report of Hann's trip of June-November, 1872, was published. During his stay in London he received the distinction of C.M.G.

On 24th April, 1872, Daintree read "Notes on the Geology of The Colony of Queensland" before the Geological Society of London. This paper still ranks as a classic in the geology of Queensland, and it was accompanied by a small Geological MAP of the Colony, on which the "work" significantly stops short at the Mitchell River. It is stated that the data for the paper were " collected while prosecuting the search for new goldfields on behalf of the Queensland Government." It is a résumé and review of his field work, and inasmuch as it gives an analysis of the Saxby River hot spring " near Gibson's Station," it confirms the surmise that he had personally travelled in the Lower Flinders region.

Failing health led to his resignation of the Agent-Generalship, and in 1876 he was succeeded by the Hon. Arthur Macalister. He died at Mentone on 2oth June, 1878. 


\section{CHAPTER XLIX}

\section{MORESBY}

\section{FIRST CRUISE OF THE "BASILISK" TO TORRES STRAIT, I87I}

Captain Moresby takes Steam Cruiser "Basilisk" by Inner Route to Cape York. Carries Horses and Stores for Somerset. Abuses in Labour Traffic. Meets and takes Possession of Schooner "Peri," with Thirteen Solomon Islanders. Their Story. Cargo of Kidnapped Islanders taken to Fiji by the "Nukalow" and hired out. Eighty transferred to "Pert " for Conveyance to Other Islands of Fijian Group. Short Rations and Harsh Treatment at Sea cause Rising. White Officers and Fijian Crew thrown overboard. Solomon Islanders ignorant of Navigation. "Peri " drifted I,800 Miles. Starvation. Only Thirteen of the Eighty Men left. These taken to Cardwell. Afterwards to Sydney and ultimately returned to their Homes. Frank Jardine at Somerset. The Aborigines. Charting in Torres Strait. Moresby Rock. Saddle and Gabba Islands. Mourilyan Reff. Pearlshelling at Gabba. Inquiry into Recruiting in the South Sea Islands for Pearl-shelling Industry. Douglas and Chester agree in denouncing Abuses. Legislation follows. Licensing and Government Supervision of Labour Vessels and Contracts with Labourers. Charting Saibai Island. Warrior Island. A Powerful Tribe. Comparatively Advanced Natives. Pearl-shelling Station. Missionaries (Natives of Loyalty Group) from Cornwallis and Saibai Islands begging at Warrior Island. "Basilisk" through Basilisk Pass. To Lizard Island. To Cook's Landing-Place in Endeavour Estuary (Cooktown founded Two Years later). To Cardwell. Brig "Maria," with Prospectors for New Guinea, wrecked on Bramble Regf. Captain and Six Men make for Cardwell in Boat. Land at Tam O' Shanter Point. Captain and Three Men killed by Natives. Three Men reach Cardwell. The Boat found by Lieutenant Sabben, who had hurried in Gig from Cardwell. Heavy Attack on Sabben's Party by Natives repulsed. Two Rafts and Three Boats leave the Wreck. Nine Men clinging to Rigcing of Sinking Ship. Boats reach Cardwell after Great Hardships. Mate, in charge of One Boat with Thirteen Men, goes mad. Tate, Acting Surgeon, Was in charge of Two Boats with Fifteen men. "Basilisk" reaches Cardwell. Police Magistrate requests Naval Assistance. Moresby lends a Lieutenant and Fourteen Men, who join Native Troopers in a Visit to Scene of Captain's Death. “ Bloody Vengeance." "Basilisk" to Cooper's Point and rescues Eight Men out of the Thirteen on the Larger Reef. They had beEn Kept alive by the Kindness of the Natives, who gave them Food. Smaller Raft (carrying Twelve Men) found. All the Men had been killed. "Basilisk" to Percy Island, Rockhampton, Brisbane and Sydney, 6th AprIL, I871.

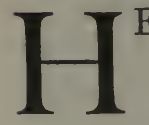

ER Majesty's cruiser " Basilisk," commanded by CAPTAIN (afterwards Admiral) John MoResby, R.N., was a paddlesteamer of $\mathrm{I}, 03 \mathrm{I}$ tons burthen and 400 horse-power and carried five guns. 


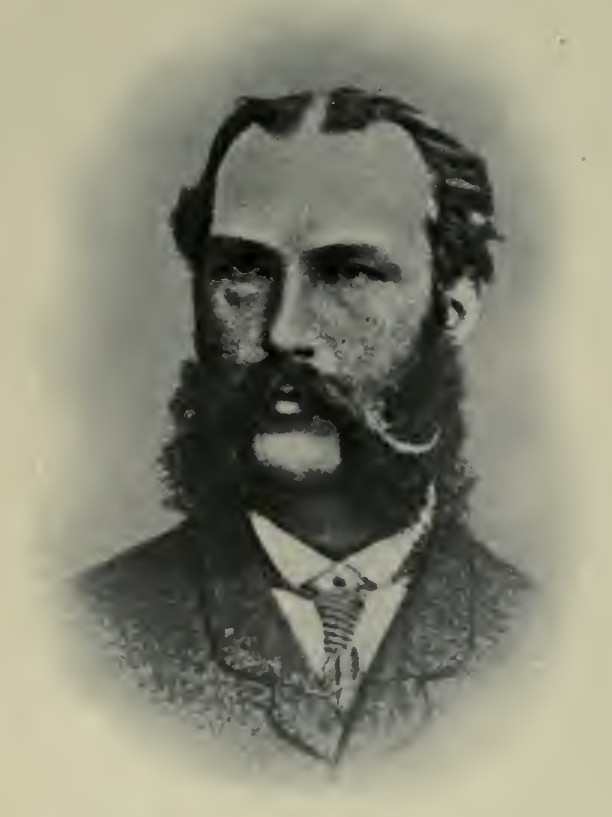

NORMAN TAYLOR, 1873 . 


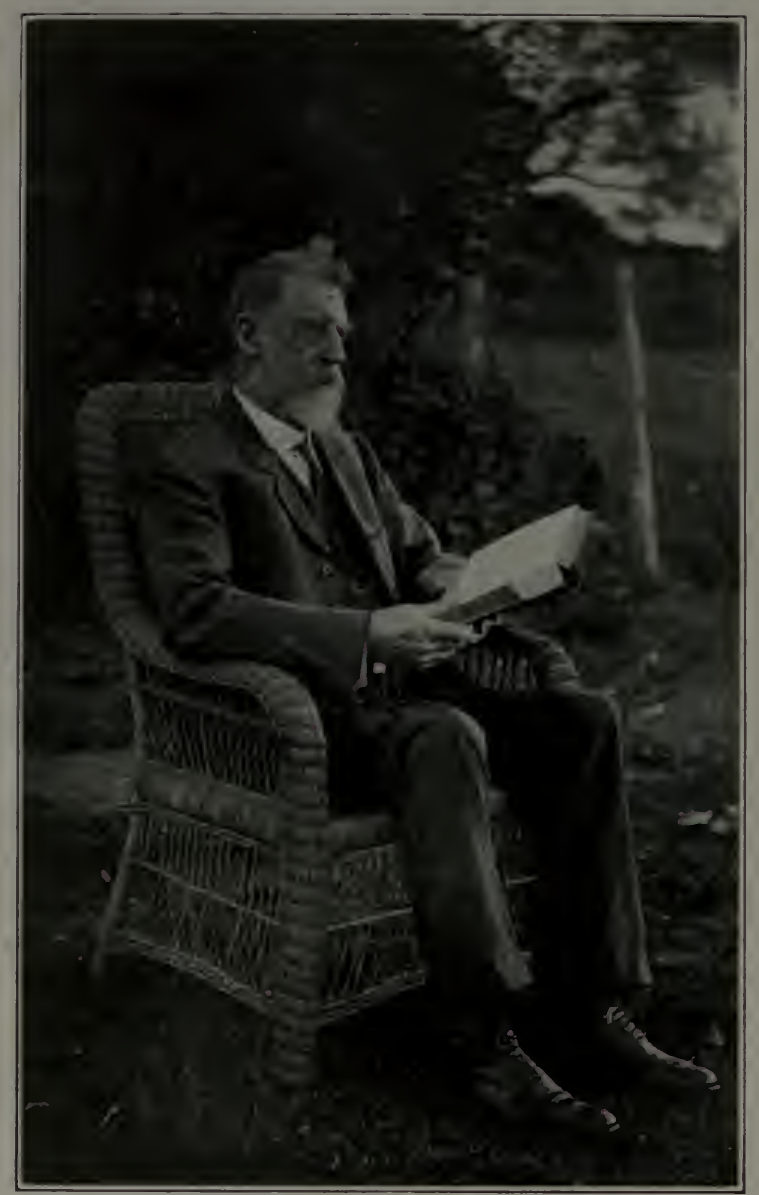

THOMAS TATE, 25TH JUNE, I9I 3 ( $/$ IST BIRTHDAY). 
The Commander's narrative ${ }^{1}$ is full of interest and brings vividly before the eye of the reader not only the progress accomplished in the twelve years which had elapsed since the separation of Queensland from New South Wales, but also some of the abuses which had followed the scramble for wealth in a little-known sea far from the seat of government.

The cruiser left SydNey on 15 th and Brisbane on 28th January, 1871, taking on board at the latter port horses and stores for Somerset, and following the "inner route," which had already been charted by Captains Owen Stanley and Francis Blackwood and others. (SeE MAP O.)

The "Basilisk's" work began at the base of the Cape York Peninsula. Thirty miles from Cardwell, and therefore about the PaLm IsLANDS, a small fore-and-aft schooner was met, apparently in a helpless condition, and was boarded. She proved to be the "Peri," and there was neither food nor water on board, and no boat. The crew, of Solomon Islanders, were "living skeletons, creatures dazed with fear and mortal weakness. . . . Some were barely alive, and the sleeping figures were dead bodies, fast losing the shape of humanity, on a deck foul with blood." The first thing that had to be done was to bury six bodies.

"The story of the 'Peri," " says Moresby (p. 5), "proved to be this: A noted kidnapping vessel, the 'Nukalow,' had brought a cargo of some I 80 kidnapped natives to Rewa River, Fiji, some two months previous to our falling in with the 'Peri.' At Rewa they were disposed of by being hired out to planters at the rate of ten to fifteen pounds a head, paid to the owners of the 'Nukalow,' and about eighty of them were transferred to the 'Peri' for conveyance to the various islands of the Fiji group, in charge of three white men and a Fijian crew. On getting to sea, insufficient food was served to the natives, who were quite unsecured, and they clamoured for more, on which some rice was issued; but one of the white men, angered by the clamour for food, was heartless enough to throw the rice overboard as the natives were cooking it, and the maddened creatures rose at once and threw him over after the rice. The other two whites and the Fijians followed; and the savages, thus left to themselves, and wholly unable to manage the ship, drifted helpless and starving before the southeast trade wind for about five weeks, accomplishing a distance of nearly I, 800 miles through a sea infested with coral reefs and full of islands; finally passing over a submerged part of the Barrier Reef, or through one of its narrow openings, to the place where the 'Basilisk' found them. Thirteen only were then alive out of the eighty natives who had sailed from Rewa. We took these survivors to Cardwell, 30 miles distant, which was then, excepting Cape York, the most northerly point of Queensland, and here, under the humane care of Mr. Brinsley Sheridan, the Police Magistrate, they recovered strength in time, and were afterwards taken by us to Sydney, whence they were carried by one of H.M. ships to their various islands in the Solomon group."

It will be remembered that in 1848 , KENNEDY, who landed at Tam O' Shanter Point, opposite Dunk Island, had been unable to

1 Discoveries and Surveys in Now Guinea and the D'Entrecasteaux Islands, A Cruise in Polynesia and Visits to the Pearl-shelling Stations in Torres Straits, of H.M.S. "Basilisk." By Captain John Moresby, R.N. London, I876.

Two Admirals: Admiral of the Fleet Sir Fairfax Moresby $(1786-1877)$ and His Son John Moresby. By Admiral John Moresby. London, John Murray, 1909. 
get away from the coast until he had been forced southward to about 2 miles north of the site of the present town of Cardwell, which by the time of the "Basilisk's" visit, twenty-three years later, had become an agricultural centre and the port for the Etheridge goldfield.

"Various tribes of aborigines," says Moresby, "range about the vicinity and not unnaturally regard the white men who are rapidly dispossessing them of their homes as mortal enemies. They show this feeling by committing murders and outrages, and suffer terrible retaliation at the hands of our countrymen, who employ native troopers, commanded by white men, to hunt down and destroy the offenders."

Mr. SABBEN, Navigating Lieutenant of the "Basilisk," was left in charge of the "Peri." (SEE MAP K.) The "Basilisk" after leaving Cardwell, took in wood and water at Fitzroy Island, ${ }^{1}$ off Cape Grafton (see Map G), and left for Cape York on 9th February. SOMERSET was reached on the I6th and the steamer lay there at anchor for six nights. (SEE MAP A.)

The settlement had been founded in 1866 , but had failed to attract a trading population. Captain Moresby found only Frank Jardine, the explorer of 1865 , now acting as Police Magistrate, and the five white men of his boat's crew, with some fifteen or twenty coloured men, some of them native troopers and the rest pearl-divers. The removal of the settlement to a better site was already contemplated.

During the detention of the "Basilisk" at Somerset, an attempt to visit some of the islands in boats, piloted by Mr. CHESTER, formerly Police Magistrate at Somerset, was rendered abortive by stormy weather, which set in as soon as the Albany Passage had been cleared. Moresby visited a NATIVE CAMP about 3 miles from the settlement and was impressed by the low type of humanity presented by the idle, depressed and shiftless natives, who, in sharp contrast to those of New Guinea, attempted no cultivation and built no permanent dwellings.

The "Basilisk" left Somerset on 22nd February, and in a few days located a reported danger, now known as the MoresBY Rock, east of Saddle Island (10 $\mathrm{I}^{\prime} \mathrm{S}$. ; $142^{\circ} 42^{\prime} \mathrm{E}$.). Two vessels had already been wrecked on it. SADDLE IsLAND is described as "fertile and hilly, though uninhabited."

About 30 miles north of Saddle Island lies GABBA IsLand, or The Brothers $\left(9^{\circ} 45^{\prime} \mathrm{S}\right.$.), and this was visited next. The large reef south of the island, charted as Mourilyan ReEF (after Lieutenant Mourilyan), was surveyed.

Gabba Island is distinguished by a couple of "twin" hills,

1 In 1877 , the writer was on board the "Normanby," from Singapore, when 250 Chinese, bound for the Palmer goldfield, were landed on Fitzroy Island, to be quarantined because of cholera on board. 
which explains the growing use of the English, in preference to the native, name, and was, at the time of the visit, one of the chief centres of the pearl-shelling industry. Moresby made inquiries into the conditions under which island labour was recruited to man the pearl-shelling boats, and concluded that in many instances the divers had only imperfectly understood alleged verbal agreements with their employers, who detained them for years, in slavery, by force or fraud; while in still worse cases there was "nothing more nor less than an organised system of KIDNAPPING, attended at times with atrocities that it blanches the cheek and makes the blood run cold to hear of." At the close of the year, the boats were wont to sail for Sydney, each with thirty or forty tons of shell, worth from $\oint_{150}$ to $£_{1} 80$ per ton. The islanders, thus taken to Sydney, soon spent their earnings and were glad to ship for further services. These statements, it must be pointed out, were not made of Gabba Island in particular, but applied to the whole industry and region. The existence of abuses of this kind was corroborated by the Hon. John Douglas and Mr. Chester, P.M., and led to legislation under which island labour was regulated and supervised, the pearlers having to be licensed to recruit and employ labour and being forced to make proper agreements and to carry them out.

Although the survey of the Mourilyan Reef was reserved for the "Basilisk," Gabba Island itself was already well known. BLIGH had passed it in 1792, with the "Providence" and "Assistance," and Captains BAmpton and Alt, in the "Hormuzeer" and "Chesterfield," in 1793, Dumont D'URville, with the "Astrolabe" and "Zèlée," in I840, and BLAckwood, in the "Fly," in 1846 .

"Due north of The Brothers, the high peak of Cornwallis IsLAND could be seen about 20 miles off, and occasionally, when raised by the mirage, the low, wooded outline of SAIBAI IsLAND, lying about 4 miles from the New Guinea coast, not marked on any chart, and only recently brought into knowledge by the pearl-shellers" (p. 27). Saibai Island was, in fact, first charted as an island by Moresby on this occasion (p. 132).

From Gabba, the "Basilisk" went eastward to WARrior

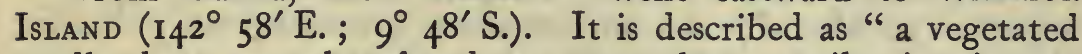
sandbank on a coral reef and not more than 2 miles in circumference, and yet the home of one of the most powerful tribes in Torres Strait." It was also, at the date of the "Basilisk's" visit, the headquarters of a pearl-shelling station belonging to $\mathrm{Mr}$. Merriman, of Sydney, "the largest and best-conducted in the Straits," and in charge of Mr. Bedford, who gave a cordial welcome to the "Basilisk." The Natives evidently impressed Moresby with their (comparative) advancement. They had war canoes 50 or 60 feet in length, 6-foot bows and poisoned arrows. 
Moresby remarks that the name of the island had been given in commemoration of an attack on a man-of-war " in former years." This vague reference is to the attack on the "Providence" and "Assistant," commanded by Bligh and Portlock, in I792. He saw a "war dance" of natives.

On the island were two teachers or Missionaries, natives of the Loyalty group of islands. They had been brought, with others, some nine months previously, by the Revs. S. Macfarlane and A. W. Murray, from Cape York and landed on Cornwallis and Saibai Islands, where they were left with a small stock of "trade" for the purchase of their requirements and the propitiation of the native chiefs. When food and trade were exhausted, the two men came to Warrior Island to beg for relief for the wives they had left sick and starving at Cornwallis Island, and were fortunate enough to obtain alms, first from Mr. Merriman's employees and afterwards from the men of the "Basilisk."

The "Basilisk" returned to Sydney by the inner passage, calling at Lizard IsLand and the ENDEAvour River. In all probability the course was outside of the Dungeness Reef, and, if so, this would be the first occasion on which she cleared the strait now known as Basilisk PAss, between Warrior and Dungeness Reefs. The pass had already been used, though not named, by Bligh and Portlock, in the "Providence" and "Assistant," in 1792; and by Bampton and Alt, in the "Hormuzeer" and "Chesterfield", in 1793; while Dumond D'Urville, with the "Astrolabe" and "Zielee," had the misfortune to discover the "Mauvais Canal," on the wrong side of Warrior Island.

Moresby took the "Basilisk," on the 5th March, 1871, to the spot where Cook had landed in 1770 , and found it just as Cook had left it. Before he had found time to pen his narrative, the discovery of the PaLmer GoldField had created on this spot the township of Cooktown, with " a population of Io,000 people, three banks, a daily newspaper and all the appointments of a full-grown city."

The "Basilisk" arrived at CARDwell on 9th March, 1871, and came in touch with a tragedy which has become historical.

Sabben, who had been left in charge of the captured "Peri," reported to Moresby the circumstances attending and following the WRECK OF THE "MARIA," a brig of 167 tons. Sixty-seven adventurous spirits had clubbed together in Sydney, contributing fio each towards the expenses of an expedition, of which the chief item was the purchase of the leaky and ill-found old craft in which they eventually sailed with the intention of prospecting in New Guinea. Four hundred miles short of their destination, they met the north-westerly monsoon and just escaped shipwreck. In an almost helpless condition they drifted southward for a time before they managed to steer westward through the Barrier Reef. 
When, at length, they had begun to believe that their troubles were about to end, the ship struck (on 26th February, before daylight) on Bramble Reef, on the south side of Rockingham Bay. (See MaP K.) The Captain, taking six men, according to the information given to Sabben, deserted the ship with the best boat (which would have held twenty) in the early morning, under the pretence of going for assistance, Cardwell being about 30 miles to the west. This boat's crew landed at 'TAM O' Shanter Point, where the Captain and three of his men met their death at the hands of the natives. The three survivors (who had only dared to travel by night) crawled into Cardwell some days afterwards. Sabben at once took the gig and hurried (4th-5th March) to Tam O' Shanter Point, with two of his own men and six volunteers from Cardwell. They found the Captain's Boat drawn up into the scrub, where preparations had been made to burn her. The party, who had been without food for twelve hours, hauled the boat to the water and had begun to cook a meal on shore, when they were suddenly RUSHED BY 120 NATIVES, who emerged from the mangroves, armed with spears. The assailants were beaten off, with a loss of eight killed and eight wounded. The gig then returned to Cardwell, with the Captain's boat.

Almost simultaneously with the departure of the gig from Cardwell, Mr. Brinsley Sheridan, Police Magistrate, chartered the small steamer "Tinonee," which visited the scene of the wreck ; but nothing was to be seen of the "Maria," even her masts having sunk.

The fact that the Captain left the ship secretly and before daybreak certainly favours the theory of desertion, but as his death deprived him of an opportunity of explaining his conduct, it is charitable to surmise that he wished to avoid a panic and that he hoped to organise a speedy rescue from Cardwell; in short, that he only added one more to the numerous errors of judgment which he had already made.

When the absence of the Captain and the boat was discovered, the mate, who took charge, had two RAFTs constructed. These had barely been launched when the ship heeled over, slipped from the reef, and sunk to her lower yards. Thirteen men scrambled into the larger raft and twelve into the smaller, while some clung to the rigging of the ship. At this critical moment, there were only two boats belonging to the ship, and one of them was pursuing the other, which had broken adrift. Both boats then returned to the ship and took as many men as could be accommodated, leaving nine clinging to the rigging. The воATs then made for the nearest land, I 5 miles distant; but it was five days before they reached Cardwell, a devious course having probably been forced upon them by the weather; or perhaps the occupants of the boats may have been unaccustomed to navigation and unprovided with charts 
and consequently ignorant of the exact locality of the then infant settlement. ${ }^{1}$

Six days later (9th March), on the arrival of the "Basilisk," Mr. Sheridan claimed the assistance of the warship in punishing the murderers of the captain of the "Maria" and his three men, having by this time come to the conclusion that the existence of the settlement itself was threatened by the blacks. The request was met by the detail of fourteen men from the "Basilisk," under Lieutenant Francis Hayter, who were joined by a detachment of native troopers, led by Sub-Inspector R. Johnstone, on board the "Peri." "The tribe was surprised before daylight," and a bloody vengeance was meted out.

Moresby himself took the "Basilisk" in search of the rafts, and at Cooper's Point (lat. $17^{\circ} 25^{\prime}$ S.) descried white men on the beach. Eight emaciated and half-naked wretches were all that remained of the thirteen men who had left the "Maria" on the 26th February, on the LARGER RAFT, unprovided with food or water. They had but a single oar; and a tent which was fashioned into a sail was soon lost. It was not long before two men became insane and two others were drowned. On the third day, another man went raving mad and died. At night another went mad, but was restrained from violence by his companions. In the small hours of the following morning the raft grounded, and the men scrambled to the beach, where they slept till daylight, when they found fresh water and some wild fruits. Shortly afterwards they met a party of natives, who entertained them with generous hospitality, lodging them in their own gunyahs and giving them a share of their own scanty provisions. Both hosts and guests were on the verge of starvation when the "Basilisk" came to their rescue.

On the same day (12th March) that the eight men were rescued from the larger raft, Lieutenant Sydney Smith, in the "Basilisk's" cutter, found the remains of the SMALLER RAFT on the beach, not more than 6 miles from the point where the larger had grounded, the two localities being separated by what Moresby afterwards

1 Thomas Tate, who had been a medical student, was Acting Surgeon on the "Maria" and was generally spoken of as Doctor Tate. Later in 1872 , he joined William Hann's expedition as Botanist. According to his narrative, "An Old-Time Story" (Norman Chronicle, 1903, and North Queensland Register, 13th December, 1915), the mate took charge of one of the boats, with thirteen men, and Tate of two boats, with fifteen men. The boats were beached on the seaward side of Hinchinbrook Island, where the starving men spent five wretched days, the weather being too rough to permit of their putting to sea again. Afterwards they coasted the island southward and entered the Hinchinbrook Passage, between the island and the mainland and, turning northward, reached Cardwell in two days. Tate's story leaves little doubt that the Captain (a German) deliberately deserted the wreck and the men for whom he was responsible. The mate became temporarily insane from excitement and exposure, and had to be put under restraint on his arrival at Cardwell. Tate, as the only other surviving officer of the "Maria," went with Moresby in the "Basilisk" to the scene of the wreck. 
named the Gladys River." Here the bodies of two men were found. Two days later, the naked body of another castaway was discovered, and its condition pointed to a violent death, the skull having been beaten in. "Still further search, afterwards made by Navigating Lieutenant Gowland, of the New South Wales Government steamer 'Governor Blackall,' discovered six more bodies further to the south, which showed that those who had landed from the smaller raft had endeavoured to reach Cardwell by walking along the beach, but, meeting hostile natives, had been murdered." Although only nine of the twelve men on the raft are accounted for, there is no reason to doubt that three more met a similar fate.

The contrast between the conduct of the natives in the case of the Captain's boat and the smaller raft on the one hand and that of the larger raft on the other is very remarkable. It is possible that some difference in the attitude of the castaway parties may have led to murder in one case and succour in the other. Or there may have been different tribes of natives, actuated by different ideas. It is to be hoped that the "tribe" which received exemplary punishment for the murder of the captain and his three men had no connection with that which saved the lives of the occupants of the larger raft.

In the course of the search for the shipwrecked men, Moresby discovered the admirable little landlocked harbour which he named after his Navigating Lieutenant, Mourilyan, with the Moresby River (which he named after himself) "flowing into the sea at its south head." It may be noted that the country behind Mourilyan Harbour was shortly afterwards surveyed by GEORGE Elphinstone Dalrymple, who pronounced it fit for the cultivation of sugar cane, and that it has since become an important centre of the SUGAR INDUSTRY.

The "Basilisk" returned to Cardwell on 15 th March, 1871, and sailed for Sydney two days later, with the "Peri" in tow. The survivors of the "Maria" were taken on board the "Governor Blackall," which had been sent to Cardwell for the purpose by the Government of New South Wales.

In the course of her voyage south, the "Basilisk" called at the Percy Islands and KePPEL Bay, and the officers had the pleasure of attending a ball in " the rising town of Rockhampton." MORETON BAY was reached on 27th March, I871, and Moresby had an interview with the Governor, Lord Normanby, and the Premier, the Hon. (afterwards Sir) Arthur Palmer. SYDNEY was reached on 6th April.

1 The mouth of this river now bears the name of Gladys Inlet. In 1873 , Dalrymple named the river the Johnstone, after Sub-Inspector Johnstone, believing him to be the first to trace it inland, and the name has stuck beyond remedy. As a matter of fact, Lieutenant Sydney Smith, of the "Basilisk," had been ro miles up the river in a boat during the search for the survivors of the "Maria." 


\section{CHAPTER L}

\section{MORESBY, continued}

\section{SECOND CRUISE OF THE “BASILISK" IN TORRES STRAIT, I873}

Leaves Sydney, 8Th December, 1872. Reaches Cardwell, 2nd January, 1873. Schooners " Melanie" and "Challenge" captured and taken to Fitzroy Island. Uncovenanted South Sea Islanders on Board, recently employed in diving for Pearl-shell. Shits condemned as Prizes in Brisbane. Decision reversed on Appeal to Privy Council. Retrospective Evidence disallowed. Another Prize, the Barque “Woodbine." Pearl-shell and Uncovenanted Labourers on Board. Was the Shell gathered before the New Legislation? "Woodbine" sent to Brisbane. Released for Want of Evidence. Barque "Crishna," with South Sea Islanders on Board, sent to Brisbane. Condemned and sold. There ought to be a River entering Lloyd Bay. NetWork of Swamps, but No River. Lockhart River discovered later. "Basilisk" to Somerset. Frank Jardine. The Naturalist, Cockerill, and his Collection of Birds. "Basilisk" surveying in Torres Strait. Saddle Island. Gabba Islands. Jervis Island. Pearling Stations. Cornwallis Island, 30th January, 1873. Saibai and Cornwallis Islands and Part of New Guinea Coast surveyed by Whale-boat Party. "Basilisk" to Warrior Island. Pearlers idle, waiting till Licences could be obtained. Through Basilisk Pass to Coco-nut Island. Pearling. A Model Village. Darnley Island, now Centre of Bêche de Mer Industry. Sago Palms. Murray Islands (11th February). To Redscar Bay, New Guinea. Discovery of Port Moresby. To Somerset (7th March). Rejoined by Whale-boat. Survey of Somerset Harbour. "Basilisk " looks for Better Site for Settlement. Moresby recommends Hammond Island. Another Cruise among Islands. Pearling suspended. Awaiting Licences. Cornwallis and Warrior Islands. Yule Island. Eastern End of New Guinea surveyed. China Strait and Hayter, Basilisk and Moresby Istands discovered. Islands claimed for Great Britain. To Somerset. Boat Parties report Extensive Surveys of Warrior Reef and New Guinea Coast. Another Cruise among Pearling Stations. Work suspended. Waiting for Licences. Leaves Somerset, 24th May. Arrives at Brisbane, 21st June, I873.

FTER cruising among the islands of Polynesia from I4th May till 24th September, the "Basilisk" left SyDNEY on 8th December, 1872, for Torres Strait and New Guinea. On calling at Brisbane, Moresby again met the Governor, Lord Normanby, and Mr. Palmer, the Premier, of Queensland, from whom he learned, among other things, that the Government contemplated the establishment of a MAIL SERvICE to be carried on by 
a line of steamers running between Brisbane and Singapore. A survey of such portions of the mail route as lay in her way, therefore, became a part of the "Basilisk's" objective, and it was with much satisfaction that Navigating Lieutenant Connor, R.N., was added to the surveying staff.

Reaching Cardwell (Sem Map K) on 2nd January, 1873, Moresby went ashore to see Mr. Brinsley Sheridan, the Police Magistrate, by whom he was informed that "the pearl-shellers had received warning that the new Kidnapping Act, which rendered the employment of natives illegal, without licence, had come into force, and that they knew of the 'Basilisk's' coming, and were clearing out of the straits as fast as possible," "on which," says Moresby, "I determined to make all haste north."

On 5 th January, the two schooners, the "Melanie," with fifty-five, and the "Challenge," with thirty-three South Sea Islanders on board, were captured and taken to Fitzroy IsLand. ${ }^{1}$ As the result of an investigation held there, it appeared that the islanders, who had been employed as divers in Torres Strait, had, in many cases, understood that their service was to be of limited duration, whereas some of them had served for six years, for nothing more than food, clothing and tobacco. Others stated that they had shipped voluntarily; some were on the ships' books as having been legally engaged at Sydney; seven alleged that they had been "kidnapped"; others, according to their own account, had been run down in their canoe by a schooner named the "Maria Renny," and taken on board ; while another had been " seized from a reef." There is nothing to show that the officers of the schooners were given an opportunity of presenting their side of the story, beyond the statement that "to secure themselves from the penalties of the new Act, the pearl-shellers had induced these natives to sign an agreement to serve them for five months from August, and had fixed wages for them." "After the investigation," says Moresby, "we sent the vessels as prizes to Sydney, where they were condemned; but on a subsequent appeal to the Privy Council, the highest appeal court for the colonies, the vessels were restored, on paying all costs connected with the case, on the grounds that retrospective evidence could not be entertained and that an intention to procure a licence had been proved."

While the "Basilisk" lay at anchor off Fitzroy Island, and the investigation was in progress, the poor "slaves" had a merry time diving and scrubbing her copper sheathing. As "some eighty" of them (out of a possible eighty-eight) were engaged at once in this pastime, it was evidently a very popular amusement.

On 8th January, the barque "Woodbine" was taken as a prize. She had on board 20 tons of pearl-shell, gathered by coloured

1 Off Cape Grafton. See Map G. 
labour, ${ }^{1}$ and three South Sea Islanders, without licence, and her men were suffering dreadfully from scurvy.

"I sent this vessel," says Moresby, "to Brisbane, in charge of Lieutenant S. G. Smith, where she was eventually released for want of sufficient evidence."

"On the I 4 th," continues Moresby, "we boarded the barque 'Crishna,' of Sydney, and found that she had thirty-five South Sea Islanders on board, whose history was so similar to that of the 'Melanie' natives that I need not relate it. We sent her to Brisbane, where she was condemned and sold for $\mathcal{L} 3,900$, with her cargo, intelligence of which was very cheering to the ship's company. 'This amount has since been heavily cut, down by law expenses, and the Imperial Government has claimed half the remainder."

The owners of the "Crishna" do not appear to have followed the course pursued by the owners of the "Melanie" in appealing to the Privy Council.

"Wishing to clear up doubt," says Moresby, " as to the existence or non-existence Of a RIVER REPORTED AT THE BOTTOM OF LLOYD's BAY, we stood in and anchored near Low Island on the evening of the 15 th [January, 1873]. [SEE MAP C.] The chart at this point is marked 'apparent opening of a large river'; and it will be seen, by a glance at the map of North Queensland, that a river would be a rich gift of Nature here, as affording an opening into the country and a highway for the transit of agricultural produce. Navigating Lieutenant Connor and I, in the galley, and Mr. Mourilyan, in the gig, came to an anchor accordingly, off the supposed entrance of the river, at II p.m. . . At daybreak we began our search for the river, and explored one salt-water creek after another; but each was a failure, and led only to entanglement in the swamp, where clouds of mosquitoes resented our invasion of their holds. THERE WAS NO RIVER. The drainage of a hill range, 6 or 7 miles inland, had created a swamp of many miles extent, covered with mangroves and intersected by these salt-water creeks; and that was all."

But that was not all. The boats had simply got lost, as they very well might, in the network of channels formed by the outlet of a large river. Greater persistence, or a stroke of luck, would have revealed a channel leading up to deep fresh-water reaches. Seven years later, the writer stood on an eminence from which he sketched the windings of a river in the bottom of a valley which fell to the north, parallel to the coast-line, from near its head to its mouth in Lloyd Bay. The right, or eastern, wall of the valley was formed by a sierra to which he gave the name of MACrossan RANGE." The left was formed by a portion of the " Great Dividing Range," which parts the waters of the Pacific and the Gulf of Carpentaria, and which, for the reason that in this locality it is a distinct geographical entity, he called the McIlwraith Range.' The river itself he named the Lockнart.' Shortly afterwards,

1 The presumption is that the shell had been gathered before the Act came into force : at all events, no evidence to the contrary is adduced. Moresby, in his zeal, not only anticipated the attitude of the labour unions of recent days in treating as " black" any commodity which had been handled by non-union workmen, but even made his condemnation retrospective.

2 After the Hon. John Macrossan, Minister for Mines.

- After Sir Thomas McIlwraith, Premier of Queensland.

- After Hugh Lockhart, S.S.C., Edinburgh, a friend of his boyhood. 
this river became a waterway for sandalwood getters and gold prospectors operating in the McIlwraith and Macrossan Ranges. These pioneers of industry established Giblet's Landing, at the head of the tidal reaches. Mr. Jонn EMbLEY afterwards surveyed the lower reaches of the river and laid out a township. (SEE MAPS B AND A.)

From Lloyd Bay, the "Basilisk" proceeded to SomERSET, where she anchored on I8th January, 1873. Her officers were welcomed by FRAN K JARDINE, the leader of the exploring expedition of 1865 , now acting as Police Magistrate. A service was held on the ship by the Rev. A. W. Murray, who had been conducting missionary work in the South Seas for thirty-five years. The wet season had set in. Here an interesting personage was met, a naturalist named CocKERILL, who lived, with his son, and a couple of natives, in an 8-ton boat, and had amassed a magnificent collection of tropical birds.

The "Basilisk" left Somerset on 24th January, 1873, and anchored at SAdDle IsLAnd. (See Map A.) Thence a survey was made to GabBa, or The Brothers IsLANDS. Jervis IsLand was next visited, and in this neighbourhood the "Basilisk" stuck on a shoal, but got clear on the rise of the tide. Jervis Island, which is said to be volcanic, rises to 525 feet. It was, at the date of the "Basilisk's" visit, the headquarters of three pearling stations. The anchorage was surveyed and named Philip Harbour. Moresby remarks that "the space of 36 miles which lies between Jervis Island and the low mangrove-covered coast of New Guinea is a mass of coral reefs and contains no passage for ships and scarcely any for boats. Thus all the passages by which ships can enter Torres Straits lie between Jervis Island and Cape York, and are now British waters." $\mathrm{He}$ adds: "The natives of Jervis Island are black Papuans, quite uncivilised and unclothed." (Cf. Douglas on Islands of Torres Straits, I866.)

Cornwallis IsLand was next visited (3oth January, 1873). It is described as high and healthy, a granite mountain rising to an altitude of 790 feet. It had hitherto been held to be part of the mainland of New Guinea. SAIbaI IsLand was the next anchorage, and was described as low and probably malarious, with 600 inhabitants, with two-story houses raised on poles, and some cultivation. It had for the first time been charted as an island by Moresby, who saw it in 1871 from the neighbourhood of Gabba Island. Lieutenant Connor, and Mr. Pitt, Midshipman, with nine seamen, in the pinnace and a whale-boat lent by Mr. Jardine, were left at Saibai Island to make a survey, while the "Basilisk" sailed for the eastern islands of Torres Strait and the New Guinea COAST. On the $4^{\text {th }}$ February, she touched at WarRIOR ISLAND, to find that pearl-sheling had come to a standstill, thirty-two South Sea Islanders being idle while waiting till their employers 
had secured licences. Next day she went through the Basilisk Pass to Coco-nUt IsLand, where a Scotchman had recently established a pearl-shell fishery and a model village. The population was estimated at 150 . Fresh water had to be brought, in bamboo tubes, from Sue Island, I 5 miles distant.

On 8th February, Darnley IsLand was visited. This mountainous island was then the centre of the bêche de mer industry. This dainty, destined for the Chinese market, was at the time worth from $£^{80}$ to $£^{1} 40$ per ton." "This," remarks Moresby, " is the only island in Torres Straits in which sago Palms GROw."

The Murray Istands were touched at and left behind on I Ith February, and the "Basilisk" "stood across the Gulf of Papua for REDSCAR Bay [ $\left.9^{\circ} \mathrm{I} 0^{\prime} \mathrm{S}.\right]$, about 200 miles distant, on the east New Guinea coast [presumably she went out by Flinders Passage, and north of Portlock and Lagoon Reefs, and thence E. $12^{\circ} \mathrm{N}$. to Redscar Bay. - R. L. J.], to visit the missionary station established there, where the MISSIONARIES were said to be sick and half-starving, and to glean KIDNAPPING INFORMATION. "Some large rivers," says Moresby, "were reported to exist in this neighbourhood, and we determined to explore sufficiently to make sure." This portion of the coast had been partly surveyed by Captain Owen STANLey in I849, but it was reserved for Captain Moresby to discover and survey Port MOREsBy ( $9^{\circ} 30^{\prime} \mathrm{S} . ; 147^{\circ} \mathrm{IO}^{\prime} \mathrm{E}$.) and the Inner or Fairfax Harbour.

On 5th March, the "Basilisk" returned to Somerset. On the 7 th she was joined by Messrs. Connor and Pitr, who, with nine men, had been left at Saibai Island six weeks before. They had made a survey of SaIbai and Cornwallis Islands and a part of the adjacent New GuinEa coast.

The barque "Springbok" was lying at Somerset, with eighty-five disappointed diggers, returning from the goldfields behind Port Darwin, and was short of provisions and stores. Moresby acted with promptitude and vigour, convened a naval court, deposed the skipper, whose incompetence for command was established, and put the barque in charge of Sub-Lieutenant Allan Waters, who navigated her to Newcastle, New South Wales.

The Rev. A. W. Murray and his wife, from Sydney, had recently arrived at Somerset, where they were housed in quarters provided by Mr. Jardine. From this station, without even possessing a boat, Murray had essayed the impossible task of conducting, controlling and protecting the various mission stations scattered among the islands of Torres Strait and as far as Redscar Bay. Moresby addressed to him a remonstrance in the form of a report on the wretched condition of the missionaries whom he had met with. The result was that the missionary

1 It rose to $£^{600}$ per ton in 1920 . 
society provided Murray with a small steamer and some young assistants. ${ }^{1}$

The tender "Restless" was at Somerset, with rations for the "Basilisk," which had to remain in this neighbourhood till the beginning of June, when a relieving ship was due. By this time the air was full of rumours concerning the true object of various Russian, French, Italian and American scientific expeditions to New Guinea.

During the stay of the "Basilisk" at Somerset, Navigating LieUtenant Connor made a trigonometrical survey of the harbour. When the "Basilisk" left, he was left behind, with Mr. Midshipman Grant as his second-in-charge, to survey the northern shores of Torres Strait.

The "Basilisk" left Somerset on 2oth March, Moresby having been requested by Lord Normanby to assist Jardine in looking for a better site for the settlement than Somerset. Considerations of safe anchorage and a plentiful water supply led him to recommend HAMMOND IsLand, after a short visit.

With the object of seeing that all was right on the pearling stations, the "Basilisk" visited several islands, to find the industry at a standstill, while the Government licences were awaited.

Cornwallis Island was revisited, and the "Basilisk" left for WARRIOR IsLAND on 26th March. She left again for the east coast of New Guinea on 28th March. Bramble Cay and Yule Island were visited and the Robert Hall Sound, New Guinea $\left(146^{\circ} 3^{\prime} \mathrm{E}\right.$.), was surveyed, and the eastern limit of New Guinea was for the first time correctly defined. The survey of a portion of the north-east coast of New Guinea was then commenced.

On 21st April, 1873, Moresby took the "Basilisk" through the China Strait, round the eastern end of New Guinea. The strait and the islands to the east, viz., Hayter, Basilisk and Moresby, were his own discoveries. On the 24 th, he Tоok Possession of these islands for Queen Victoria. Shortly afterwards he left the China Strait for Somerset, which was reached in ten days. Here Connor and GRANT reported themselves, having spent two laborious months in open boats, and having surveyed 46 miles of the great WARRIOR REEF and I 48 miles of the southern coast of New Guinea and islands, including Saibai and Cornwallis.

Once more the "Basilisk" toured the pearling stations, to find the industry still stagnant, work having been suspended pending the arrival of licences, and all the Polynesian labourers sent to their homes. She finally LEFT SOMERSET on 24th May, arriving at Brisbane on 2 Ist June, and SydNeY on 22nd July, I873.

1 The Rev. S. Macfarlane and the Rev. A. W. Murray first established a mission at Somerset. In $187 \mathrm{r}$, they established another in Murray Island. Past and Present of Thursday Island and Torres Strait, by the Hon. John Douglas, C.M.G., Government Resident. Thursday Island. Brisbane, 1900. 
This was practically the last of Moresby's exploring and surveying voyages so far as they affected the shores of Cape York Peninsula and the islands of Torres Strait; but a vast amount of useful work was done by him on the east and north of New Guinea before the "Basilisk" was finally paid off at Sheerness on $15^{\text {th }}$ December, 1874 .

END OF VoL. I. 

ran 

